Utah State University

DigitalCommons@USU

\title{
Long-Term Vegetation Change in Utah's Henry Mountains: A Study in Repeat Photography
}

Charles E. Kay

Utah State University

Follow this and additional works at: https://digitalcommons.usu.edu/aspen_bib

Part of the Agriculture Commons, Ecology and Evolutionary Biology Commons, Forest Sciences

Commons, Genetics and Genomics Commons, and the Plant Sciences Commons

\section{Recommended Citation}

Kay, C. E. 2015. Long-term vegetation change in Utah's Henry Mountains: a study in repeat photography. USDI, Bureau of Land Management, Salt Lake City, Utah. 274 p.

This Report is brought to you for free and open access by the Aspen Research at DigitalCommons@USU. It has been accepted for inclusion in Aspen Bibliography by an authorized administrator of DigitalCommons@USU. For more information, please contact

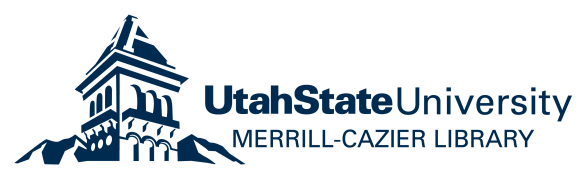


Long-Jern Vegetatjon Change in Uiah's fensy Moustajsss

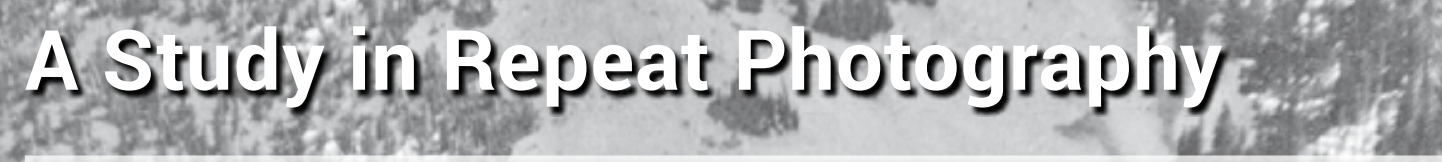

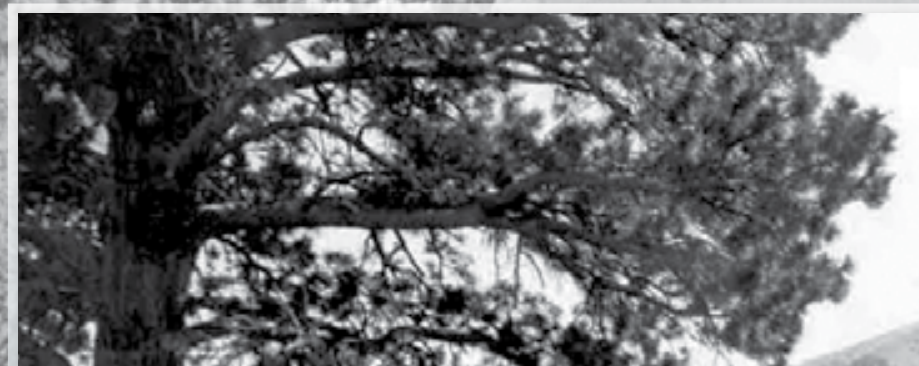

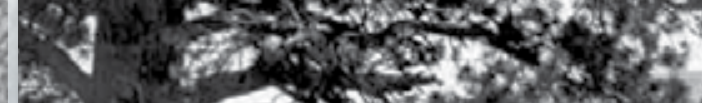

$3>20.03$

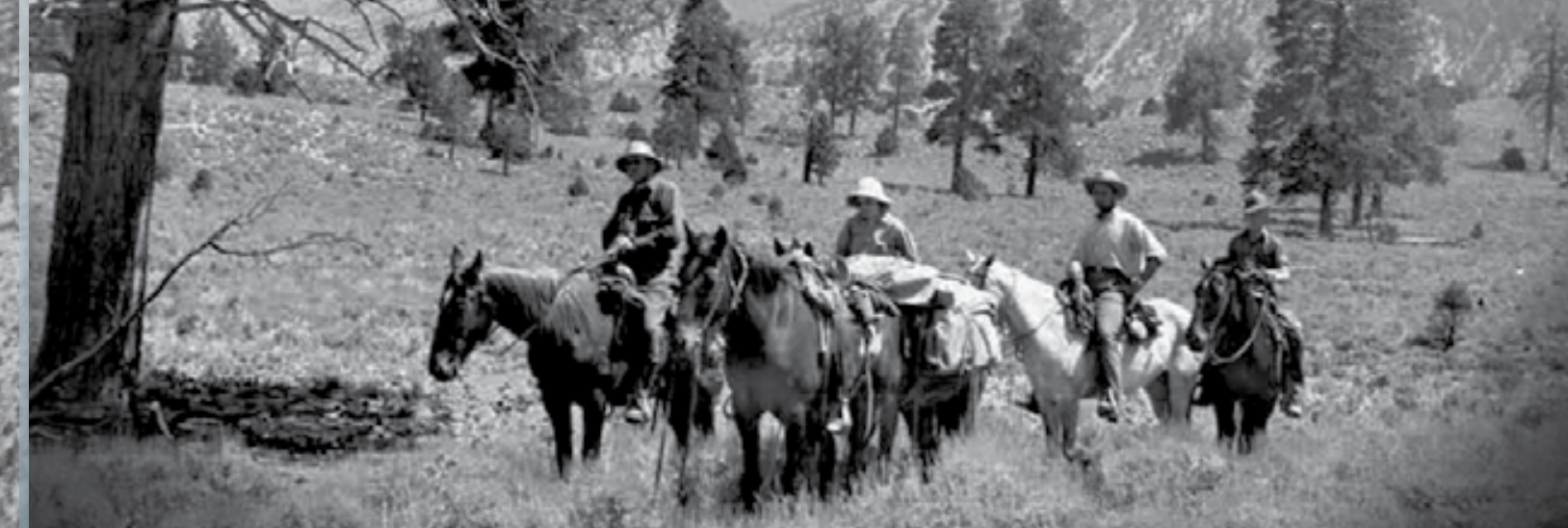

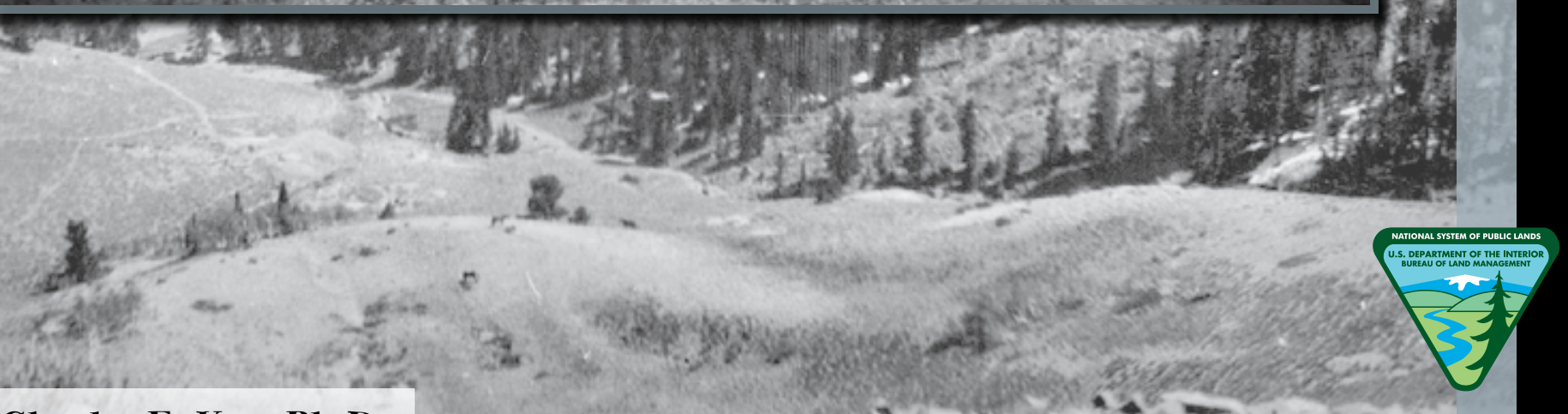

Charles E. Kay, Ph.D. June 2015

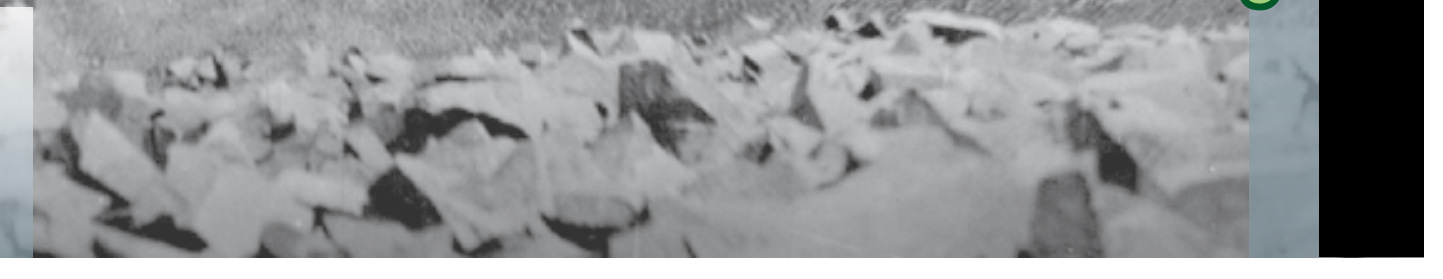


BLM-UT-GI-14001-8002+REV15 


\section{Long-Term Vegetation Change in Utah's Henry Mountains A Study in Repeat Photography}

Charles E. Kay, Ph.D.

June 2015 


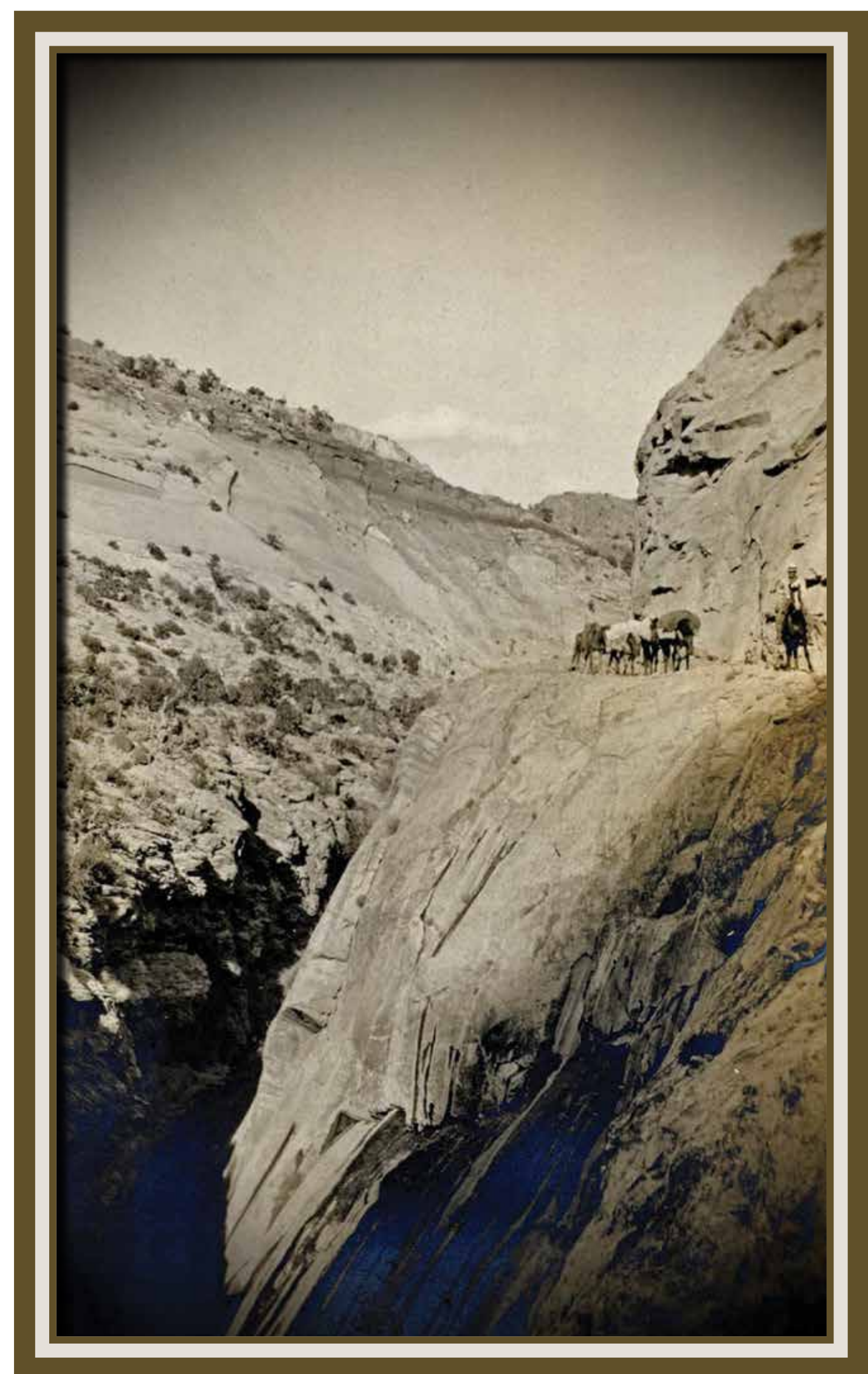

mak Creek Canyon - 1915 \% 


\section{ABSTRACT}

An extensive search was conducted of archival and other sources to locate as many historical photographs as possible for the Henry Mountains in south-central Utah. Those images were then taken into the field, the original camera stations relocated, and modern pictures made of the historical scenes to evaluate long-term vegetation change and land management activities. In all, 626 repeat photo sets were compiled- 608 by the author and 18 by Earl Hindley. This book includes 126 photo sets that were representative of the areas studied.

As might be expected, most photo sets contained more than one vegetation type. Grasslands were depicted in 152 photo sets, sagebrush in 99 , pinyon-juniper in 293 , mountain brush in 72 , aspen in 37 , conifers in 145 , blackbrush in 71 , and woody riparian species in 142 . In addition, all photo sets were evaluated for plant cover and to determine whether the sites showed accelerated soil erosion.

In general, grasslands, sagebrush, and aspen have declined, while blackbrush, mountain brush, pinyon-juniper, and conifers have increased. Utah's rangelands are generally in much better condition today than they were during the early 1900s because plant cover has increased and soil erosion has declined. Repeat photos also show that woody riparian vegetation has significantly increased regardless of whether livestock have been excluded. Contrary to popular perception, coniferous trees and forests are more abundant today than at any time in the past. In fact, the overriding problem on most Utah rangelands has been a major increase in woody plants, which in turn has dramatically reduced forage production for both livestock and wildlife. As conifers, including pinyon and juniper, have increased, so have forest fuels, thereby setting the stage for large-scale, high-intensity crown fires (a type of fire behavior that seldom, if ever, occurred in the past). As judged by stand age and forest conditions seen in early photographs, large stand-clearing fires are outside the normal range of historical variability. Historically, frequent, low-intensity surface fires, most likely set by Native Americans, kept most conifers from increasing.

\section{Aвout the Author}

Charles E. Kay received his Ph.D. in wildlife ecology from Utah State University, his M.S. in environmental studies from the University of Montana, and his B.S. in wildlife biology also from the University of Montana. He has conducted ecological research for Parks Canada, the U.S. Forest Service, the Bureau of Land Management, the Agricultural Research Service, and the Utah Division of Wildlife Resources, among others. Dr. Kay specializes in ungulate ecology, range ecology, large mammal predation, and riparian management. In addition, he is one of the foremost experts on aspen ecology and has personally made more than 3,000 repeat photographs throughout the western United States and Canada.

Dr. Kay has co-edited a book on aboriginal influences and the original state of nature, Wilderness and Political Ecology, published by the University of Utah Press. His research has appeared in Human Nature, the Journal of Range Management, Conservation Biology, The Canadian Field-Naturalist, the Western Journal of Applied Forestry, the Wildlife Society Bulletin, and the Journal of Forestry, among other publications. Dr. Kay has 
contributed to the books The Greater Yellowstone Ecosystem; Humans as Components of Ecosystems; Plants and Their Environment; and Ecology and Conservation of Wolves in a Changing World. Dr. Kay's work on Long-Term Ecosystem States and Processes in Banff National Park and the Central Canadian Rockies was published as an Occasional Paper by Parks Canada. Utah State University Extension and the U.S. Forest Service published a selection of Dr. Kay's earlier repeat photographs in Long-Term Vegetation Change on Utah's Fishlake National Forest: A Study in Repeat Photography.

Charles E. Kay

480 East 125 North

Providence, UT 84332

435-753-0715

Charles.kay375@gmail.com

\section{Acknowledgments}

This study was begun in 2008 at the request of Utah State Senator Dennis Stowell and was initially supported by a grant from the Utah Department of Agriculture and Food. In 2010 the study was funded by a 4-year contract with the Bureau of Land Management (BLM).

I would like to extend my appreciation to Senator Stowell and Commissioner Leonard Blackham, as well as BLM officials Doug Page, Kyle Jackson, Sam Brown, and Sue Fivecoat. I would also like to thank the many archivists who helped locate photographs for this study, as well as the private property owners, who allowed access to their lands so that I could reoccupy several original camera stations. Ranch manager Steve Dalton allowed me to repeat photographs on the Sandy Ranch, while Forrest Sims permitted access to his private lands along the Fremont River and Calvin Bastian gave permission to repeat early images on his Trachyte Ranch. Borge Andersen Photo, now Atelier A.F.A. Foto Digital, in Salt Lake City processed and printed the black-and-white film. 


\section{Contents}

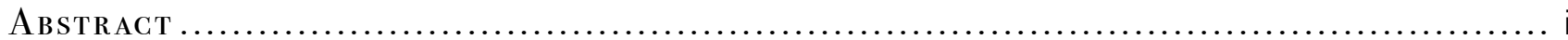

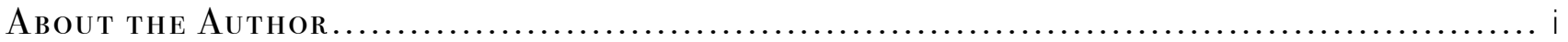

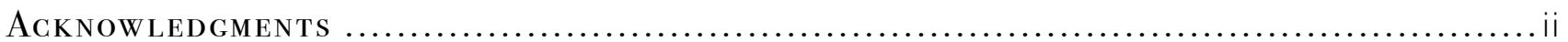

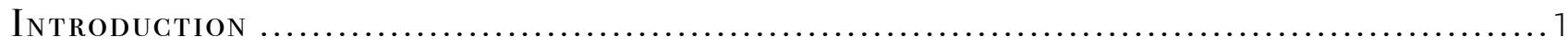

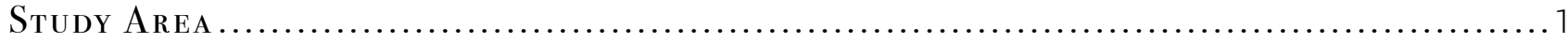

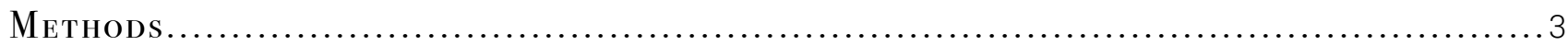

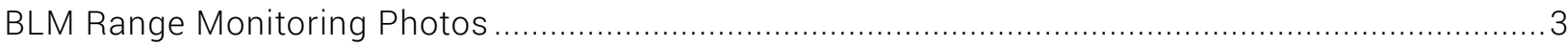

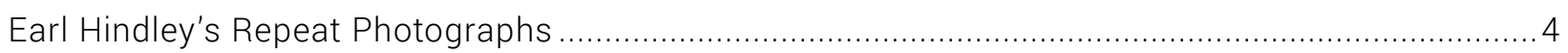

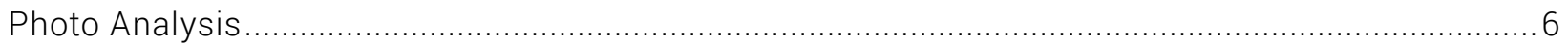

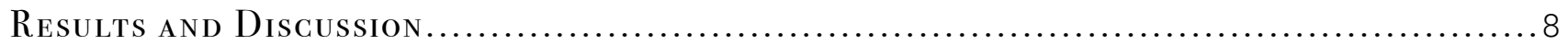

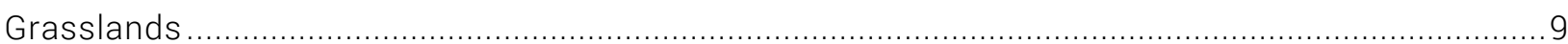

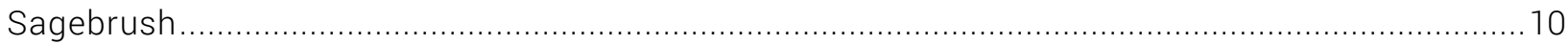

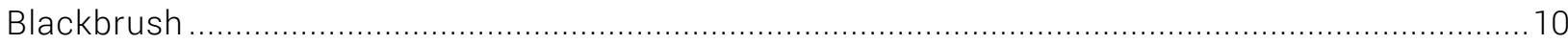

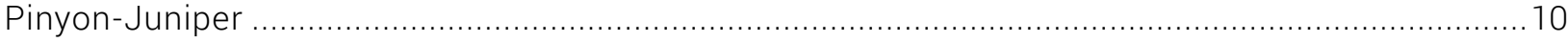

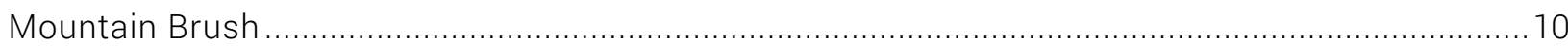

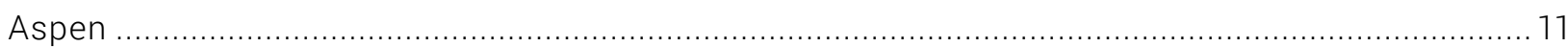

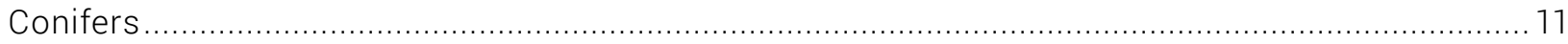

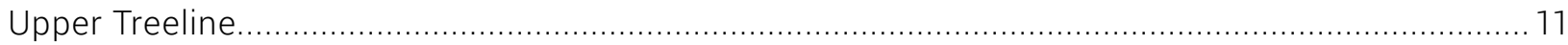

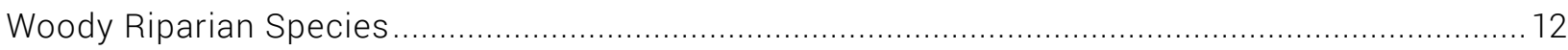

Plant Cover and Soil Erosion .................................................................................................. 13

Comparison with Other Repeat Photo Studies........................................................................ 14

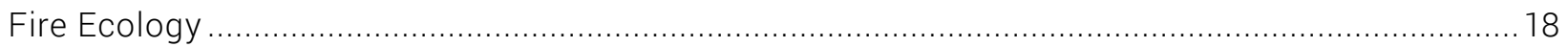

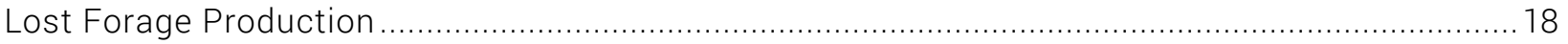

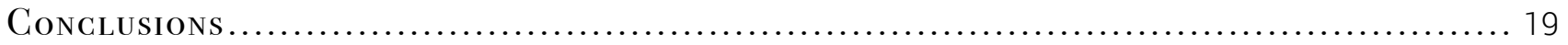

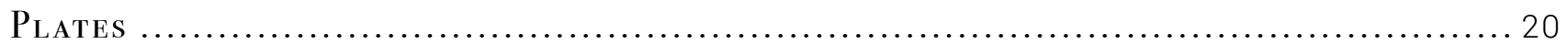

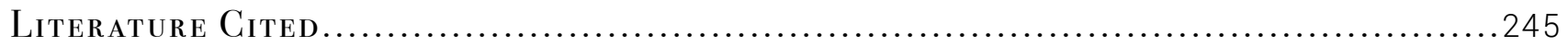

Appendix A, Henry Mountains Repeat Рhoto Logations and Elevations ...................225

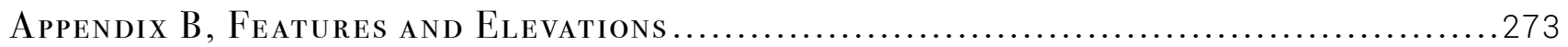

Appendix C, Common and Scientific Names of Plants in the Study ........ Inside Back Cover 


\section{Figures}

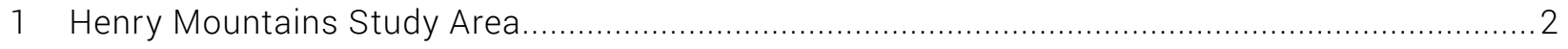

2 Earl Hindley's Repeat Photo Sites in the Henry Mountains ….................................................. 5

3 Locations of the 608 Photo Sets Made in the Henry Mountains …....................................... 7

4 Lightning Strikes and Fire Occurrence in the Henry Mountains, 1990-2011 ........................ 17

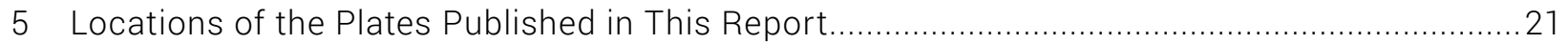

\section{TABLES}

1 The Decade in Which the Original Photographs Were Taken in the Henry Mountains ................ 8

2 Photo Point Elevations in the Henry Mountains (per 1,000 ft.) …....................................... 8

3 Summary of Vegetation Changes in the Henry Mountains .................................................. 9

4 Comparison of Long-Term Vegetation Change in the Henry Mountains and on the Fishlake and Dixie National Forests. 


\section{INTRODUCTION}

Many people are concerned about Utah's forests and rangelands. Are ecological conditions better today than they were in the past? Or are they worse? One way to address these and similar issues is through repeat photography, where scenes depicted in historical photographs are rephotographed as they appear today, forming sets of images taken or repeated from the same camera stations (Rogers et al. 1984; Hall 2002a, 2002b; Webb et al. 2007, 2010). Repeat photographs are extremely valuable because they provide a long-term perspective that is often missing from other studies and because the photo pairs can readily be interpreted by the public. Want to know what things were like a hundred years ago? Find an old photograph. Want to see how things have changed? Locate the original camera station, and rephotograph the scene as it appears today. After all, if a picture is worth a thousand words, repeat photographs are priceless.

Repeat photography works best for vegetation types that are clearly identifiable by photographic analysis, such as grasslands, sagebrush, pinyon-juniper, aspen, cottonwoods, willows, and conifers (including Abies spp., Picea spp., Pinus spp., and Pseudotsuga sp.). Repeat photographs can also be used to estimate rates of soil erosion and plant cover (Rogers et al. 1984; Webb et al. 2010). While the process seems simple, it can often be very time-consuming, because early photographers usually failed to record exactly where their pictures were taken. It may take days to find the camera station for a single photograph.

\section{Study Area}

The Henry Mountains study area is bounded by the Fremont River in the north and extends east to the Dirty Devil River, south to Lake Powell, and west to the Waterpocket Fold and Capitol Reef National Park (Figure 1, Henry Mountains Study Area). Even by Utah standards, the Henrys are a very remote and little-known mountain range. The U.S. Geological Survey sent G.K. Gilbert to the Henrys in 1875 and 1876, but it was not until the 1930s that Charles Hunt finally worked out the geology for the entire mountain range (Hunt et al. 1953; Hunt 1977). Newell and Talbot (1998), Murphy (1999), and Hunt et al. (1953) provide an overview of the area's history, while Thompson (1982) and Carr (2009) provide additional information on ghost towns in the Henrys, most of which occur along the Fremont River. Kelsey (2009) provides a modern guide to the roads and hiking trails in the study area, while Hunt et al. (1953) provide a general overview of the area's plant communities and vegetation types.

The overwhelming majority of lands within the study area are managed by the Bureau of Land Management (BLM). There is very little private land in the Henrys, although there are the usual number (i.e., 4 sections per township; sections 2, 16, 32, and 36) of state-owned sections. The Utah Division of Wildlife Resources (DWR) manages the area's mule deer as a premiere, trophy-hunting unit-not only the best in Utah but one of the best in the entire western United States. Landowner rifle permits have sold for as much as $\$ 75,000$ (Steve Dalton, personal communication). The Henrys are also noted for their free-ranging bison, which originally came from Yellowstone National Park (Nelson 1965; Van Vuren 1983; Van Vuren and Bray 1983, 1986). As with mule deer, all bison hunting in the Henrys 
is by limited-entry state permits. Only a handful of elk live in the study area, and it is DWR's policy not to allow any increase in elk numbers. Historically, as many as 100,000 domestic sheep may have grazed the Henrys during the late 1800s and early 1900s. Since the Taylor Grazing Act passed in 1934 and the BLM was established in 1946, however, sheep use has gradually been converted to cattle use. Today, most of the study area is grazed by cattle under BLM-managed grazing permits and regulations.

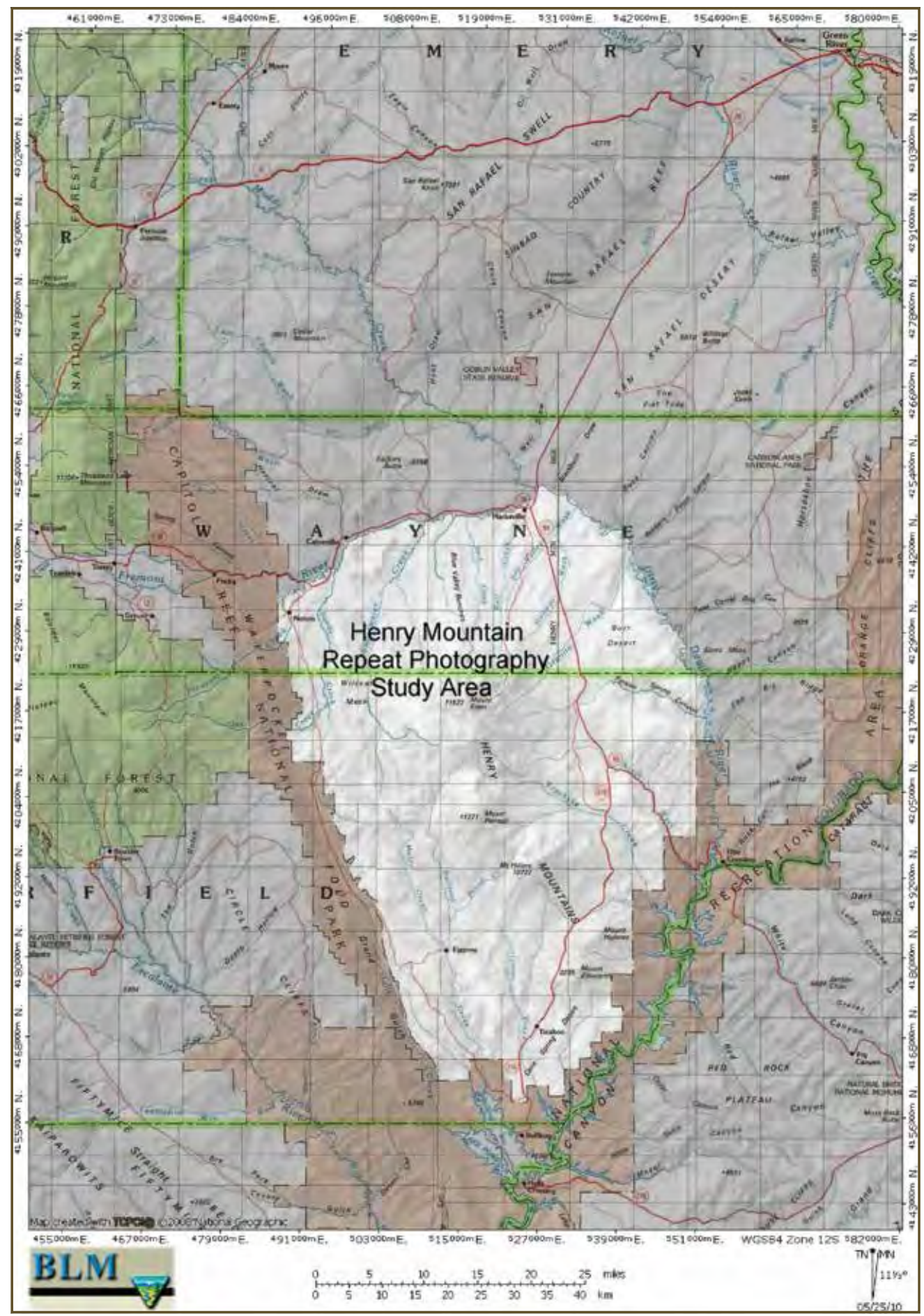

Figure 1. Henry Mountains Study Area. GIS map produced by Doug Page, BLM, Cedar City, UT. 


\section{Methods}

I first searched various archives for historical photographs taken in the Henry Mountains. My search included: (1) the U.S. Geological Survey’s Photographic Library in Denver, CO; (2) the Utah State Historical Society in Salt Lake City, UT; (3) the LDS Church History Department archives in Salt Lake City, UT; (4) Southern Utah University’s Special Collections and Archives, Cedar City, UT; (5) Utah State University's Special Collections and Archives, Logan, UT; (6) the University of Utah’s Special Collections and Archives, Salt Lake City, UT; (7) the George C. Fraser (2005) collection in the Princeton University Archives, Princeton, NJ; (8) the Rancho Santa Ana Botanic Garden Collection of slides taken by Marcus E. Jones in 1894 (Gray 2011); and (9) the range files held by the BLM at the agency's field office in Hanksville, UT. An effort was also made to locate photographs in private collections. A total of 608 repeat photo sets was taken, and 126 were selected as representative of the areas covered.

Repeat photographs were taken with both color slide film (Fujichrome 100) and black-and-white print film (Kodak Plus-X). I used a Nikon FM2 with a 24-50mm lens and an L-37 filter for the color slides, and a Nikon FM2 with a 24-50mm lens and a Y-48 filter for the black-and-white prints. Nikon 28-80mm and 80-200mm lenses were also used, as needed, to match original focal lengths. Multiple images were made at each site with both color and blackand-white film. Depending on the focal length of the original photograph, wider-angle retakes were also taken. All retakes were generally made at the same time of day as the original photograph. In addition, each photo point was marked on U.S. Geological Survey 1:24,000 scale topographic maps. A hand-held global positioning system (GPS) was used to record camera station elevation and UTM coordinates (NAD 83). During each site visit, a description of the present vegetation was recorded, as were any changes from the original photograph. Upon returning from the field, a systematic evaluation of all photo sets was conducted and detailed descriptions written for each photo pair (Kay 2003; Kay and Reid 2011). The photo sets or plates were consecutively numbered according to the order in which the repeat photographs were completed-i.e., Plate HM-1, or photo set one, was made first and Plate HM-608 last.

Upon my retirement, all project photographs, maps, and notes were donated to the Special Collections and Archives housed at Southern Utah University (SUU) in Cedar City. All photographs, prints, and slides have been clearly identified and have been checked by SUU Archivist Janet Seegmiller. All photographs are protected in clear, archival quality, plastic sheets-plus all prints and documents for each of the photo sets are stored in numbered, Velcro-sealed, individual plastic envelopes, while all slide pages are housed in numbered three-ring binders. Finally, all repeat photo sets and descriptive text will eventually be placed on Utah State University's Extension website by Chad Reid-and will be accessible at http://extension.usu.edu.rra-once that work is completed (Kay and Reid 2011).

\section{BLM Range Monitoring Photos}

In the 1950s and early 1960s, the BLM established a number of Parker 3-step transects on agency grazing allotments in the Henrys to measure range conditions (Hutchings and Holmgren 1959; Smith 1962; Francis et al. 1972). Each of those plots was marked with a numbered wooden sign attached to a thin steel post visible from the nearest road. There also were written directions on how to reach the actual monitoring plot, or plots, from each signpost. 
In addition, each Parker 3-step transect was marked with a short, usually less than 1-foot tall, section of steel rebar. Landscape photos were taken of each transect with a $50 \mathrm{~mm}$ normal lens mounted on a $35 \mathrm{~mm}$ camera. As the Parker 3- step method was later shown to be a poor measure of long-term range conditions (Reppert and Francis 1973; Cook et al. 1992), the BLM abandoned those plots. Many of those files were subsequently misplaced; however, some photos still exist in the BLM's range files. Although most of the roadside steel posts have gone missing, I was able to repeat many of the photographs that still exist, or at least those that could be located. Where multiple landscape photos were taken in different directions, I was able to locate all the short, unpainted steel stakes through triangulation.

If, however, the landscape photos were taken in only one direction, some of the short steel stakes could not be relocated. In those instances, repeat photographs were made as near as possible to the original location, judging by distant landmarks.

During the late 1960s and early 1970s, the BLM established new range monitoring sites throughout the Henry Mountain Resource Area, including the Henry Mountains. Each of those sites was marked with a steel fencepost, as well as a 1-meter-square plot 100 feet north of said fencepost. The 1-meter-square plots, in turn, were marked with short steel stakes, usually painted yellow. In addition to various plant measurements (not reported here), every 1-meter-square plot was photographed each time the BLM monitored a site. The BLM also made a general landscape photo from above the 1-meter-square plot looking south to the steel fencepost every time a range monitoring site was visited. The BLM's landscape photos were taken with a $28 \mathrm{~mm}$ wide-angle lens mounted on a $35 \mathrm{~mm}$ camera. Only the general landscape photos were repeated for the present study. As the BLM visits its range monitoring sites at least once every 5 years, multiple photos exist for each monitoring site, but only the earliest photos are included in this report. The other images are in the BLM's range files at the agency's Hanksville office.

At most of BLM's current range monitoring sites, both the steel fencepost and the shorter steel stakes marking the 1-meter-square plot still exist, while at some, one or more of the steel marking devices are missing-either the steel fencepost or the shorter steel stakes. At a few sites, though, all the steel stakes are missing. In those instances, retake photographs were made by matching distant landscape features.

\section{Earl Hindley's Repeat Photographs}

In 2005 the BLM contracted Earl Hindley to repeat some early images in the Henrys (see Figure 2, Earl Hindley's Repeat Photo Sites in the Henry Mountains). Hindley’s study was limited primarily to forest ecotones. In all, Hindley repeated 79 photos at 60 different camera stations. Most of the historical photographs that Hindley used in his project were also repeated during the present study. I did not, however, revisit 18 of Hindley's photo sets, as it was deemed more important to repeat other early images not used in Hindley's study. Nevertheless, to be as thorough as possible, I included the Hindley photo pairs that I did not redo in my 2013 report to the BLM, and they are tabulated here as well. A copy of Hindley's entire 2005 report is on file in the BLM’s Hanksville office, and in my personal files. 


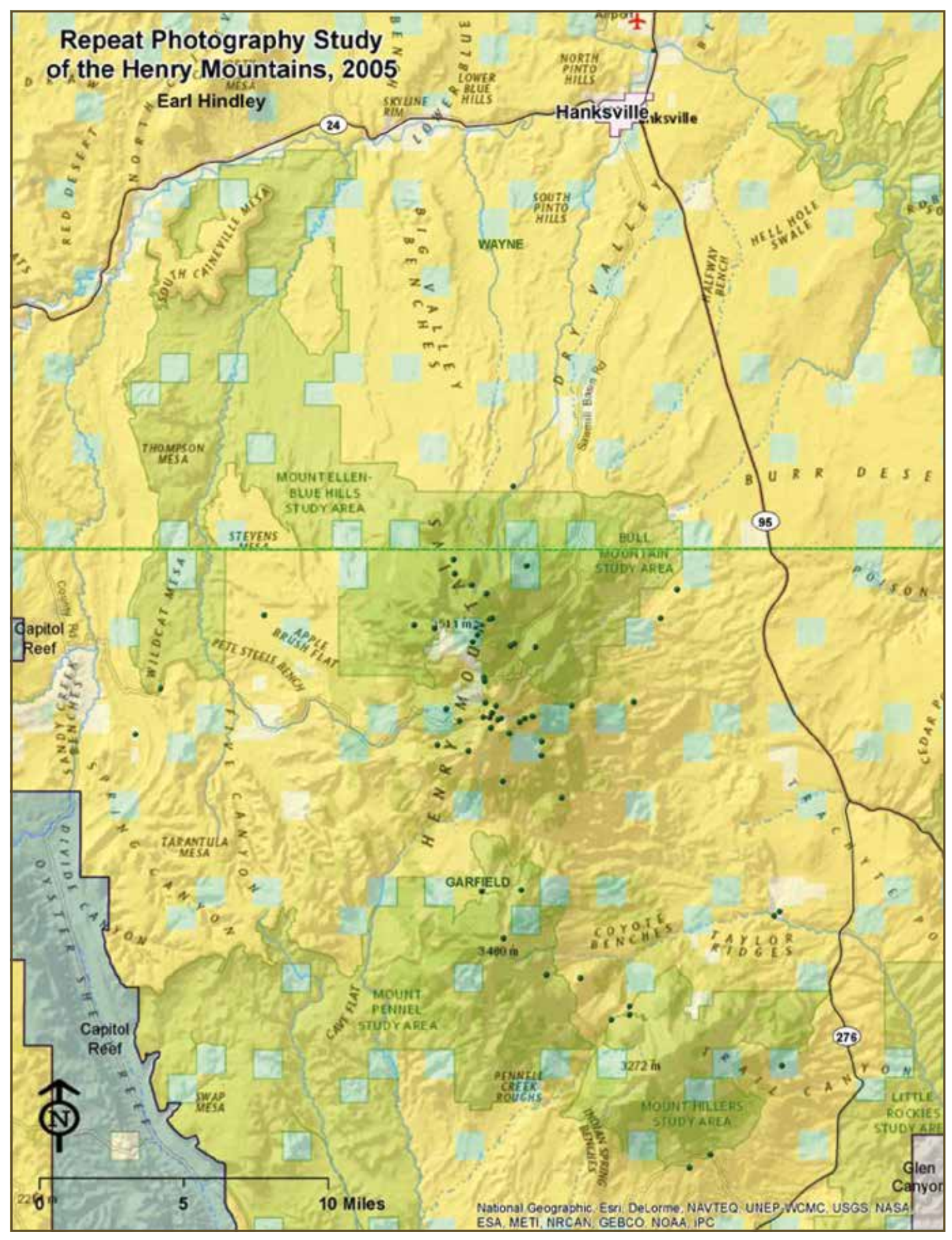

Figure 2. Earl Hindley's Repeat Photo Sites in the Henry Mountains. GIS map produced by Doug Page, BLM, Cedar City, UT. 


\section{Photo Analysis}

Once all photo sets were completed, each photo pair was visually evaluated to determine if the following vegetation types were present and to assess plant cover, erosion, and evidence of change:

- Grasslands

- Sagebrush (all species included)

- Pinyon-juniper

- Mountain brush (including primarily oak brush, Utah serviceberry, true or birch-leaf mountain mahogany, curl-leaf mountain mahogany, and chokecherry)

- Aspen

- Conifers (including primarily ponderosa pine, limber pine, Douglas-fir, and spruce)

- Woody riparian species (including primarily willows, cottonwoods, tamarisk, water or river birch, and Russian olive)

- Blackbrush

- Plant cover (including primarily grasses, low-growing shrubs, and forbs)

- Soil erosion

- If the vegetation and conditions listed above had increased, remained unchanged, or decreased since the original photograph based on previously established protocols (Kay 2003; Kay and Reid 2011). That is to say, an increase or decrease refers to a change in the abundance (number), area (acreage), and/or size of the species in question. A change in one or more of these factors results in change in the density and dominance of the species in question. 


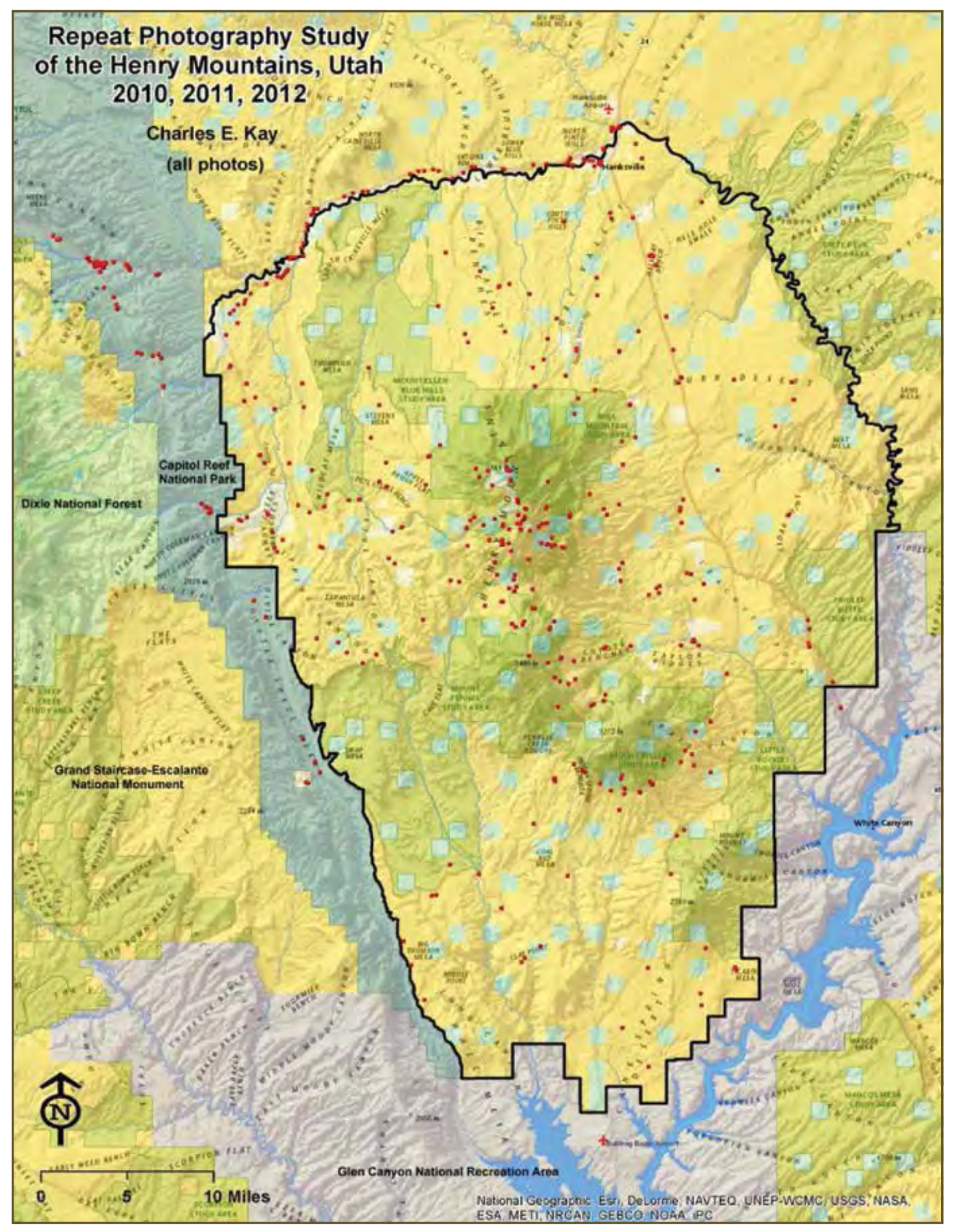

Figure 3. Locations of the 608 Photo Sets Made in the Henry Mountains. Multiple photo sets were made from some camera stations. GIS map produced by Doug Page, BLM, Cedar City UT. 


\section{Results And Discussion}

To eliminate possible bias, I attempted to locate as many early photographs as possible for Utah's Henry Mountains. To be repeated, however, photographs need to contain features that can be relocated in the field. Closeups of vegetation, or pictures in which there were no clearly identifiable landmarks, proved impossible to relocate, despite help from long-time area residents. In all, 608 photo sets were completed, with 3 dating to the 1872 Powell survey (Fowler 1989) (see Figure 3, Locations of the 608 Photo Sets made in the Henry Mountains). As the photo sets cover a broad array of vegetation types, time periods, elevation zones, and historical photo collections, I believe they are representative of the changes that have occurred throughout the study area. See Table 1, The Decade in Which the Original Photographs Were Taken in the Henry Mountains, and Table 2, Photo Point Elevations in the Henry Mountains (per 1,000 ft.).

While repeat photos can readily be used to document various woody species and changes in major plant community boundaries, they are of limited value in monitoring the species composition of herbaceous and grassland communities. This is especially true in mesic environments, where many similar species grow in close proximity (Webb 1996; Webb et al. 2010). That is to say, repeat photographs are usually incapable of detecting herbaceous plant community composition shifts, as may occur when grassland and forb communities are grazed. For a summary of long-term vegetation changes, see Table 3, Summary of Vegetation Changes in the Henry Mountains. Estimated changes for each individual photo set are found on the Utah State University Extension website previously referenced. This includes the 18 photo sets compiled by Earl Hindley, for a total of 626 (i.e., $608+18=626$ ).

\begin{tabular}{|c|c|}
\hline \multicolumn{2}{|c|}{$\begin{array}{c}\text { Table I. The Decade } \\
\text { in Which the Original } \\
\text { Photographs Were Taken } \\
\text { in the Henry Mountains } \\
(\mathrm{N}=626)\end{array}$} \\
\hline Decade & $\begin{array}{c}\text { Number of } \\
\text { Photographs }\end{array}$ \\
\hline 1870 & 3 \\
\hline 1880 & $o$ \\
\hline 1890 & 12 \\
\hline 1900 & 1 \\
\hline 1910 & 48 \\
\hline 1920 & 33 \\
\hline 1930 & 261 \\
\hline 1940 & 49 \\
\hline 1950 & 62 \\
\hline 1960 & 117 \\
\hline 1970 & 21 \\
\hline 1980 & 19 \\
\hline
\end{tabular}

\begin{tabular}{c:c} 
Table 2. Photo Point \\
Elevations in the \\
Henry Mountains $(\mathrm{N}=626)$ \\
Elevation (ft.) & $\begin{array}{c}\text { Number of } \\
\text { Photo Points }\end{array}$ \\
\hline 3,000 & 2 \\
\hline 4,000 & 167 \\
\hline 5000 & 229 \\
\hline 6,000 & 67 \\
\hline 7,000 & 36 \\
\hline 8,000 & 48 \\
\hline 9,000 & 30 \\
\hline 10,000 & 17 \\
\hline 11,000 & 30 \\
\hline \hline
\end{tabular}




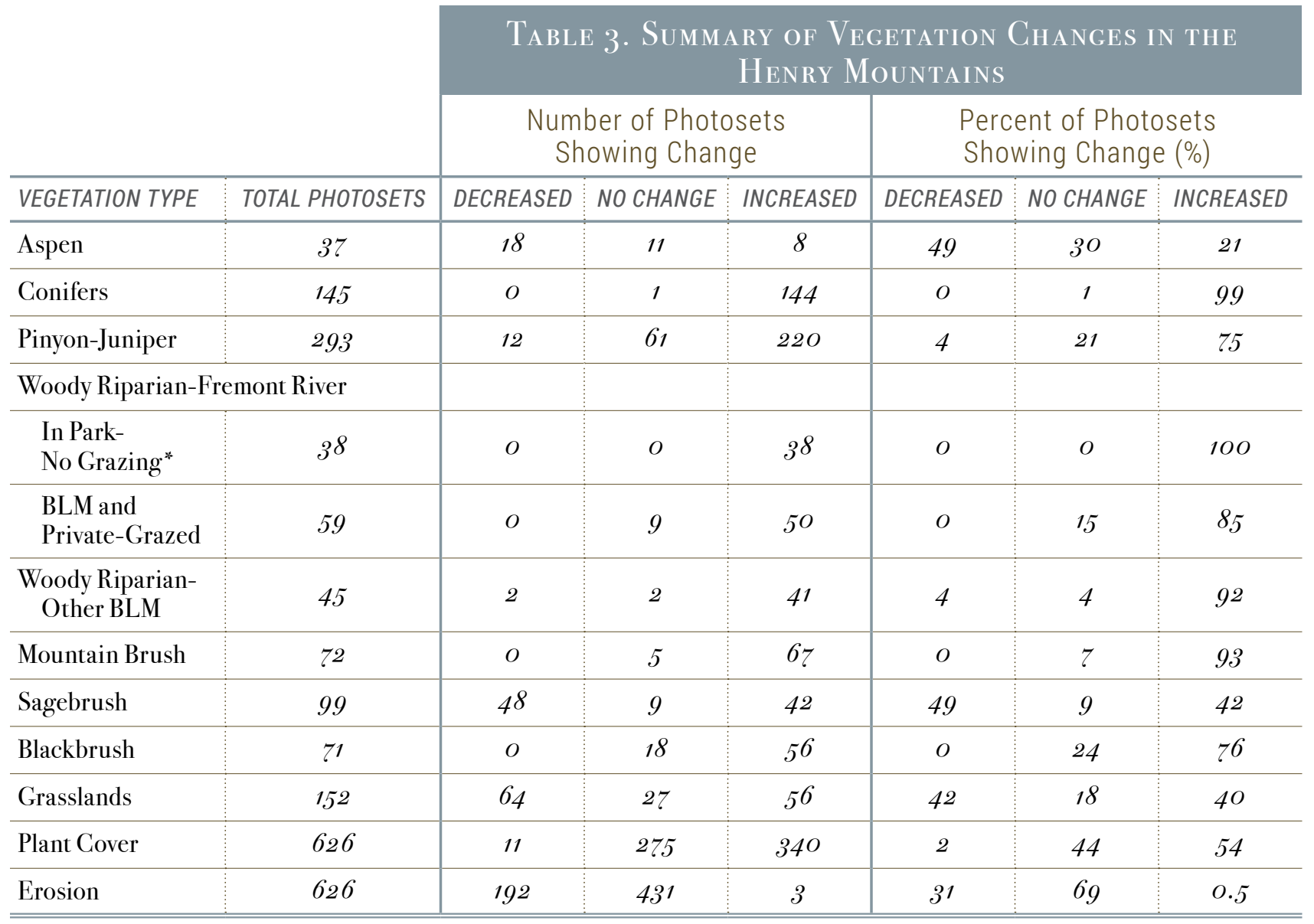

* Inside Capitol Reef National Park, where there is no livestock grazing, compared with the BLM and private lands outside the park, which are grazed by cattle.

\section{Grasslands}

Grassland communities were depicted in 152 repeat photo sets and in $42 \%$ of those photographs, grasslands declined in aerial extent or canopy cover. This decline was due primarily to replacement of grasslands by sagebrush, blackbrush, pinyon-juniper, and conifers. That is to say, woody species expanded into grasslands, and by shading and/ or competition, eliminated the herbaceous communities that were depicted in the earlier photos. In only a few cases did grassland communities appear more heavily grazed in the retakes than they did in the originals. Instead, most grasslands appeared more heavily grazed in the past than they did when rephotographed. In $18 \%$ of the photo sets, grasslands showed little or no change, while in 56 photo sets (40\%), grasslands increased where vegetation treatments had removed competing woody species. This included not only pinyon-juniper chainings, but areas burned by wildfires in 2003 (as described further below). 


\section{Sagebrush}

Sagebrush, mostly Artemisia tridentata, communities occurred in 99 repeat photo sets. In $49 \%$ of those cases, sagebrush declined; it appeared unchanged in $9 \%$ and increased in $42 \%$. Most of the decrease in sagebrush occurred because pinyon, juniper, and other conifers replaced shrub communities. Sagebrush also declined where it had been burned. Conversely, sagebrush increased by invading grasslands, especially in seeded chainings (Kay and Reid 2011). Sagebrush communities in the Henry Mountains appear to be heavily used by mule deer during winter, as judged by the number of pellet groups that were observed.

\section{Blackbrush}

In the Henrys, blackbrush is found at lower elevations than sagebrush. Blackbrush occurred in 71 photo sets, and in none of those images did blackbrush decline. Instead, blackbrush increased in $76 \%$ of the photo pairs and remained unchanged in $24 \%$. Domestic sheep will readily graze blackbrush but, in general, cattle will not. Thus, the increase in blackbrush is most likely due to the elimination of sheep grazing. Very few mule deer pellet groups were observed in blackbrush communities. Where blackbrush increased, grass cover declined.

\section{Pinyon-Juniper}

Pinyon-juniper was depicted in 293 photo sets, and in $75 \%$ of those photo pairs it increased, often dramatically. Pinyon-juniper readily expanded into grasslands, sagebrush, mountain brush, and even conifers. That is to say, pinyon-juniper increased both up-slope and down-slope. Because the Henry Mountains are so dry compared with other mountain ranges in south-central Utah, at some locations there was no down-slope movement of pinyonjuniper. In other instances where pinyon-juniper was growing on harsh sites, such as rocky slopes, it showed little change. In $21 \%$ of the photo sets, pinyon-juniper appeared unchanged, and in only $4 \%$ of the photo pairs had it declined. Pinyon-juniper declined where it was burned by the 2003 Bulldog and Lonesome Beaver wildfires. Judging by the lack of pinyon-juniper in early images, however, and the prevalence of fire-killed pinyon-juniper in the retakes, pinyon-juniper had increased before the 2003 wildfires. Unlike the fire behavior that was observed in 2003, where large areas of pinyon-juniper woodlands were killed by high-intensity crown fire (Bureau of Land Management 2003), there is no evidence of crown fire behavior in any of the early pinyon-juniper photographs.

\section{Mountain Brush}

Mountain brush species occurred in 72 repeat photo sets. In $93 \%$ of those instances mountain brush increased, while it remained unchanged in 7\%, and did not decline in any photo pair. Mountain brush readily replaced grassland and sagebrush communities. In nearly all cases, mountain brush species increased in height and density, as well as aerial extent. Oak brush temporarily declined where it had been overrun by wildfire in 2003 , but those plants all resprouted and many actually increased in aerial extent. Aside from a few blackened stems, in many areas it is hard to imagine that the oak brush burned in 2003, as that species' recovery has been so prolific. 


\section{Aspen}

Aspen was depicted in 37 repeat photos. In $49 \%$ of the photo sets aspen declined; it remained unchanged in $30 \%$, and increased in $21 \%$. Other research has similarly reported a major decline in aspen across the Intermountain West (Houston 1982; Kay 1985, 1990, 1997a, 1997b, 1997c, 1997d; Kay and Wagner 1994; Kay and White 1995; Baker et al. 1997; Bartos and Campbell 1998; White et al. 1998; Kay and Bartos 2000; Rogers and Mittanck 2013; Seager et al. 2013). Where aspen had declined, it usually was replaced by conifers. Compared with other mountain ranges in south-central Utah, though, there is not much aspen in the Henry Mountains. Unlike other areas in Utah where repeated elk browsing has suppressed or eliminated aspen regeneration following fire (Kay 2011), aspen burned by the Bulldog and Lonesome Beaver fires in the Henrys has successfully regenerated and is not heavily browsed. This undoubtedly is due to the fact that there are few elk in the Henrys and that mule deer numbers are also low. In all photo sets, individual aspen stems (ramets) increased in height over time, and otherwise matured, even though the aerial extent of some clones declined.

\section{Conifers}

Conifers were depicted in 145 repeat photo sets, and in $99 \%$ of those images conifers increased, often markedly. This increase generally occurred at the expense of grasslands, aspen, sagebrush, mountain brush, and even some pinyon-juniper communities. In no photo sets did conifers decline, and in only 1 photo set were conifers unchanged. Large areas of conifers were killed by the Bulldog and Lonesome Beaver wildfires in 2003, but the number of dead trees in the repeat photographs makes it clear that conifers had increased before being burned. This occurred in 46 photo sets. Unlike photos taken after the 2003 fires, none of the earliest photographs show any evidence of largescale, crown-fire behavior in conifers. Historical photographs clearly show that prior to European settlement there were few old-growth coniferous forests, as that term is commonly used today, except for open, parklike ponderosa pine communities (see Plate HM-124). Fire history studies (Arno and Gruell 1983, 1986; Chapell 1997; Ogle and DuMond 1997; Murray et al. 1998; U.S. Forest Service 1998) and stand-age models (Johnson et al. 1995; Lesica 1996; Andison 1998) support this conclusion. Since the late 1800s, however, conifers have increased not only in height but also in density, numbers, and aerial extent. There are now coniferous forests where none existed in the past. This has led to a decline in biodiversity (Covington et al. 1994, 1997), and a decrease in forage production (Ffolliott and Clary 1982; Kay 2003), as conifers have increased at the expense of aspen, meadows, and even riparian communities.

\section{Upper Treeline}

In the Henrys both Mount Pennell and Mount Hillers have conifers all the way to their summits. Only North Summit Ridge, South Summit Ridge, and Mount Ellen Peak have alpine areas about treeline. Nevertheless, upper treeline was depicted in 49 photo sets, and it remained unchanged in all photo pairs. Conifers at treeline increased in height, but they did not generally increase in numbers or invade new areas. Subalpine forests immediately below treeline, however, have both grown up and thickened up since the early 1900s. Similar observations have been reported 
throughout western North America (Klasner and Fagre 2002; Korner 2012), where the pattern has usually been attributed to climatic change. A slight drying and warming trend since the mid- to late-1800s is thought to have favored tree growth at higher elevations (Hansen-Bristow, Ives, and Wilson 1988; Rochefort et al. 1994; Taylor 1995; Weisberg and Baker 1995; Woodward et al. 1995; Rochefort and Peterson 1996; Hessl and Baker 1997a, 1997b; Lloyd and Graumlich 1997). As discussed below, however, I believe that this has more to do with fire suppression and the elimination of native burning (Kay 1995, 1998, 2000, 2003, 2007) than with climatic variation.

\section{Woody Riparian Species}

The condition and trend of riparian communities has been and is a major issue throughout the Intermountain West, where their decline has generally been attributed to livestock grazing (Platts 1991; Kauffman et al. 1997; Donahue $2007,2010)$, especially by those who would like to eliminate all livestock from public lands. Fleischner (2010), for instance, specifically stated that all livestock should be removed from BLM and U.S. Forest Service lands to protect riparian areas. Fleischner (2010) also claimed that woody riparian vegetation along the Fremont River in Capitol Reef National Park recovered only after livestock grazing was eliminated. He implied that areas along the Fremont River outside the park, on BLM and private lands where cattle still occur, are in exceedingly poor condition and will never recover until all livestock are removed.

To test Fleischner's (2010) assertion, I made a special effort to repeat every early photo that I could find of the Fremont River inside Capitol Reef National Park, as well as photos from the park boundary downstream to Hanksville, Utah, which lies at the northeast corner of the Henry Mountain study area. The land along the Fremont River outside the park is a mixture of BLM and private property and is grazed by cattle every year. I was able to repeat 38 photographs dating to 1894 inside the park. In all cases, woody riparian vegetation had increased, often dramatically. In addition, I repeated 59 images along the Fremont outside the park. In 50 of those photo sets woody riparian vegetation had increased, such that there was no difference inside or outside the park.

In 9 photos outside the park, however, there was no change in woody riparian vegetation. All 9 of those images, though, were of the old irrigation dam and former highway bridge just west of Hanksville. Due to the disturbance in that area caused by frequent dam washouts, there was no woody riparian vegetation in any of the 9 original images or in any of the retakes. If those 9 photo sets are not included because of their unique disturbance history, then all the repeat photographs along the Fremont outside the park show the same dramatic increase in woody vegetation, contrary to Fleischner's (2010) claims.

In addition to taking repeat photo sets along the Fremont River, I repeated 45 historical images of other riparian areas in the Henry Mountains. In 41 or $92 \%$ of those photo pairs, woody riparian vegetation had increased. Two of those photo sets showed a decline in woody riparian species; both were at Notom, Utah, where irrigated hay fields had been enlarged at the expense of native plant communities. In two other photo sets, one at Muddy Creek and the other at Bull Creek, there was no apparent change in woody riparian vegetation. 
Thus, in the Henry Mountains there has been no widespread decline in woody riparian species attributable to livestock grazing. This finding is similar to what I found on Utah's Fishlake National Forest (Kay 2003) and in the Centennial Mountains along the Montana-Idaho border (Kay and Walker 1997; Kay 1999). It is also similar to what has been observed in Utah's San Juan County (Hindley et al. 2000) and to what has been reported along Kanab Creek in southern Utah (Webb et al. 1991). In addition, Klement et al. (2001) noted that woody riparian vegetation had increased on the northern Great Plains despite continued livestock grazing.

More recently, Webb et al. (2007) reported on 3,103 repeat photo sets they had compiled of riparian vegetation in the Southwest, primarily in Arizona and southern Utah. Woody riparian species increased in $\mathbf{8 0 \%}$ of their photo pairs, declined in $10 \%$, and remained unchanged in $10 \%$ (Webb et al. 2007, 390). Webb et al. (2010) also found no evidence that $90 \%$ of riparian vegetation had been lost in the southwestern United States, as commonly claimed by various environmental groups and reported in the popular press (Wuerthuer and Matteson 2002). Webb et al. (2007) noted that "[woody] riparian vegetation...increased significantly in many reaches [of major waterways] irrespective of the presence of grazing animals." Both Donahue (2010) and Fleischner (2010) failed to mention, let alone discuss, the massive repeat photo collection in Webb et al. (2007), or the work of Webb et al. (1991), Hindley et al. (2000), or Kay (2003).

\section{Plant Cover and Soil Erosion}

According to early accounts, the Henrys were very heavily grazed during the late 1800s and early 1900s (Hunt et al. 1953; Hunt 1977, 1988; Newell and Talbot 1998; Murphy 1999). “Mount Pennell had been so overgrazed [by domestic sheep] that [we] had trouble finding a place where [we] could pasture our horses.... En route we came on a sheep herd and stopped to visit with the herder. Under the boulder [where we were] sitting, I noticed a blade of grass, the first of the day. I commented on it [and] the herder almost apologetically said, 'Yeh yu see, we've only been over this part once" (Hunt 1977, 103). "At the time of our fieldwork (1935-1939) the range in the Henry Mountains region had been greatly damaged, not only by erosion, but by deterioration in the type and quantity and forage. In large parts of the desert, the shrubs were closely trimmed and stubby; [while] in the mountains oak brush thickets were leafless as high as sheep could reach [termed highlining].... The overgrazing was caused not only by too many animals but by grazing too early in the spring and by crowding stock near watering places" (Hunt et al. 1953, 35).

Before the Taylor Grazing Act was passed and the BLM was established, grazing in the Henry Mountains was not regulated in any way. There were no restrictions on animal numbers, season of use, or areas grazed. Everyone tried to beat everyone else to the first and last blades of grass. Under this system of scramble competition, there was no incentive to practice range management or conservation. Not only did the BLM establish livestock use permits, but those grazing permits were tied to base property as a way to eliminate the itinerant bands of domestic sheep, once common in the West. As management improved, so did conditions out on the range (Kay 2003).

Plant cover and soil erosion were compared on all 626 repeat photos to determine if Henry Mountain rangelands were being negatively impacted by livestock grazing and other multiple-use activities. In $44 \%$ of the photo pairs, there was no apparent change in plant cover; in $54 \%$ plant cover had increased, often markedly. In only $2 \%$ of the photo sets was plant cover judged to have declined. Similarly, in $69 \%$ of the photo pairs, there was no apparent evidence of 
accelerated soil erosion; in $31 \%$ of the paired images, active soil erosion had declined. In only $3(0.5 \%)$ photo sets was soil erosion judged to have increased. While rangelands throughout Utah were very heavily grazed during the late 1800s and early 1900s (Cottam 1929, 1947, 1976; Bailey et al. 1934, 1937; Cottam and Evans 1945; Copeland 1960), repeat photographs show that is no longer true in the Henry Mountains and that, in general, range conditions have improved. Other repeat photo studies in Utah show that same pattern-i.e., range conditions have improved since the turn of the last century (Rogers 1982; U.S. Forest Service 1993a; Hindley 1996; Hindley et al. 2000; Kay 2003).

\section{Comparison with Other Repeat Photo Studies}

Repeat photo studies throughout the Intermountain West have reported long-term vegetation changes similar to those observed in the Henry Mountains. (See Bureau of Land Management 1969, 1971, 1979, 1980, 1984; Progulske 1974; Wyoming State Historical Society 1976; Heady and Zinke 1978; Vankat and Major 1978; Gruell 1980a, 1980b, 1983, 2001; Hastings and Turner 1980; Houston 1982; Pierce 1982; Rogers 1982; Rogers et al. 1984; Sallach 1986; Baker 1987; Johnson 1987; Kay 1990, 1997d, 2003; McGinnies et al. 1991; Reid et al. 1991; Veblen and Lorenz 1991; Webb et al. 1991, 2007; Goin 1992; Webb and Bowers 1993a, 1993b; U.S. Forest Service 1993a, 1993b; Vale and Vale 1994; Skovlin and Thomas 1995; Hart and Laycock 1996; Webb 1996; Athearn 1998; Jackson et al. 1999; Gifford and Terrill 2000; Hersh 2000; Hindley et al. 2000; Idso and Idso 2000; Till 2000; Klement et al. 2001; Fuchs 2002; Grafe and Horsted 2002; Turner et al. 2003; Bradford et al. 2004; Klett et al. 2004, 2005; Clinger et al. 2006; Shea and Key 2006; White and Hart 2007; Kay and Reid 2011; Amundson 2013.) That is, continued grazing has not destroyed major plant communities, and western rangelands are generally in better condition today than they were during the early 1900s. Rangelands across the West, though, are being lost to encroaching conifers and increasing sagebrush due to an absence of fire (Vale 1981; Arno and Gruell 1983, 1986). Historically, low-intensity surface fires repeatedly swept the range, limiting woody vegetation, and promoting biodiversity (Covington et al. 1997; Kay 2000, 2007). The problem now is one of too many trees, not too few trees, as many people believe.

See also Table 4, Comparison of Long-Term Vegetation Change in the Henry Mountains and on the Fishlake and Dixie National Forests. In addition to the 626 repeat photographs in the Henrys, I repeated 355 early images on the Fishlake and 1,524 on the Dixie for a total of 2,505 repeat photo sets. This is the largest repeat photo collection in Utah and the second largest in the West (Webb et al. 2007). Aside from the fact that there is no blackbrush on the Fishlake or Dixie national forests, other vegetation trends are similar, given that the Henrys contain fewer upper elevation areas than either of these national forests. 


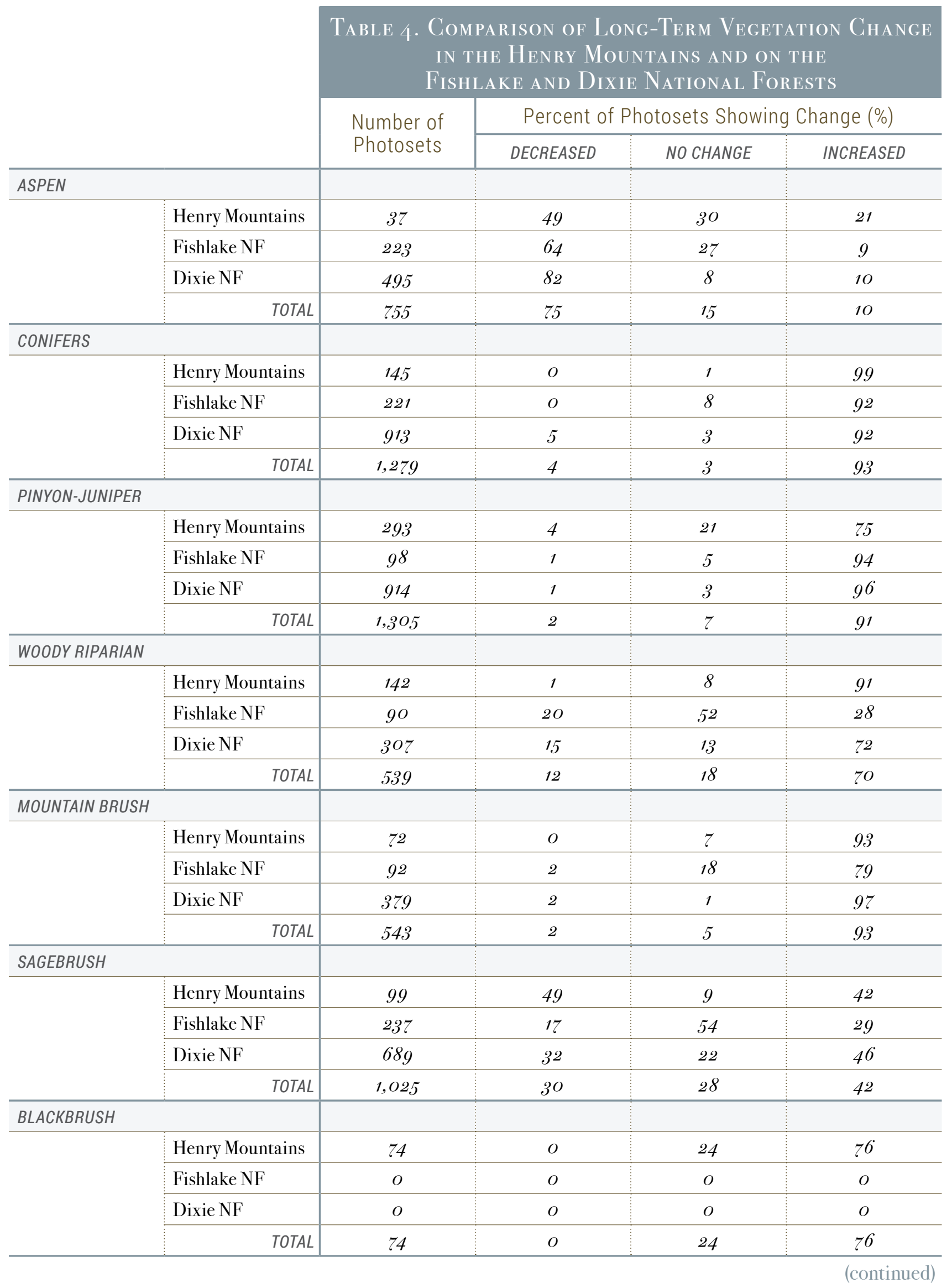




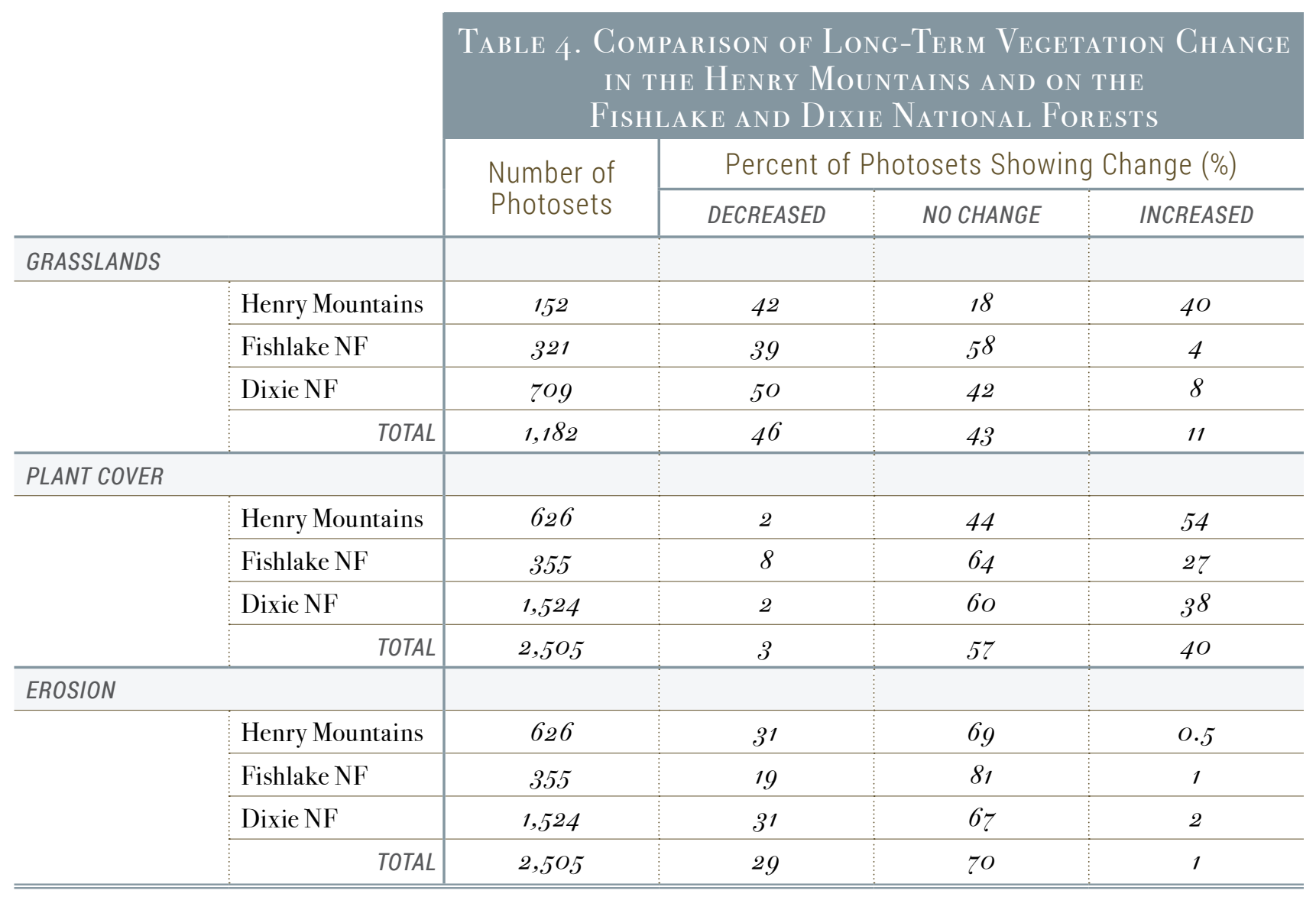




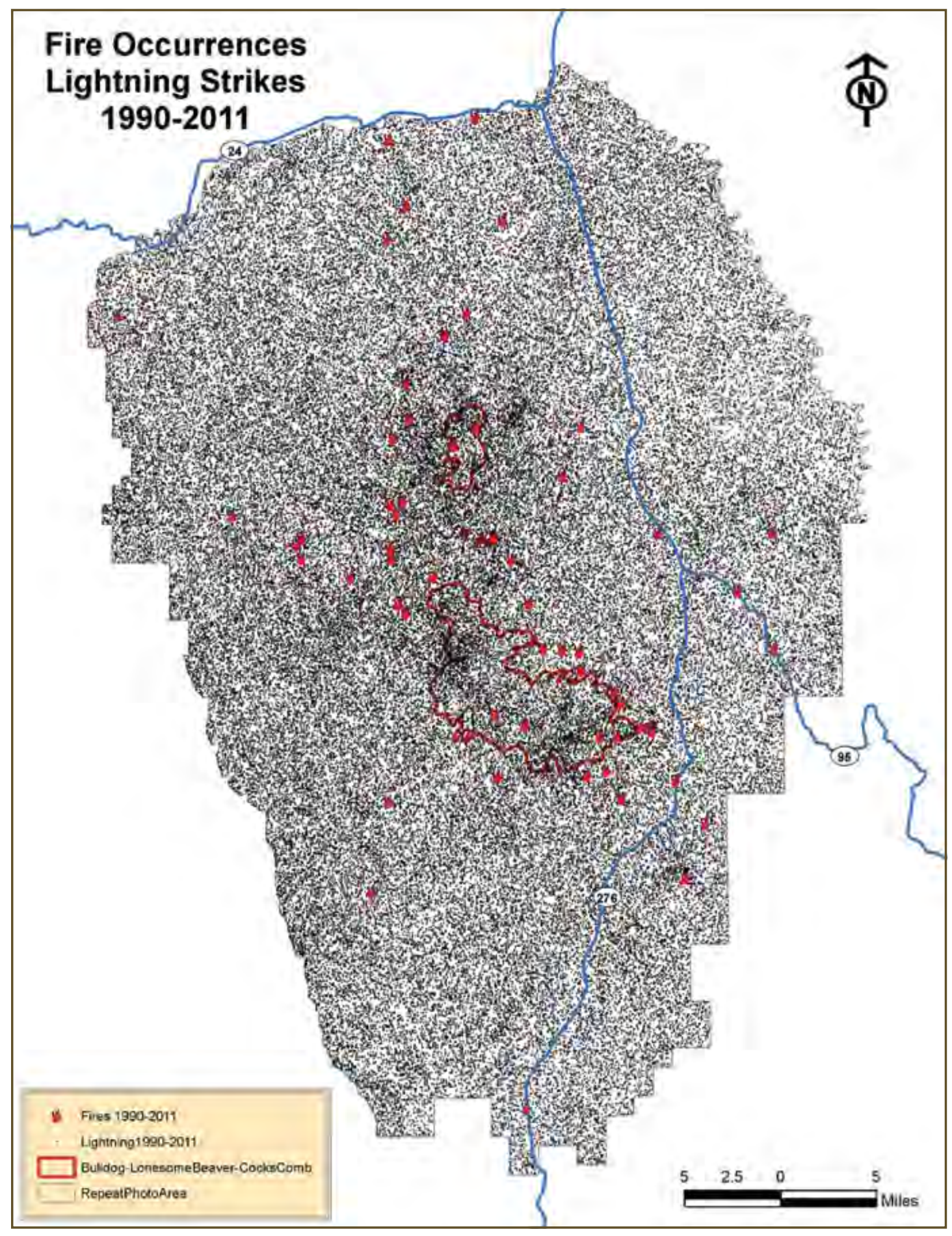

Figure 4. Lightning Strikes and Fire Occurrence in the Henry Mountains, 1990-2011. GIS map produced by Doug Page, BLM, Cedar City, UT. 


\section{Fire Ecology}

Heyerdahl et al. $(2006,2011)$ collected fire history data in Utah and Nevada, including the Henry Mountains. They sampled 30 plots over an area of 2,280 acres near Willow, Dugout, and North Fork creeks on the west side of Mount Ellen in the Henrys (Heyerdahl et al. 2006, 33-45; Heyerdahl et al. 2011, 19-27). The data they collected showed that low-intensity surface fires were common in the Henrys until about 1870, after which there were no fires. Although Heyerdahl et al. $(2006,2011)$ cored, or aged, only trees greater than 8 inches DBH, conifers increased markedly after 1870 (see Plate HM-124, which is in their study area). That is to say, once burning ceased, woody vegetation and forest fuels increased. Heyerdahl et al. $(2006,2011)$ also reported that fires before1870 were small and that there was no evidence of large-scale crown fires, as was observed in the Henry Mountains during 2003.

While lightning strikes are common in the Henrys, lightning-caused fires are very rare, averaging only 1.5 fires per year (see Figure 4, Lightning Strikes and Fire Occurrence in the Henry Mountains, 1990-2011). This most likely is due to the fact that summer thunderstorms, which generate lightning, also bring rain, making lightning ignition and spread less likely. Besides, the absence of fires since 1870 cannot be attributed to a lack of lightning strikes during the last 144 years. Elsewhere, I have calculated known lightning-fire ignition rates for every national forest in the contiguous 48 states and then compared those data with data about potential fires started by Native Americans (Kay 2007). I documented that potential fires started by aboriginal peoples were 270 to 30,000 times more frequent than known lightning-ignition rates. The first Europeans to enter the Henrys reported an extensive network of Indian trails (Hunt 1988, 4), while Martineau $(1992,155)$ noted that a band of Southern Paiutes permanently occupied the Henrys at historical contact. With the low rate of lightning-caused fires in the Henrys, it should then come as no surprise that, historically, the vast majority of natural fires were set by native people to manage their environment. Once the original inhabitants were displaced by white settlers around 1870, landscape burning ceased.

Determining how fires started is critical because "fires set by hunter-gatherers differ from [lightning] fires in terms of seasonality, frequency, intensity, and ignition patterns" (Lewis 1985, 75). Most aboriginal fires were set during spring, between snowmelt and vegetation greenup, or late in the fall when burning conditions were not severe. Unlike lightning fires, which tend to be infrequent, high-intensity infernos, native burning produced a higher frequency of low-intensity fires. So, aboriginal burning and lightning fires create different vegetation mosaics and in many instances, entirely different plant communities (Lewis 1973, 1977; Lewis and Ferguson 1988; Turner 1991; Anderson 1993, Blackburn and Anderson 1993). Moreover, aboriginal burning reduces or eliminates the number of high-intensity, lightning-caused fires (Pyne 1982, 1991, 1993, 1994, 1995a, 1995b; Reid 1987, 34; Gottesfeld 1994; Boyd 1999). Once aboriginal fires opened up the vegetation, then subsequent lightning fires behaved like those set by Native Americans.

\section{Lost Forage Production}

There is also a correlation between sagebrush, pinyon-juniper, and conifer encroachment and herbaceous forage production (Ffolliott and Clary 1982; Riggs et al. 1996). As woody species increase, the production of forbs, grasses, and palatable shrubs declines in a nonlinear, negative relationship. That is to say, a small increase in 
sagebrush, pinyon-juniper, or conifers can cause a significant decrease in forage production (Cook and Lewis 1963; Frischknecht 1963; Hedrick et al. 1966; Sneva 1972; Rittenhouse and Sneva 1976; Sturges 1983; Tanaka 1986; Uresk and Severson 1989, 1998; Moore and Deiter 1992; Bates et al. 2000; Kay 2003; Kay and Reid 2011). Thus, as sagebrush, pinyon-juniper, and conifers have encroached on grasslands, aspen stands, and meadows in the Henry Mountains, the amount of available forage has declined. If this trend is allowed to continue, there will be less and less forage for domestic livestock and wildlife-circumstances that can lead to overgrazing, as animals are forced to concentrate on smaller and smaller areas.

\section{Conclusions}

Based on 626 repeat photo sets, the following long-term vegetation changes were observed in the Henry Mountains:

- Grasslands and aspen communities have generally declined.

- Conifers, both montane and subalpine, have increased, invading and replacing grasslands and aspen.

- Mountain brush and pinyon-juniper have increased.

- Woody riparian species have increased, except where dams or other developments have altered riparian vegetation.

- Fires were once common in the Henrys, and most were likely started by native people as a way to manage their environment.

- In earlier times, fires were frequent, but most were low-intensity surface fires, not stand-replacing crown fires.

- Modern fire suppression and the elimination of aboriginal burning are primarily responsible for the long-term vegetation changes seen in the Henrys.

- Dense coniferous forests were historically very rare and are more common today. The problem is one of too many trees, not too few. On most sites, forest fuels have increased markedly.

- As conifers and pinyon-juniper have increased, forage production has fallen precipitously. This fall has decreased the carrying capacity of the range for both domestic livestock and wildlife.

- Unless fire is restored to its historical role, forage production will continue to decline, and grazing opportunities for both livestock and wild ungulates will steadily be eliminated. Where appropriate, mechanical treatments can have effects similar to fire, but without the associated risk. In addition, mechanical treatments may be necessary to reduce fuel loads before fire can be reintroduced.

- At present, there is little sign of widespread overgrazing in the Henry Mountains, and range conditions are generally better today than they were during the early 1900 s.

- Soil erosion occurred on some sites in the past, but improved management has largely corrected that problem. 


\section{Plates}

The plates that follow were selected because they are representative of the long-term vegetation changes observed in Utah's Henry Mountains (see Figure 5, Locations of the Plates Published in This Report). As the photo sets were initially made, they were assigned a number in the order they were completed in the field (i.e., Plate 1 was completed first and Plate 608 last). To make this report and Utah State University's Extension website compatible, the original numbers have been retained on the plates selected for this publication. That is, the plates were not renumbered for this report but follow the numbers found on the website. Thus, while the plates herein are presented sequentially, there are often gaps in the numbering sequence. If readers are interested in the other plates, those images may be found on the Extension website (http://extension.usu.edu/rra) or in the annual reports that were submitted to the BLM. 


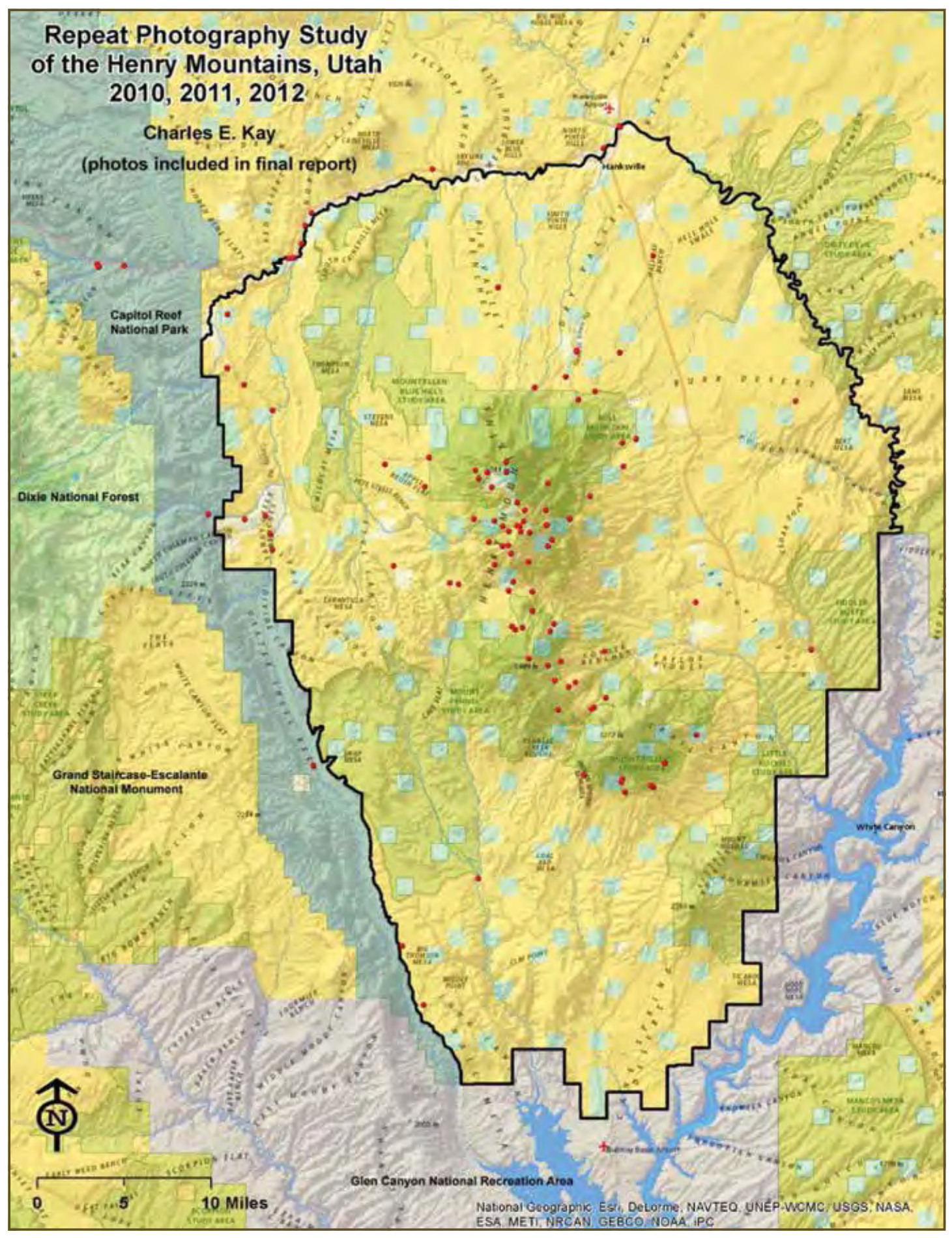

Figure 5. Locations of the Plates Published in This Report. Multiple photo sets were made from some camera stations. GIS map produced by Doug Page, BLM, Cedar City, UT. 


\section{Plate HM-1}

\section{Fremont River - Capitol Reef National Park}

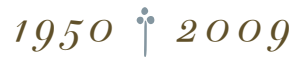

Viewed northwest up the Fremont River in Capitol Reef National Park. The original photograph was taken before Utah Highway 24 was built along the river. Because woody riparian vegetation is abundant today, unlike in the past, the retake had to be made from the nearest open area to show the distant sandstone formations.

The highway is at the base of the cliffs on the left but is hidden from view by woody riparian vegetation-primarily cottonwood and willows. The river channel, which is now at the base of the cliffs on the right, has narrowed and deepened. Beaver have felled some of the cottonwoods, and the National Park Service has removed nonnative tamarisk and Russian olive.

Original photograph taken by Charles Kelly ca. 1950; retake made by Charles E. Kay on June 27, 2009 (Photo No. 5941-17). Section 13, Range 6 East, Township 29 South; UTM 480746E, 4237574N; elevation 5,338 ft. Original image (P0100, Number 1-33-18) held by the University of Utah, Marriott Library Special Collections, Salt Lake City, UT. 


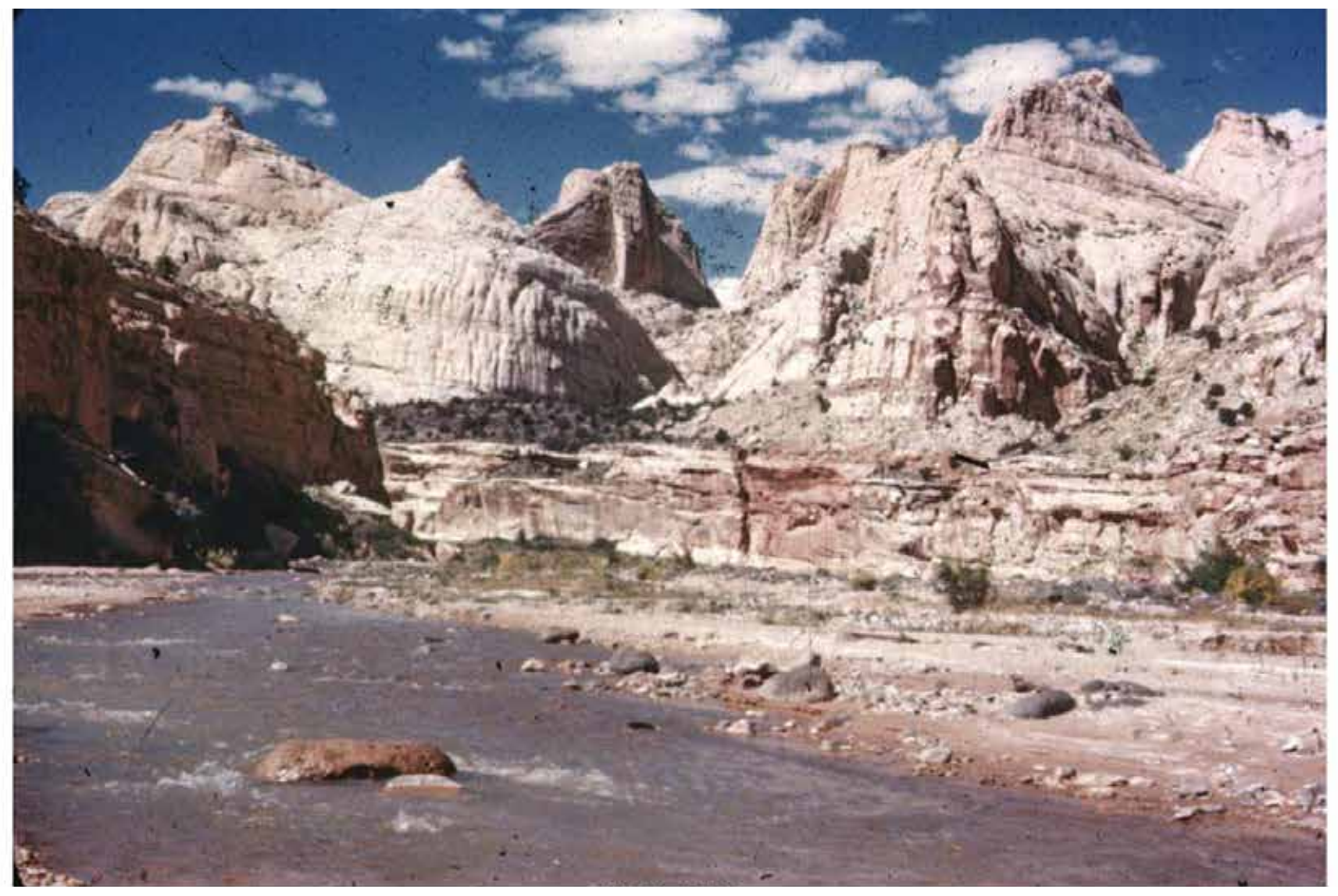

HM-1, 1950

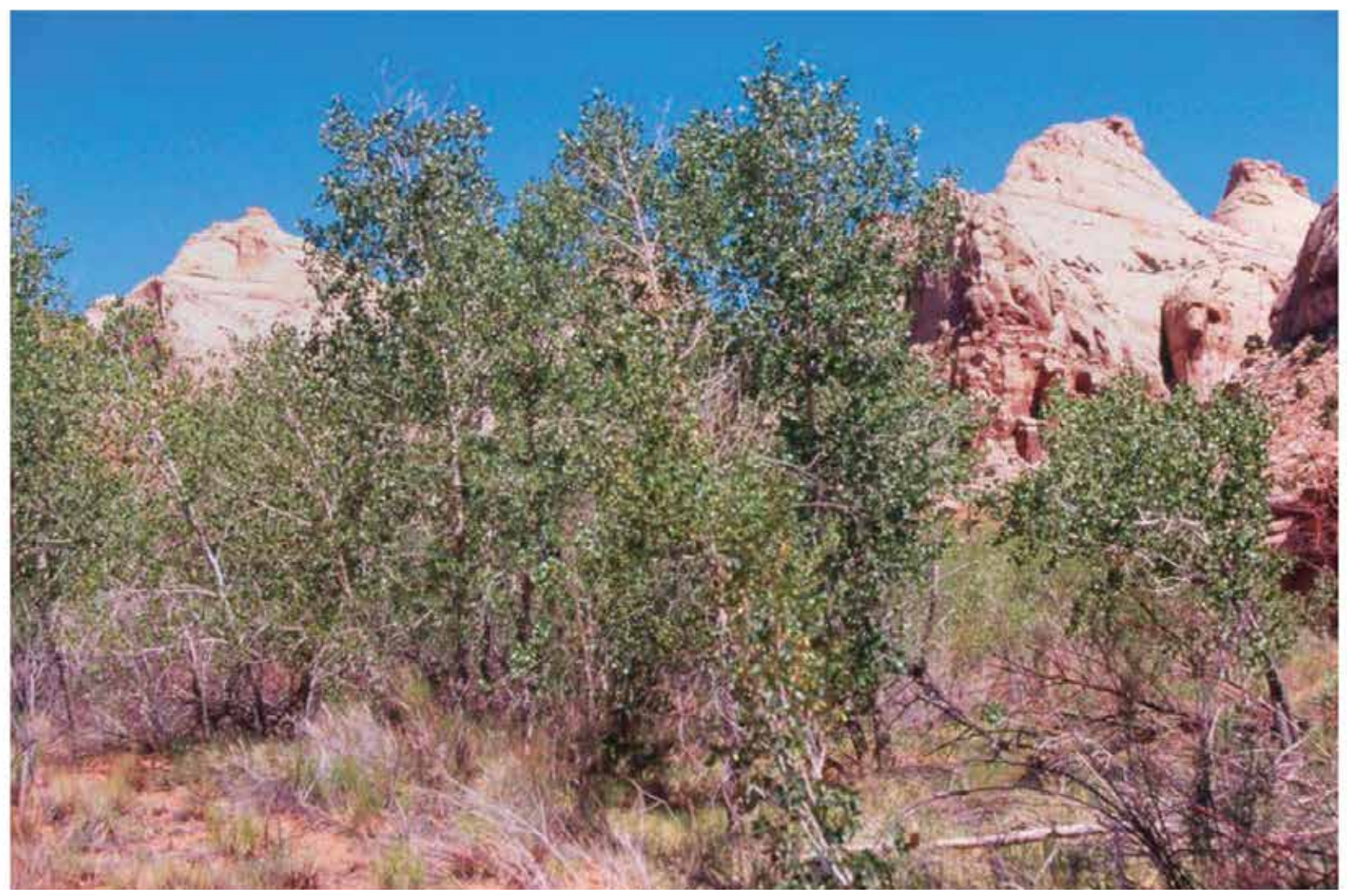

HM-1, 2009 


\section{Plate HM-32}

\section{Fremont River}

$1937 \because 2010$

Viewed to the northeast down the Fremont River approximately 3 1 12 miles southwest of Caineville, the valley bottom at this location is a mixture of private lands and BLM lands. A dense growth of cottonwoods now blocks the original camera station, so the retake was made from the southwest corner of the bridge on Utah Highway 24.

In 1937 the Fremont River was wide and shallow, and the banks generally lacked woody riparian vegetation.

Today, the stream has stabilized, while the channel has narrowed and deepened. Cottonwoods and willows are abundant, despite yearly cattle grazing.

Original photograph taken by an unknown photographer on April 19, 1937; retake made by Charles E. Kay on June 10, 2010 (Photo No. 6025-4A). Section 15, Range 8 East, Township 29 South; UTM 495980E, 4238279N; elevation 4,678 ft. Original image (C-231, Box 10, Number 254) held by the Utah State Historical Society, Salt Lake City, UT. 


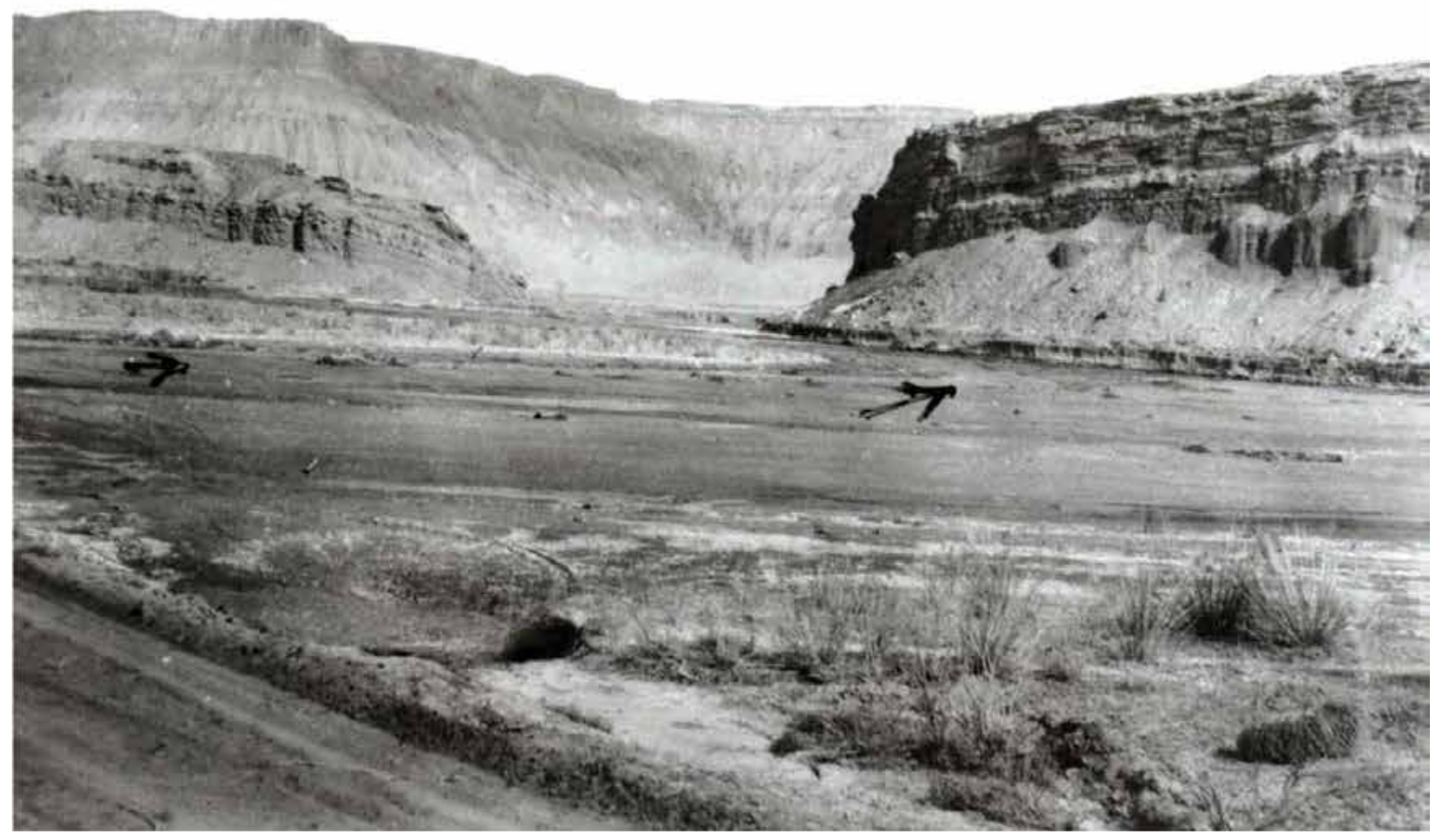

HM-32, 1937

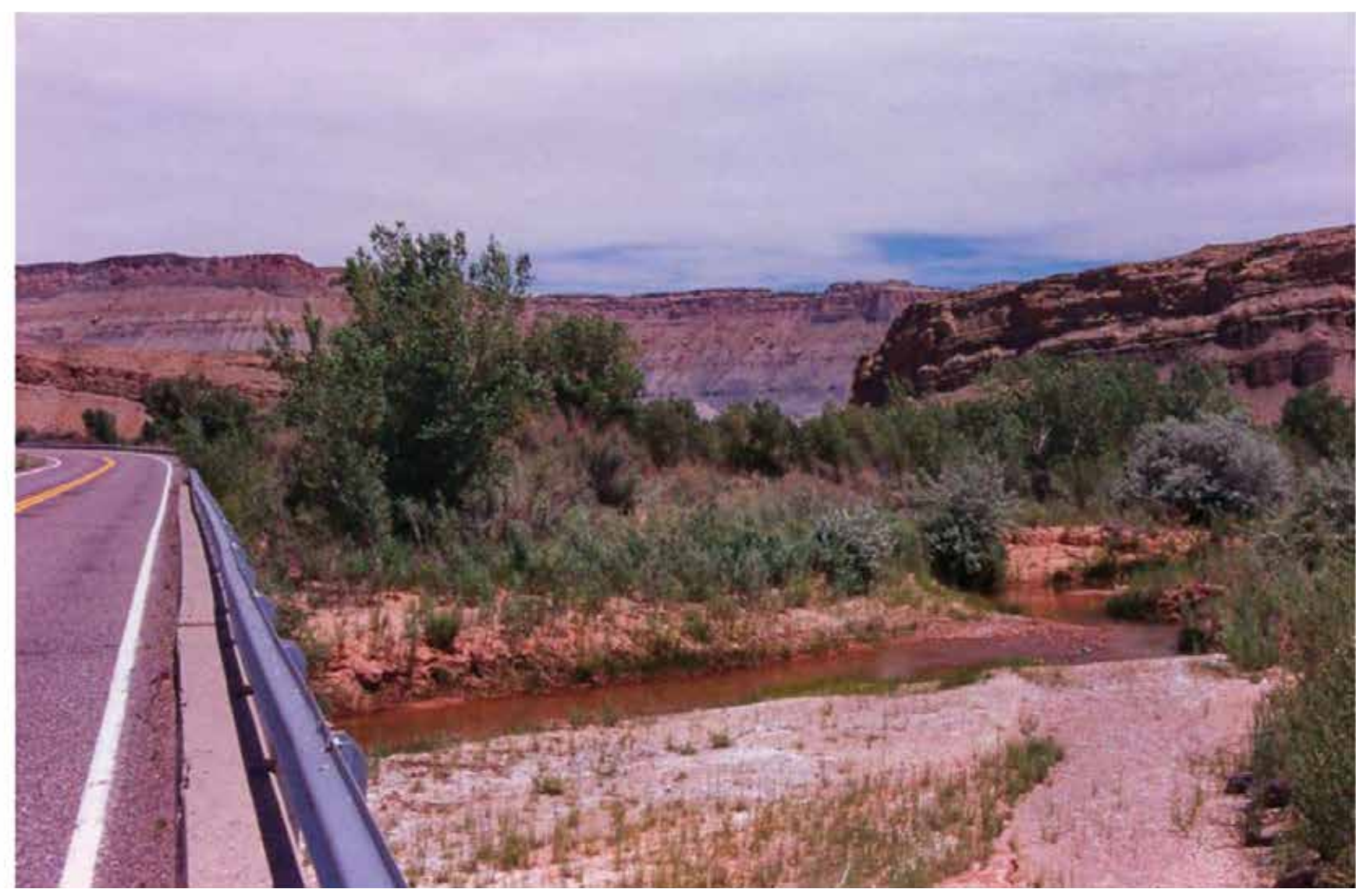




\section{Plate HM-40}

\section{Fremont River}

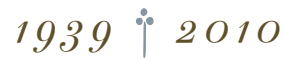

Viewed northeast down the Fremont River about 2 1/2 miles southwest of Caineville on the old gravel road.

South Caineville Mesa is on the right. North Caineville Mesa is in the distance.

In 1939 the Fremont River was wide and shallow, and the banks generally lacked woody riparian vegetation.

Today, the river has narrowed and deepened, and woody riparian vegetation-primarily cottonwoods and

willows-is abundant. The valley bottom at this location is private property and is grazed yearly by cattle.

Contrary to Fleischner's 2010 report, there is no evidence that livestock grazing is destroying riparian areas along the Fremont River below the national park boundary.

Original photograph taken by Arther Leroy Inglesby in 1939; retake made by Charles E. Kay on June 10, 2010

(Photo No. 6029-2). Section 10, Range 8 East, Township 29 South; UTM 497265E, 4239619N; elevation

4,679 ft. Original image (C-345, Box 2, Folder 8, Number 16) held by the Utah State Historical Society,

Salt Lake City, UT. 


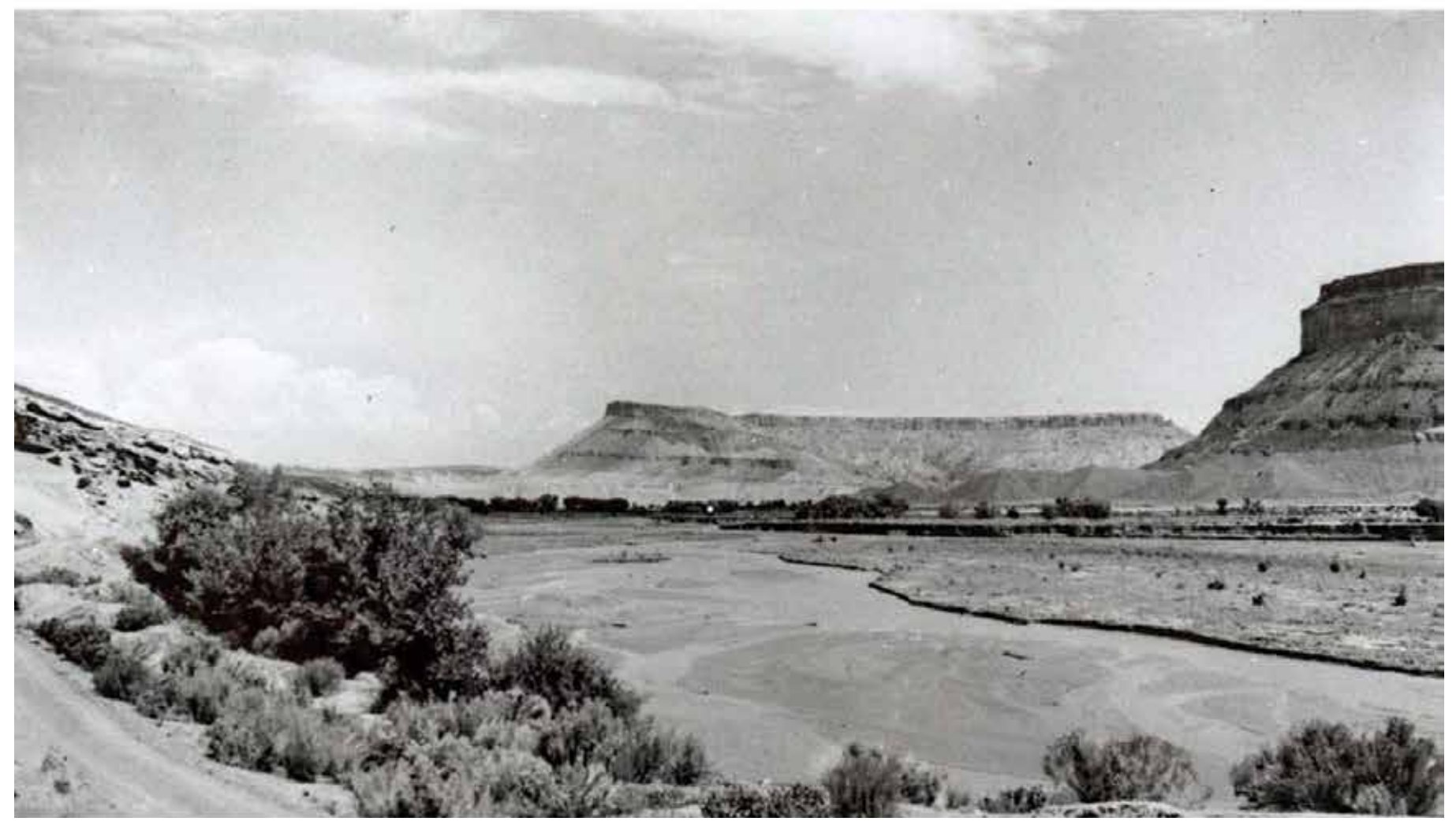

HM-40, 1939

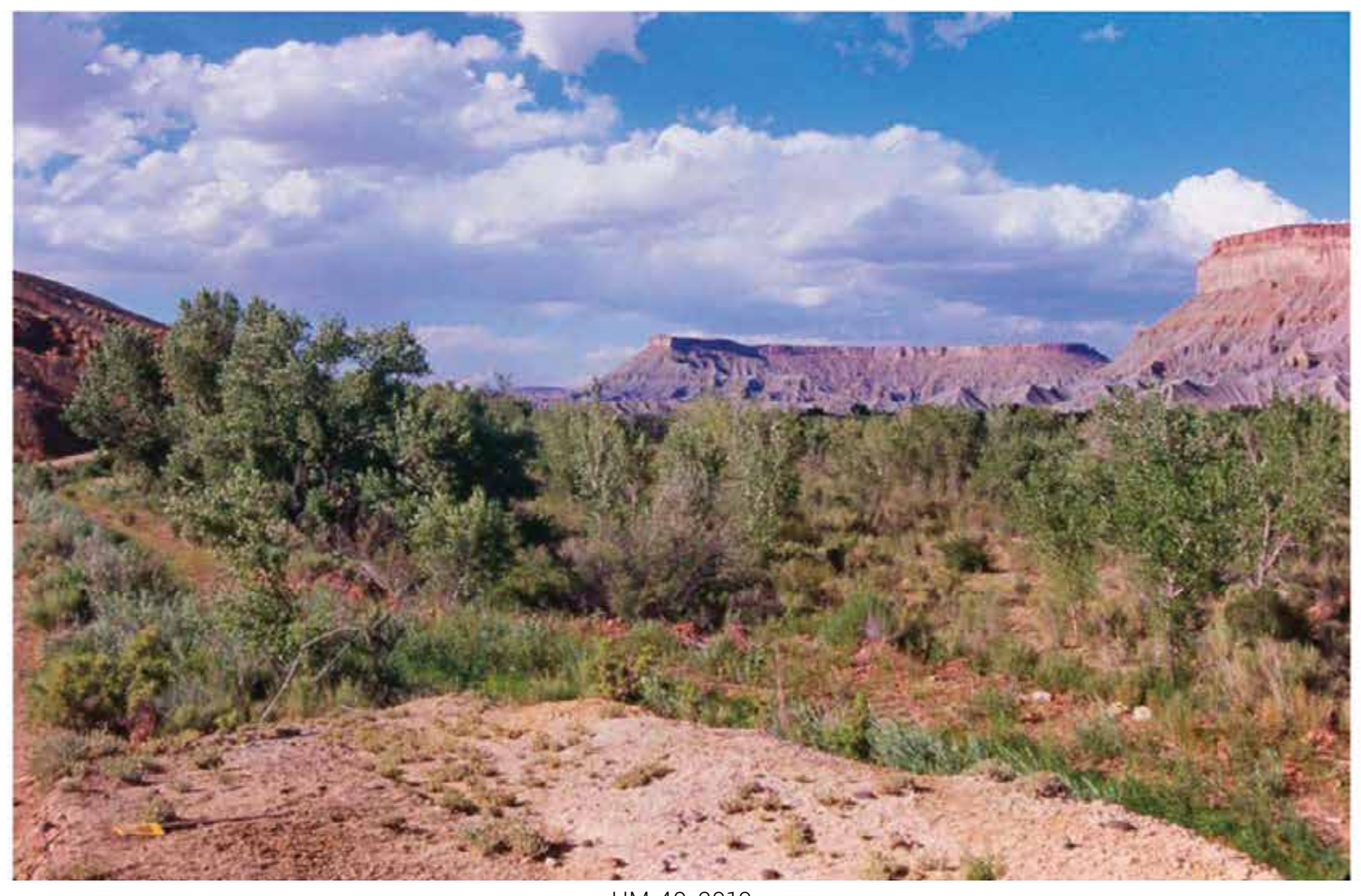

HM-40, 2010 


\section{Plate HM-44}

\section{Factory Butte}

$1935 \div 2010$

Viewed north-northwest to Factory Butte, west of Hanksville. The camera station is just north of Utah Highway 24 and just east of the Factory Butte road.

Shrubs and grasses appear to have increased. The main species include fourwing saltbush, Indian ricegrass, Mormon tea, curly grass (a local term for galleta), and desert trumpet. The foreground in the retake has been disturbed by construction-related activities.

Original photograph taken by Charles B. Hunt (Number 412) in 1935; retake made by Charles E. Kay on June 11, 2010 (Photo No. 6029-27). Section 24, Range 9 East, Township 28 South; UTM 509425E, 4246581N; elevation 4,637 ft. Original image held by the U.S. Geological Survey Photographic Library, Denver, CO. 


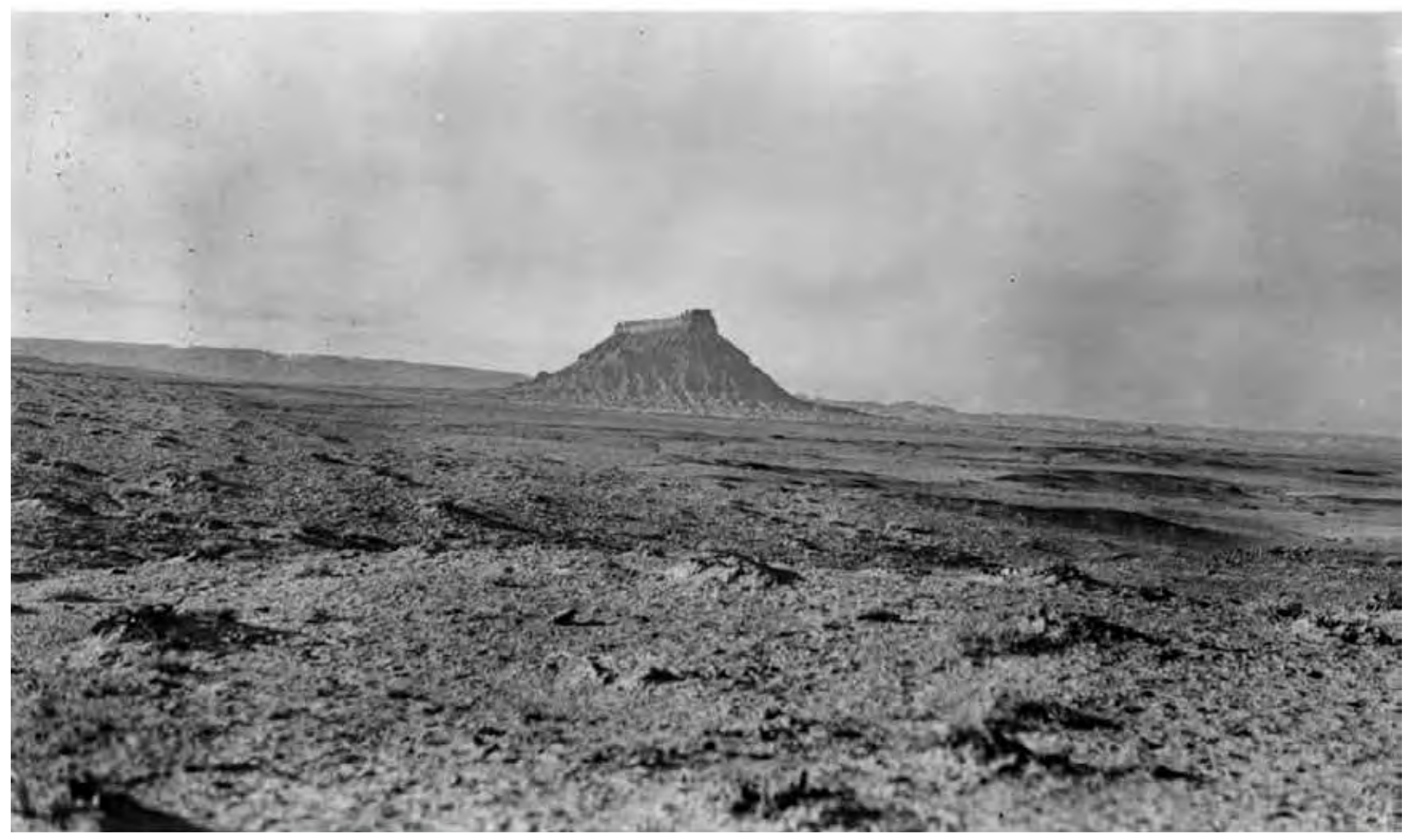

HM-44, 1935

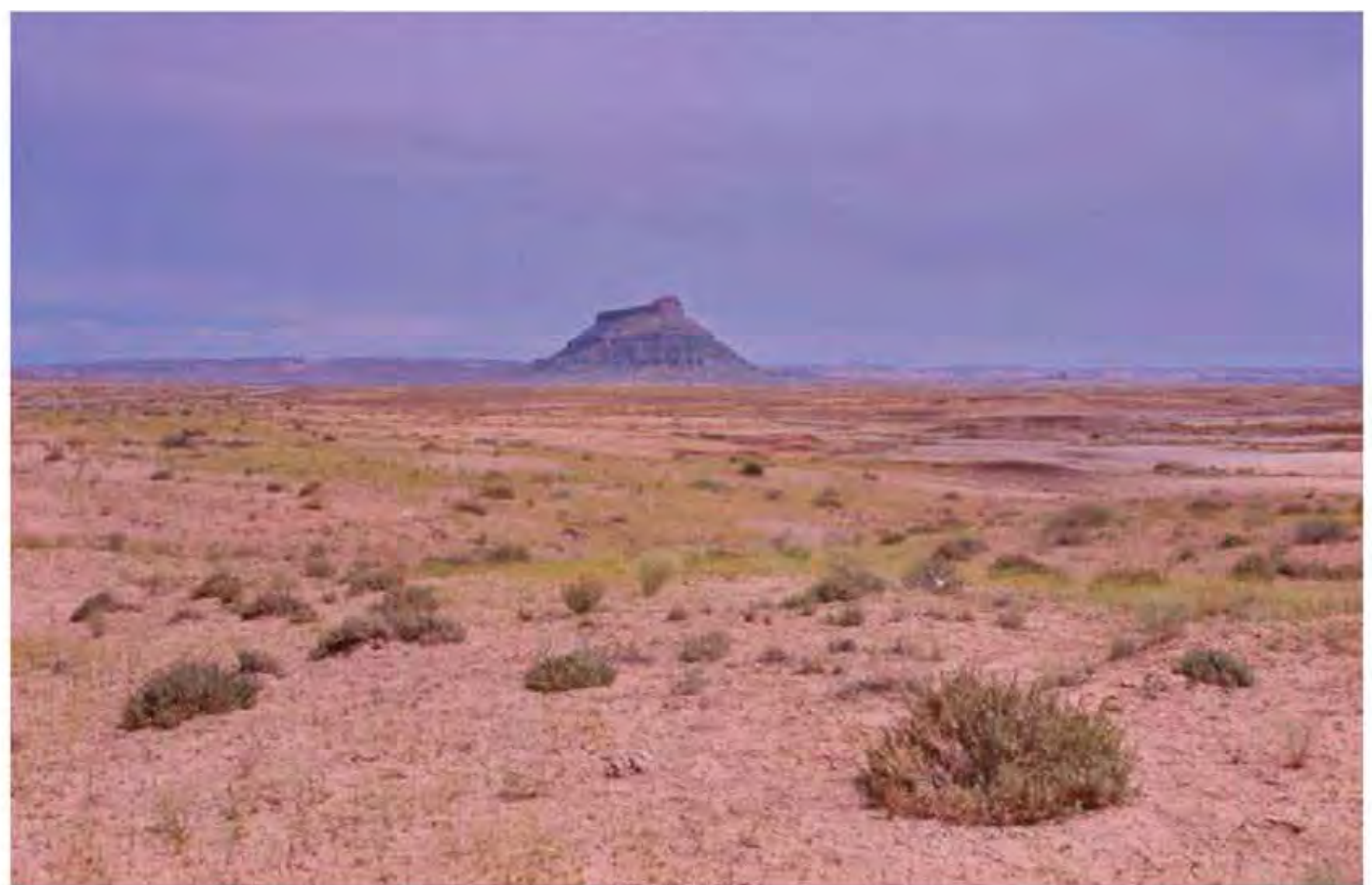

HM-44, 2010 


\section{Plate HM-51}

\section{Fremont River}

$1921 \div 2010$

Viewed northeast down the Fremont River, immediately north of Hanksville. The photo point is on the old gravel road north of town. The original camera station was washed away before the channel stabilized, hence the slightly different view in the retake. Note the old bridge abutment (left-center in both photos). The bridge was destroyed by floodwaters sometime before 1921.

Clearly, the river has stabilized and excessive erosion has ceased. Today the banks are heavily vegetated, unlike conditions in the past. Cottonwoods and willows are common, as are tamarisk and Russian olive. Contrary to Fleischner's 2010 report, continued livestock grazing is not destroying riparian areas along the Fremont River on BLM lands or private lands; instead, ecological conditions have improved.

Original photograph taken by an unknown photographer on September 1, 1921; retake made by Charles E. Kay on June 11, 2010 (Photo No. 6032-27). Section 10, Range 11 East, Township 28 South; UTM 525320E, 4248528N; elevation 4,290 ft. Original image (C-231, Box 10, Number 231) held by the Utah State Historical Society, Salt Lake City, UT. 


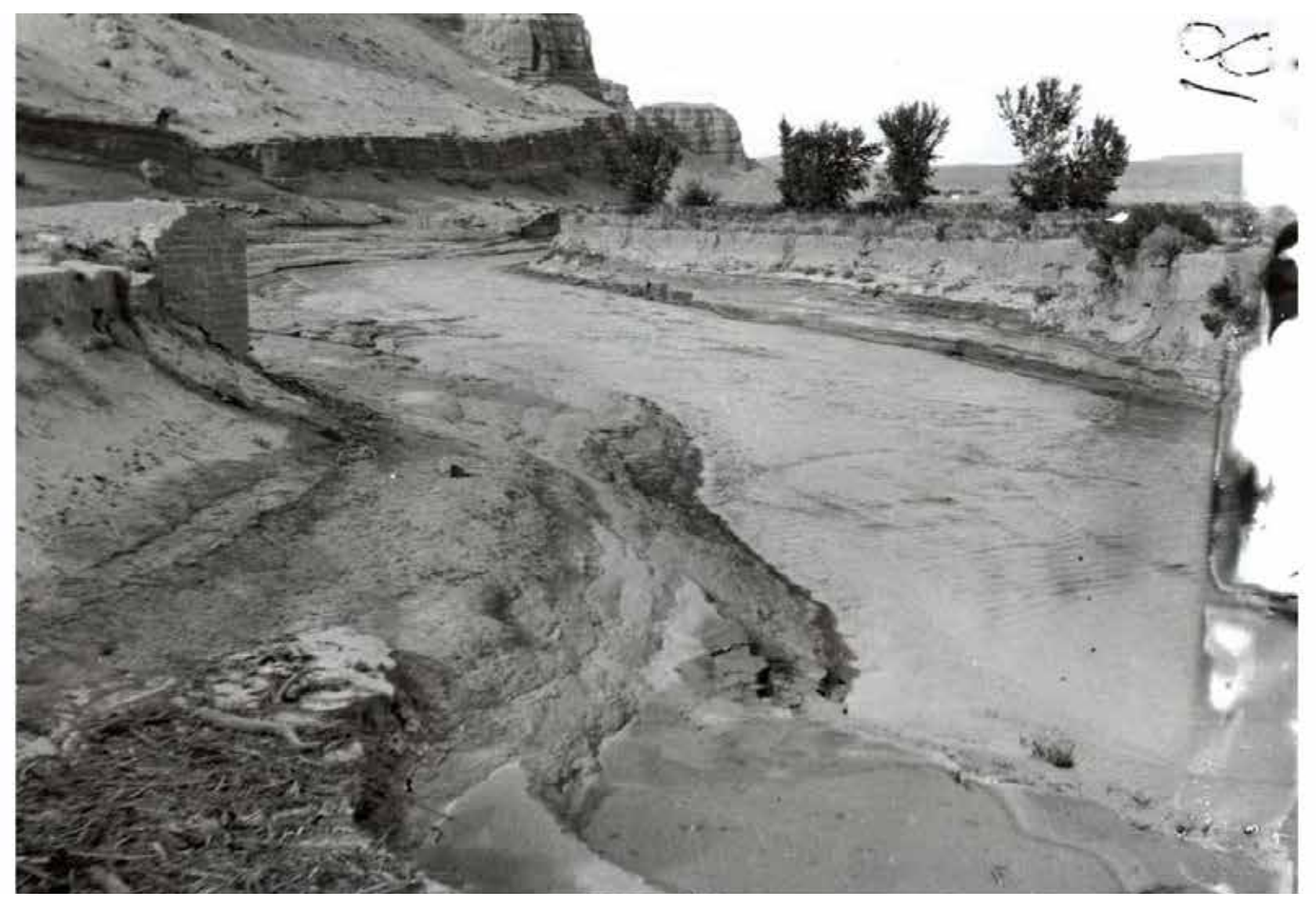

HM-51, 1921

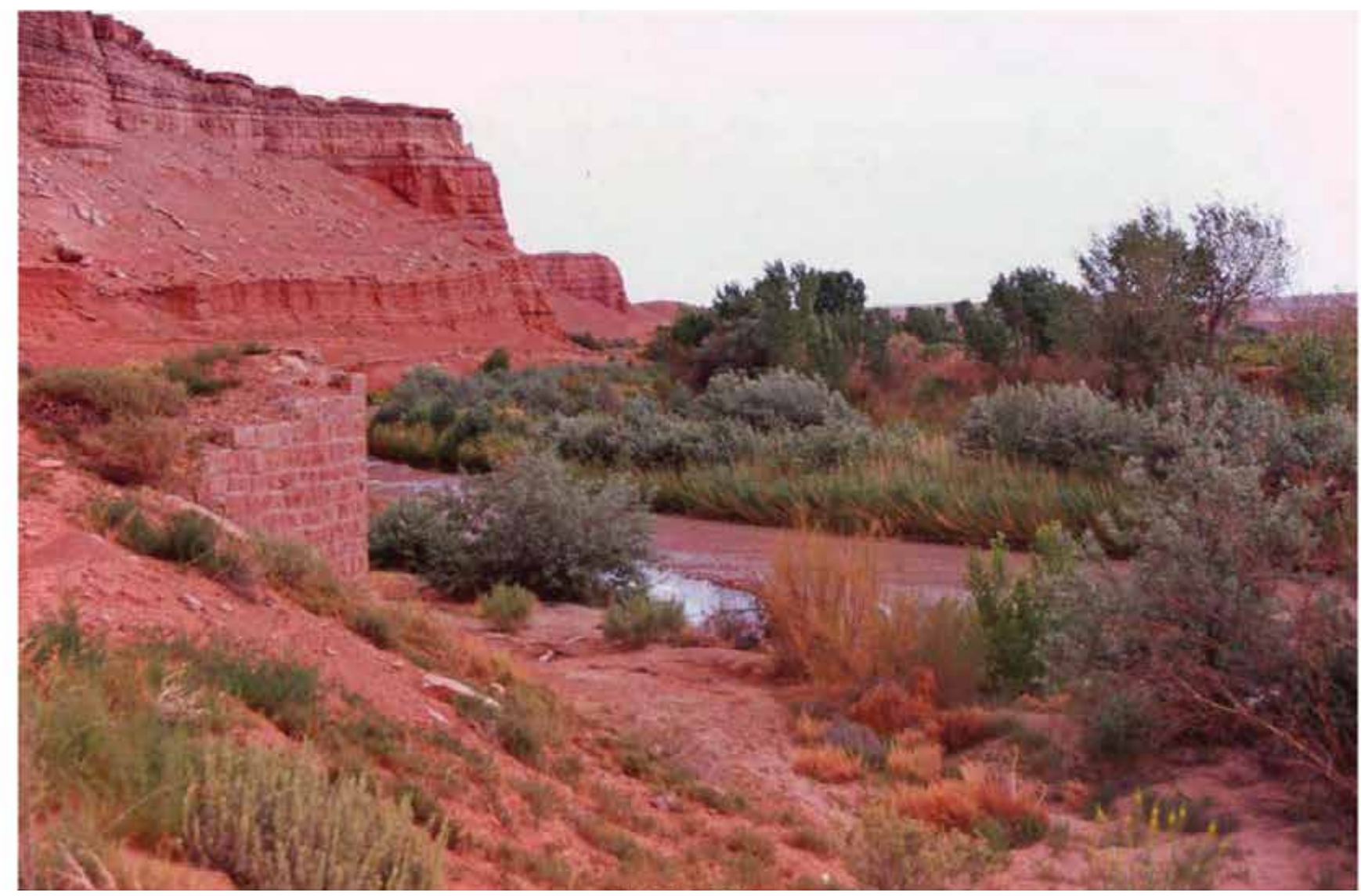

HM-51, 2010 


\section{Plate HM-56}

\section{Dirty Devil and Fremont Rivers}

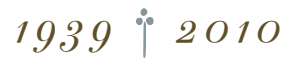

Viewed southwest up the Dirty Devil River and Fremont River to the Henry Mountains in the distance.

Muddy Creek enters the Fremont on the right, 200 yards upstream, to form the Dirty Devil River seen in the

foreground. The camera station is northwest of the present-day Utah Highway 24 bridge and just to the west of the old wooden bridge pilings.

In 1939 both rivers were wide, shallow, and nonvegetated, except for a few mature cottonwoods. As upstream erosion has been controlled, the rivers have stabilized and narrowed, allowing woody riparian vegetation to become established, despite continued livestock grazing. This plate provides another example of the error of Fleischner's 2010 report that claimed livestock were denuding the Fremont River drainage. Note that what was riverbed in 1939 is now an irrigated field. Willows and cottonwoods are common, as are tamarisk and Russian olive.

Original photograph taken by Charles B. Hunt (Number 840) in 1939; retake made by Charles E. Kay on June 12, 2010 (Photo No. 6034-13A). Section 2, Range 11 East, Township 28 South; UTM 526792E, 4250631N; elevation 4,311 ft. Original image held by the U.S. Geological Survey Photographic Library, Denver, CO. 


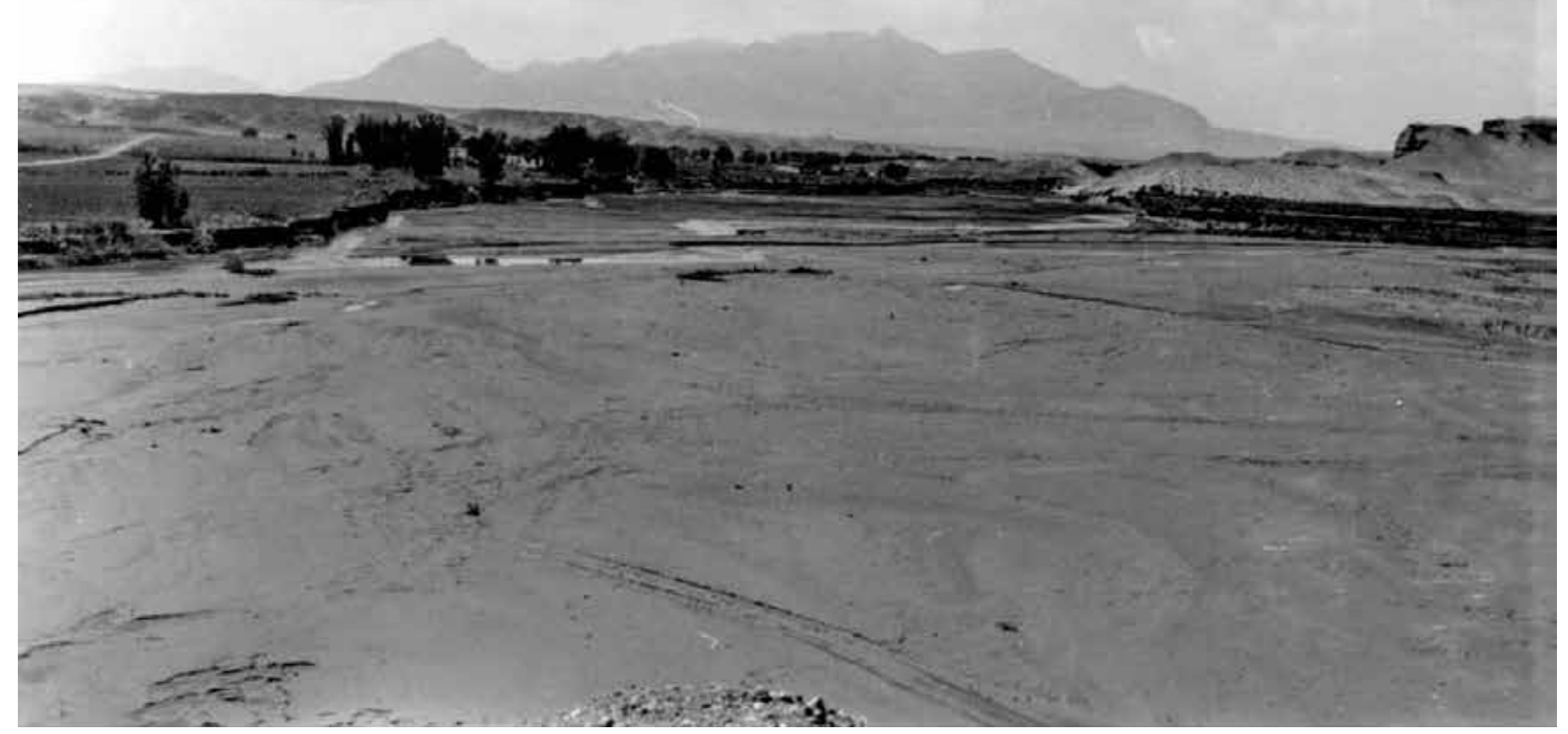

HM-56, 1939

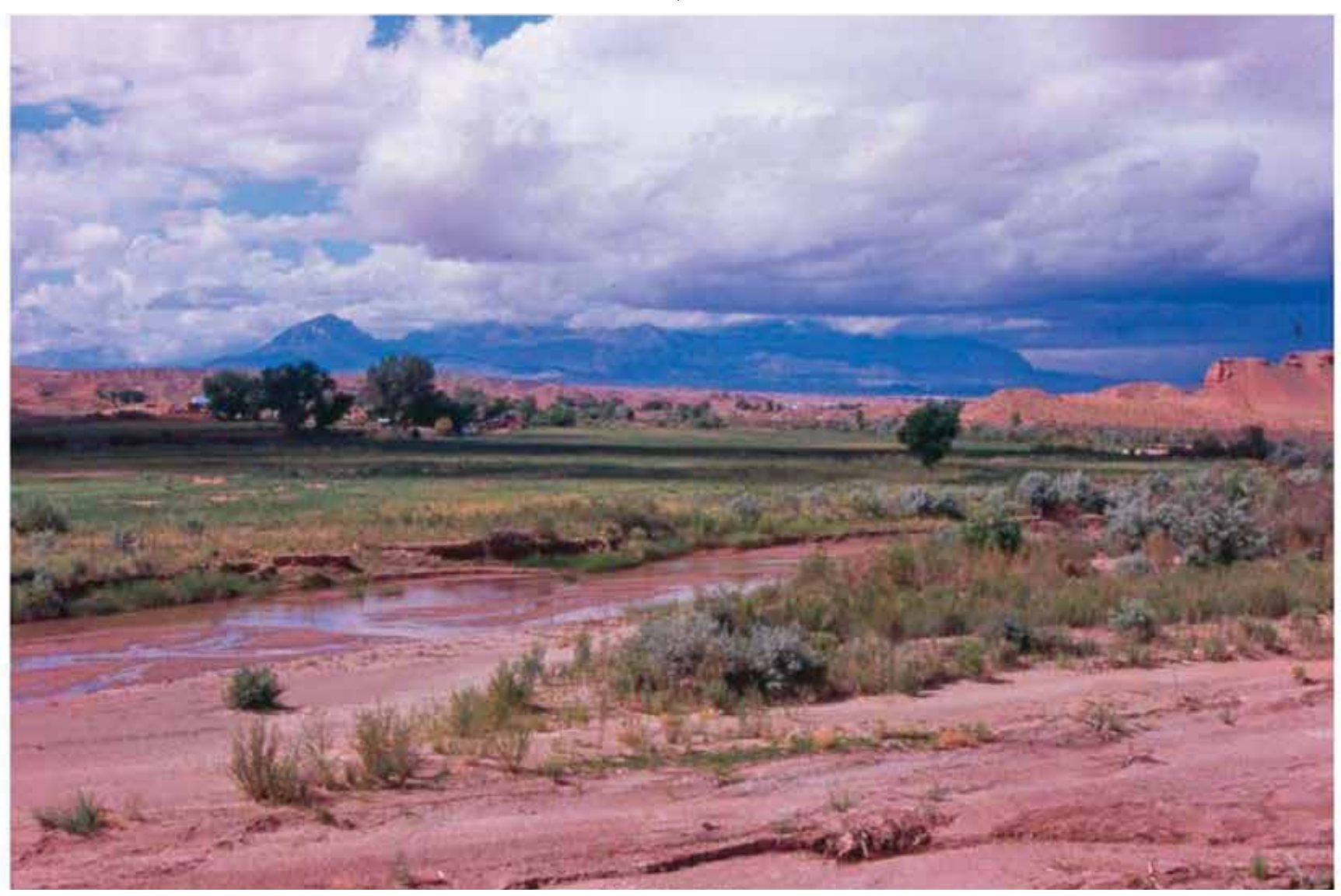

HM-56, 2010 


\section{Plates HM-74, HM-75, and HM-76}

\section{Mount Hillers and Big Ridge}

$1937 \because 2010$

Viewed south to Mount Hillers (right distant skyline) and Big Ridge. Plates HM-74, HM-75, and HM-76

form a panorama and were taken from a camera station just north of the Stanton Pass road and southwest of Quaking Aspen Spring.

The vegetation in 1937 was primarily Douglas-fir, oak brush, and sagebrush, with a scattering of pinyon-juniper. In 2003 the area was swept by high-intensity crown fire, a type of fire behavior not seen in any early photograph taken in the Henry Mountains. Based on the number of dead trees in the retake, Douglas-fir, pinyon-juniper, and oak brush increased before the 2003 Bulldog Fire. In part, that increase in forest fuels drove the extreme fire behavior seen in 2003, where nearly 32,000 acres burned in a matter of days (Bureau of Land Management 2003). Look carefully at the 1937 photos. There is no evidence of large-scale, crown fire behavior or even any dead trees or snags. Oak brush resprouted after the 2003 fire.

Original photographs taken by Charles B. Hunt (Numbers 653, 654, 655) in August 1937; retakes made by Charles E. Kay on July 7, 2010 (Photo Nos. 6042-2, 6042-4, and 6042-9). Section 21, Range 11 East, Township 33 South; UTM 525524E, 4197320N; elevation 7,065 ft. Original images held by the U.S. Geological Survey Photographic Library, Denver, CO. Photo mosaic compiled by Doug Page, BLM, Cedar City, UT. 

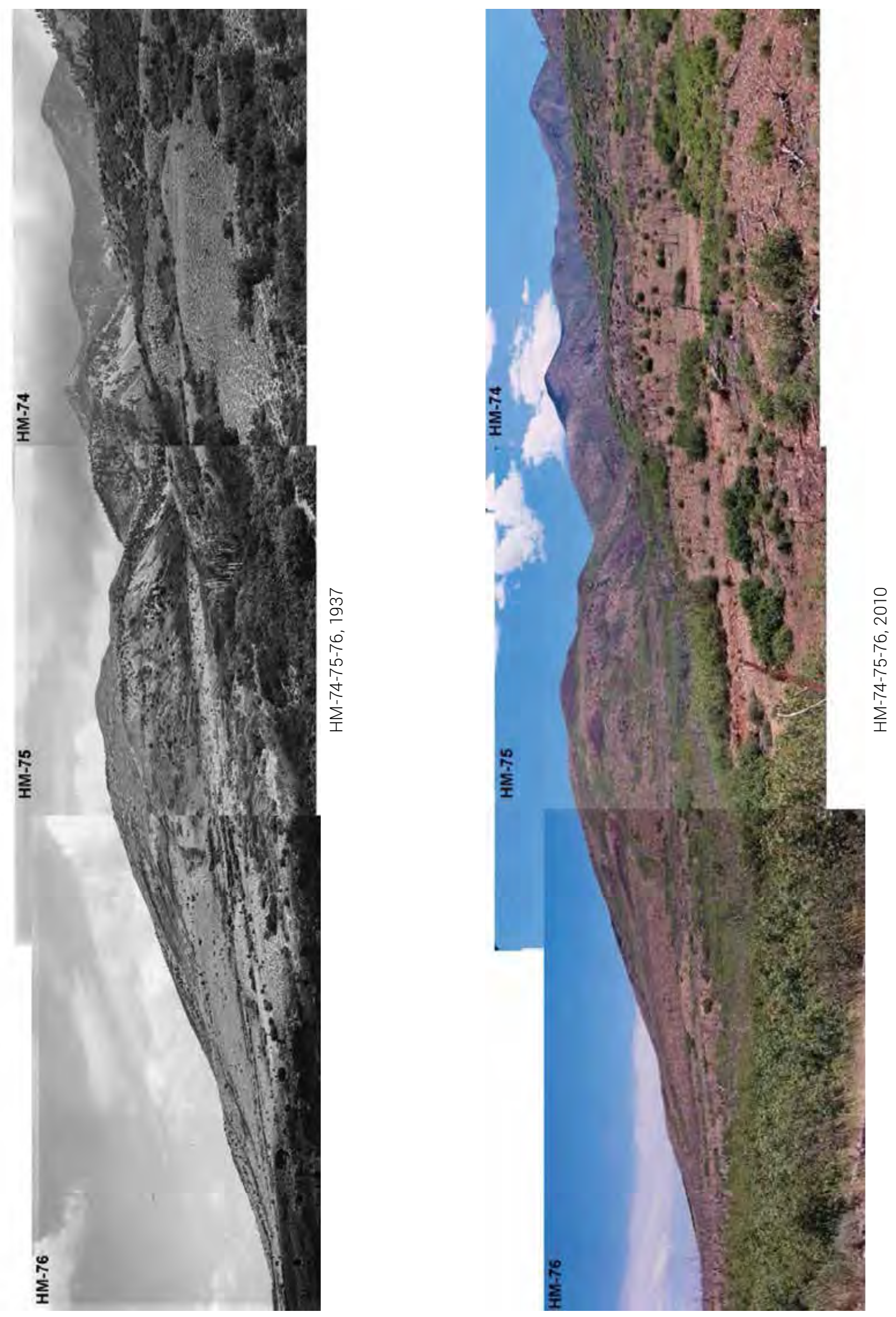


\section{Plate HM-77}

Cass Creer Peak

$1937: 2010$

Viewed southeast to Cass Creek Peak from just east of Stanton Pass.

In 1937 the vegetation was primarily oak brush and sagebrush, with a scattering of pinyon-juniper on the lower slopes and more widely spaced Douglas-fir at higher elevations. In 2003 the area was swept by a high-intensity crown fire known as the Bulldog Fire. Based on the number of dead trees in the retake, Douglas-fir, pinyonjuniper, and oak brush increased before that fire. In part, that increase in forest fuels (along with dry conditions and high winds) drove the extreme fire behavior in 2003 , where nearly 32,000 acres burned in a matter of days (Bureau of Land Management 2003). Look carefully at the 1937 photo, there is no evidence of large-scale, crown-fire behavior or even any dead trees or snags. Oak brush resprouted after the 2003 fire.

Original photograph taken by Charles B. Hunt (Number 656) in August 1937; retake made by Charles E. Kay on July 7, 2010 (Photo No. 6042-16). Section 20, Range 11 East, Township 33 South; UTM 524453E, 4196429N; elevation 7,410 ft. Original image held by the U.S. Geological Survey Photographic Library, Denver, CO. 


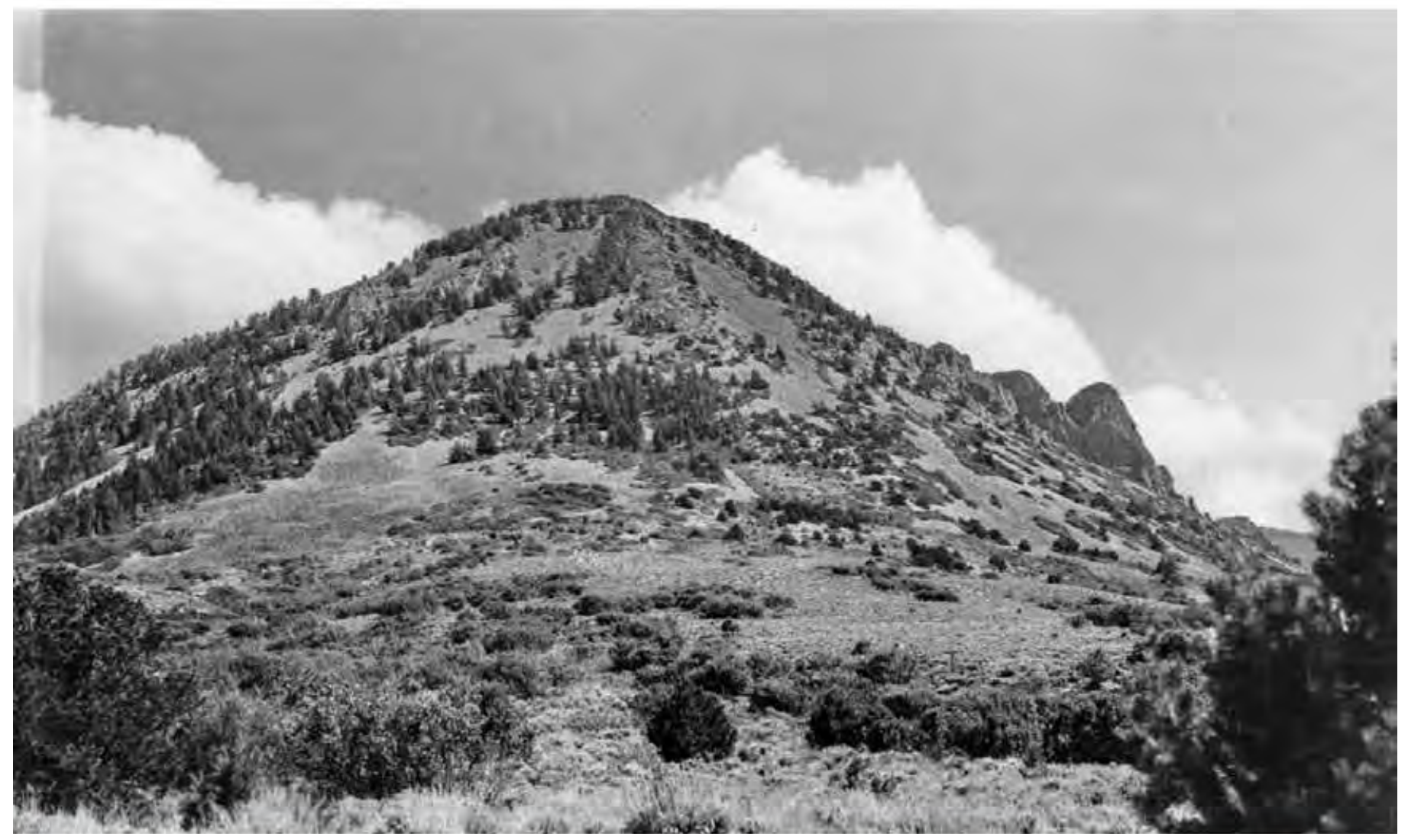

HM-77, 1937

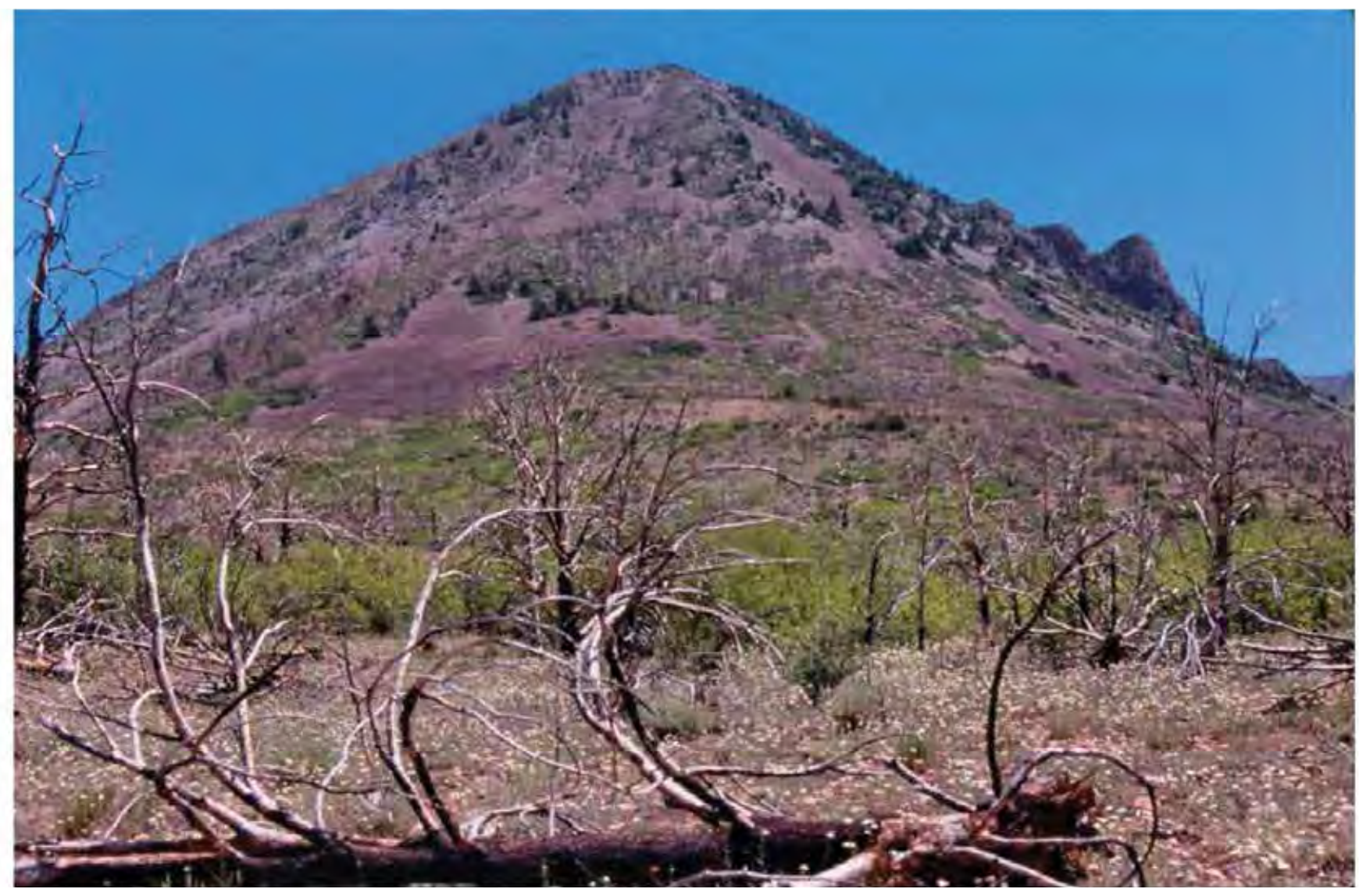

HM-77, 2010 


\section{Plate HM-80}

\section{Bulldog Ridge}

$1937 \because 2010$

Viewed southwest to Bulldog Ridge on the southeast flank of Mount Pennell. The camera station for this photo point is the same as that for Plates HM-78 and HM-79.

In 1937 the vegetation was primarily sagebrush, oak brush, and Douglas-fir. There were also several patches of aspen. In fact, one of the aspen stands near the top of the distant ridge (upper-right-center) appears to have regenerated after a small burn. Both the Douglas-fir forest and oak brush appear to have been subjected to repeated, low-intensity fires. Much of the area was swept by the 2003 Bullog Fire that blackened nearly 32,000 acres in a matter of days (Bureau of Land Management 2003). Nonetheless, it is clear from the standing dead material that oak brush and Douglas-fir had increased before the 2003 wildfire, while aspen had declined. Aspen has since resprouted vigorously, but this is difficult to see in the retake. As would be expected, oak brush also resprouted after the 2003 fire.

Original photograph taken by Charles B. Hunt (Number 610) in July 1937; retake made by Charles E. Kay on July 7, 2010 (Photo No. 6042-27). Section 13, Range 10 East, Township 33 South; UTM 520794E, 4198944N; elevation 8,351 ft. Original photograph held by the U.S. Geological Survey Photographic Library, Denver, CO. 


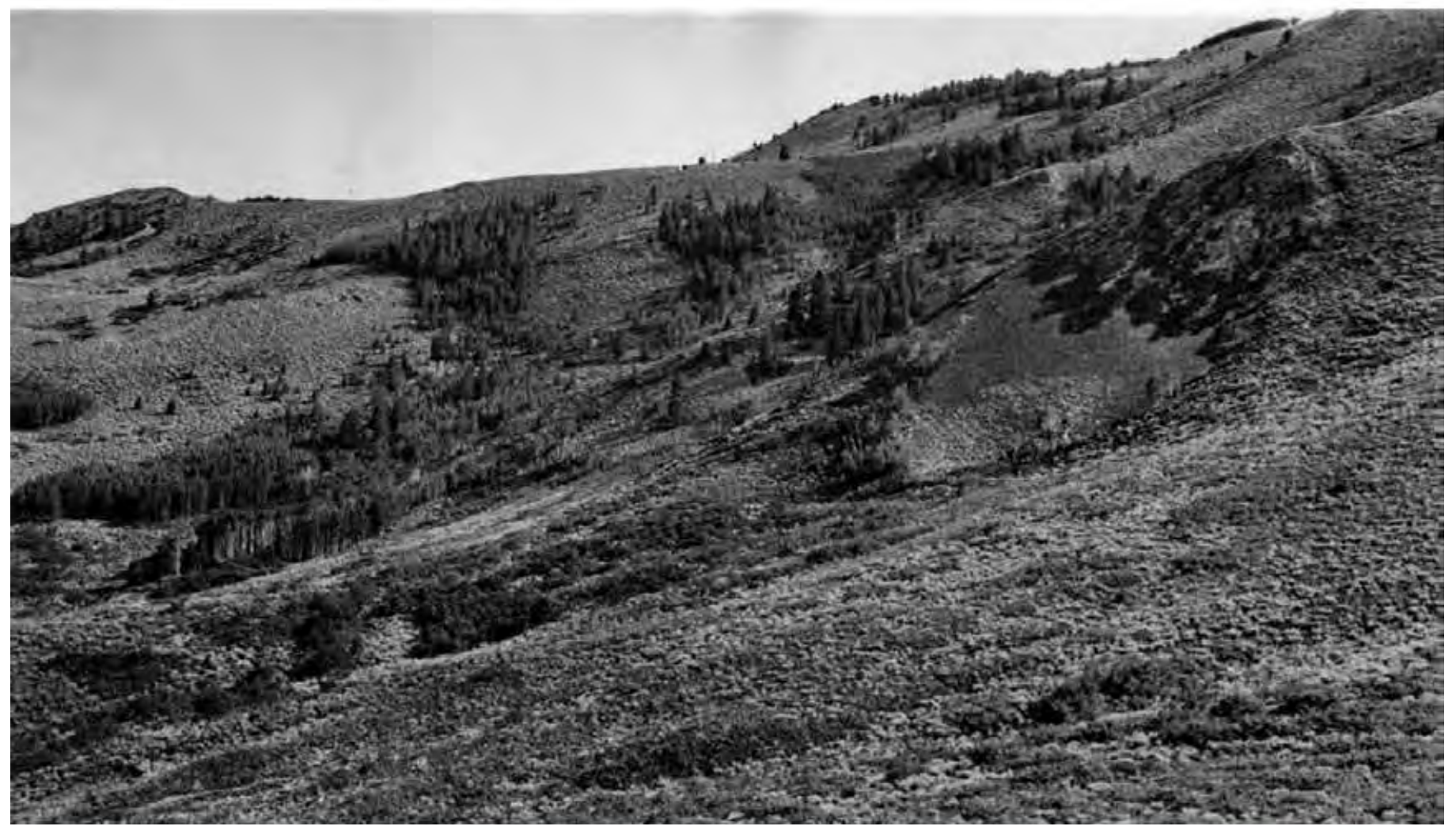

HM-80, 1937

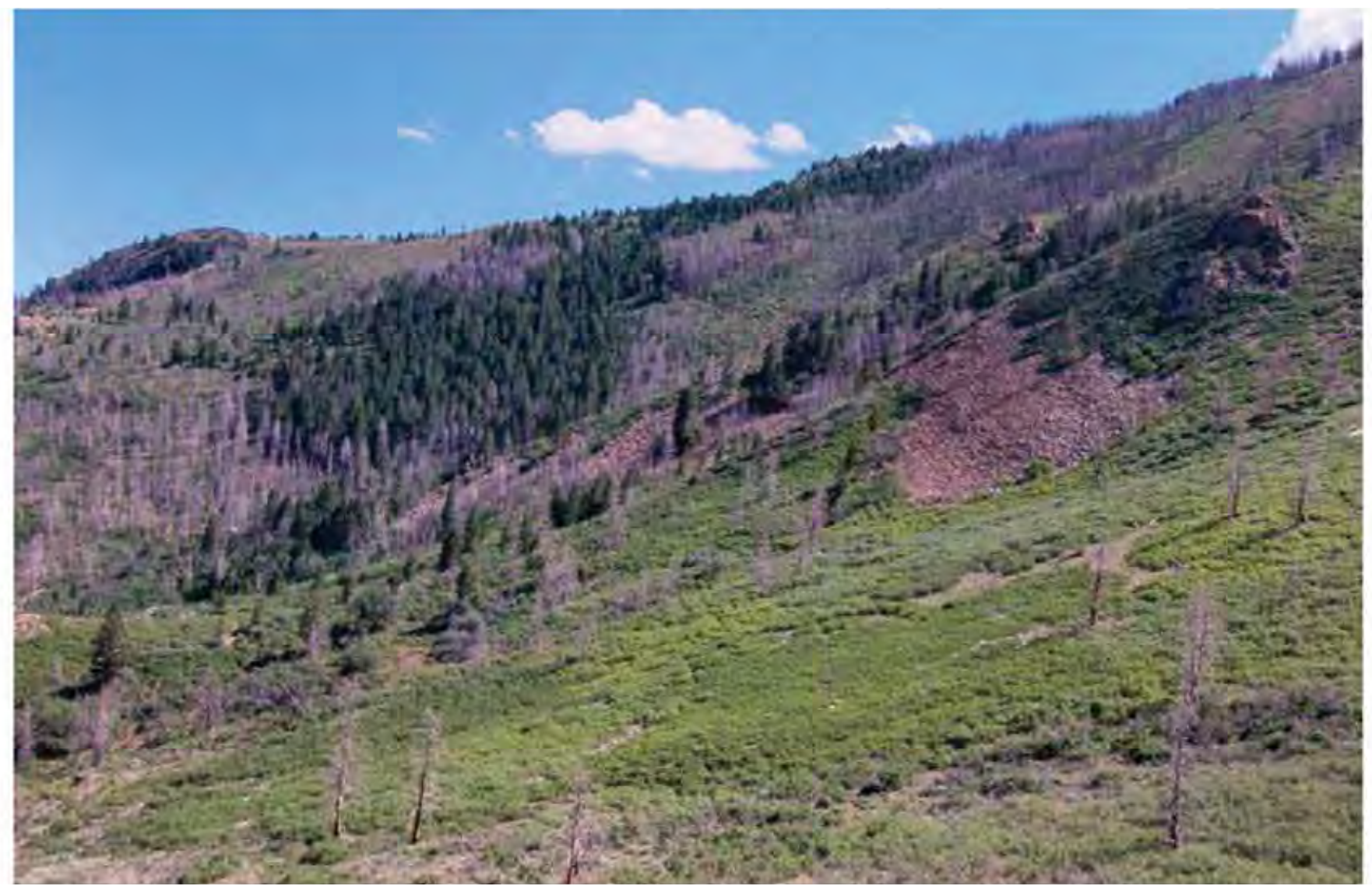

HM-80, 2010 


\section{Plate HM-81}

\section{Mount Pennell}

$1937 \because 2010$

Viewed northwest from Browns Knoll to Mount Pennell.

In 1937 there were no pinyon or juniper in the area shown in the foreground. Utah serviceberry and birchleaf mountain mahogany appear to have been very heavily grazed, most likely by domestic sheep. Grasses, too, were absent near the camera station. In the distance, oak brush was common on the lower slopes of Mount Pennell, as were open areas and sagebrush. Douglas-fir was restricted to the highest slopes on Mount Pennell. There was a stringer of aspen down Straight Creek. Except for the uppermost rocky pinnacles, everything in the photo was swept by high-intensity crown fire in 2003.

Based on what can be seen in the retake, as well as the standing dead material, Douglas-fir, oak brush, and pinyon-juniper all increased before the wildfire. In fact, the increase in forest fuels, in part, drove the 2003 fire. Domestic sheep are no longer present in the Henrys, and the shrubs in the foreground today appear largely ungrazed. Grasses have increased, as several species were reseeded after the fire. Although the stringer of aspen along Straight Creek appears in the retake as a line of dead trees, these aspen regenerated profusely after the wildfire (this may be hard to pick out in the photo, but it is easy to see when onsite where the road crosses the creek and from the road up Straight Creek). As would be expected, oak brush resprouted after the 2003 fire. A road now traverses the eastern slopes of Mount Pennell.

Original photograph taken by Charles B. Hunt (Number 607) in July 1937; retake made by Charles E. Kay on July 8, 2010 (Photo No. 6045-2). Section 18, Range 11 East, Township 33 South; UTM 522684E, 4198774N; elevation 8,163 ft. Original photograph held by the U.S. Geological Survey Photographic Library, Denver, CO. 


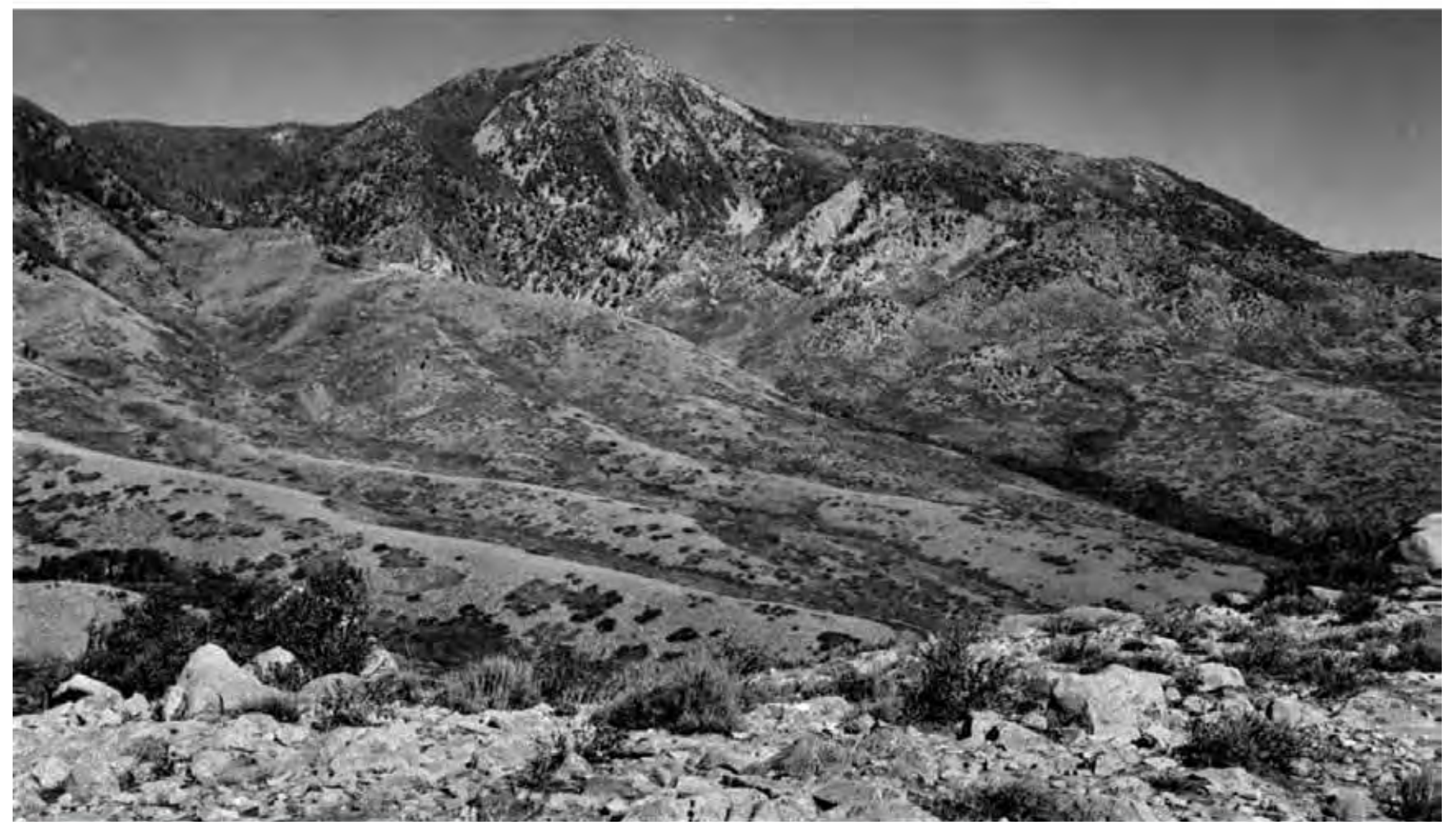

HM-81, 1937

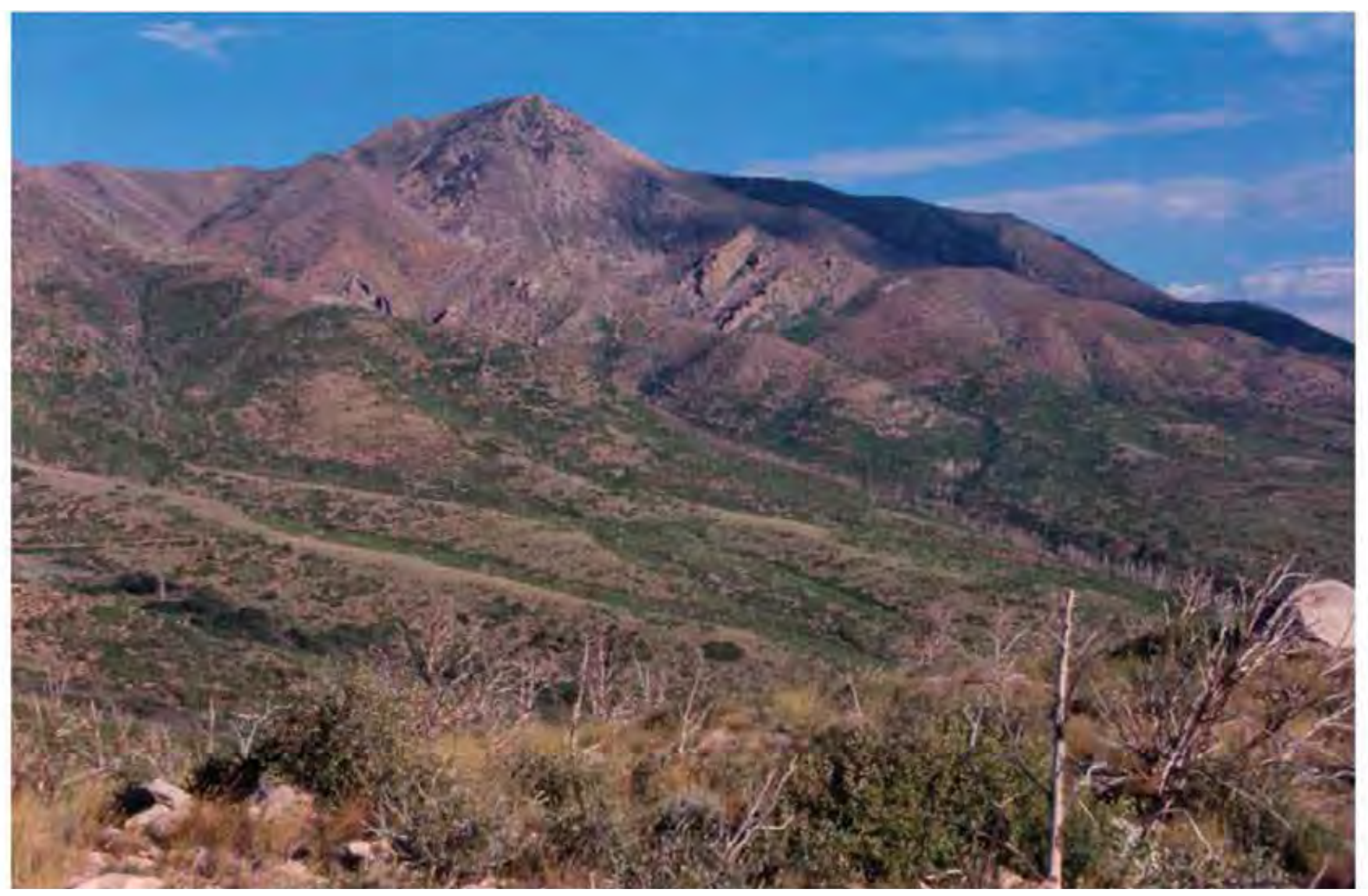

HM-81, 2010 


\section{Plate HM-84}

\section{Mount Pennell}

$1985: 2010$

Viewed west up Corral Canyon to Mount Pennell.

The vegetation in the foreground area of the original image is primarily oak brush, Utah serviceberry, and sagebrush, with a scattering of invading pinyon, juniper, and Douglas-fir, while Douglas-fir and spruce grew at higher elevations. The 2003 Bulldog Fire swept most of the area. Both oak brush and Utah serviceberry resprouted thereafter.

Original photograph taken with a normal lens by Charles E. Kay on May 23, 1985 (print from a color slide); retake made by Charles E. Kay on July 8, 2010 (Photo No. 6045-16). Section 12, Range 10 East, Township 33 South; UTM 521356E, 4200705N; elevation 7,910 ft. Original photograph held by Charles E. Kay in his private collection. 


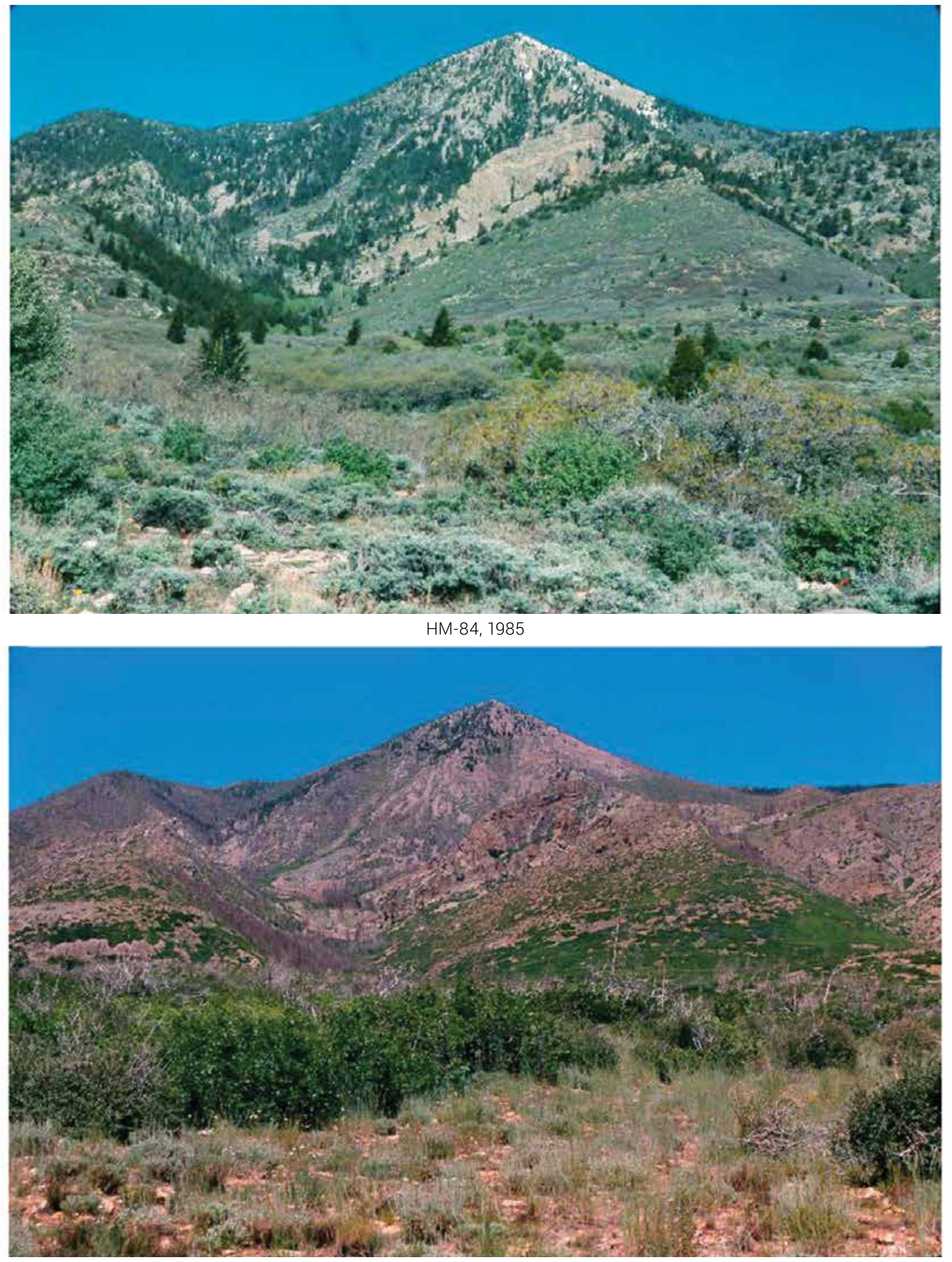

HM-84, 2010 


\section{Plate HM-87}

\section{Mount Pennell}

$1985: 2010$

Viewed south to Mount Pennell from just above the road to Willow Spring.

In 1985 the vegetation on the northern slopes of Mount Pennell was primarily Douglas-fir, spruce, aspen, and oak brush, with areas of sagebrush and grass. In addition, pinyon, juniper, and Douglas-fir were invading the open areas. The 2003 Bulldog Fire swept most of Mount Pennell, significantly reducing all coniferous species except those in the area shown in the foreground, which was not burned.

Original photograph taken by Charles E. Kay on May 23, 1985, with a normal lens (print from a color slide); retake made by Charles E. Kay on July 8, 2010 (Photo No. 6045-25). Section 35, Range 10 East, Township 37 South; UTM 520355E, 4203498N; elevation 8,403 ft. Original photograph held by Charles E. Kay in his private collection. 


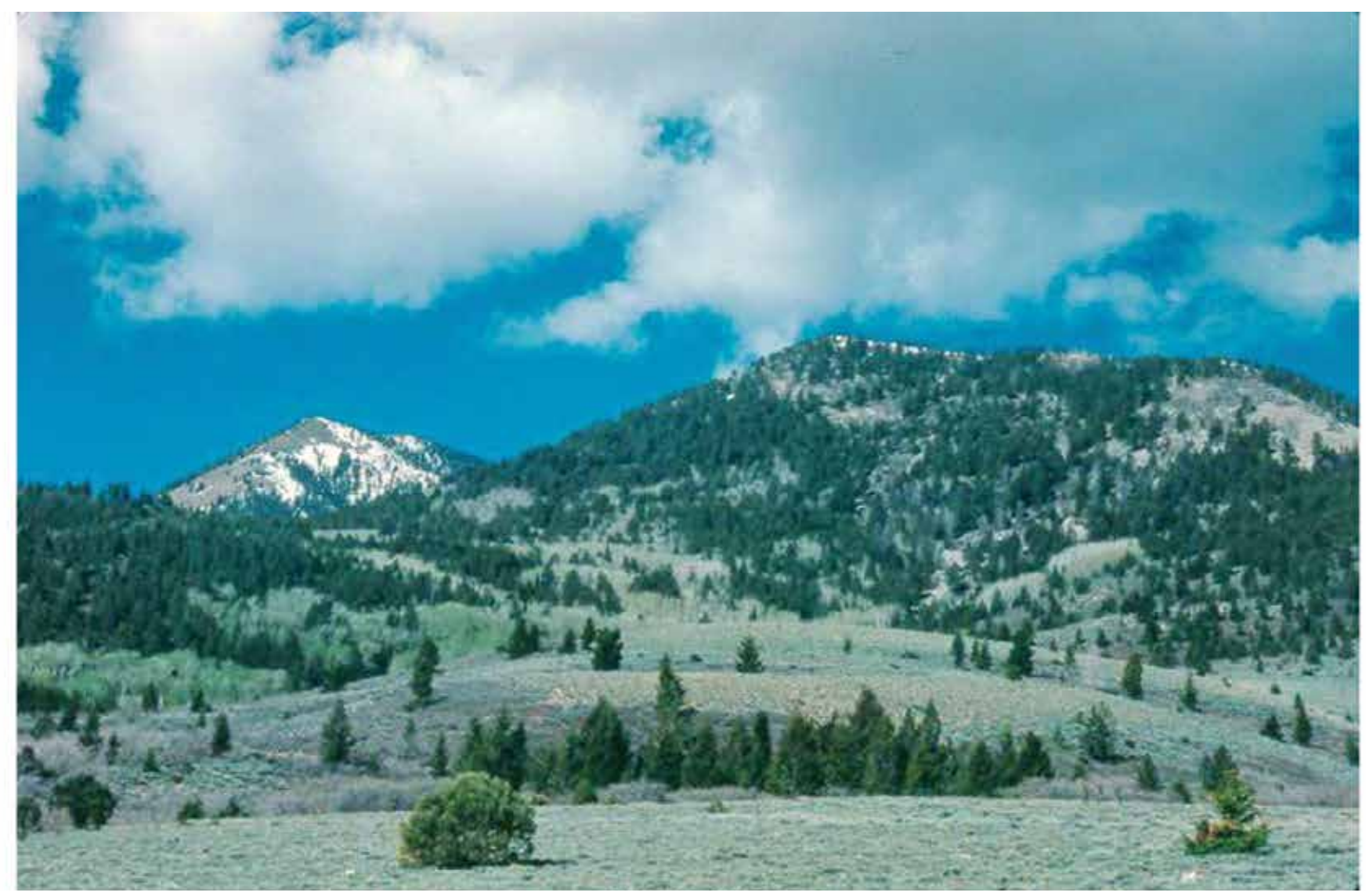

HM-87, 1985

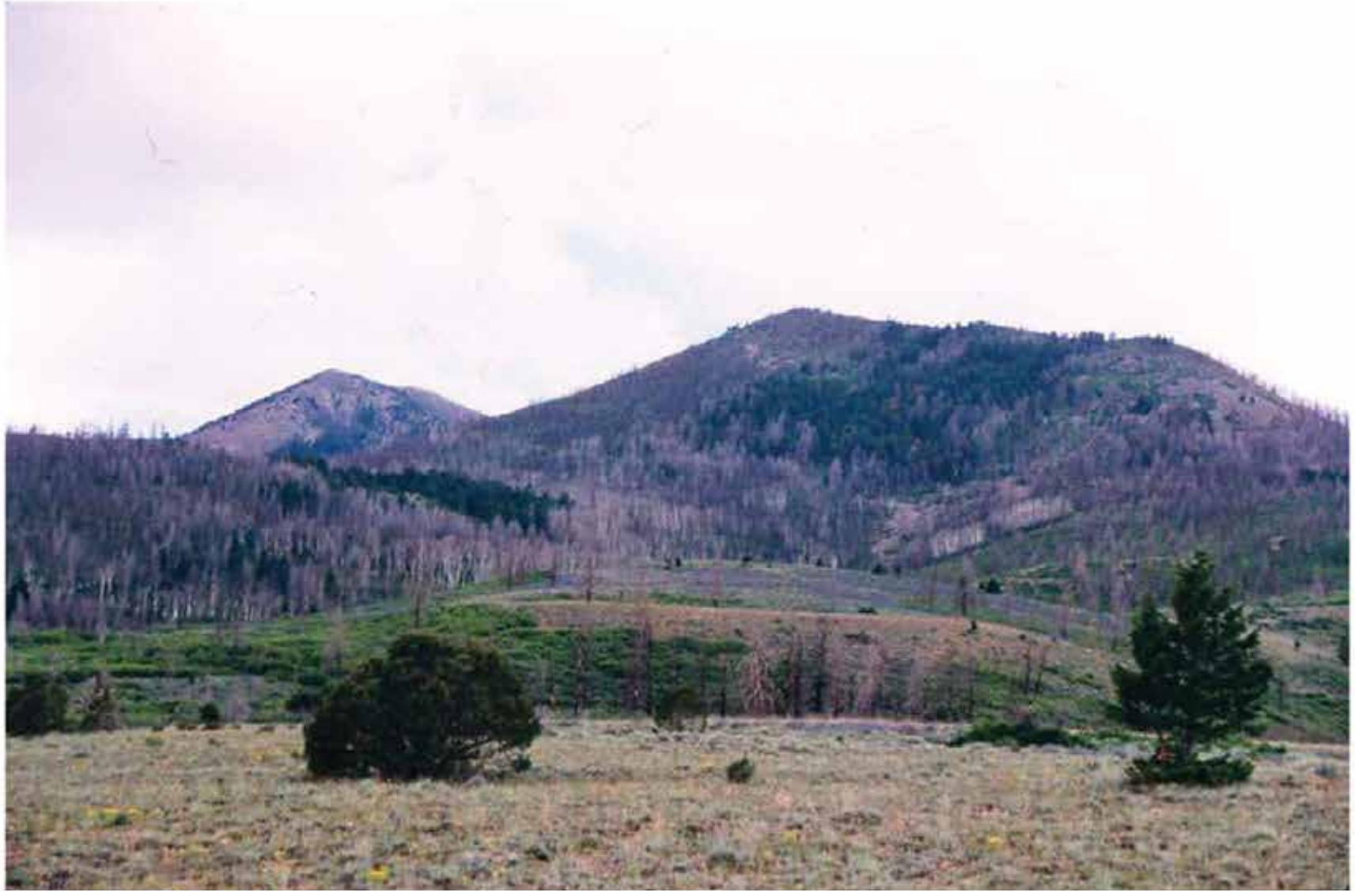




\section{Plate HM-88}

\section{Ragged Mountain}

$1937 \because 2010$

Viewed north across Slate Creek to Ragged Mountain, from northwest of Gibbons Springs on the northeast slopes of Mount Pennell.

Pinyon and juniper appear to have increased except in the foreground and on the far left, areas that were both burned by the high-intensity Bulldog Fire in 2003. Pinyon and juniper have not increased on the dry, south-facing, rocky slopes of Ragged Mountain.

Original photograph taken by Charles B. Hunt (Number 625) in July 1937; retake made by Charles E. Kay on July 8, 2010 (Photo No. 6045-27). Section 36, Range 10 East, Township 32 South; UTM 520724E, 4204159N; elevation 8,094 ft. Original image held by the U.S. Geological Survey Photographic Library, Denver, CO. 


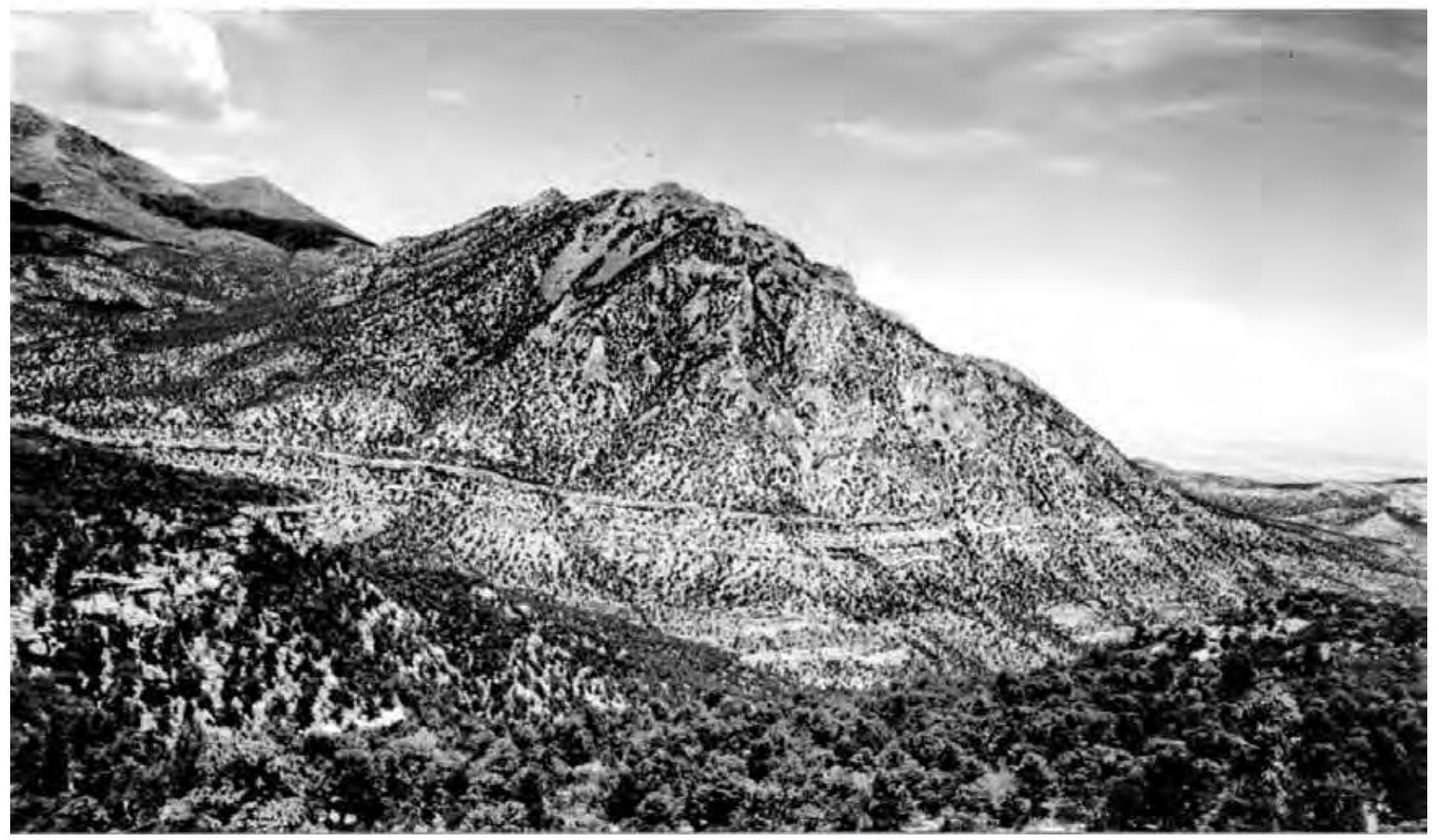

HM-88, 1937

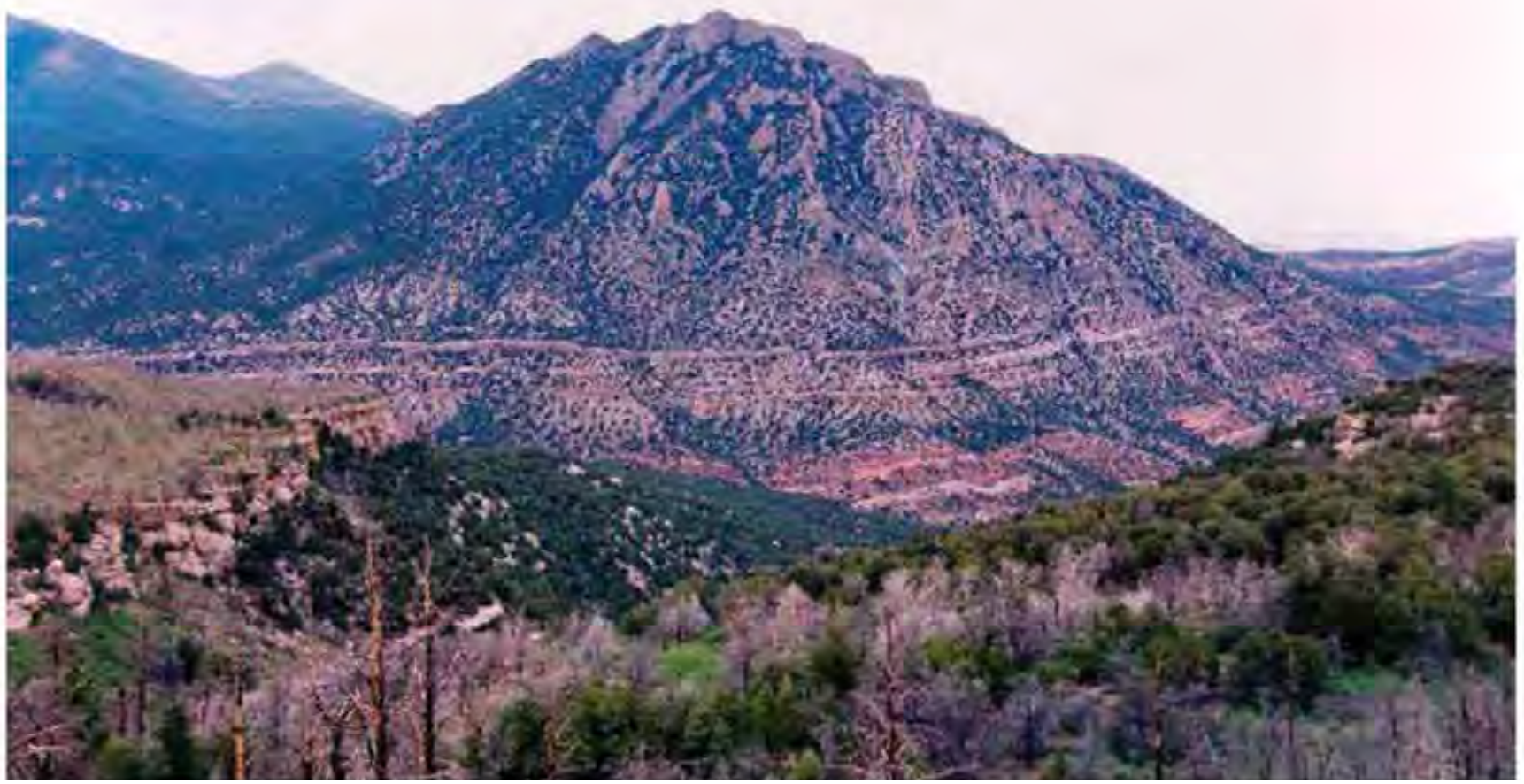




\section{Plate HM-89}

\section{Mount Pennell}

$1937 \because 2010$

Viewed east to the western slopes of Mount Pennell. This part of Mount Pennell was not burned by the 2003

Bulldog Fire. Pinyon and juniper now block the original camera station, so the retake was made from the nearest open area, which is below where the road forks. One fork goes east toward Hancock Spring; the other goes south into the head of Pipe Spring Canyon.

In the absence of fire, woody vegetation has increased, including pinyon, juniper, oak brush, Douglas-fir, spruce, and ponderosa pine. Black sage, mountain big sagebrush, needle and thread, squirreltail, and Sandberg bluegrass may be found in the foreground area. Note how conifers have invaded the open areas. Current tree mortality was caused by the Douglas-fir beetle.

Original photograph taken by Charles B. Hunt (Number 637) in August 1937; retake made by Charles E. Kay on July 8, 2010 (Photo No. 6045-32). Section 33, Range 10 East, Township 32 South; UTM 517120E, 4203641N; elevation 8,707 ft. Original image held by the U.S. Geological Survey Photographic Library, Denver, CO. 


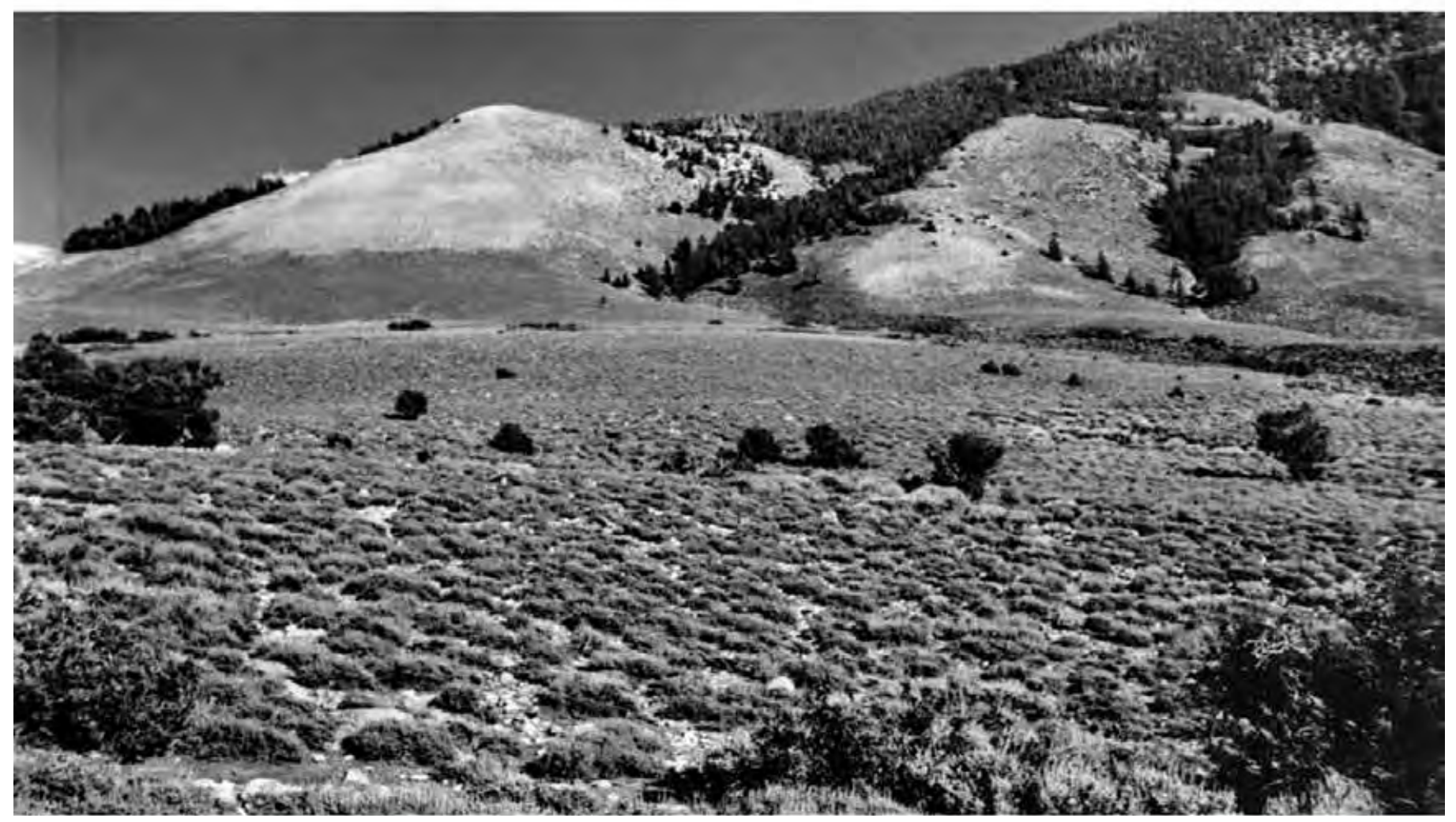

HM-89, 1937

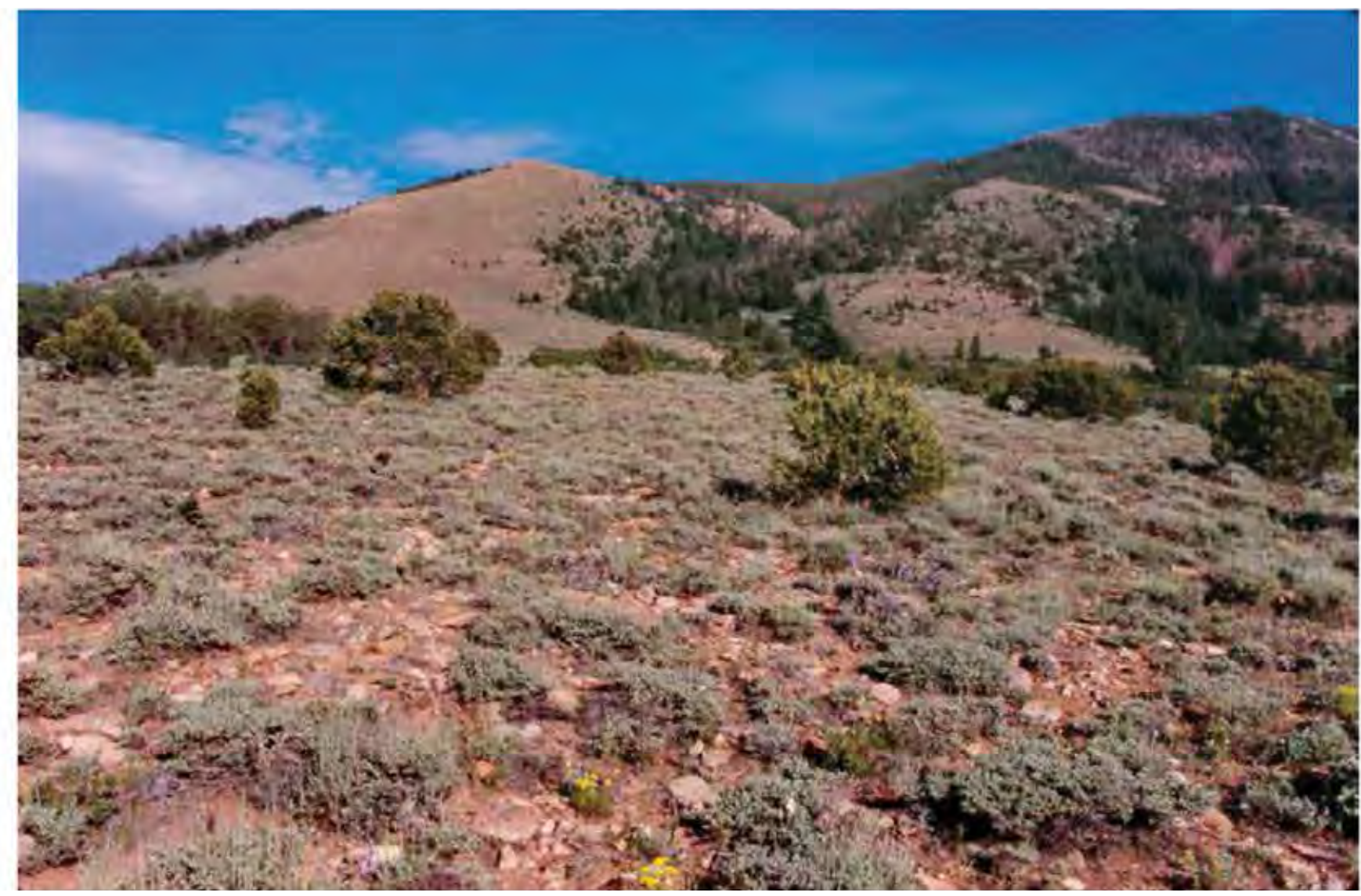

HM-89, 2010 


\section{Plate HM-91}

\section{The HorN}

$1938 \div 2010$

Viewed west to The Horn on the north side of Mount Pennell.

The tall shrubs in the foreground of the 1938 image are oak brush, beyond which is a scattering of pinyon-juniper. The trees immediately above and on the cliff are ponderosa pine. In 2003 the area was swept by the Bulldog Firea high-intensity crown fire that burned nearly 32,000 acres in a matter of days (Bureau of Land Management 2003). Based on the standing dead materials in the retake, it is clear that pinyon and juniper invaded the site between 1938 and when the area was overrun by wildfire. Oak brush has resprouted, but it will be a long time before ponderosa pine becomes reestablished.

Original photograph taken by Charles B. Hunt (Number 821) in September 1938; retake made by Charles E. Kay on July 9, 2010 (Photo No. 6048-10A). Section 27, Range 10 East, Township 32 South; UTM 518716E, 4205369N; elevation 7,912 ft. Original image held by the U.S. Geological Survey Photographic Library, Denver, CO. 


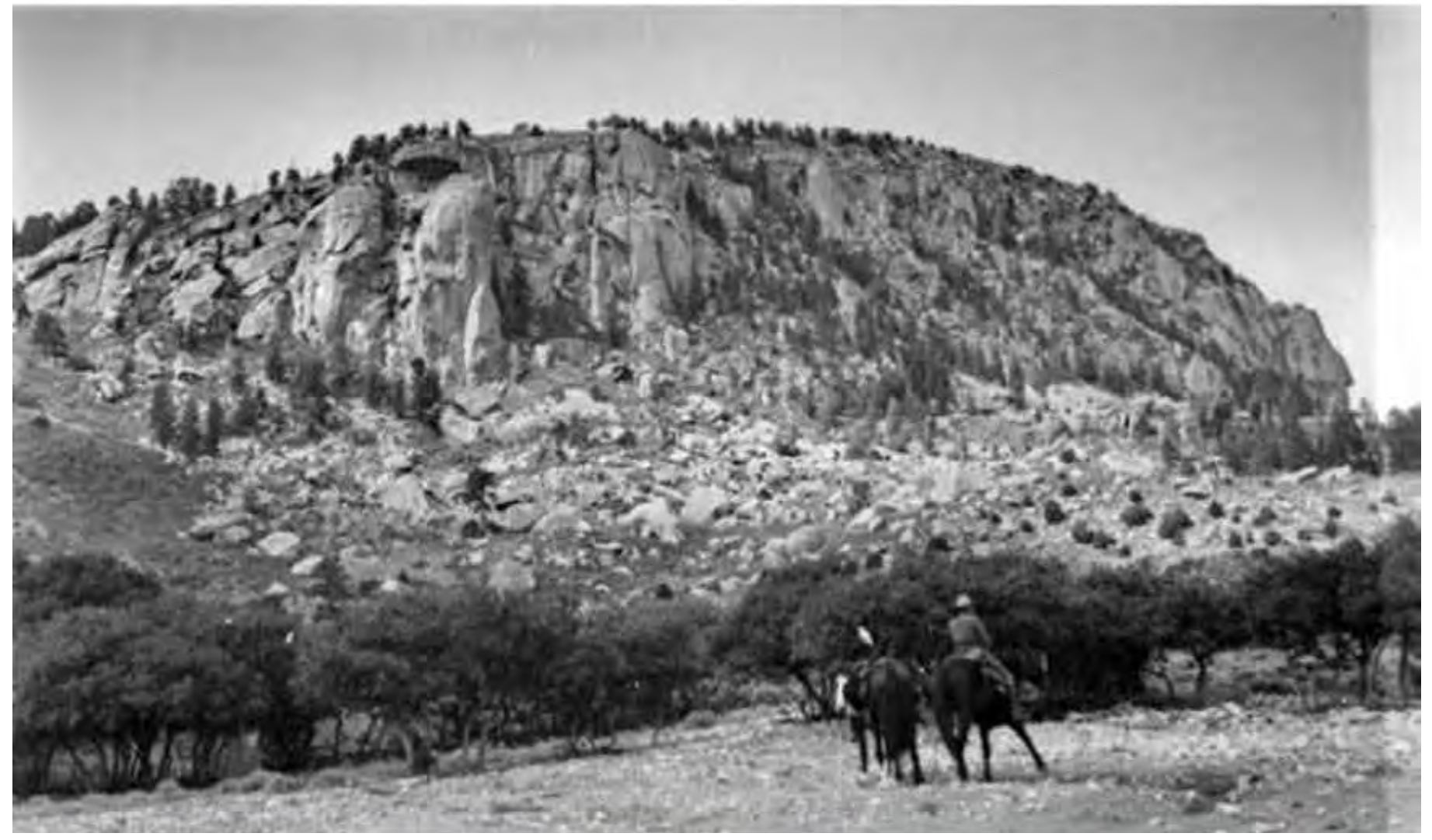

HM-91, 1938

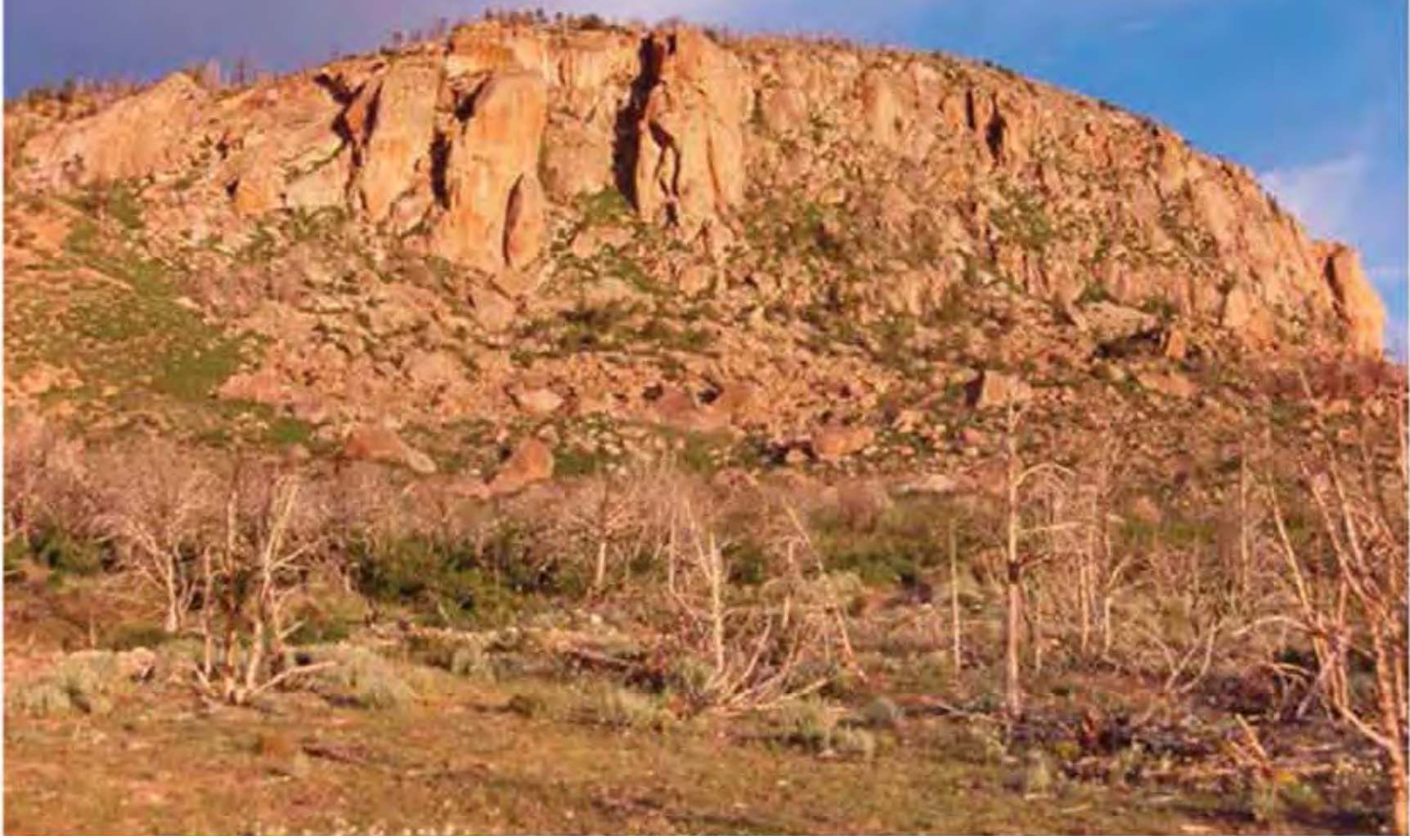




\section{Plates HM-93 and HM-94}

\section{Mount Ellen}

$1937 \because 2010$

Viewed north-northeast across the head of the North Fork of Bullfrog Creek to South Summit Ridge on Mount Ellen. The Horn is on the far right. Plates HM-93 and HM-94 form a panorama. The camera station for these photo sets is on a ridge south of Horn Hole Spring.

Note how open the foreground to midground area was in 1937. Sagebrush and grasses were common, with scattered oak brush and only a handful of pinyon-juniper. Just beyond the open areas was a stringer of ponderosa pine descending from The Horn. Pennellen Pass and the area to the west (left), however, were covered with a dense growth of pinyon-juniper.

Pinyon, juniper, and Douglas-fir have increased near the camera station, as has birchleaf mountain mahogany. Pinyon-juniper has also expanded up-slope on Mount Ellen. Oak brush has spread and thickened. In 2003 the Bulldog Fire burned a small part of the area. As pinyon and juniper have expanded and thickened, forage production for wildlife and livestock has been lost (Kay 2003). Note the new road through Pennell Pass and across the slopes of South Summit Ridge.

Original photographs taken by Charles B. Hunt (Numbers 634 and 635) in August 1937; retakes made by Charles E. Kay on July 9, 2010 (Photo Nos. 6048-15A and 6048-25A). Section 33, Range 10 East, Township 32 South; UTM 516807E, 4203945N; elevation 8,519 ft. Original images held by the U.S. Geological Survey Photographic Library, Denver, CO. Photo mosaic compiled by Doug Page, BLM, Cedar City, UT. 


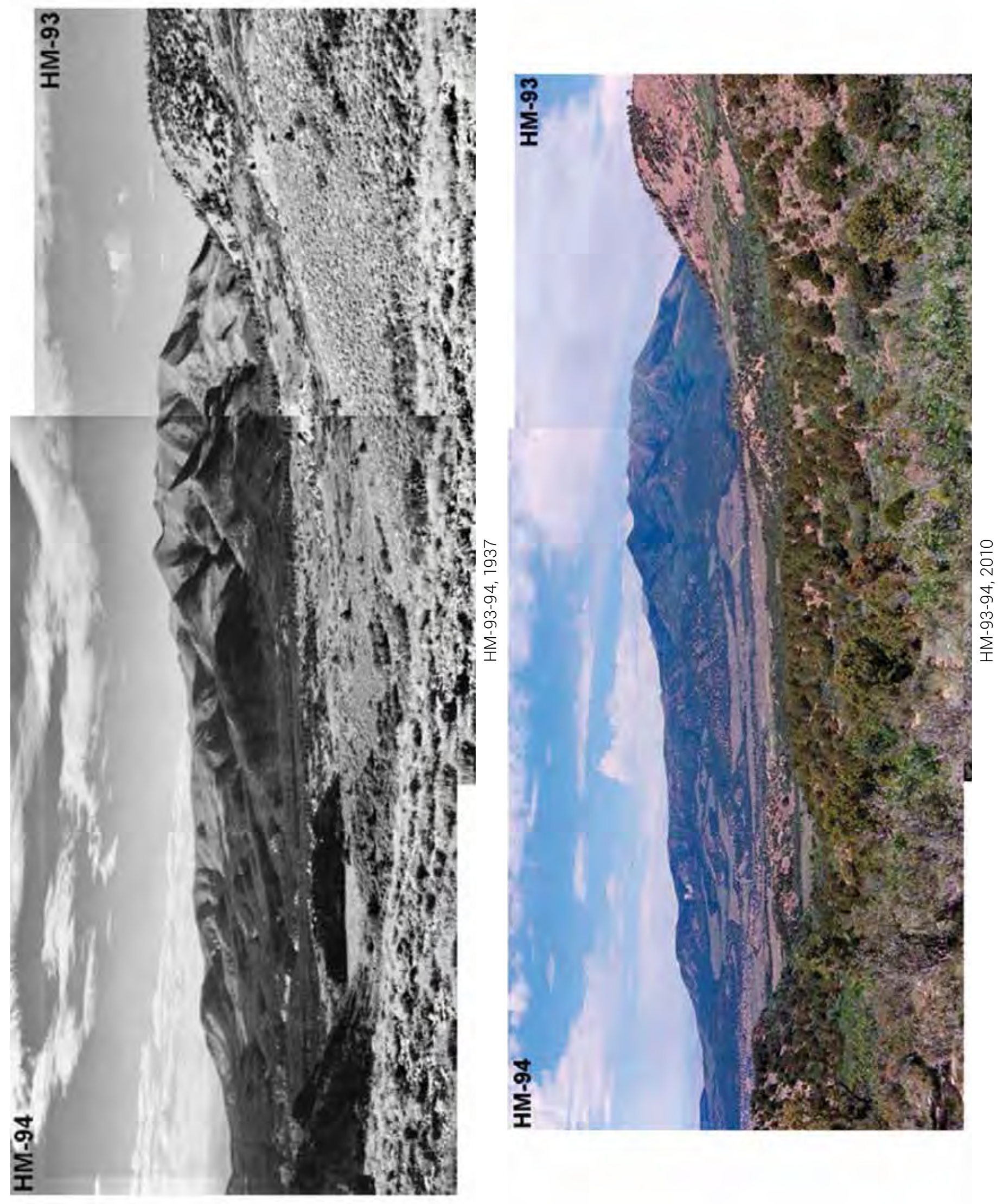




\section{Plate HM-97}

\section{Pennellen Pass}

$1985 \div 2010$

Viewed south to Pennellen Pass, with The Horn and Mount Pennell in the distance.

In 1985 the slope below The Horn was open, with a scattering of pinyon, juniper, and ponderosa pine.

Because the 2003 Bulldog Fire swept from east to west, that entire area now lacks conifers. In the original image, the foreground and the open areas in the midground had just been treated to remove pinyon-juniper.

In the retake, mountain big sagebrush has increased in the foreground area. Pinyon and juniper also increased until the latter were recently hand-felled to maintain the chaining for wildlife, both mule deer and bison, and livestock. The chainings in the midground were not treated, and pinyon-juniper has heavily invaded those areas.

Original photograph taken by Charles E. Kay with a 28mm wide-angle lens on May 23, 1985 (print from a color slide); retake made by Charles E. Kay on July 10, 2010 (Photo No. 6050-7). Section 16, Range 10 East, Township 32 South; UTM 516952E, 4208084N; elevation 7,953 ft. Original image held by Charles E. Kay in his private collection. 


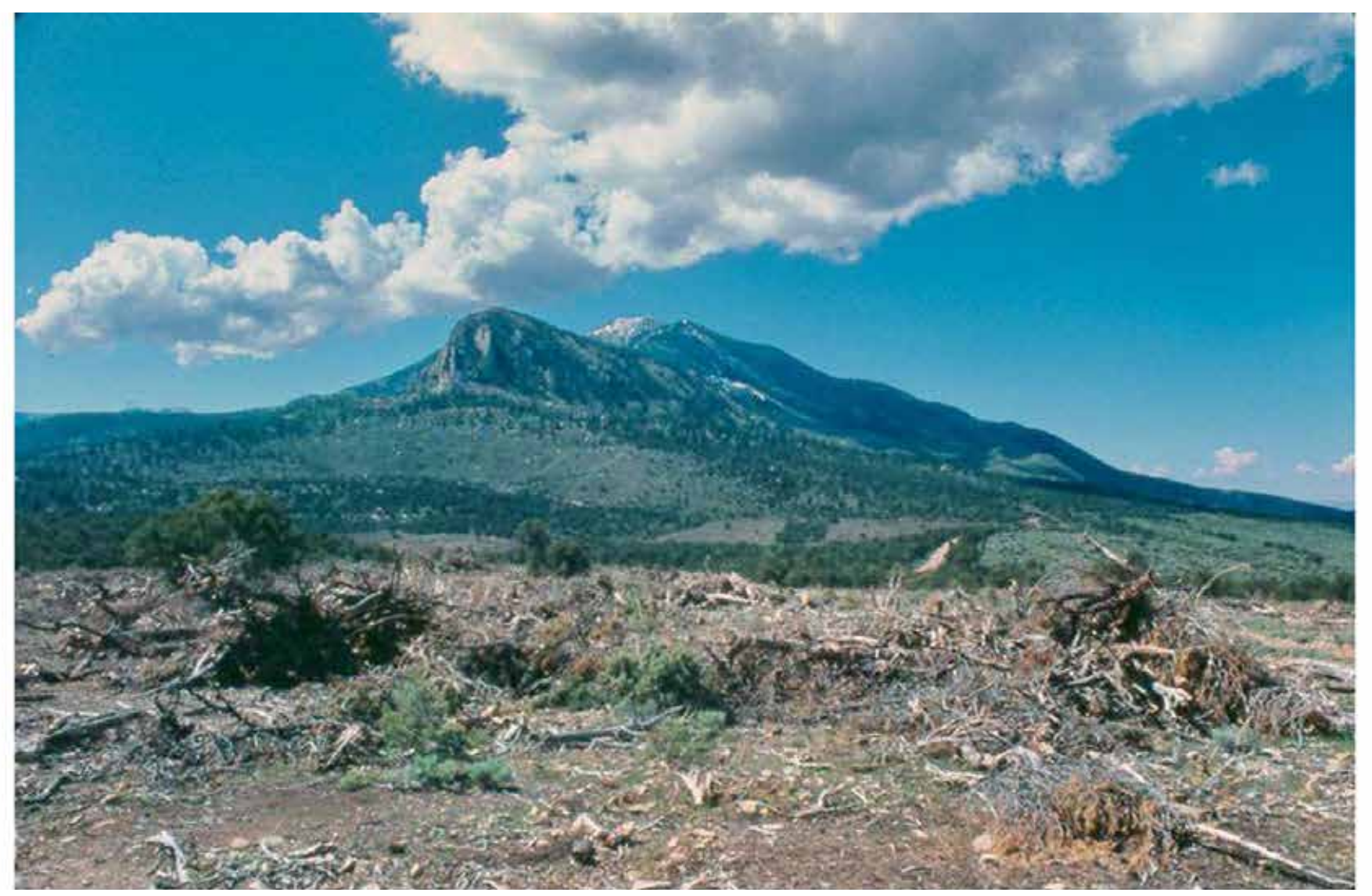

HM-97, 1985

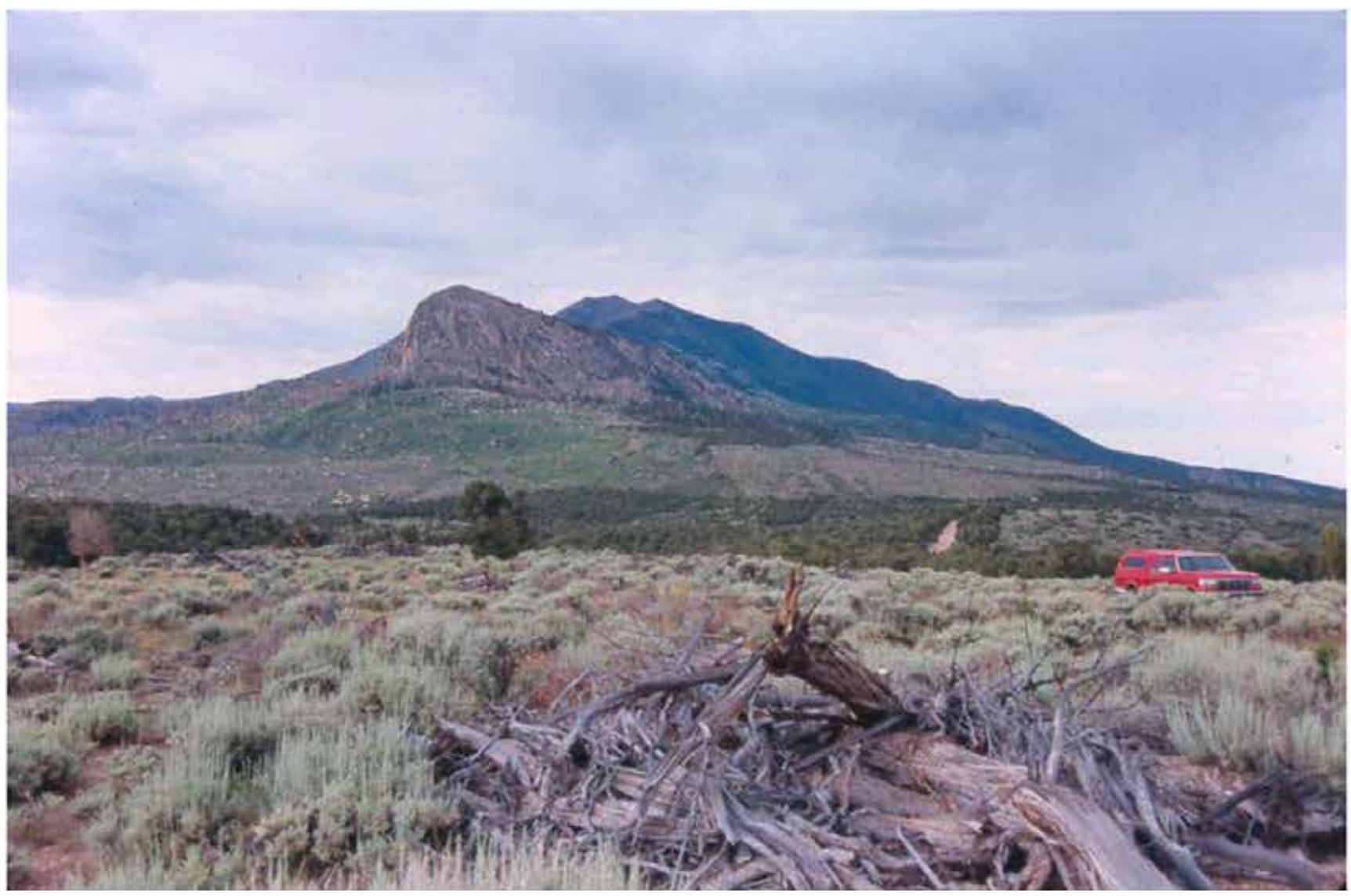

HM-97, 2010 


\section{Plate HM-99}

\section{Slate Creek}

$1937 \because 2010$

Viewed north up Slate Creek to South Summit Ridge on Mount Ellen. Since the original camera station is now

blocked by a dense growth of pinyon-juniper, the retake was made from the only open area available, the main road that runs from Pennellen Pass to Copper Ridge.

Note how open and parklike the area was in 1937. All that has changed. Pinyon, juniper, oak brush, limber pine, ponderosa pine, Douglas-fir, spruce, Utah serviceberry, and birchleaf mountain mahogany have all increased. In the past, the open nature of the vegetation would not have allowed large-scale, high-intensity crown fires to occur. As forest fuels have increased, however, the stage has been set for extreme fire behavior, such as occurred in 2003 on both the Bulldog and Lonesome Beaver fires (Bureau of Land Management 2003). The aspen along Slate Creek in the 1937 image is still present.

Original photograph taken by Charles B. Hunt (Number 564) in May 1937; retake made by Charles E. Kay on July 10, 2010 (Photo No. 6050-10). Section 10, Range 10 East, Township 32 South; UTM 518352E, 4209962N; elevation 8,573 ft. Original image held by the U.S. Geological Survey Photographic Library, Denver, CO. 


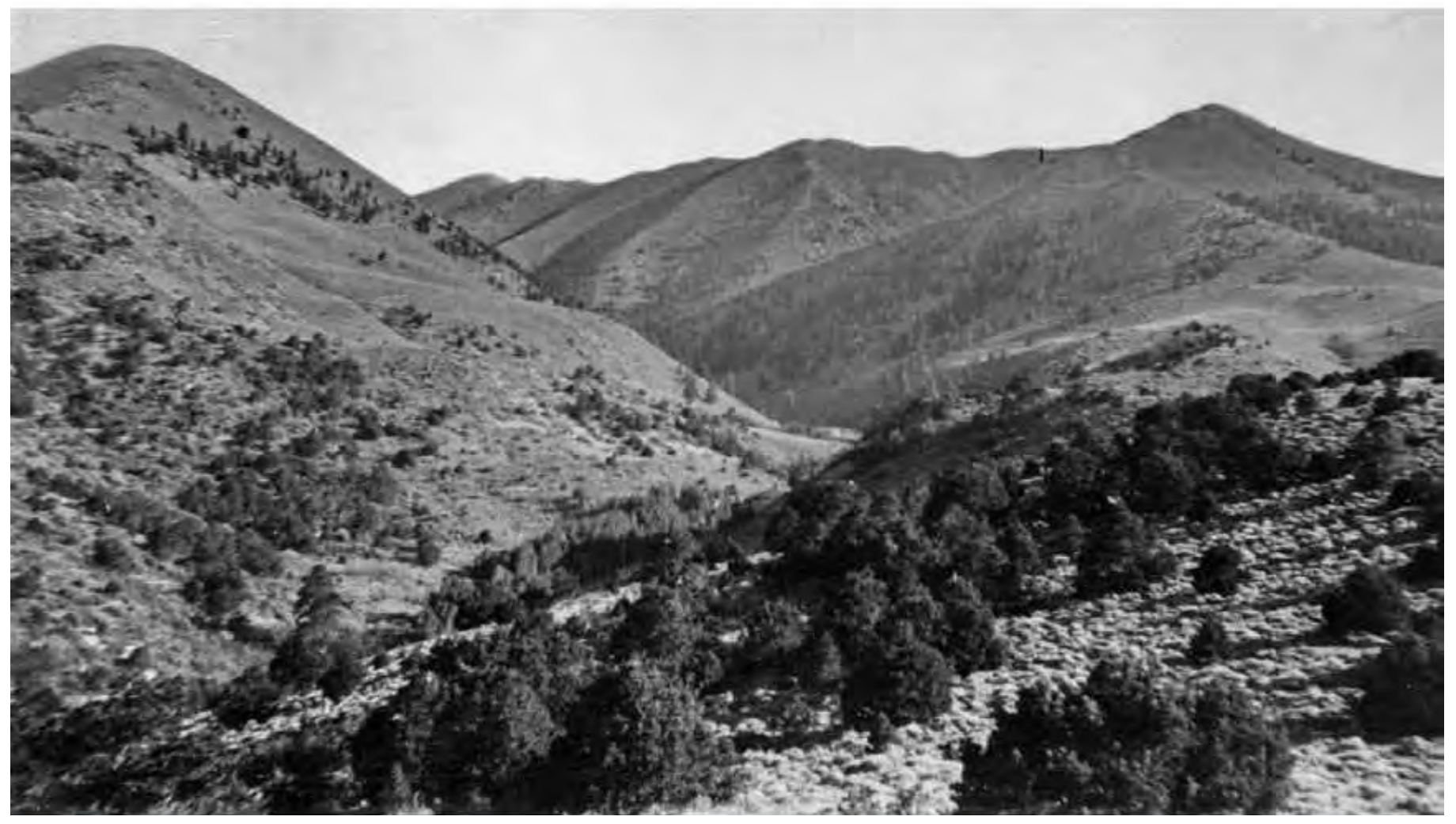

HM-99, 1937

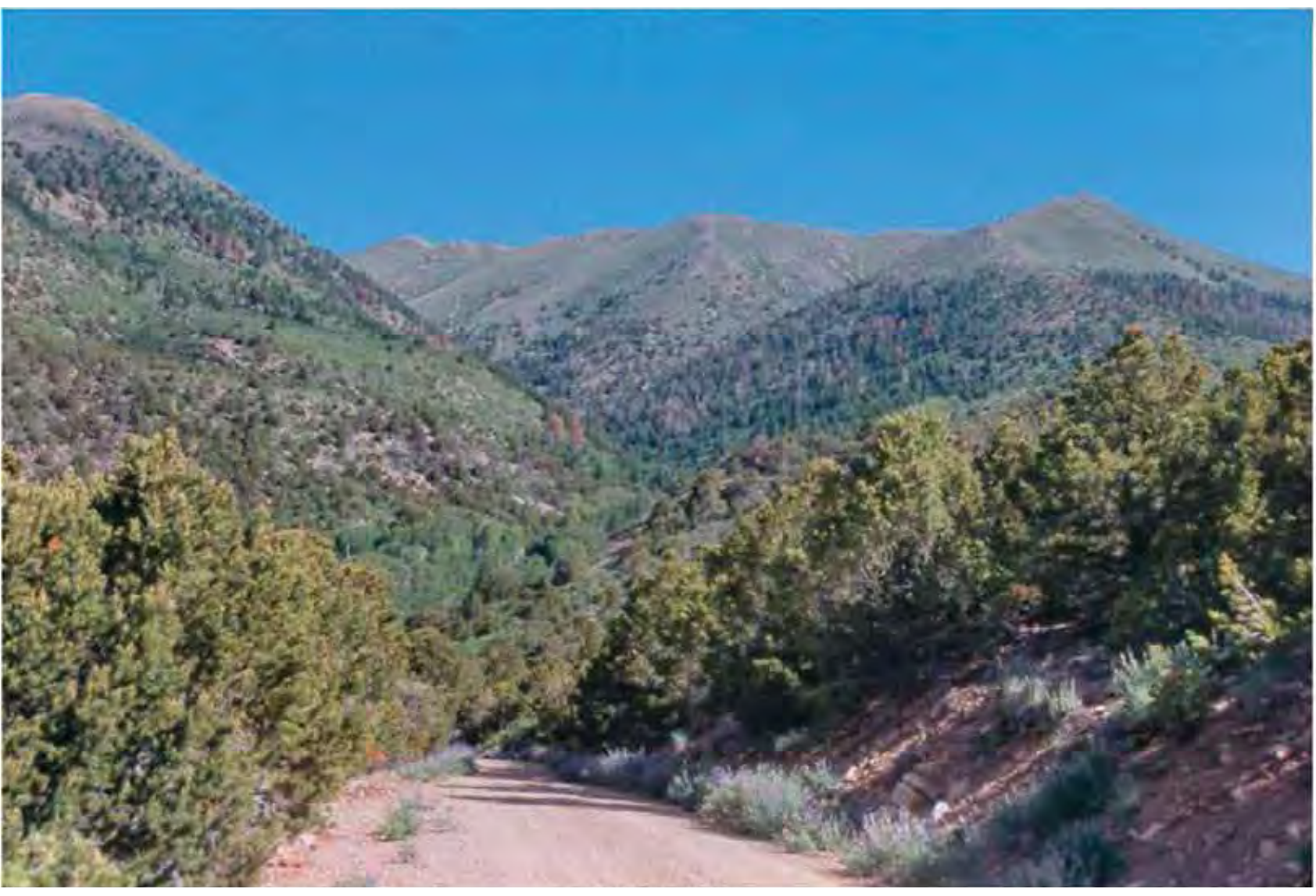

HM-99, 2010 


\section{Plate HM-100}

\section{Ragged Mountain}

$1915: 2010$

Viewed south-southeast to Ragged Mountain from Copper Ridge. In the distance, Mount Pennell is on the right; Mount Hillers is on the left. Although the original image is slightly out of focus, this is still a highly instructive photo set.

In 1915 the area, including Ragged Mountain, was open and parklike. The dark shrubs in the 1915 photo are oak brush. At that time there was only a scattering of pinyon, juniper, and ponderosa pine. Today, a dense growth of pinyon-juniper covers much of the area, and oak brush, Utah serviceberry, birchleaf mountain mahogany, and ponderosa pine have increased. As forest fuels have increased, so has the probability that the area will be overrun by a high-intensity crown fire.

Original photograph taken by David Rust in 1915; retake made by Charles E. Kay on July 10, 2010 (Photo No. 6050-29). Section 2, Range 10 East, Township 32 South; UTM 520168E, 4211405N; elevation 9,050 ft. Original image (Box 1, Folder-Fraser second trip, Number 8-9) held in the David Rust Collection by the LDS Church Archives, Salt Lake City, UT. 


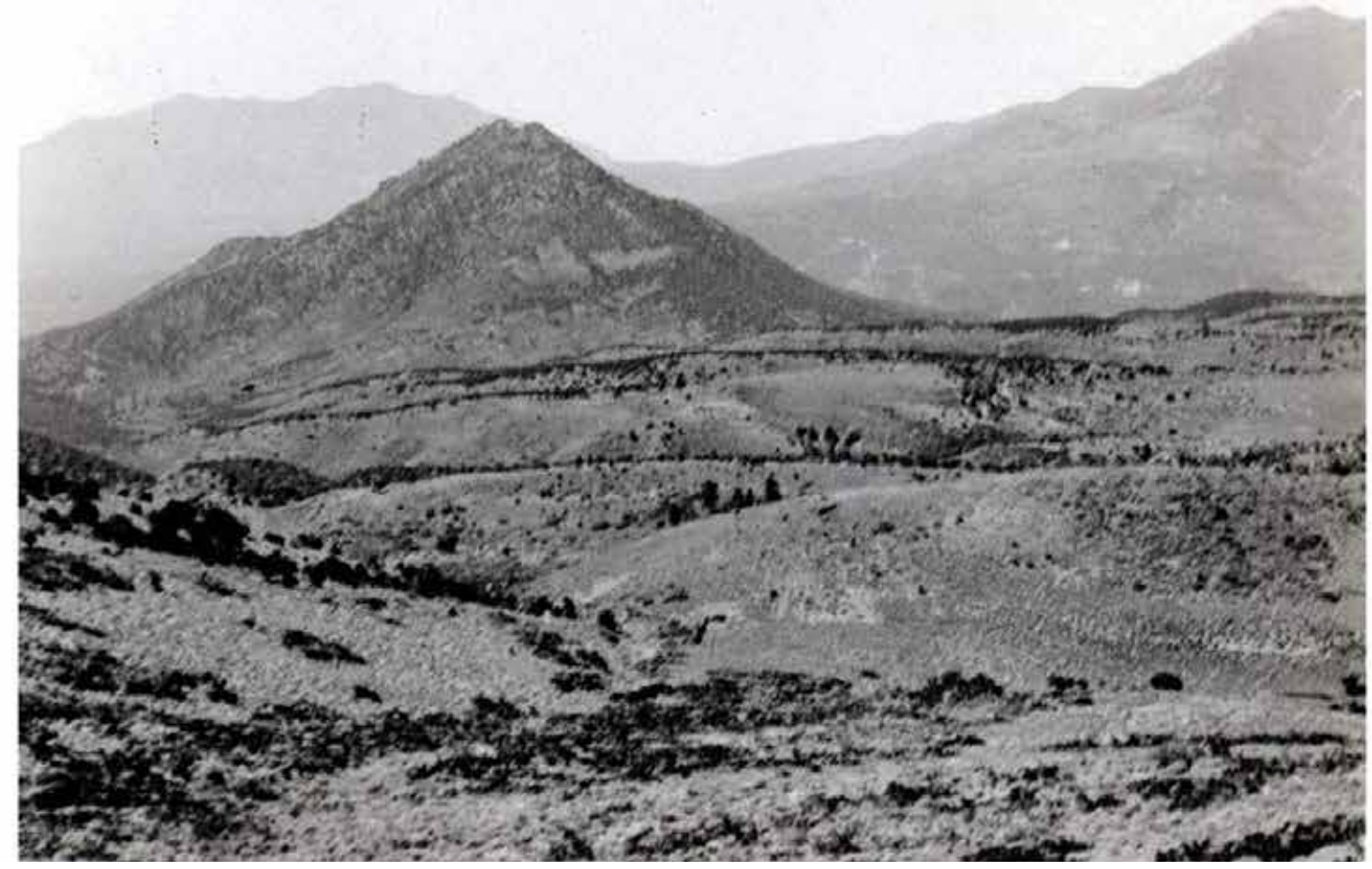

HM-100, 1915

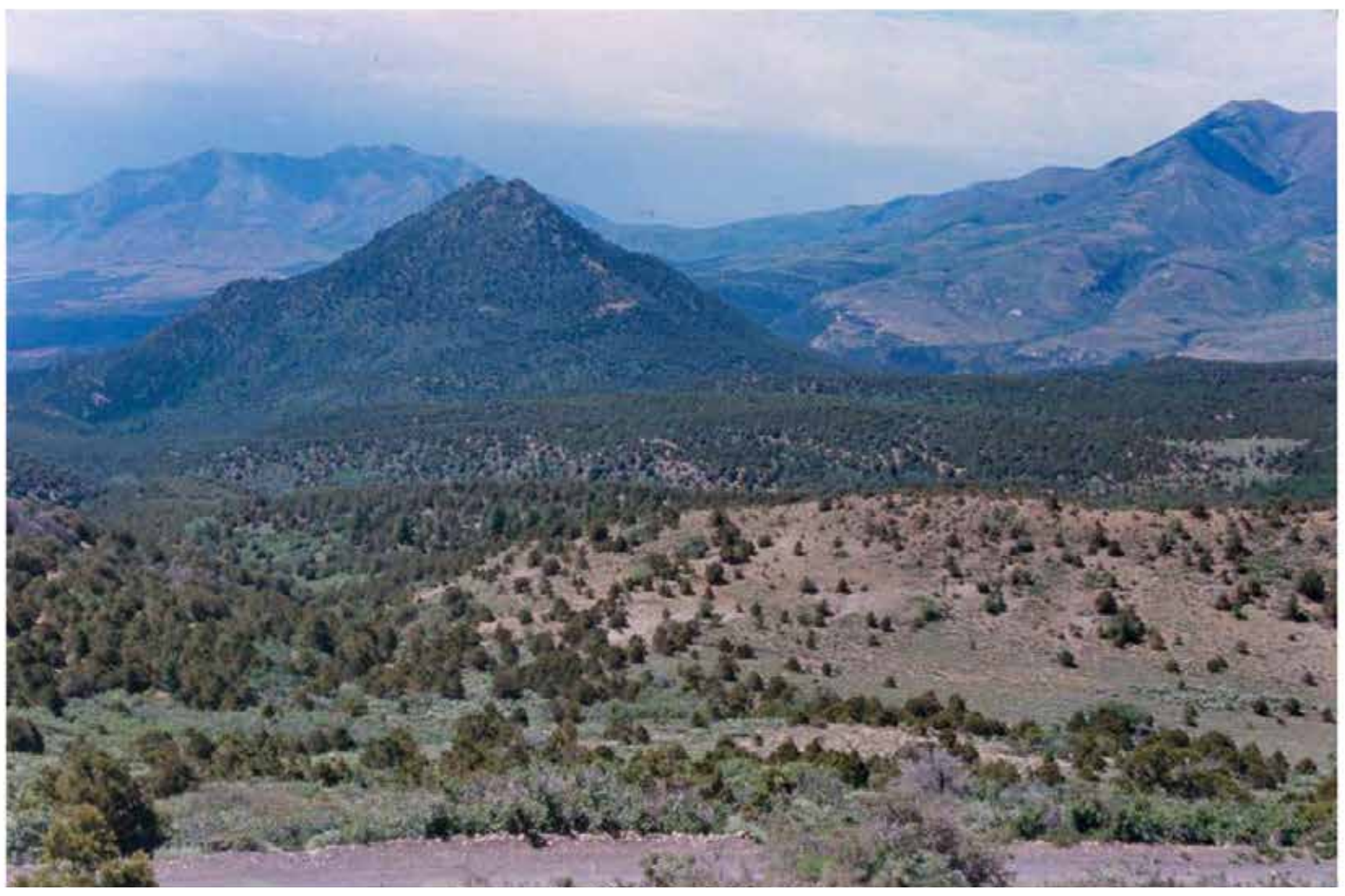

HM-100, 2010 


\section{Plate HM-106}

Copper Basin Spring

$1937 \because 2010$

Viewed northwest to Copper Basin Spring, with Bartons Peak in the distance.

The area in the foreground was very heavily grazed in 1937, and soil erosion was evident. Today, that area is more vegetated, and soil erosion has ceased. Aspen around Copper Basin Spring and in the next drainage to the north, Copper Creek, appears to have increased. As the original image was made in May, aspen had not yet leafed out. Mountain big sagebrush has increased in the foreground area. Elsewhere in the photo pair, oak brush, pinyon, juniper, Douglas-fir, limber pine, Utah serviceberry, and birchleaf mountain mahogany have all increased, as have forest fuels. Cattle and mule deer currently use the spring. Note the road in the retake.

Original photograph taken by Charles B. Hunt (Number 547) in May 1937; retake made by Charles E. Kay on July 11, 2010 (Photo No. 6054-10). Section 1, Range 10 East, Township 32 South; UTM 520534E, 4211972N; elevation 8,734 ft. Original image held in the U.S. Geological Survey Photographic Library, Denver, CO. 

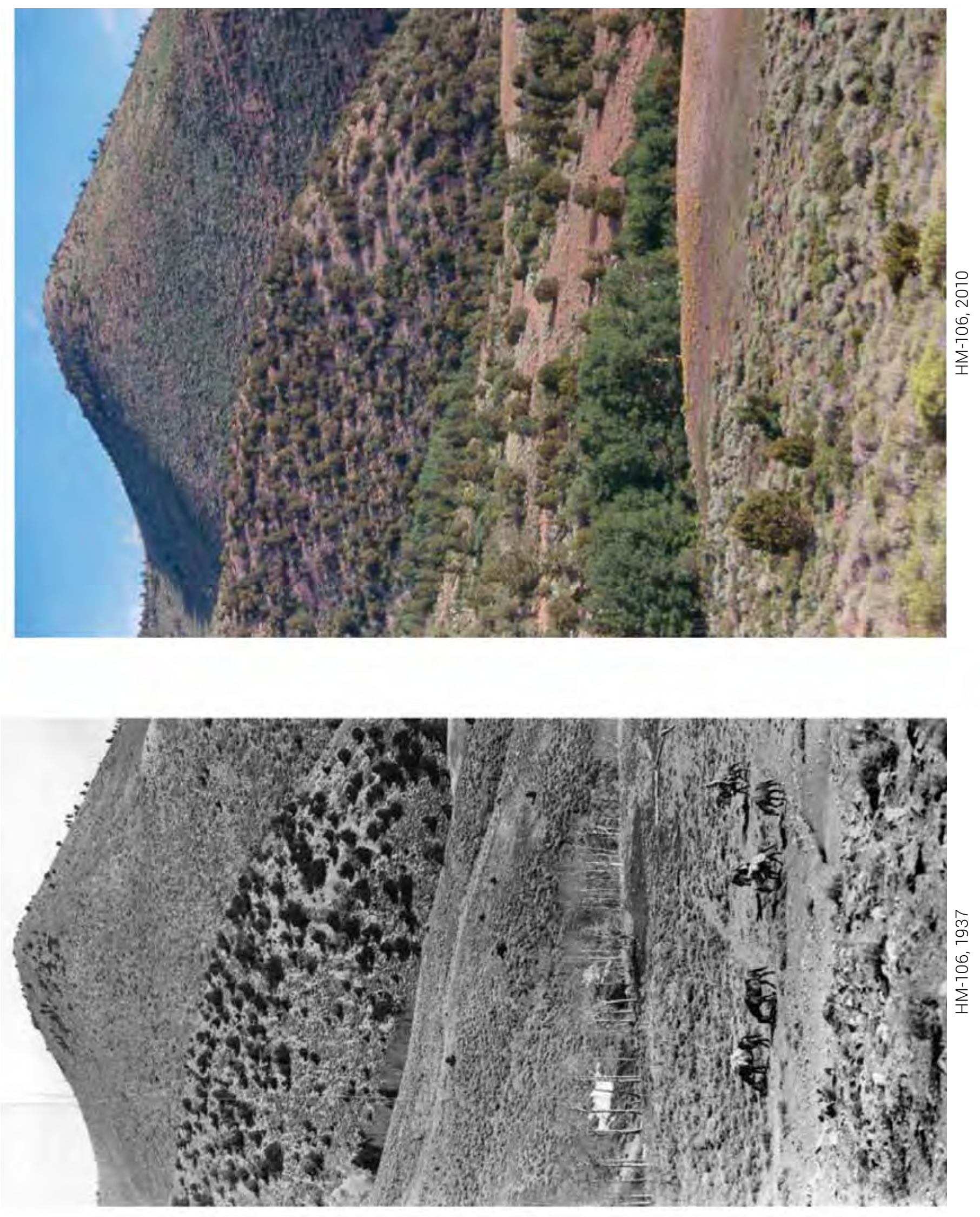


\section{Plates HM-107 and HM-108}

\section{Mount Ellen and North Summit Ridge}

$1937 \because 2010$

Viewed north and west across Bull Creek to Mount Ellen and North Summit Ridge from Wickiup Ridge.

Plates HM-107 and HM-108 form a panorama.

Ponderosa pine, Douglas-fir, spruce, limber pine, pinyon, juniper, and oak brush have all increased, as have forest fuels. Parts of the area burned in the 2003 Lonesome Beaver Fire (Bureau of Land Management 2003). Aspen appears unchanged and has successfully regenerated where it was burned in 2003.

Original photographs taken by Charles B. Hunt (Numbers 545 and 546) in May 1937; retakes made by Charles E. Kay on July 11, 2010 (Photo Nos. 6054-15 and 6054-19). Section 13, Range 10 East, Township 31 South; UTM 520169E, 4217291N; elevation 9,779 ft. Original images held in the U.S. Geological Survey Photographic Library, Denver, CO. Photo mosaic compiled by Doug Page, BLM, Cedar City, UT. 

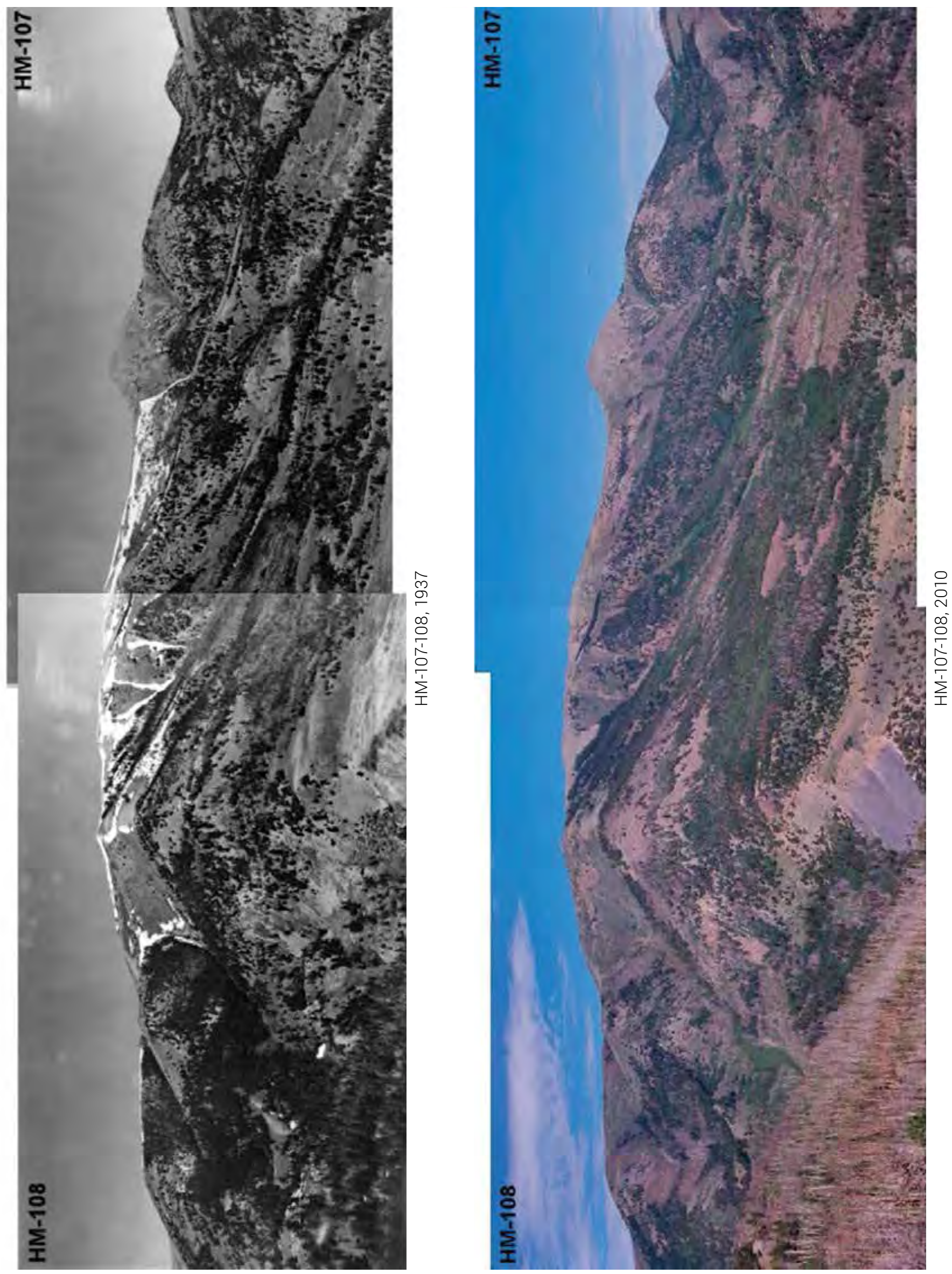


\section{Plate HM-112}

\section{Bull Creek Pass}

$1937 \because 2010$

Viewed south to Bull Creek Pass.

Note the road and parking area in the retake. The spruce forest has thickened. In the very center of the 1937 image are two white tents, which was the U.S. Geological Survey camp. Note the opening in the forest to the right of the tents, which was likely caused by a small, wind-driven crown fire. That area was very heavily eroded in 1937, as was the area below the patch of timber on the right. Except for a couple of gullies below the road, that erosion has stopped. Spruce has been very slow to reforest the opening, so the burn pattern has been visible for at least 100 years.

Original photograph taken by Charles B. Hunt (Number 599) in June 1937; retake made by Charles E. Kay on July 11, 2010 (Photo No. 6057-1). Section 27, Range 10 East, Township 31 South; UTM 517289E, 4215499N; elevation 10,503 ft. Original image held in the U.S. Geological Survey Photographic Library, Denver, CO. 


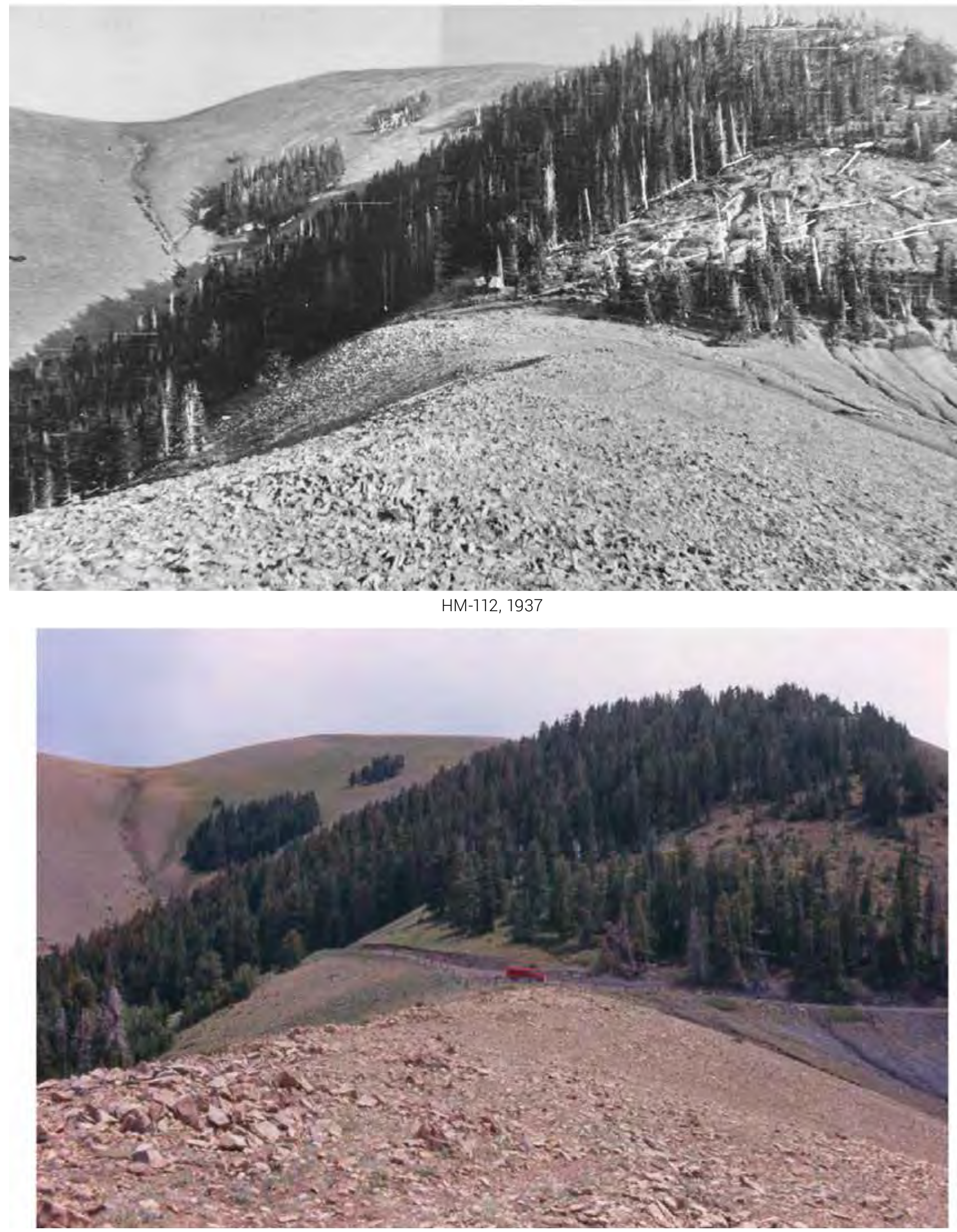

HM-112, 2010 


\section{Plates HM-116 and HM-117}

\section{Durfey Butte}

$1937: 2010$

Viewed south-southeast across the head of South Creek from Durfey Butte. In the distance are Dry Lake Flat, South Creek Ridge, and Mount Pennell.

Note how open and parklike the ponderosa pine forest was in 1937 in contrast with the forest shown in the 2010 photo. Douglas-fir, ponderosa pine, limber pine, pinyon, juniper, oak brush, and Utah serviceberry have all increased. The dead and dying conifers in the 2010 retake are Douglas-fir, killed by the Douglas-fir beetle and overly dense stand conditions. Some aspen clones have increased, while others have been replaced by conifers.

In 1937 the forest would not carry a crown fire, as the trees were too widely spaced. With the observed increase in forest fuels, however, high-intensity crown fires are now possible, as happened on Mount Pennell in 2003 (Bureau of Land Management 2003). As seen in the distance, the eastern portion of Pennell was burned by the 2003 Bulldog Fire, while the western side was not. (See the earlier plates on Mount Pennell for additional details.) Note the roads in the retake and the BLM radio tower on South Creek Ridge.

Original photograph taken by Charles B. Hunt (Number 569) in May 1937; retake made by Charles E. Kay on July 12, 2010 (Photo No. 6057-19). Section 32, Range 10 East, Township 31 South; UTM 515183E, 4213802N; elevation 9,590 ft. The original image is held in the U.S. Geological Survey Photographic Library, Denver, CO. 


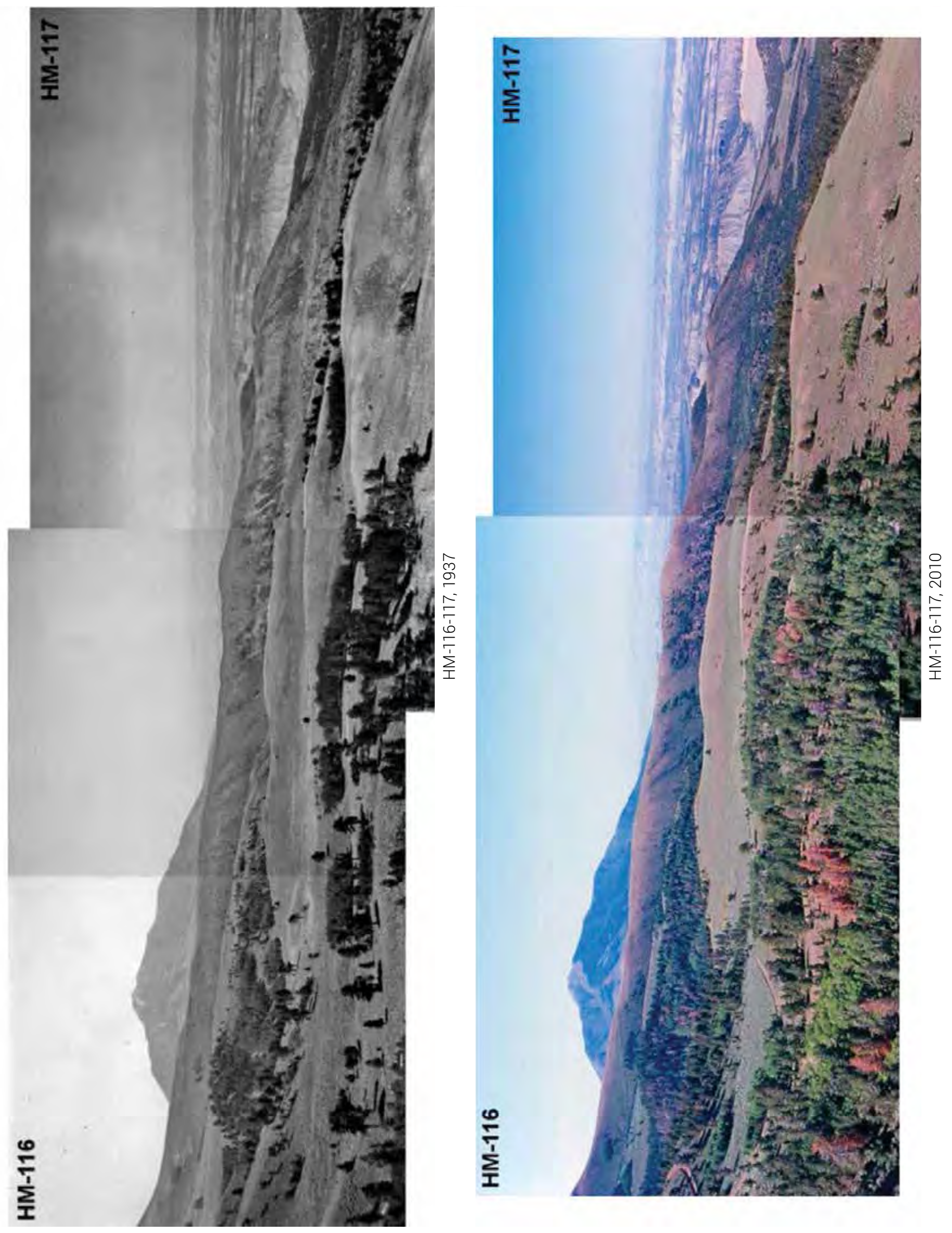




\section{Plate HM-121}

Nasty Flat and Durfey Butte

$1937 \because 2010$

Viewed west to Nasty Flat and Durfey Butte from the western slope of South Summit Ridge. Dugout Creek is on the right; South Creek is to the left. The Waterpocket Fold and Boulder Mountain are in the far distance.

Douglas-fir, ponderosa pine, spruce, limber pine, and pinyon-juniper have all increased, as have forest fuels. The open areas in the retake below and to the west of Nasty Flat are sites where the pinyon-juniper has been treated to improve forage production for wildlife and livestock (Kay 2003). A few aspen stands have increased, but many more have declined or been replaced by conifers. Some aspen clones successfully regenerated in the past, but today those new aspen saplings and trees are being high-lined by mule deer (Kay and Bartos 2000).

Original photograph taken by Charles B. Hunt (Number 577) in June 1937; retake made by Charles E. Kay on July 12, 2010 (Photo No. 6059-7). Section 34, Range 10 East, Township 31 South; UTM 517254E, 4213339N; elevation 10,467 ft. The original image is held in the U.S. Geological Survey Photographic Library, Denver, CO. 


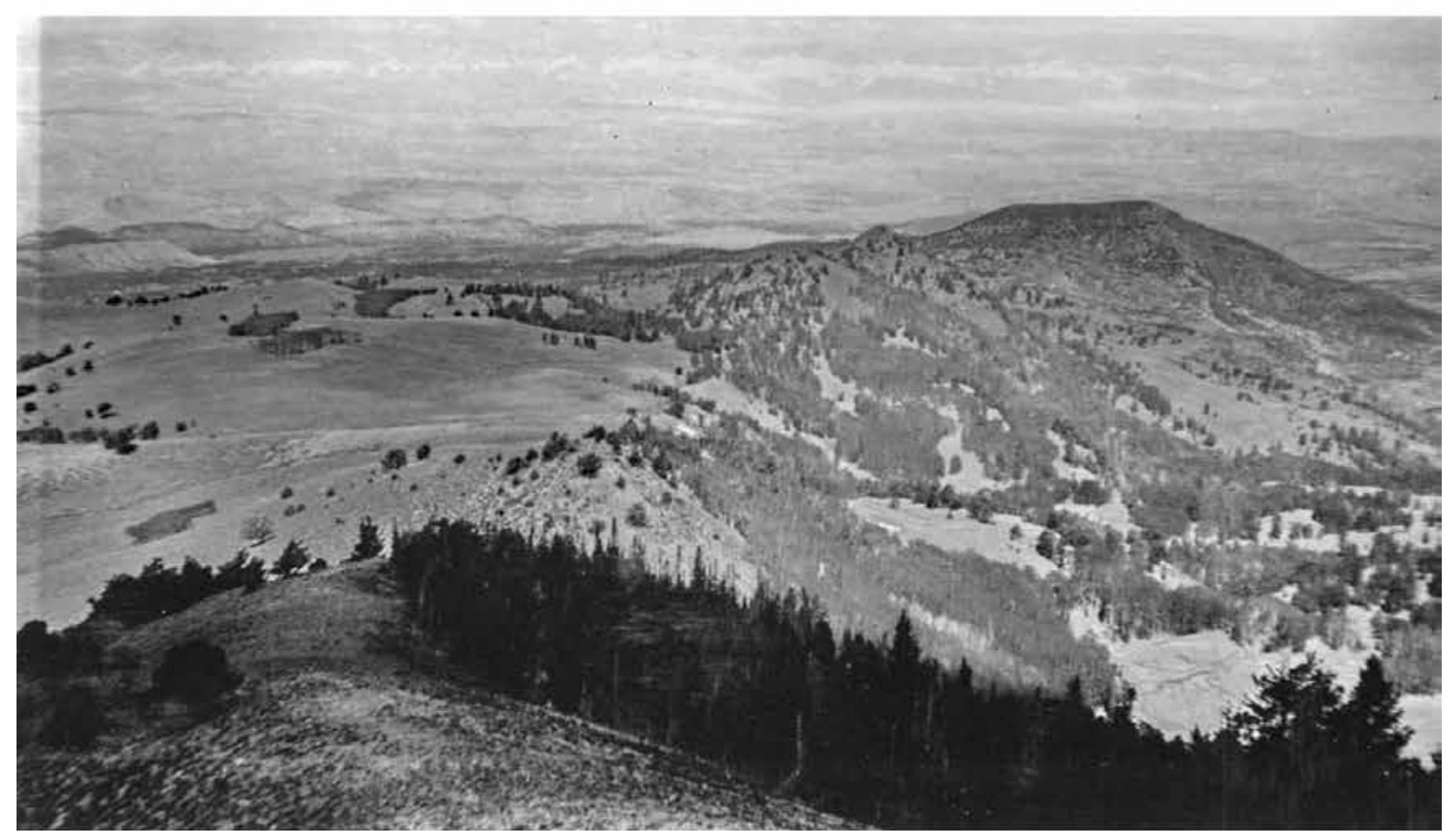

HM-121, 1937

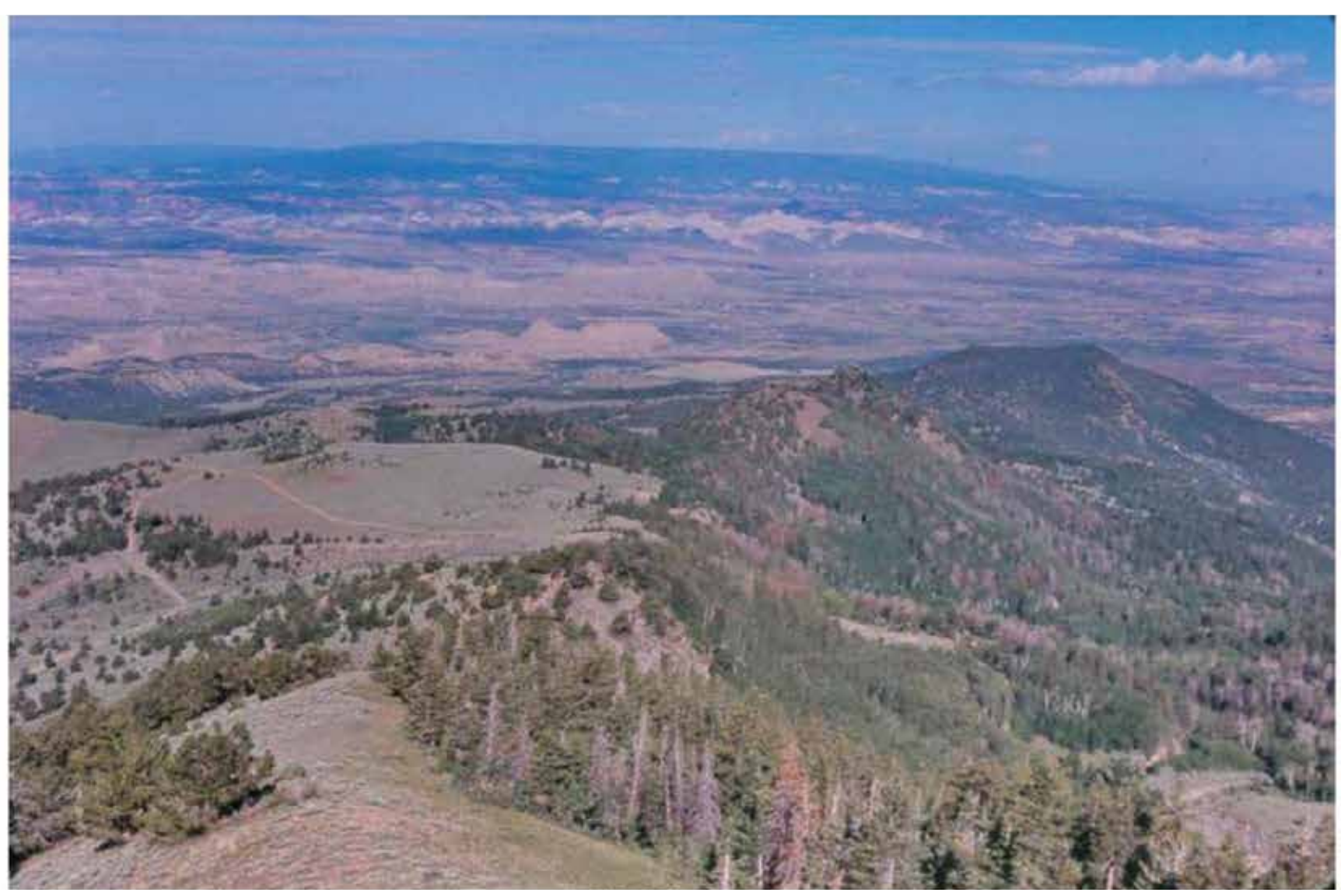

HM-121, 2010 


\section{Plates HM-122 and HM-123}

\section{South Creek}

$1937 \because 2010$

Viewed north-northwest across South Creek. In the distance are Dry Lake Flat (left-center), Durfey Butte

(left-center), Nasty Flat (center), North Summit Ridge (right-center skyline), and South Summit Ridge

(right skyline). The camera station is on the upper part of South Creek Ridge. Plates HM-122 and HM-123

form a panorama.

Douglas-fir, limber pine, ponderosa pine, spruce, and pinyon-juniper have all increased, as have forest fuels. In general, aspen has declined, especially where it has been replaced by conifers. Upper treeline appears unchanged.

Original photographs taken by Charles B. Hunt (Numbers 572 and 573) in June 1937; retakes made by Charles E. Kay on July 12, 2010 (Photo Nos. 6059-16 and 6059-14). Section 4, Range 10 East, Township 32 South; UTM 516488E, 4211474N; elevation 9,978 ft. The original image is held in the U.S. Geological Survey Photographic Library, Denver, CO. Photo mosaic provided by Doug Page, BLM, Cedar City, UT. 

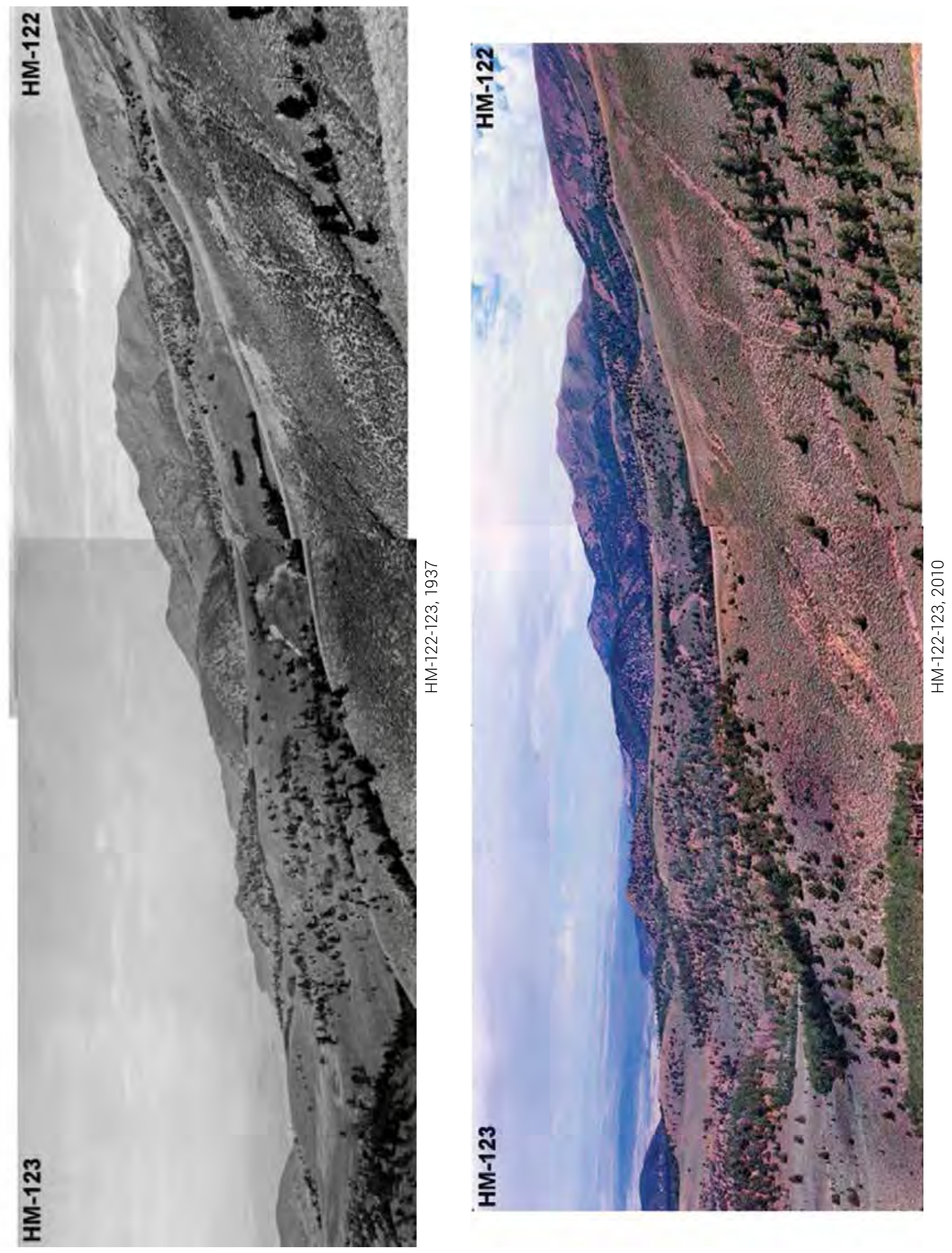


\section{Plate HM-124}

\section{MaClellan Spring}

$1915 \div 2010 \AA 2012$

Viewed northeast from just above McClellan Spring. In the distance are Corral Point and North Summit Ridge. The camera station for this photo point is in the BLM McMillan Spring Campground, approximately 100 feet southwest of campsite number eight.

The first retake (2010) was made from the original camera station. To help prevent wildfires, the BLM reduced forest fuels by pruning off the lower branches of conifers.

The 2012 retake was made after the area was treated under a BLM stewardship contract in which the BLM removed most of the small pinyon and juniper trees from around the ponderosa pines. Unlike most areas of the West, the large ponderosa pines in this area have never been logged, because the site is remote with poor access. Most ponderosa pine in-growth has not been eliminated and still blocks much of the original distant view.

The open, parklike character of the pine forest in 1915 resulted from frequent low-intensity surface fires, which were most likely set by native people (Kay 2007). Historically, the trees were few and widely spaced, with an understory of grasses, forbs, and shrubs. Due to the very low level of forest fuels, high-intensity crown fires were impossible, as was extreme fire behavior, even during droughts or high-wind events.

Original photograph made by David Rust ca. 1915; first retake made by Charles E. Kay on July 13, 2010 (Photo No. 6059-29); second retake made by Charles E. Kay on September 15, 2012 (print from a color slide). Section 31, Range 10 East, Township 31 South; UTM 513271E, 4213970N; elevation 8,383 ft. Original image (Box 6, unnumbered negative) held in the David Rust Collection of the LDS Church Archives, Salt Lake City, UT. 


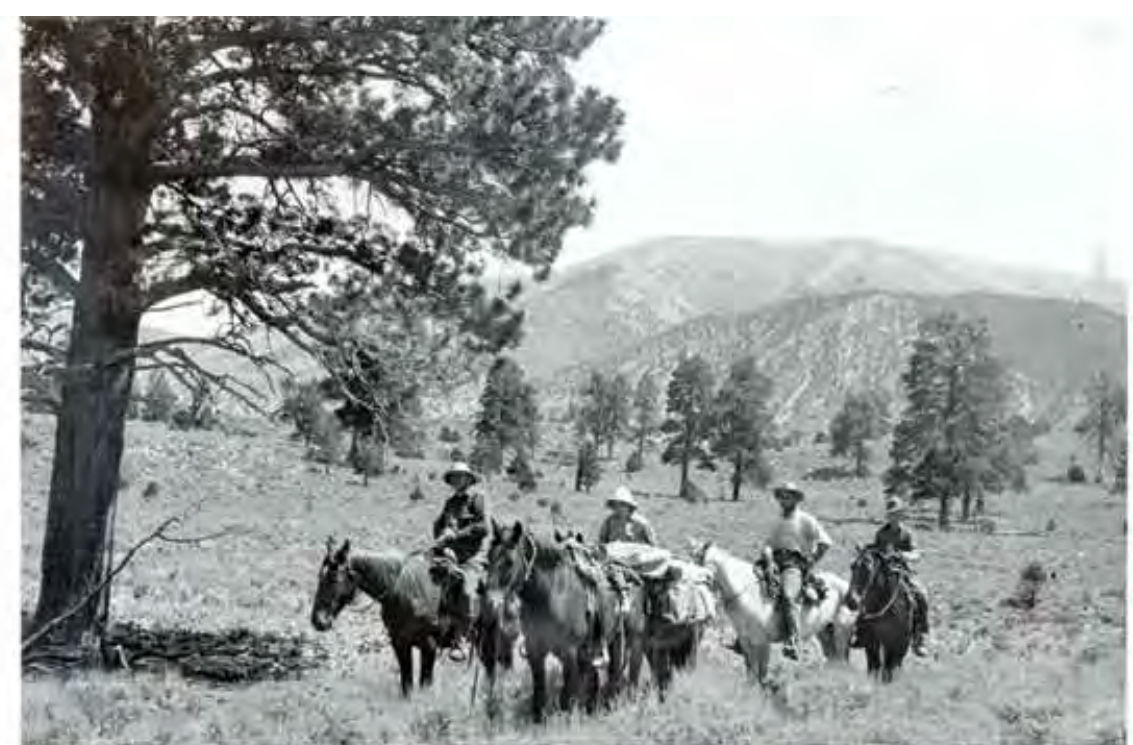

HM-124, 1915

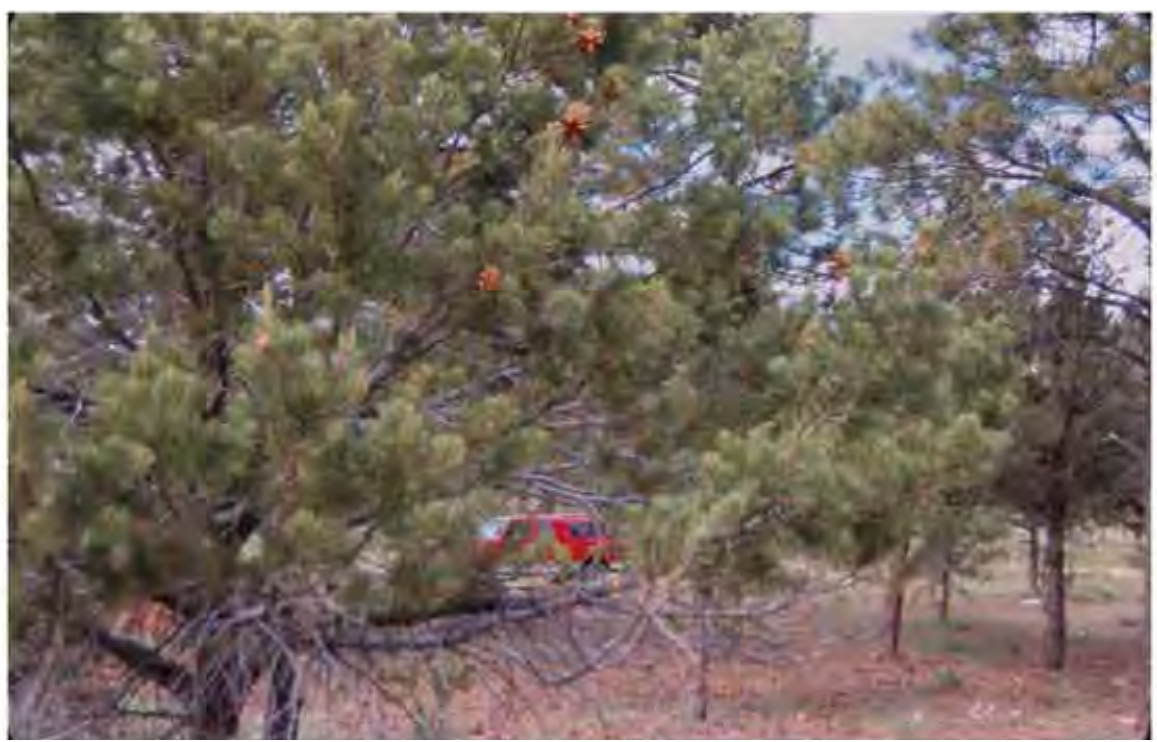

HM-124, 2010

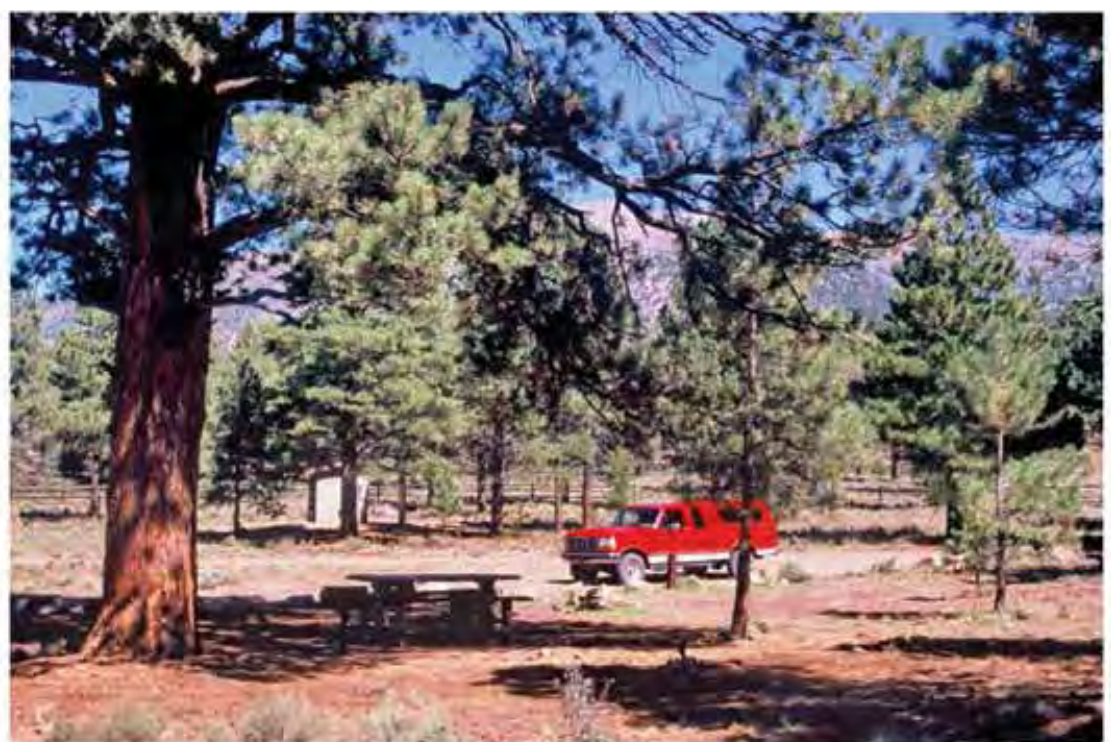

HM-124, 2012 


\section{Plates HM-132 and HM-133}

\section{Mount Ellen Peak}

$1936 \div 2010$

Viewed south-southeast up Birch Creek on the north side of Mount Ellen. The mountain on the far right is

Dry Lakes Peak; Mount Ellen is immediately to the left. Further on the left is Horseshoe Ridge, part of which was burned in the 2003 Lonesome Beaver Fire (Bureau of Land Management 2003). Plates HM-132 and HM-133 form a panorama.

Pinyon and juniper have increased markedly; therefore, most stands would now support a high-density crown fire. Oak brush, Utah serviceberry, and birchleaf mountain mahogany have increased at higher elevations, as have Douglas-fir and spruce. Pricklypear cactus has increased in the foreground area, along with snakeweed, curly grass, and blue grama.

Original photographs taken by Charles B. Hunt (Numbers 449 and 450) in May 1936; retakes made by Charles E. Kay on September 16, 2010 (Photo Nos. 6067-8A and 6067-2A). Section 24, Range 10 East, Township 30 South; UTM 518926E, 4226245N; elevation 6,180 ft. Original images held by the U.S. Geological Survey Photographic Library, Denver, CO. Photo mosaic compiled by Doug Page, BLM, Cedar City, UT. 


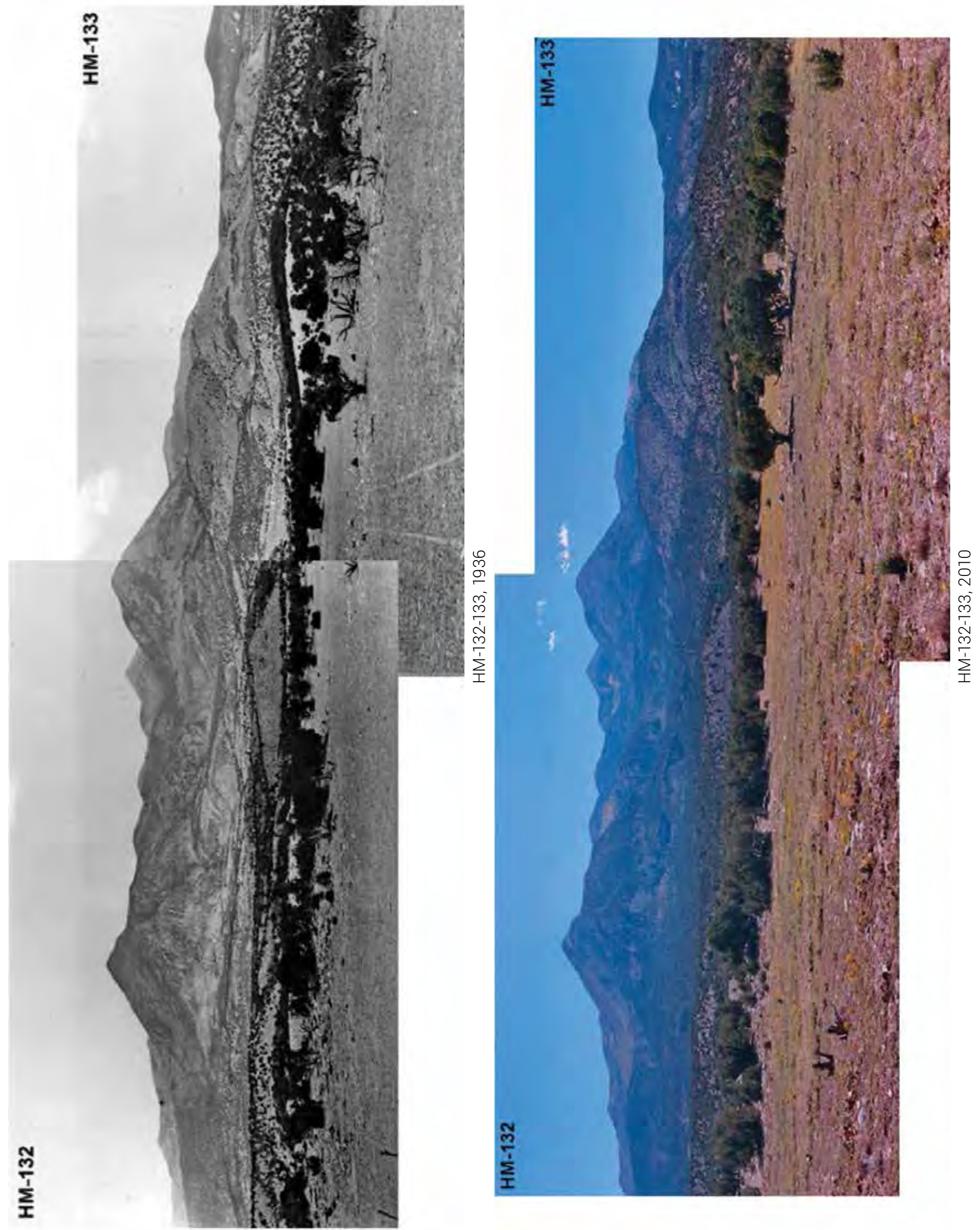




\section{Plate HM-146}

\section{Cottonwood Wash}

$1937 \div 2010$

Viewed north across Cottonwood Wash from Trachyte Point.

The 1937 image shows the old Trachyte Ranch road, which was abandoned in favor of an alignment 200 yards to the west (left). That alignment was also abandoned and is now passable only to ATVs. Although the old roadway was 3-4 feet lower than the surrounding area, it has naturally revegetated. The most common shrub is blackbrush, followed by Mormon tea. Indian ricegrass and curly grass have also increased.

Original photograph taken by Charles B. Hunt (Number 701) in September 1937; retake made by Charles E. Kay on September 18, 2010 (Photo No. 6098-28). Section 20, Range 12 East, Township 32 South; UTM 533911E, 4206183N; elevation 5,012 ft. Original image held by the U.S. Geological Survey Photographic Library, Denver, CO. 


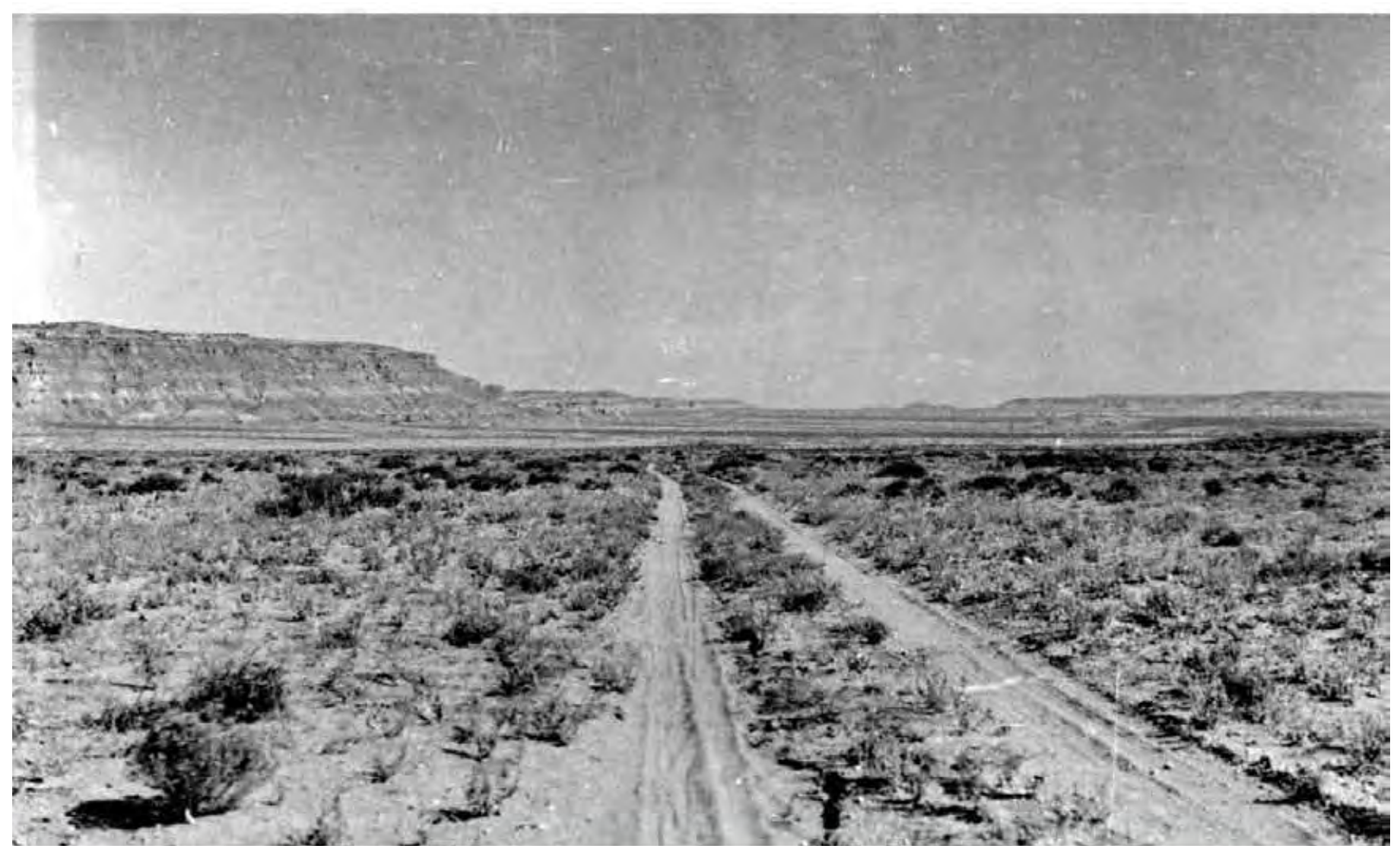

HM-146, 1937

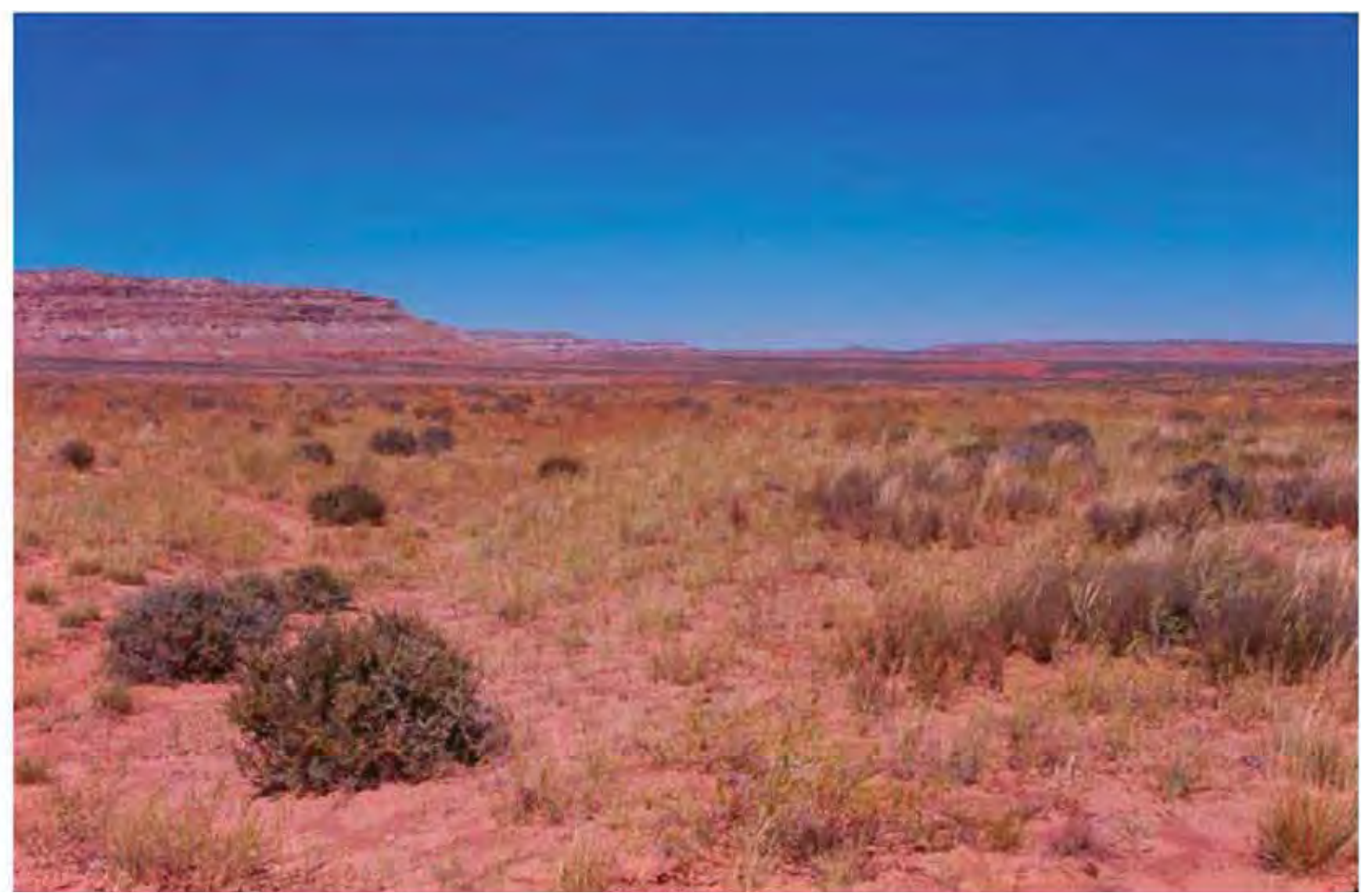

HM-146, 2010 


\section{Plate HM-153}

\section{Mount Hillers}

$1953 \therefore 2010$

Viewed southwest to Mount Hillers from the Hogsback road, about 5 miles from where it leaves Utah Highway

276. The camera station is just to the east of the present-day road and the older road at the top of the divide.

The 1953 image was taken before the current road was built.

Pinyon and juniper have increased in the distance, as have oak brush and other conifers on Mount Hillers. Much of Mount Hillers was burned by high-intensity crown fire in 2003. Trail Canyon is the first canyon on the right;

Gold Creek is the second. Both canyons burned in 2003.

Original photograph taken by Gregory Crampton in March 1953; retake made by Charles E. Kay on

September 20, 2010 (Photo No. 6102-16). Section 32, Range 12 East, Township 33 South; UTM 533960E, 4193840N; elevation 6,244 ft. Original image held by University of Utah, Marriott Library Special Collections, Salt Lake City, UT. 


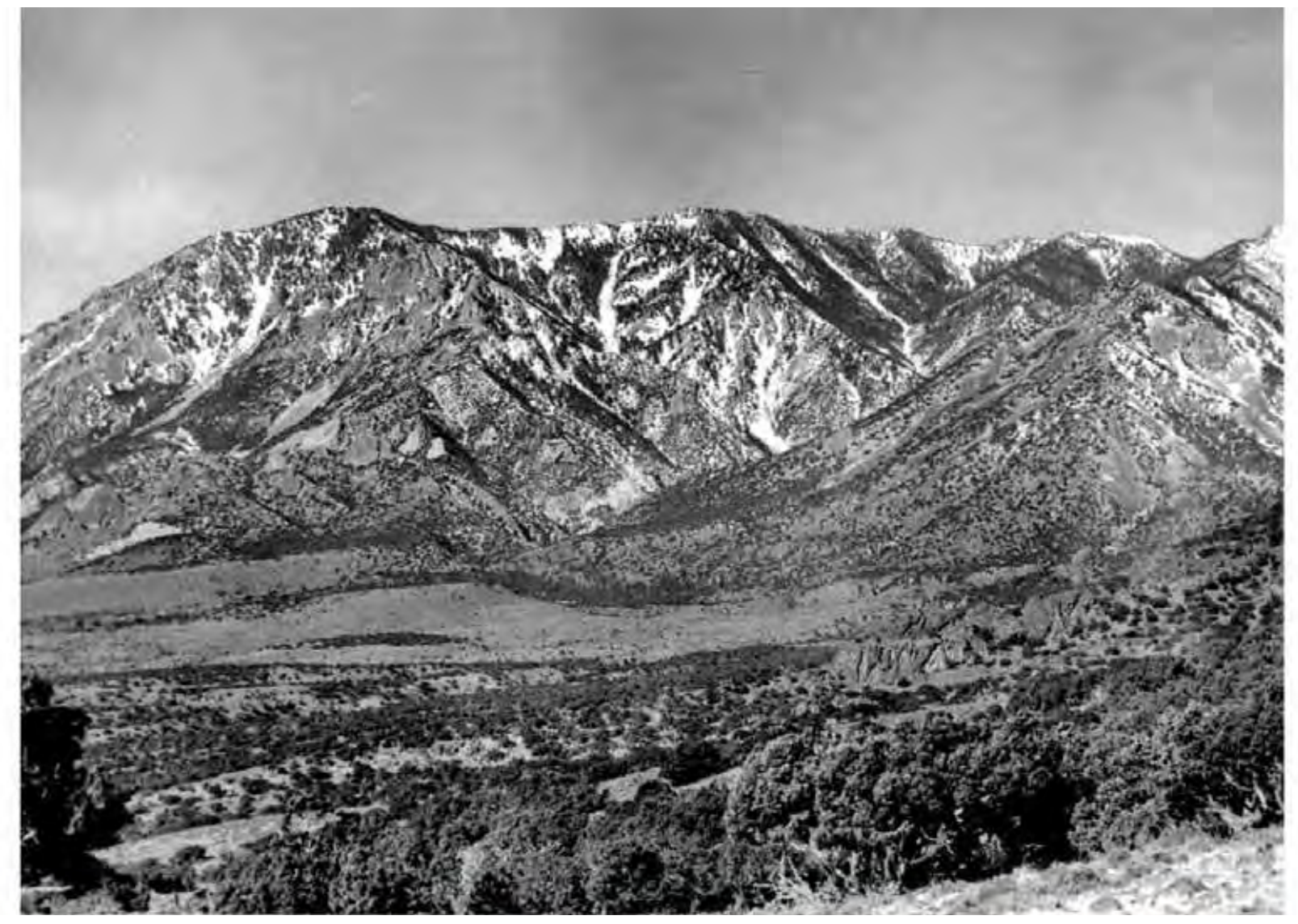

HM-153, 1953

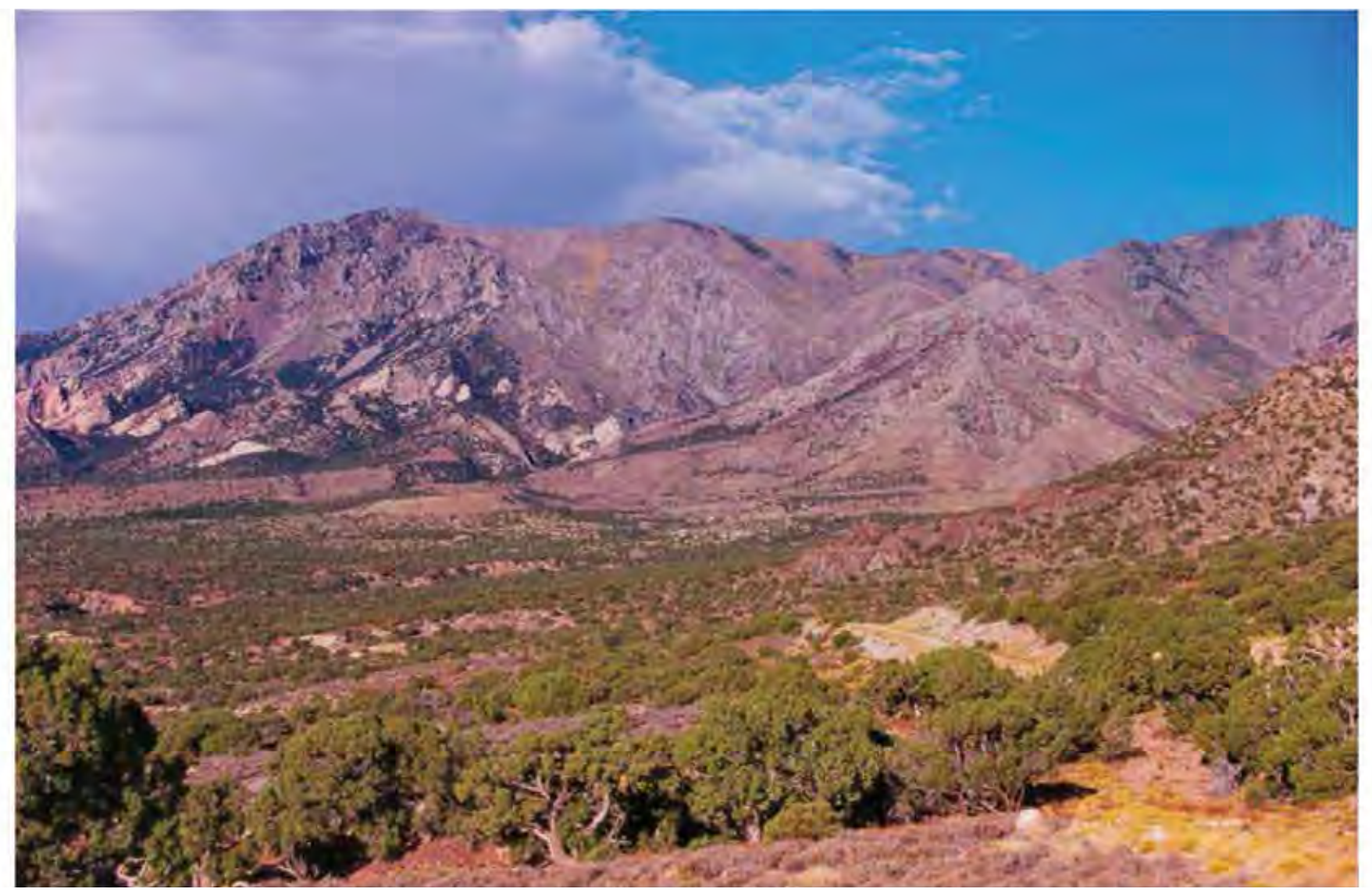

HM-153, 2010 


\section{Plate HM-154}

\section{STAR RANCH}

$1953 \therefore 2010$

Viewed northwest to the southern slopes of Mount Hillers from Star Ranch. The meadow from which the original photo was taken is now a dense growth of willows and rubber rabbitbrush, so the retake was made from the nearest open area on top of a low hill east of the Hogsback road and north of the road to the Star Springs Campground.

Oak brush and pinyon-juniper have increased in the distance. Cottonwoods have increased around the meadow.

Original photograph was taken by R.G. Luedke (Number 25) ca. 1953; retake made by Charles E. Kay on September 20, 2010 (Photo No. 6104-9). Section 14, Range 11 East, Township 34 South; UTM 529976E, 4188974N; elevation 6,091 ft. Original image held by the U.S. Geological Survey Photographic Library, Denver, CO. 


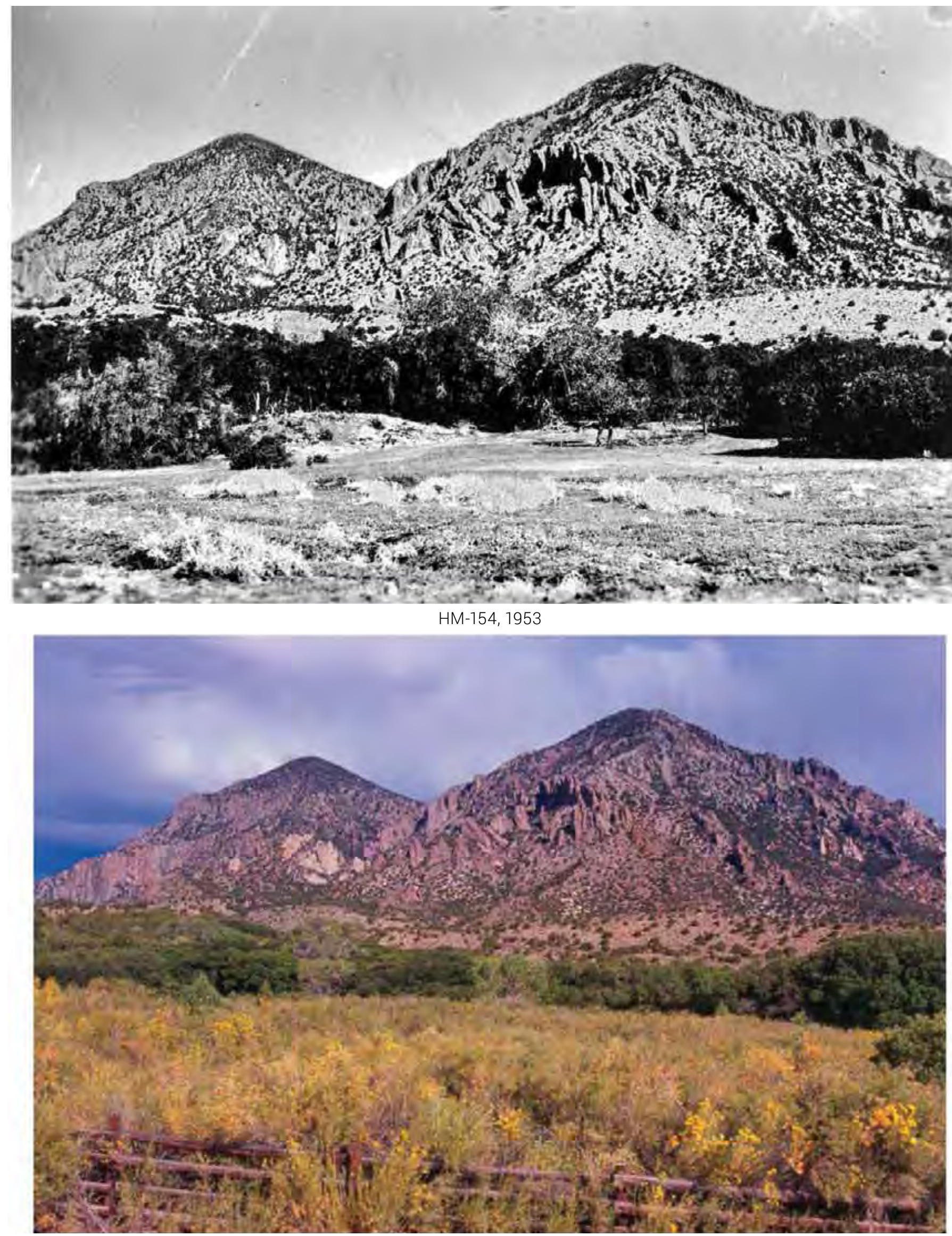

HM-154, 2010 


\section{Plate HM-168}

\section{Bert Avery Seep}

$1936 \div 2010$

Viewed northeast from Bert Avery Seep down the Birch Creek Valley. The original camera station was destroyed by road construction.

Note the U.S. Geological Survey camp in the 1936 photo. This photo was taken shortly after a thunderstorm had passed over the area, and the normally dry wash was in flood. Note how steep-walled the gully was in 1936, as well as the total lack of woody riparian vegetation. Today the wash has stabilized, and tamarisk is common. There are two parts to Bert Avery Seep. The part south of the present road, and the part north of the present road (seen in this photo set). The BLM has fenced both parts of the seep to exclude livestock. Fourwing saltbush and Russian thistle are common below the seep.

Original photograph taken by Charles B. Hunt (Number 462) on July 10, 1936; retake made by Charles E. Kay on October 26, 2010 (Photo No. 6110-5). Section 22, Range 10 East, Township 29 South; UTM 515517E, 4235573N; elevation 4,879 ft. Original image held by the U.S. Geological Survey Photographic Library, Denver, CO. 


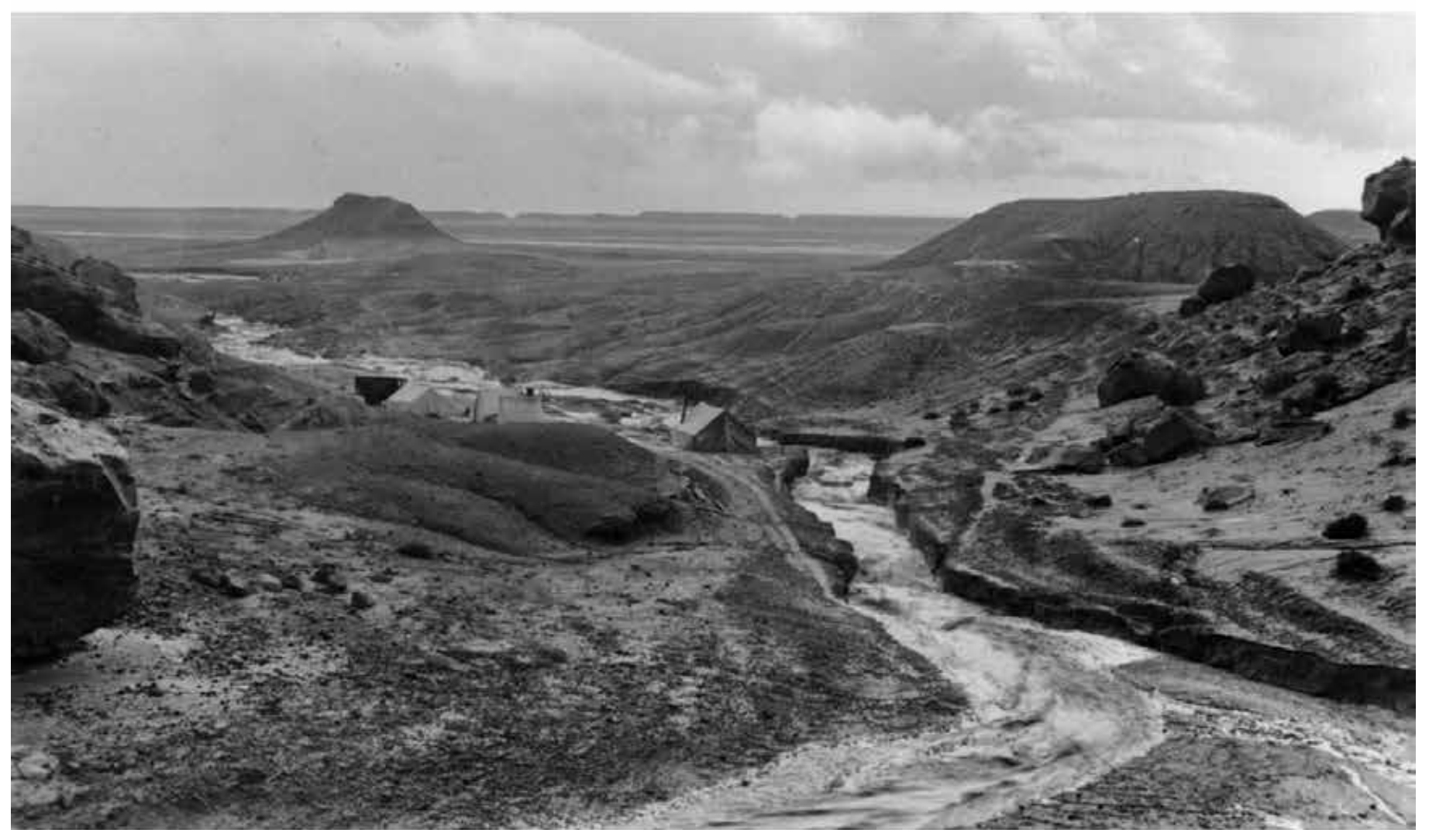

HM-168, 1936

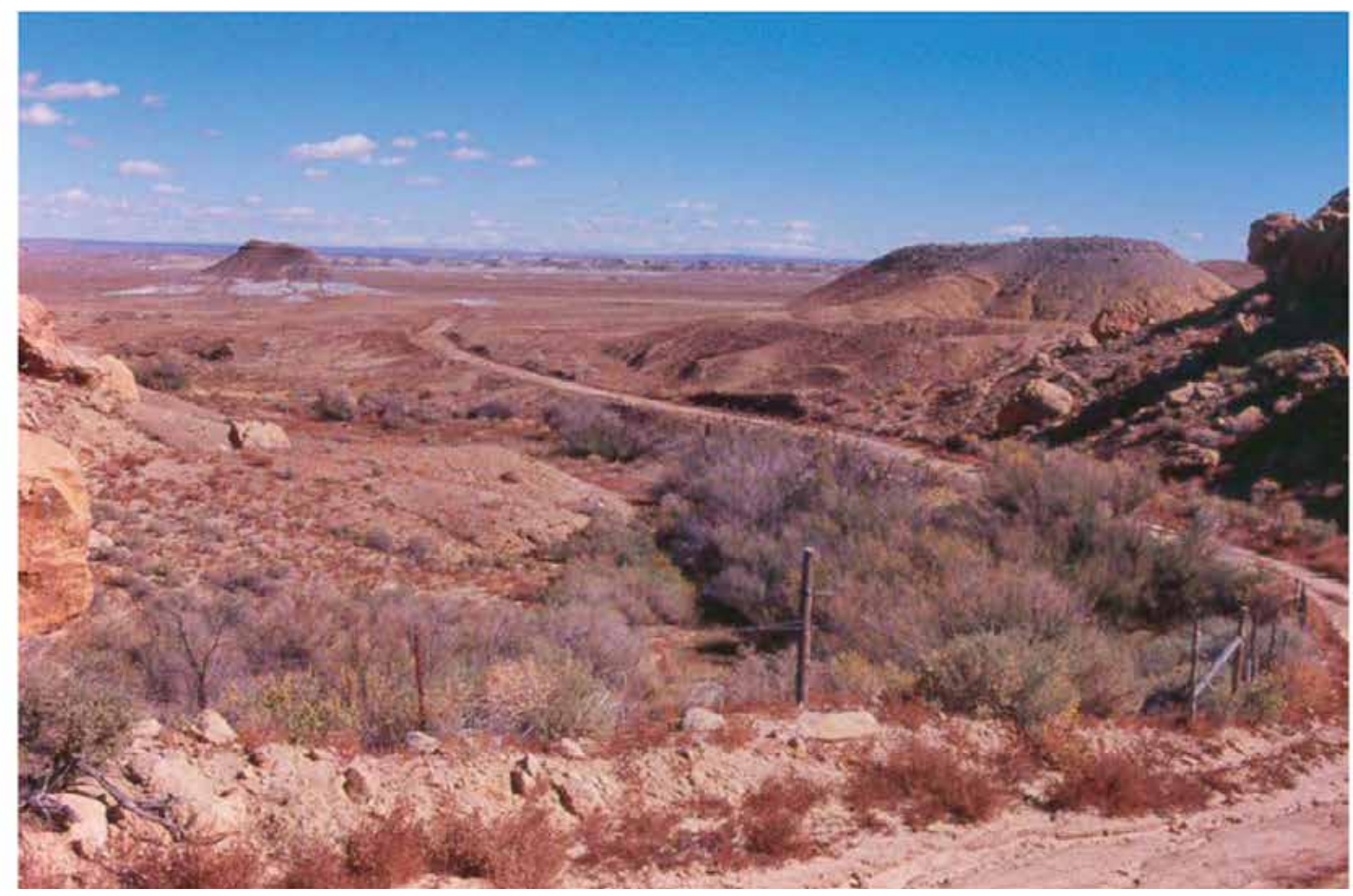




\section{Plate HM-201}

\section{Fremont River}

$1930 \div 2011$

Viewed east-northeast down the Fremont River to South Caineville Mesa about 1 1/2 miles south of Caineville, on the old gravel road.

The active river channel has narrowed and moved to the right, where it is now hidden from view by a new growth of willows and cottonwoods. Except for a few old cottonwoods, woody riparian vegetation was absent when the original photograph was taken. It is, however, abundant today despite continued livestock grazing by the private landowner. Today, cattails and beaver are also common, unlike conditions in the past.

Original photograph taken by Hattie Mulford Robison ca. 1930; retake made by Charles E. Kay on May 8, 2011 (Photo No. 6125-5A). Section 3, Range 8 East, Township 29 South; UTM 497614E, 4241335N; elevation 4,640 ft. Original photograph published by Robinson and Robinson $(2004,35)$. 


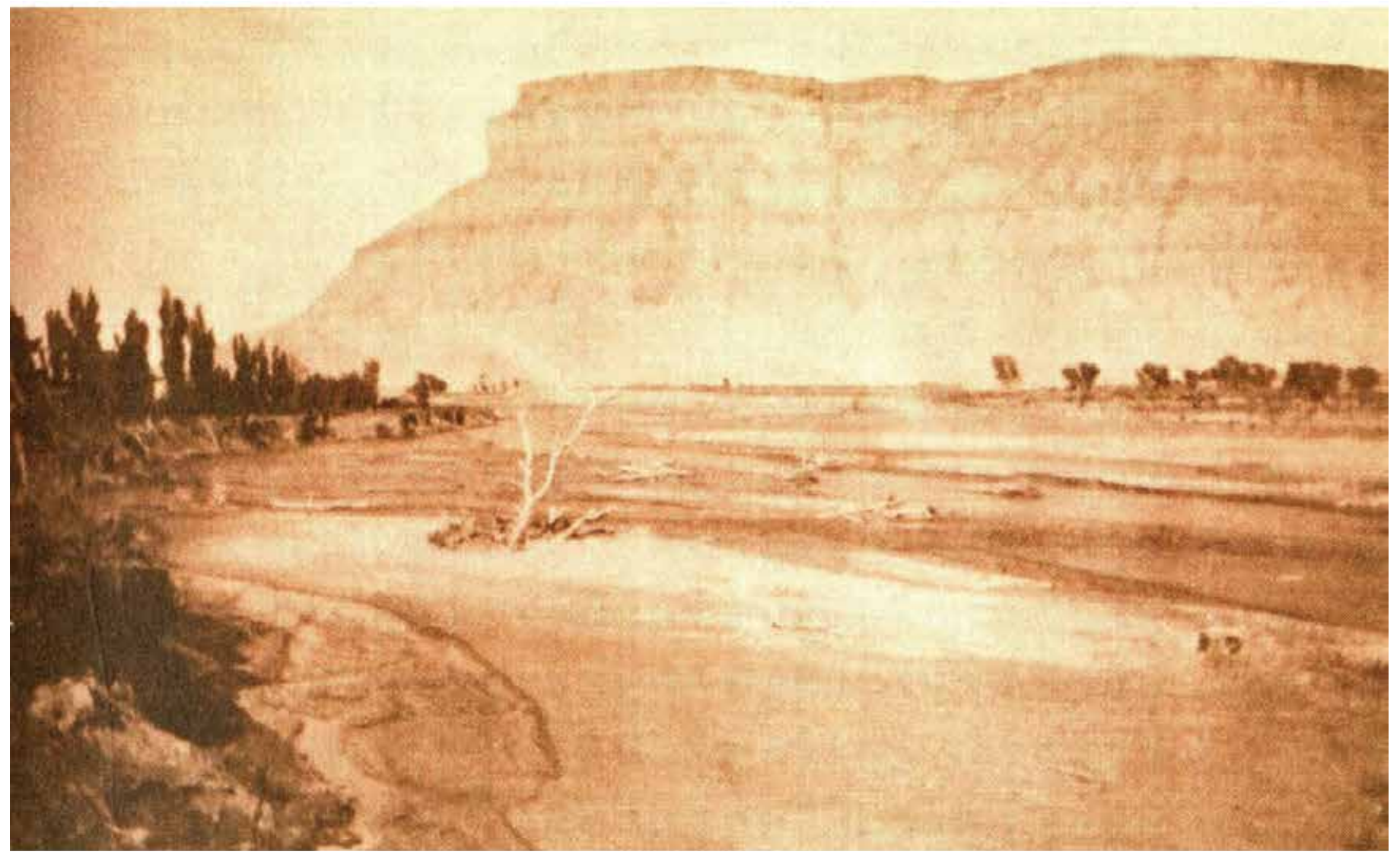

HM-201, 1930

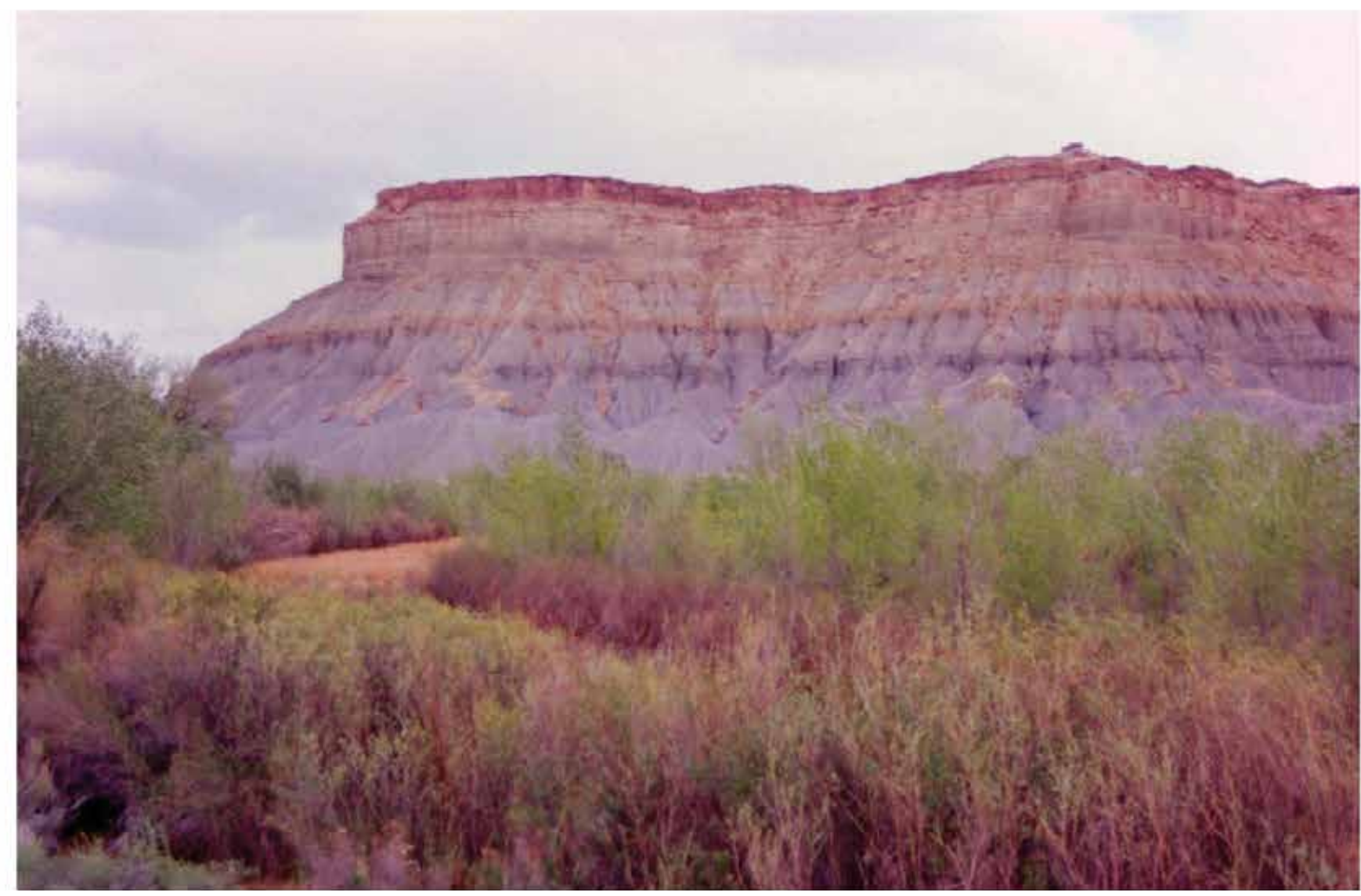

HM-201, 2011 


\section{Plate HM-215}

Stanton Pass

1969 ¡ 2011

In 1969 the BLM established the Bulldog 6 range monitoring site in Stanton Pass on the Pennell Allotment.

The view is to the south, with Cass Creek Peak on the left. Note the steel fencepost in the original and the retake.

Cass Creek Peak burned in the 2003 Bulldog Fire that blackened nearly 32,000 acres. The land in the foreground of the more recent photograph has been root-plowed and reseeded to crested wheatgrass. The seeding is heavily used by cattle and bison.

Original photograph taken by the BLM on September 11, 1969; retake made by Charles E. Kay on May 13, 2011 (print from a color slide). Section 29, Range 11 East, Township 33 South; UTM 524206E; 4196297N; elevation 7,392 ft. Original photograph held in the BLM’s range files, Hanksville, UT. 


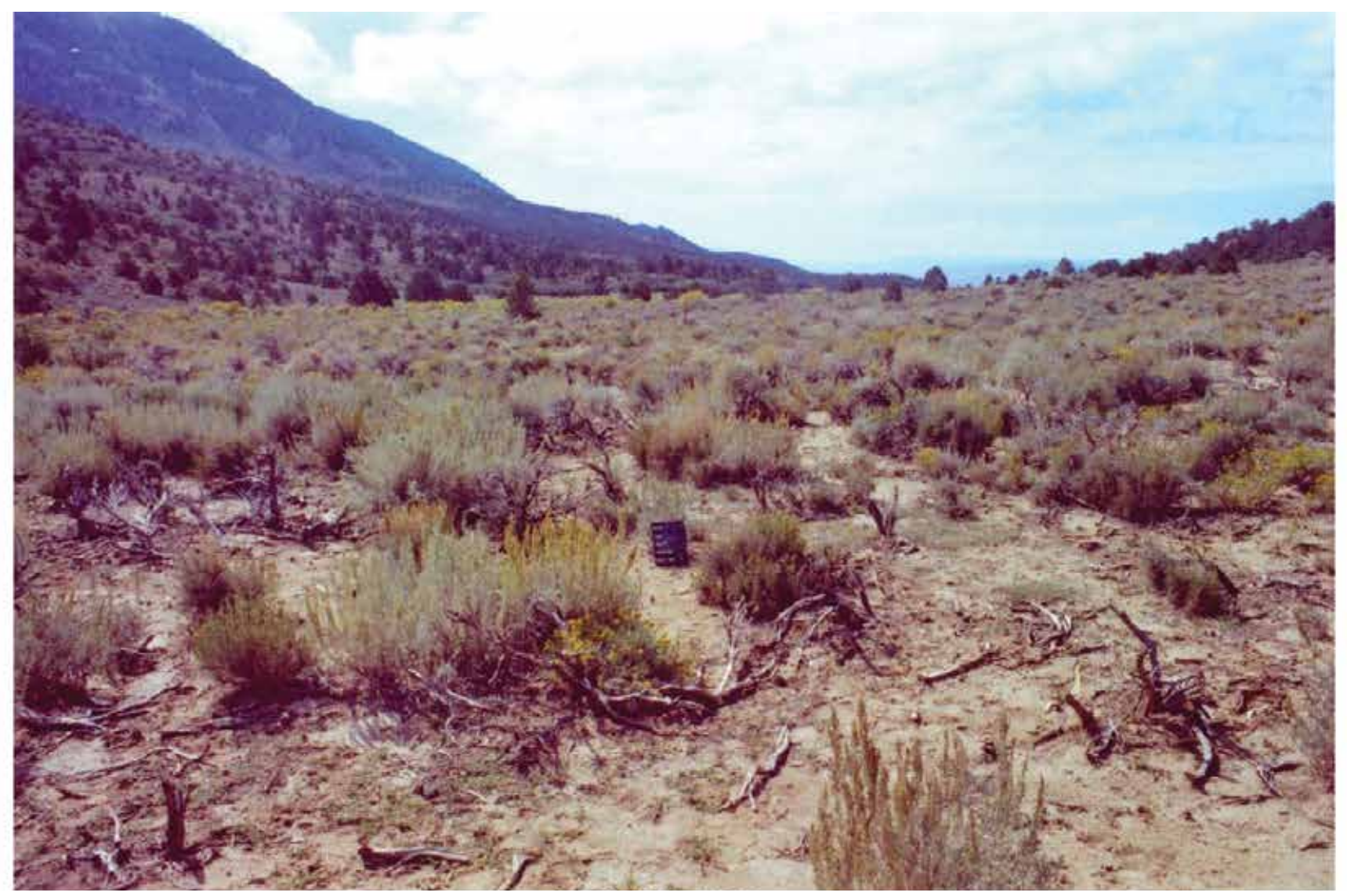

HM-215, 1969

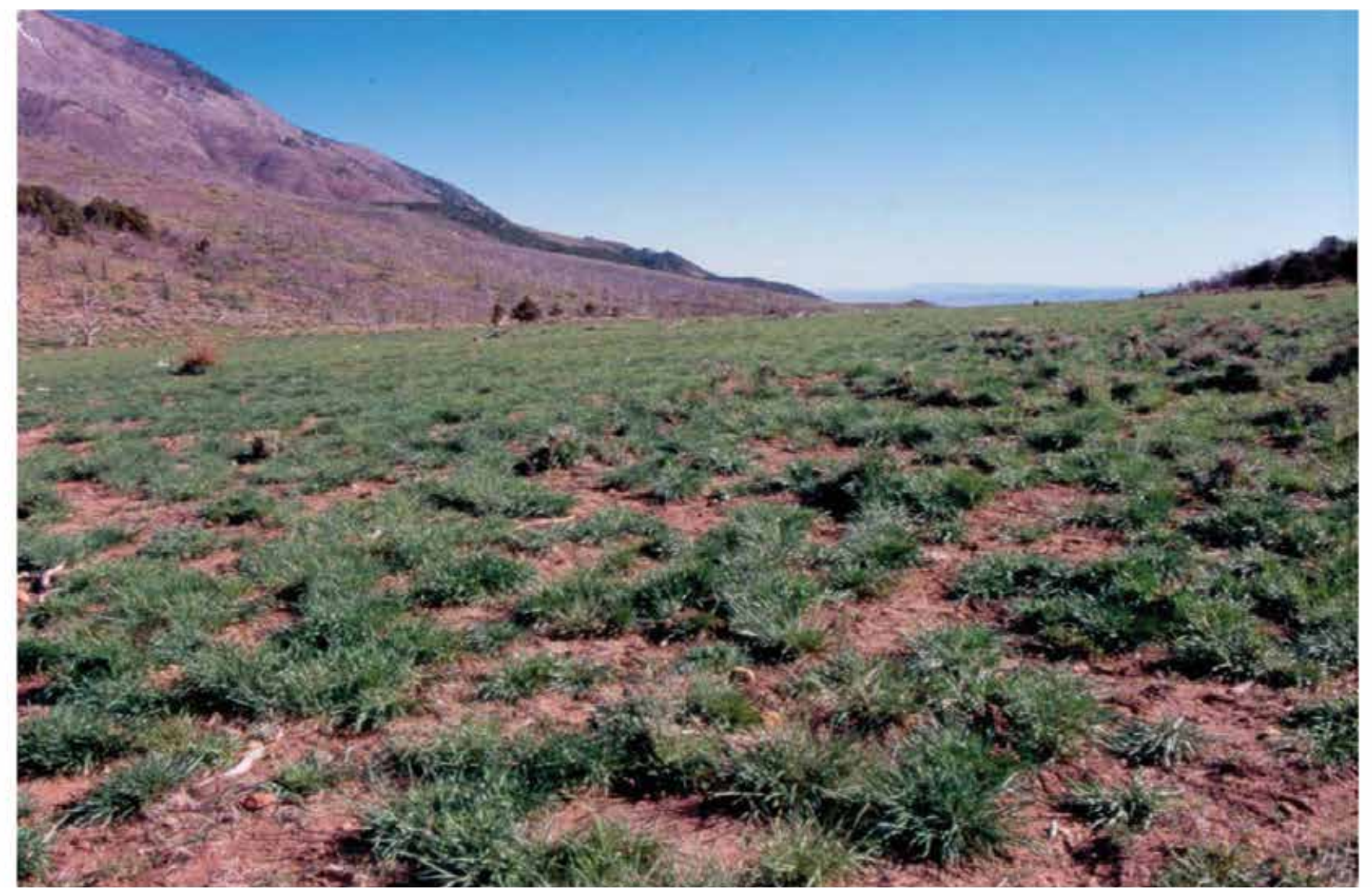

HM-215, 2011 


\section{Plate HM-216}

\section{Indian Spring Bench}

$1968 \div 2011$

In 1968 the BLM established the Blue Hills 6 range monitoring site about 1 1⁄2 miles southwest of Squaw Spring, on the Bullfrog Allotment. The view is to the south. All the steel stakes are still present (note the red steel fencepost in the original and that same fencepost painted yellow in the retake). Navajo Mountain is on the left skyline in the retake.

Juniper has increased, as has mountain big sagebrush. Blue grama is the most abundant native grass. Phlox, locoweed, and pricklypear cactus are also present. There was little sign of livestock use.

Original photograph taken by the BLM on August 30, 1968; retake made by Charles E. Kay on May 14, 2011 (print from a color slide). Section 18, Range 11 East, Township 34 South; UTM 523496E; 4190125N; elevation 6,486 ft. Original photograph held in the BLM's range files, Hanksville, UT. 


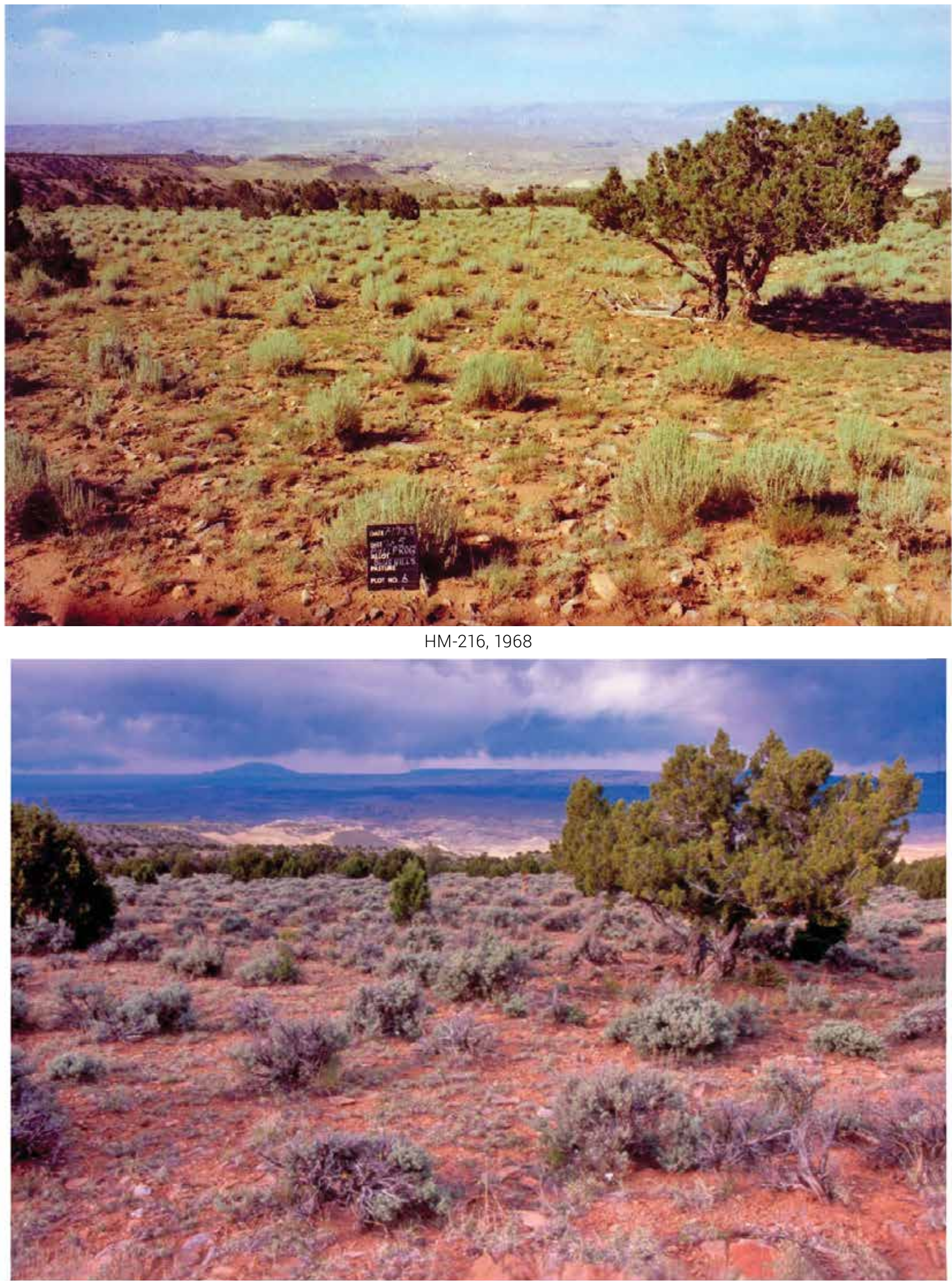

HM-216, 2011 


\section{Plate HM-223}

Sandy Creek Bench

$1964: 2011$

The view is to the southeast, approximately 600 yards south of where the main road crosses Dogwater Creek.

The photo point is just east of the road.

The BLM took this photo to illustrate the "severe wind erosion" that was occurring on the Sandy 3 Allotment in 1964. "Note [the] pedestaling of plants and lack of ground cover" in the original photograph. Today, that is no longer the case, as perennial grass and shrub cover have increased, stabilizing the site. The most common species are Indian ricegrass and fourwing saltbush. Juniper appears to have increased in the distance.

Original photograph taken by Sheridan Hansen and Kenneth Drew on February 25, 1964; retake made by Charles E. Kay on May 15, 2011 (Photo No. 6132-10). Section 31, Range 8 East, Township 31 South; UTM 494347E, 4212504N; elevation 5,359 ft. Original image held in the BLM’s range files, Hanksville, UT. 


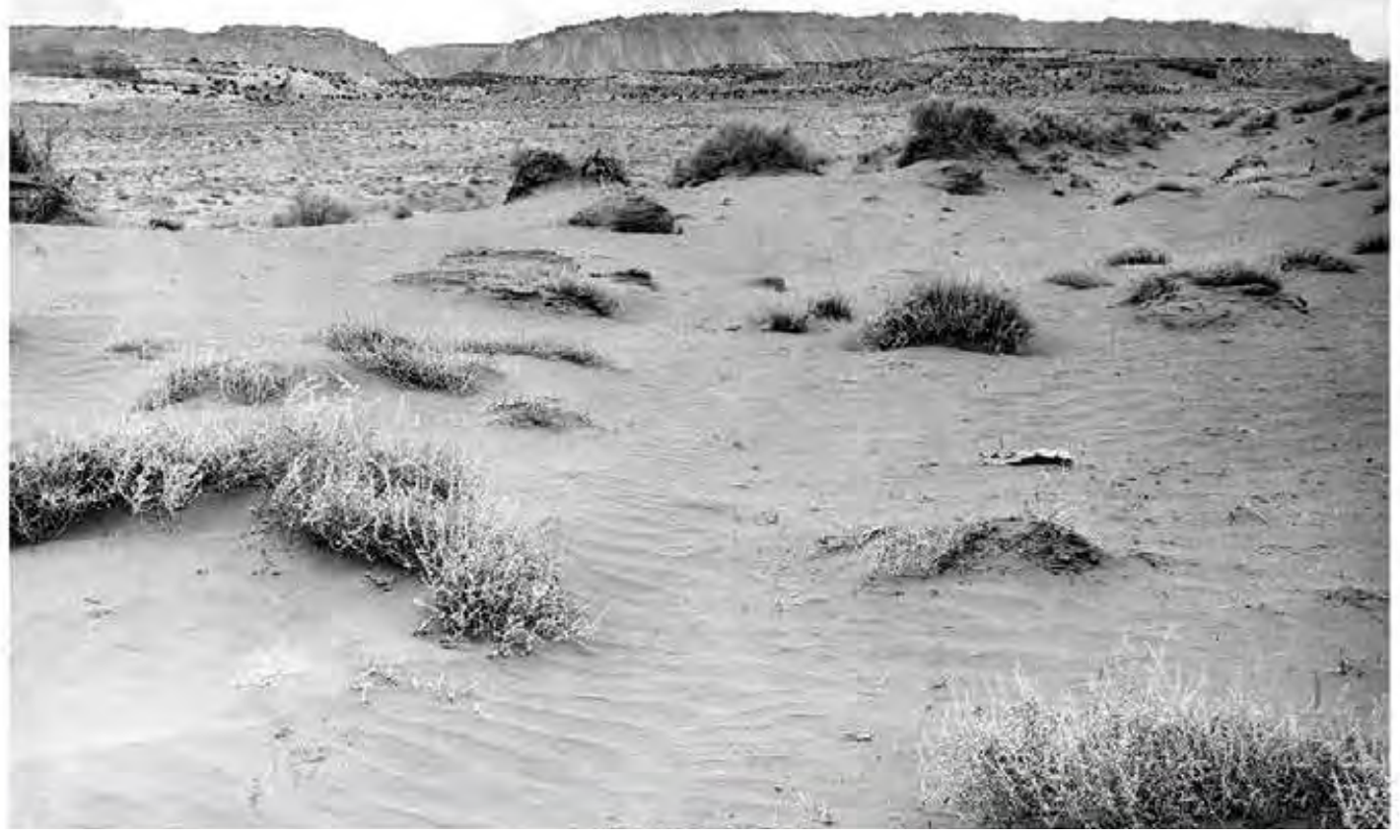

HM-223, 1964

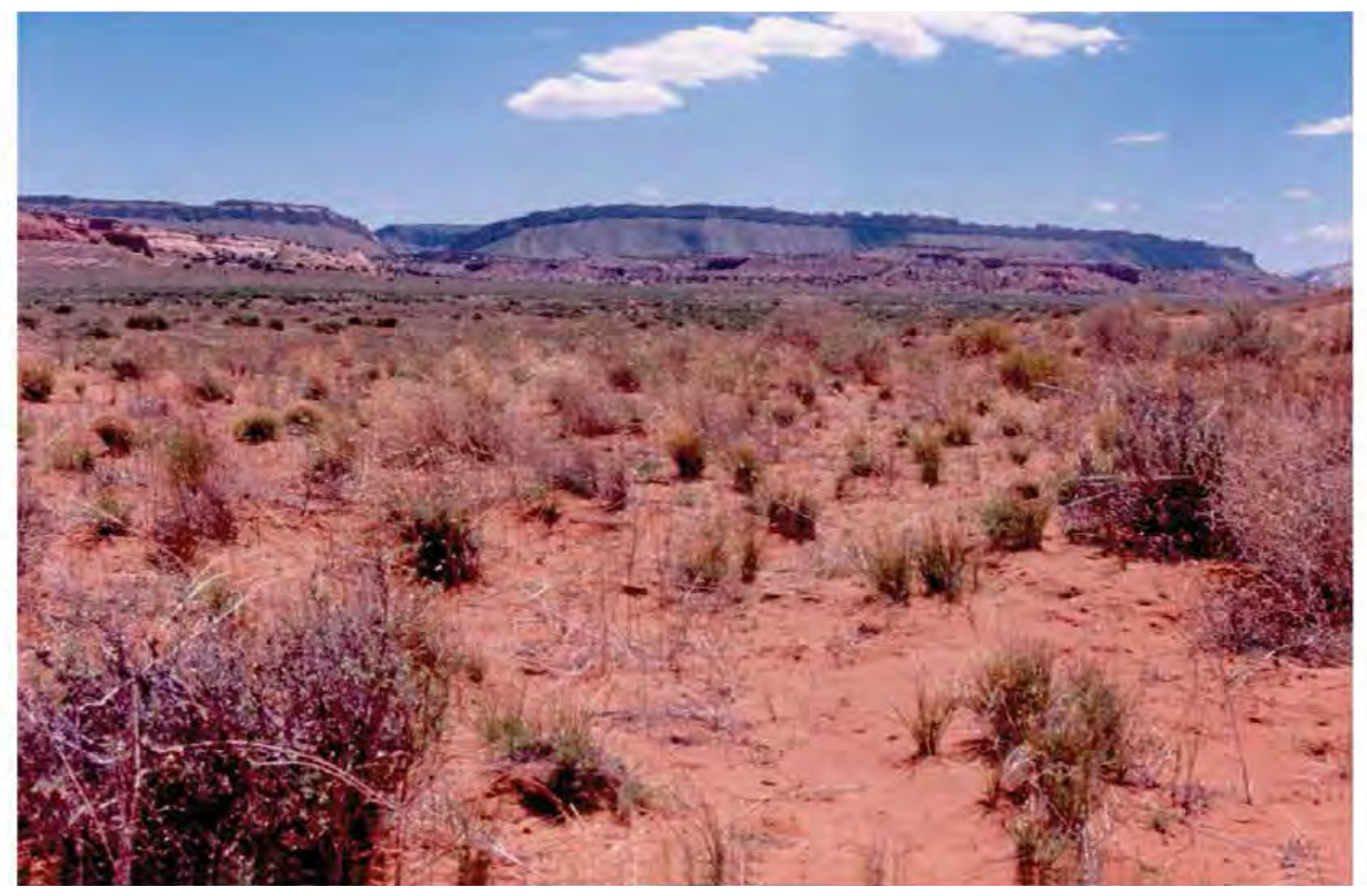

HM-223, 2011 


\section{Plate HM-224}

Sandy Creek Bench

$1964: 2011$

The view is to the northwest, approximately 2 miles south of where the main road crosses Dogwater Creek. The

photo point is located about 100 yards east of the main road and is on the Sandy 3 Allotment. Note the short steel stake in the original and the retake.

Greasewood and cheatgrass have both increased, as has juniper in the distance. Indian ricegrass and pricklypear cactus are also present.

Original photograph taken by Sheridan Hansen and Kenneth Drew on February 25, 1964; retake made by Charles E. Kay on May 15, 2011 (Photo No. 6132-13). Section 7, Range 8 East, Township 32 South; UTM 494550E, 4211059N; elevation 5,407 ft. Original image held in the BLM’s range files, Hanksville, UT. 


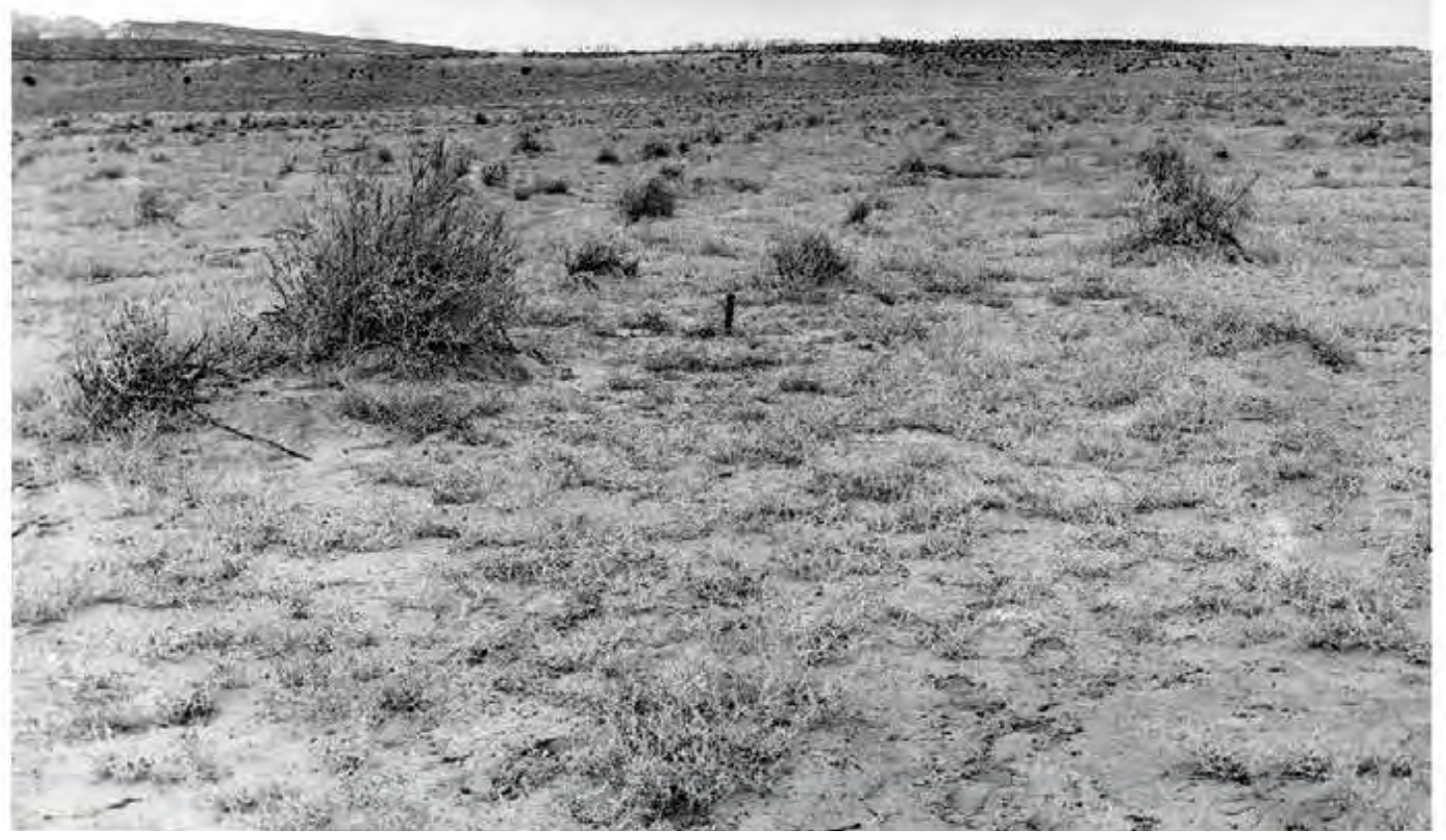

HM-224, 1964

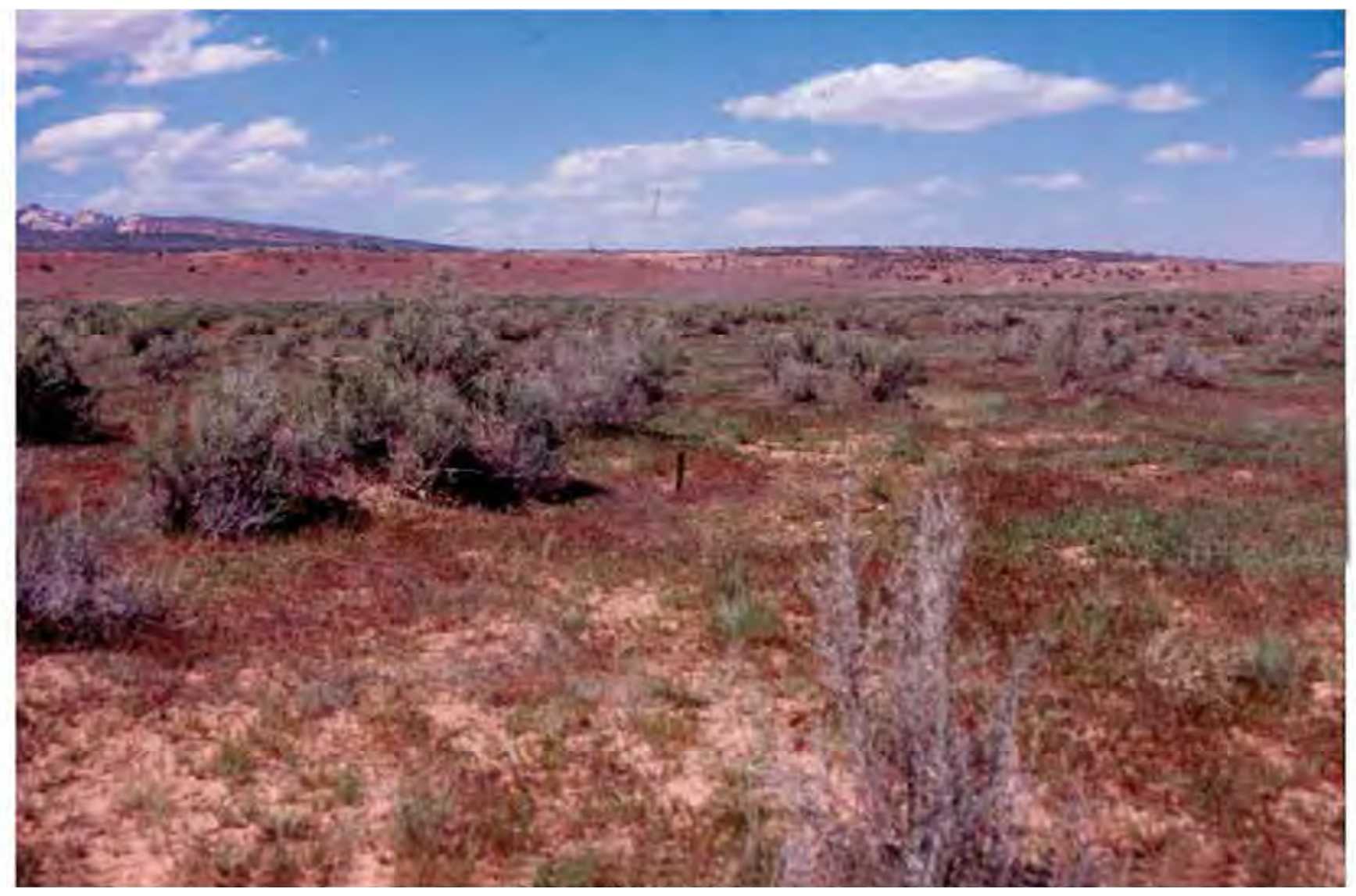

HM-224, 2011 


\section{Plate HM-229}

SAndy Creek Benches

$1964 \div 2011$

Viewed southwest to the Sandy Creek Benches. The photo point is on the west edge of the main county road, about 100 feet south of where that road drops over the hill on the Sandy Ranch. Note the two large lava boulders (lower right) in both the original and the retake. The area from the camera to behind the dunes seen in the distance is owned by the Sandy Ranch and is still grazed by cattle.

The lack of plant cover and the shifting sand in the 1964 image are signs of overgrazing. Today, plant cover has increased, and all but one of the sand dunes has stabilized. Indian ricegrass, Mormon tea, and fourwing saltbush are the most common plants. Juniper appears to have increased.

Original photograph taken by Sheridan Hansen and Kenneth Drew on February 25, 1964; retake made by Charles E. Kay on May 16, 2011 (Photo No. 6132-31A). Section 30, Range 8 East, Township 31 South; UTM 493876E, 4214235N; elevation 5,537 ft. Original photograph held in the BLM’s range files, Hanksville, UT. 


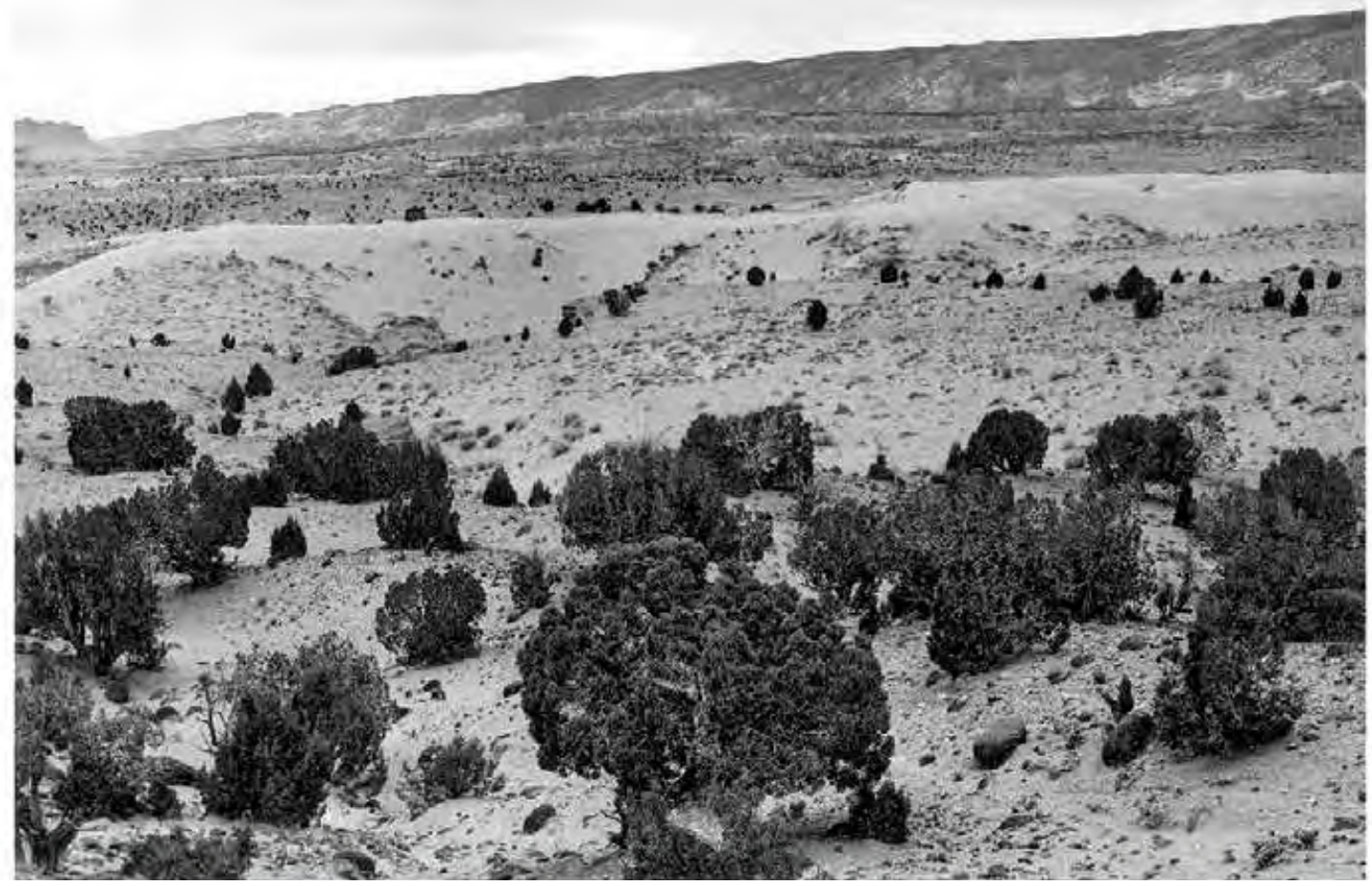

HM-229, 1964

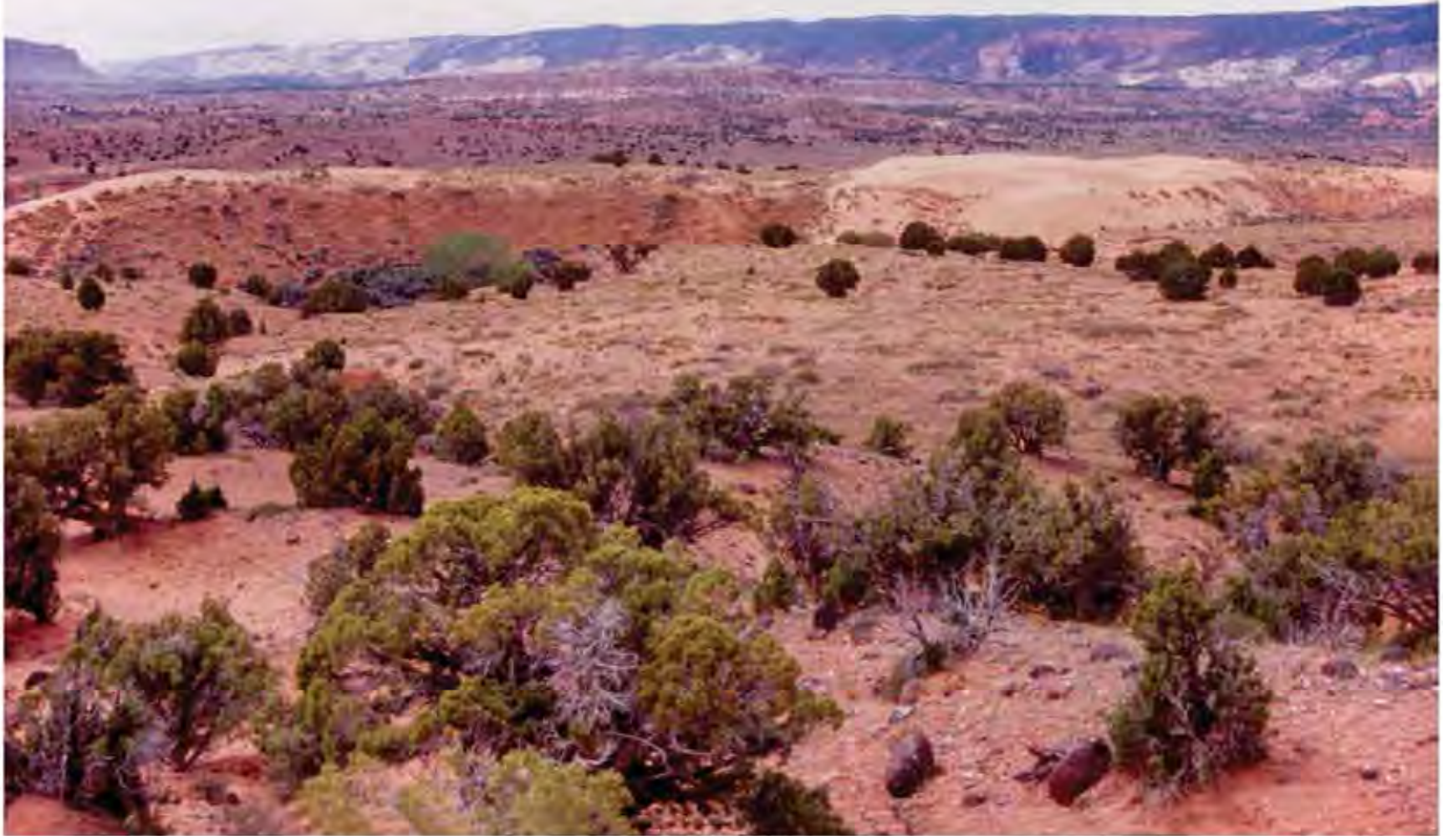

HM-229, 2011 
Plate HM-246

North Fork of Bulldog Creek

$1967 \div 2011$

In 1967 the BLM established the Plot 1 range monitoring site on the Steele Butte Allotment. The view is south, down the North Fork of Bulldog Creek, about 1 mile north of the turnoff to Tarantula Mesa (right skyline). Mount Pennell is on left skyline. The camera station is 100 yards west of the Sweetwater road. All the steel stakes are still present. The red steel fencepost, now painted yellow, is difficult to see in the retake due to growth of sagebrush and juniper.

The area is heavily used by wintering mule deer. Juniper and mountain big sagebrush have both increased.

Shadscale, Indian ricegrass, blue grama, needle and thread, snakeweed, locoweed, and pricklypear cactus are also present, as is a minor amount of cheatgrass.

Original photograph taken by the BLM on September 27, 1967; retake made by Charles E. Kay on May 20, 2011 (print from a color slide). Section 13, Range 9 East, Township 32 South; UTM 511854E, 4207891N; elevation 6,665 ft. Original photograph held in the BLM’s range files, Hanksville, UT. 


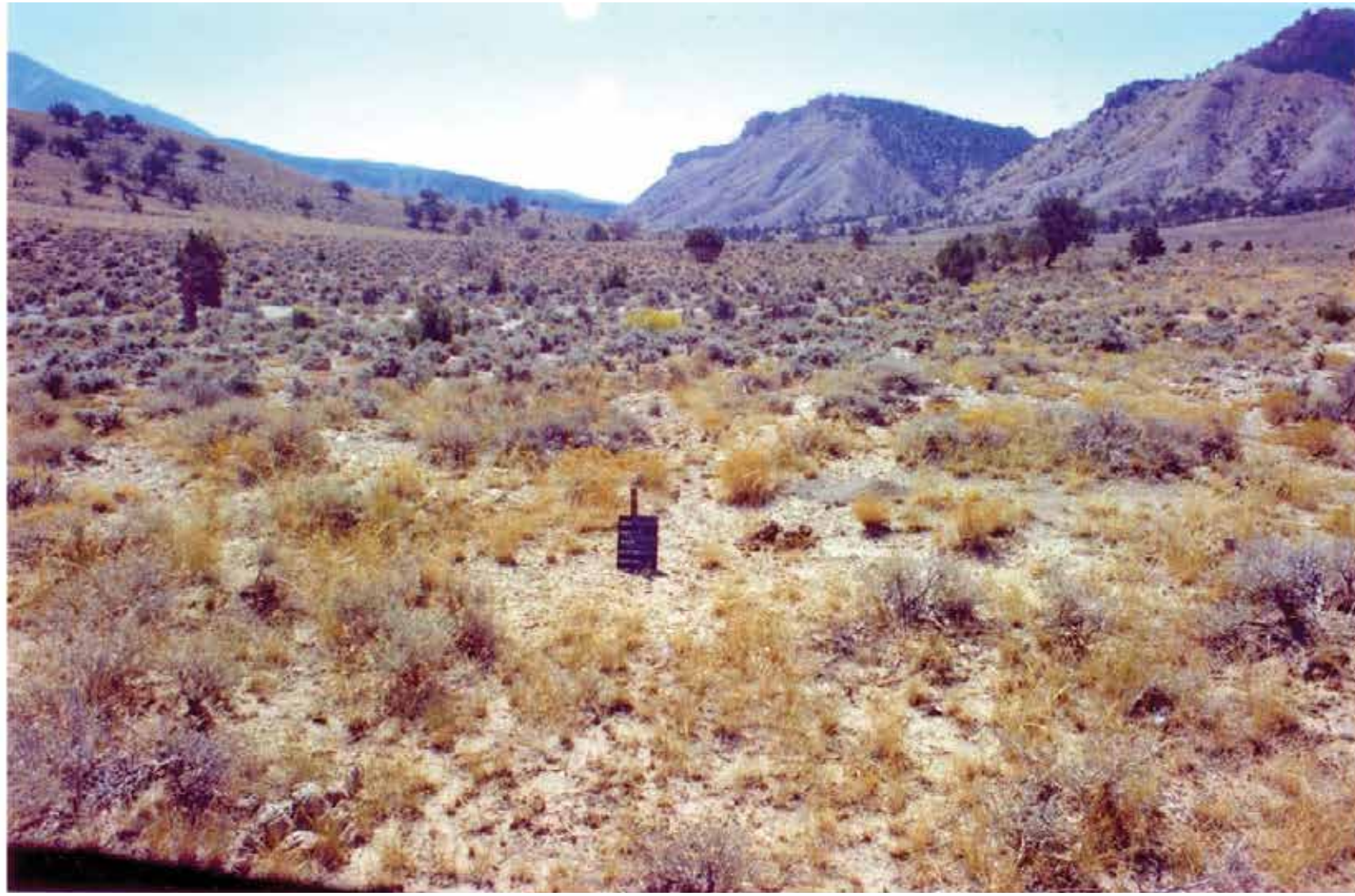

HM-246, 1967

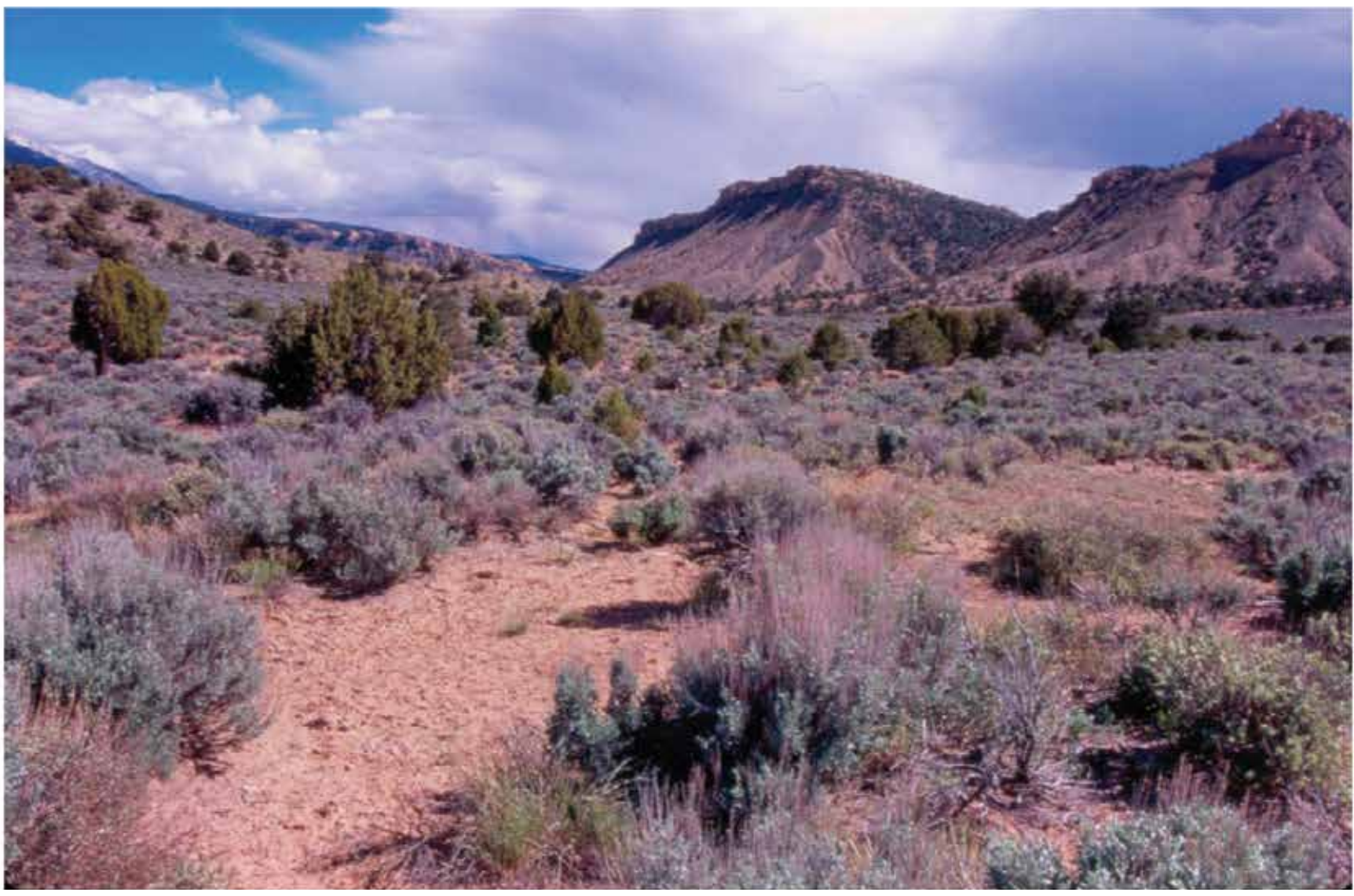

HM-246, 2011 
Plate HM-247

\section{Apple Brush Flat}

$1911 \div 2011$

Viewed east, up Dry Wash to Mount Ellen from the lower part of Apple Brush Flat.

Pinyon and juniper have increased, both in the foreground and on the lower slopes of Mount Ellen, except for the gray marine shales (right-center), which are naturally nonvegetated. Other species include fourwing saltbush (mostly dead), Mormon tea, snakeweed, curly grass, Indian ricegrass, needle and thread, locoweed, and globemallow.

Original photograph taken by C.T. Lupton (Number 281) in 1911; retake made by Charles E. Kay on May 21, 2011 (Photo No. 6142-28). Section 8, Range 9 East, Township 31 South; UTM 504998E, 4219046N; elevation 5,789 ft. Original image held by the U.S. Geological Survey Photographic Library, Denver, CO. 


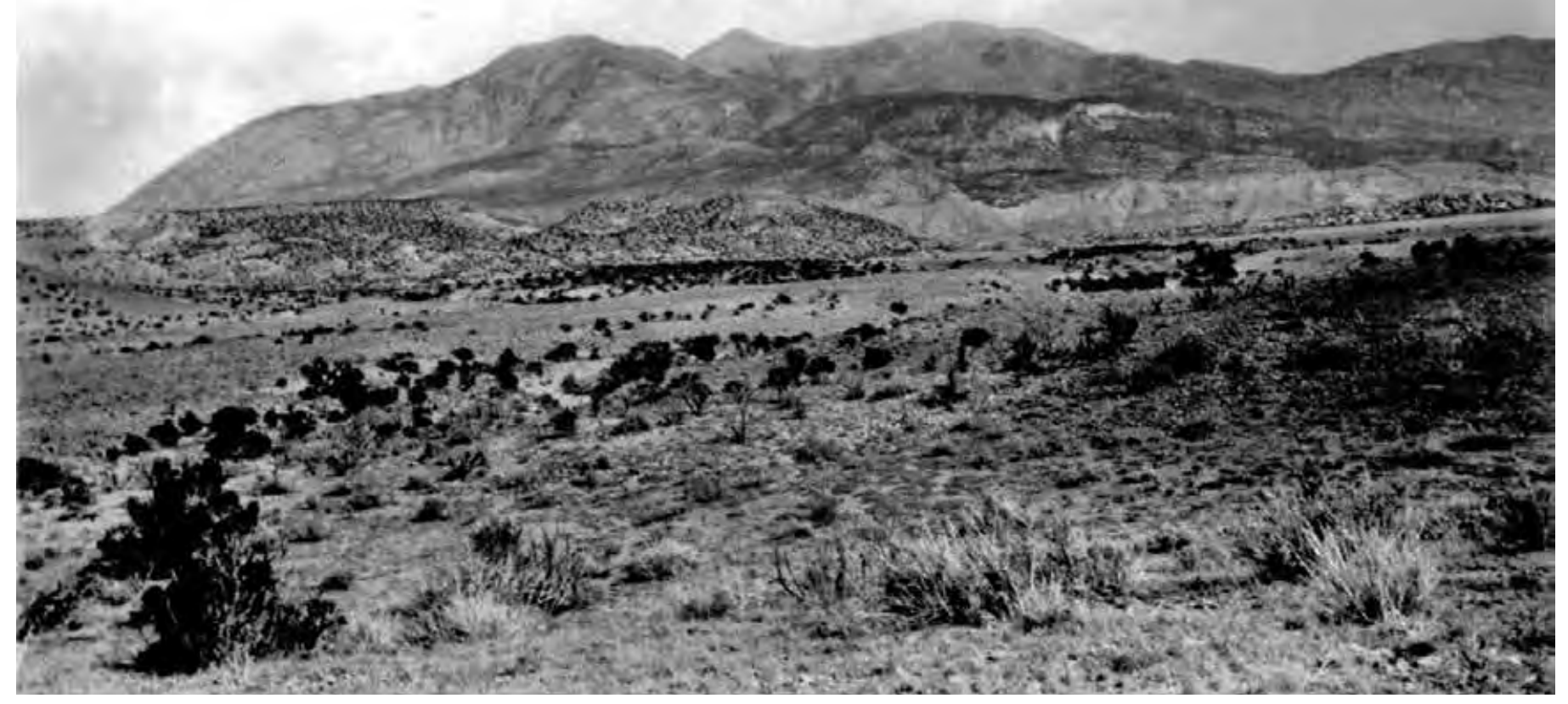

HM-247, 1911

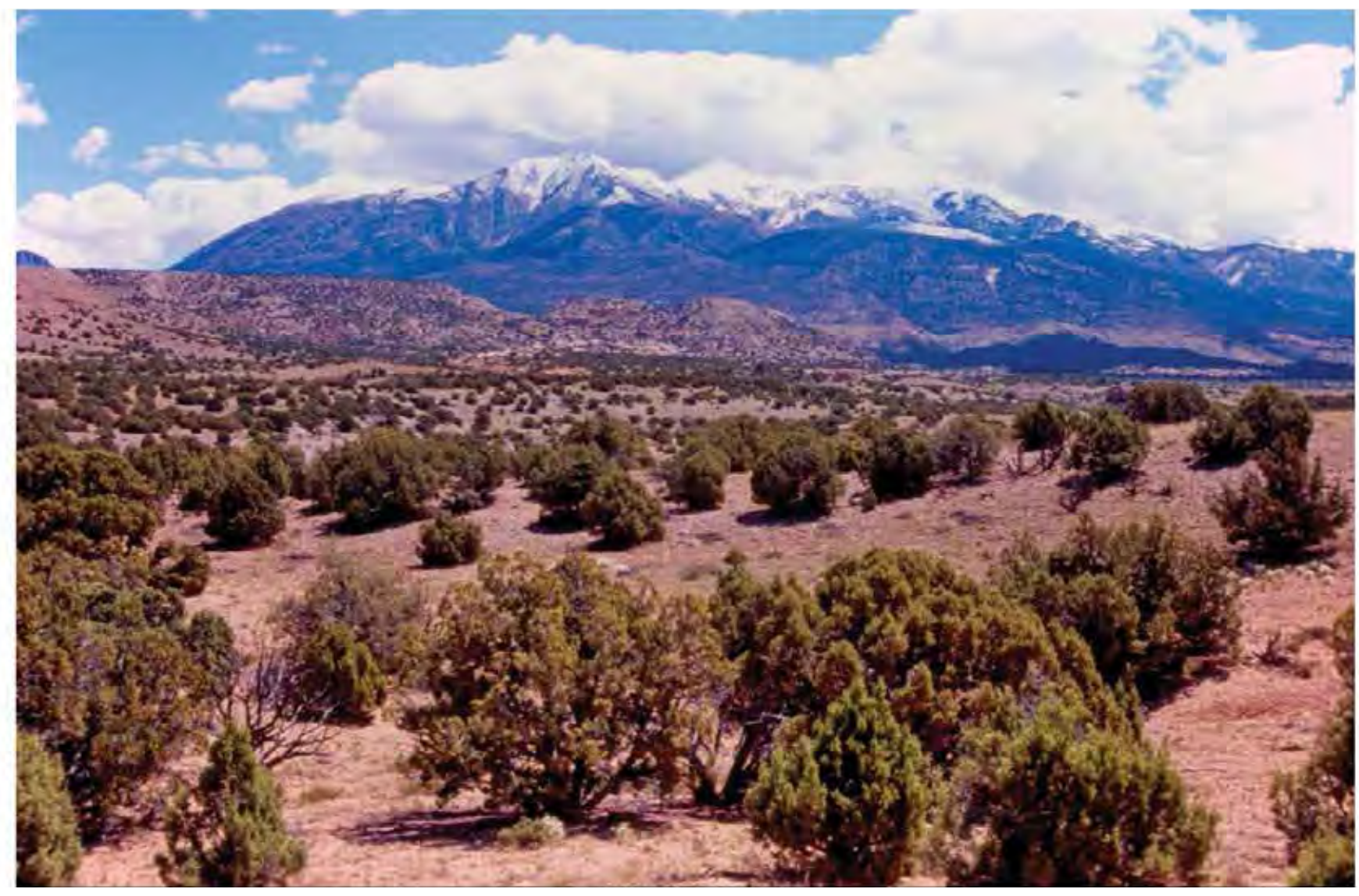

HM-247, 2011 


\section{Plate HM-251}

\section{Swap Ganyon}

$1918 \div 2011$

Viewed east-southeast across upper Halls Greek and Grand Gulch to the mouth of Swap Canyon. The photo point is approximately 200 yards east of the Notom road and about 1 mile north of Burr Canyon.

Greasewood appears to have declined. Tamarisk has become established along Halls Creek (not a perennial stream). A few juniper have become established. Other plants include Indian ricegrass, shadscale, curly grass, and cheatgrass.

Original photograph taken by Herbert E. Gregory in June 1918; retake made by Charles E. Kay on May 21, 2011 (Photo No. 6149-4). Section 10, Range 8 East, Township 34 South; UTM 498334E, 4191026N; elevation 5,084 $\mathrm{ft}$. The original image is damaged. Original image (P0013, Box 8, Number 1429) held by the University of Utah, Marriott Library Special Collections, Salt Lake City, UT. 


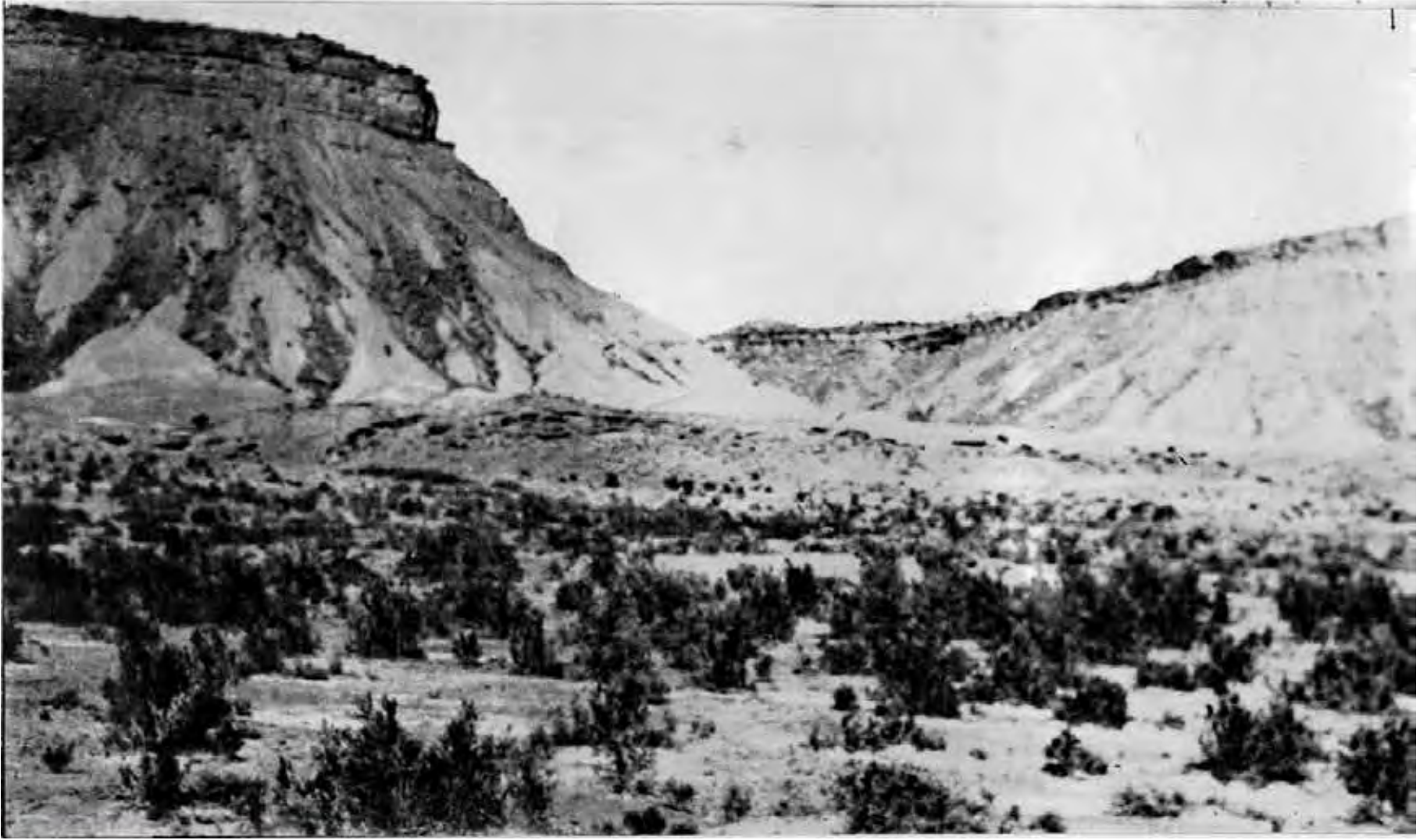

HM-251, 1918

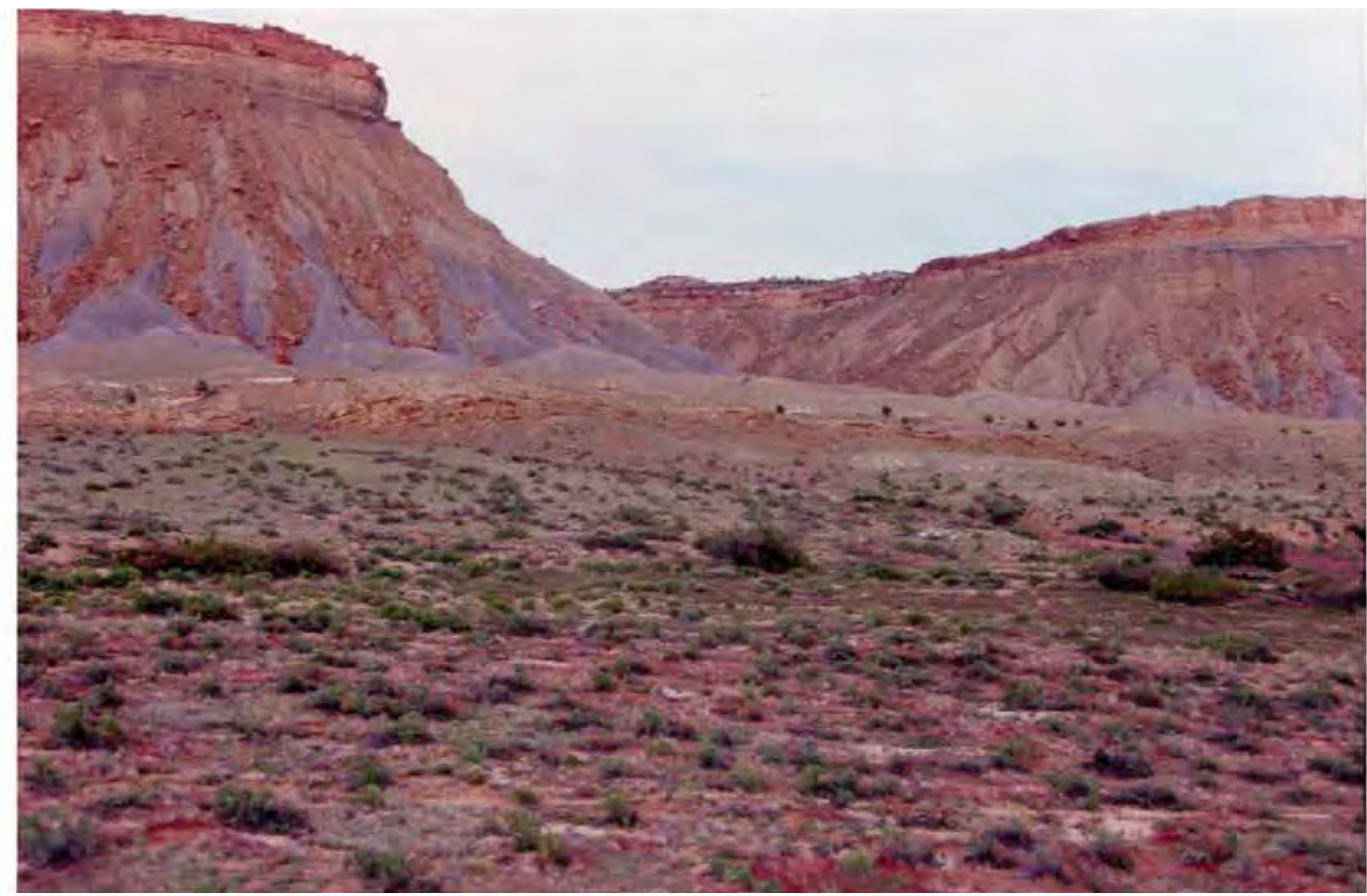




\section{Plate HM-265}

\section{Bull Mountain}

$1974 \div 2011$

In 1974 the BLM established the Plot 5 range monitoring site on the Hanksville Allotment. The photo point is near the head of Halfway Wash; the view is southwest to Bull Mountain. All the steel stakes are still present, but the red steel fencepost in the original photo has been painted white.

Blackbrush has increased, as has pinyon-juniper in the distance. Horseshoe Ridge (far-right skyline) burned in the 2003 Lonesome Beaver Fire. Other plants in the foreground include curly grass, cheatgrass, rubber rabbitbrush, Mormon tea, and big sagebrush. Mule deer have heavily browsed the sagebrush.

Original photograph taken by the BLM on August 22, 1974; retake made by Charles E. Kay on June 16, 2011 (print from a color slide). Section 28, Range 11 East, Township 30 South; UTM 524529E, 4225861N; elevation $5,742 \mathrm{ft}$. Original image held in the BLM’s range files, Hanksville, UT. 


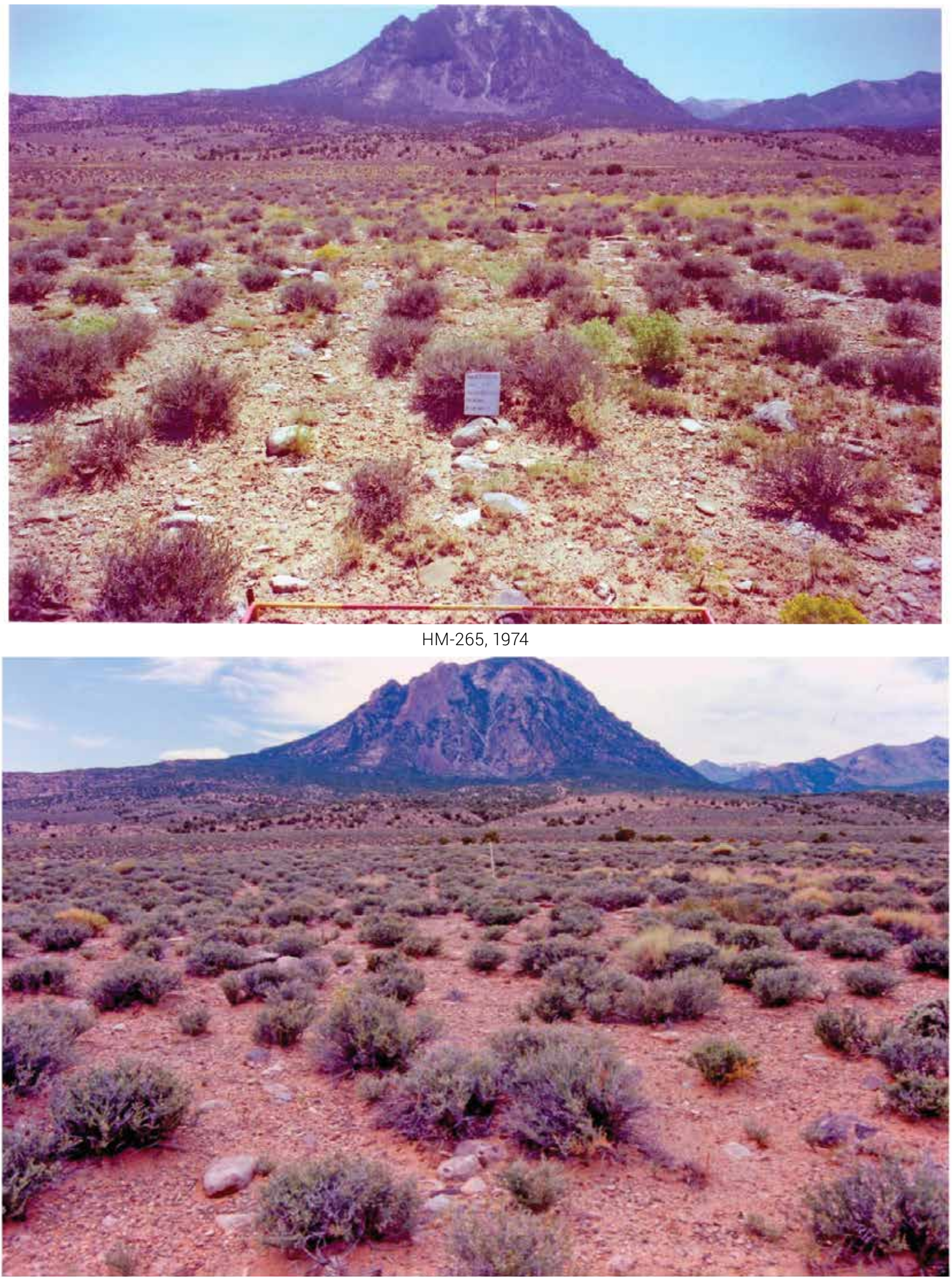

HM-265, 2011 


\section{Plate HM-269}

\section{Upper Poison Spring Flat}

1972 ¡ 2011

In 1972 the BLM established the Plot 1 range monitoring site on the Burr Point Allotment. The photo point is approximately $1 \frac{1}{1} 2$ miles west of Poison Spring. The view is to the southeast, and all the steel stakes are still present.

Blackbrush has increased, as has juniper in the distance. Other species include curly grass, snakeweed, cheatgrass, and locoweed. Ground cover appears to have improved.

Original photograph taken by the BLM on August 17, 1972; retake made by Charles E. Kay on June 17, 2011 (print from a color slide). Section 3, Range 11 East, Township 31 South; UTM 528345E, 4221421N; elevation 5,445 ft. Original image held in the BLM’s range files, Hanksville, UT. 


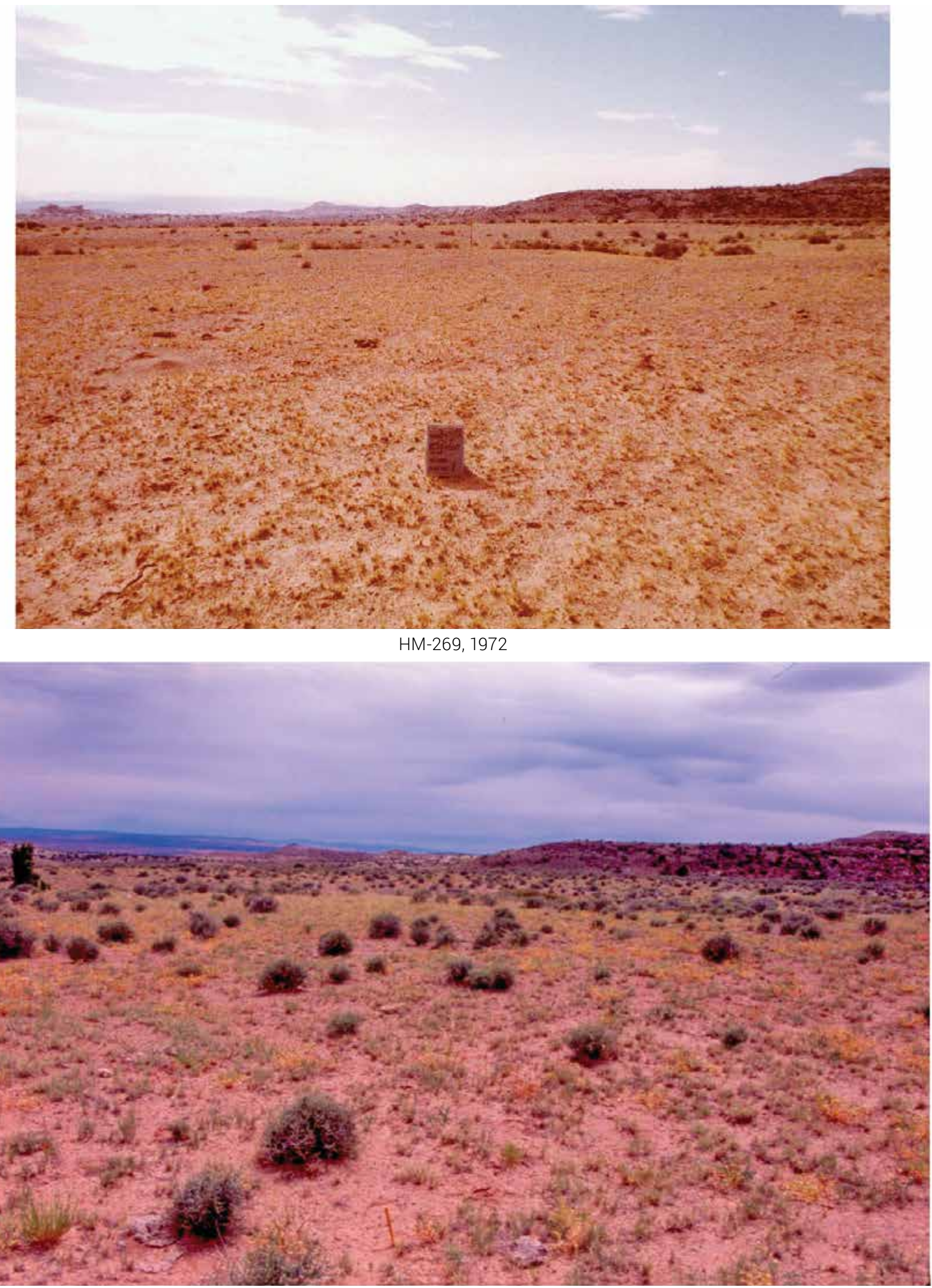

HM-269, 2011 


\section{Plate HM-270}

\section{Granite Creek}

$1937 \because 2011$

Viewed northwest across Granite Creek to the northeastern slopes of Bull Mountain. The photo point is approximately 2 miles east of Poison Spring and is on top of a small, white-colored hill.

Blackbrush has increased, as has juniper. Mormon tea and rubber rabbitbrush are also present, as is curly grass and Indian ricegrass.

Original photograph taken by Charles B. Hunt (Number 551) in May 1937; retake was made by Charles E. Kay on June 17, 2011 (Photo No. 6156-1). Section 3, Range 11 East, Township 31 South; UTM 527094E, 4221083N; elevation 5,658 ft. Original image held by the U.S. Geological Survey Photographic Library, Denver, CO. 


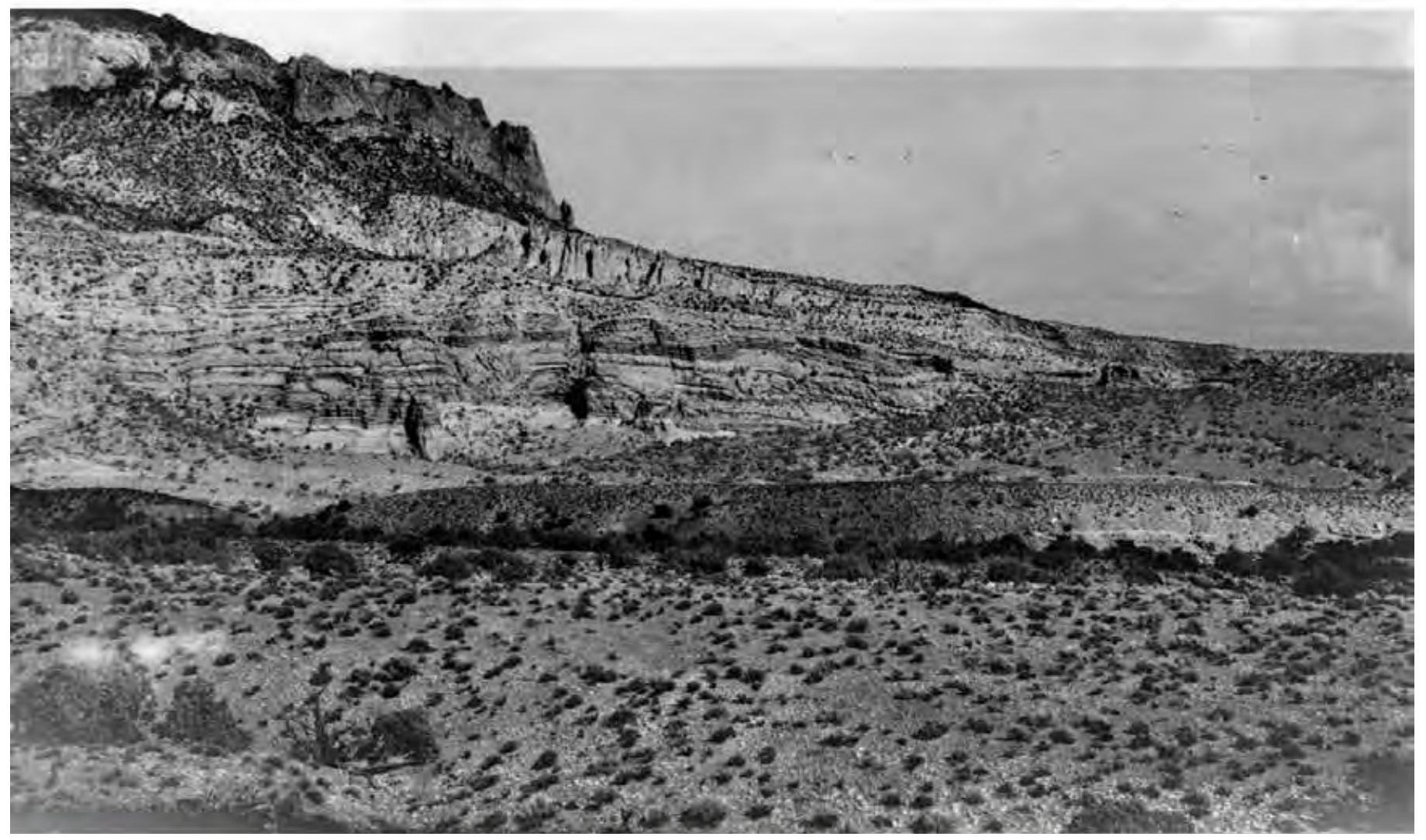

HM-270, 1937

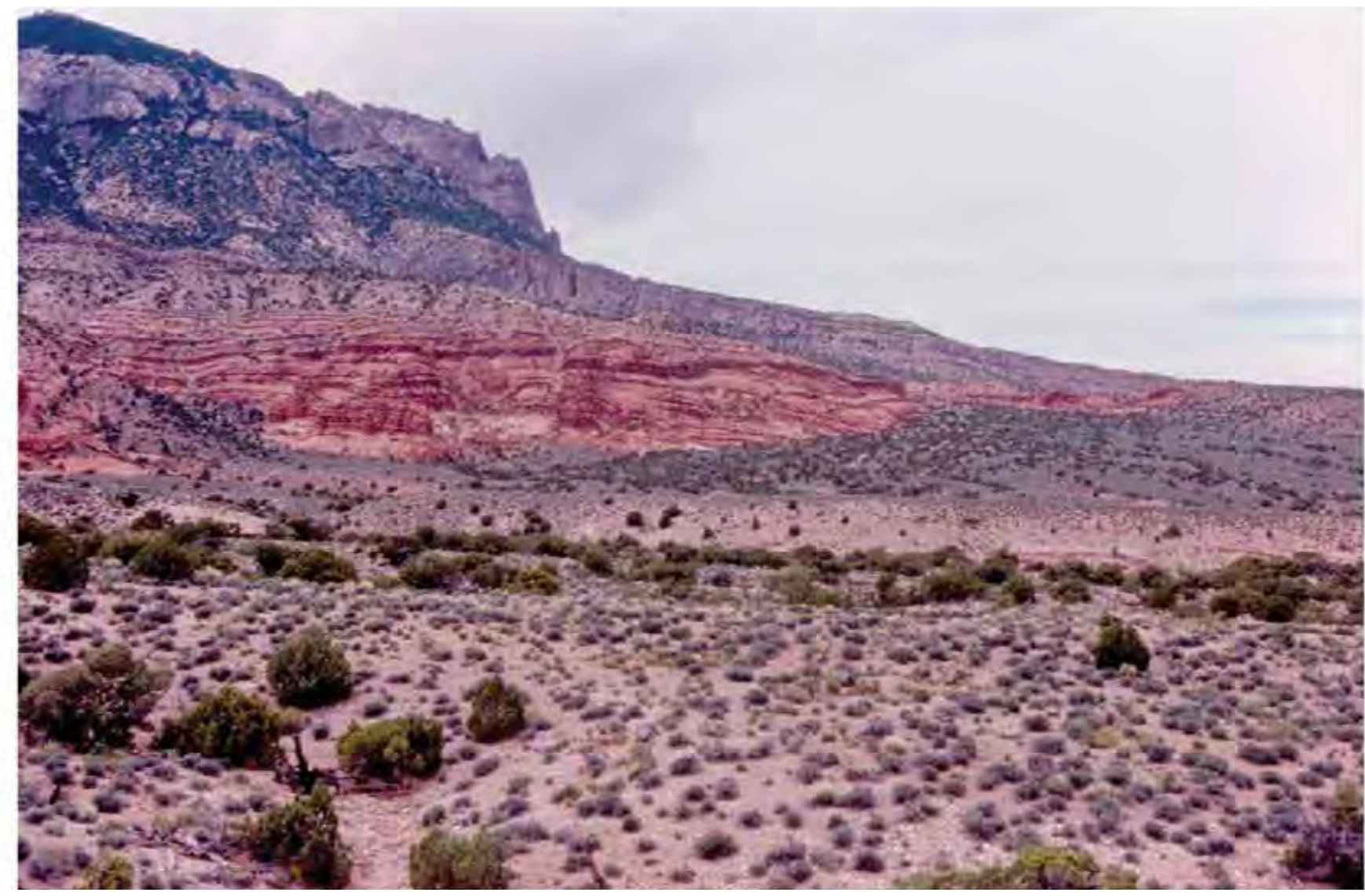

HM-270, 2011 


\section{Plate HM-272}

\section{Butler Wash Bench}

$1967 \div 2011$

In 1967 the BLM established the Eagle Bench 2 range monitoring site on the Crescent Creek Allotment, just after the area had been treated to remove pinyon-juniper. The view is to the south across Butler Wash, with Mount Hillers on the distant skyline. All the steel stakes are still present.

Pinyon and juniper that became established after the 1967 treatment were recently cleared by hand-felling. Mountain big sagebrush and black sagebrush have increased. Other plants include snakeweed, phlox, Mormon tea, crested wheatgrass, and squirreltail.

Original photograph taken by the BLM on August 31, 1967; retake made by Charles E. Kay on June 18, 2011 (print from a color slide). Section 20, Range 11 East, Township 31 South; UTM 524075E, 4216071N; elevation $6,866 \mathrm{ft}$. Original image held in the BLM’s range files, Hanksville, UT. 


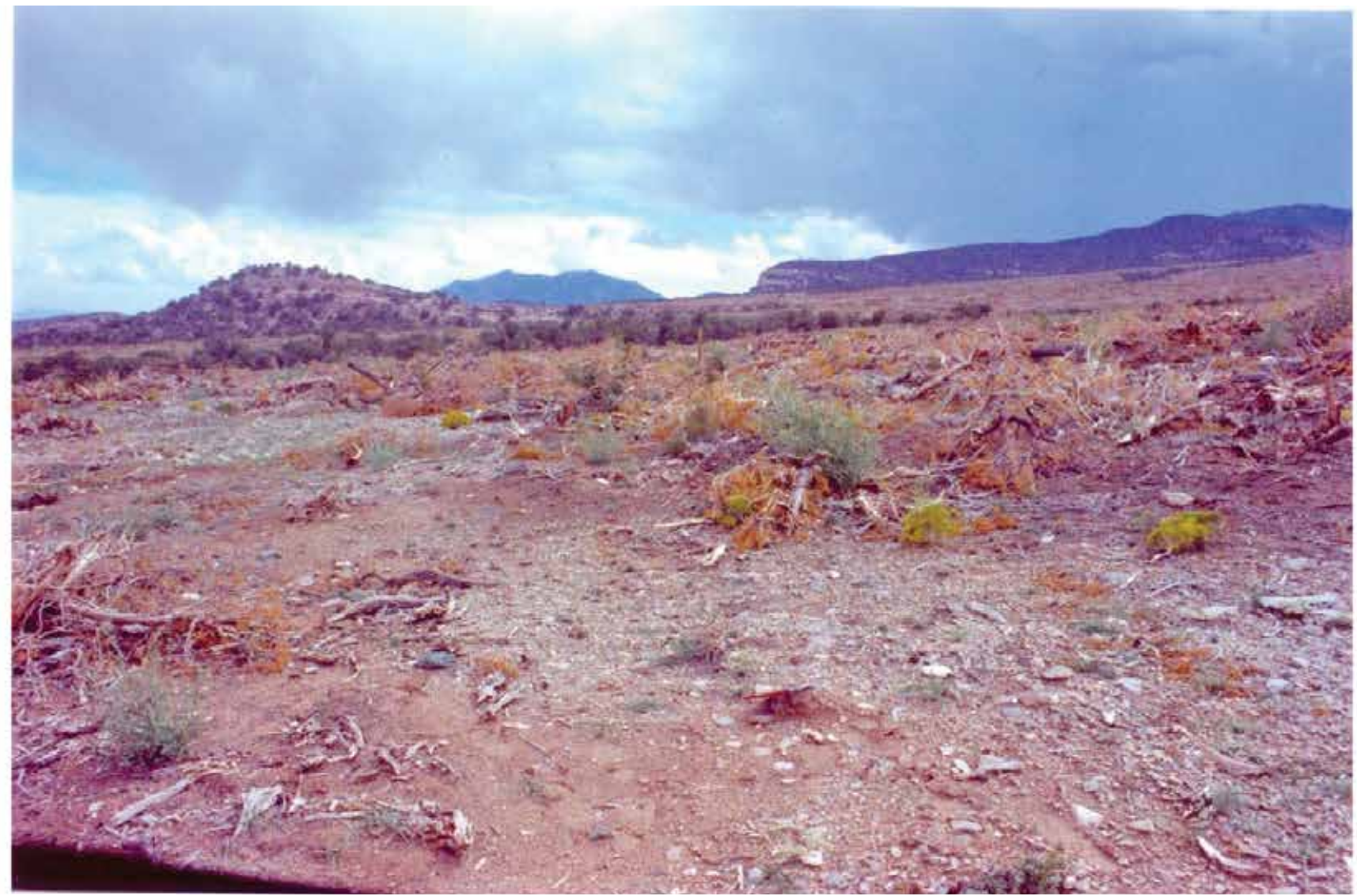

HM-272, 1967

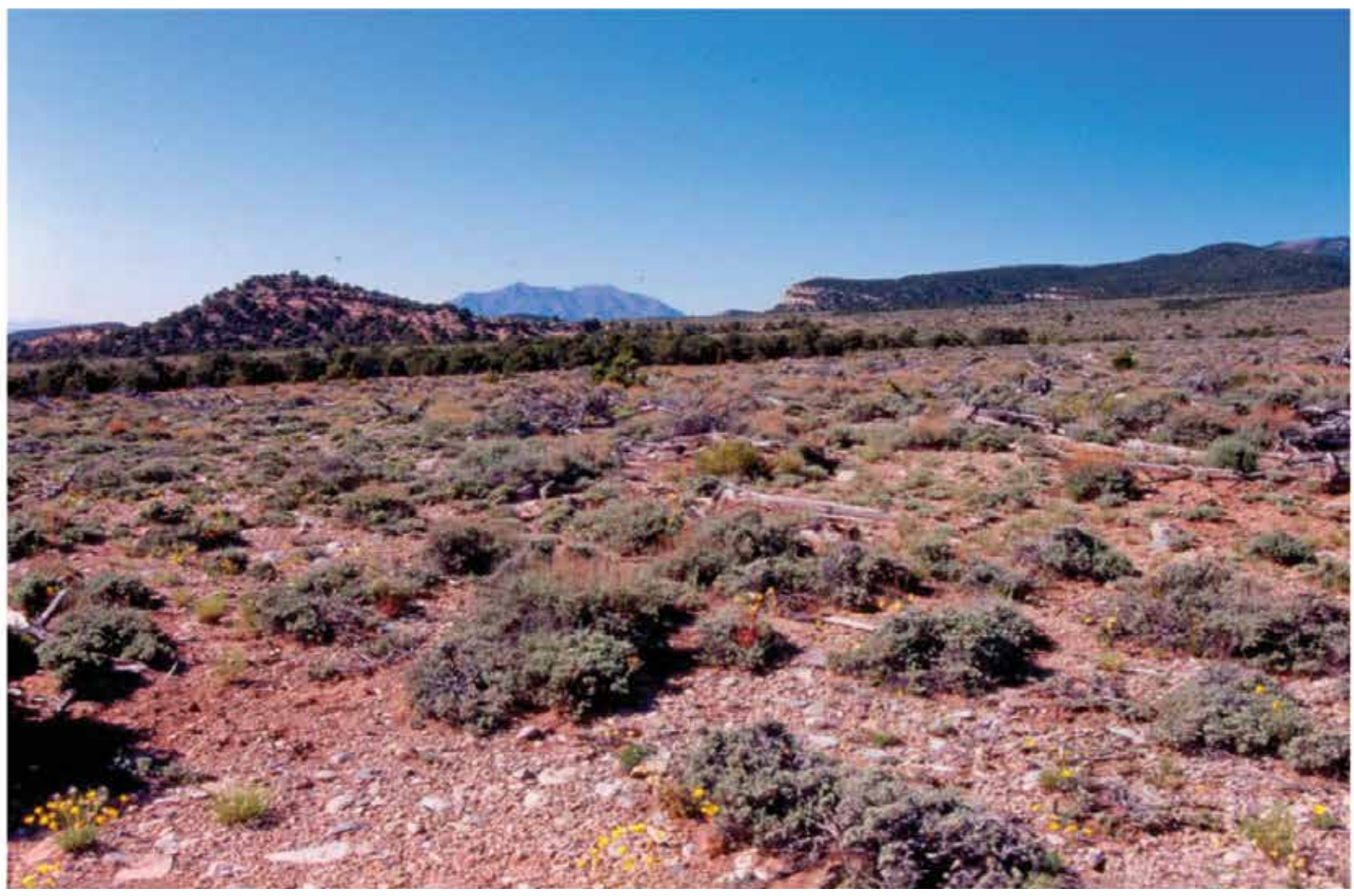

HM-272, 2011 


\section{Plate HM-277}

\section{Coyote Benches}

$1968 \div 2011$

In 1968 the BLM established the Wolverton 6 range monitoring site on the Pennell Allotment. The view is south to Mount Hillers, most of which burned in the 2003 Bulldog Fire.

This monitoring site was established shortly after the area was chained to remove pinyon and juniper, but before the area was reseeded with crested wheatgrass. Much of the area shown in the foreground was recently re-treated to remove pinyon and juniper established since the earlier treatment, and in that process all the steel stakes were destroyed. The area on the right and in the distance was not re-treated and is again dominated by pinyon-juniper. The most common plants in the foreground include crested wheatgrass, alfalfa, and mountain big sagebrush, with only a trace of cheatgrass.

Original photograph taken by the BLM on July 25, 1968; retake made by Charles E. Kay on June 19, 2011 (print from a color slide). Section 4, Range 11 East, Township 33 South; UTM 525426E, 4201679N; elevation 6,467 ft. Original image held in the BLM's range files, Hanksville, UT. 


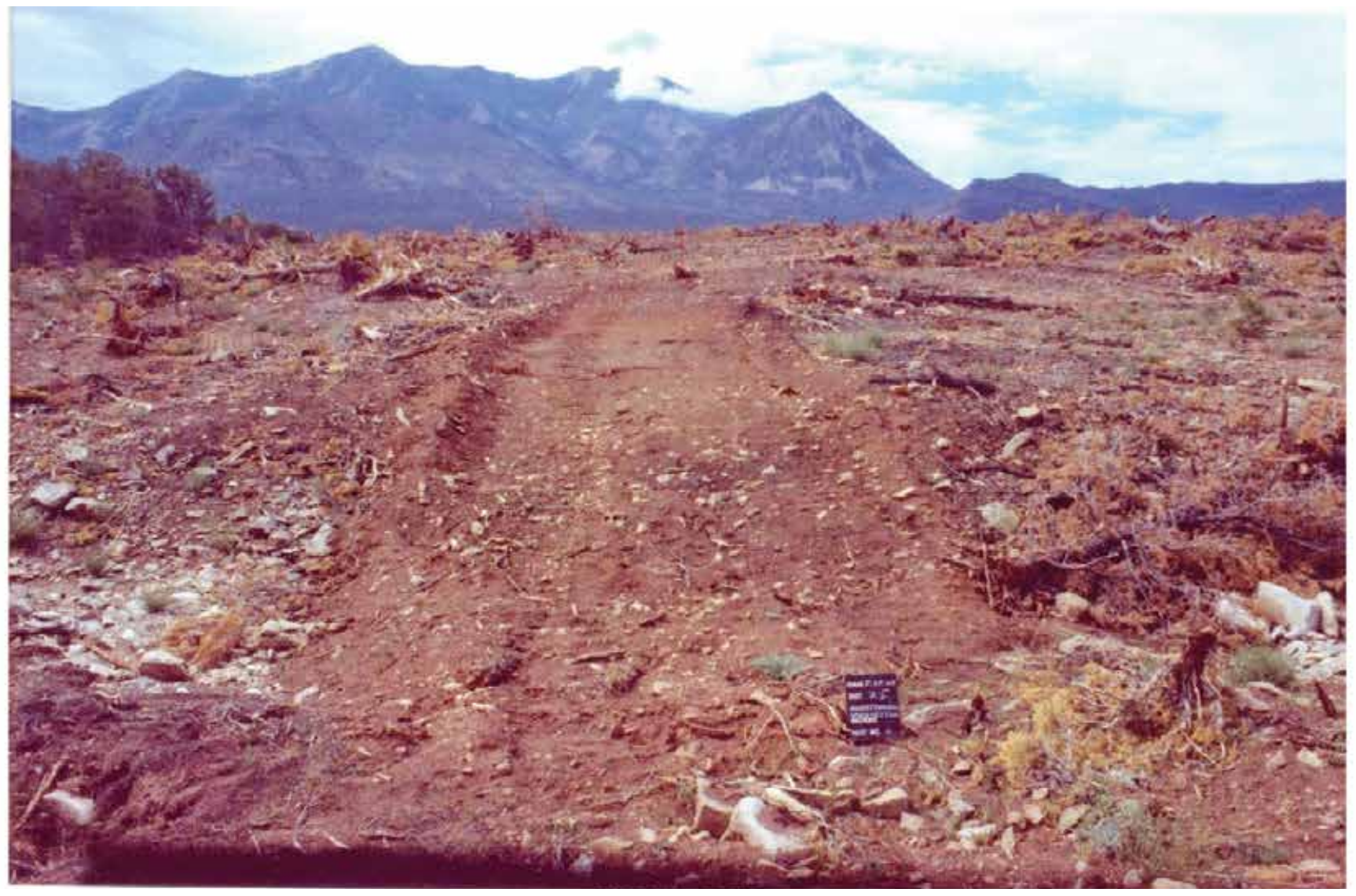

HM-277, 1968

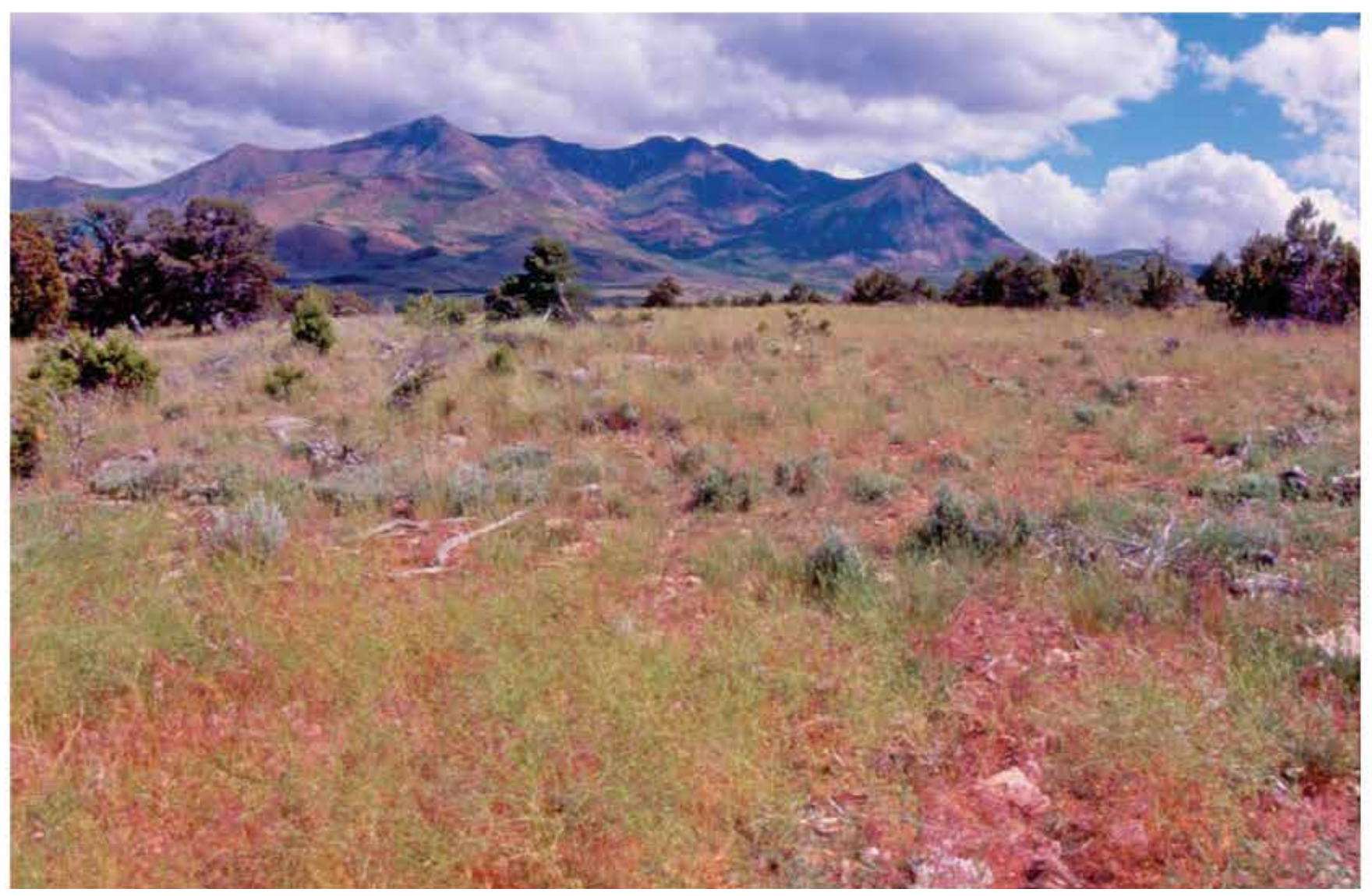




\section{Plate HM-278}

\section{BROWNS KNOLL}

$1969: 2011$

In 1969 the BLM established the Bulldog 8 range monitoring site on the Pennell Allotment. The view is to the southwest. The entire area burned in the 2003 Bulldog Fire. All the steel stakes were destroyed when, after the fire, the site was scarified before reseeding. The boulder seen behind the red steel fencepost in the 1969 image was moved down-slope to plug a small gully.

Mountain big sagebrush, which is killed by fire, has decreased; oak brush, which resprouts after fire, has increased. The grasses are primarily crested and intermediate wheatgrass, both of which were planted. Lupine and yarrow are also present.

Original photograph taken by the BLM on August 31, 1969; retake made by Charles E. Kay on June 20, 2011 (print from a color slide). Section 18, Range 11 East, Township 33 South; UTM 522083E, 4198357N; elevation 8,011 ft. Original image held in the BLM’s range files, Hanksville, UT. 


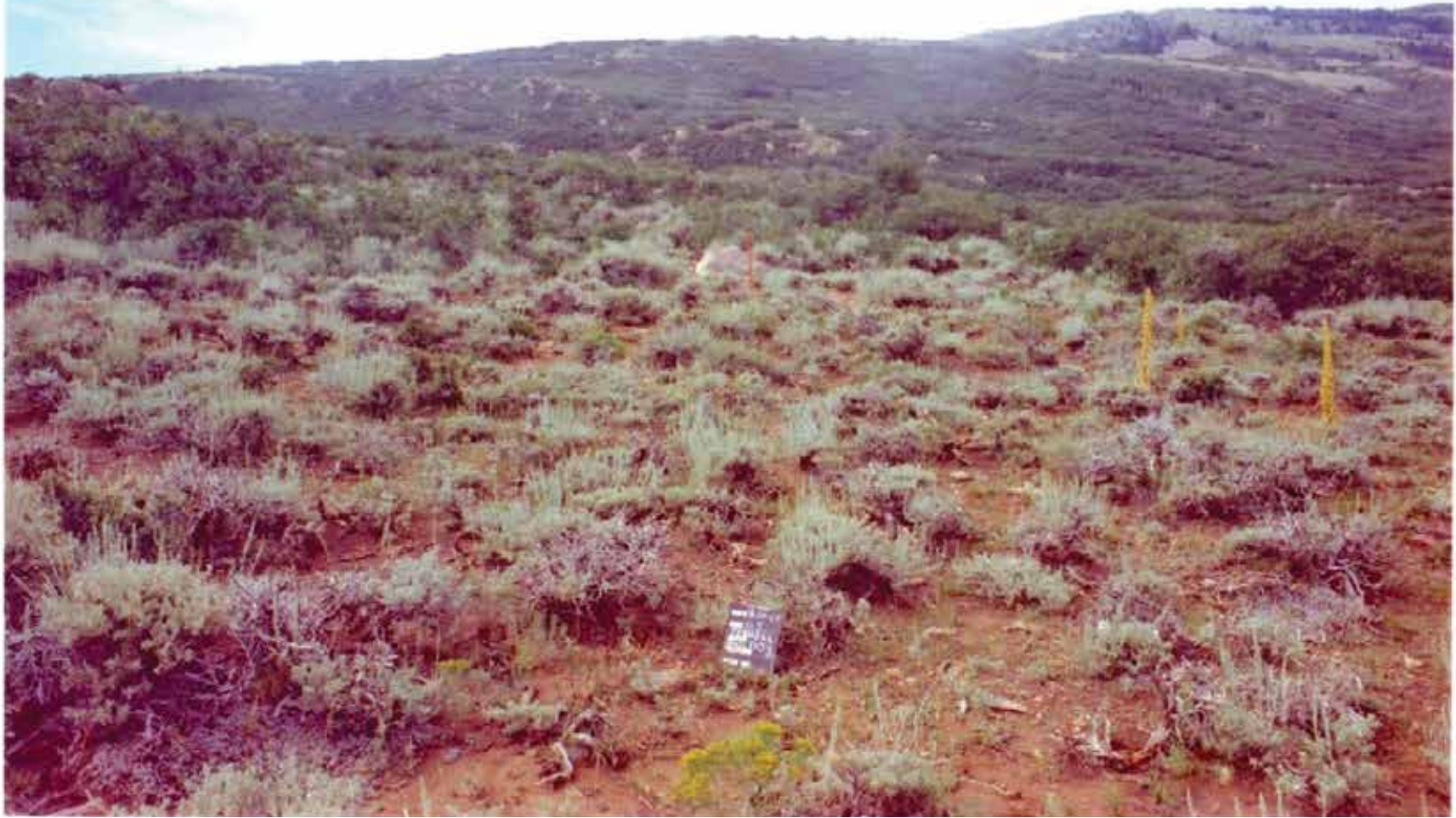

HM-278, 1969

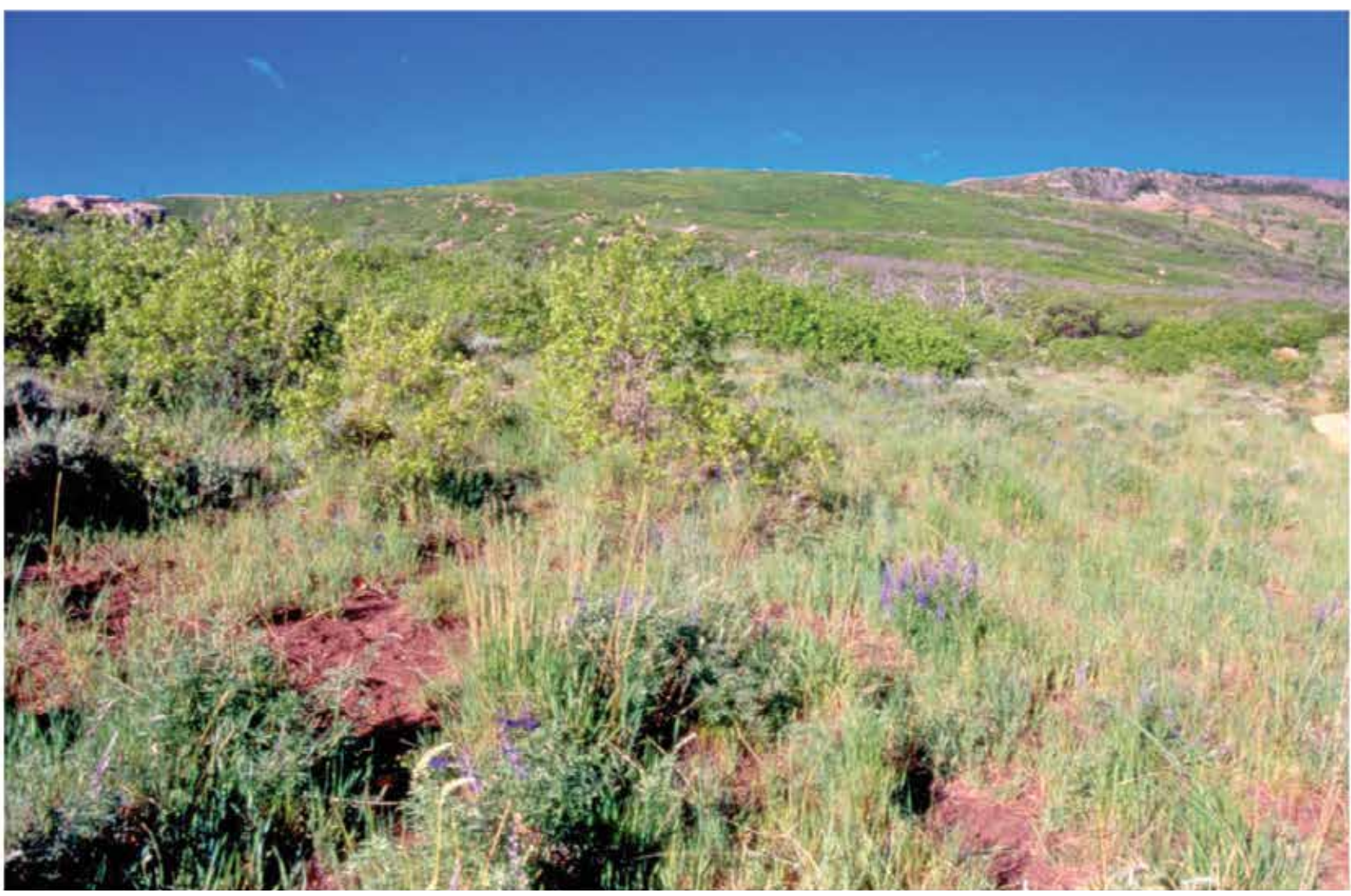

HM-278, 2011 


\section{Plate HM-279}

\section{Mud Spring}

$1968 \div 2011$

In 1968 the BLM established the Bulldog 7 range monitoring site on the Pennell Allotment. The view is to the southwest and is approximately $3 / 4$ of a mile west of the fenced area at Mud Spring, on the southern shoulder of Mount Pennell. Most of the area was burned by the 2003 Bulldog Fire. The site, though, was not reseeded after the fire, and all the steel stakes still exist. The camera station is 50 yards north of where the $4 \times 4$ track forks (note the vehicle in the retake).

Oak brush has resprouted in the distance, and mountain big sagebrush has regrown from seed. The area is heavily used by cattle and bison, and there are few grasses-needle and thread and cheatgrass being the most common. Lupine and yarrow are also present.

Original photograph taken by the BLM on July 31, 1968; retake made by Charles E. Kay on June 20, 2011 (print from a color slide). Section 25, Range 10 East, Township 33 South; UTM 521106E, 4196187N; elevation 7,731 ft. Original image held in the BLM's range files, Hanksville, UT. 


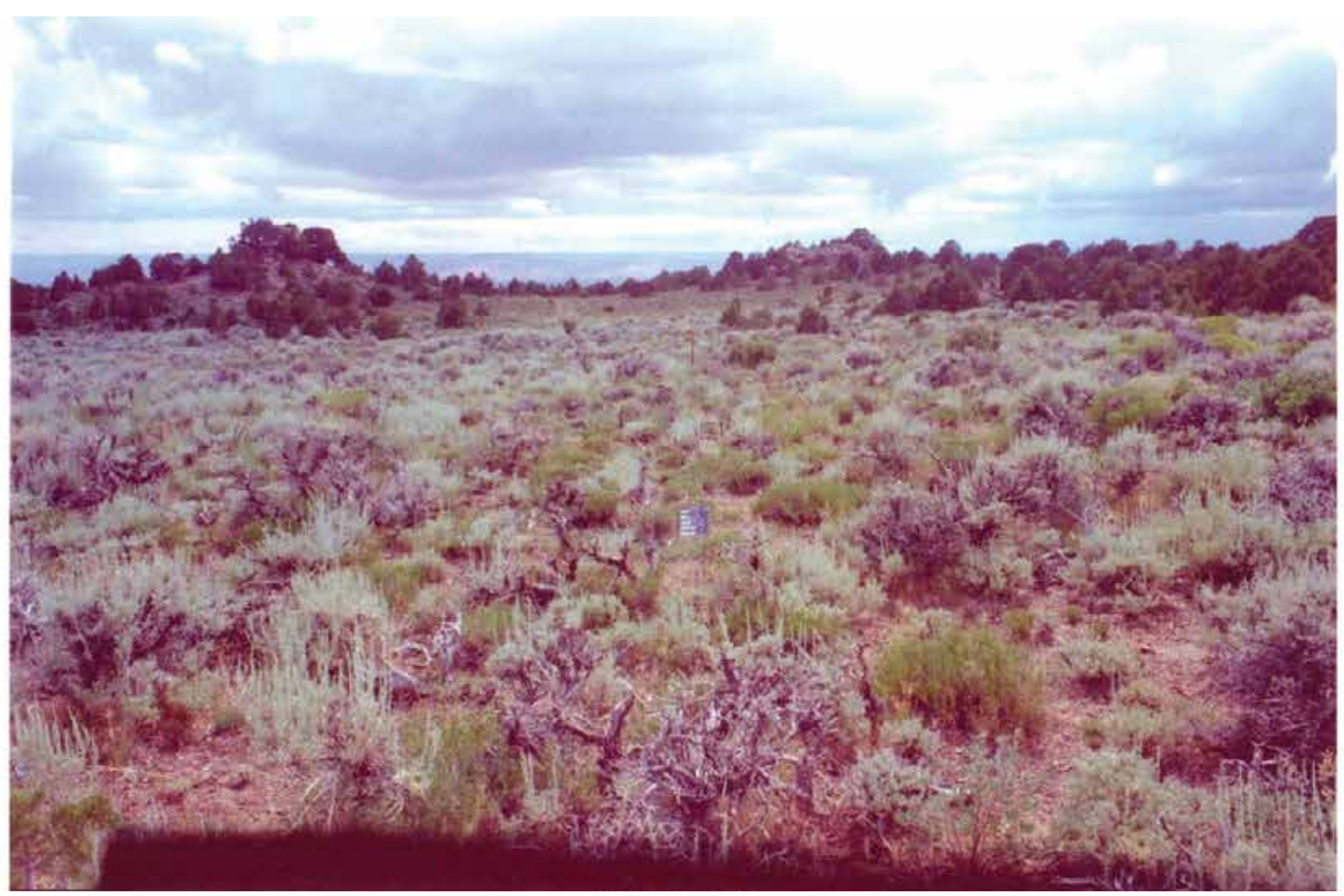

HM-279, 1968

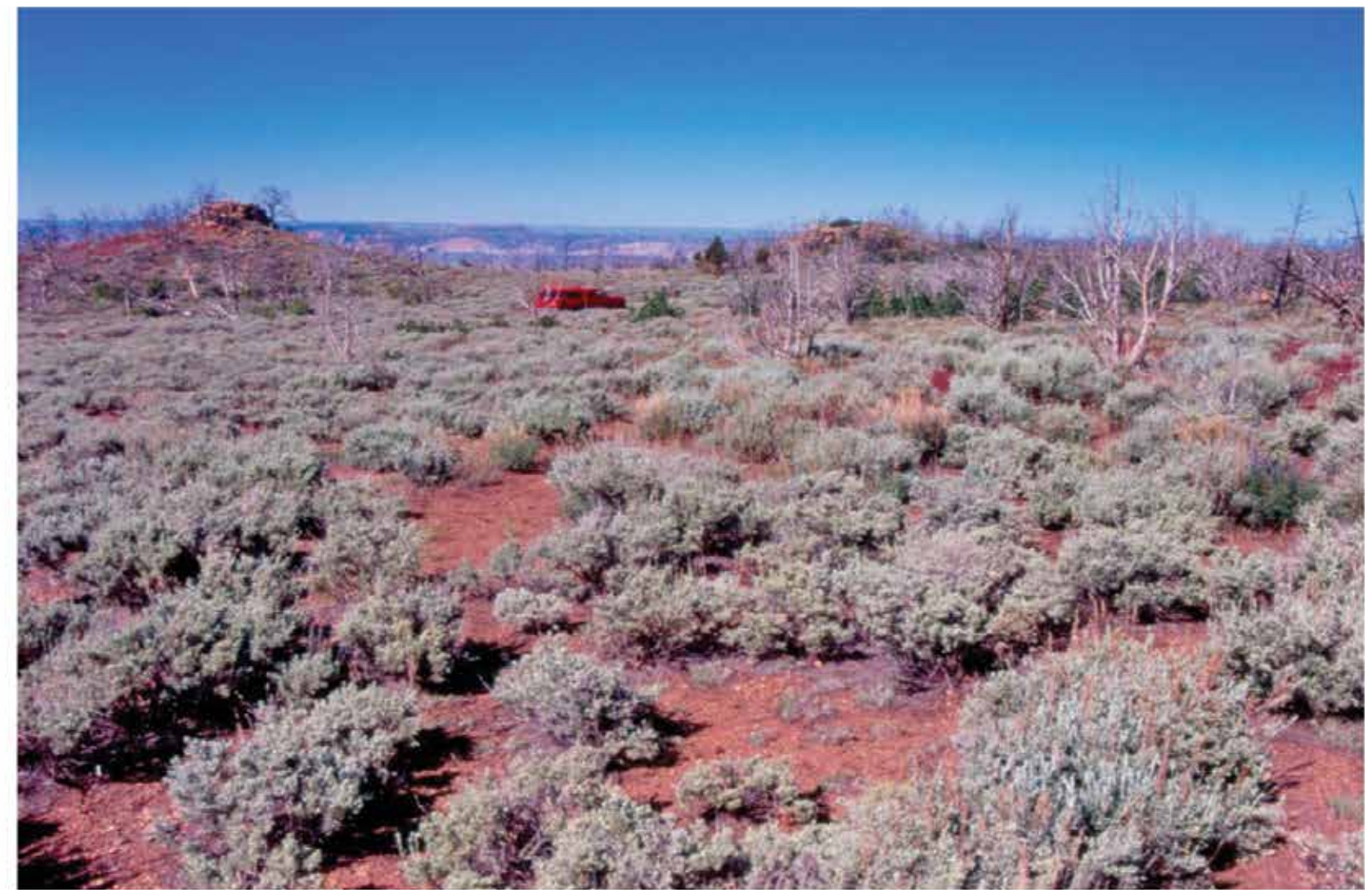

HM-279, 2011 


\section{Plate HM-283}

\section{Horn Spring Basin}

$1968: 2011$

In 1968 the BLM established the Horn 7 range monitoring site on the Pennell Allotment. The view is to the south, on the northern slopes of Mount Pennell. The site is about 300 yards north of the road to Hancock Spring. All the steel stakes are still present.

Conifers, primarily Douglas-fir and limber pine, have increased on the distant hill, while aspen (right-center edge) has successfully regenerated without fire or other disturbance. In the retake, significant tree mortality caused by the Douglas-fir beetle can be seen on the peak in the distance. Mountain big sagebrush and black sage have increased, as has soil erosion from the gully (left-center). The low mound (left-center edge) is the berm of a stock pond. Sheep fescue, locoweed, phlox, groundsel, and fleabane daisy are also present.

Original photograph taken by the BLM on August 23, 1968; retake made by Charles E. Kay on June 20, 2011 (print from a color slide). Section 34, Range 10 East, Township 32 South; UTM 517785E, 4203840N; elevation 8,850 ft. Original image held in the BLM's range files, Hanksville, UT. 


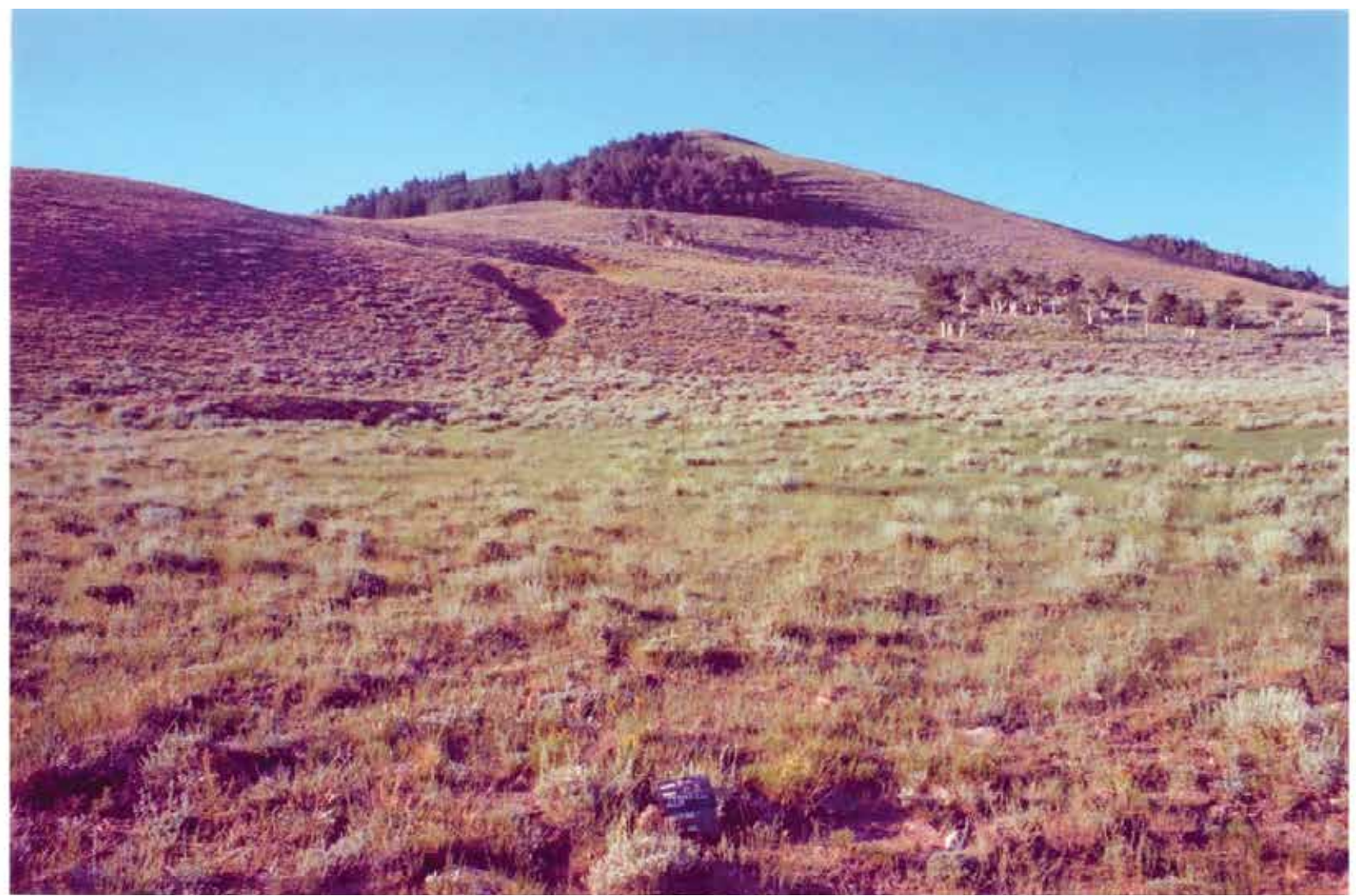

HM-283, 1968

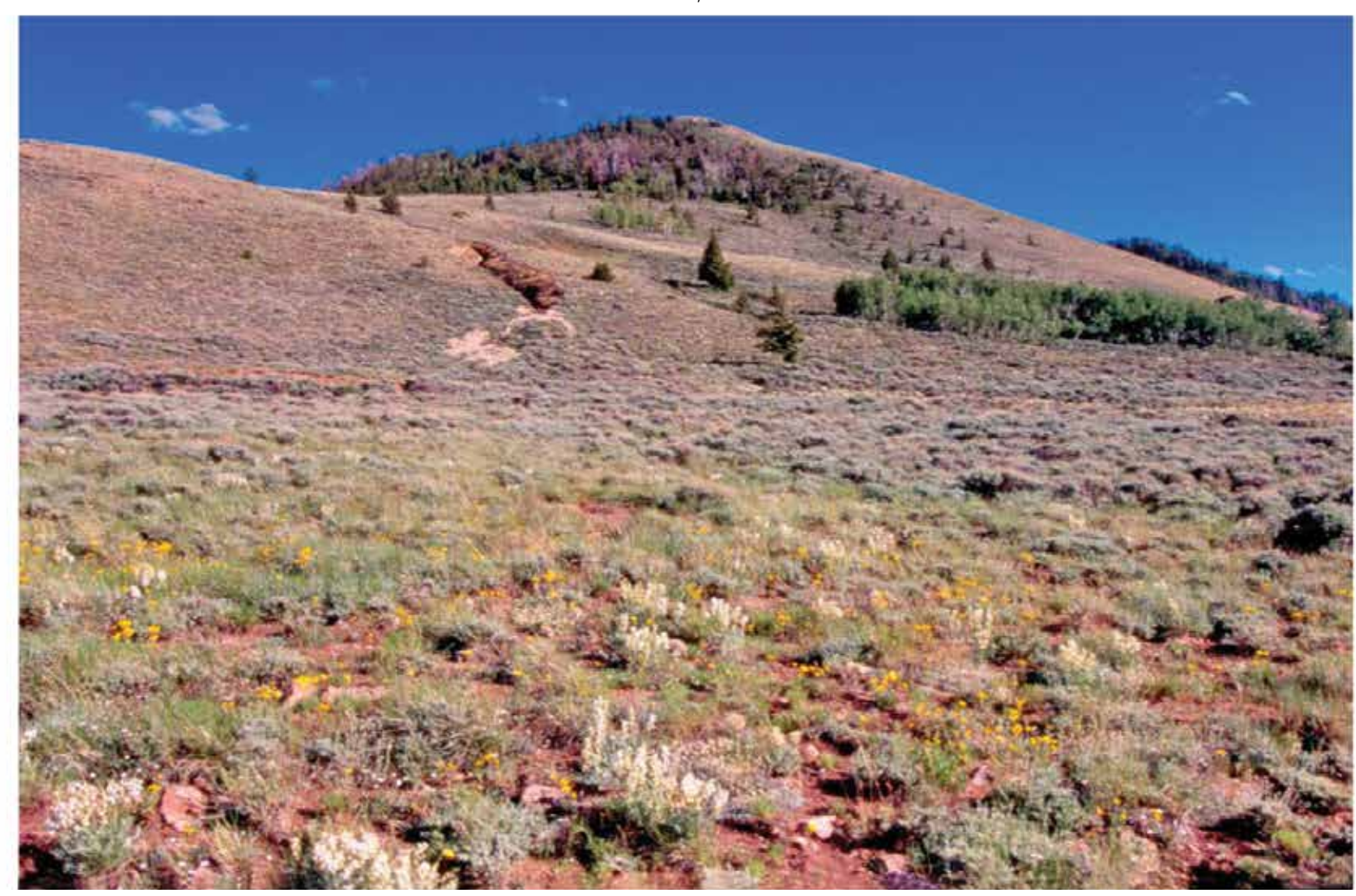

HM-283, 2011 


\section{Plate HM-284}

\section{Pennell Pass}

$1969: 2011$

In 1969 the BLM established the Horn 1 range monitoring site on the Pennell Allotment. The site is approximately 400 yards northwest of Pennell Pass. Mount Pennell is on the left skyline. All steel stakes are still present, although the original red steel fencepost has been painted yellow.

Immediately before the 1969 photo, the site had been chained to eliminate pinyon-juniper and was reseeded with crested wheatgrass. Pinyon and juniper that subsequently became established were recently removed by hand-felling. The tall, dark green shrubs in the retake are Utah serviceberry. Mountain big sagebrush and bitterbrush have also become established. The most common grass is crested wheatgrass.

Original photograph taken by the BLM on September 10, 1969; retake made by Charles E. Kay on June 21, 2011 (print from a color slide). Section 21, Range 10 East, Township 32 South; UTM 516532E, 4207239N; elevation 7,775 ft. Original image held in the BLM’s range files, Hanksville, UT. 


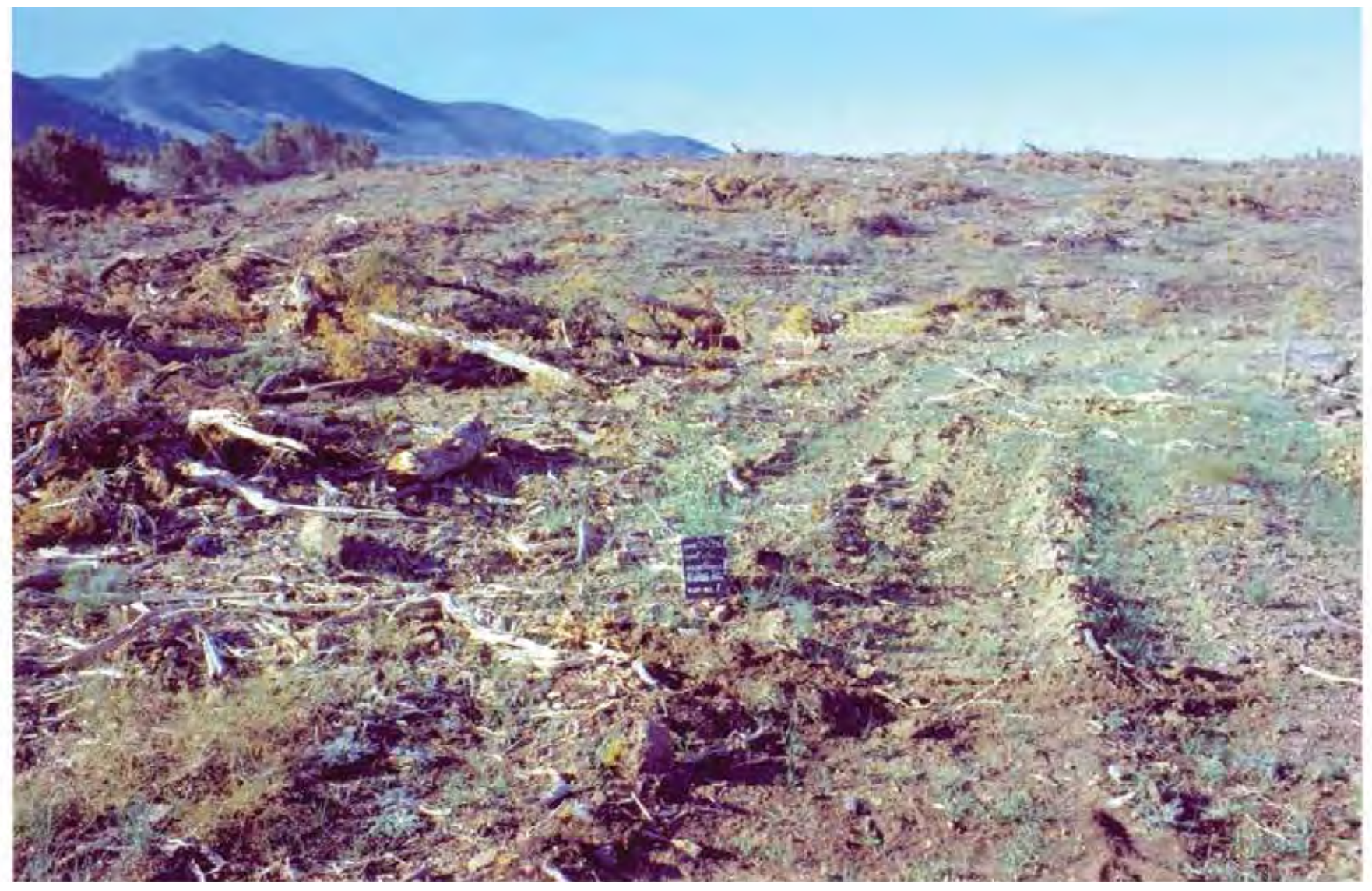

HM-284, 1969

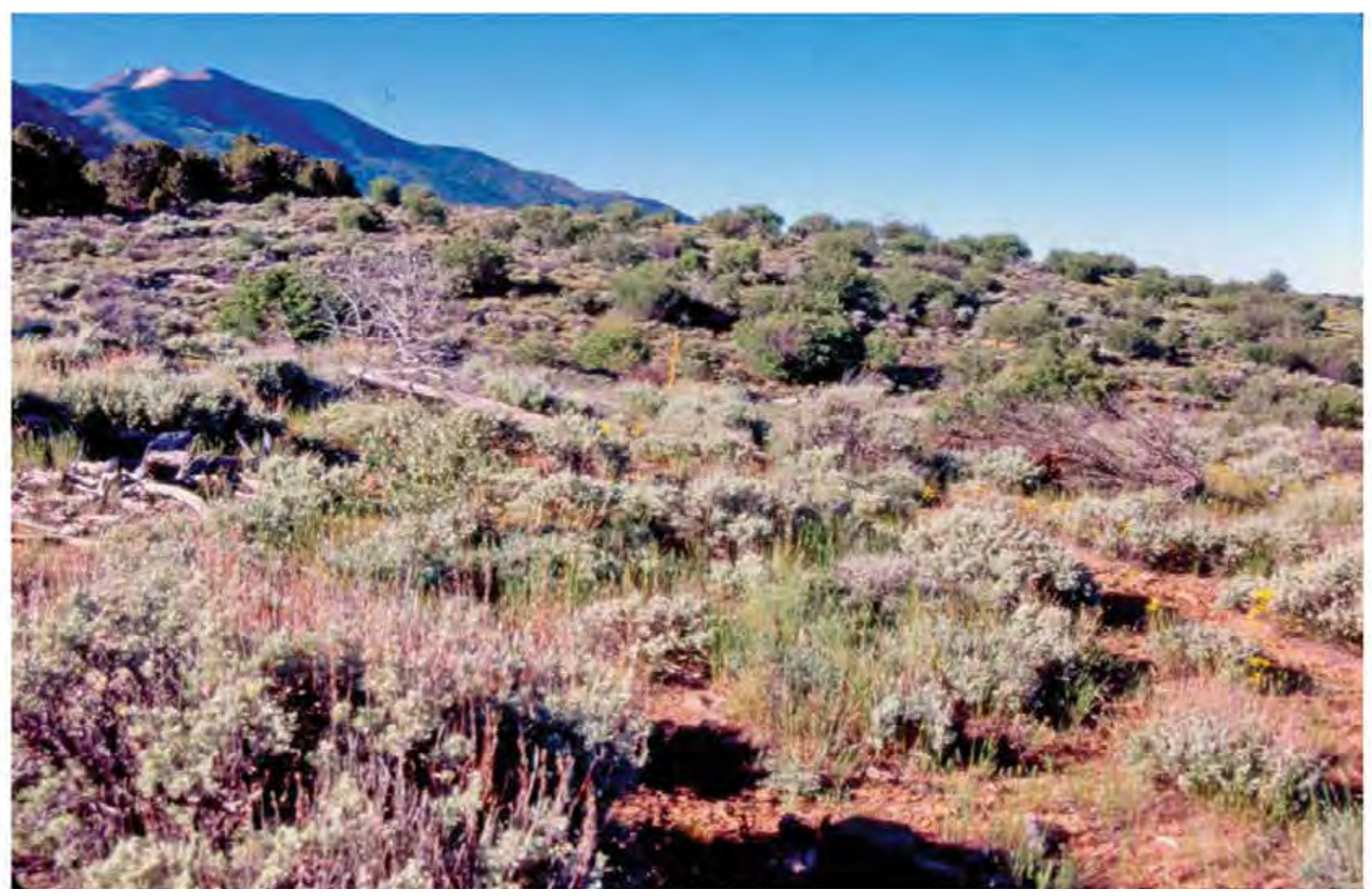

HM-284, 2011 


\section{Plate HM-289}

Slate Creek

$1938 \div 2011$

Viewed north-northwest up Slate Creek to South Summit Ridge. To provide an unobstructed view, the retake was made from the top of a large boulder. The photo point is northeast of The Horn and about $2 / 3$ of a mile below the main road.

Pinyon, juniper, oak brush, and other woody species have all increased. (See also Plate HM-99.) The area in the lower left of the retake burned in the 2003 Bulldog Fire.

Original photograph taken by Charles B. Hunt (Number 818) in September 1938; retake made by Charles E. Kay on June 21, 2011 (Photo No. 6162-14). Section 22, Range 10 East, Township 32 South; UTM 518712E, 4207179N; elevation 7,669 ft. Original image held by the U.S. Geological Survey Photographic Library, Denver, CO. 


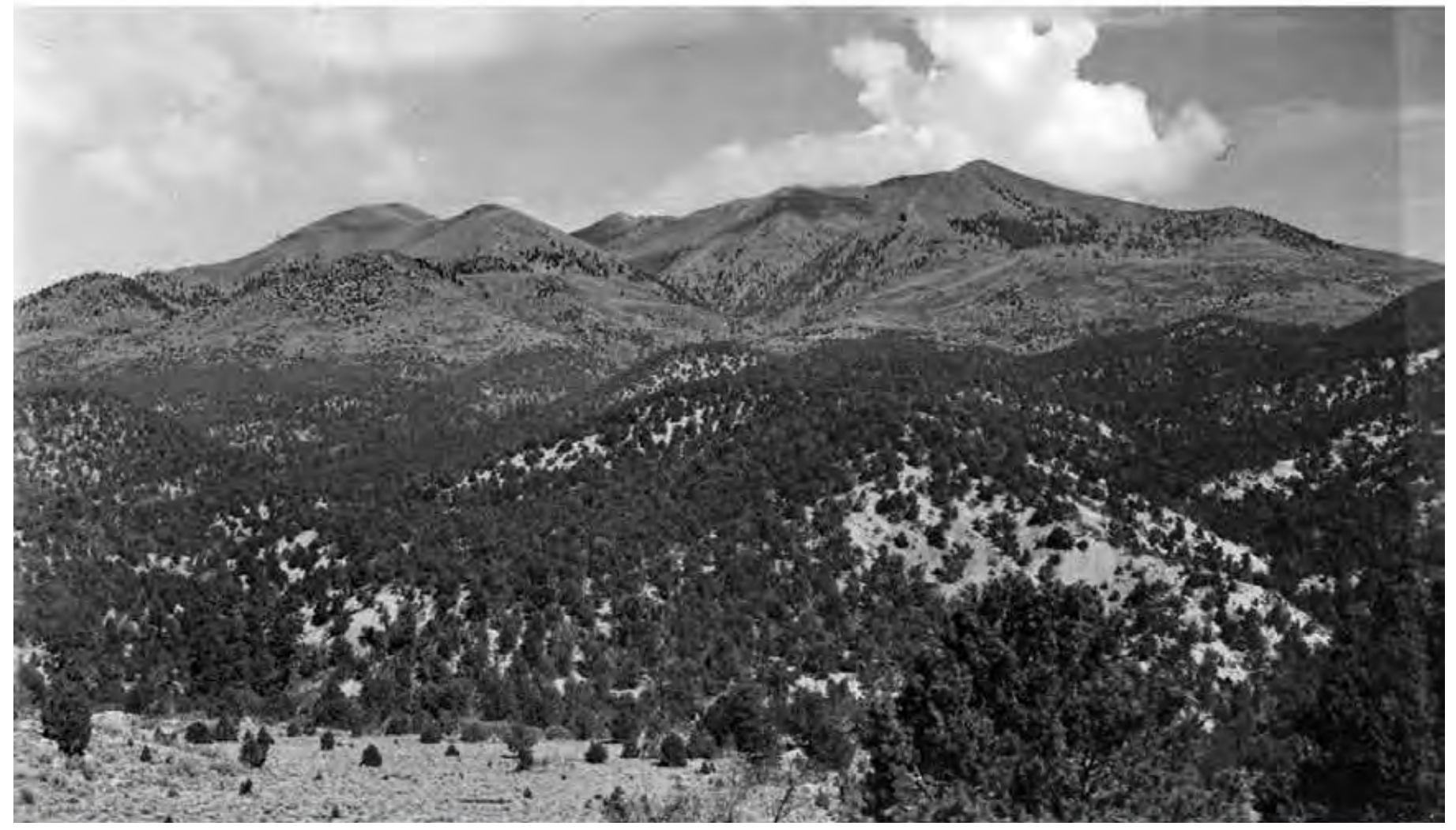

HM-289, 1938

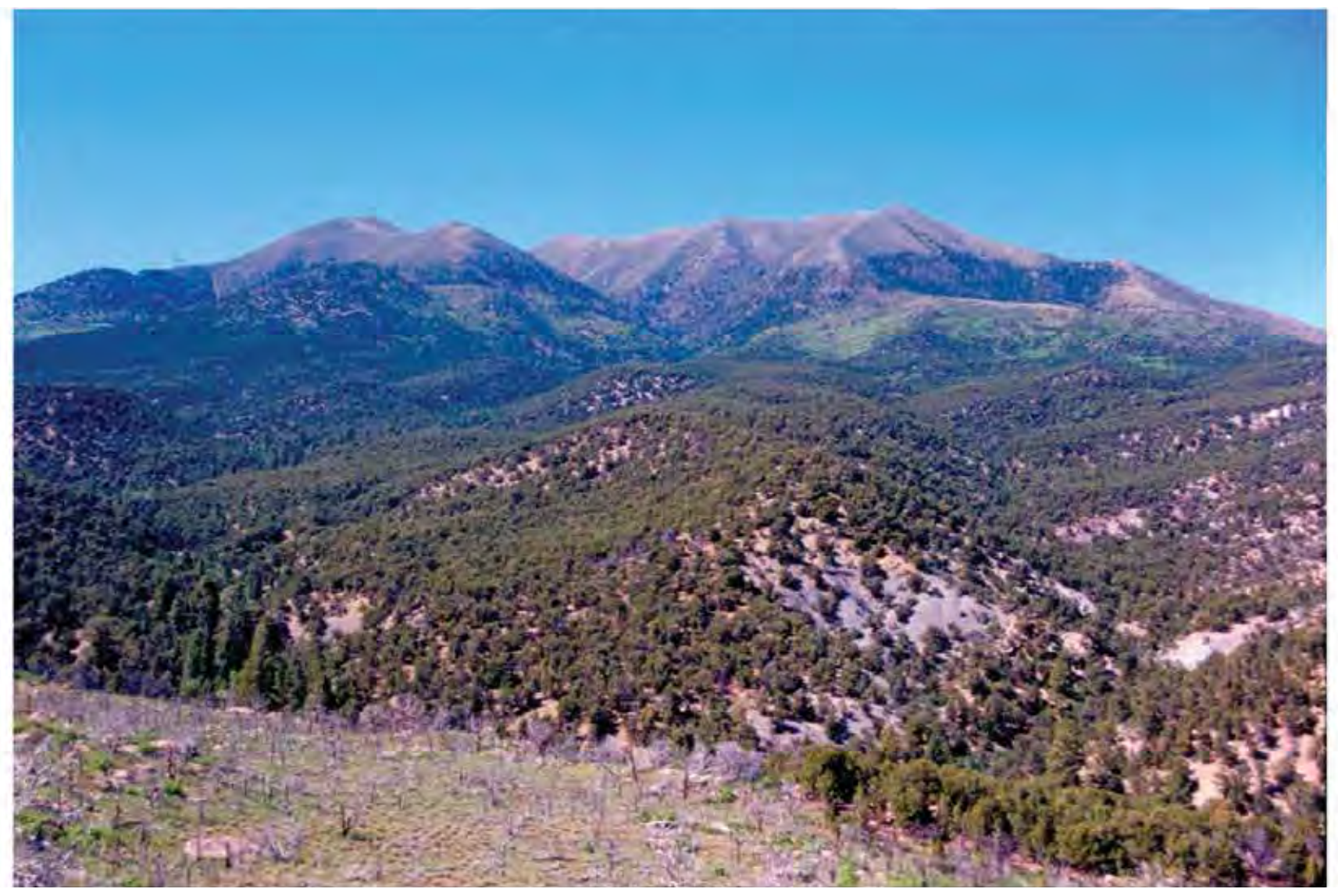

HM-289, 2011 


\section{Plates HM-292 and HM-293}

\section{Cedar Creek Bench}

$1936 \div 2011$

Viewed southwest across Dry Wash from Cedar Creek Bench. Apple Brush Flat is in the distance; Steele Butte is on the skyline (right-center). Plates HM-292 and HM-293 form a panorama. Range monitoring site Steele Butte 7 is on the flat below the $4 \times 4$ track in the retake.

Pinyon and juniper have increased.

Original photographs taken by Charles B. Hunt (Numbers 493 and 494) in 1936; retakes made by Charles E. Kay on June 23, 2011 (Photo Nos. 6162-34 and 6162-31). Section 11, Range 9 East, Township 31 South; UTM 509086E, 4219704N; elevation 6,409 ft. Original images held by the U.S. Geological Survey Photographic Library, Denver, CO. Photo mosaic compiled by Doug Page, BLM, Cedar City, UT. 
㳯
(1)

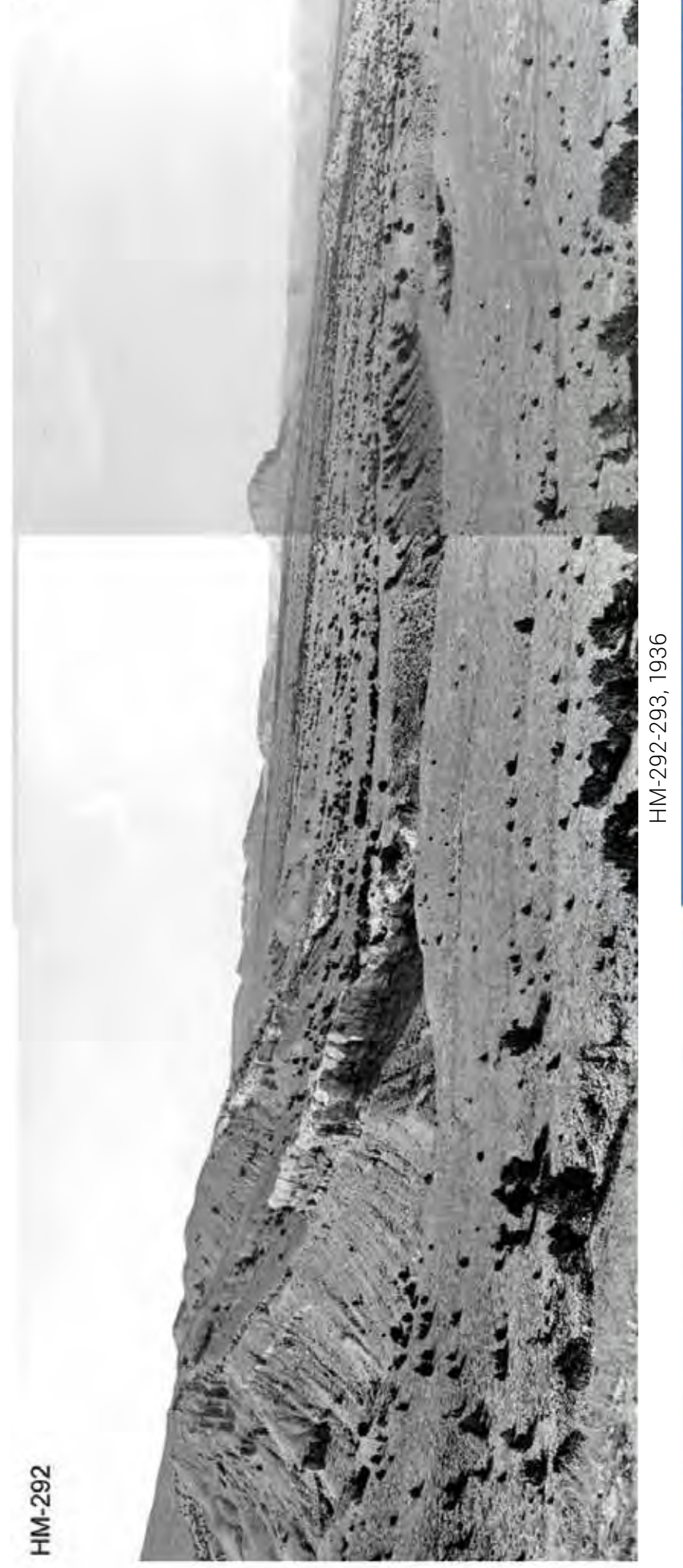

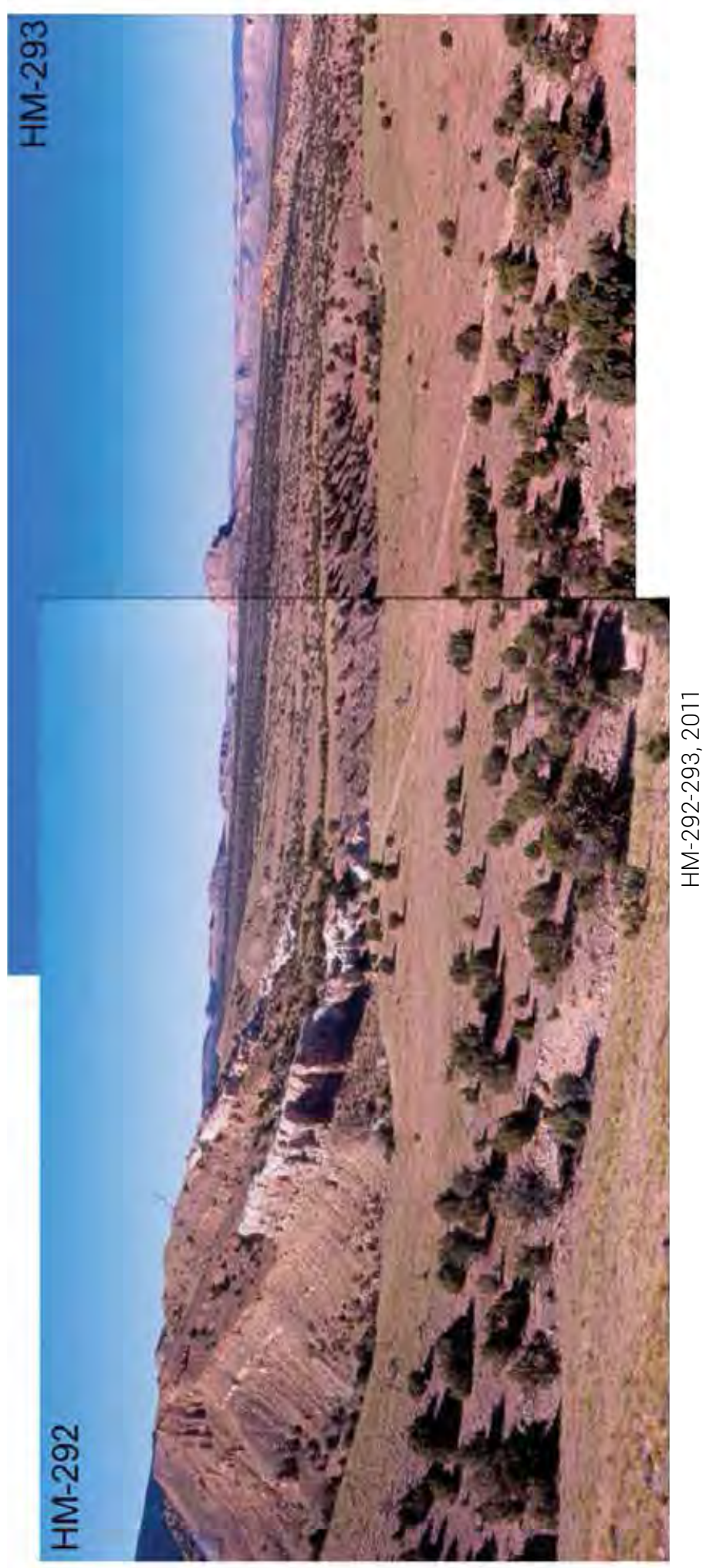


Plate HM-294

Nasty Flat

$1968 \div 2011$

In 1968 the BLM established the Homestead 1 range monitoring site on the Nasty Flat Allotment. The view is to the south, and all the steel stakes still exist.

Mountain big sagebrush has increased, while the aspen stand on the right skyline has declined.

Original photograph taken by the BLM on August 26, 1968; retake made by Charles E. Kay on July 18, 2011 (print from a color slide). Section 33, Range 10 East, Township 31 South; UTM 515957E, 4213277N;

elevation 9,570 ft. Original image held in the BLM’s range files, Hanksville, UT. 


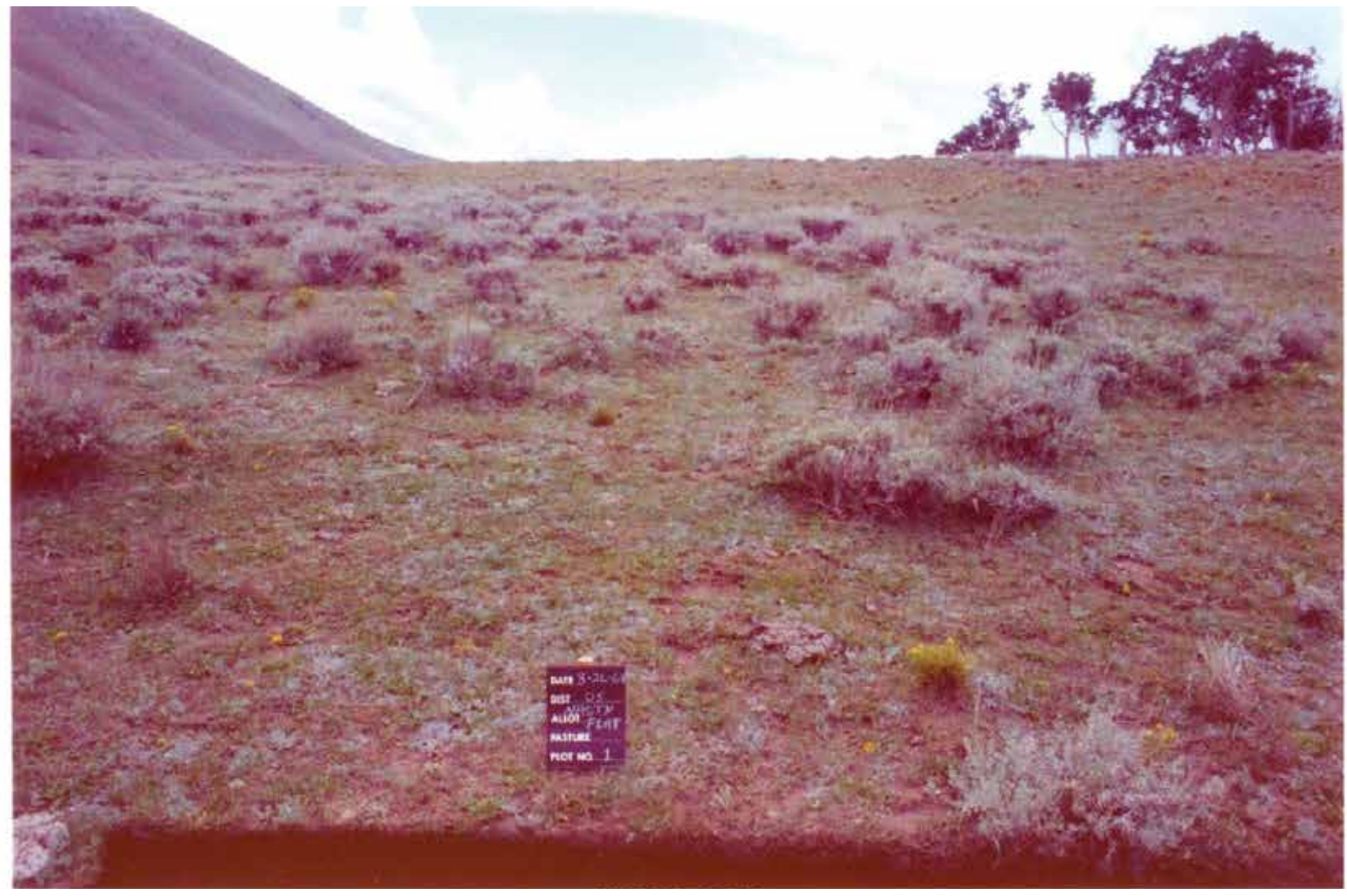

HM-294, 1968

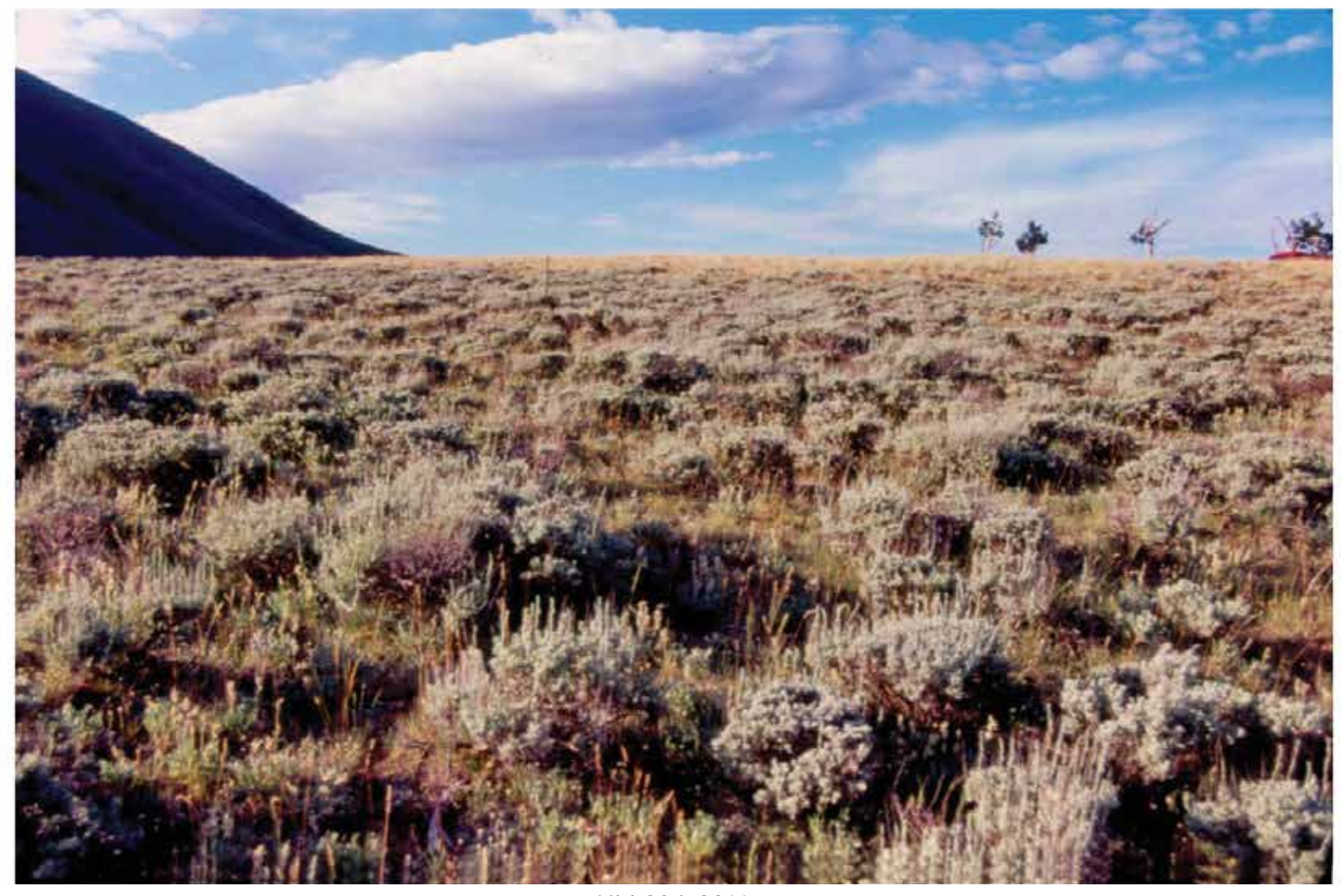

HM-294, 2011 


\section{Plate HM-296}

\section{North Fork of South Creek}

$1937 \div 2011$

Viewed south-southwest across the North Fork of South Creek on the western slopes of South Summit Ridge.

Note the white wall tent and horses in the 1937 image (lower-right-center) for scale. The exposure on the 1937 image was adjusted so that the tent could be seen more readily. The photo point is just above the main road, as seen in the retake.

Conifers, primarily Douglas-fir and limber pine, have increased. Aspen has increased in the foreground area; on the distant ridge, conifers have invaded the aspen. Sagebrush has also increased. Aspen above the stream regenerated 30-40 years ago when mule deer numbers fell, but it has not done so since, as mule deer repeatedly browse any new suckers (Kay and Bartos 2000).

Original photograph taken by Charles B. Hunt (Number 578) in June 1937; retake made by Charles E. Kay on July 18, 2011 (Photo No. 6165-14A). Section 33, Range 10 East, Township 32 South; UTM 516528E, 4212793N; elevation 9,596 ft. Original image held in the U.S. Geological Survey Photographic Library, Denver, CO. 

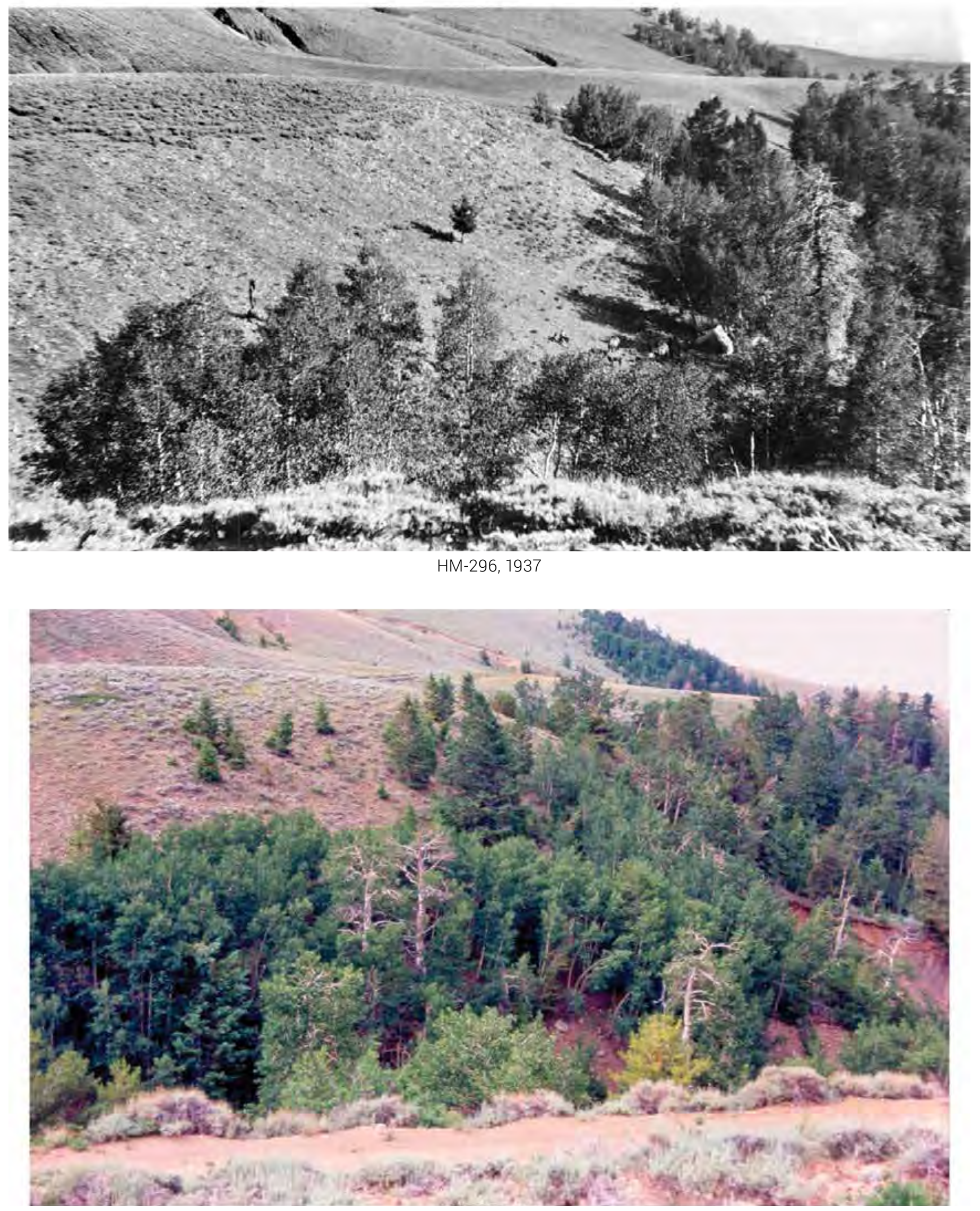
Plate HM-297

North Fork of South Creek

$1937 \because 2011$

Viewed northeast up the North Fork of South Creek to South Summit Ridge. The original photo point, which is on a small hill, is now blocked by a dense growth of pinyon-juniper, so the retake was made from the nearest open area.

Pinyon and juniper have increased, as have oak brush, Douglas-fir, limber pine, and ponderosa pine. In the distance aspen has been invaded by conifers and has declined. Also present are snowberry, birchleaf mountain mahogany, and mountain big sagebrush.

Original photograph taken by Charles B. Hunt (Number 571) in June 1937; retake made by Charles E. Kay on July 18, 2011 (Photo No. 6165-21A). Section 5, Range 10 East, Township 32 South; UTM 514667E, 4211801N; elevation 8,608 ft. Plates HM-297 and HM-298 (available on Utah State University's Extension website) were taken from the same camera station, but they do not form a panorama. Original image held in the U.S. Geological Survey Photographic Library, Denver, CO. 


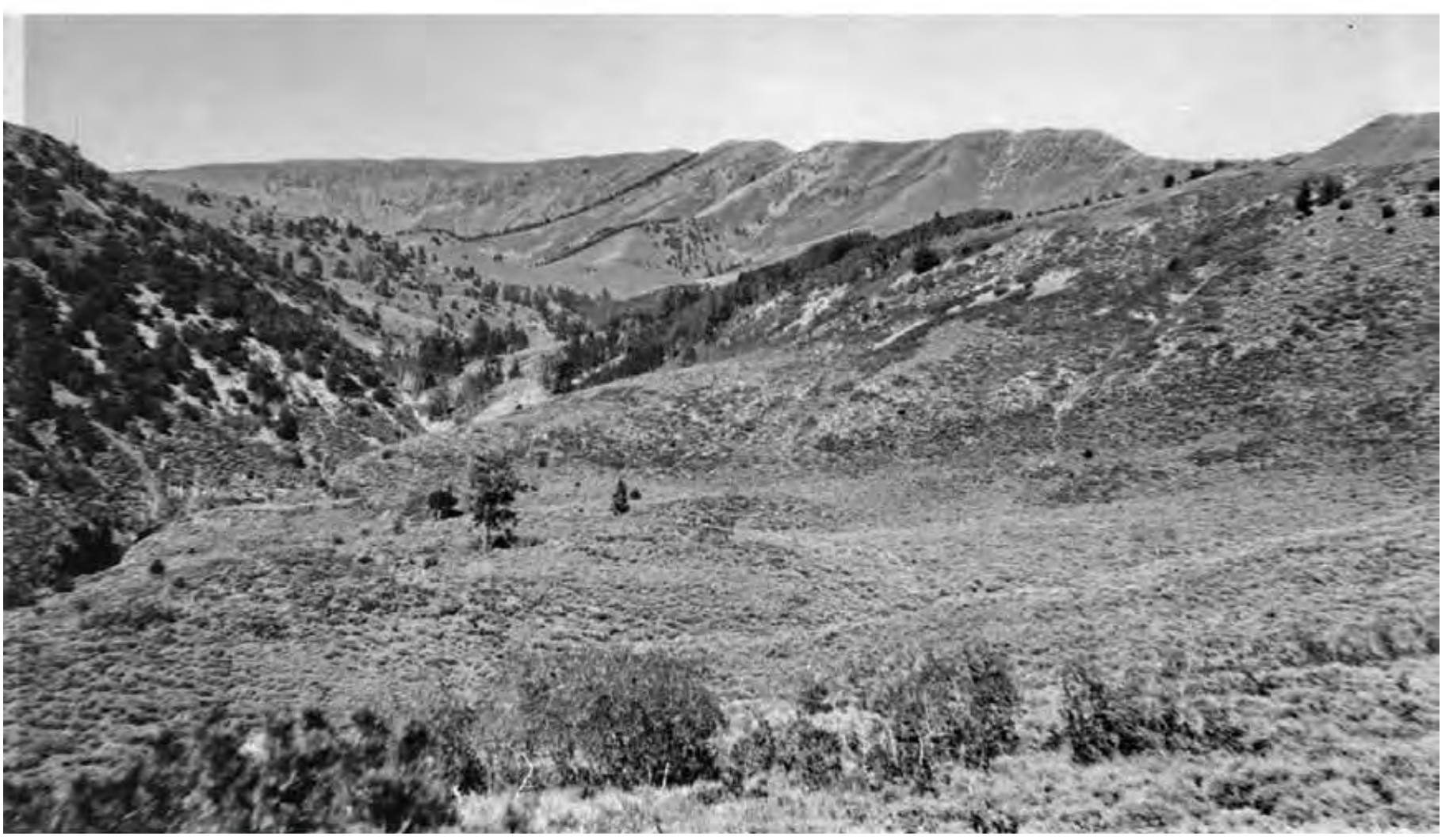

HM-297, 1937

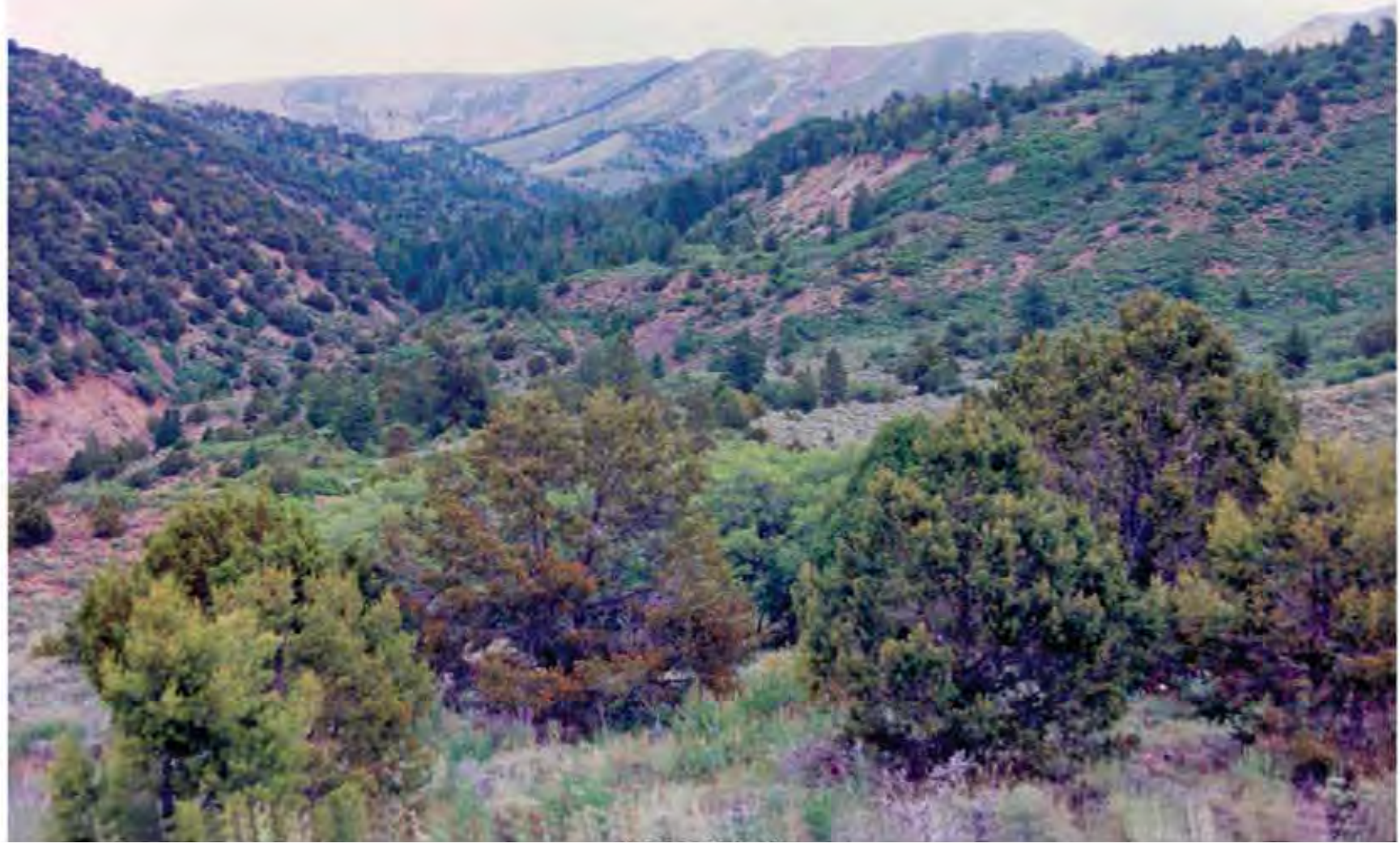

HM-297, 2011 


\section{Plates HM-302 and HM-303}

\section{Bromide Basin}

$1938 \div 2011$

Viewed south-southwest across the head of Bromide Basin from South Summit Ridge. Plates HM-302 and

HM-303 form a panorama. Note the new mining roads.

The eastern slopes of Mount Pennell in the distance burned in the 2003 Bulldog Fire. The upper treeline has been stable, but the spruce-subalpine fir forest has increased in height and density. The patches of shrubs are mostly currants. The landslide on the lower, northern slopes of Kimble and Turner Peak has naturally reforested.

Original photographs taken by Charles B. Hunt (Numbers 807 and 807b) in September 1938; retakes made by Charles E. Kay on July 20, 2011 (Photo Nos. 6167-9 and 6167-9). Section 34, Range 10 East, Township 31 South; UTM 517878E, 4213769N; elevation 11,267 ft. Original images held by the U.S. Geological Survey Photographic Library, Denver, CO. Photo mosaic compiled by Doug Page, BLM, Cedar City, UT. 

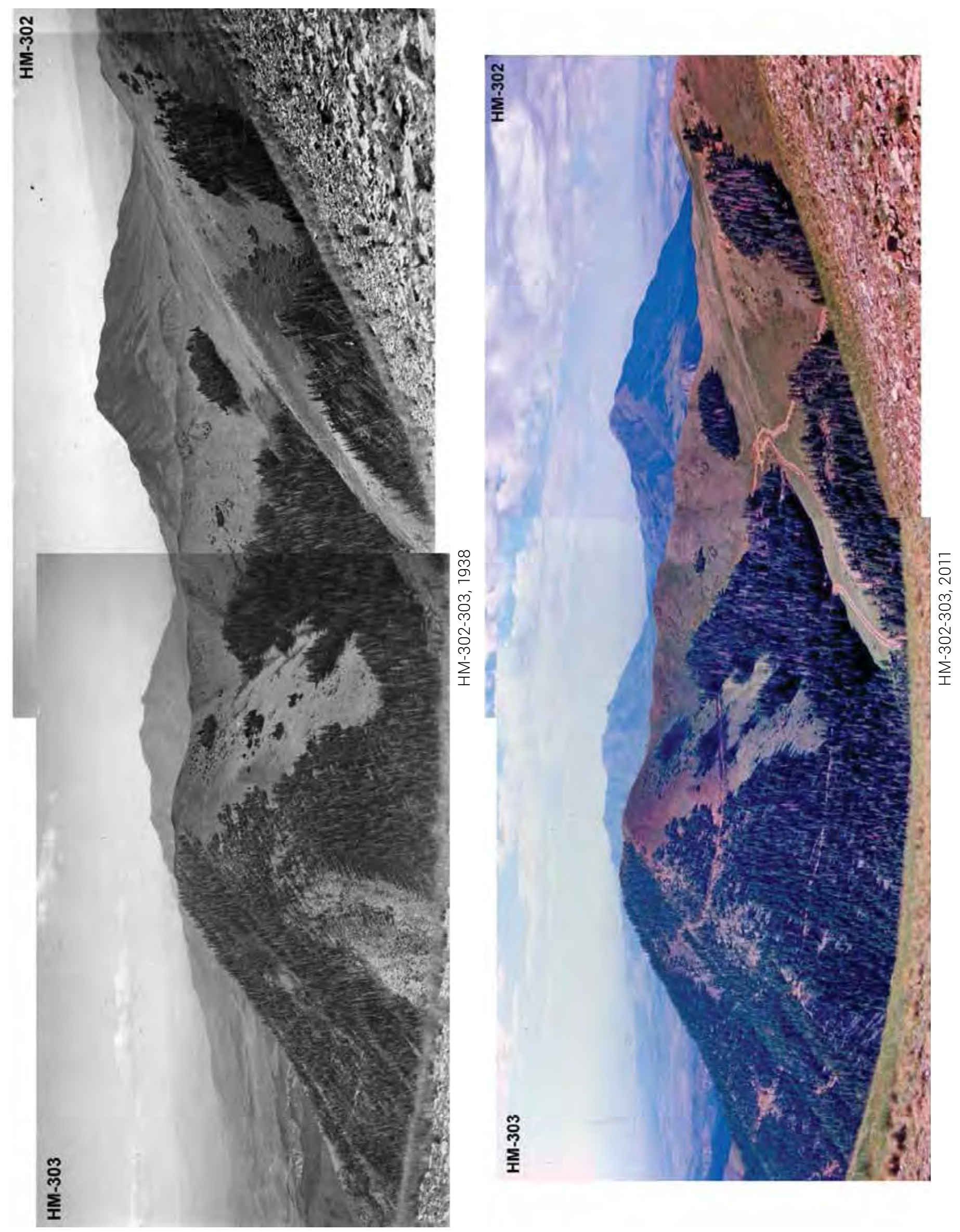


\section{Plate HM-304}

\section{South Summit Ridge}

$1938 \div 2011$

Viewed north-northwest along the upper slopes of South Summit Ridge, with Mount Ellen in the distance.

The camera station for the photo point is the same as that for Plates HM-302 and HM-303.

The upper treeline has been stable. The patches of shrubs are mostly currants.

Original photograph taken by Charles B. Hunt (Number 804) in September 1938; retake made by Charles E. Kay on July 20, 2011 (Photo No. 6167-20). Section 34, Range 10 East, Township 31 South; UTM 517878E, 4213769N; elevation 11,267 ft. Original image held by the U.S. Geological Survey Photographic Library, Denver, CO. 


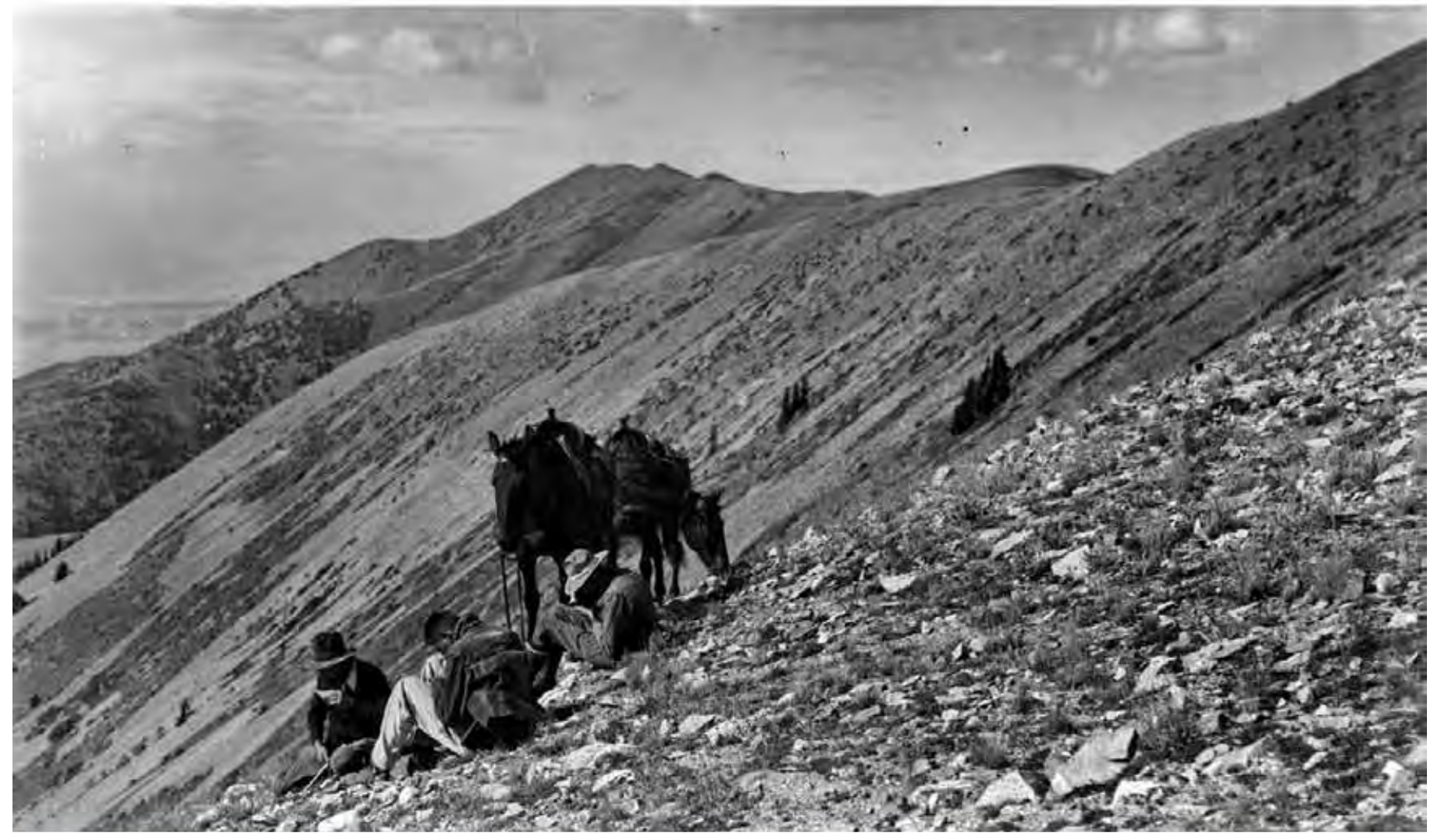
HM-304, 1938

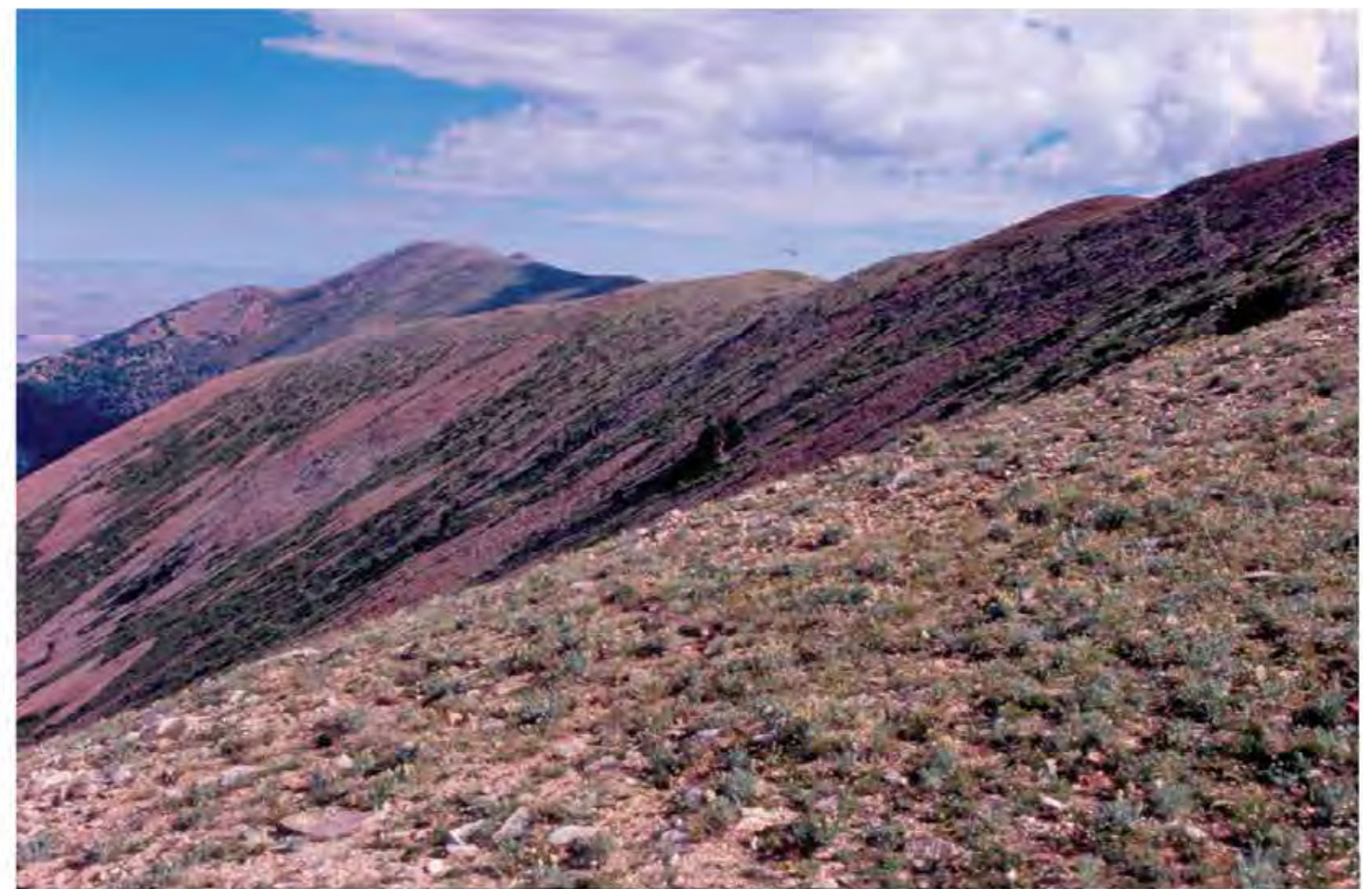




\section{Plate HM-310}

\section{South Creek}

$1937 \div 2011$

Viewed west-southwest down South Creek from South Summit Ridge. Nasty Flat is on the lower right;

South Creek Ridge is on the left.

Conifers have increased, including pinyon, juniper, Douglas-fir, limber pine, spruce, and ponderosa pine. In general, aspen has declined as conifers have invaded the various stands. Some aspen clones regenerated 30-40 years ago when mule deer numbers fell. They have not done so since, however, as any new suckers are repeatedly browsed, mostly by wildlife (Kay and Bartos 2000).

Original photograph taken by Charles B. Hunt (Number 591) in May 1937; retake made by Charles E. Kay on July 20, 2011 (Photo No. 6173-3). Section 34, Range 10 East, Township 31 South; UTM 517556E, 4213292N; elevation 11,067 ft. Original image held by the U.S. Geological Survey Photographic Library, Denver, CO. 


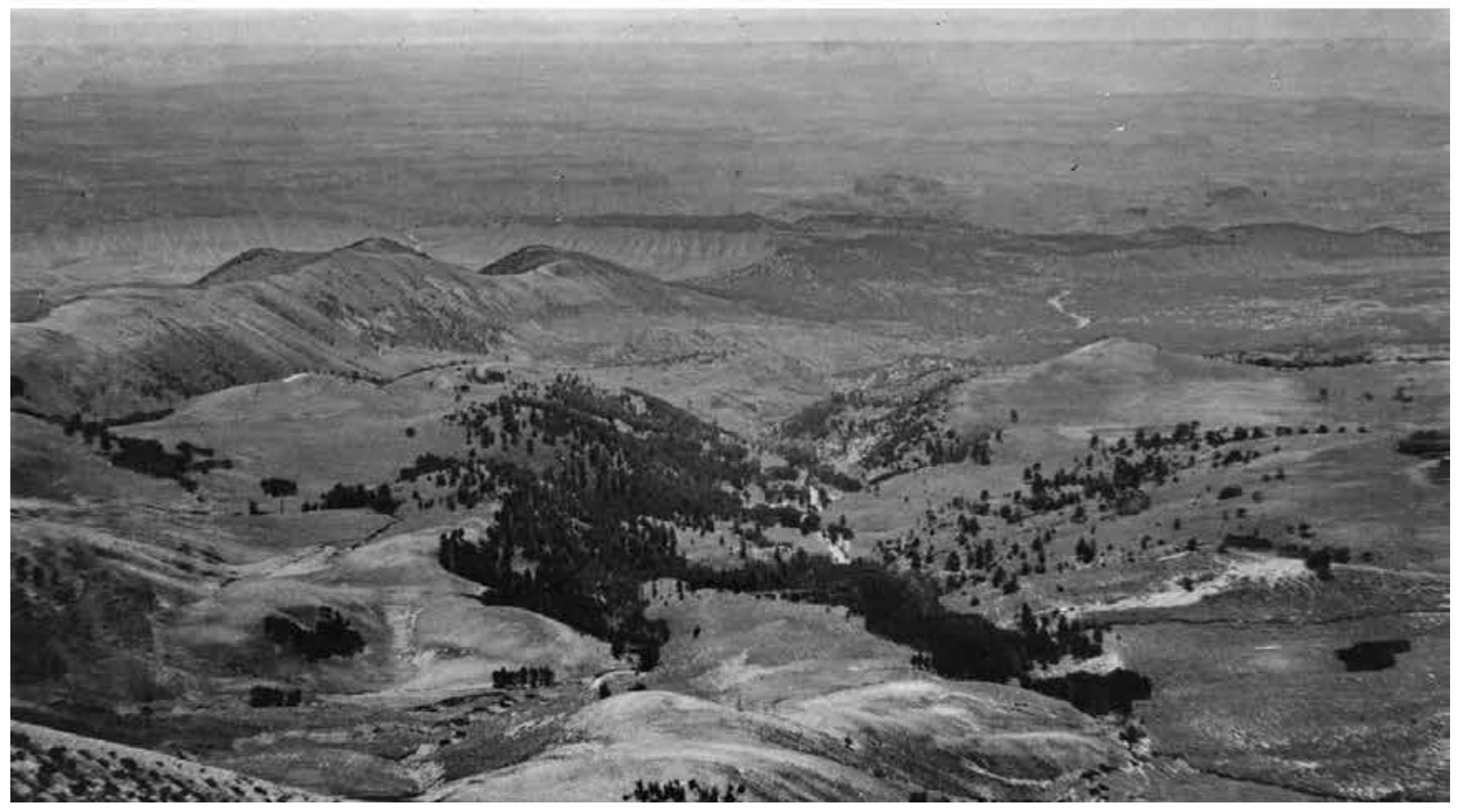

HM-310, 1937

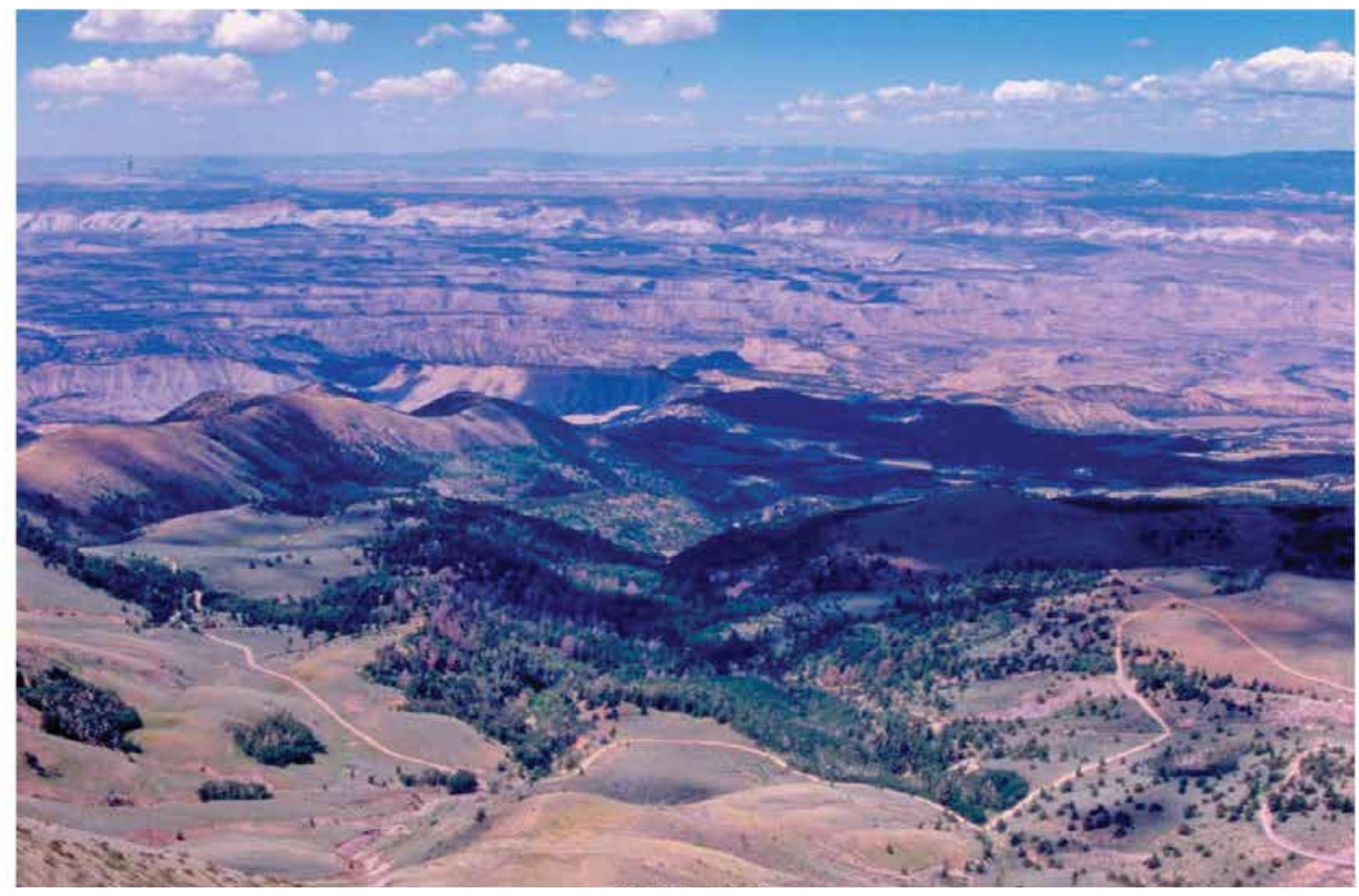

HM-310, 2011 


\section{Plates HM-312 and HM-313}

\section{Bromide Basin}

$1938 \div 2011$

Viewed southeast across the head of Bromide Basin to Kimble and Turner Peak. Plates HM-312 and HM-313 form a panorama. The horsemen in the 1938 images moved between photographs. Note the new mining roads.

The upper treeline has not changed, but the mixed conifer forest has increased in height and density. The dark-colored shrubs are currants. Ground cover appears to have increased.

Original photographs taken by Charles B. Hunt (Numbers 800 and 801) in September 1938; retakes made by Charles E. Kay on July 20, 2011 (Photo Nos. 6173-16 and 6173-22). Section 34, Range 10 East, Township 31 South; UTM 517633E, 4212776N; elevation 11,005 ft. Original images held by the U.S. Geological Survey Photographic Library, Denver, CO. Photo mosaic compiled by Doug Page, BLM, Cedar City, UT. 

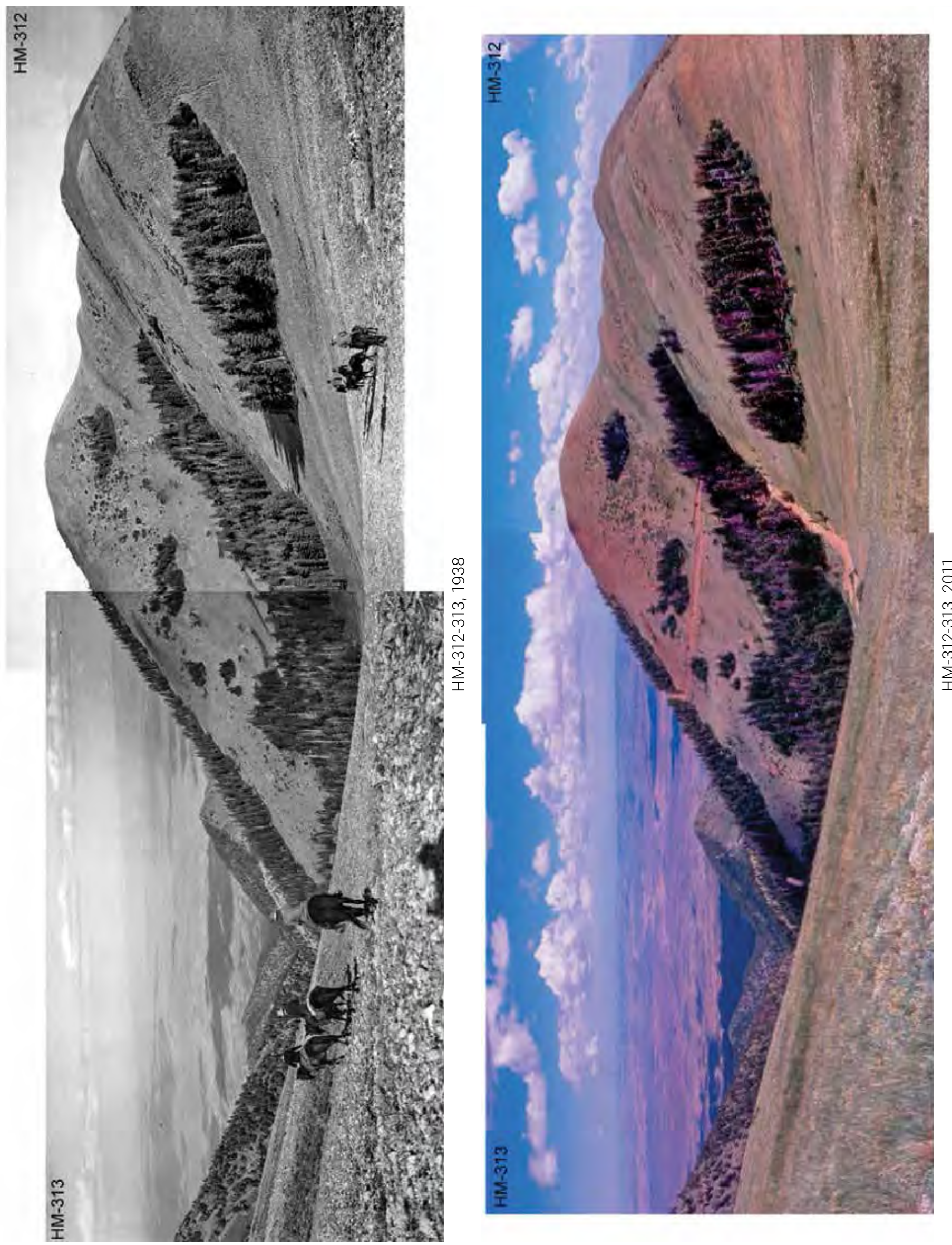


\section{Plate HM-314}

\section{Bromide Basin}

$1937 \because 2011$

Viewed north-northwest across Bromide Basin, from Kimble and Turner Peak to the crest of South Summit Ridge.

The upper treeline appears unchanged. Most of the trees are spruce or limber pine. The dark-colored shrubs are currants. Ground cover appears to have increased. A number of new mining roads have been constructed.

Original photograph taken by Charles B. Hunt (Number 589) in June 1937; retake made by Charles E. Kay on July 20, 2011 (Photo No. 6173-28). Section 34, Range 10 East, Township 31 South; UTM 518474E, 4212704N; elevation 11,086 ft. Original image held by the U.S. Geological Survey Photographic Library, Denver, CO. 


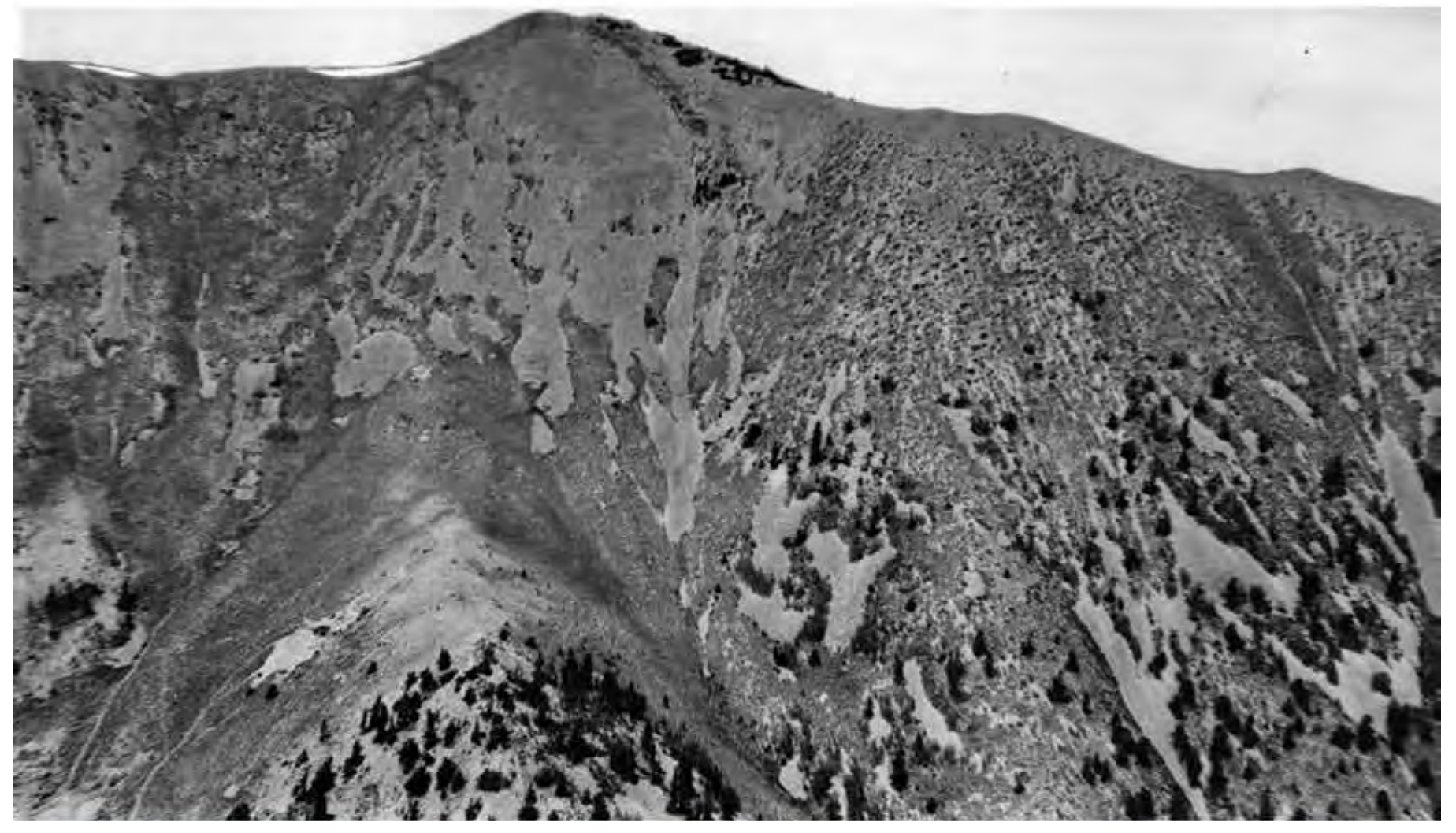

HM-314, 1937

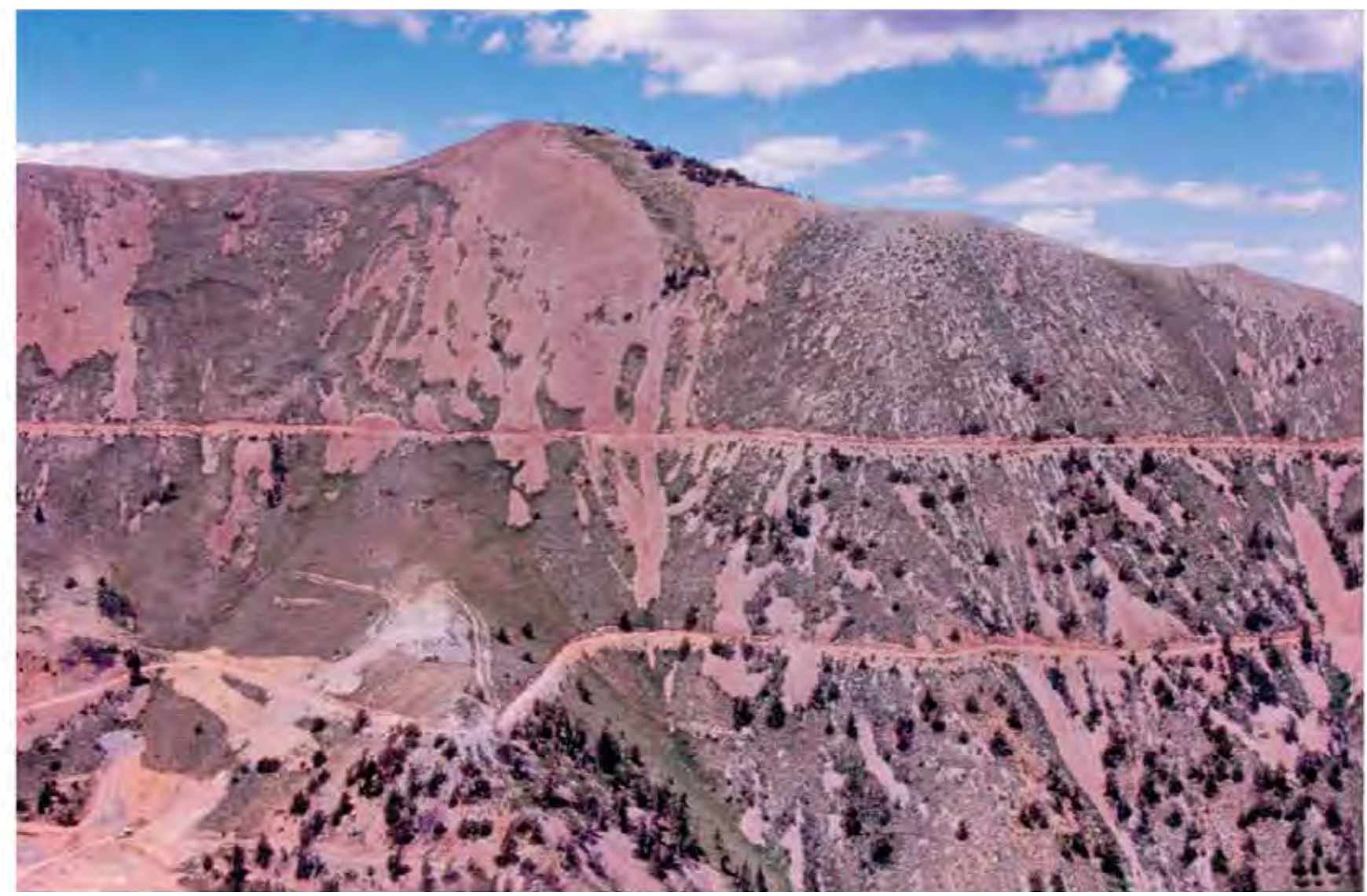

HM-314, 2011 


\section{Plate HM-318}

\section{Upper Cedar Creek}

$1936 \div 2011$

Viewed east, up Cedar Creek to Mount Ellen and North Summit Ridge.

The area around the photo point burned a number of years ago, as did the area to the left of Cedar Creek

(left-center edge). Otherwise, conifers have increased, including pinyon, juniper, Douglas-fir, ponderosa pine, spruce, and subalpine fir. The upper treeline, though, appears unchanged. Undisturbed aspen has not regenerated in many years due to repeated browsing of any new suckers, primarily by wildlife. In the recently burned area to the left of Cedar Creek, however, aspen has successfully regenerated (defined as producing new stems more than 6 feet tall). This area is heavily used by summering bison and mule deer.

Original photograph taken by Charles B. Hunt (Number 500) in September 1936; retake made by Charles E. Kay on July 22, 2011 (Photo No. 6177-15). Section 7, Range 10 East, Township 31 South; UTM 513392E, $4218480 \mathrm{~N}$; elevation 8,926 ft. Original image held by the U.S. Geological Survey Photographic Library, Denver, CO. 


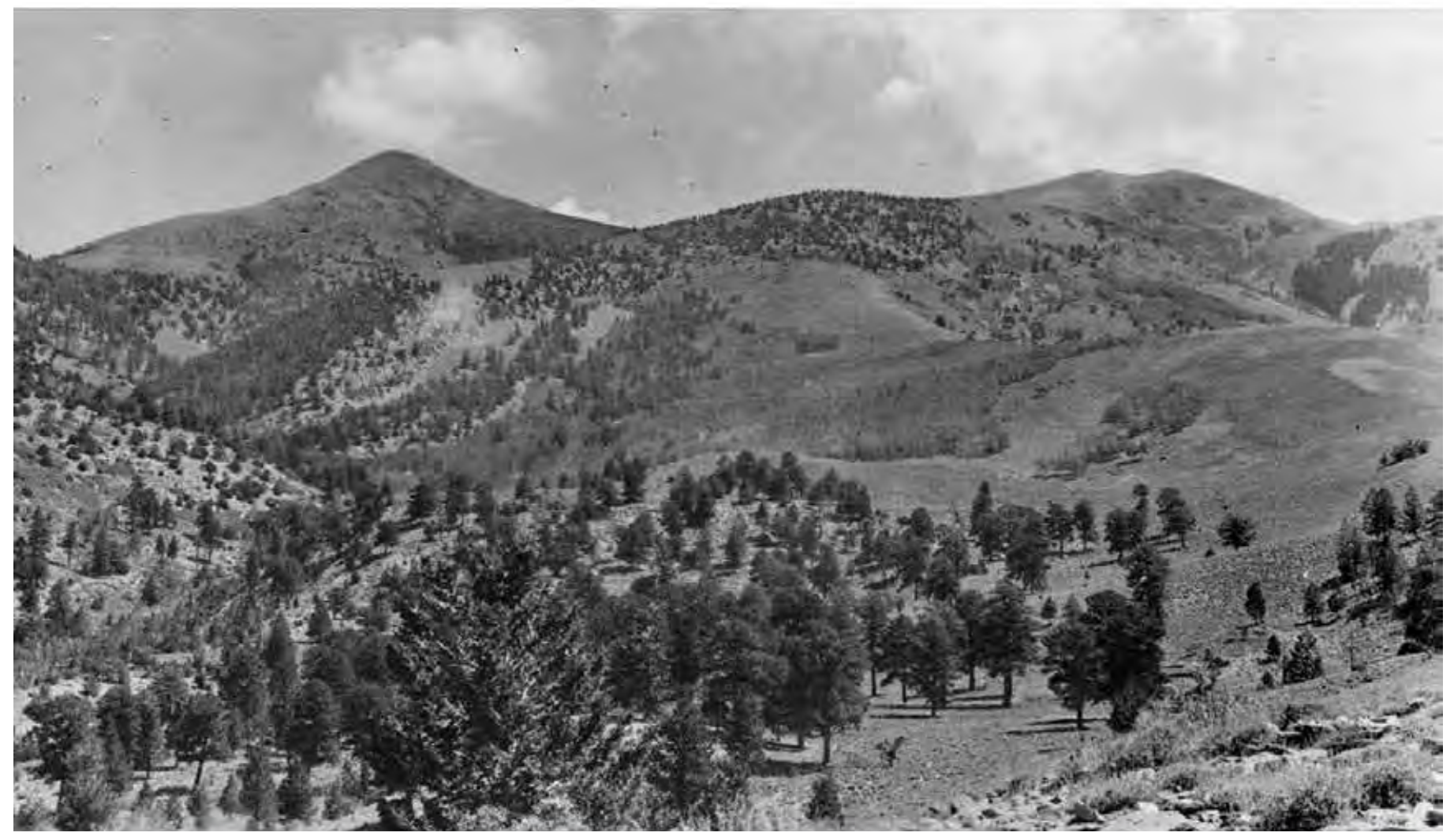

HM-318, 1936

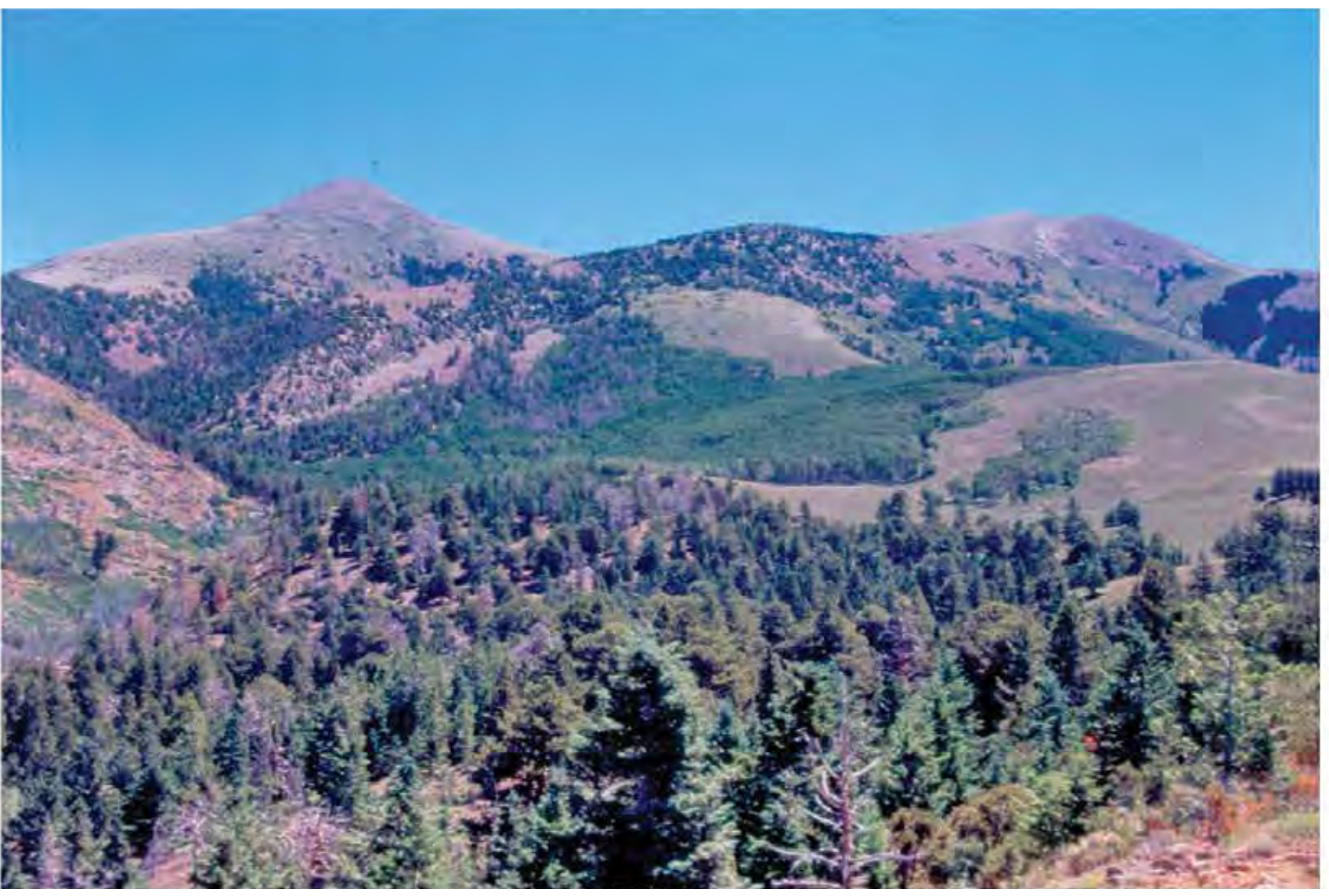

HM-318, 2011 


\section{Plates HM-320 and HM-321}

\section{Upper Cedar Creek}

$1936 \div 2011$

Viewed northwest across Cedar Creek to Deer Heaven. Plates HM-320 and HM-321 form a panorama.

Aspen has increased in height but has not successfully regenerated in many years. Conifers have increased, including Douglas-fir, limber pine, and spruce. Conifer mortality in the retake has been caused by the Douglas-fir beetle. The area shown in the foreground is heavily used by summering bison.

Original photographs taken by Charles B. Hunt (Numbers 519 and 518) in September 1936; retakes made by Charles E. Kay on July 22, 2011 (Photo Nos. 6177-24A and 6177-27A). Section 17, Range 10 East, Township 31 South; UTM 514534E, 4218312N; elevation 9,524 ft. Original images held by the U.S. Geological Survey Photographic Library, Denver, CO. Photo mosaic compiled by Doug Page, BLM, Cedar City, UT. 

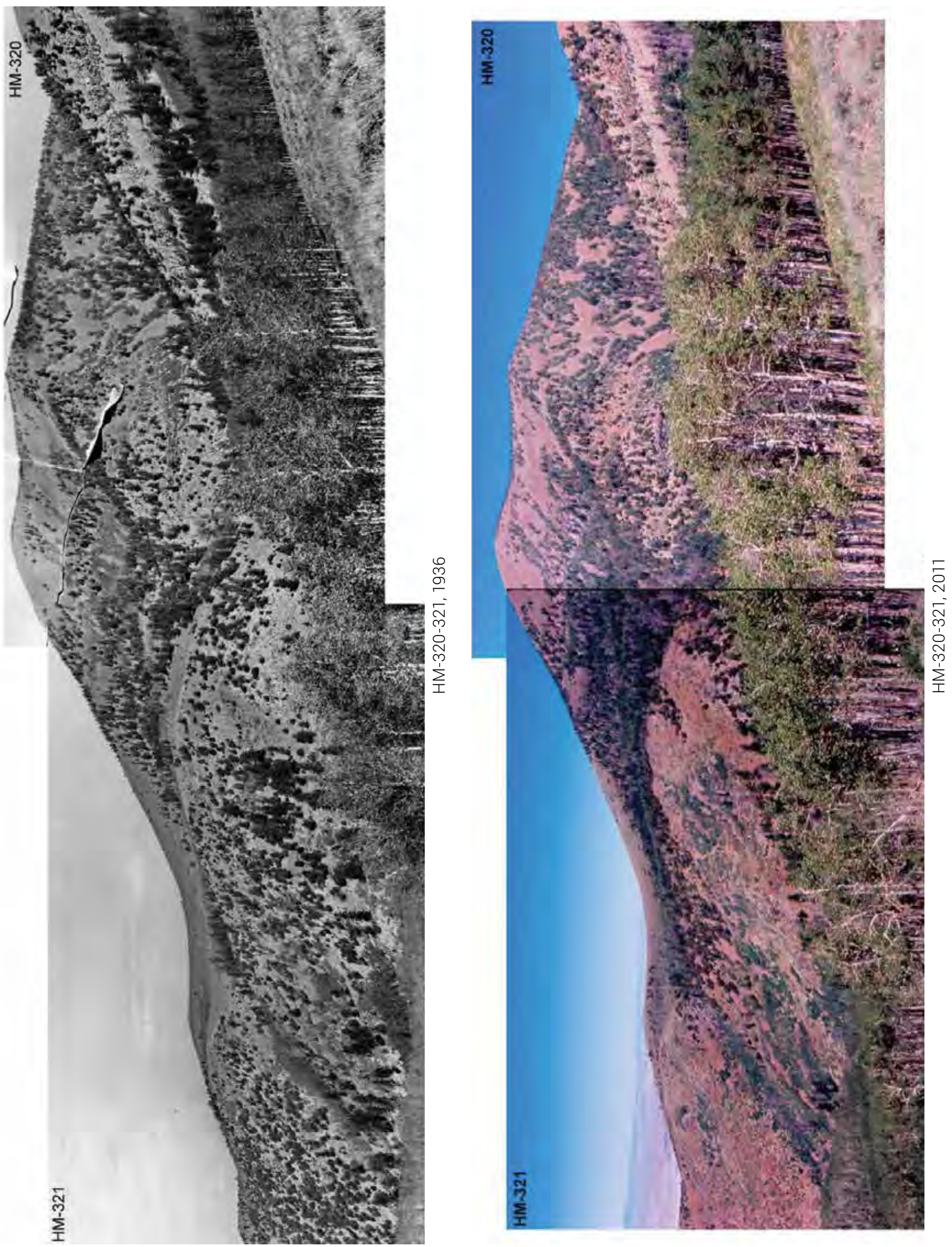


\section{Plate HM-322}

STAR FLAT

$1972 \div 2011$

In 1972 the BLM established the Homestead 4 range monitoring site on the Nasty Flat Allotment. The view is to the south on the northern edge of Star Flat. All the steel stakes are still present.

Ponderosa pine have increased, while mountain big sagebrush have declined. Other species include lupine, needle and thread, squirreltail, and Indian paintbrush. The area is heavily used by summering bison.

Original photograph taken by the BLM on August 9, 1972; retake made by Charles E. Kay on July 22, 2011 (print from a color slide). Section 18, Range 10 East, Township 31 South; UTM 513710E, 4217714N; elevation $8,856 \mathrm{ft}$. Original image held in the BLM's range files, Hanksville, UT. 


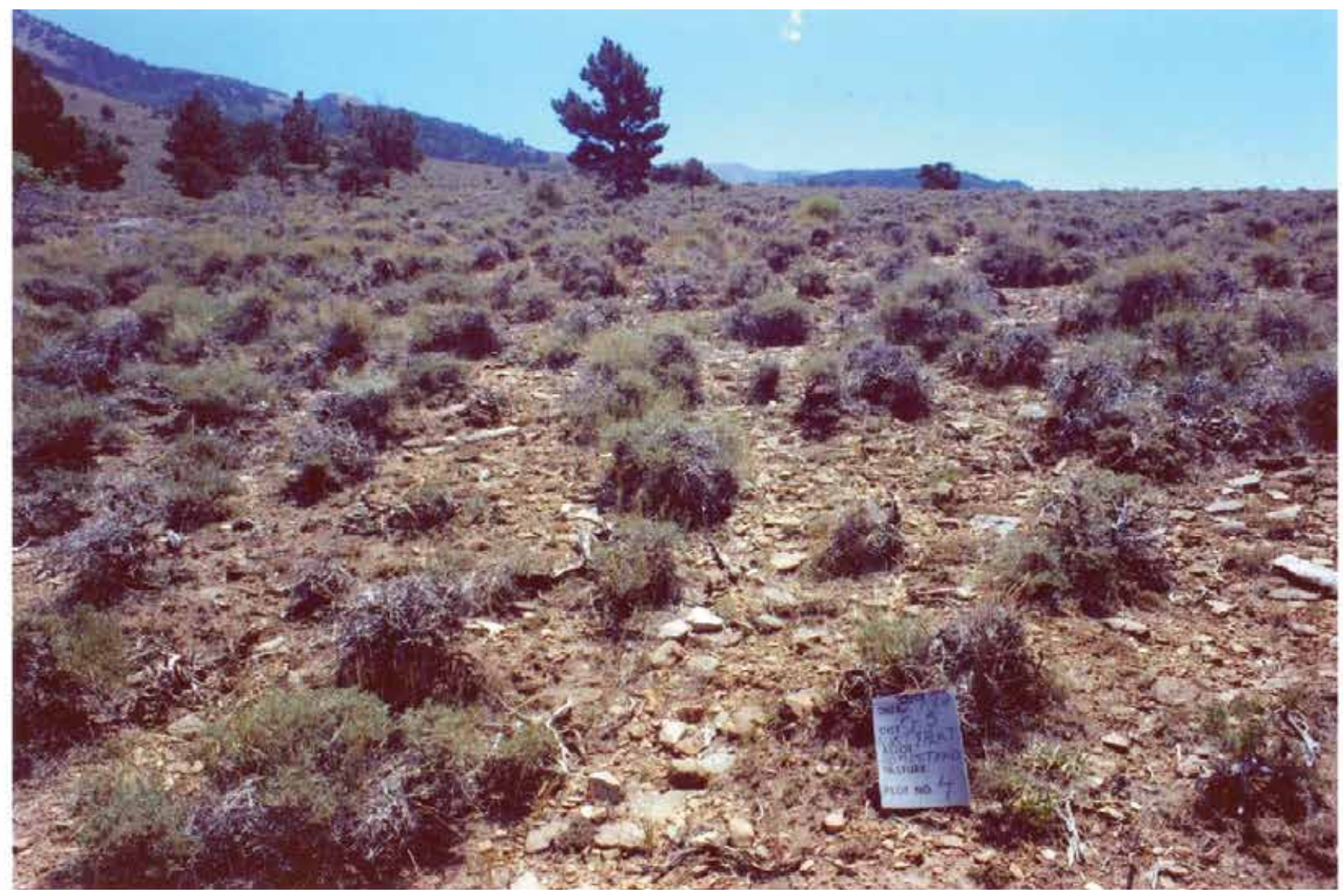

HM-322, 1972

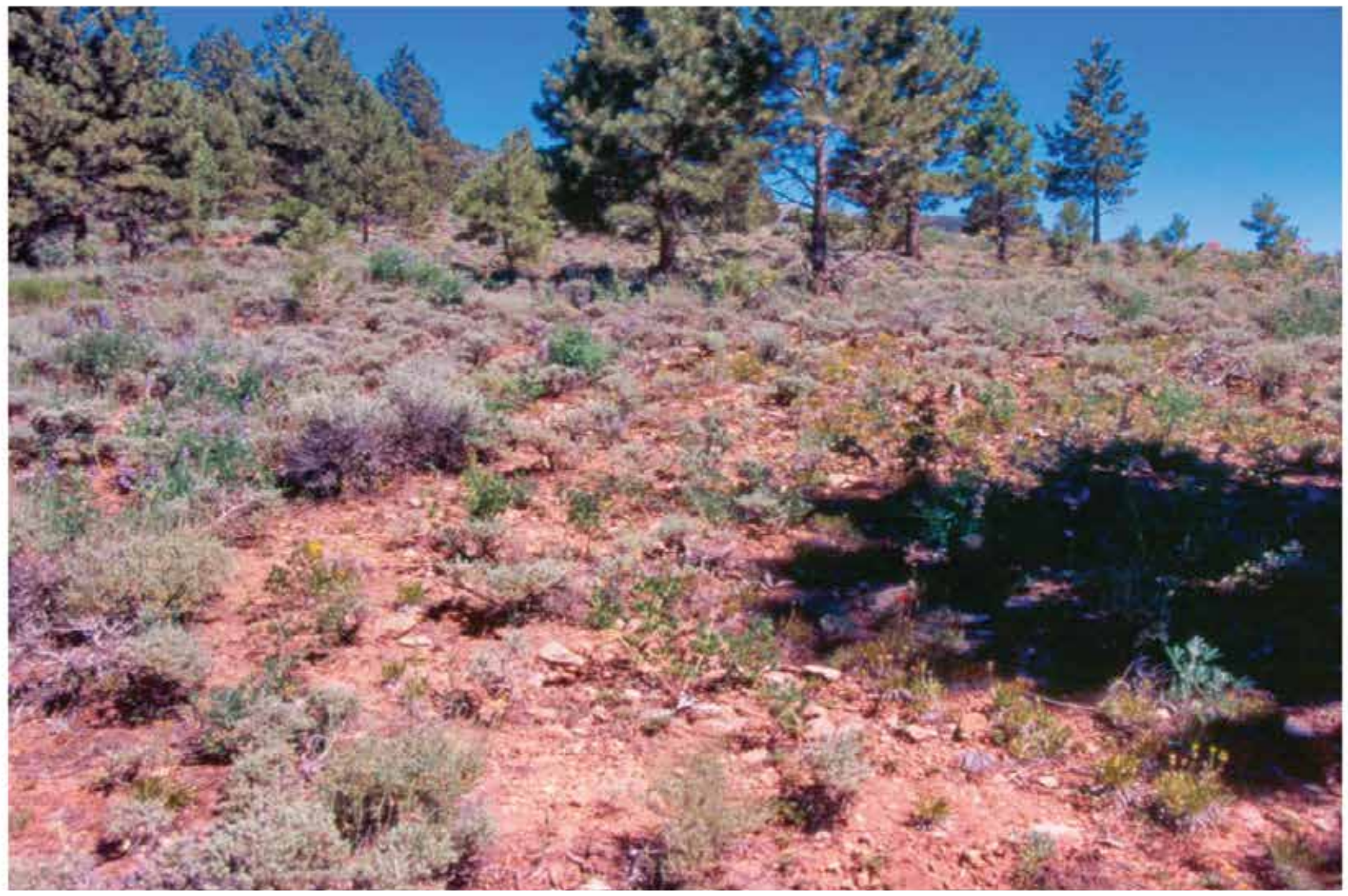




\section{Plate HM-339}

\section{Notom Desert}

$1940 \div 2012$

Viewed southeast from south of the old Notom road, approximately 1 mile northeast of Notom, Utah. In the distance are Mount Ellen (center skyline) and Mount Pennell (far-right skyline).

Shadscale is more common in the foreground today than it was in the past. Other species include curly grass, Indian ricegrass, yellow (green) rabbitbrush, and juniper.

Original photograph taken by an unknown photographer in 1940; retake made by Charles E. Kay on April 14, 2012 (Photo No. 6226-21A). Section 36, Range 7 East, Township 29 South; UTM 490352E, 4233046N; elevation 5,227 ft. Original image (No. 10,902) held by the Utah State Historical Society, Salt Lake City, UT. 


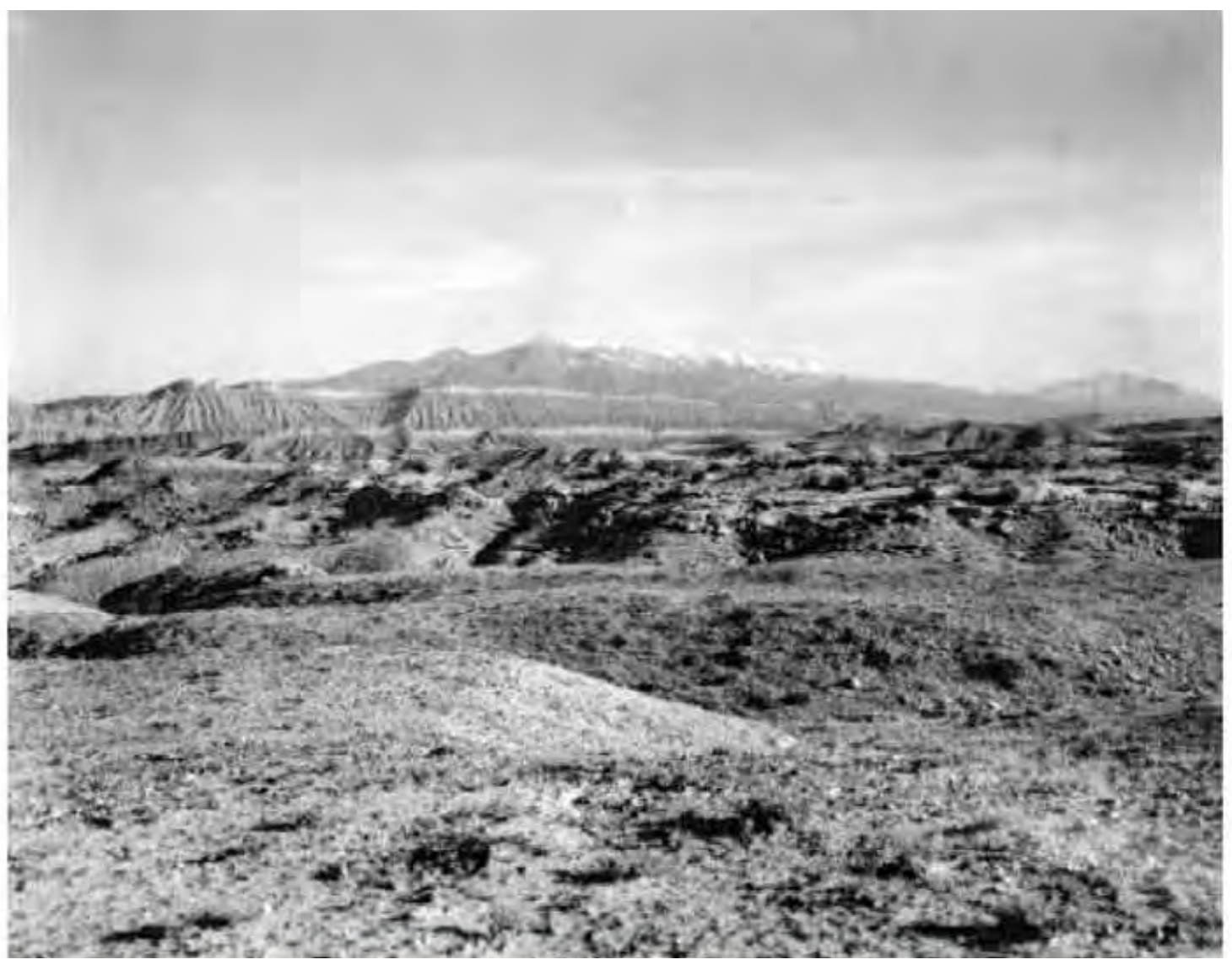

HM-339, 1940

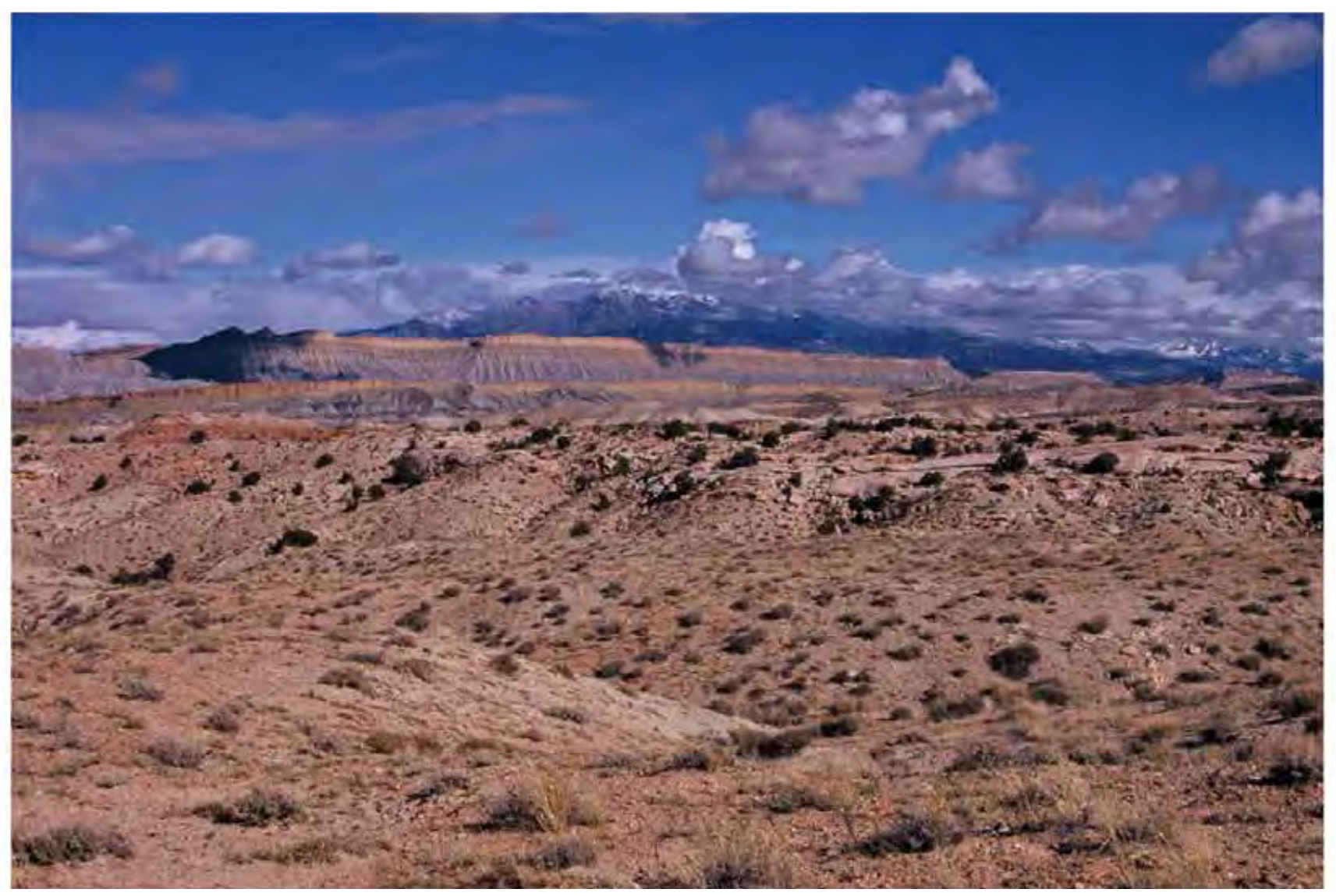




\section{Plate HM-346}

\section{Bull Creek}

$1921 \div 2012$

Viewed southeast up Bull Creek to the Henry Mountains. Horseshoe Ridge is on the left skyline, with Mount Ellen in the center, and Dry Lakes Peak on the right. Little Meadow is in the foreground. The photo point is approximately 1 1/2 miles south of the Fairview Ranch and 400 yards west of the Bull Creek road.

Pinyon and juniper have increased. The site was heavily grazed by domestic sheep in 1921, while today the area is grazed by cattle. The Lonesome Beaver Fire burned much of Horseshoe Ridge in 2003. Cottonwoods and other woody riparian vegetation appear to have increased. Common species include needle and thread grass, curly grass, sagebrush, tamarisk, Utah serviceberry, oak brush, fourwing saltbush, rubber rabbitbrush, and snakeweed.

Original photograph taken by R.C. Moore (No. 65) in 1921; retake made by Charles E. Kay on April 16, 2012 (Photo No. 6229-17). Section 18, Range 11 East, Township 30 South; UTM 521809E, 4227228N; elevation 5,608 ft. Original image held by the U.S. Geological Survey Photographic Library, Denver, CO. 


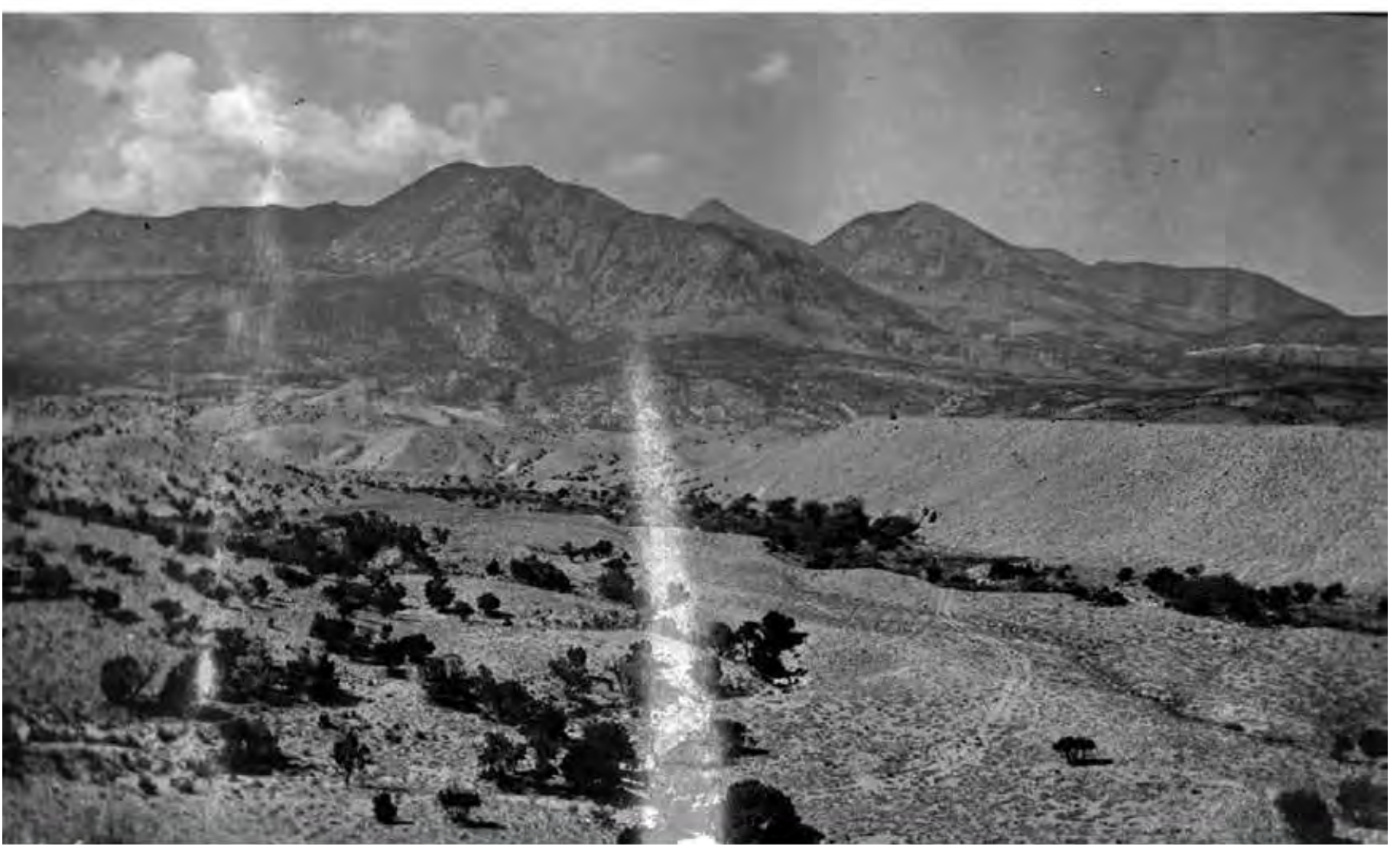

HM-346, 1921

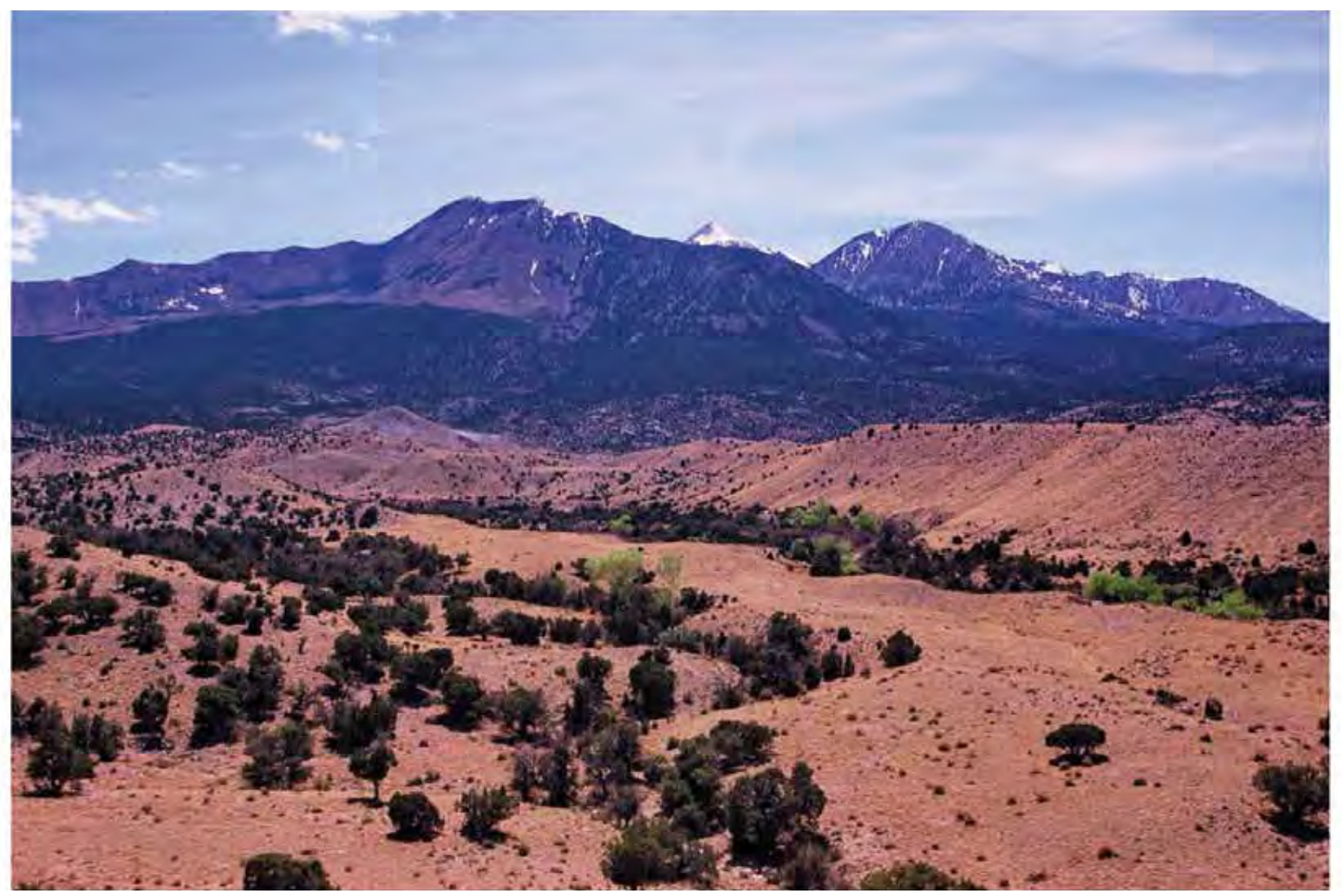




\section{Plate HM-347}

\section{Bull Mountain}

$1894 \because 2012$

Viewed southwest to Bull Mountain from just east of the Bull Creek road. Pinyon and juniper have increased and now block the original camera station, so the retake was made from the nearest open area with a somewhat clear view of the large boulder in the left foreground. The original image was printed in reverse. Today, there is an ATV trail between the photo point and the large boulder, which in 1894 most likely was the main road up Bull Creek.

Pinyon and juniper have increased. The understory vegetation is primarily blue grama and sagebrush. Of the more than 1,200 repeat photographs that I have made of pinyon-juniper in southern Utah, this is the only historical image in which pinyon and juniper stumps are visible. As this is the nearest pinyon-juniper to the town of Hanksville, 15 miles to the north, these trees were probably cut for firewood or fenceposts.

Original photograph taken by Marcus E. Jones (Slide 46) in 1894; retake made by Charles E. Kay on April 16, 2012 (Photo No. 6229-19). Section 29, Range 11 East, Township 30 South; UTM 522983E, 4225106N; elevation 6,109 ft. Original image held by the Rancho Santa Ana Botanic Garden, Claremont, CA. Image digitized and provided by Dr. William R. Gray (2011), Emeritus Professor of Biology, University of Utah, Salt Lake City, UT. 


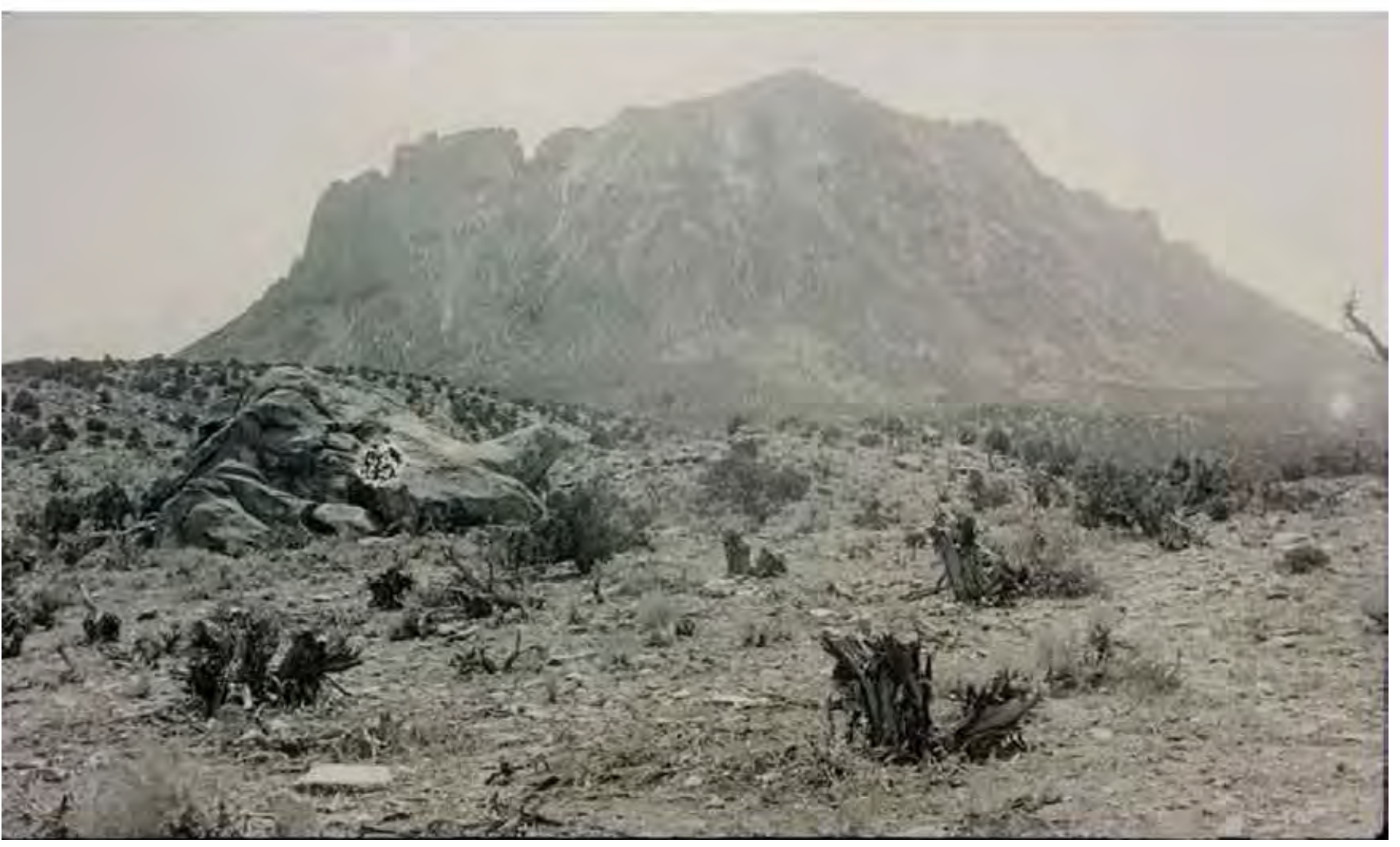

HM-347, 1894

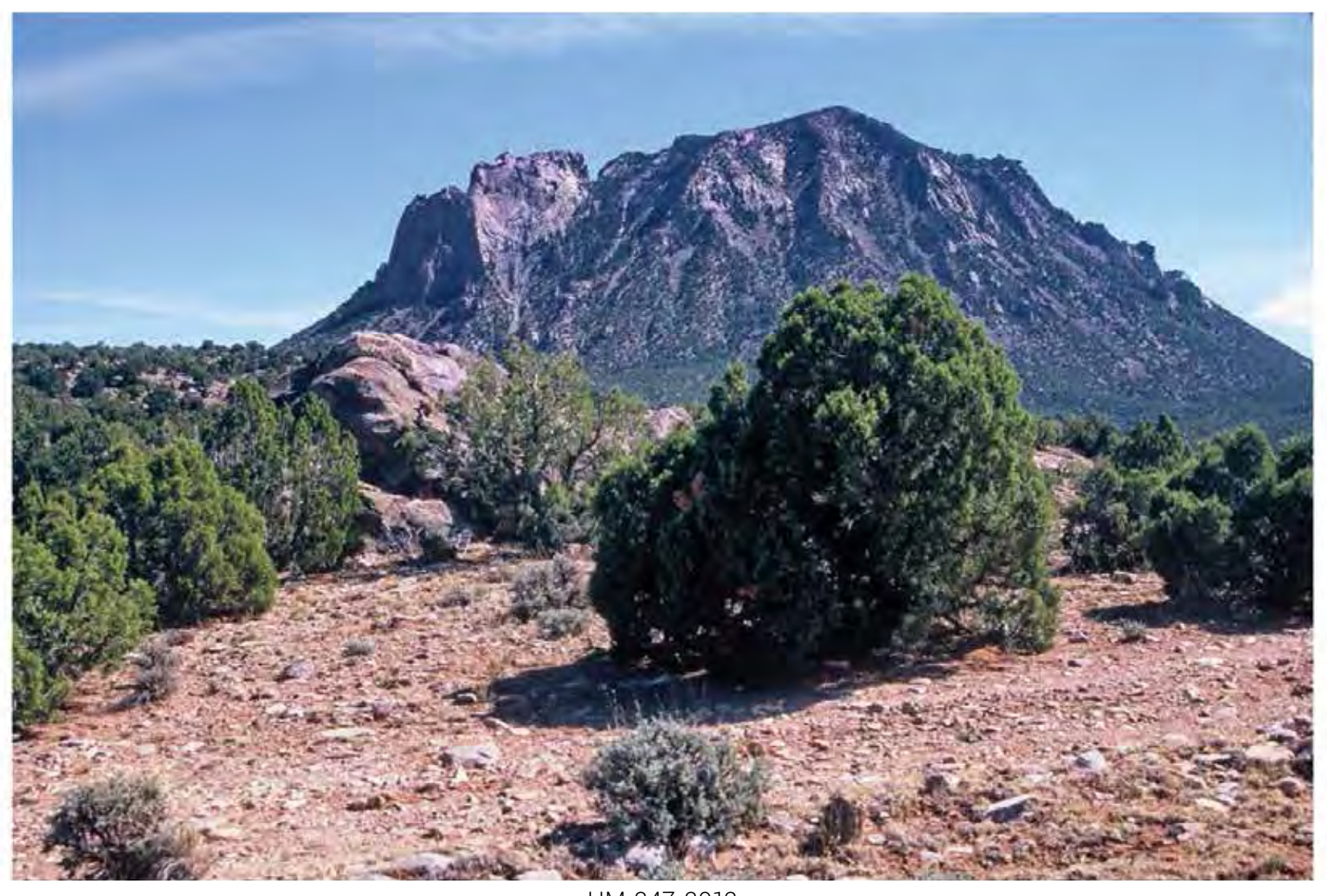

HM-347, 2012 


\section{Plate HM-349 and HM-350}

\section{Granite Creek}

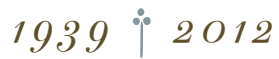

Viewed west-northwest up Granite Creek. Mount Ellen is on the left skyline; Bull Mountain is on the right-center skyline. Plates HM-349 and HM- 350 form a panorama that is most informative.

First, it is clear from the 1939 images that a surface fire thinned out the pinyon-juniper some years before those photos were made. That surface fire also removed blackbrush, which is common in the surrounding area, and lead to an increase in various grasses-primarily blue grama, needle and thread, and Indian ricegrass. Thus, fire has maintained a pinyon-juniper-grass savanna in this area. Judging by the present vegetation mosaic, this surface fire covered a relatively large area-indicating that fine fuels, mainly grasses, must have been even more abundant in the past to have allowed that fire to spread as far as it did. There is no evidence of crown fire anywhere in the original photographs.

The dead pinyon and juniper seen in the 1939 images, although weathered, are still present today, having likely lasted at least 100 years. Pinyon and juniper present in 1939 have increased in size and to a lesser extent in number. Some ecologists claim that, historically, pinyon-juniper savannas have been maintained by climate, not by fire. These photos, however, indicate that both climate and fire are important.

The area is far from water and is seldom used by cattle today. Grazing by sheep may have been more common in earlier times, though, because sheep can be herded relatively long distances to and from water. In addition to the species discussed above, Mormon tea, winterfat, and snakeweed are present, although in very small amounts. Original photographs taken by Charles Hunt (Nos. 887 and 888) in 1939; retakes made by Charles E. Kay on April 17, 2012 (Photo Nos. 6229-28 and 6229-32). Section 15, Range 11 East, Township 31 South; UTM 527195E, 4218894N; elevation 6,184 ft. Original image held by the U.S. Geological Survey Photographic Library, Denver, CO. Photo mosaic compiled by Doug Page, BLM, Cedar City, UT. 

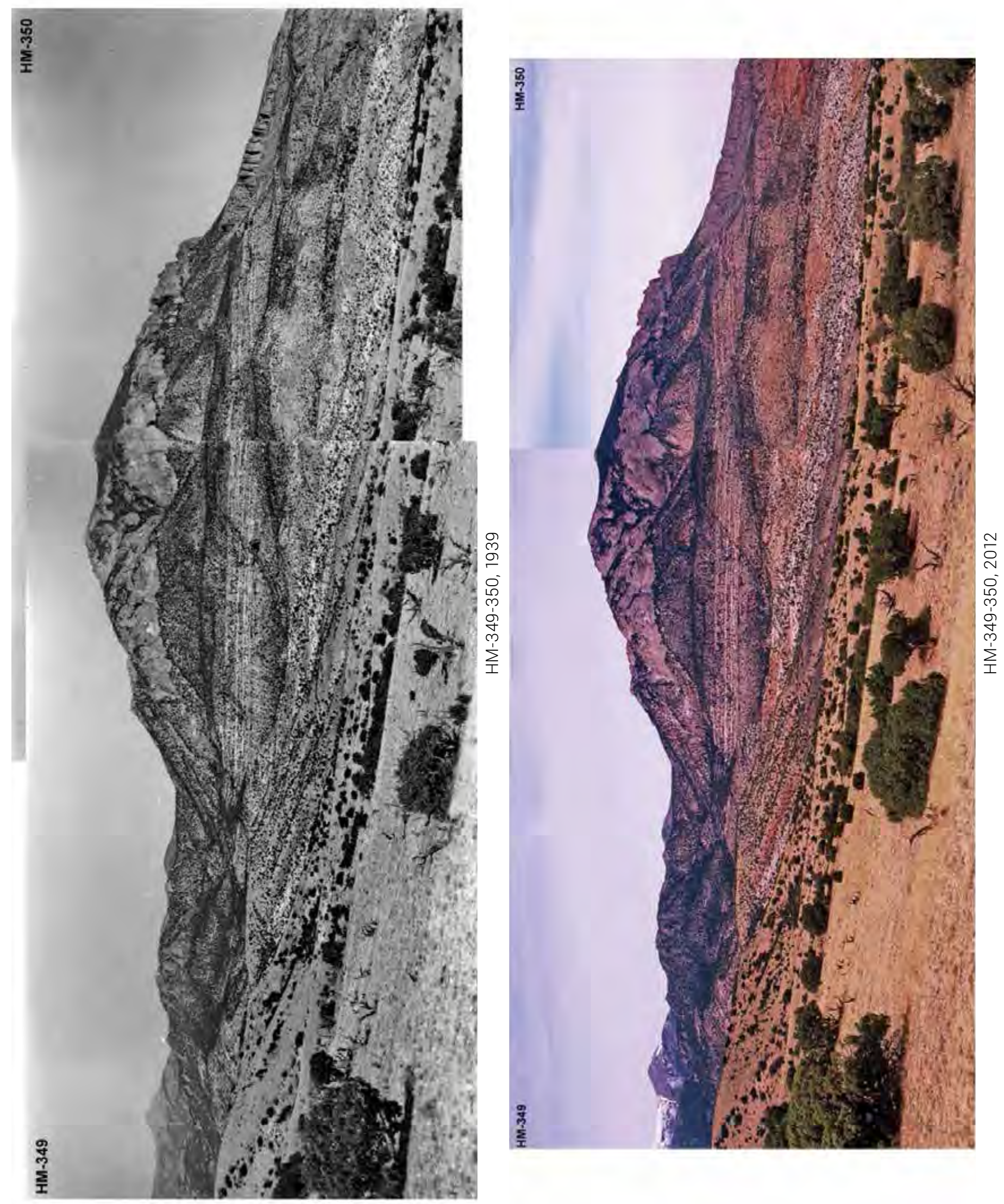


\section{Plate HM-355}

\section{NorTh WASH}

$1938 \div 2012$

Viewed northwest up North Wash, just above Hog Springs. The original photo point was eliminated when Utah Highway 95 was built along North Wash.

The cliff on the right has been blasted away, and North Wash has been channelized further to the left. Livestock grazing has been eliminated. Cottonwoods and willows have increased, as has tamarisk.

Original photograph taken by Charles Kelly in 1938; retake made by Charles E. Kay on April 19, 2012 (Photo No. 6232-26). Section 4, Range 13 East, Township 32 and 1⁄2 South; UTM 544655E, 4201817N; elevation 4,078 ft. Original image (No. 10,636) held by the Utah State Historical Society, Salt Lake City UT. 


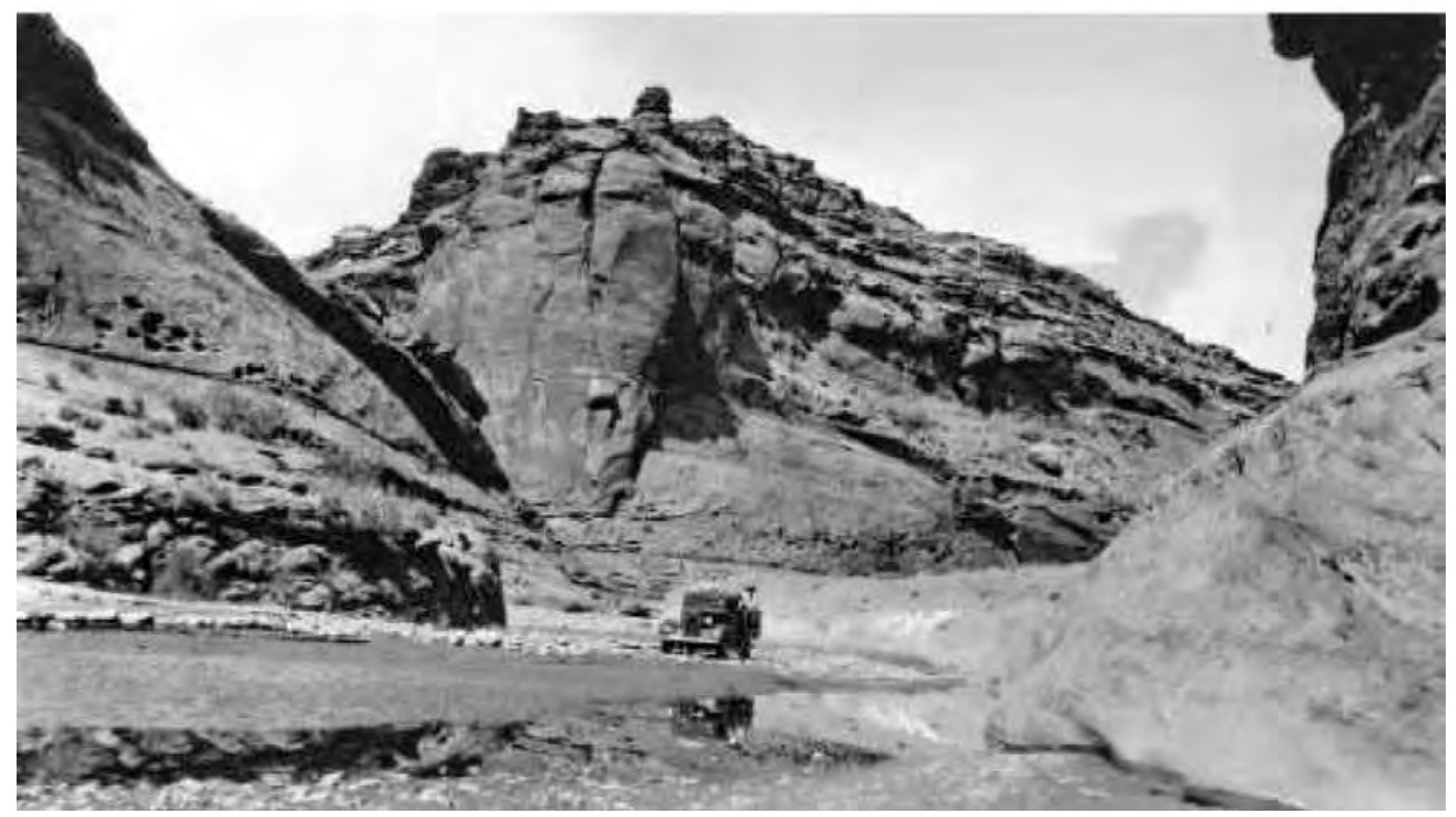

HM-355, 1938

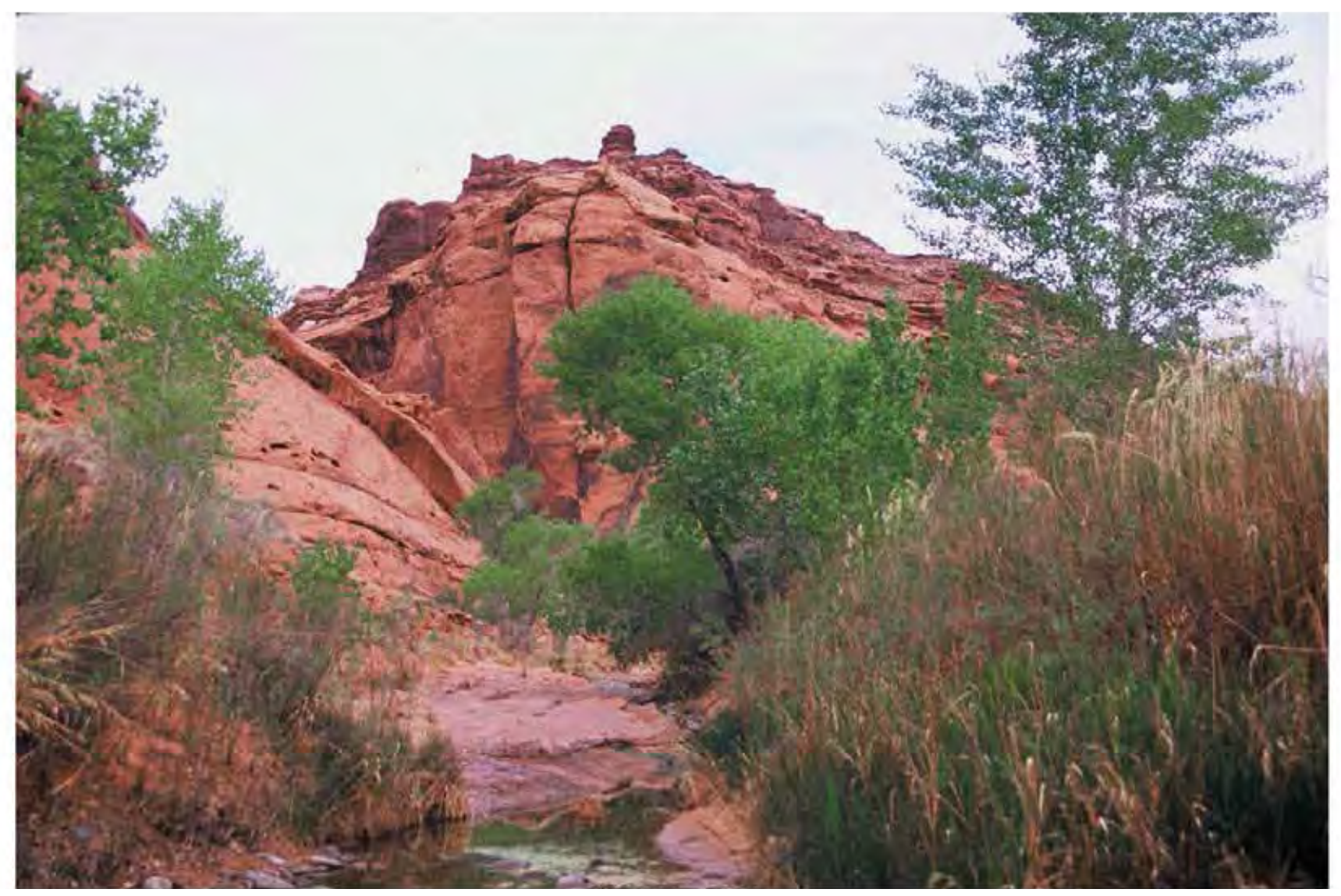




\section{Plates HM-363 and HM-365}

\section{Fairview Ranch}

$1940 \div 2012$

Viewed south-southwest from just south of the Fairview Ranch, south of Hanksville, Utah. From right to left on the skyline are Table Mountain, Deer Heaven, Dry Lakes Peak, Mount Ellen, and Horseshoe Ridge. Plates HM-363 and HM-365 form a panorama.

The area around Fairview Ranch was denuded in 1940 due to excessive grazing by thousands of domestic sheep, brought to the ranch each spring to be sheared. According to Murphy $(1999,161)$, an estimated 50,000 domestic sheep were sheared each year at Notom and the Sandy Ranch; thousands more were sheared at the Fairview and Starr ranches. Thus, as many as 100,000 sheep may have grazed the Henry Mountains in earlier times. Today, the sheep are gone, and most grazing allotments have been converted to cattle.

The few shrubs in the foreground of the 1940 image were growing along an irrigation ditch that is still in use. The cottonwood growing along the irrigation ditch in 1940 (center) is still alive, despite having recently been struck by lightning. The area is more heavily vegetated today than it was in the past. Common plants now include curly grass, rubber rabbitbrush, shadscale, snakeweed, and pricklypear cactus. In the distance, cottonwoods have increased along Bull Creek, as have pinyon and juniper. The 2003 Lonesome Beaver Fire burned part of Horseshoe Ridge.

Original photographs taken by the BLM in 1940; retakes made by Charles E. Kay on May 16, 2012 (Photo Nos. 6234-20 and 6234-28). Section 8, Range 30 East, Township 30 South; UTM 522840E, 4229700N; elevation 5,182 ft. Original images held in the BLM's range files, Hanksville, UT. Photo mosaic compiled by Doug Page, BLM, Cedar City, UT. 


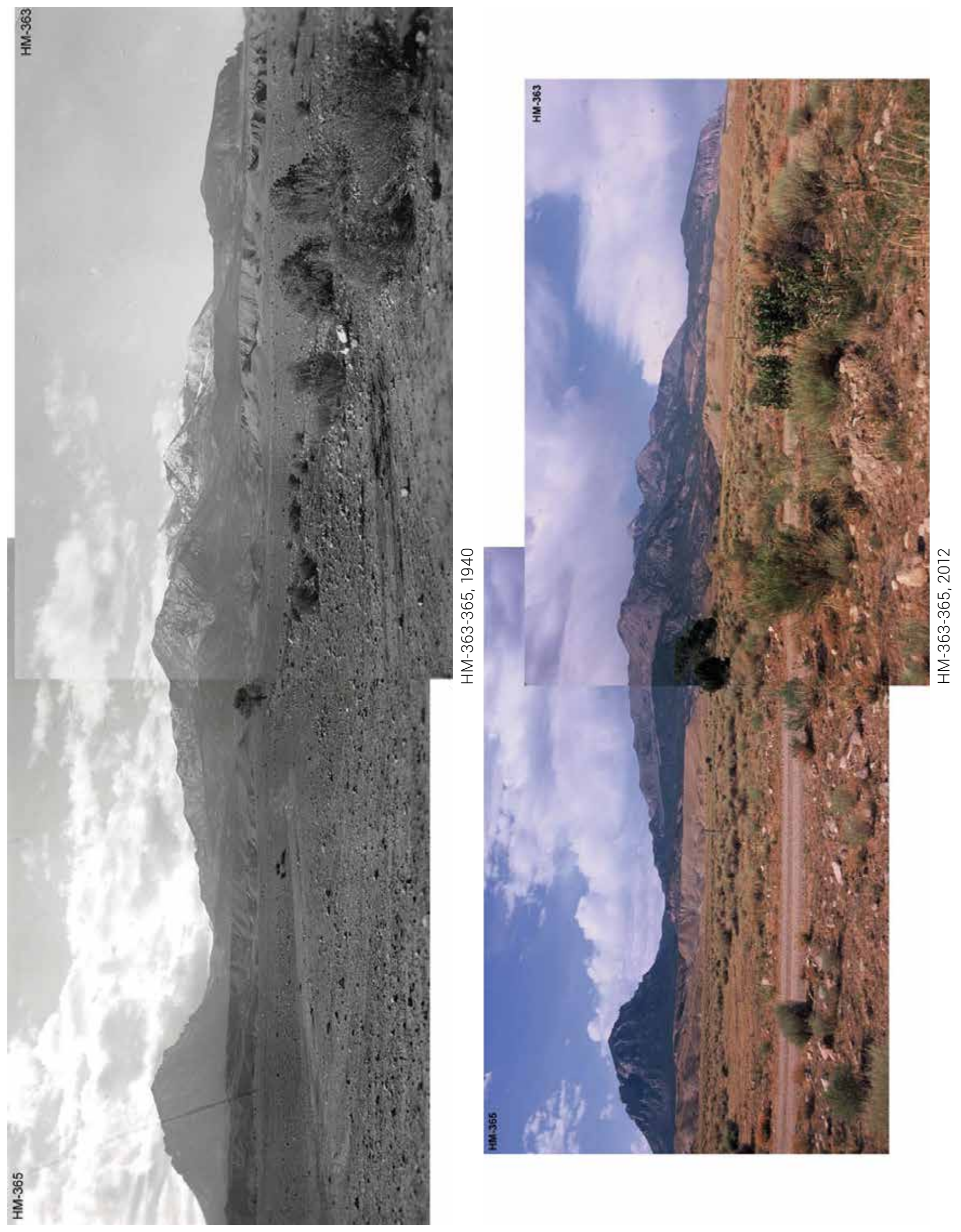




\section{Plate HM-400}

\section{Fremont River}

$1894: 2012$

Viewed east-northeast down the Fremont River, just below where Utah Highway 24 crosses the river north of the Blue Dugway. The old road to Caineville is located at the base of the nearest cliff. South Caineville Mesa is in the distance. The photo point is on privately owned property and is grazed yearly by cattle. (See also Plate HM-401.)

At this location, the river turns east and flows through a gap in the Caineville Reef. Note that in the foreground of the 1894 photo there were no willows or cottonwoods, only greasewood. Today, the area is a cottonwood forest. Clearly, this plate does not support the contention of Fleischner (2010) that continued livestock grazing has prevented the recovery of woody riparian vegetation along the Fremont River outside Capitol Reef National Park.

Original photograph taken by Marcus E. Jones (Slide 246) in 1894; retake made by Charles E. Kay on May 20 , 2012 (Photo No. 6245-33A). Section 15, Range 8 East, Township 29 South; UTM 496538E, 4238304N; elevation 4,678 ft. Original image held by the Rancho Santa Ana Botanic Garden, Claremont, CA. Image digitized and provided by Dr. William R. Gray (2011), Emeritus Professor of Biology, University of Utah, Salt Lake City, UT. 


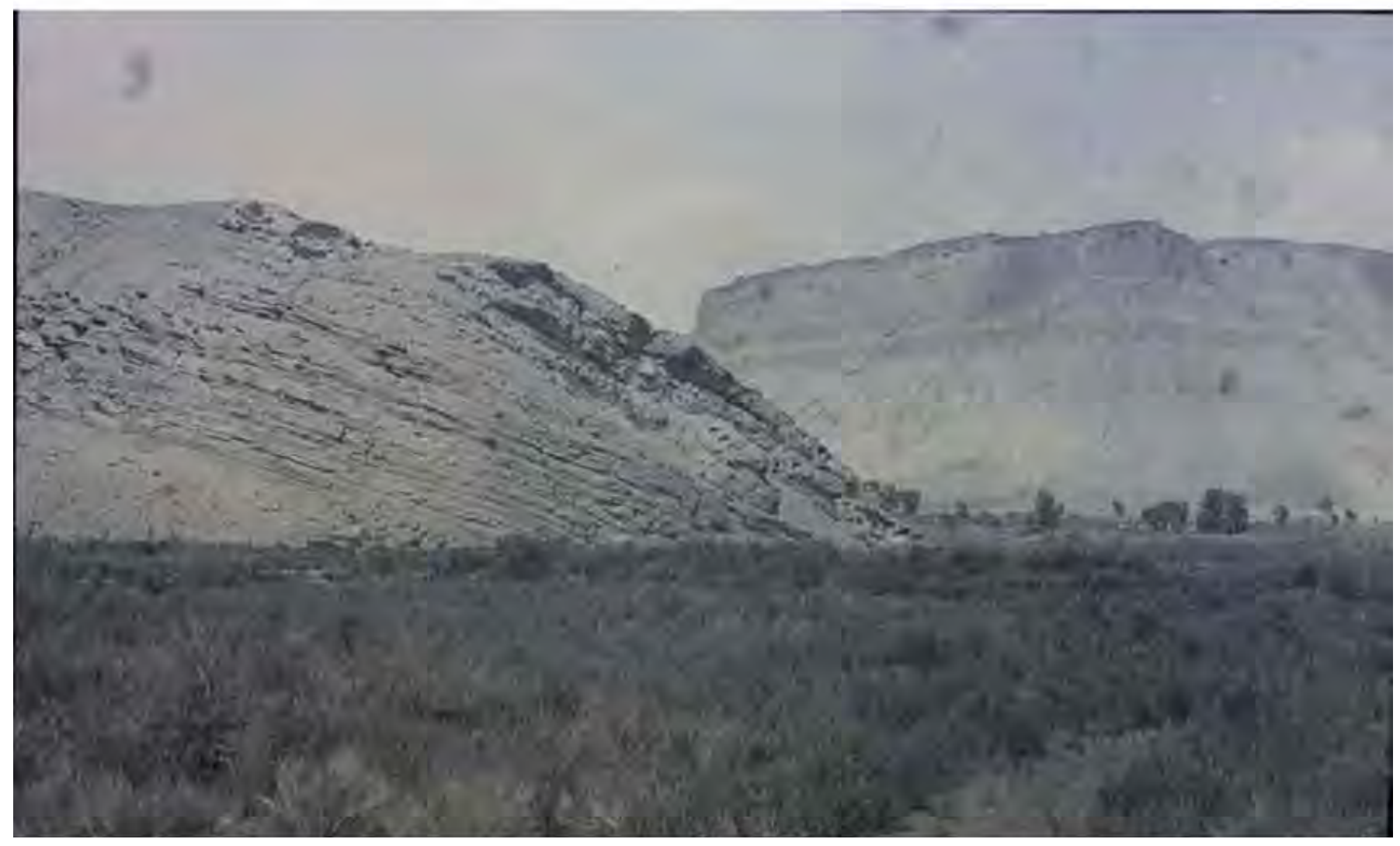

HM-400, 1894

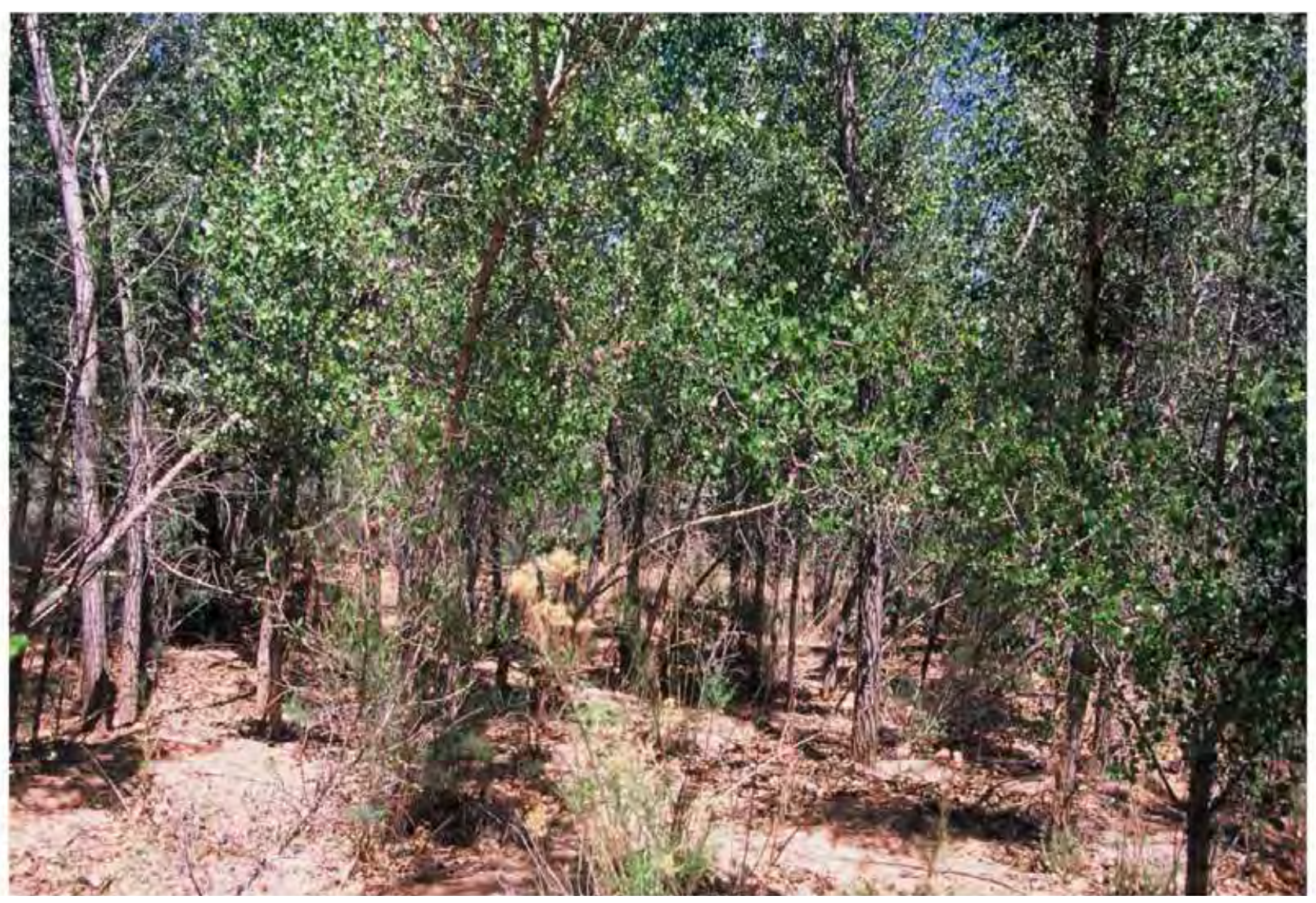

HM-400, 2012 


\section{Plate HM-401}

\section{Fremont River}

$1942 \div 2012$

Viewed east where the Fremont River flows through a gap in the Caineville Reef. (See also Plate HM-400.) The rock wall beyond the vehicle in the 1942 image is part of the Caineville Reef. The distant cliff on the left skyline is South Caineville Mesa. The original camera station is now blocked by a dense growth of cottonwoods, so the retake was made from the nearest open area that allowed a view of both the stream and Caineville Reef.

Repeated floods after 1894 completely transformed the Fremont River into a stream 200-300 yards wide, with an absence of woody riparian vegetation, as seen in this 1942 image. Since that time the river's channel has narrowed and down-cut, as seen in the retake. In contrast with conditions in 1942, the Fremont is now lined with willows and cottonwoods. Many of the cottonwoods in the retake were defoliated by tent caterpillars, while others were felled by beaver. Clearly this plate does not support the contention of Fleischner (2010) that continued livestock grazing has prevented the recovery of woody riparian vegetation along the Fremont River outside Capitol Reef National Park.

Original photograph taken by Charles Kelly on April 10, 1942; retake made by Charles E. Kay on May 20,2012 (Photo No. 6247-2). Section 15, Range 8 East, Township 29 South; UTM 496406E, 4238316N; elevation 4,685 ft. Original image (No. 10,486) held by the Utah State Historical Society, Salt Lake City, UT. 


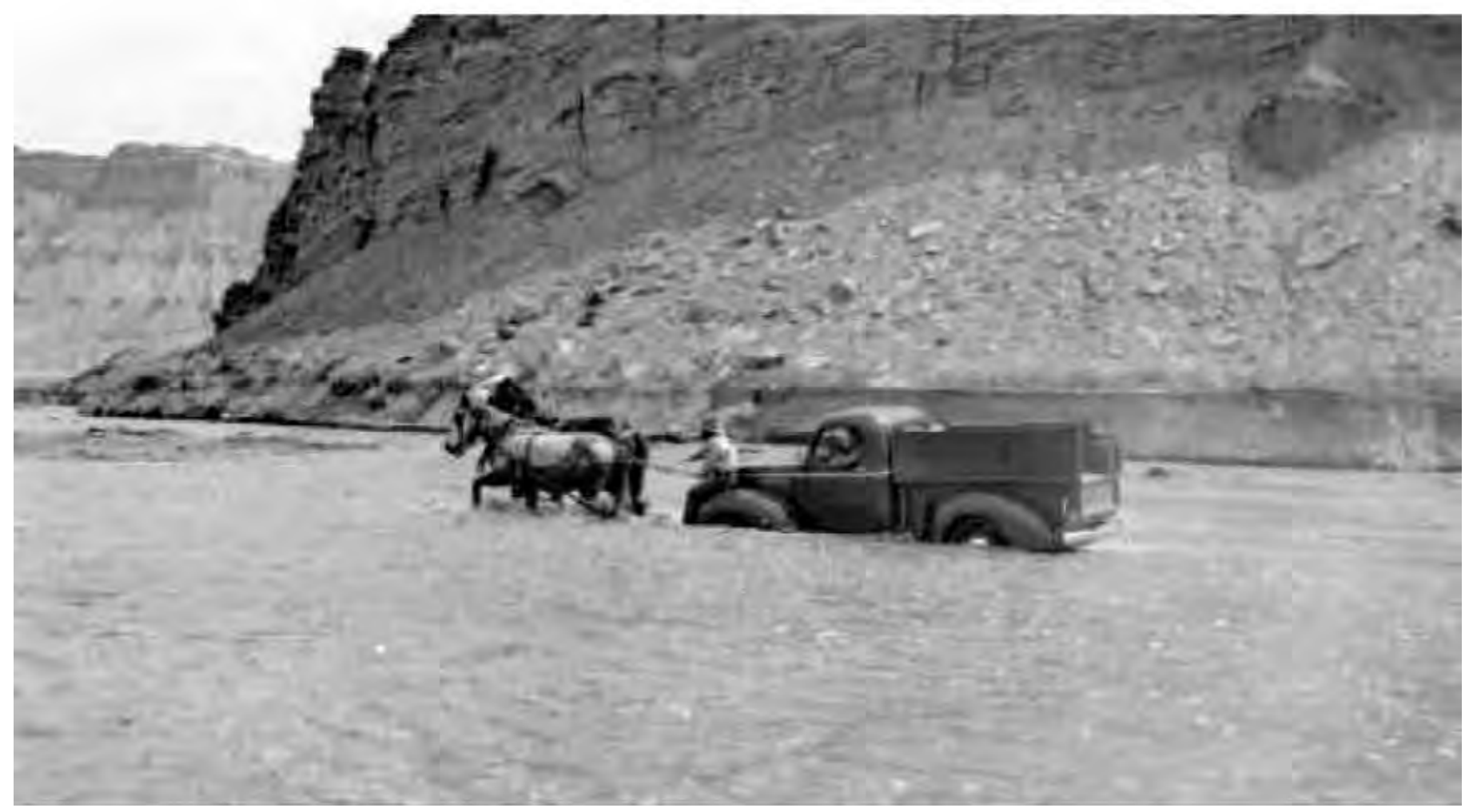

HM-401, 1942

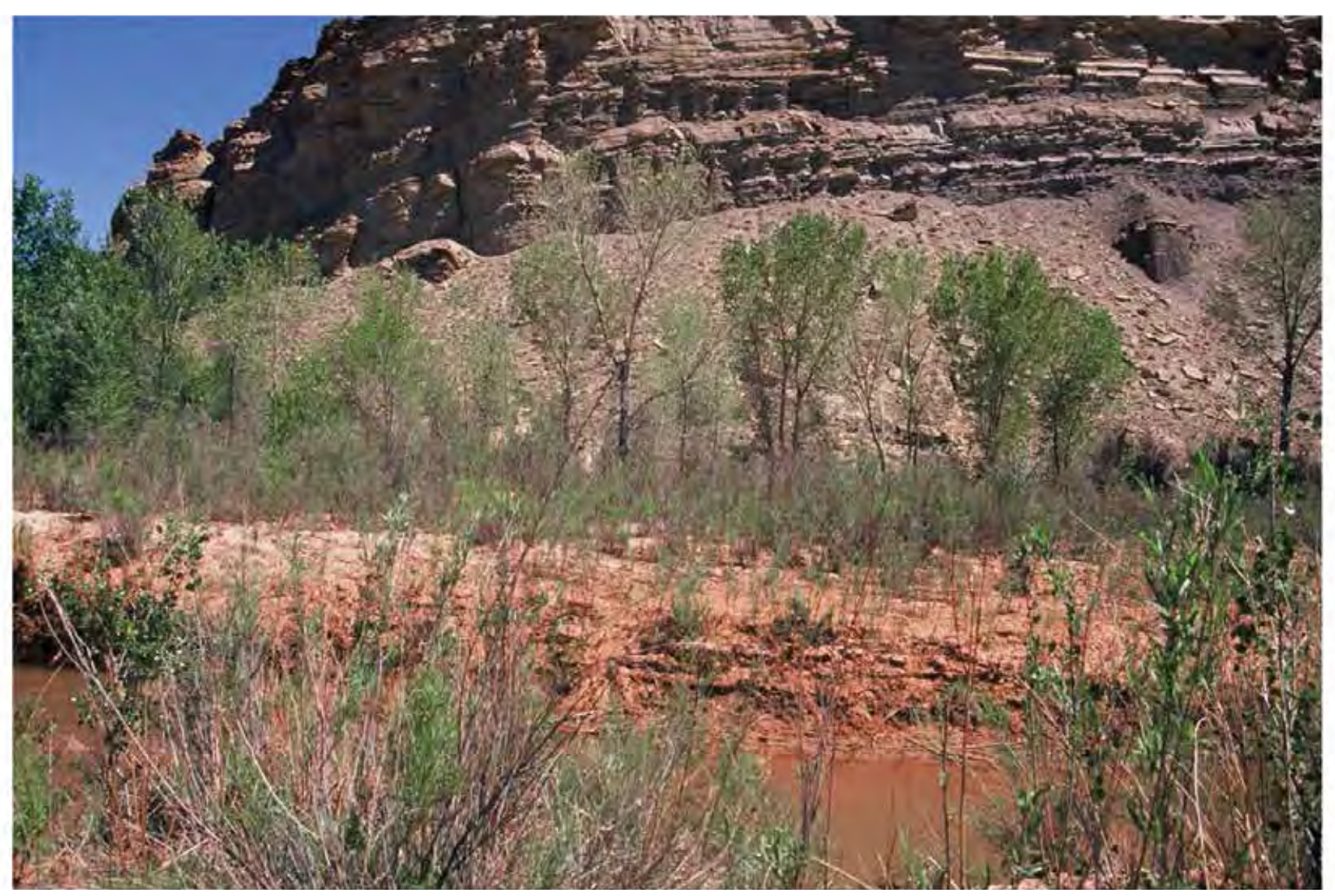

HM-401, 2012 


\section{Plate HM-404}

\section{Caineville}

$1932 \div 2012$

Viewed east-southeast down the Fremont River from the old road on the western edge of Caineville, Utah.

South Caineville Mesa is across the river on the right.

In 1932 the Fremont River was 300-400 yards wide at this point and had consumed a portion of the town.

Note the building on the left bank in the distance, about to fall into the river. Today, the channel has stabilized

and moved far to the south (right), where it is hidden from view. Tamarisk, willows, and cottonwoods have become established on what was once an active riverbed.

Original photograph taken by Reid Bailey in 1932; retake made by Charles E. Kay on May 20, 2012 (Photo No. 6247-16). Section 35, Range 8 East, Township 28 South; UTM 498169E, 4242533N; elevation 4,628 ft. Original image (G-439, Box 7, No. 270664) held by the Utah State Historical Society, Salt Lake City, UT. 


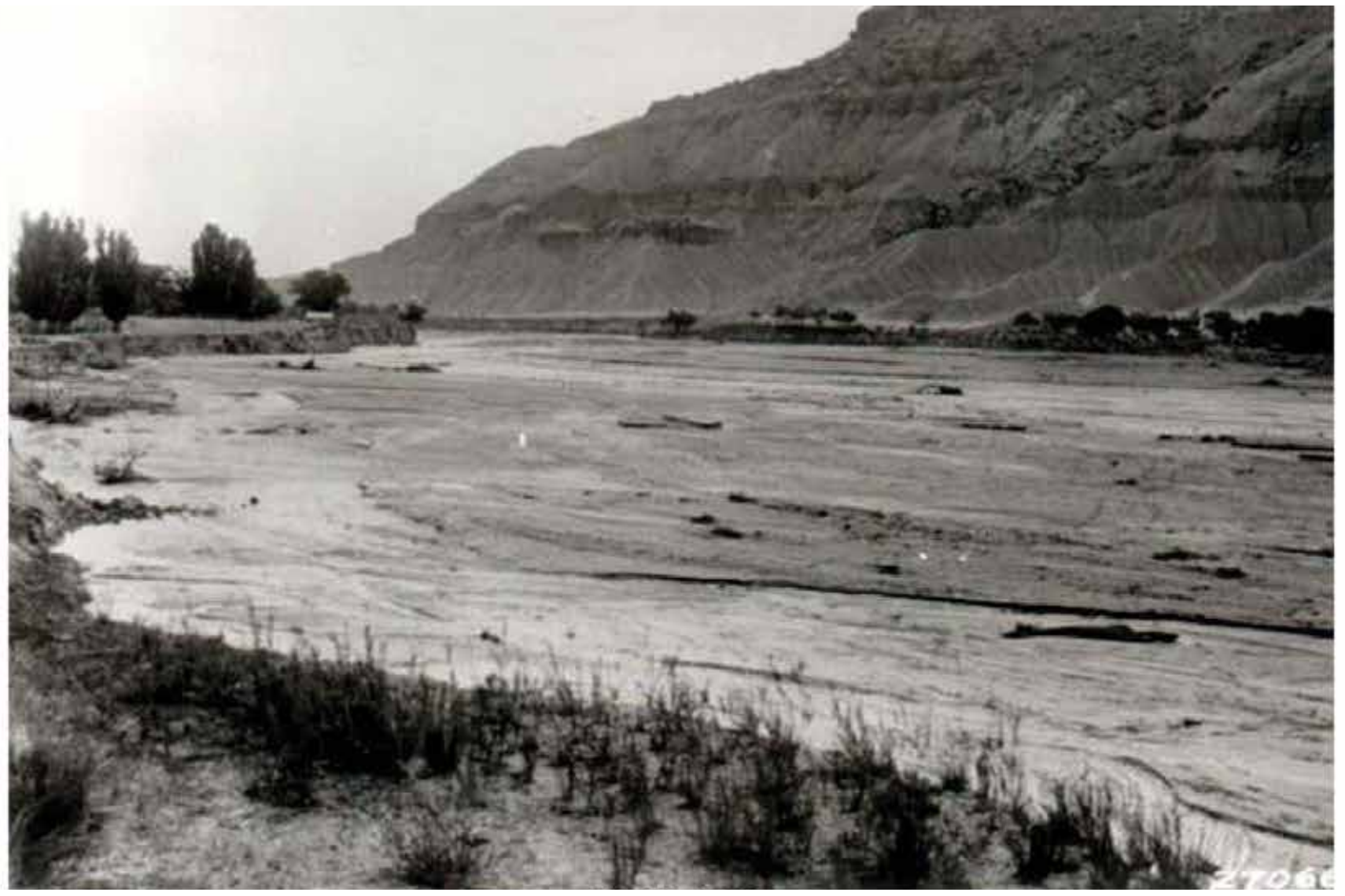

HM-404, 1932

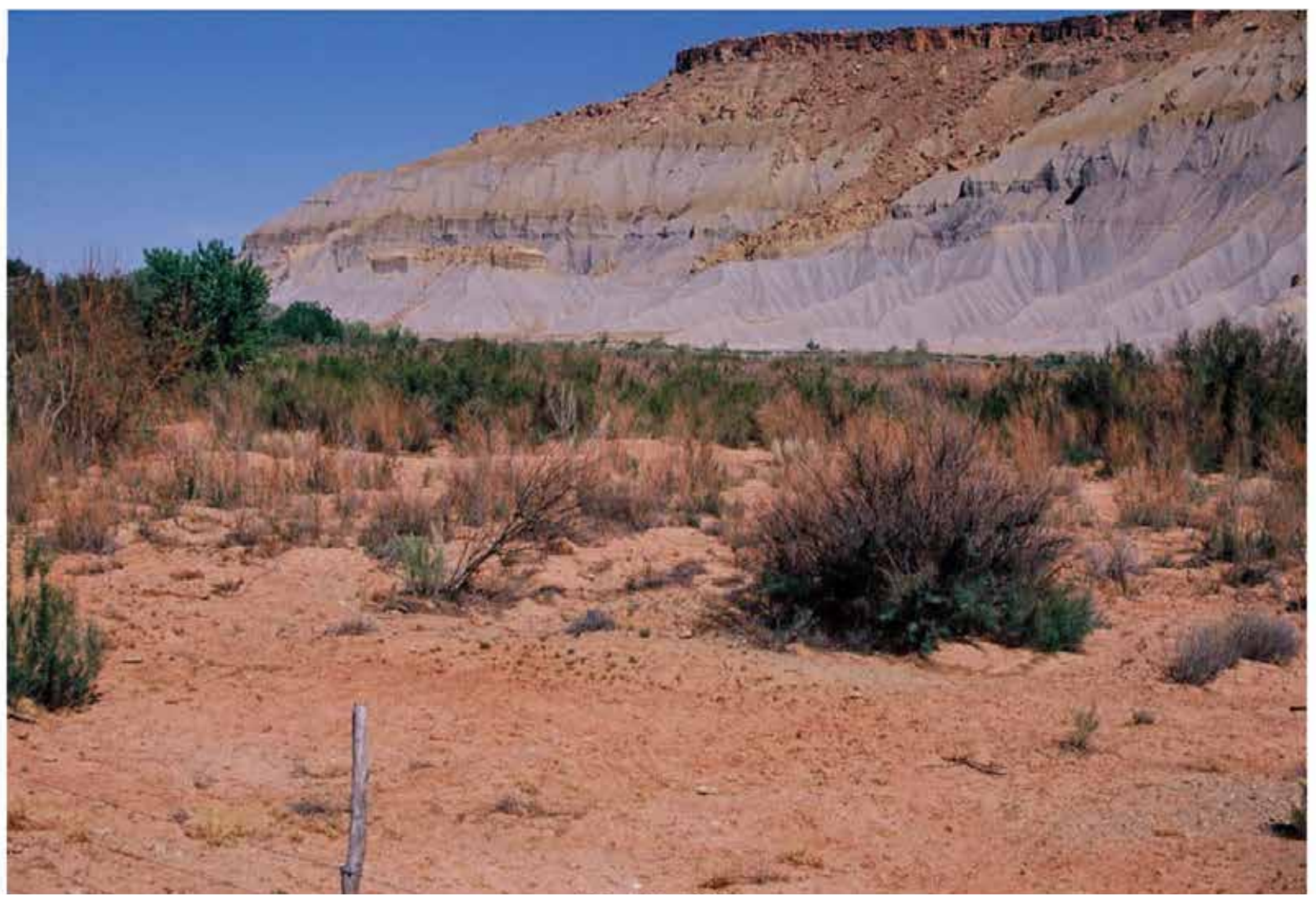




\section{Plate HM-424}

\section{Dirty Devil River}

$1984 \div 2012$

Viewed west from the southwest corner of the Utah Highway 95 bridge over the Dirty Devil River. The North Pinto

Hills are on the skyline. In the distance, Muddy Creek on the right joins the Fremont River on the left to form the Dirty Devil. The flow is toward the camera.

All stream channels have narrowed, and woody riparian vegetation has increased, including willows, cottonwoods, tamarisk, and Russian olive.

Original photograph taken by Charles Hunt in 1984 (print from a color slide); retake made by Charles E. Kay on May 22, 2012 (print from a color slide). Section 2, Range 11 East, Township 28 South; UTM 526898E, 4250548N; elevation 4,290 ft. Original image (PO-568, No. 1-4-34) held by the University of Utah, Marriott Library Special Collections, Salt Lake City, UT. 


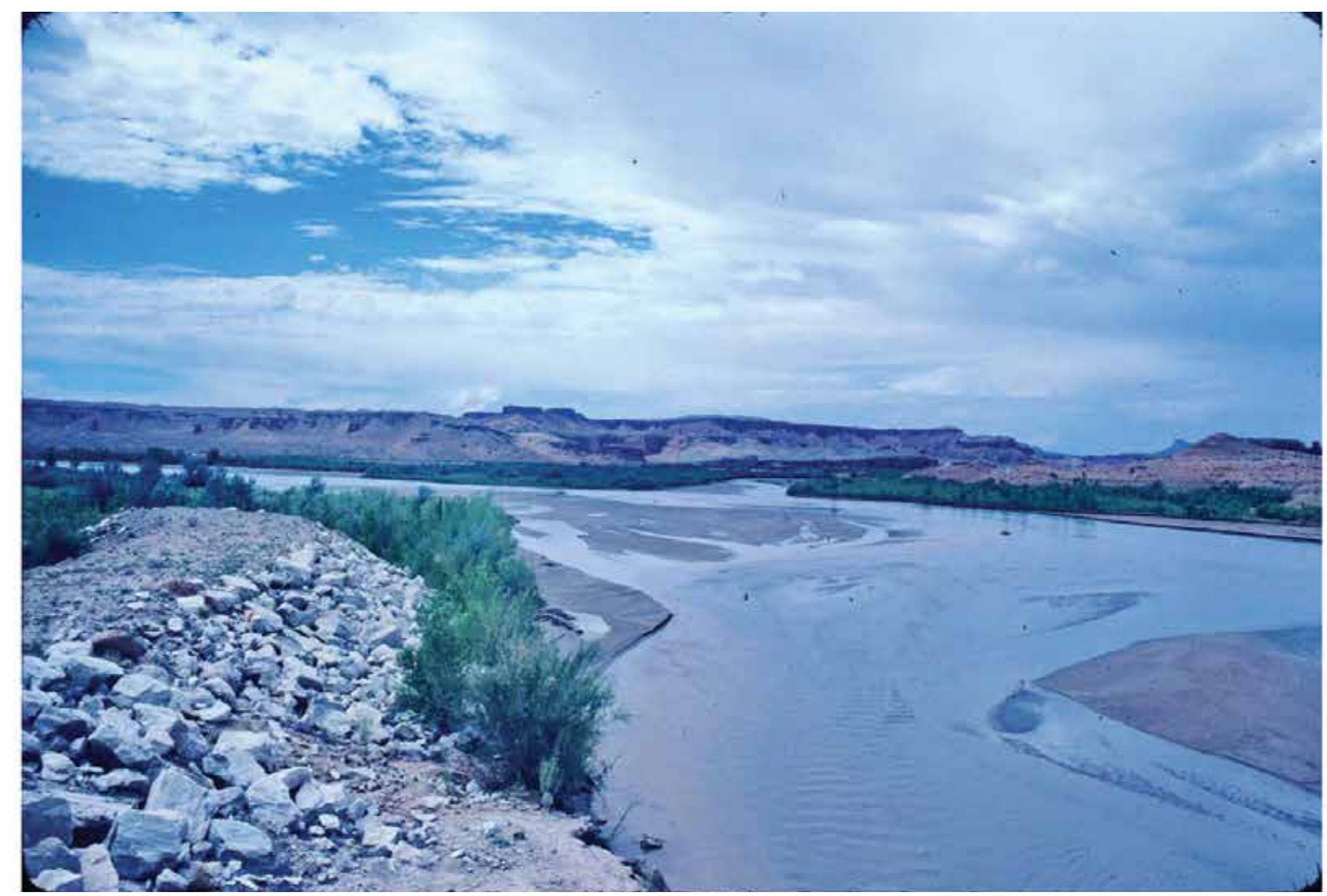

HM-424, 1984

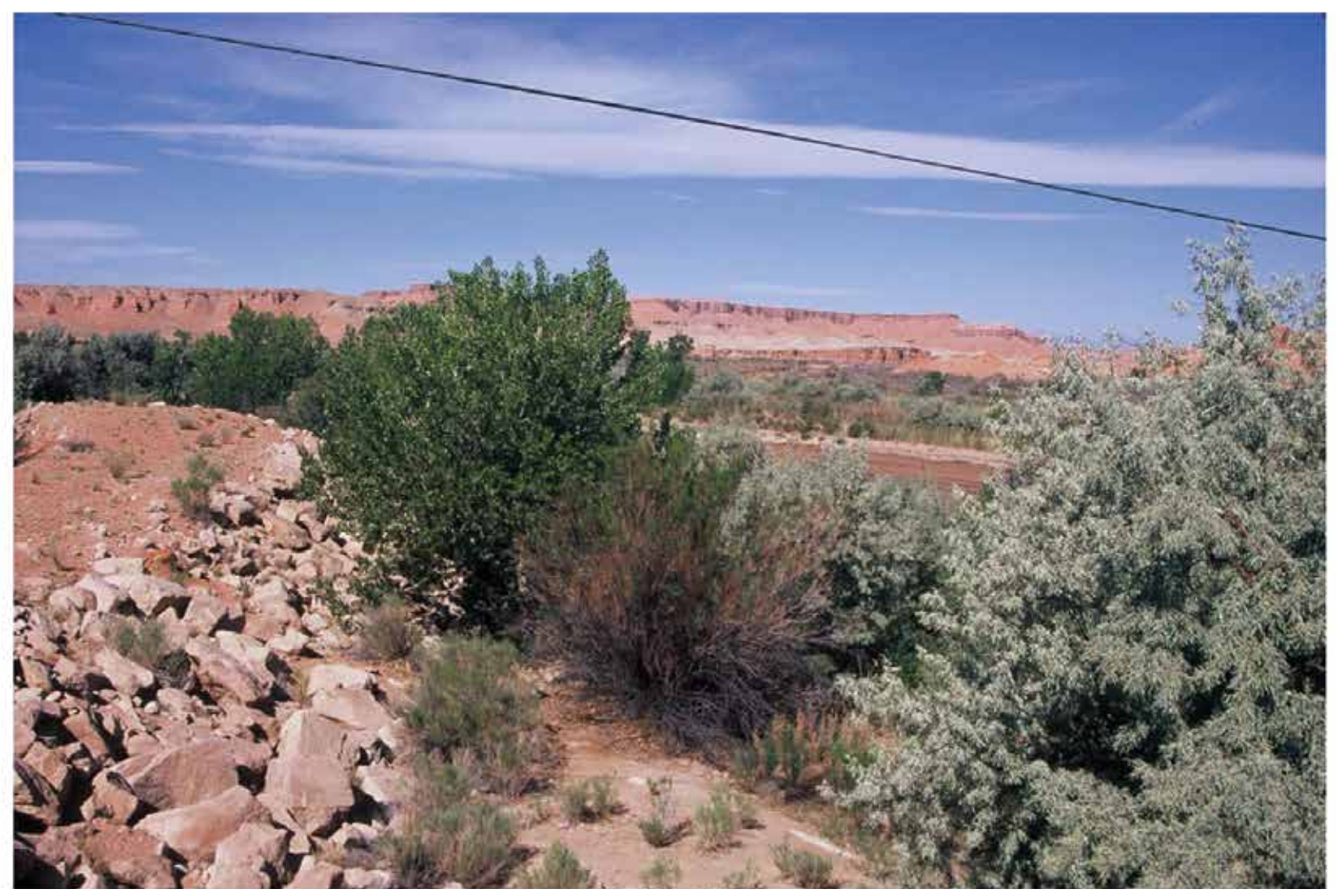




\section{Plate HM-437}

\section{Halfway Bench Exclosure}

$1967: 2012$

Viewed south down the west fence line of the Halfway Bench Exclosure, along the road to Angel Cove, southeast of Hanksville, Utah. BLM records do not indicate when the exclosure was built; however, there is a 1952 photo of the exclosure in the BLM's files. The fence apparently has been repaired or rebuilt over the years.

By 1967 a dense stand of nonnative grasses had developed inside the fenced area. Today, those nonnative grasses have died out and have been replaced by native species, including curly grass, shadscale, Indian ricegrass, winterfat, and Mormon tea. The area outside the exclosure is still heavily grazed by cattle.

Original photograph taken by the BLM on August 10, 1967; retake made by Charles E. Kay on May 23, 2012 (Photo No. 6257-4). Section 13, Range 11 East, Township 29 South; UTM 529943E, 4238488N; elevation 4,600 ft. Original image held in the BLM's range files, Hanksville, UT. 


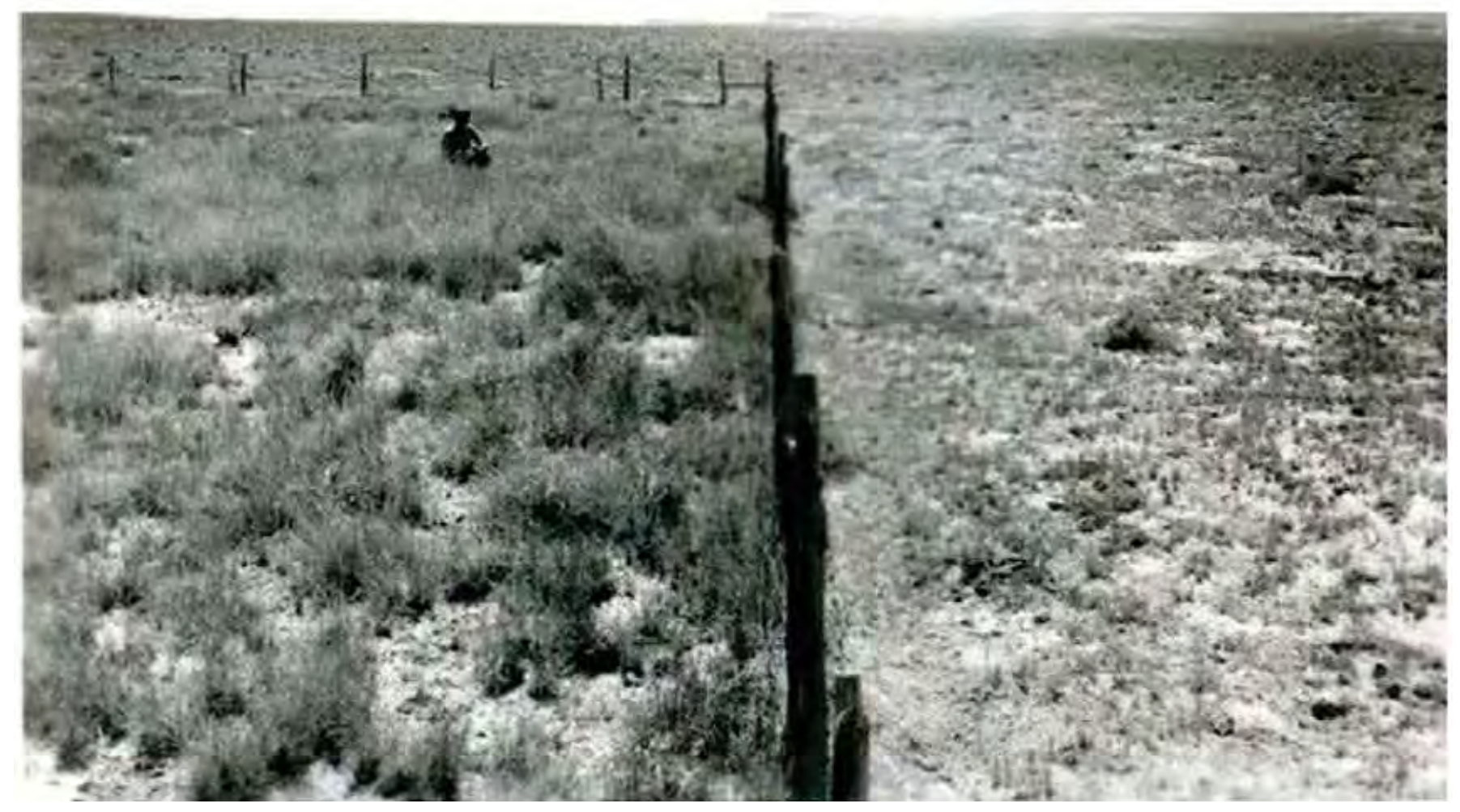

HM-437, 1967

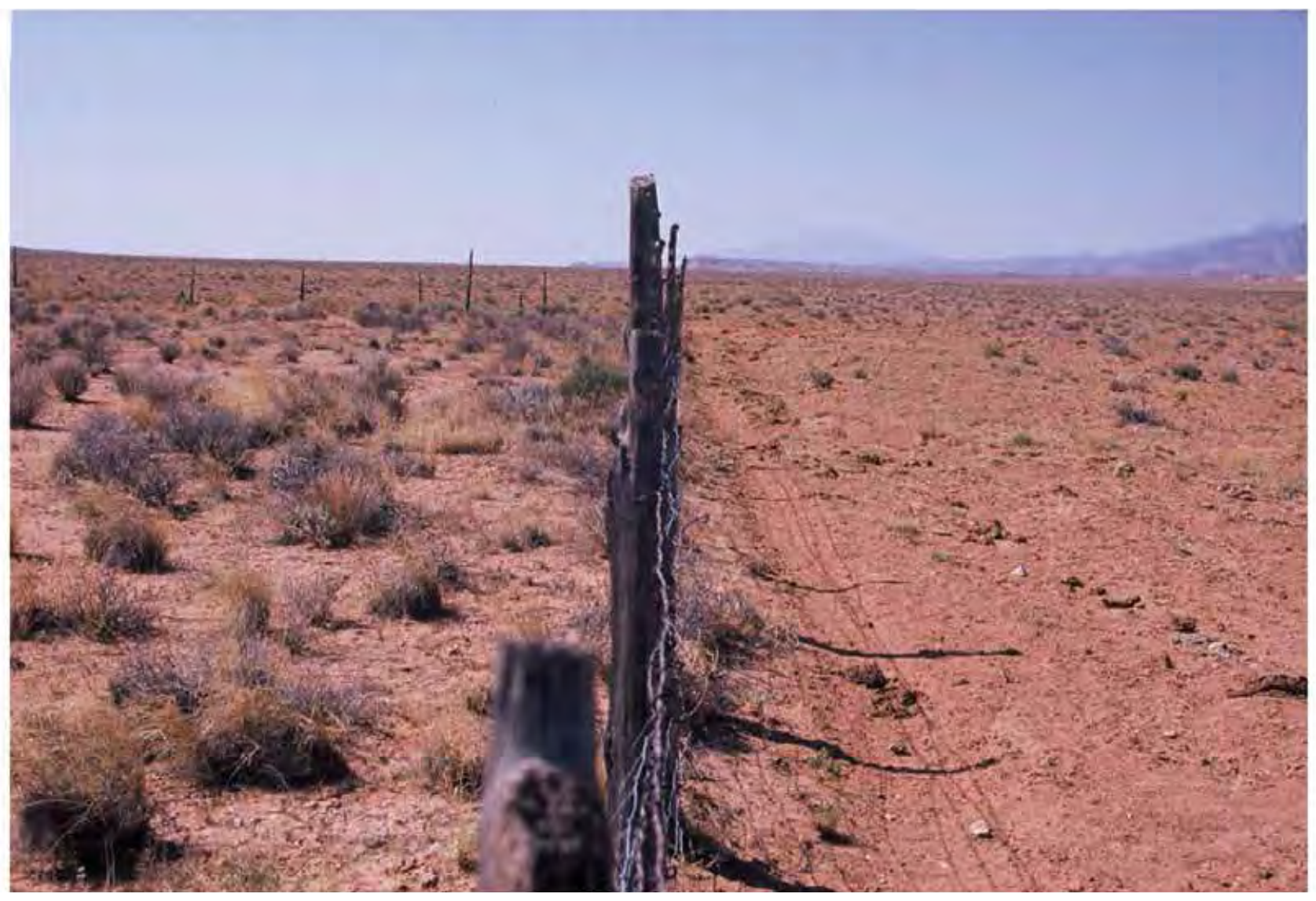

HM-437, 2012 


\section{Plate HM-442}

\section{Mount Hillers}

$1940 \div 2012$

Viewed northwest to the eastern flank of Mount Hillers, about 2 miles northeast of Starr Springs.

The area was very heavily grazed by domestic sheep in 1940. Judging by the hedged appearance in the original photo, all the blackbrush plants had been repeatedly browsed. The allotment is now grazed by cattle. Blackbrush has increased, as has pinyon-juniper. Mormon tea and sagebrush are also present, while perennial grass cover is minimal. A small amount of cheatgrass has invaded the land in the foreground. The 2003 Bulldog Fire burned parts of Mount Hillers in the distance.

Original photograph taken by the BLM in 1940; retake made by Charles E. Kay on May 24, 2012 (Photo No. 6257-23). Section 12, Range 11 East, Township 34 South; UTM 531056E, 4191223N; elevation 6,214 ft. Original image held in the BLM’s range files, Hanksville, UT. 


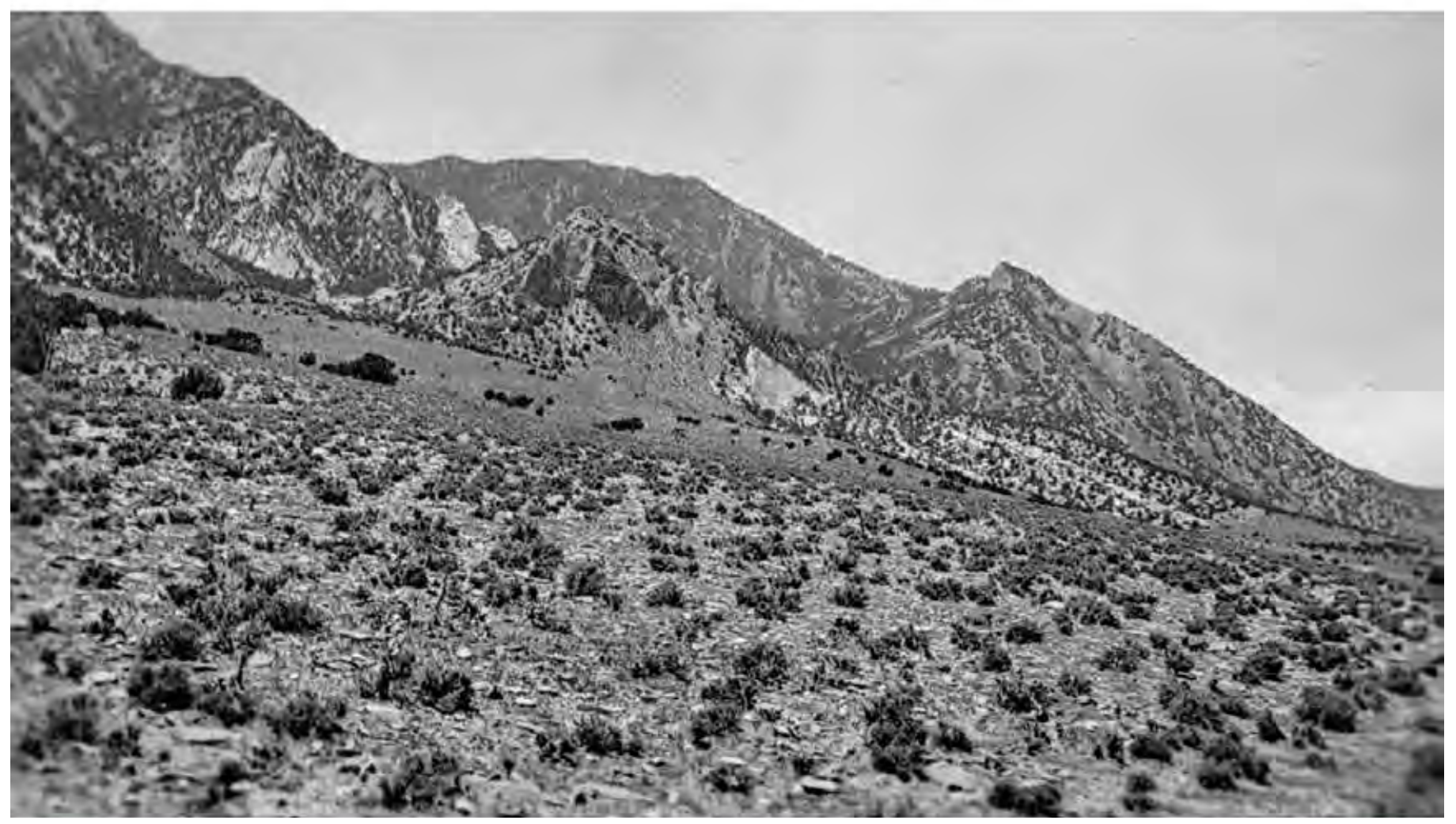

HM-442, 1940

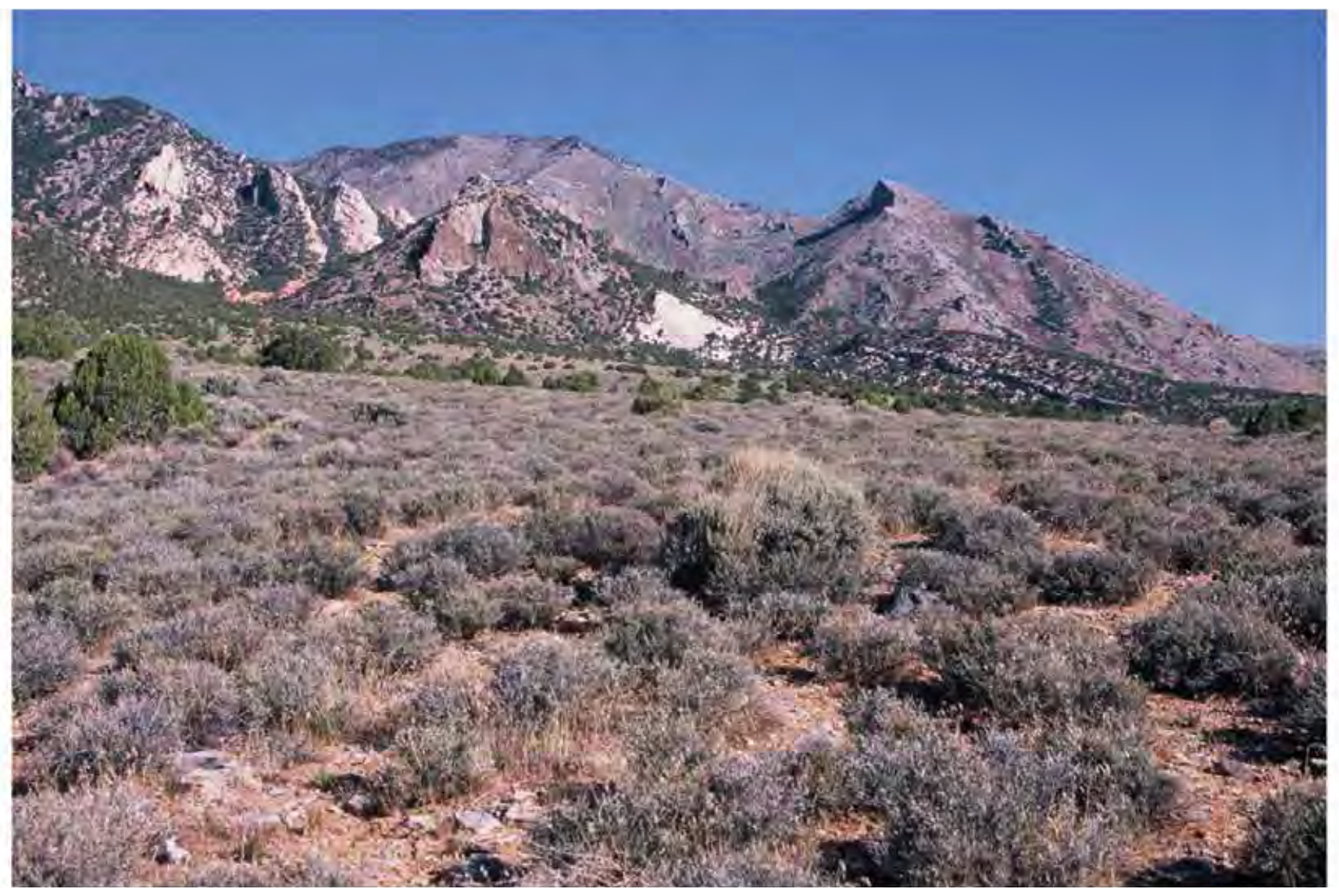

HM-442, 2012 


\section{Plate HM-443}

\section{StARr SPRingS}

$1940 \div 2012$

Viewed southwest to Starr Springs. A dense growth of willows and wild rose now blocks the original camera station, so the retake was made from the nearest open area, along the road in front of campsite number five in what is now a BLM campground (note the roof of a pit toilet, right-center).

The area was very heavily grazed in 1940. In the distance are cottonwoods. The shorter trees are oak brush.

Original photograph taken by the BLM in 1940; retake made by Charles E. Kay on May 24, 2012 (Photo No. 6257-29). Section 14, Range 11 East, Township 34 South; UTM 529743E, 4184146N; elevation 6,169 ft. Original image held in the BLM's range files, Hanksville, UT. 


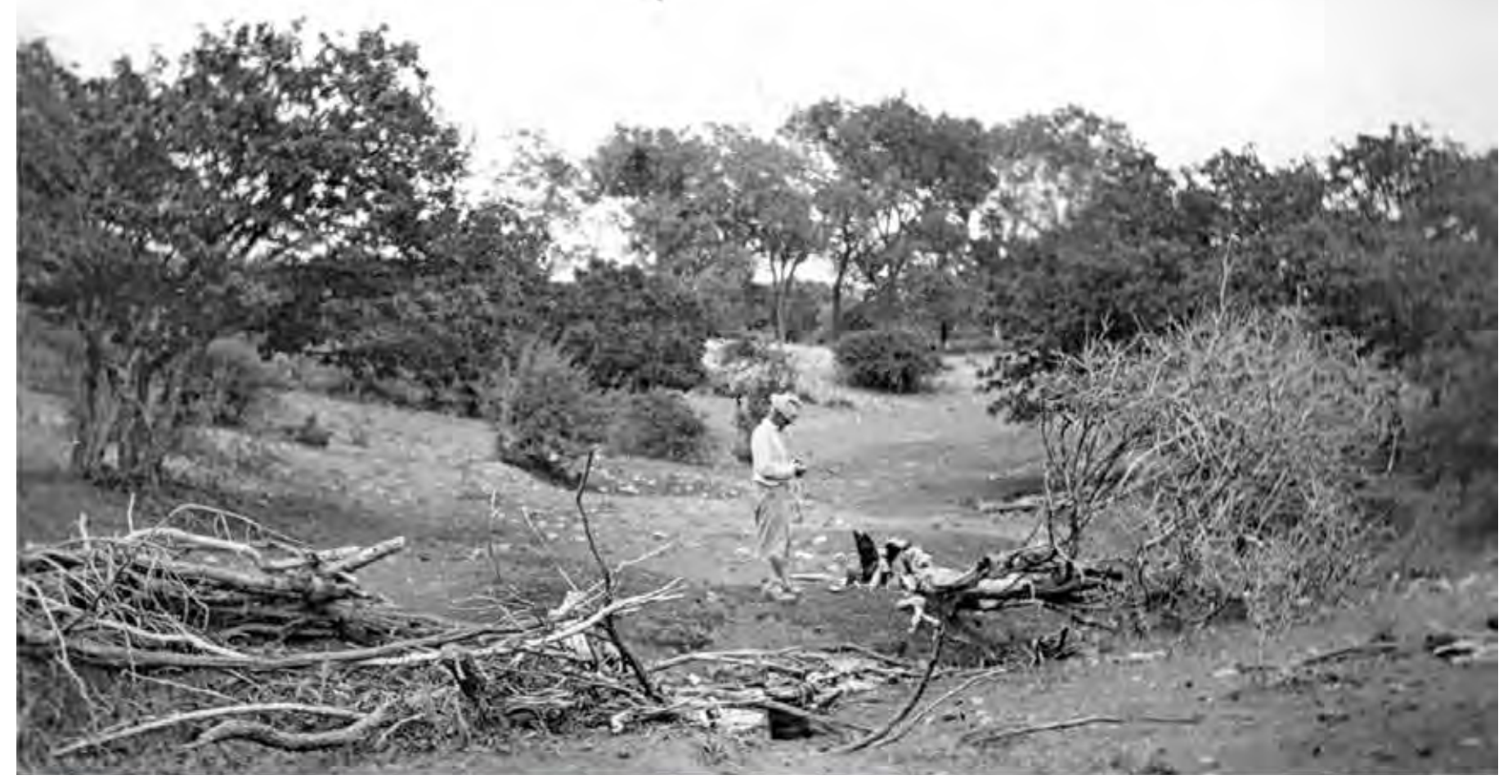

HM-443, 1940

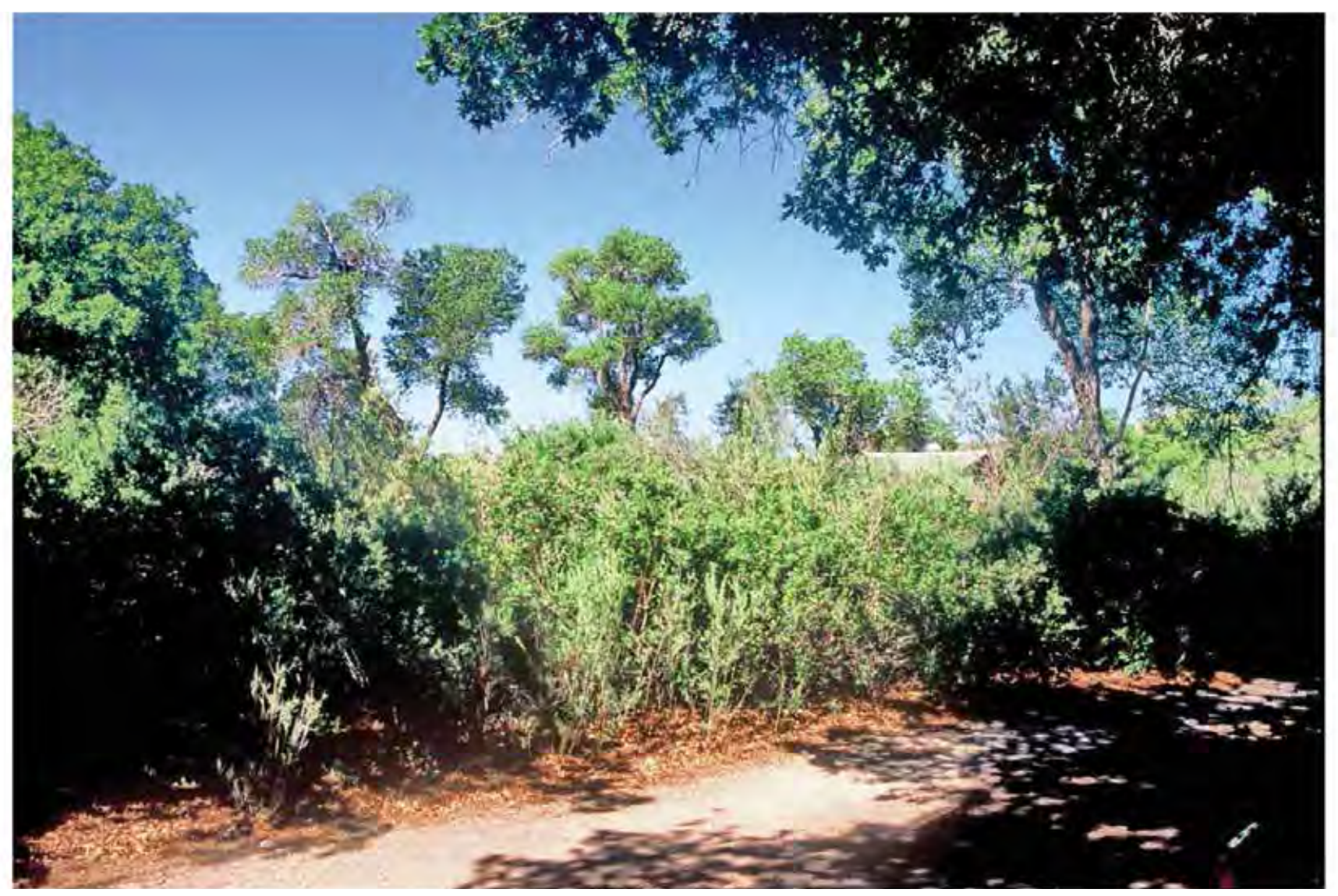




\section{Plate HM-447}

\section{Copper Creek Bench}

$1952 \because 2012$

Viewed north-northwest across upper Copper Creek Bench to the southern slopes of Mount Hillers, about 2 miles west of Starr Springs.

Pinyon, juniper, and mountain big sagebrush have all increased. Curly grass and blue grama are also present.

Original photograph taken by the BLM on May 14, 1952; retake made by Charles E. Kay on May 24, 2012

(Photo No. 6260-9). Section 15, Range 11 East, Township 34 South; UTM 527323E, 4188512N; elevation

6,161 ft. Original image held in the BLM's range files, Hanksville, UT. 


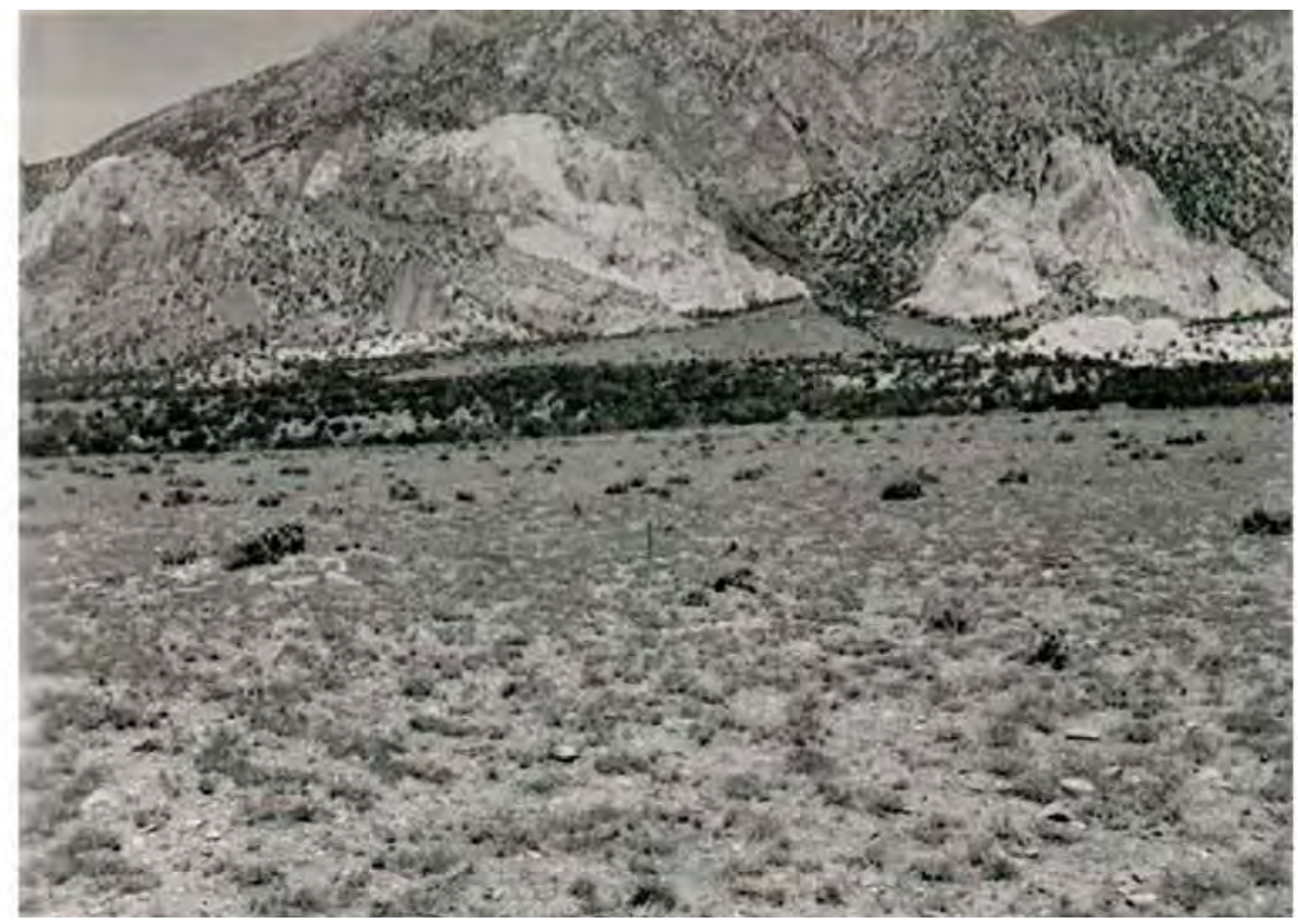

HM-447, 1952

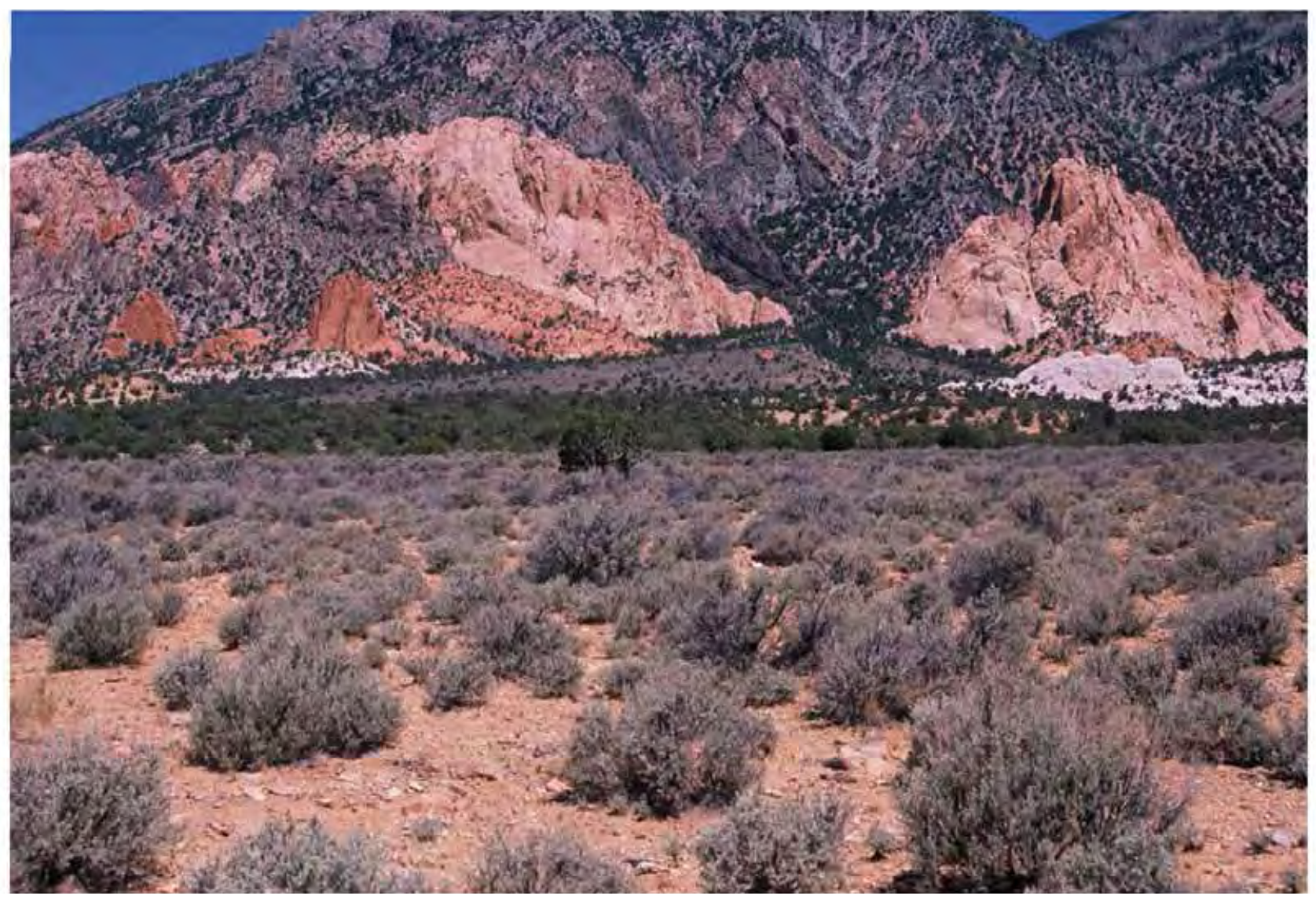




\section{Plate HM-448}

\section{Upper Copper Creek Bench}

$1967: 2012$

Viewed west to one of the sandstone spires on the southern slopes of Mount Hillers, about 2 miles west of

Starr Springs. A juniper now blocks the original camera station, so the retake was made a few feet further to the west (forward).

Years of excessive domestic sheep grazing removed the lower branches of the juniper nearest the camera in the 1967 photo. Pinyon, juniper, and sagebrush have all increased; grasses, primarily curly grass and blue grama, have declined. Cheatgrass has begun to invade the site. Apparently, livestock have not used this area in many years, but mule deer pellet groups were observed.

Original photograph taken by Charles Hunt in 1967 (print from a color slide); retake made by Charles E. Kay on May 24, 2012 (print from a color slide). Section 15, Range 11 East, Township 34 South; UTM 527075E, 4189743N; elevation 6,624 ft. Original image (PO-568, No. 1-5-83) held by the University of Utah, Marriott Library Special Collections, Salt Lake City, UT. 


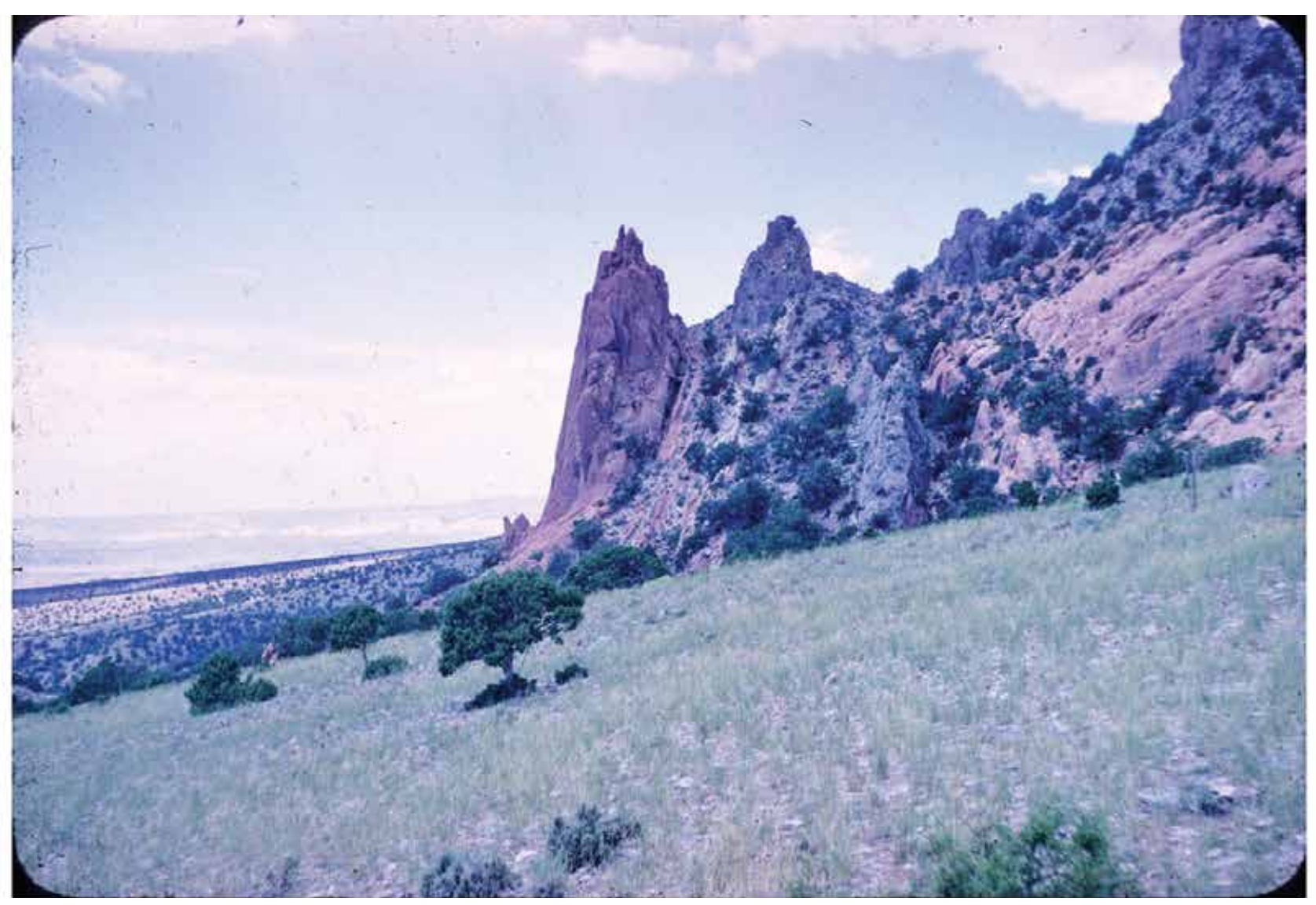

HM-448, 1967

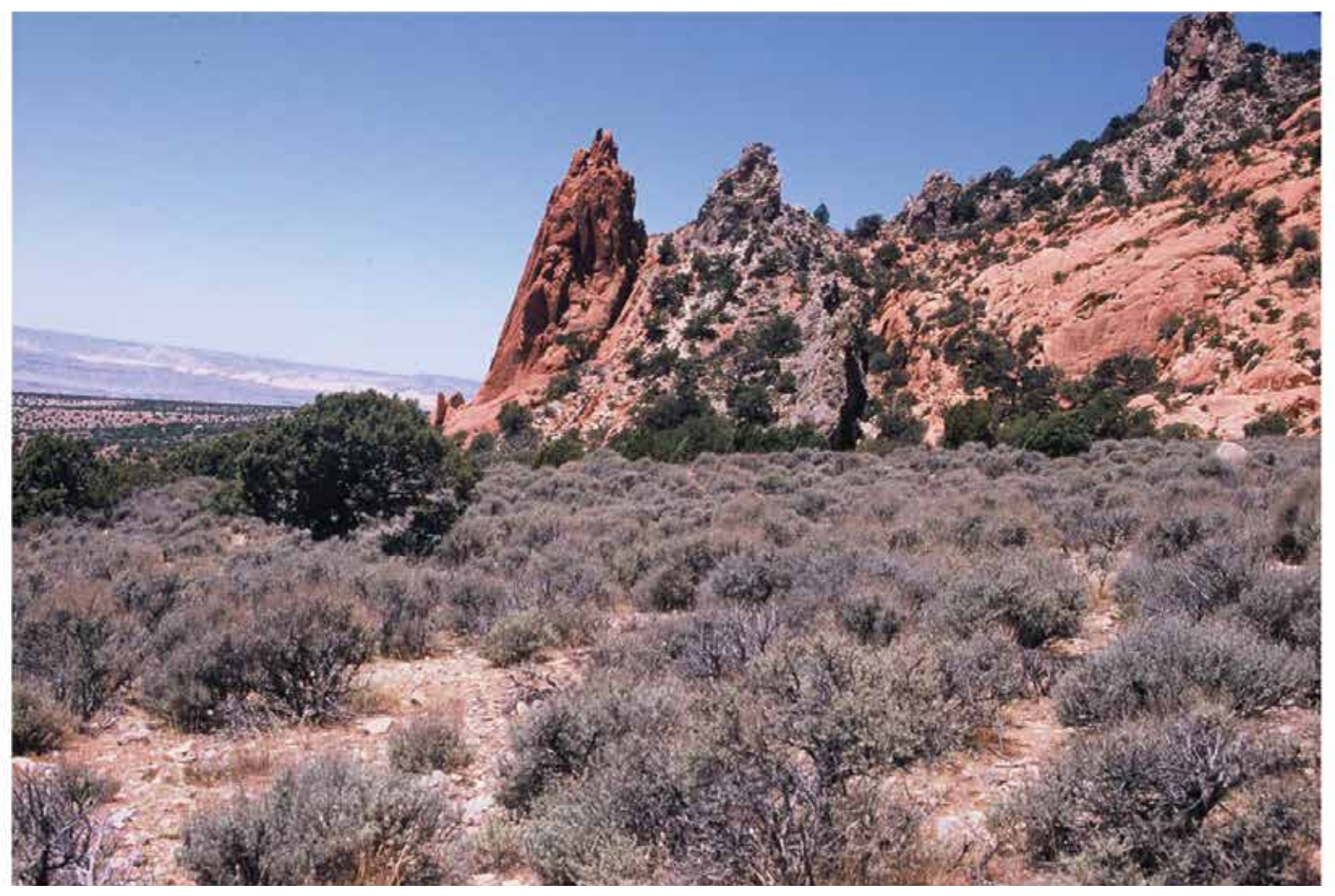

HM-448, 2012 


\section{Plate HM-449}

\section{Upper Copper Creek Benches}

$1940 \div 2012$

Viewed north-northeast to Mount Hillers, about 2 miles west of Starr Springs.

By 1940 domestic sheep had eaten everything but the rocks. Note that all junipers in the 1940 image had their lower branches consumed by years of excessive domestic sheep grazing. Although the area is now part of a cattle allotment, a lack of cow piles indicates that livestock have not used the area in recent years. Mule deer pellet groups, though, were observed. Today, mountain big sagebrush, pinyon, and juniper have all increased. Curly grass and blue grama are also present. Judging by the vegetation in Plate HM-449, one would assume that sagebrush increased once sheep grazing was eliminated. Plate HM-448, however, which is just up-slope from this photo point, suggests that may not be the case. Instead, based on Plate HM-448, the area apparently went from being overgrazed, to being a native grassland, before being overrun by sagebrush.

Original photograph taken by the BLM in 1940; retake made by Charles E. Kay on May 24, 2012 (Photo No. 6260-30). Section 15, Range 11 East, Township 34 South; UTM 526966E, 4189428N; elevation 6,443 ft. Original image held in the BLM's range files, Hanksville, UT. 


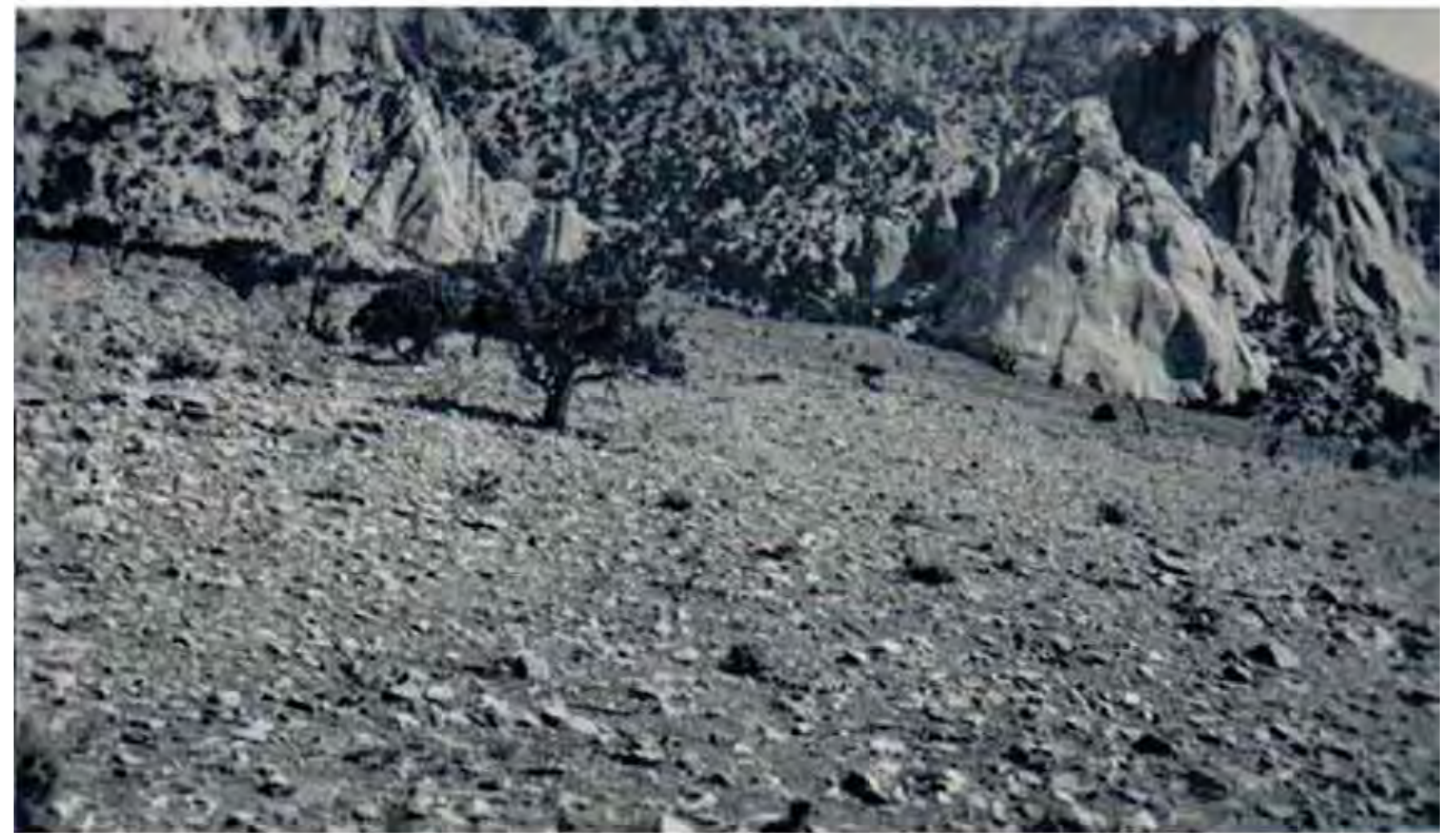

HM-449, 1940

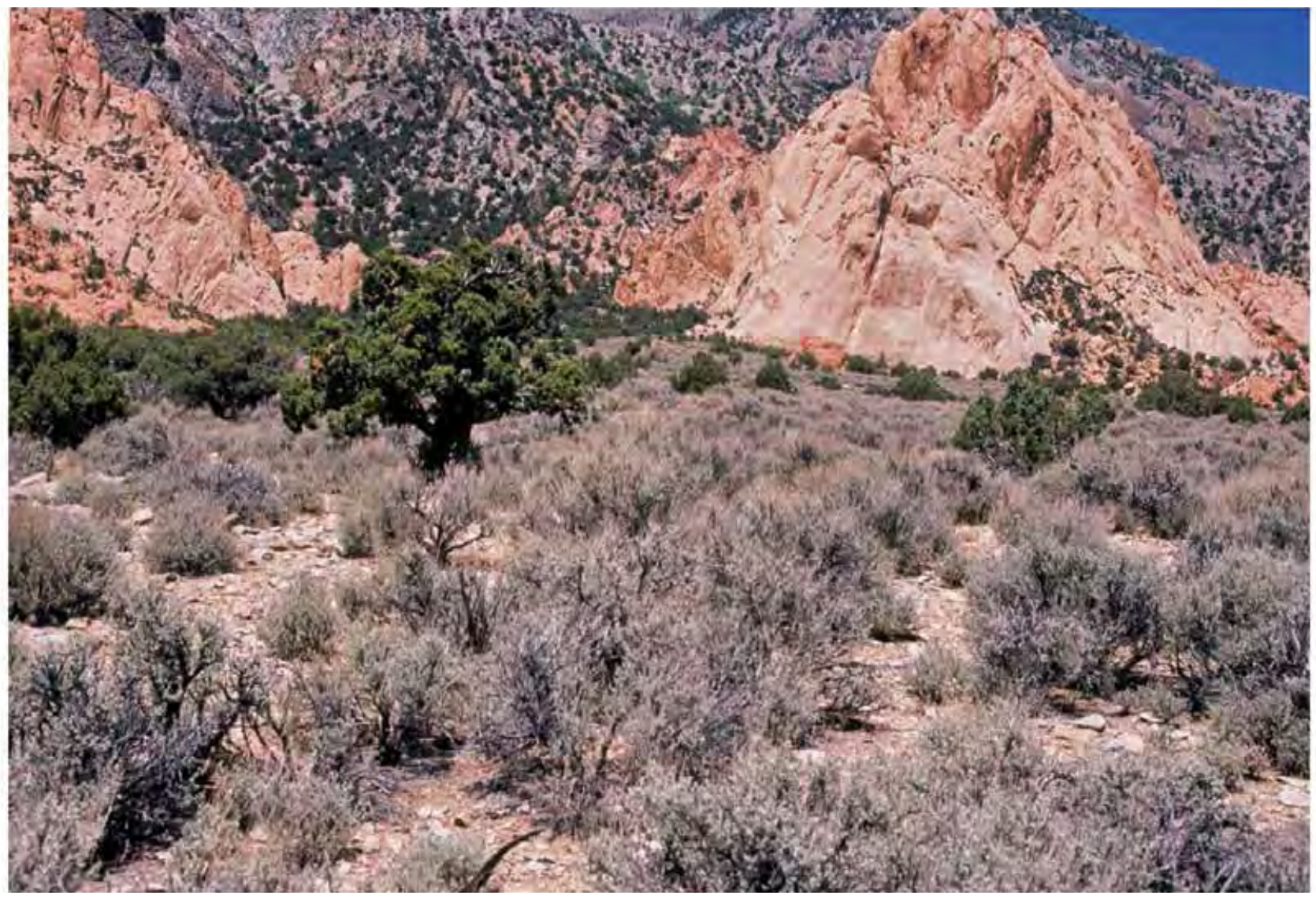


Plate HM-452

Lower Oak Ciren Canyon

$1915: 2012$

Viewed northwest across lower Oak Creek Canyon on the Sandy Ranch.

Pinyon and juniper have increased, especially on the distant slope. Shrubs in the foreground, primarily sagebrush and fourwing saltbush, have declined.

Original photograph taken by George C. Fraser (2005) on July 13, 1915; retake made by Charles E. Kay on June 15, 2012 (Photo No. 6263-6A). Section 36, Range 7 East, Township 31 South; UTM 491940E, 4213942N; elevation 5,592 ft. Original image (WC-038, Box 3, No. 8-12) held by Princeton University Library Special Collections, Princeton, NJ. 


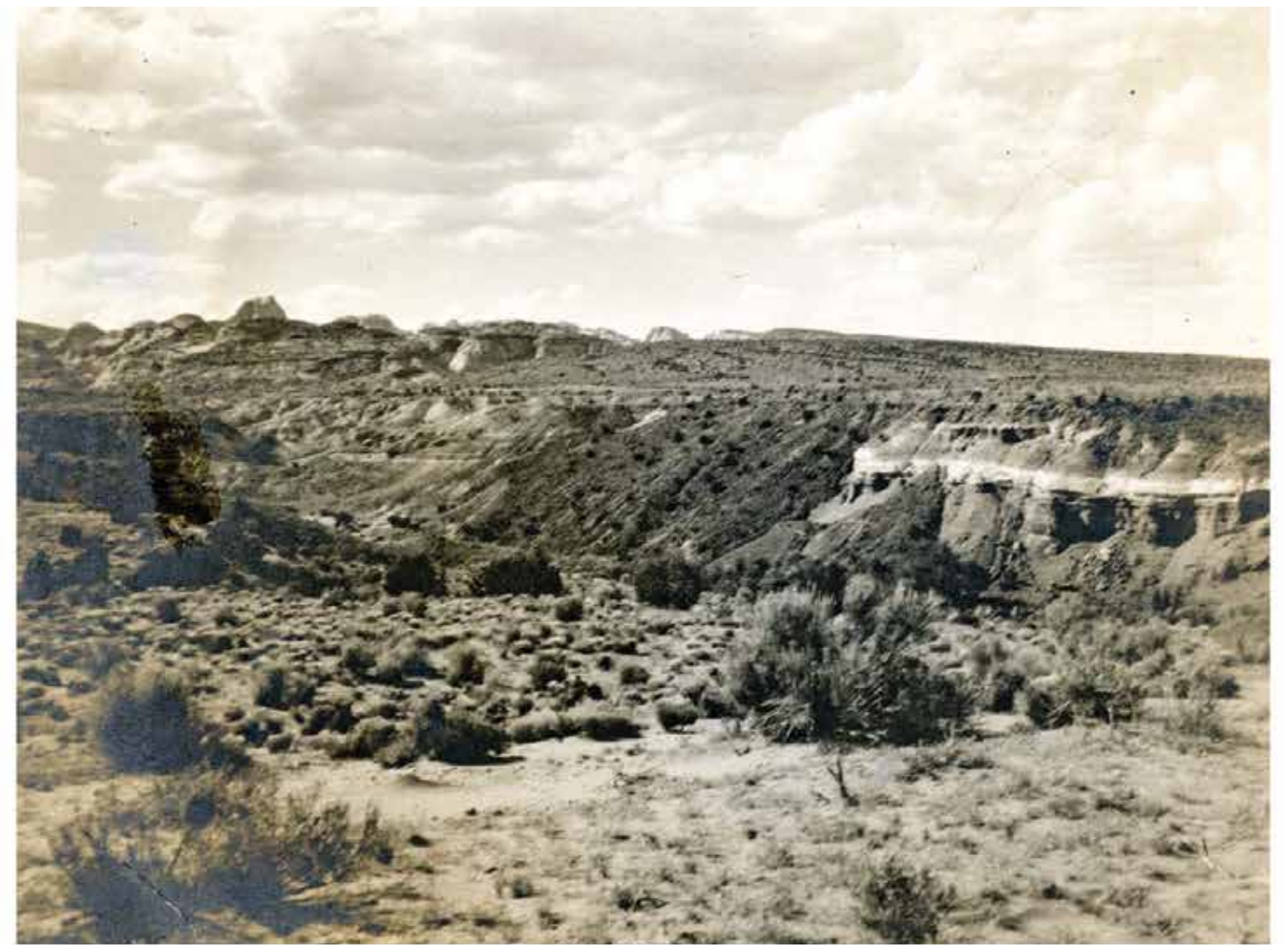

HM-452, 1915

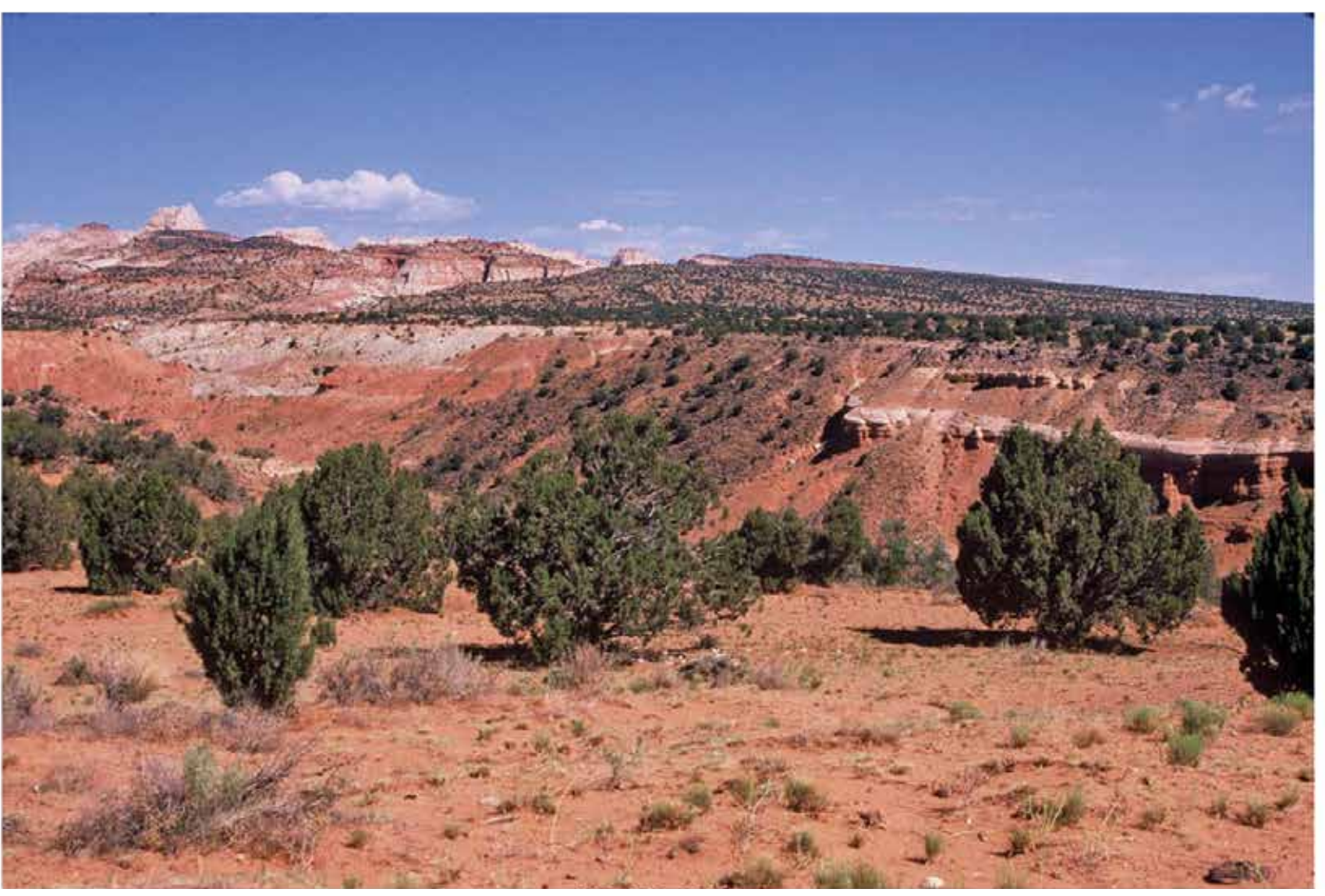

HM-452, 2012 


\section{Plate HM-457}

\section{Upper Oak Creek Bench}

$1915: 2012$

Viewed southwest across Siphon Canyon to upper Oak Creek Bench on the Sandy Ranch. The Waterpocket Fold is in the distance. Pinyon and juniper now block the original camera station, so the retake was made from the canyon rim, which is further to the south. The Sandy Ranch's Oak Creek siphon is just to the west of the photo point.

Across the canyon in the 1915 photo is a linear disturbed area running from right to left through the center of the image. This is the Sandy Ranch's Oak Creek irrigation ditch, which today is in a buried pipe next to an unimproved dirt road. Pinyon and juniper have increased; sagebrush has declined.

Original photograph taken by George C. Fraser (2005) on July 13, 1915; retake made by Charles E. Kay on June 15, 2012 (Photo No. 6263-27A). Section 27, Range 7 East, Township 31 South; UTM 488569E, 4214387N; elevation 5,809 ft. Original image (WC-038, Box 3, No. 9-1) held by Princeton University Library Special Collections, Princeton, NJ. 


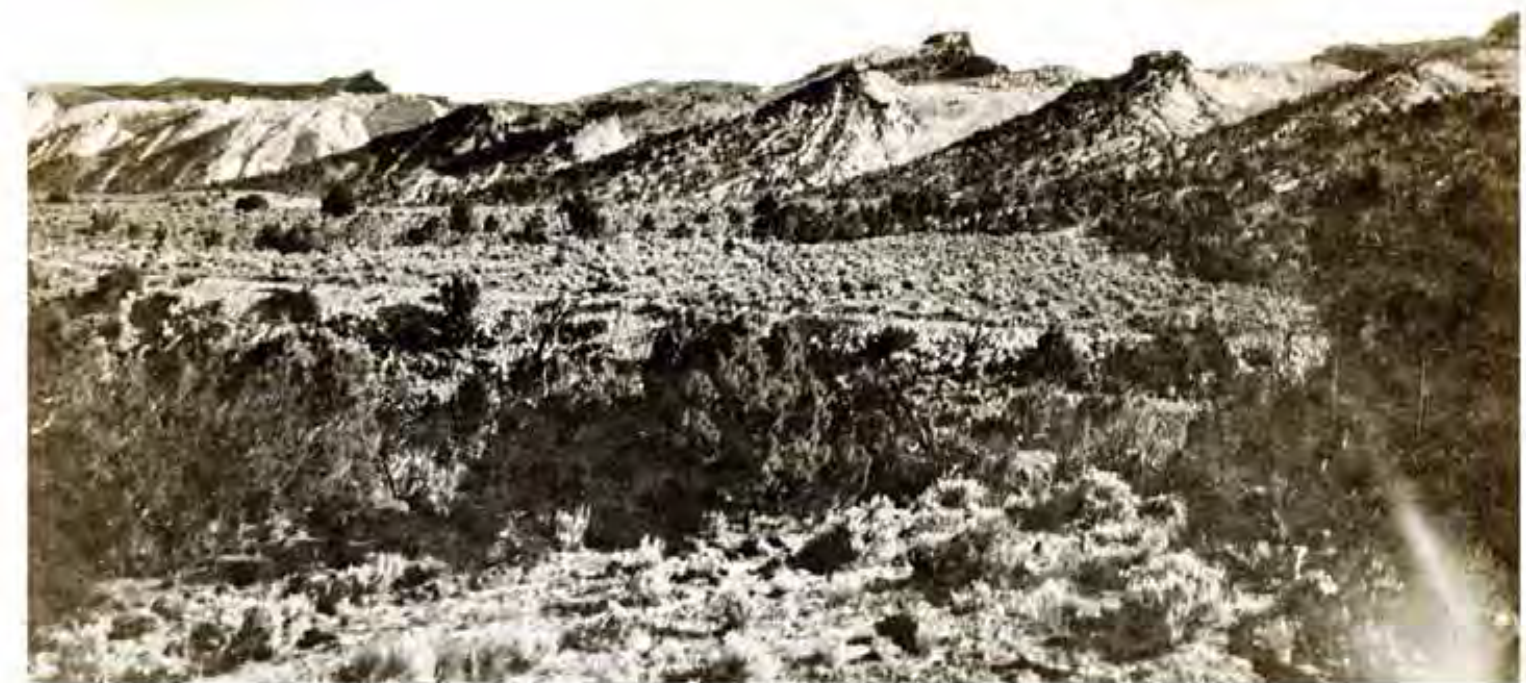

HM-457, 1915

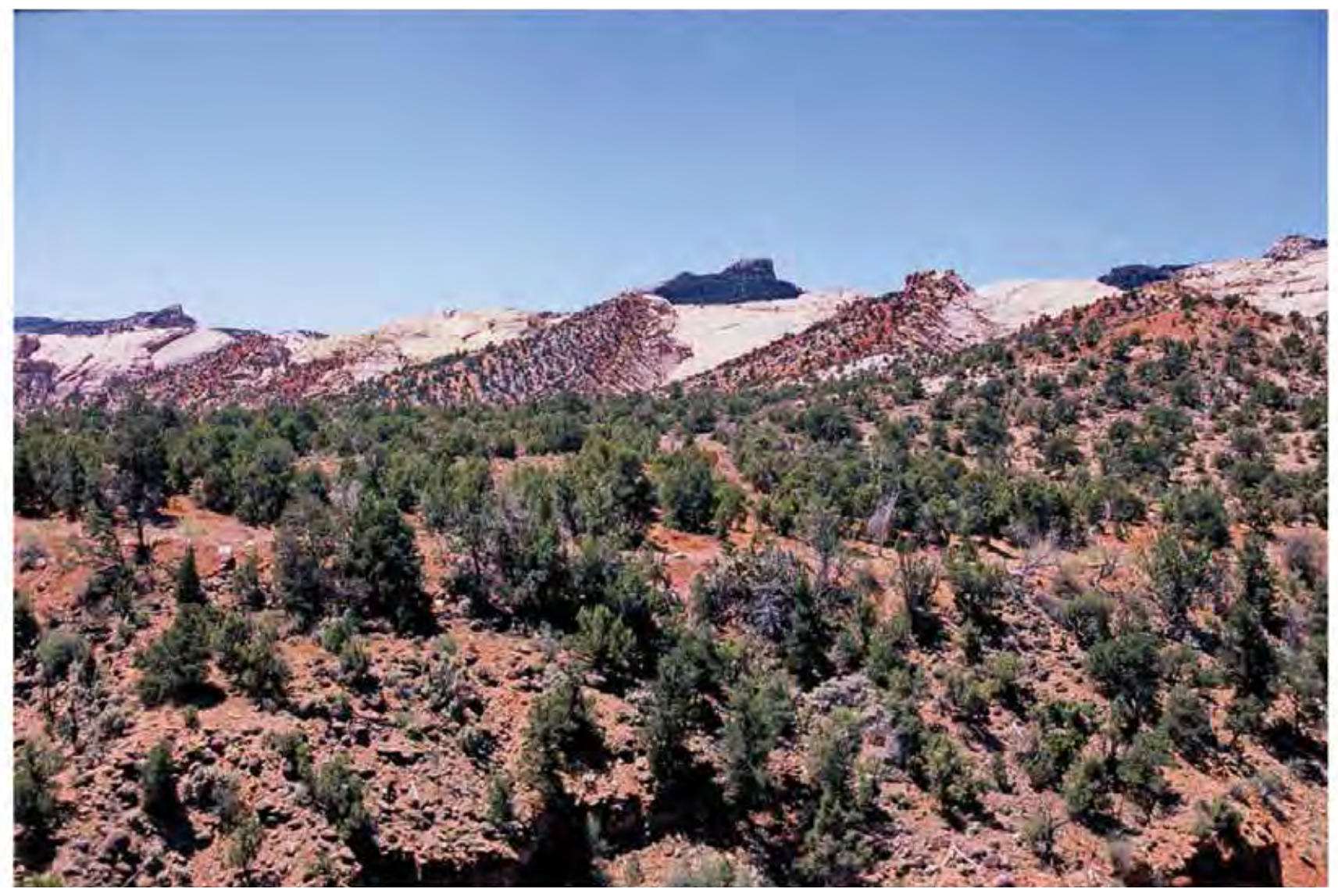

HM-457, 2012 


\section{Plate HM-461}

\section{Stevens NARrows}

$1915 \div 2012$

Viewed west just above Stevens Narrows on upper Sweetwater Creek. The original camera station is now blocked by two junipers, so the retake was made about 20 feet forward.

Sagebrush and greasewood are common in the drainage nearest the camera. The low-growing shrubs on the surrounding hills are primarily shadscale. Juniper has increased. Curly grass is also present.

Original photograph taken by George C. Fraser (2005) on July 11, 1915; retake made by Charles E. Kay on June 16, 2012 (Photo No. 6268-11). Section 13, Range 9 East, Township 32 South; UTM 511030E, 4207997N; elevation 6,524 ft. Original image (WC-038, Box 3, No. 8-10) held by Princeton University Library Special Collections, Princeton, NJ. 


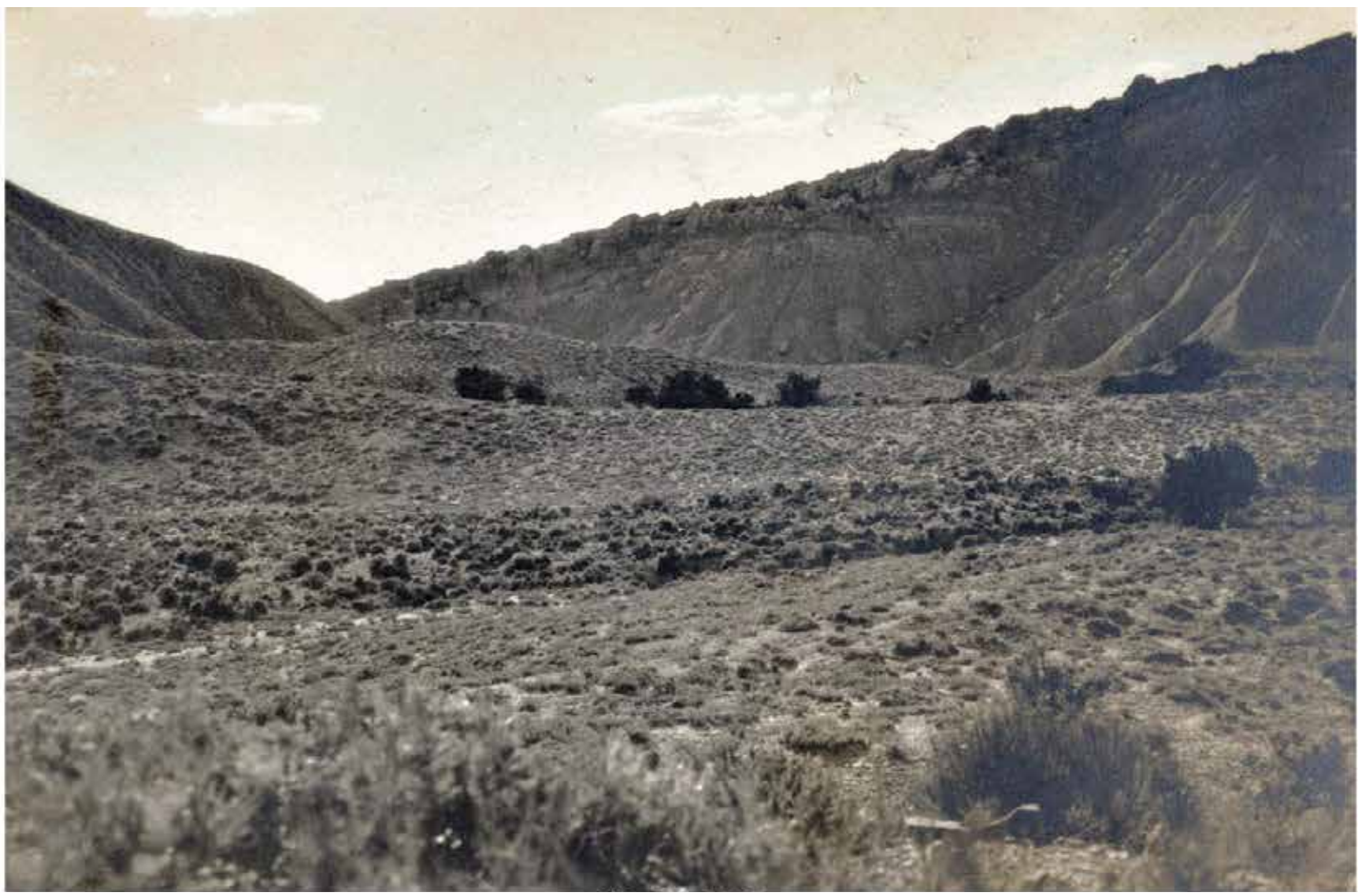

HM-461, 1915

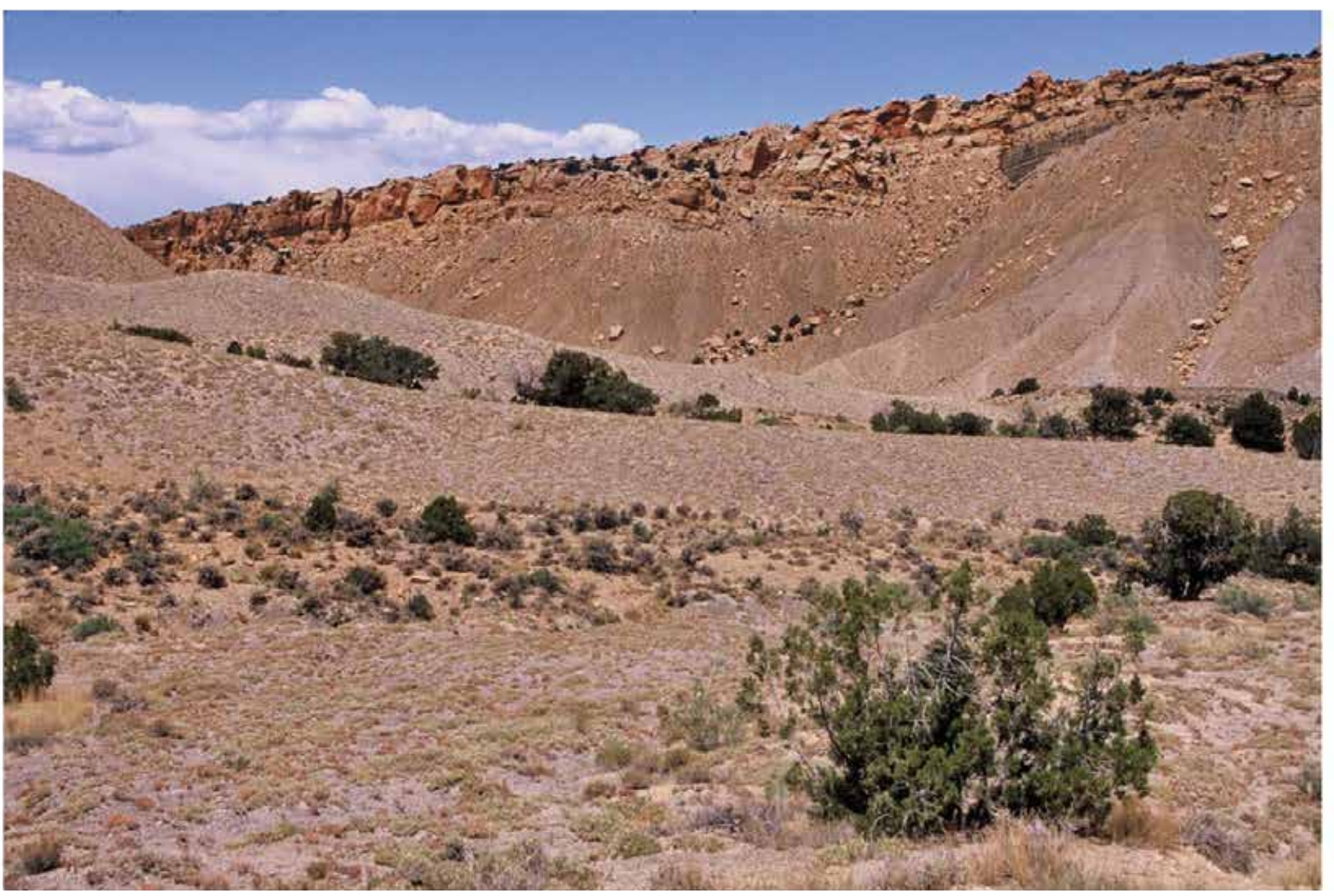

HM-461, 2012 
Plate HM-462

Apple Brush Flat

$1915: 2012$

Viewed northwest across Apple Brush Flat to the southern end of Stevens Mesa.

Sagebrush, squaw apple, and pinyon-juniper have all increased. Blue grama, Mormon tea, and snakeweed are also present.

Original photograph taken by George C. Fraser (2005) on July 9, 1915; retake made by Charles E. Kay on June 16, 2012 (Photo No. 6268-16). Section 22, Range 9 East, Township 31 South; UTM 508691E, 4216964N; elevation 6,414 ft. Original image (WC-038, Box 3, No. 7-7) held by Princeton University Library Special Collections, Princeton, NJ. 


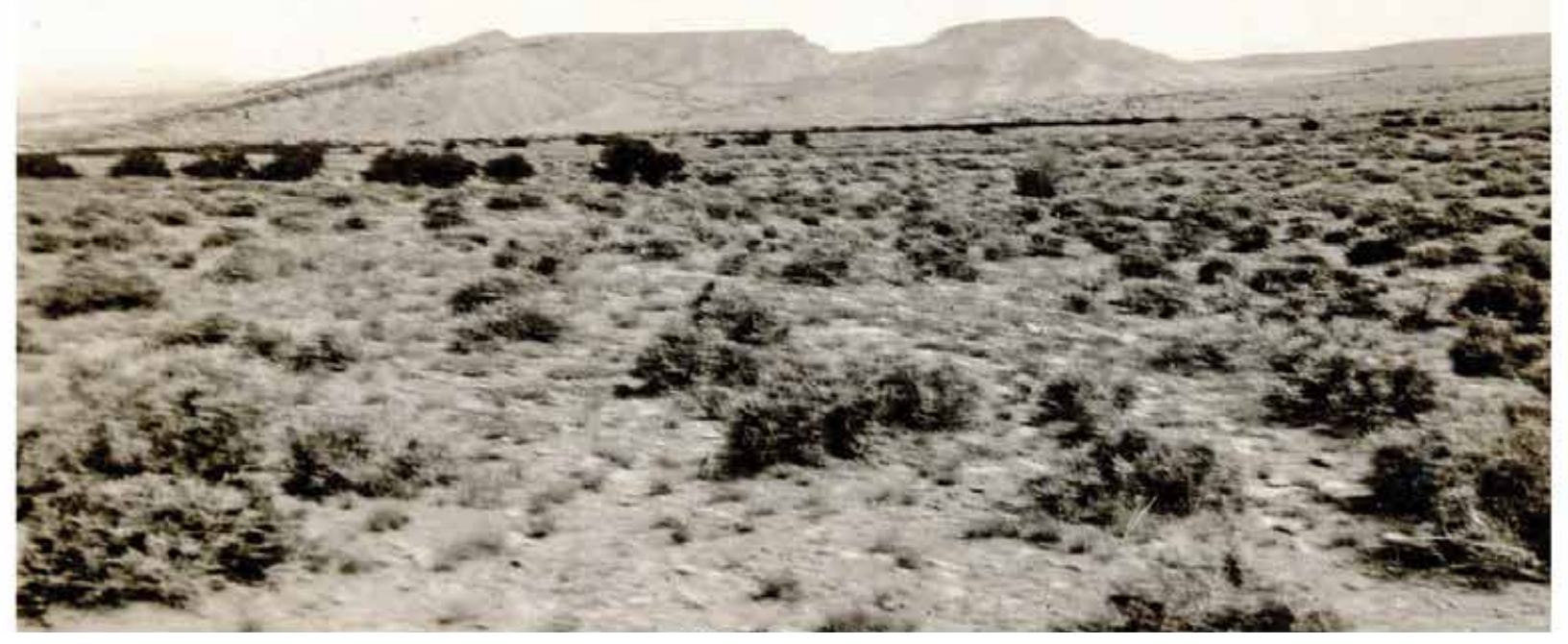

HM-462, 1915

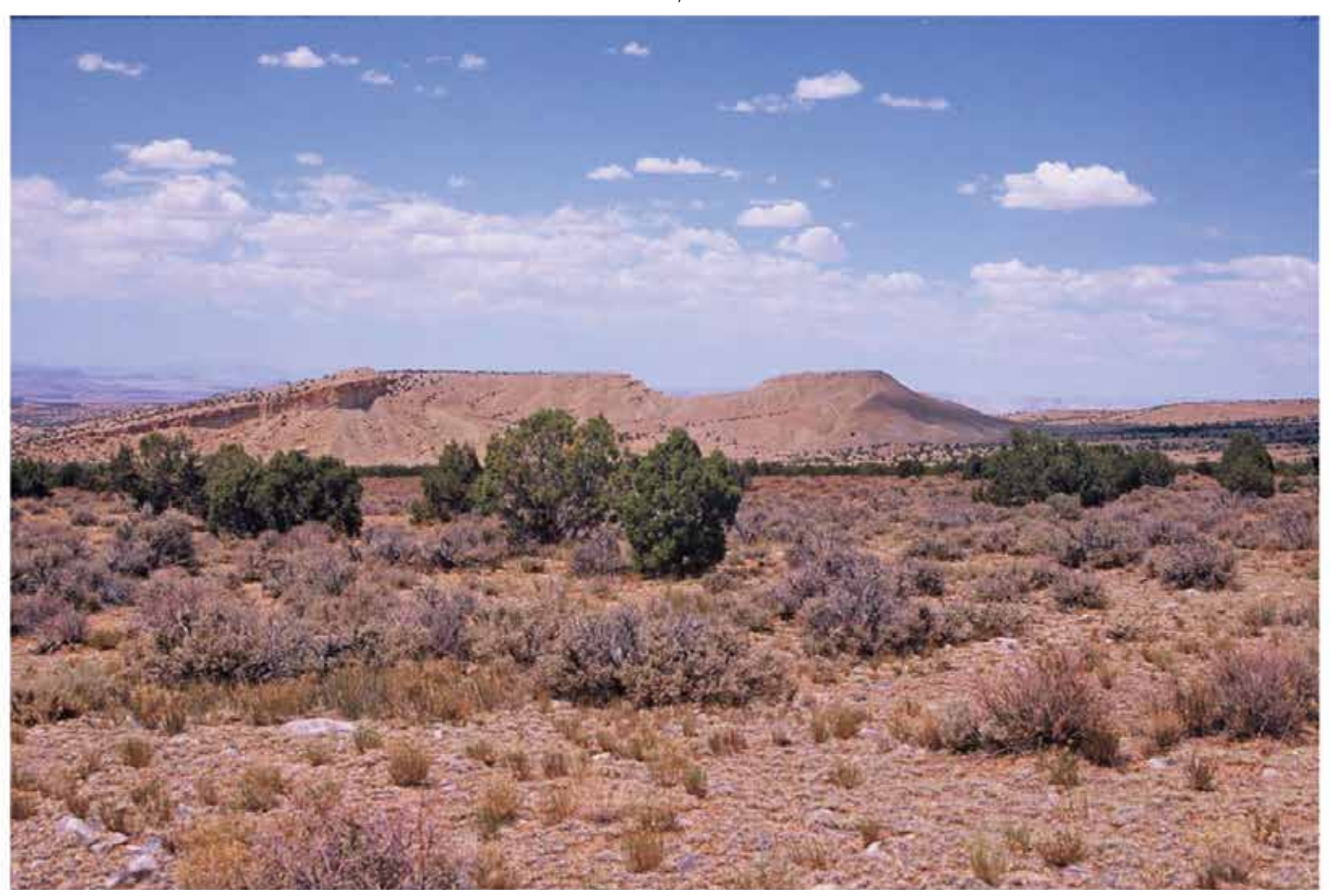

HM-462, 2012 


\section{Plate HM-465}

\section{Burro Wash}

$1940 \div 2012$

Viewed west-southwest near the head of Burro Wash, with the Waterpocket Fold in the distance. The original photo is captioned, "Gone with the Wind." The photo was taken to document the soil loss that was occurring at the time from wind erosion, which was caused by overgrazing. As domestic sheep stripped away the native vegetation, the sandy soil was exposed, allowing wind to move the soil across the landscape. Although cattle graze the Burro Wash today, erosion is minimal because grasses, including sand dropseed, curly grass, and Indian ricegrass, have increased and now hold the sandy soil in place. Mormon tea and snakeweed are also present.

Original photograph taken by the BLM in 1940; retake made by Charles E. Kay on June 17, 2012 (Photo No. 6268-26). Section 19, Range 8 East, Township 30 South; UTM 491928E, 4226472N; elevation $5,229 \mathrm{ft}$. Original image held in the BLM's range files, Hanksville, UT. 


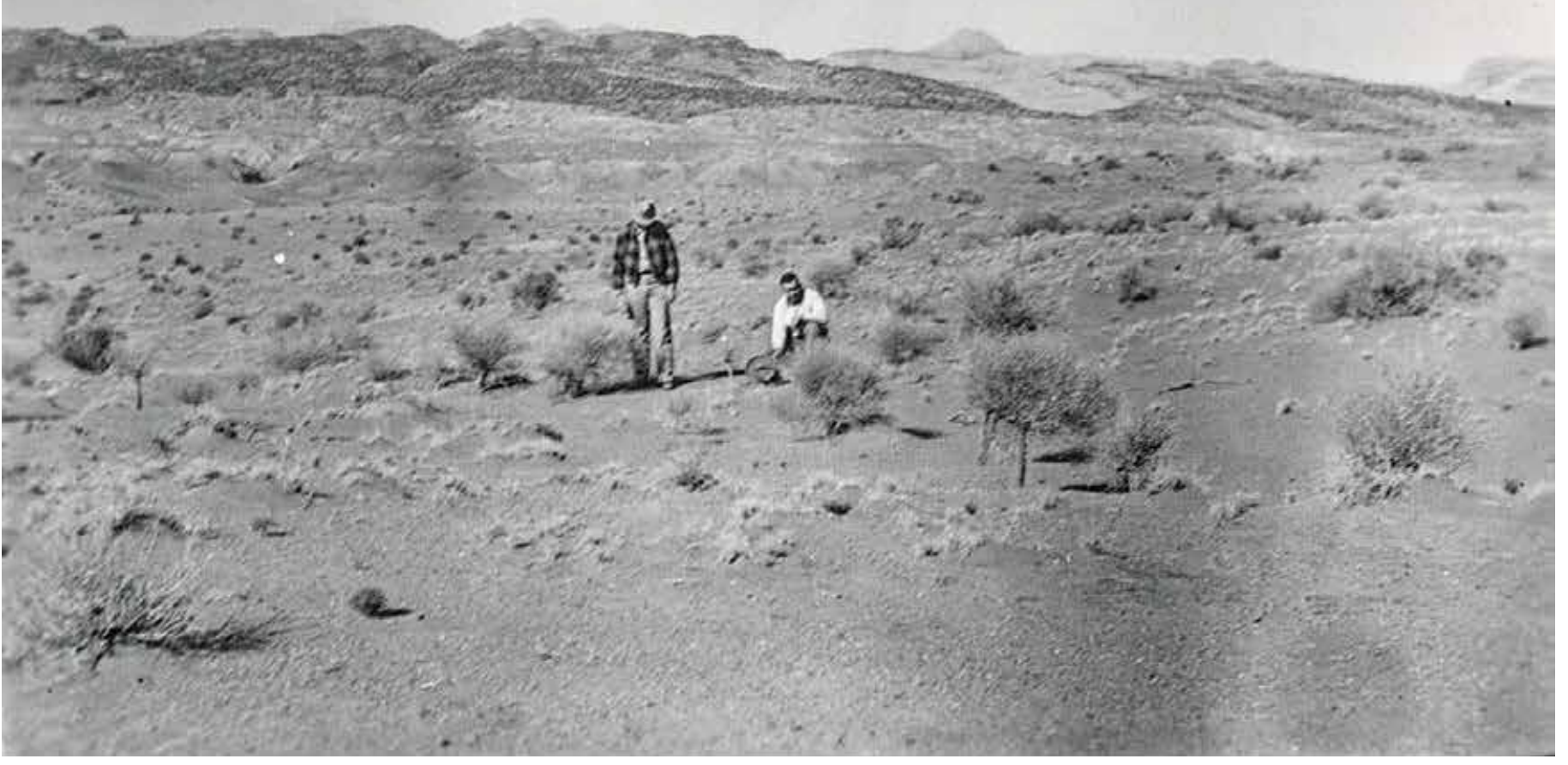

HM-465, 1940

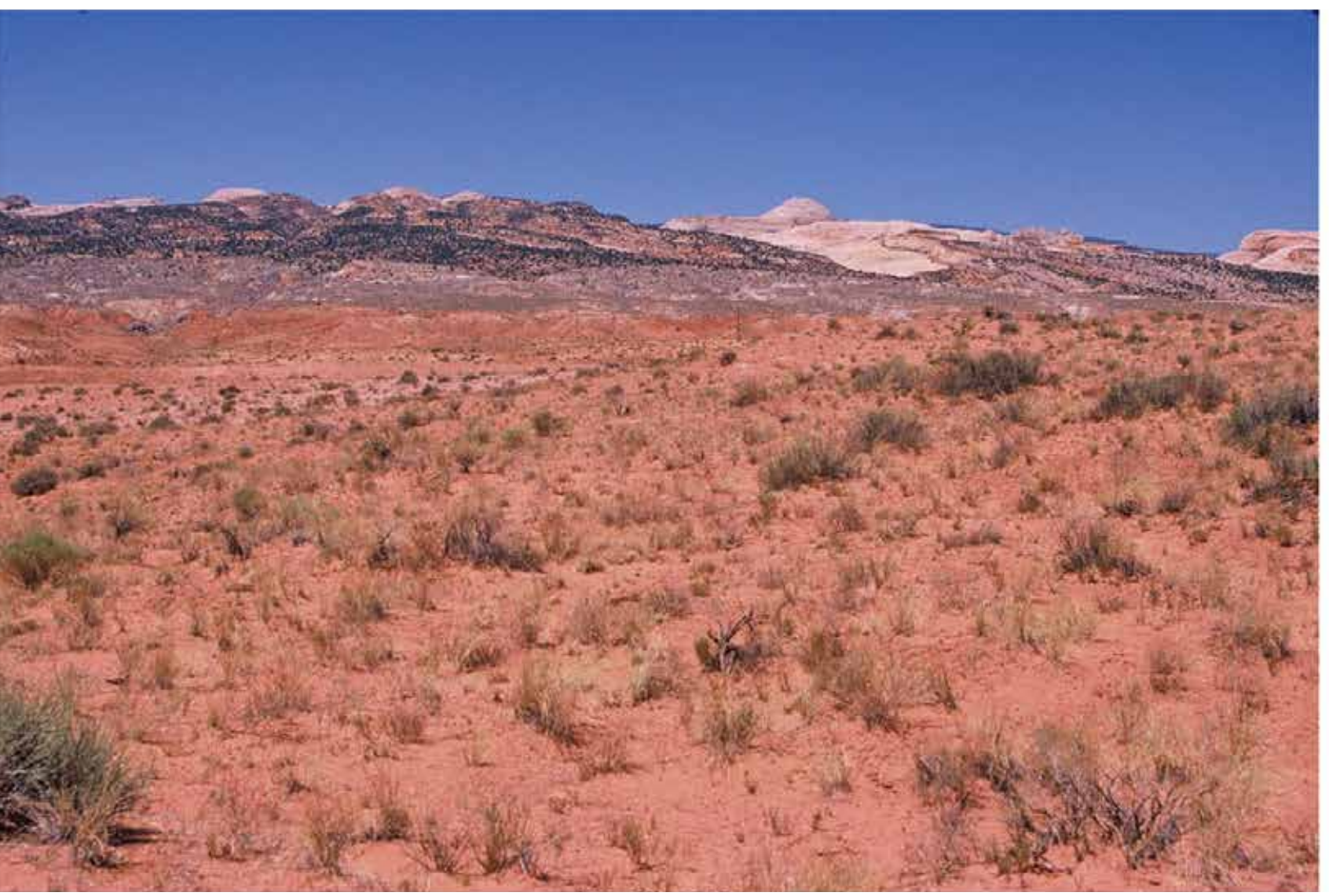




\section{Plate HM-473}

Granite Ridges

$1964: 2012$

Viewed north-northwest across the Granite Ridges to Wickiup Ridge on the right skyline.

Conifers have increased, including Douglas-fir, limber pine, pinyon, and juniper. Oak brush has also increased, as has sagebrush in the foreground. Forage production has decreased near the camera. This decrease is most likely due to drought, since that area has recently been grazed only by bison and mule deer, not by livestock, as evidenced by a lack of cow piles. The 2003 Lonesome Beaver Fire burned a portion of Wickiup Ridge, including stands of curl-leaf mountain mahogany.

Original photograph taken by the BLM in 1964; retake made by Charles E. Kay on June 18, 2012 (Photo No. 6271-24A). Section 26, Range 10 East, Township 31 South; UTM 519962E, 4214777N; elevation 9,324 ft. Original image held in the BLM's range files, Hanksville, UT. 


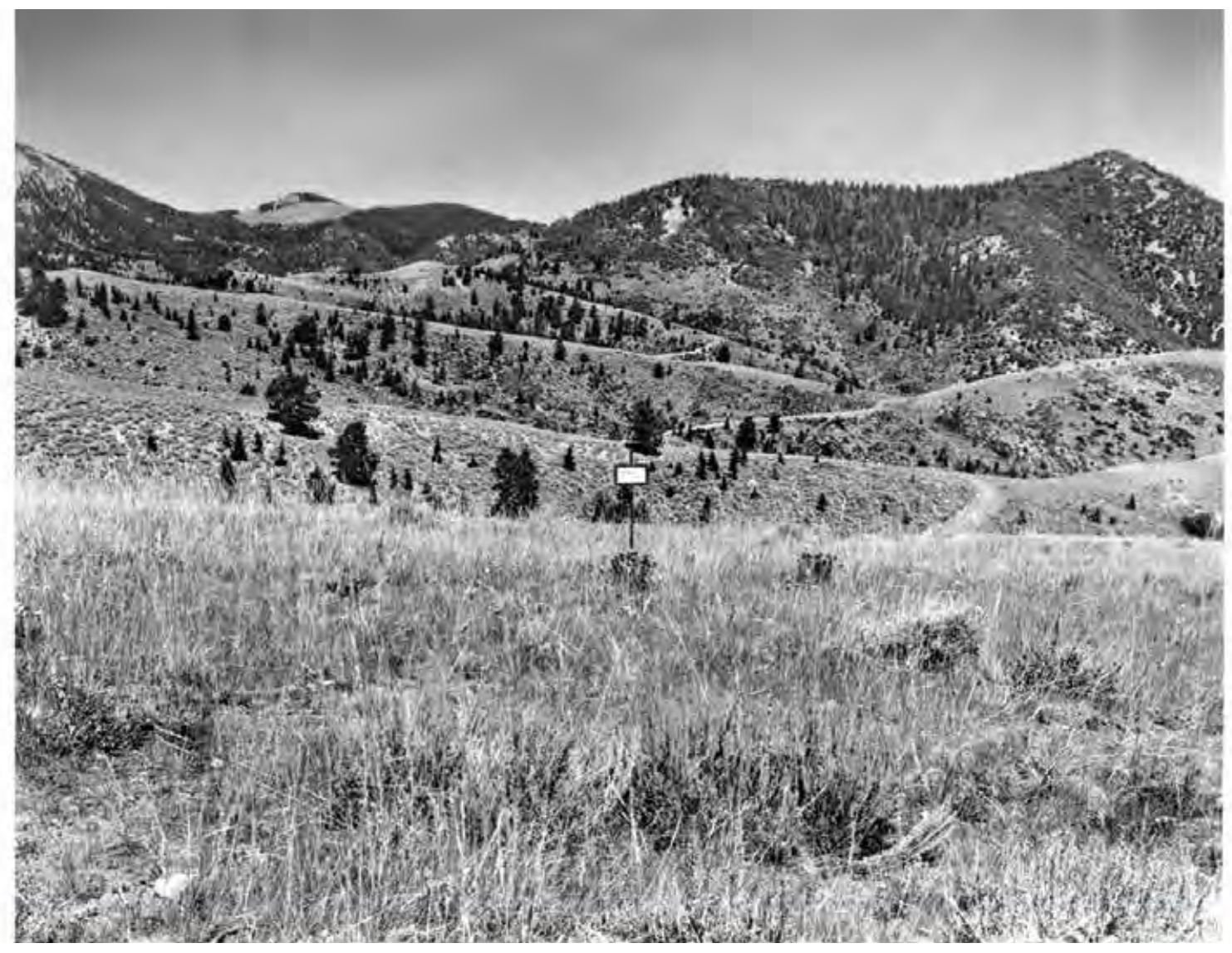

HM-473, 1964

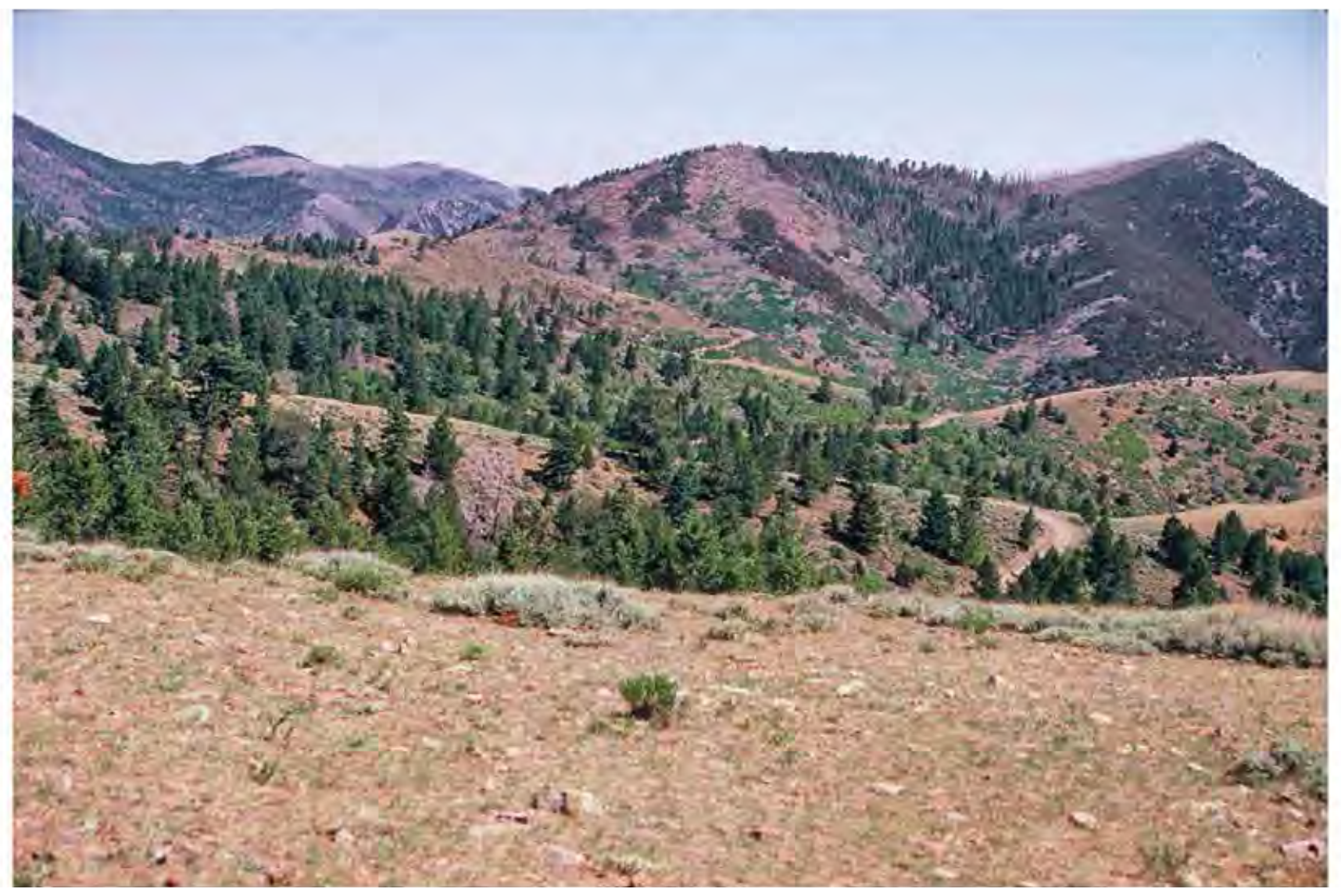

HM-473, 2012 


\section{Plate HM-474}

\section{Eagle City}

1962 ¡ 2012

Viewed west up Crescent Creek to Eagle City, which was established in 1892 (Murphy 1999, 139). The cabin seen in the original image has been removed, and none of the old logs are present.

Woody vegetation has increased, including pinyon, juniper, narrow leaf cottonwood, Utah serviceberry, oak brush, Douglas-fir, and spruce.

Original photograph taken by Packer Hamilton ca. 1962; retake made by Charles E. Kay on June 18, 2012

(Photo No. 6271-30A). Section 31, Range 11 East, Township 31 South; UTM 522178E, 4213980N; elevation 7,779 ft. Original image (No. 15,301) held by the Utah State Historical Society, Salt Lake City, UT. 


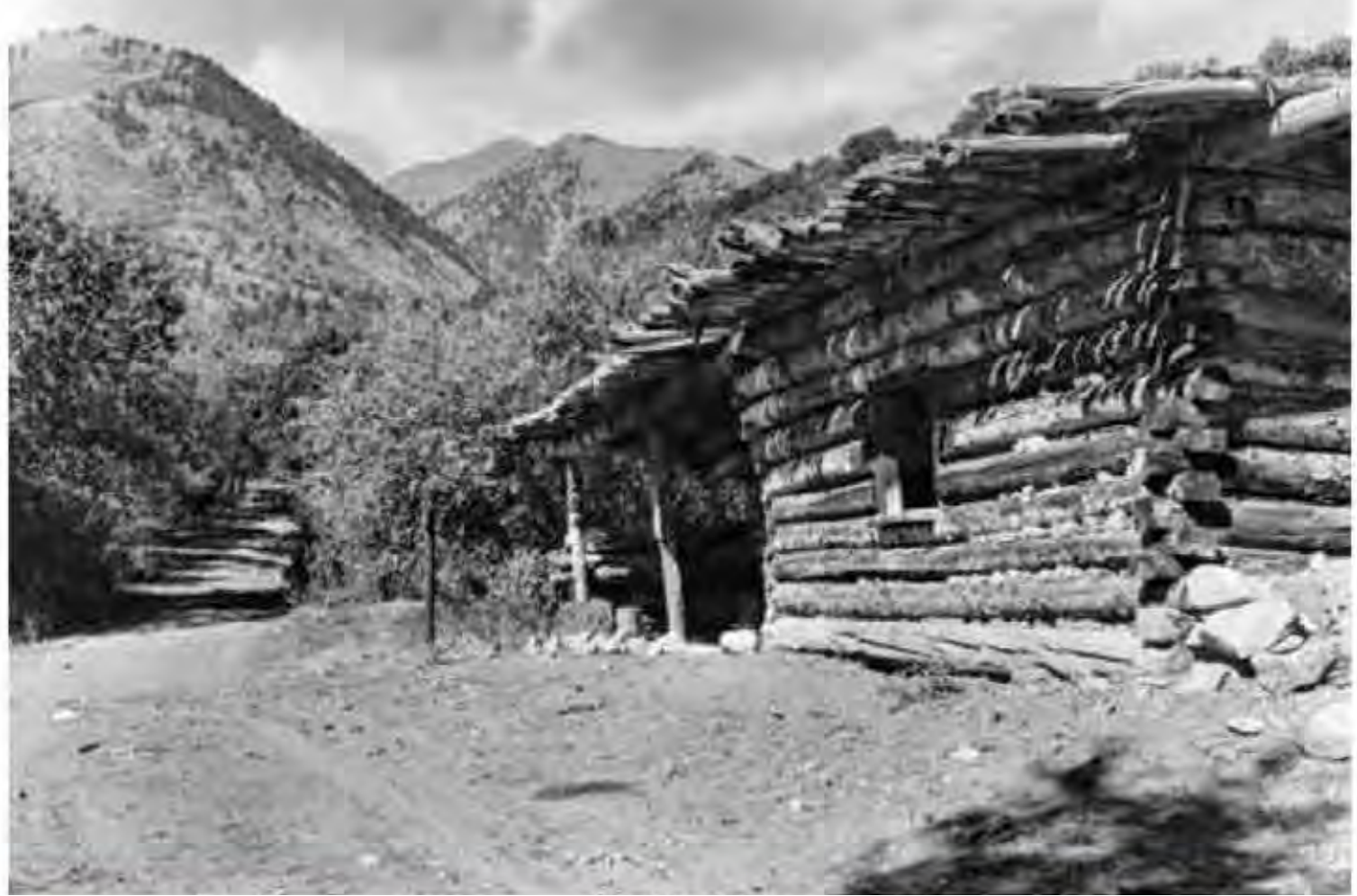

HM-474, 1962

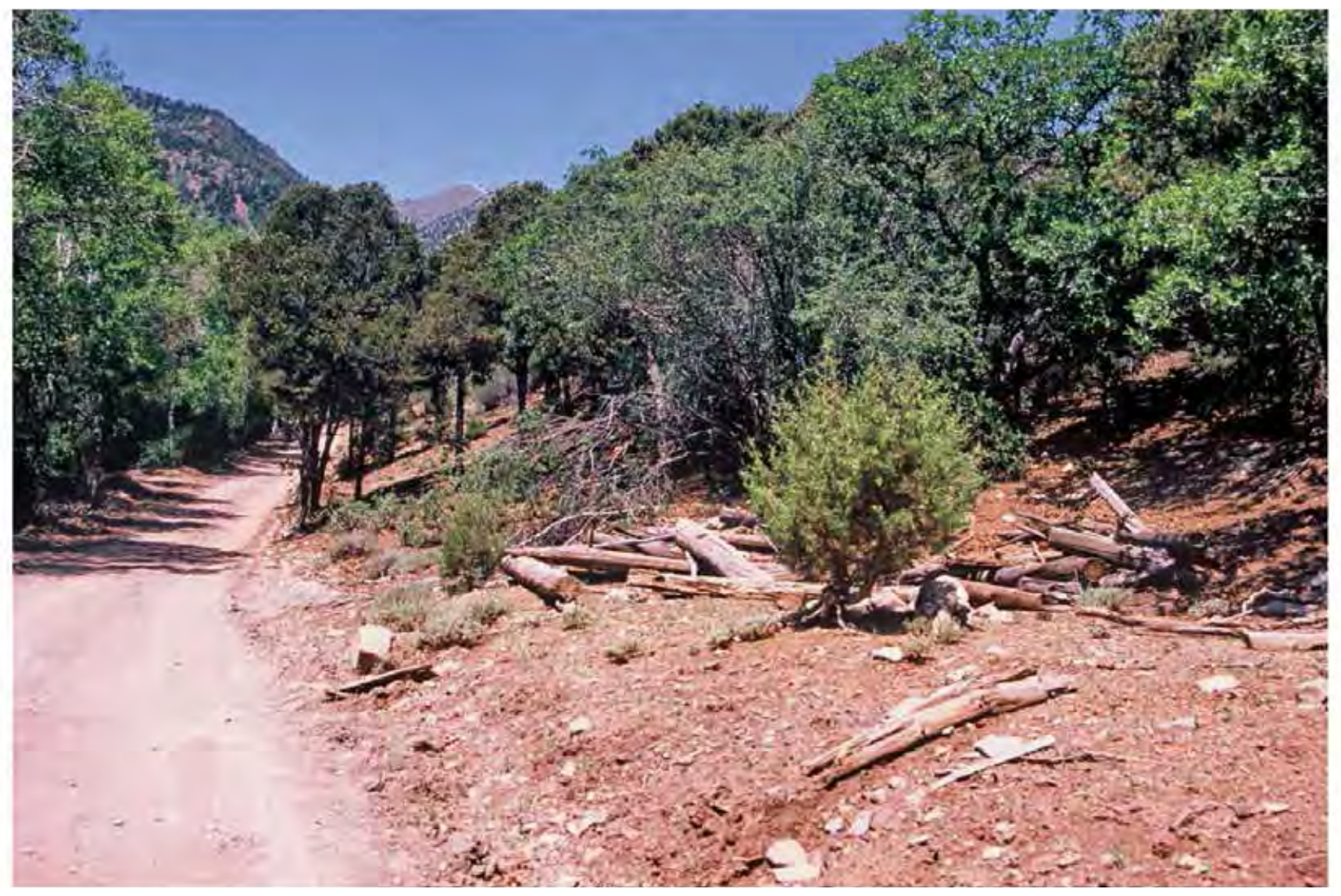




\section{Plate HM-476}

\section{Mount Pennell}

$1967: 2012$

Viewed south to The Horn and Mount Pennell, with Mount Hillers on the left skyline.

Pinyon, juniper, Douglas-fir, and limber pine have increased in the foreground. Note the chaining in the 1967 image (right edge) and how it is filling in with pinyon-juniper today. There is also a post-1967 chaining along the road to Pennell Pass in the retake. In 2003 much of Mount Pennell and all of the north side of Mount Hillers were burned by the Bulldog Fire, a high-intensity crown fire that burned everything in its path.

Original photograph taken by Charles Hunt in 1967 (print from a color slide); retake made by Charles E. Kay on June 18, 2012 (print from a color slide). Section 9, Range 10 East, Township 32 South; UTM 516735E, 4210742N; elevation 9,312 ft. Original image (PO-568, No. 1-5-182) held by the University of Utah, Marriott Library Special Collections, Salt Lake City, UT. 


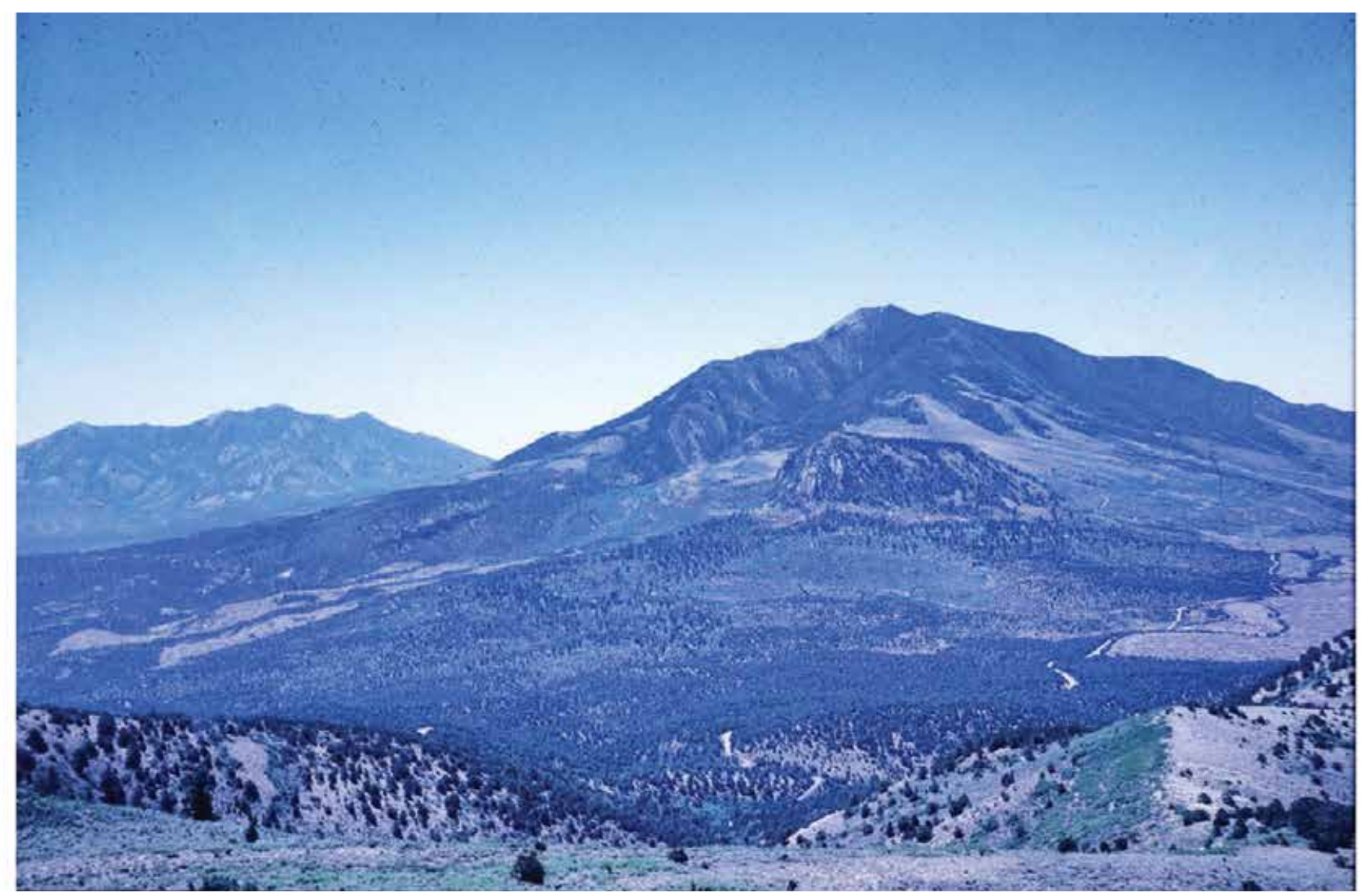

HM-476, 1967

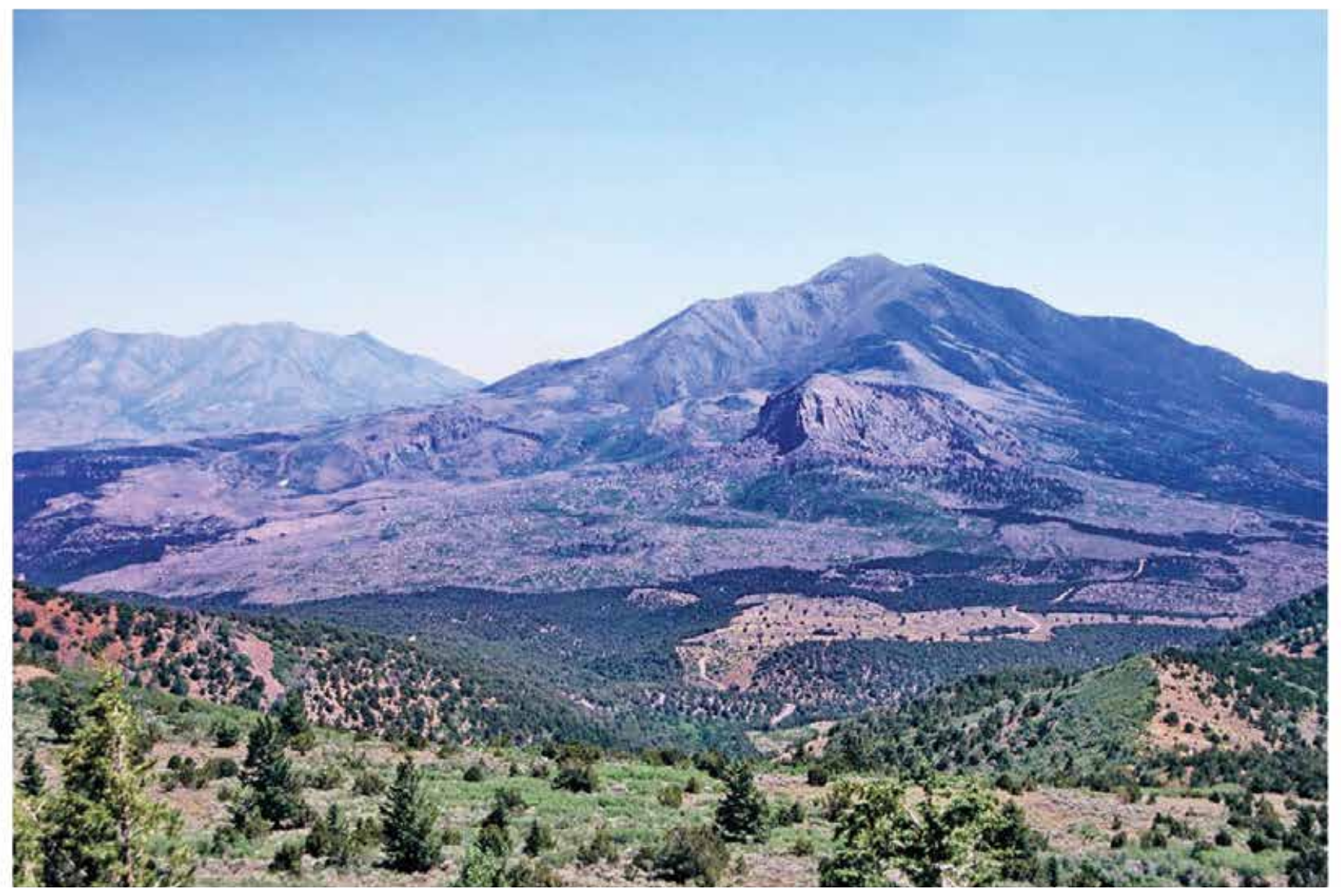

HM-476, 2012 


\section{Plate HM-478}

\section{South Creek}

$1964: 2012$

Viewed north-northwest across South Creek to Nasty Flat. North Summit Ridge is on the right-center skyline. The photo point is on South Creek Ridge, just above the main road.

Conifers have increased, including pinyon, juniper, Douglas-fir, ponderosa pine, limber pine, and spruce. Although a few aspen stands successfully regenerated 35-40 years ago when mule deer numbers were low (Kay and Bartos 2000), in general most aspen stands have declined. Today most aspen suckers have been and are repeatedly browsed by mule deer, preventing aspen height growth. Bison now heavily use the area in the foreground.

Original photograph taken by the BLM in 1964; retake made by Charles E. Kay on June 18, 2012 (Photo No. 6274-18). Section 4, Range 10 East, Township 32 South; UTM 515955E, 4211412N; elevation 9,479 ft. Original image held in the BLM's range files, Hanksville, UT. 


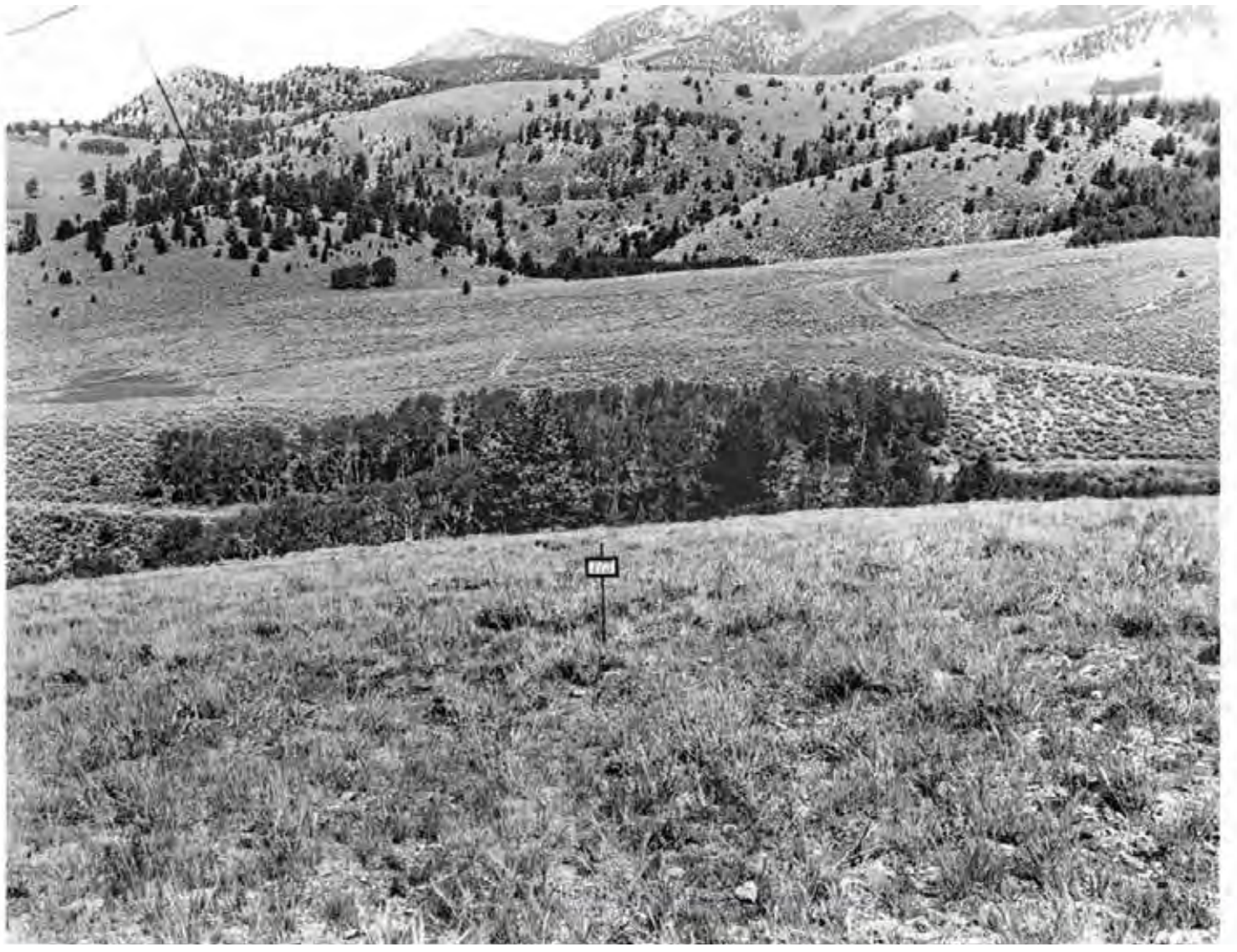

HM-478, 1964

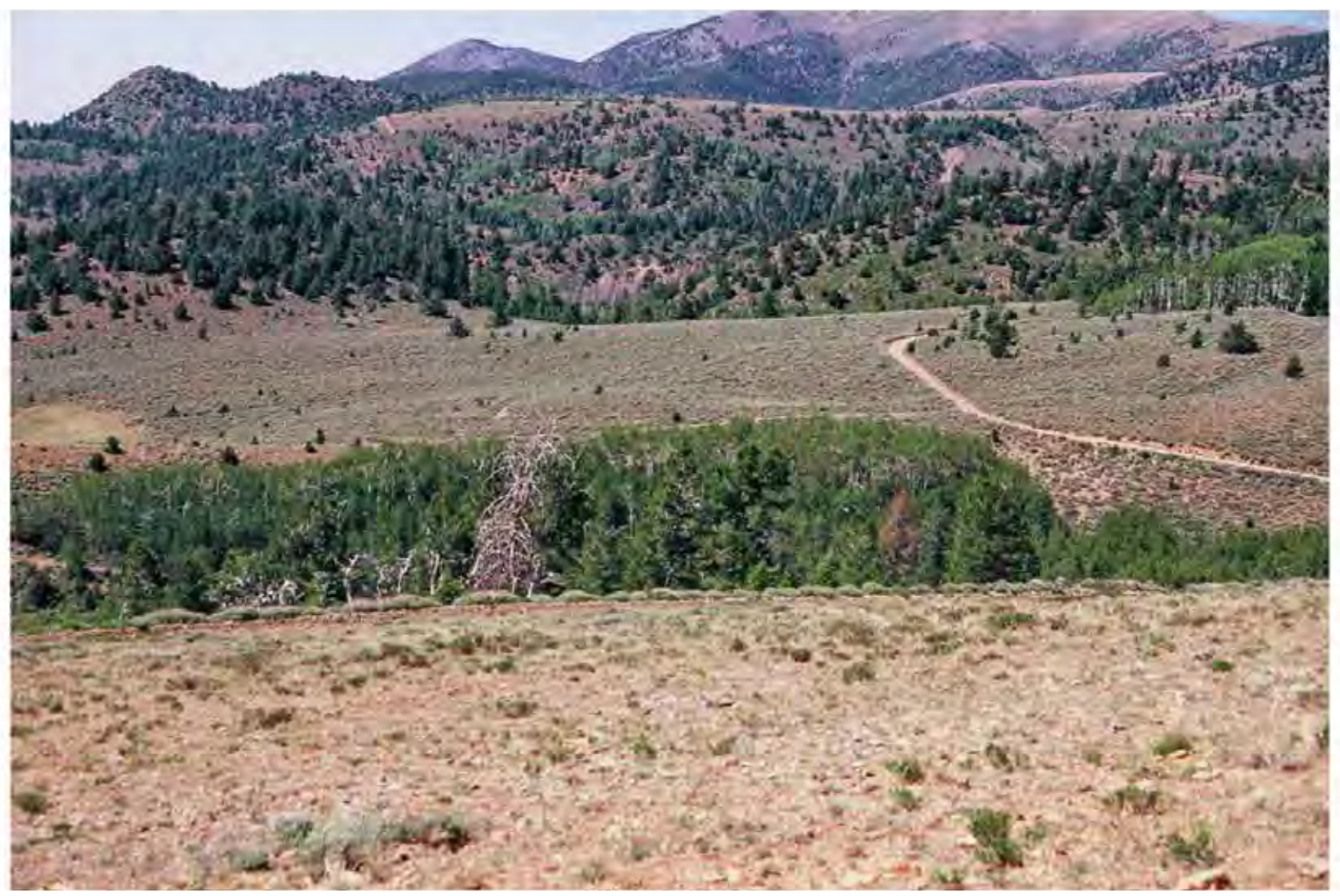

HM-478, 2012 


\section{Plate HM-484}

\section{Sweetwater VAlley}

$1958 \div 2012$

In 1958 the BLM established the C-3-1 range monitoring site on the Steel Butte Allotment. The view is to the east. The photo point is located about 2 miles south of the King Ranch and 200 yards east of the main road. All the steel stakes are still present, including the sign board along the main road.

Common species include fourwing saltbush, greasewood, snakeweed, squaw apple, curly grass, needle and thread, Indian ricegrass, and cheatgrass. A few of the small junipers that were invading the area in 1958 have died; others have become established.

Original photograph taken by the BLM on September 3, 1958; retake made by Charles E. Kay on June 19, 2012 (Photo No. 6277-11A). Section 8, Range 9 East, Township 32 South; UTM 505811E, 4209576N; elevation $5,942 \mathrm{ft}$. Original image held in the BLM's range files, Hanksville, UT. 


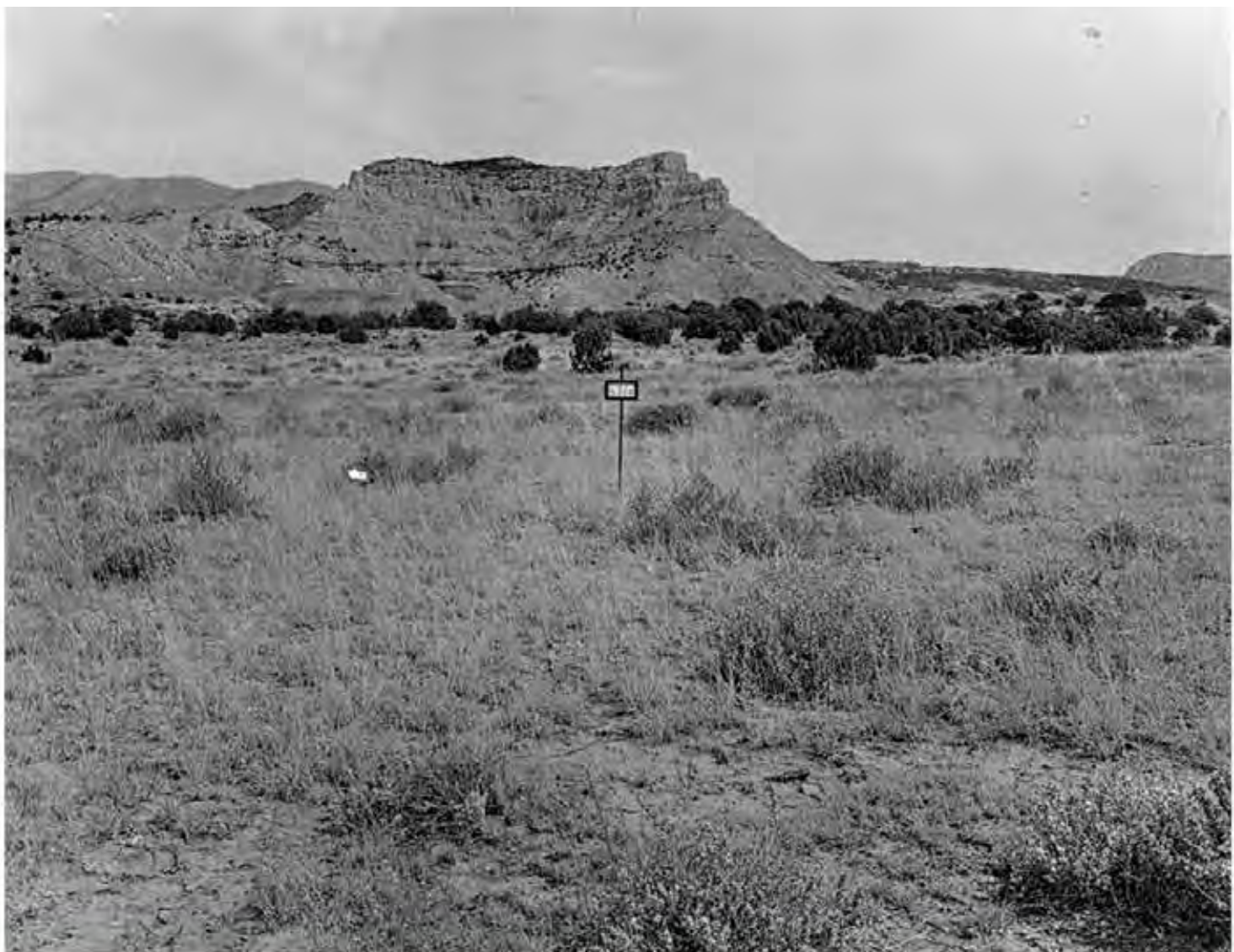

HM-484, 1958

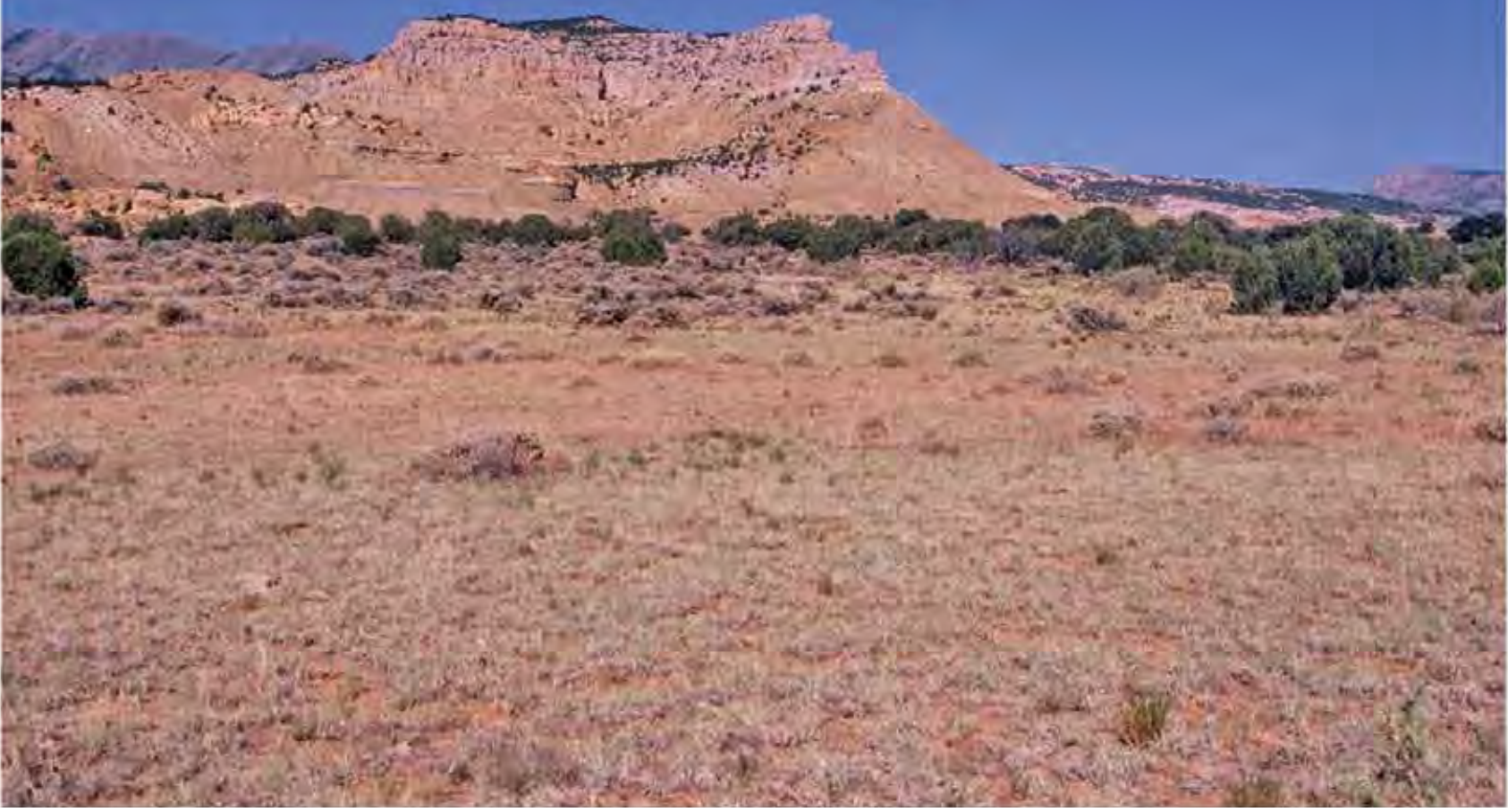




\section{Plate HM-486}

\section{Sulphur Creek}

$1932 \div 2012$

Viewed west up Sulphur Creek in Capitol Reef National Park.

Cottonwoods, willows, and other riparian vegetation have increased, while the stream channel has narrowed.

Original photograph taken by Reid Baily in 1932; retake made by Charles E. Kay on June 20, 2012 (Photo No. 6277-20A). Section 14, Range 6 East, Township 29 South; UTM 478243E, 4237725N; elevation $5,379 \mathrm{ft}$. Original image (No. C-439, Box 3, Number 270669) held by the Utah State Historical Society, Salt Lake City, UT. 


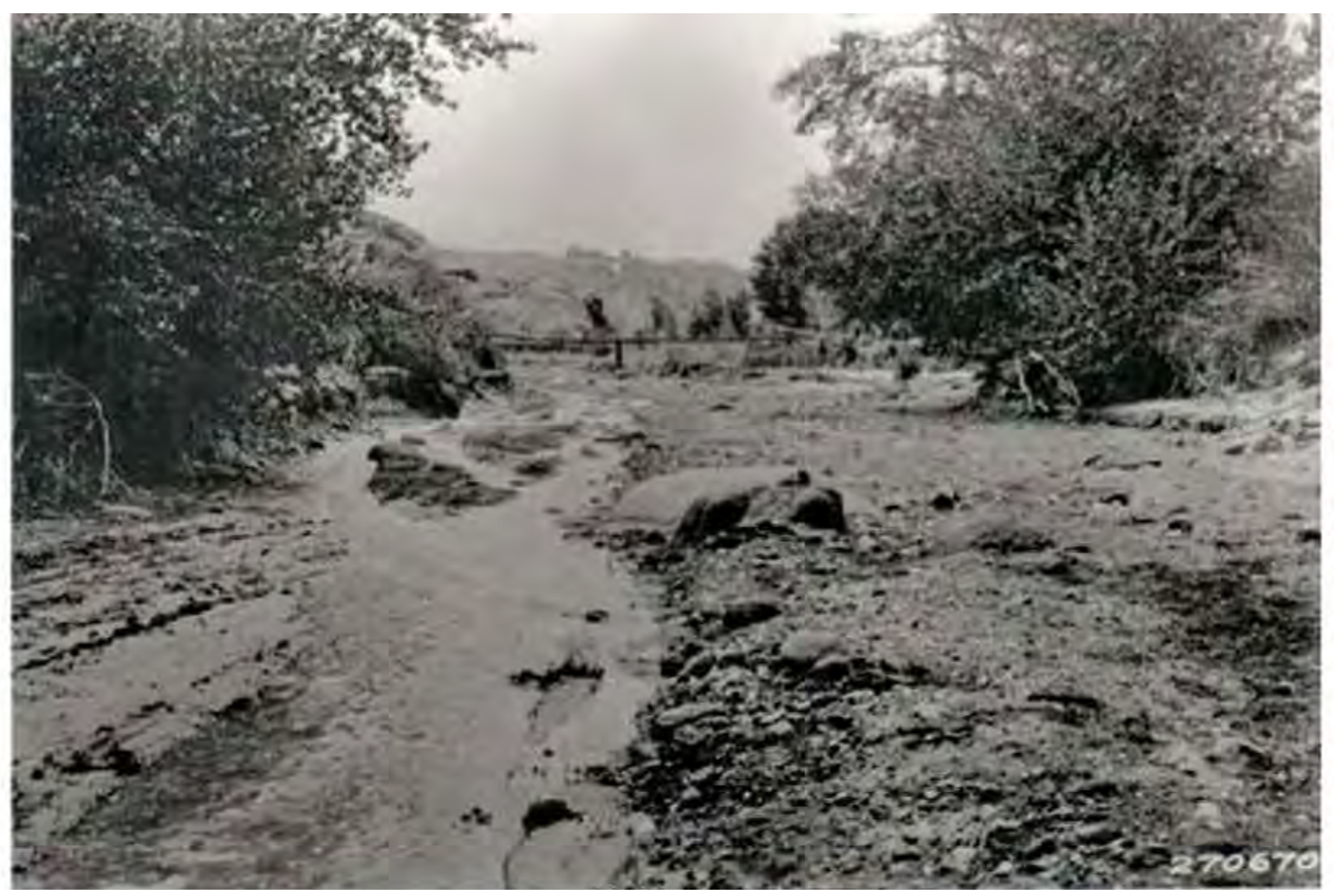

HM-486, 1932

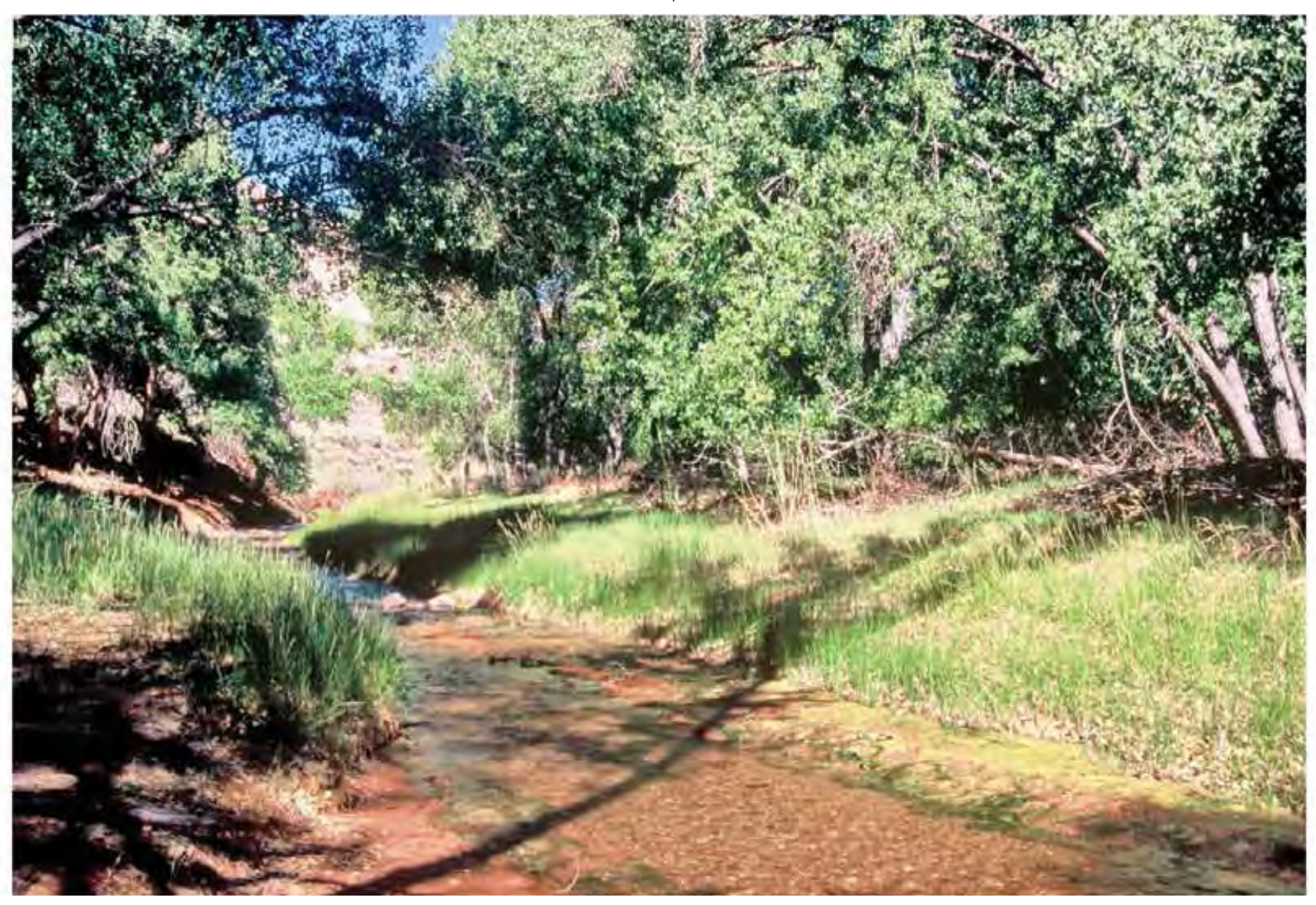

HM-486, 2012 


\section{Plate HM-501}

\section{Fremont River}

$1930 \div 2012$

Viewed east-northeast down the Fremont River, from the upper bridge in Capitol Reef National Park during a flood event.

The stream channel has narrowed, and woody riparian vegetation-primarily cottonwoods and willowshas increased.

Original photo taken by Arthur Ingelsby ca. 1930; retake made by Charles E. Kay on June 20, 2012 (Photo No. 6282-10). Section 14, Range 6 East, Township 29 South; UTM 478430E, 4237451N; elevation 5,390 ft. Original image (C-345, Box 2, Folder 4, No. 11) held by the Utah State Historical Society, Salt Lake City, UT. 


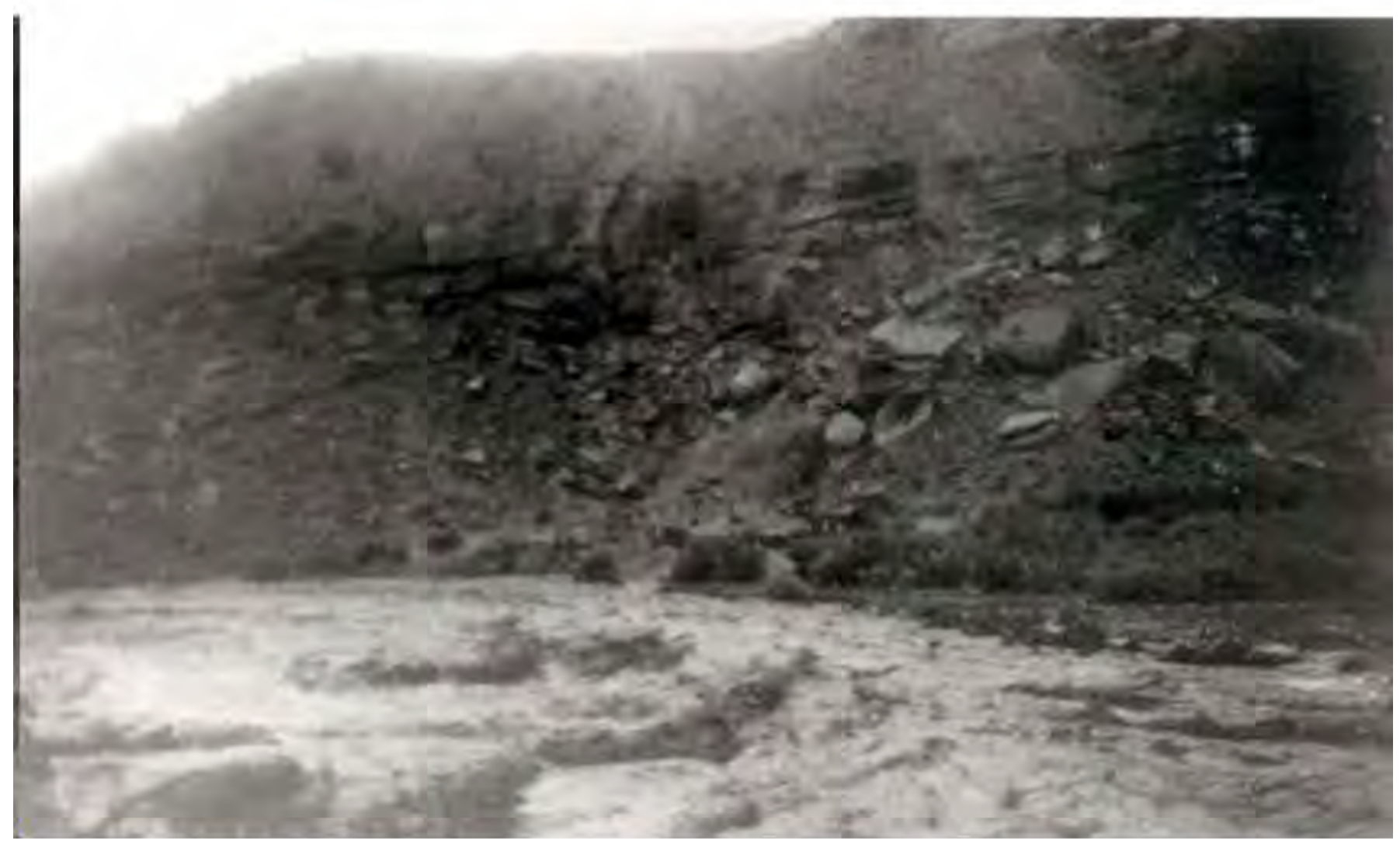

HM-501, 1930

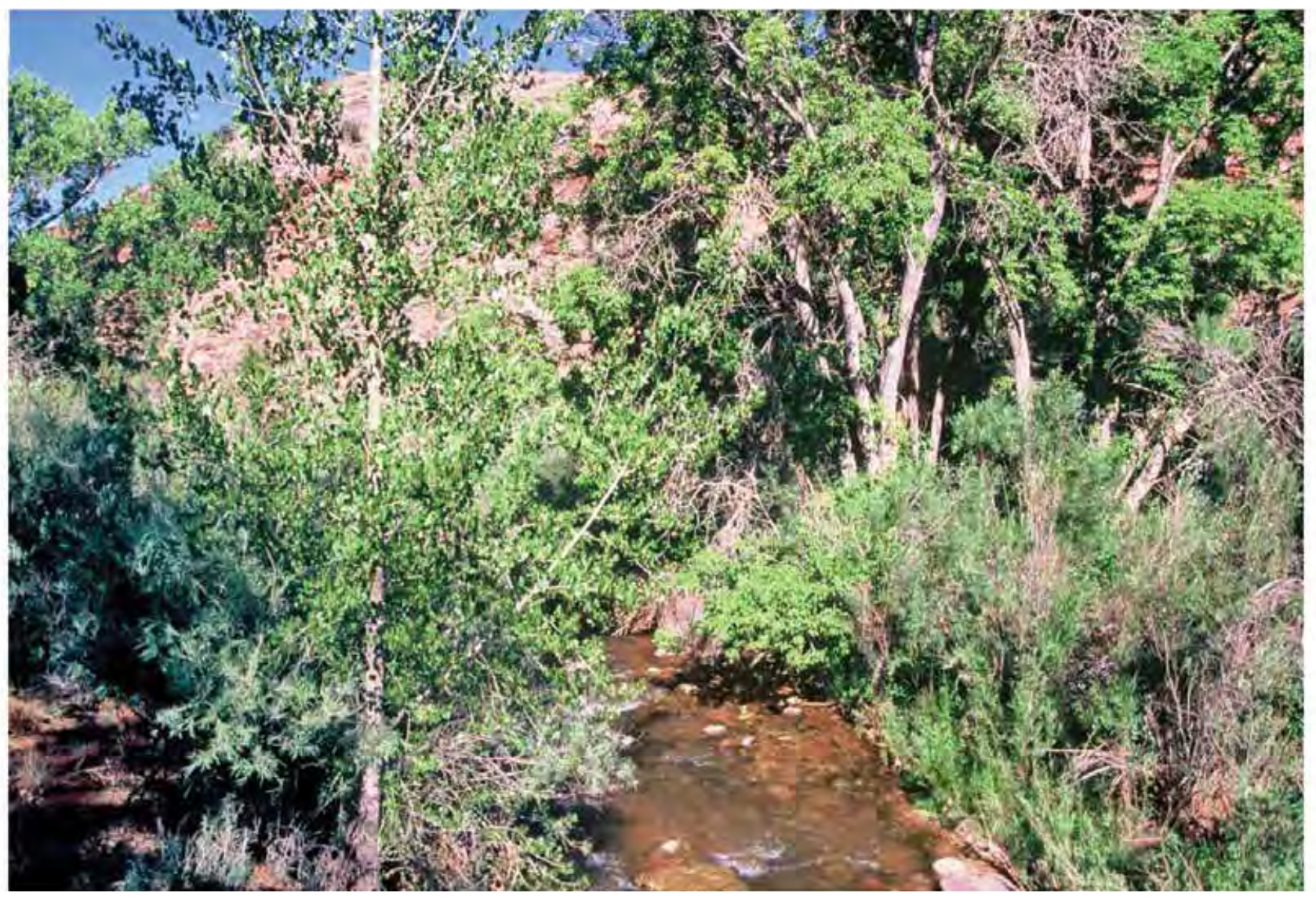

HM-501, 2012 


\section{Plate HM-502}

Notom Bench

$1958 \div 2012$

In 1958 the BLM established the C-1-2 range monitoring site on Notom Bench. The view is to the west-northwest, with the Waterpocket Fold in the distance. The steel stakes could not be relocated.

Juniper has increased, as have curly grass and Indian ricegrass. Other species include Mormon tea, yucca, and pricklypear cactus.

Original photograph taken by the BLM on September 2, 1958; retake made by Charles E. Kay on June 21, 2012 (Photo No. 6282-15). Section 13, Range 7 East, Township 30 South; UTM 490313E, 4228048N; elevation 5,487 ft. Original image held in the BLM's range files, Hanksville, UT. 


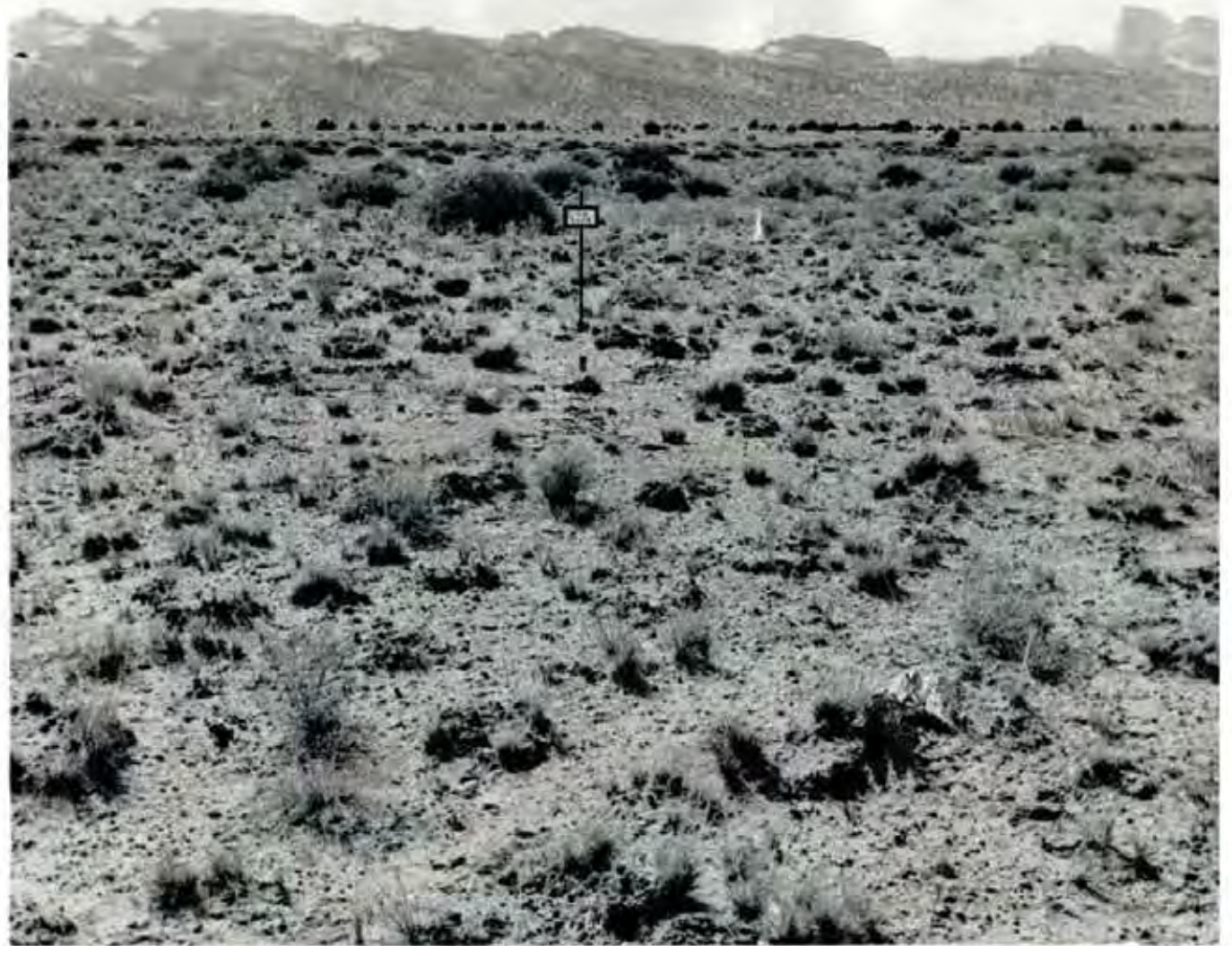

HM-502, 1958

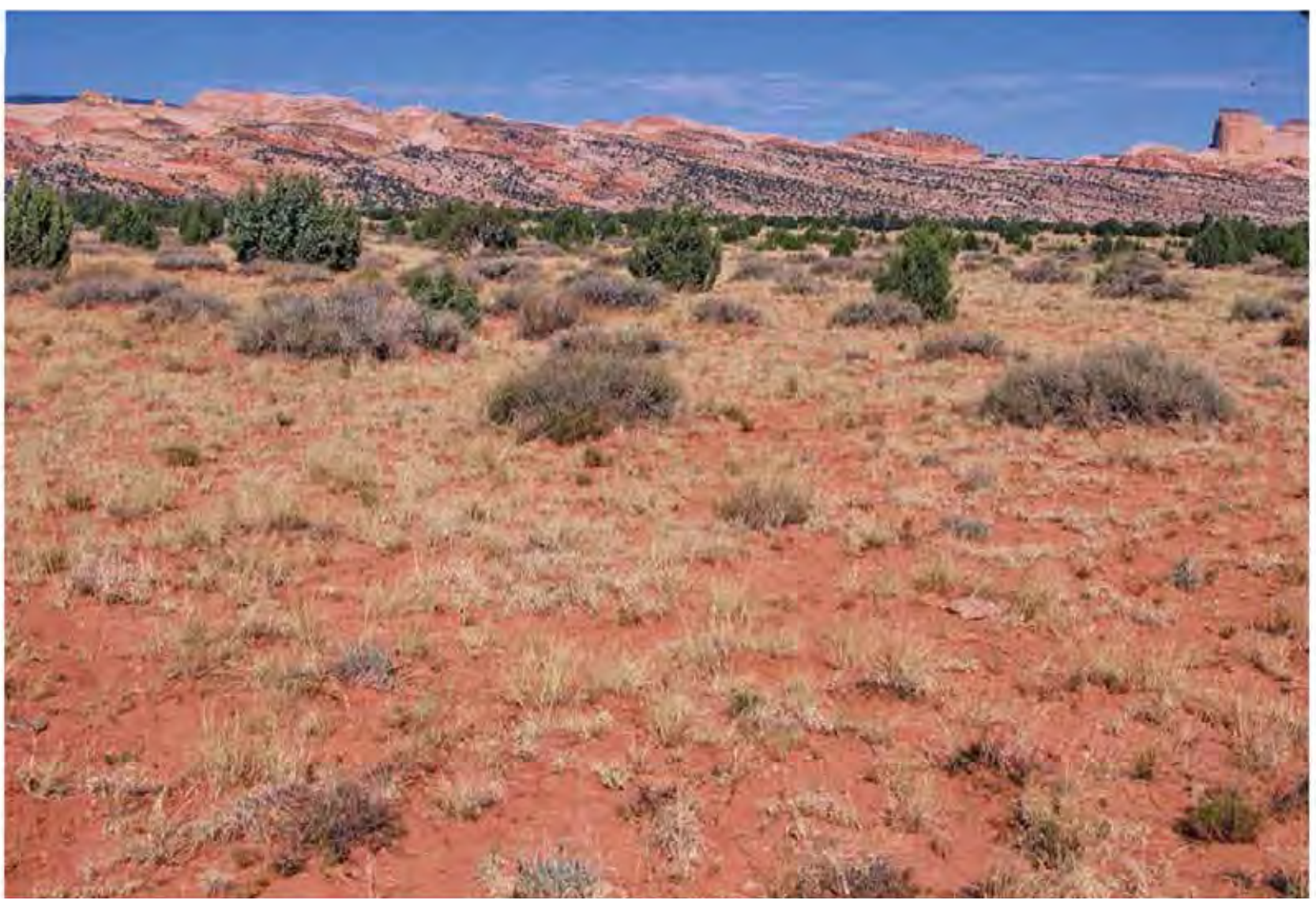

HM-502, 2012 


\section{Plate HM-504}

\section{Kimble and Turner Peak}

$1937 \div 2012$

Viewed southwest to Kimble and Turner Peak from Bartons Peak. A mining road to Bromide Basin is visible in the retake.

Conifers have increased, including Douglas-fir, limber pine, spruce, and subalpine fir. Oak brush and Utah serviceberry have also increased. There are a few small pockets of aspen in both images. The dead Douglas-fir in the retake were killed by the Douglas-fir beetle.

Original photograph taken by Charles Hunt (No. 585) in June 1937; retake made by Charles E. Kay on June 26, 2012 (Photo No. 6282-20). Section 35, Range 7 West, Township 32 South; UTM 520044E, 4213397N; elevation 10,036 ft. Original image held by the U.S. Geological Survey Photographic Library, Denver, CO. 


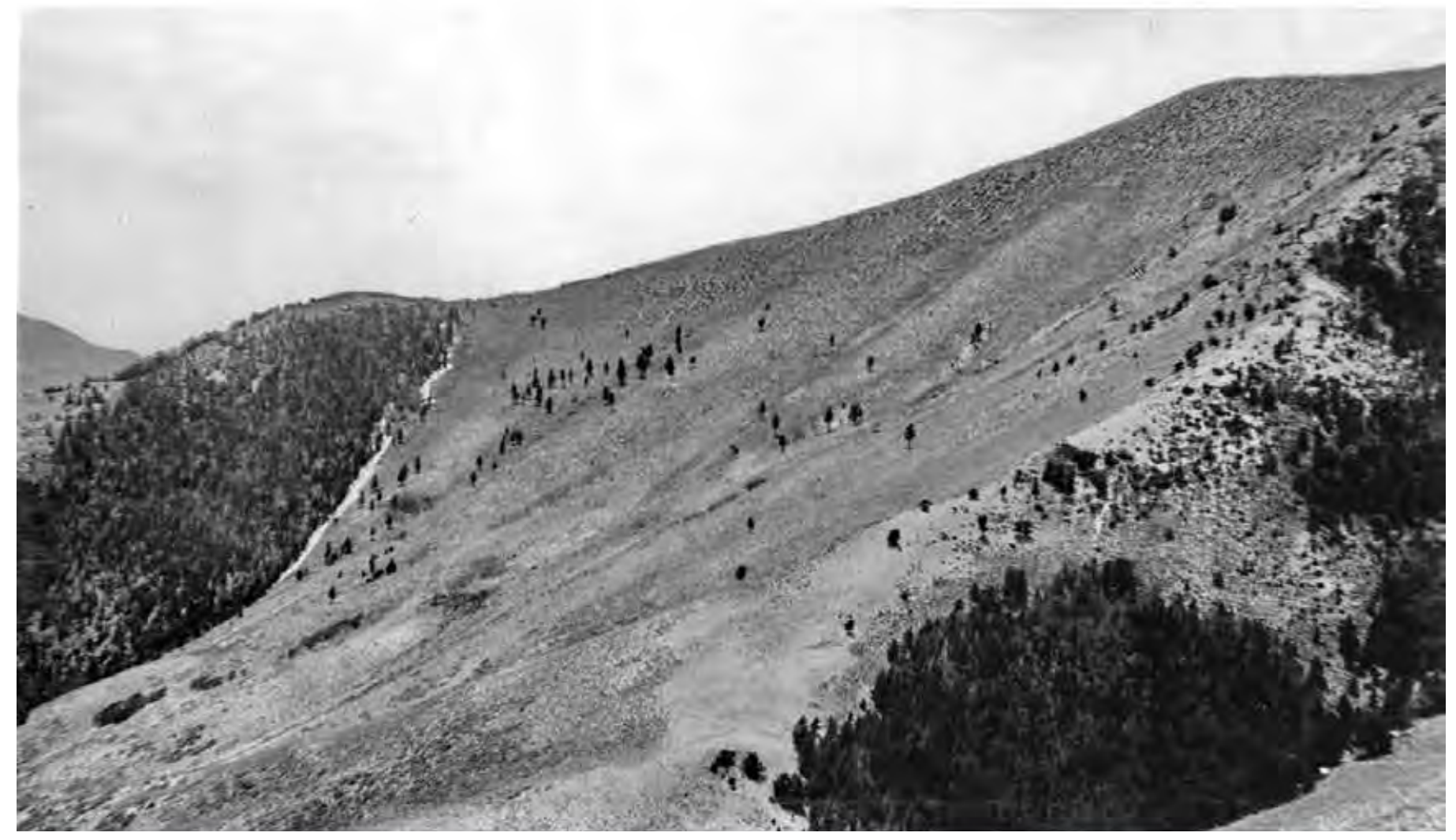

HM-504, 1937

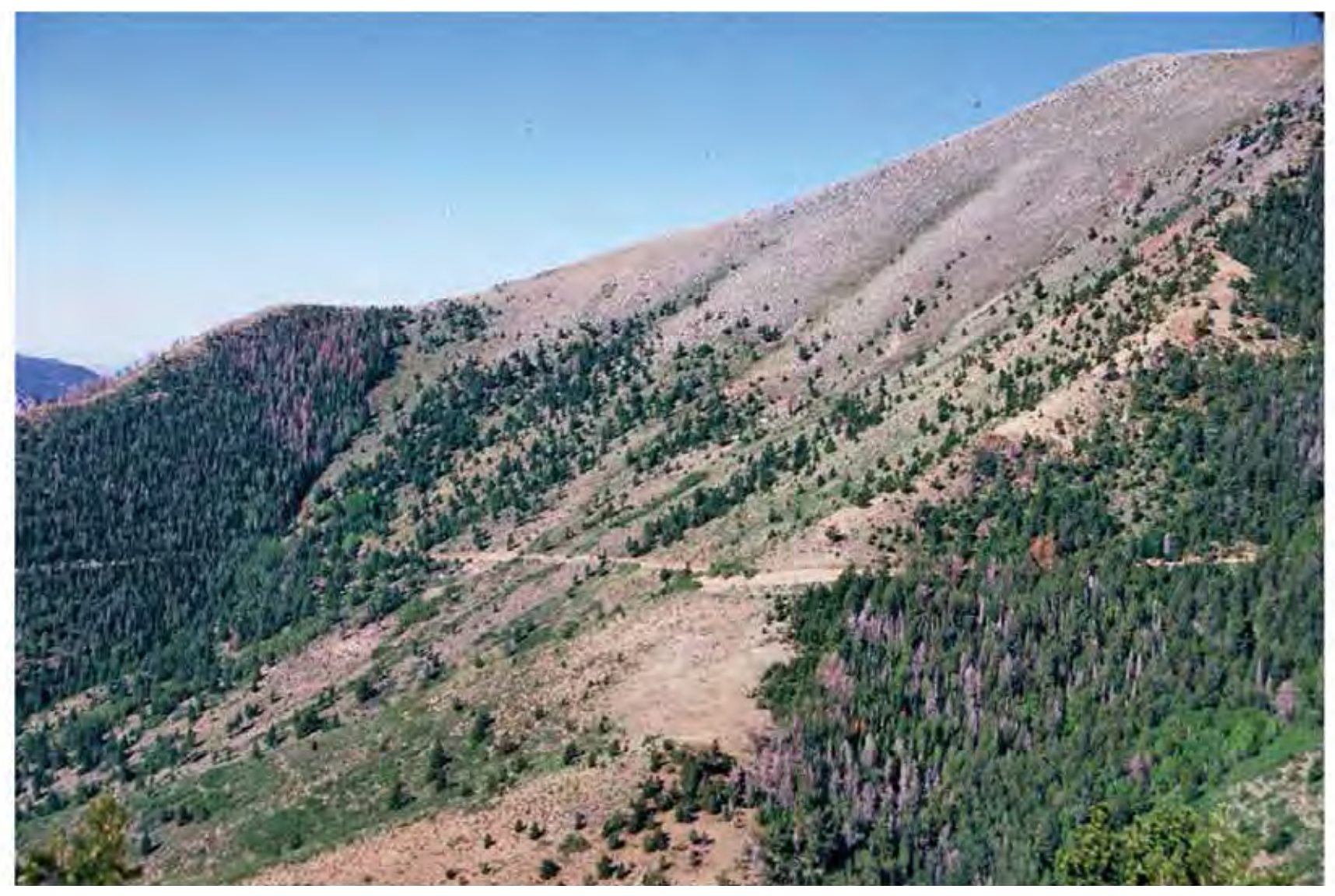




\section{Plates HM-505 and HM-506}

\section{Bartons Peak}

$1937 \div 2012$

Viewed north from Bartons Peak over the Granite Ridges and down Bull Creek. Bull Mountain is on the right

skyline. Wickiup Ridge is also on the right but nearer the camera, in the mid-distance. Plates HM-505 and

HM-506 form a panorama.

Conifers have increased, including pinyon, juniper, Douglas-fir, limber pine, spruce, and subalpine fir. Oak brush, Utah serviceberry, and curl-leaf mountain mahogany have also increased. The road to Wickiup Pass is visible in the retake (upper-left-center edge), as is part of the area burned by the Lonesome Beaver Fire in 2003.

Original photographs taken by Charles Hunt (Nos. 579 and 580) in June 1937; retakes made by Charles E. Kay on June 26, 2012 (Photo Nos. 6282-26 and 6282-29). Section 35, Range 7 West, Township 32 South; UTM 520044E, 4213397N; elevation 10,036 ft. Original images held by the U.S. Geological Survey Photographic Library, Denver, CO. Photo mosaic compiled by Doug Page, BLM, Cedar City, UT. 

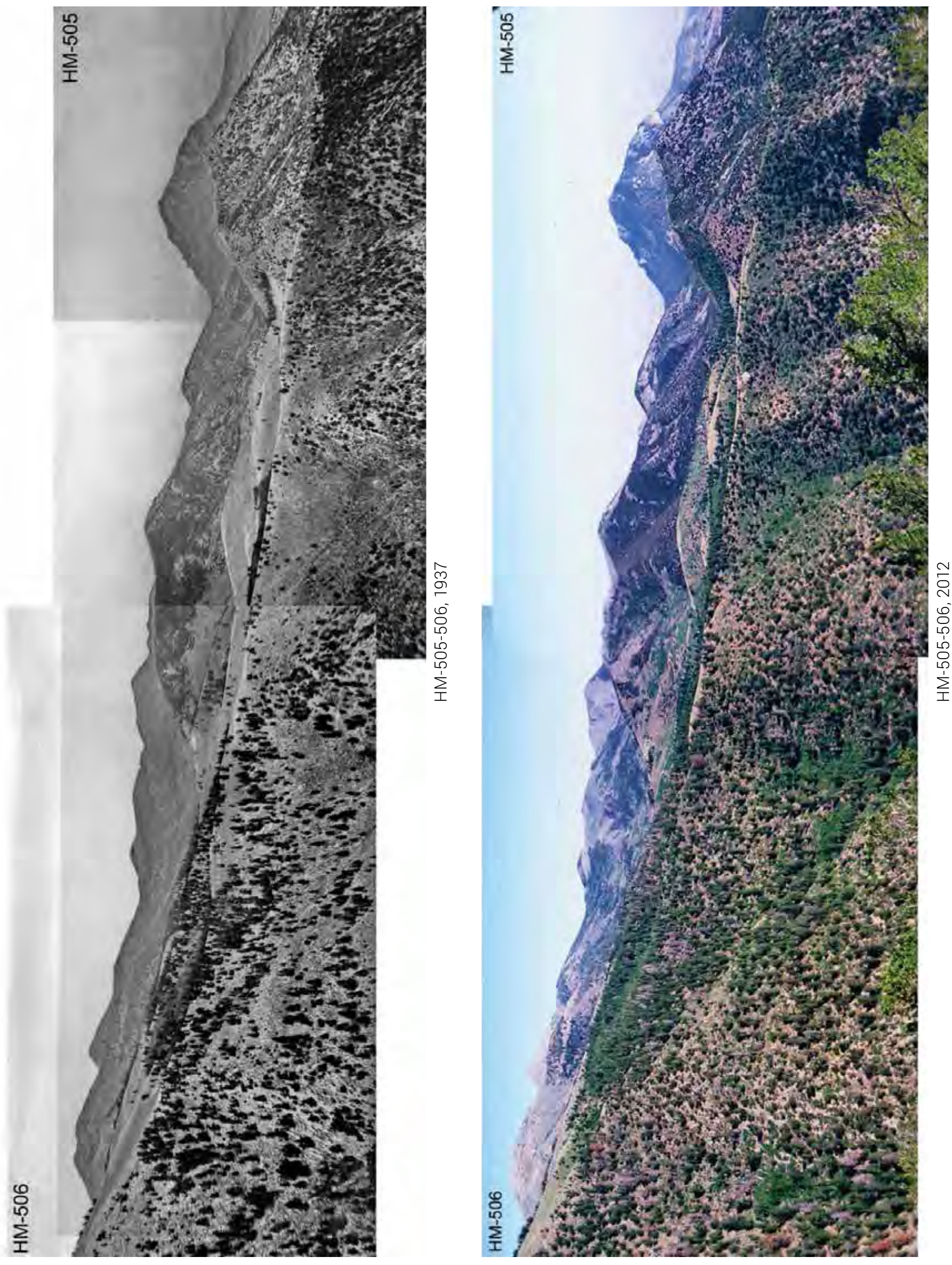


\section{Plate HM-507}

\section{Bromide Basin}

$1937 \div 2012$

Viewed west from below Bartons Peak, up Crescent Creek to Bromide Basin. Limber pine now block the original camera station, so the retake was made from the nearest open area, which is a little further down-slope. Note the new mining roads in the retake, as Bromide Basin and Crescent Creek are the main, gold-producing areas in the Henry Mountains.

Conifers have increased, including pinyon, juniper, limber pine, Douglas-fir, and spruce. Aspen has increased on the slopes above Crescent Creek (right).

Original photograph taken by Charles Hunt (No. 586) in June 1937; retake made by Charles E. Kay on June 26, 2012 (Photo No. 6281-32). Section 35, Range 7 West, Township 32 South; UTM 520020E, 4213372N; elevation 10,031 ft. Original image held by the U.S. Geological Survey Photographic Library, Denver, CO. 


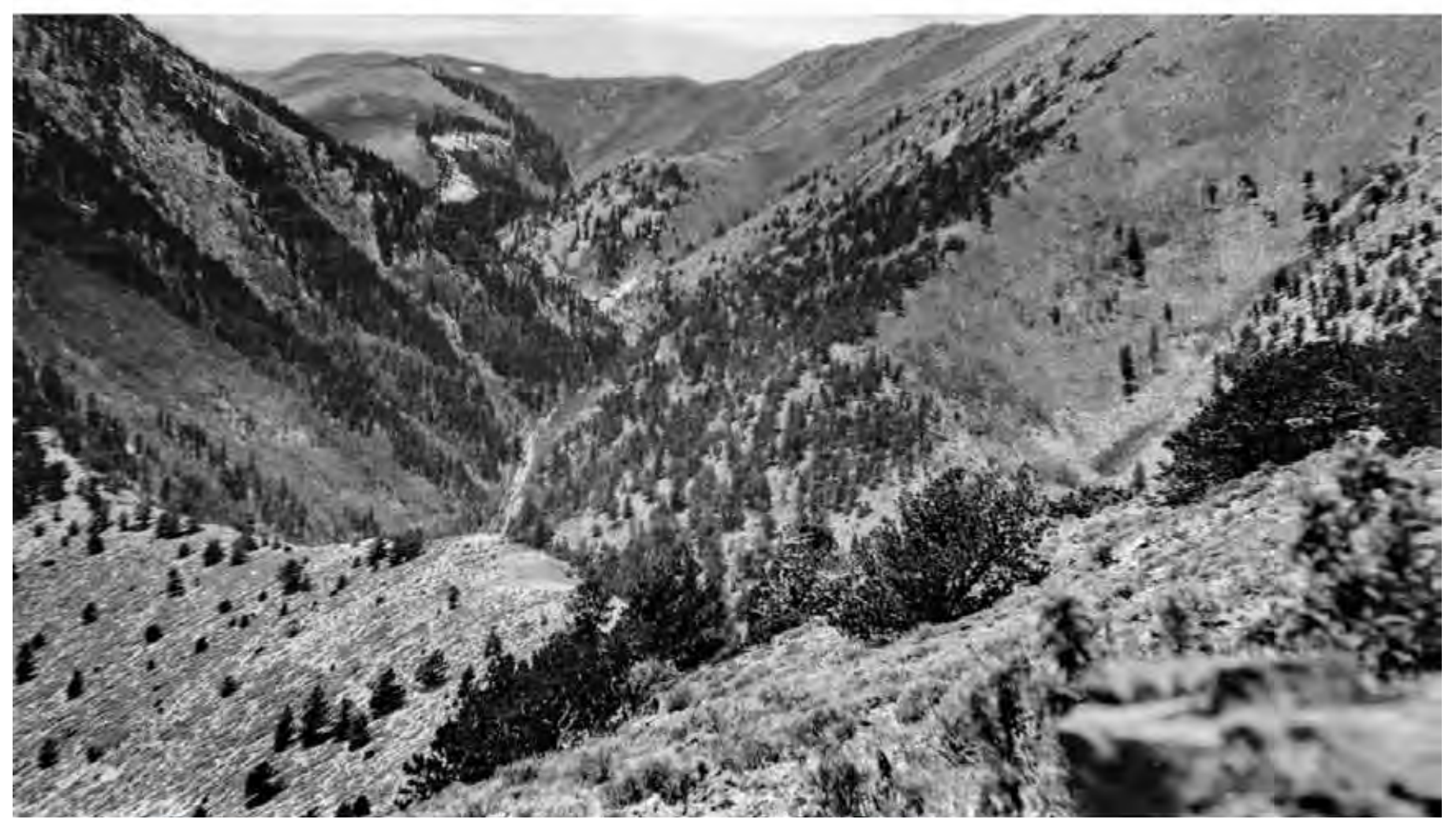

HM-507, 1937

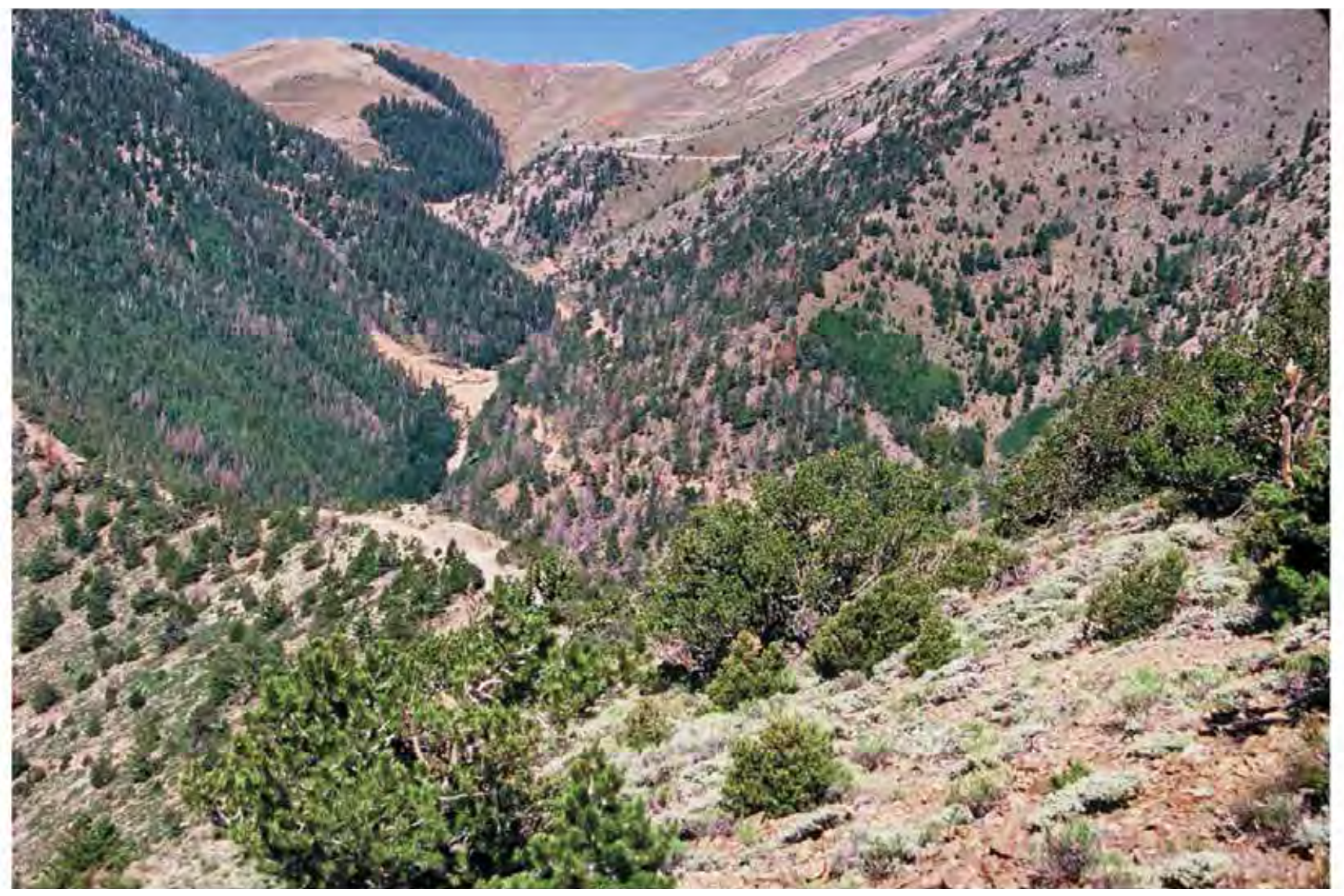




\section{Plates HM-510 and HM-511}

\section{Mount Pennell}

$1937 \div 2012$

Viewed north from the top of Mount Pennell, down Dark Canyon and across Slate Creek to South Summit Ridge (the higher ground on the left skyline). Plates HM-510 and HM-511 form a panorama.

Conifers and other woody vegetation have increased, including pinyon, juniper, Douglas-fir, ponderosa pine, spruce, subalpine fir, and oak brush. This increase is especially evident on the midslopes of South Summit Ridge. The open areas to the left of The Horn (on the left in the center of the photo) in the retake are mostly pinyon-juniper chainings. Much of the land in the foreground and the area to the right of The Horn was burned by the Bulldog Fire in 2003.

Original photographs taken by Charles Hunt (Nos. 587 and 588) in August 1937; retakes made by Charles E. Kay on June 27, 2012 (Photo Nos. 6285-11 and 6285-14). Section 10, Range 10 East, Township 33 South; UTM 518383E, 4201011N; elevation 11,410 ft. Original image held by the U.S. Geological Survey Photographic Library, Denver, CO. Photo mosaic provided by Doug Page, BLM, Cedar City, UT. 

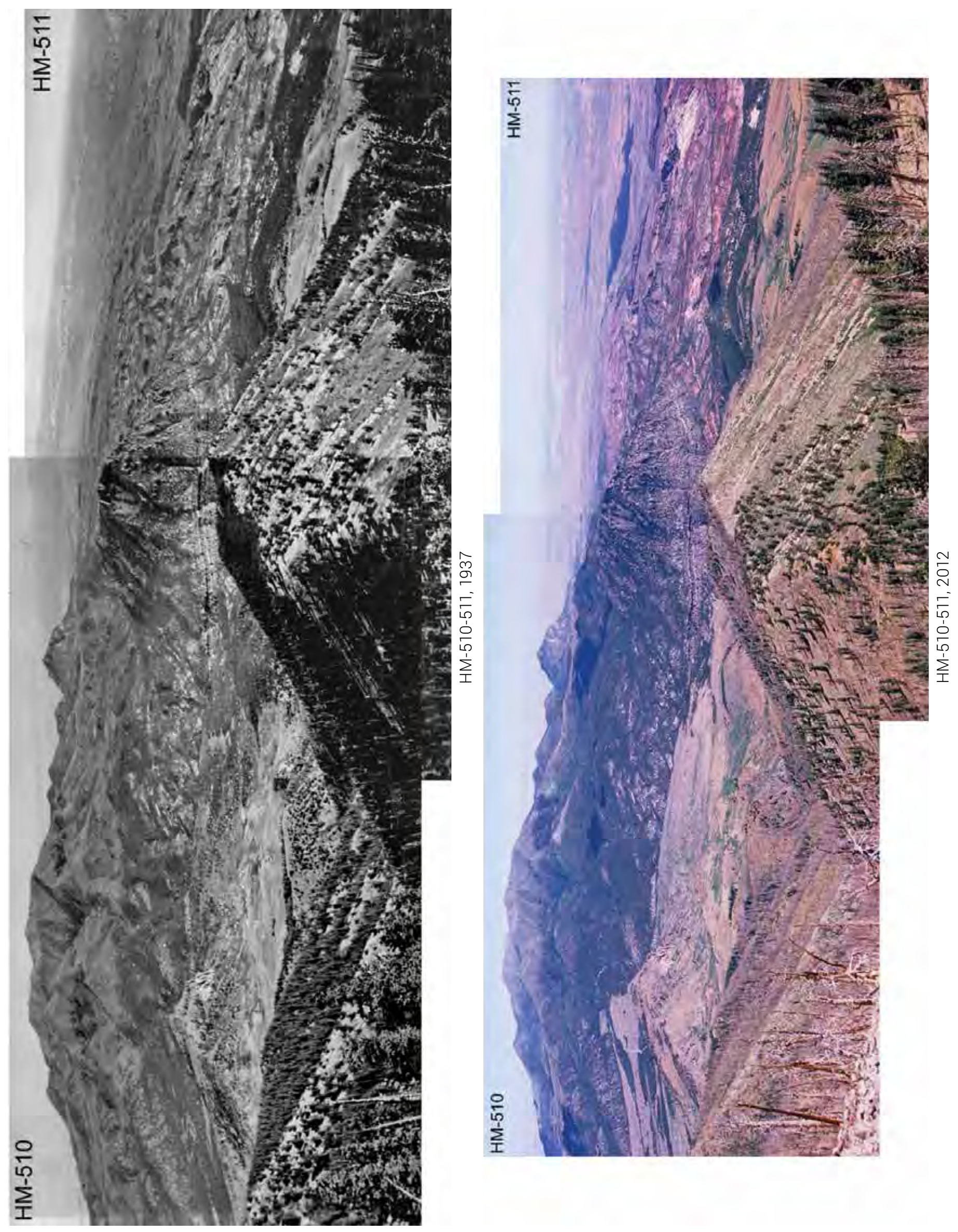


\section{Plate HM-512}

\section{Pistol Ridge}

$1915 \because 2012$

Viewed southeast from Pistol Ridge to Corral Point on the right skyline, with South Summit Ridge in the distance.

Conifers have increased, including pinyon, juniper, Douglas-fir, and spruce; aspen has declined.

Original photograph taken by George C. Fraser (2005) on July 9, 1915; retake made by Charles E. Kay on June 28, 2012 (Photo No. 6285-22). Section 20, Range 10 East, Township 31 South; UTM 514932E, 4216945N; elevation 9,559 ft. Original image (WC-038, Box 3, No. 8-10) held by Princeton University Library Special Collections, Princeton, NJ. 


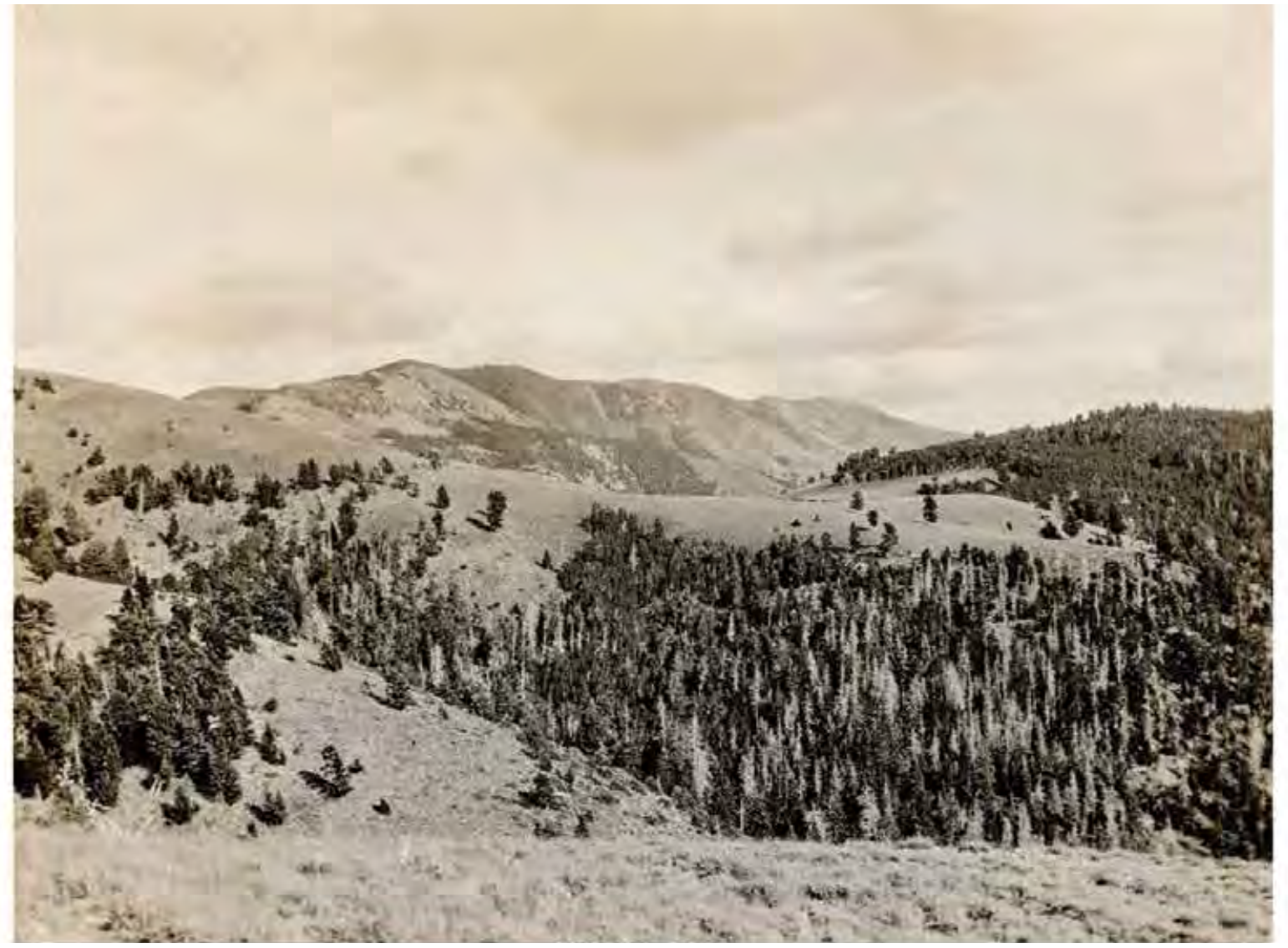

HM-512, 1915

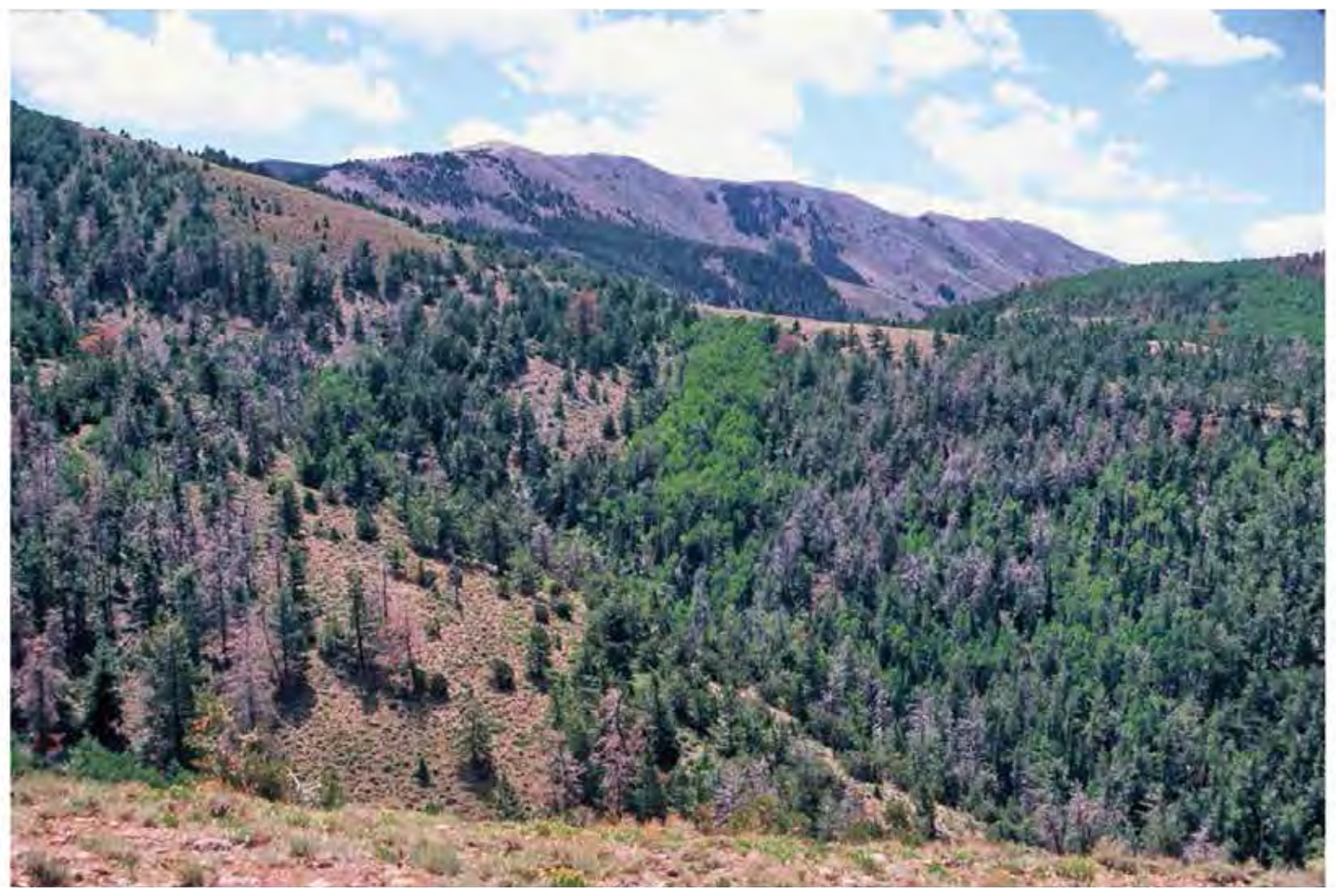

HM-512, 2012 


\section{Plate HM-514}

\section{South Summit Ridge}

$1938 \div 2012$

Viewed northwest form South Summit Ridge to Bull Creek Pass and North Summit Ridge.

Conifers have increased in the distance, including pinyon, juniper, Douglas-fir, limber pine, and spruce.

The upper treeline, however, appears unchanged. A portion of North Summit Ridge (right-center) burned in the 2003 Lonesome Beaver Fire.

Original photograph taken by Charles Hunt (No. 805) in September 1938; retake made by Charles E. Kay on August 10, 2012 (Photo No. 6302-31A). Section 27, Range 10 East, Township 31 South; UTM 518000E, 4214780N; elevation 11,111 ft. Original image held by the U.S. Geological Survey Photographic Library, Denver, CO. 


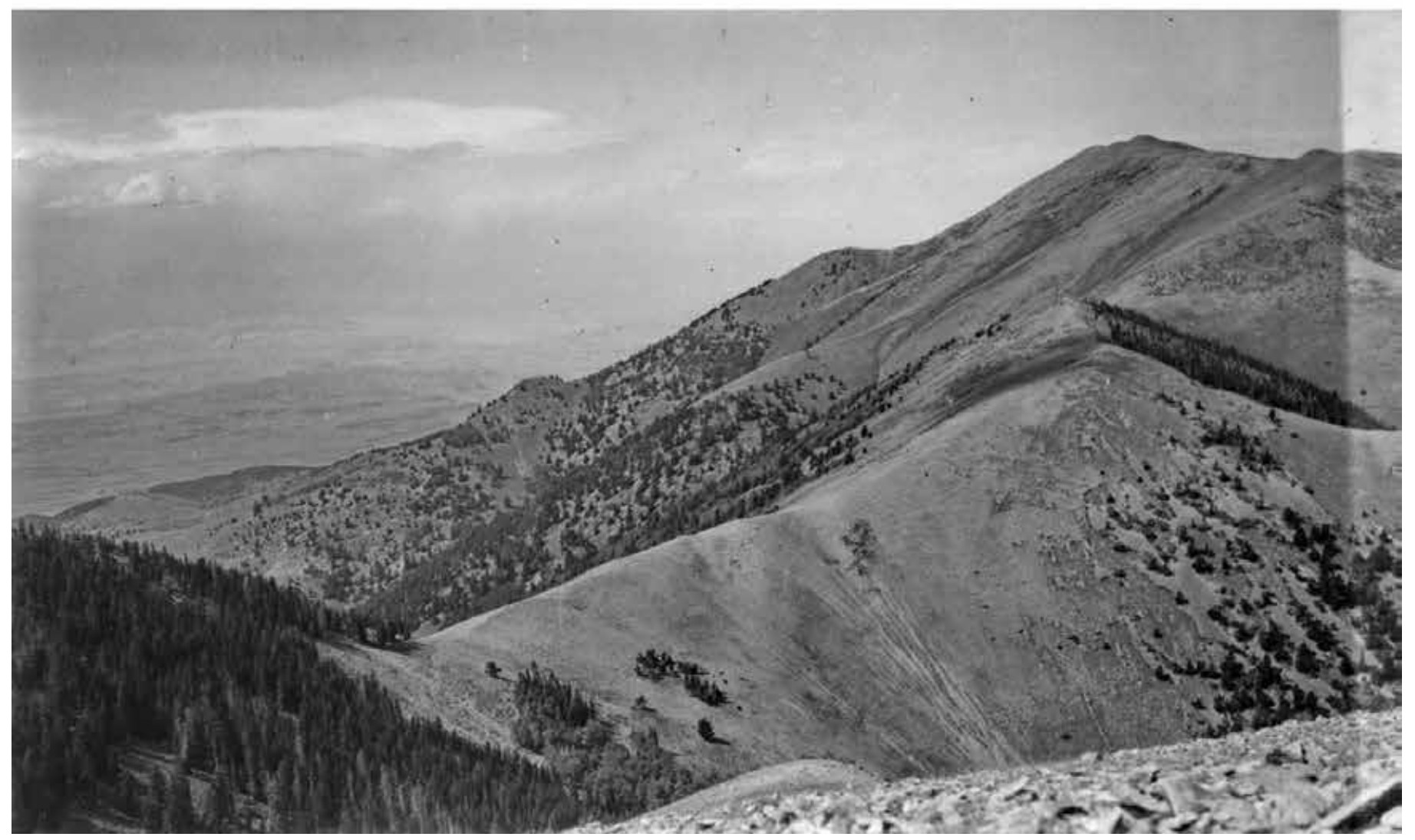

HM-514, 1938

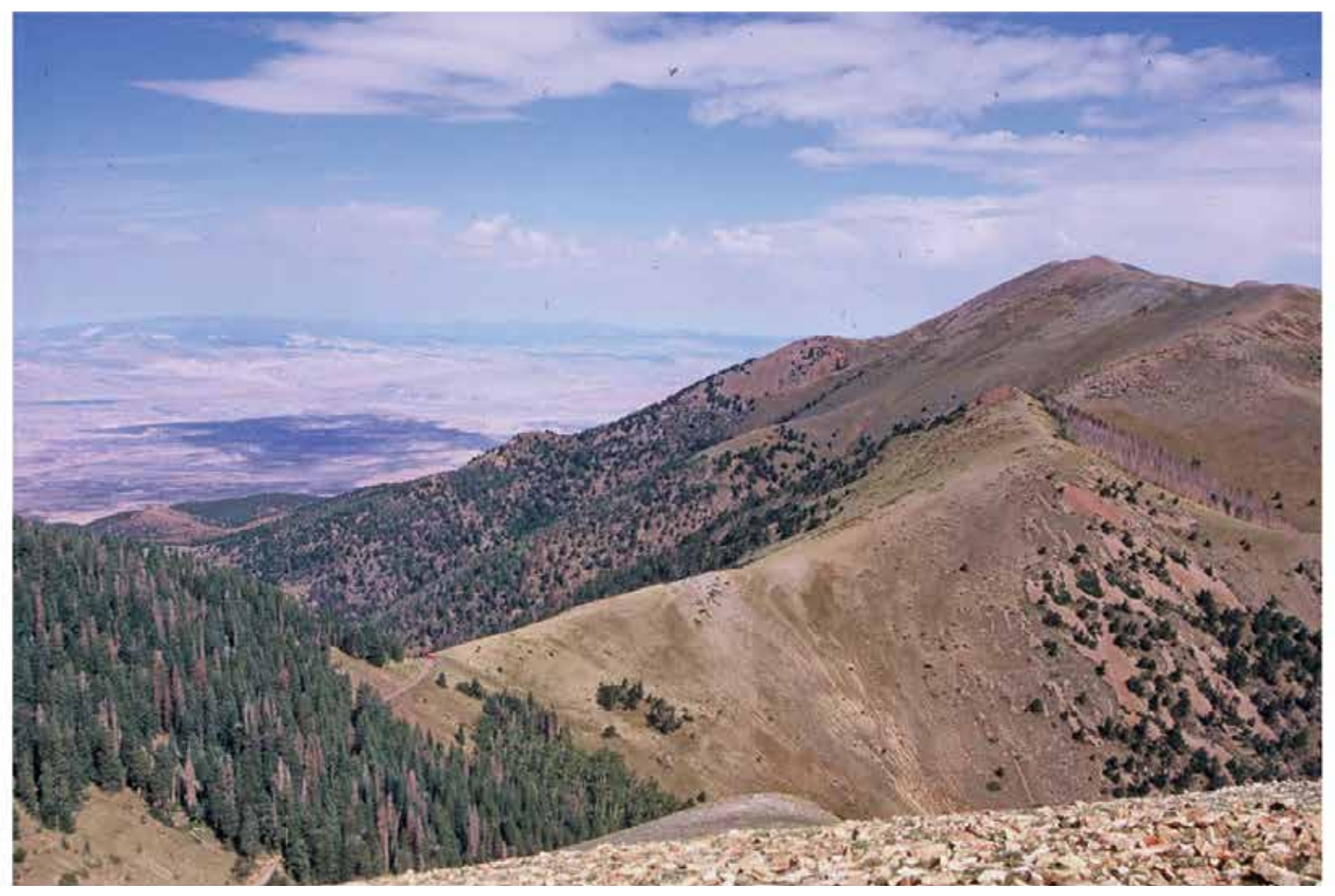


Plate HM-515

North Fork of Bulldog Creek

$1959 \because 2012$

In 1959 the BLM established the E-1-1 range monitoring site on the Pennell Allotment. The steel stakes could not be relocated.

Pinyon, juniper, and oak brush have increased. The foreground was chained and seeded with crested wheatgrass, but sagebrush now dominates the site. Pinyon and juniper that established after the earlier treatment were recently hand-felled. Utah serviceberry is also present.

Original photograph taken by the BLM on October 12, 1959; retake made by Charles E. Kay on August 11, 2012 (Photo No. 6320-2). Section 8, Range 10 East, Township 32 South; UTM 515211E, 4209700N; elevation 8,260 ft. Original image held in the BLM’s range files, Hanksville, UT. 


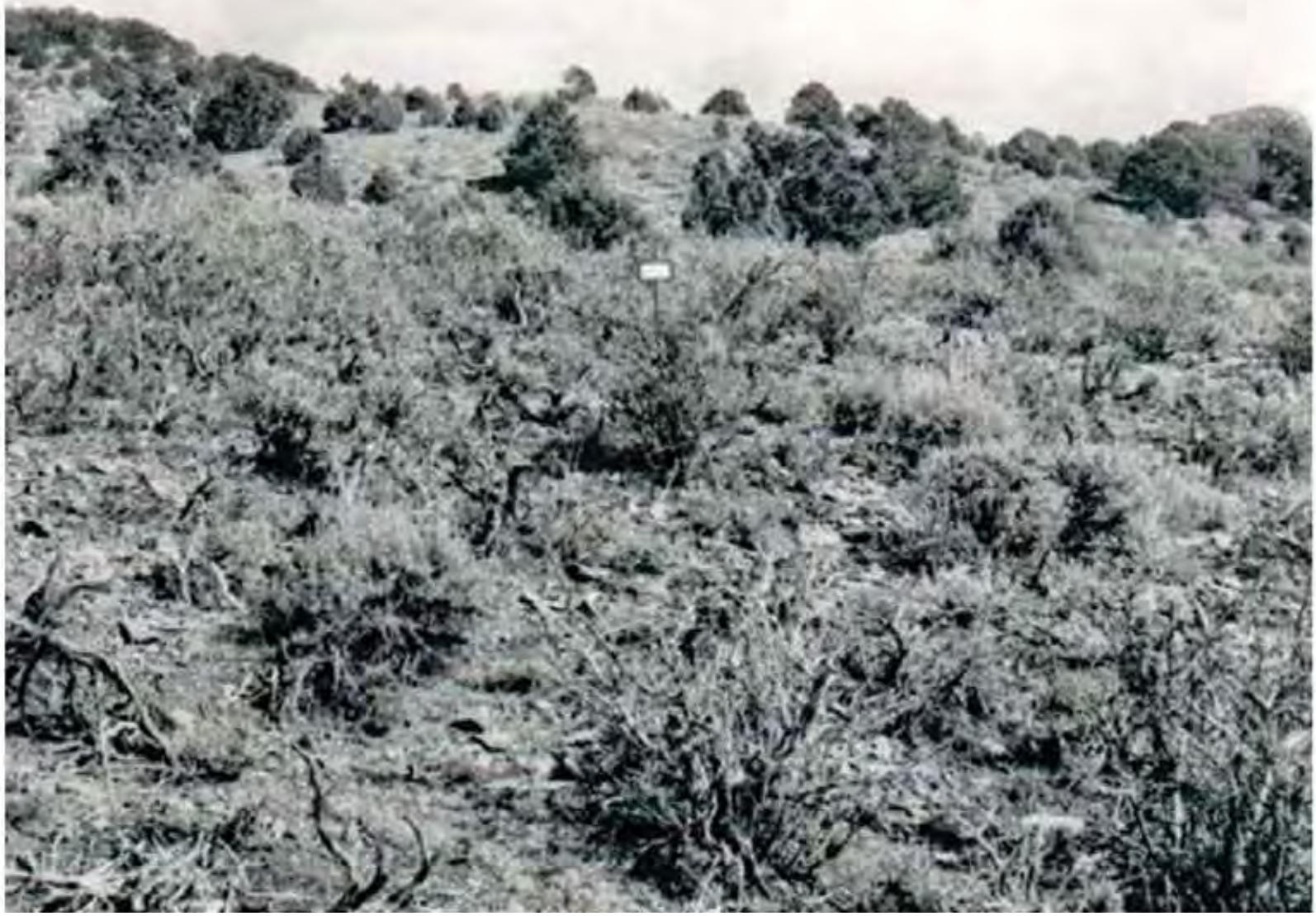

HM-515, 1959

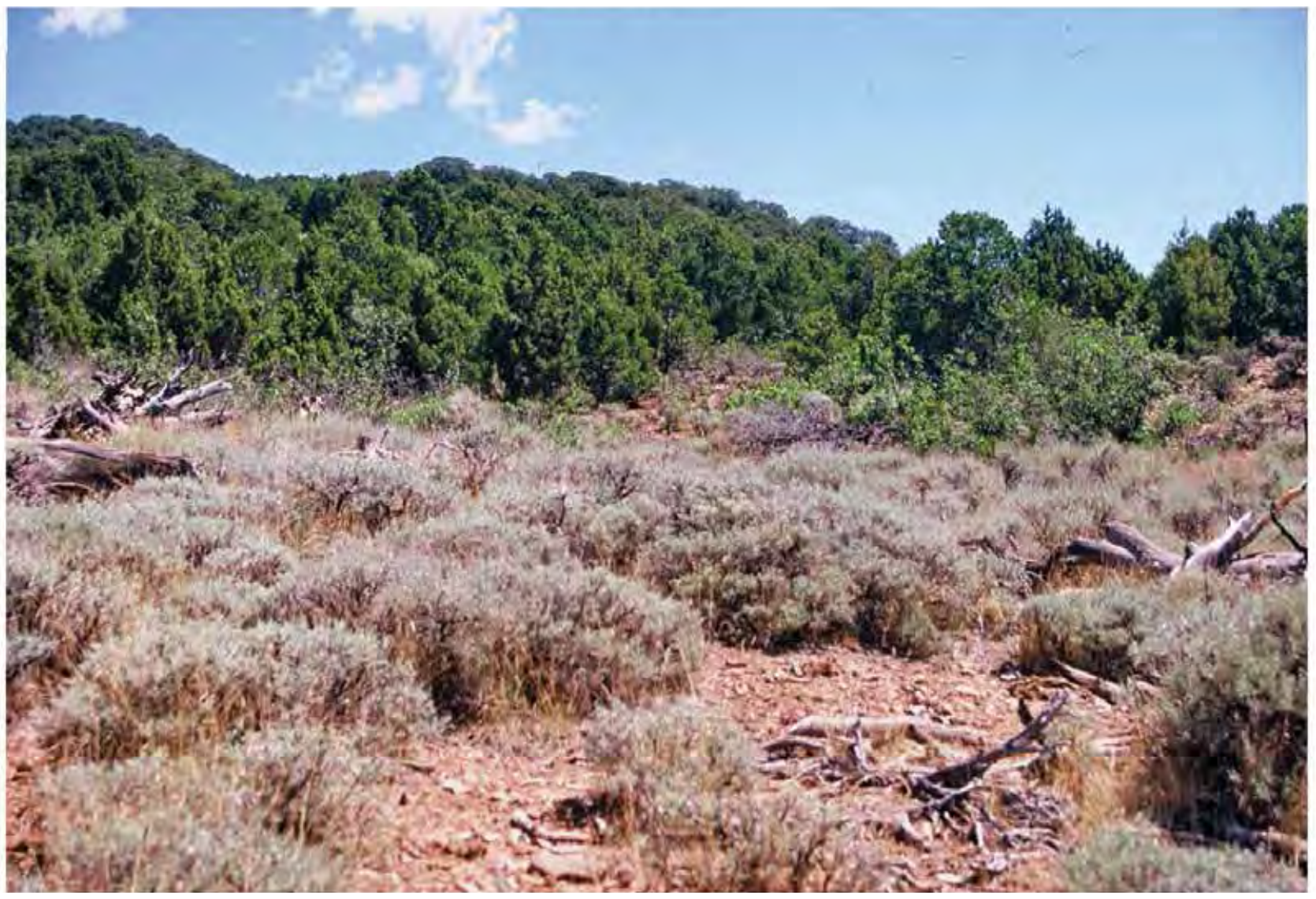

HM-515, 2012 
Plate HM-529

\section{Burro WaSh}

$1911 \div 2012$

Viewed northwest up Burro Wash, just above its confluence with Sandy Creek. There is a new road on the right.

All the dark-colored shrubs in the foreground of both images are greasewood. Burro Wash has down-cut

10-20 feet. Cottonwoods have increased. Most tamarisk was recently top-killed by the introduced tamarisk beetle. Pinyon and juniper appear to have increased in the distance.

Original photograph taken by C.T. Lupton (No. 280) in 1911; retake made by Charles E. Kay on August 14, 2012 (Photo No. 6323-23). Section 33, Range 8 East, Township 30 South; UTM 494516E, 4224107N; elevation 5,084 ft. Original image held by the U.S. Geological Survey Photographic Library, Denver, CO. 


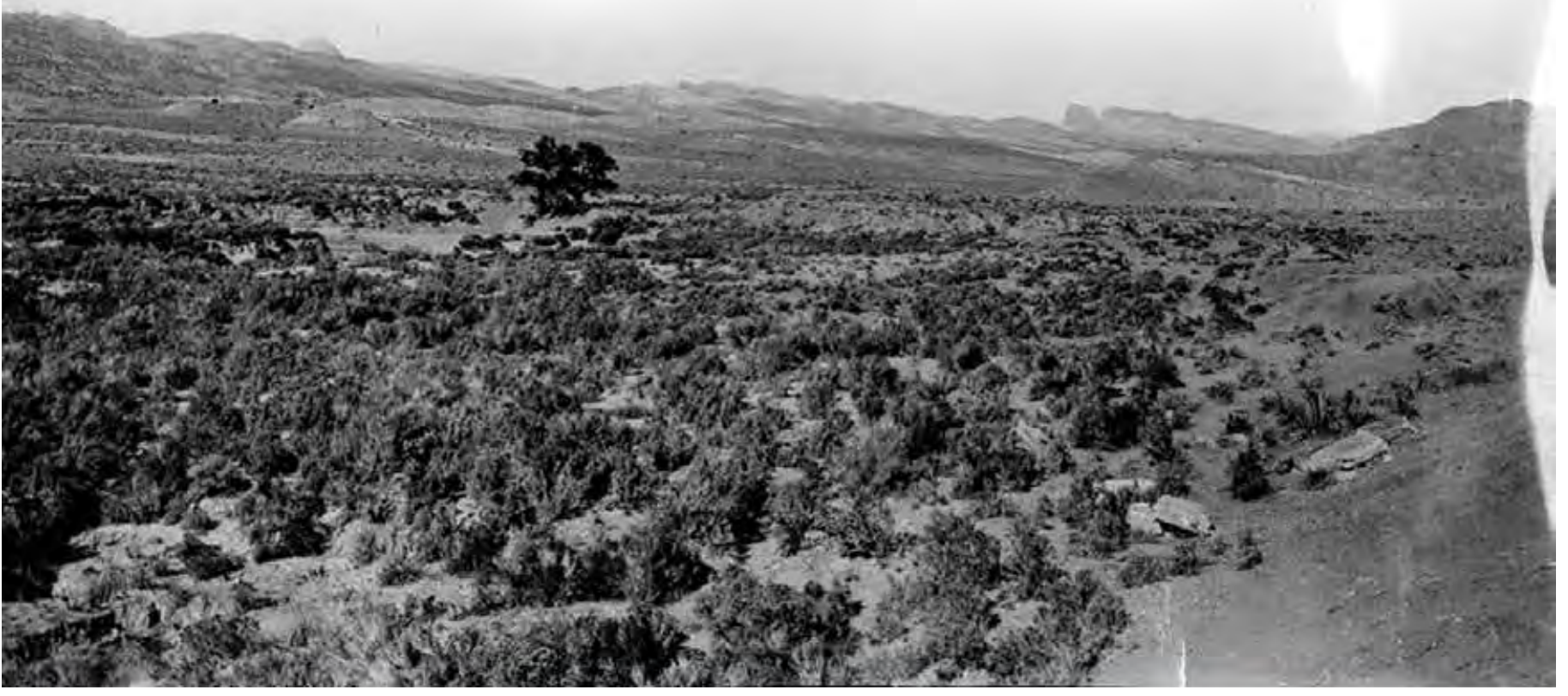

HM-529, 1911

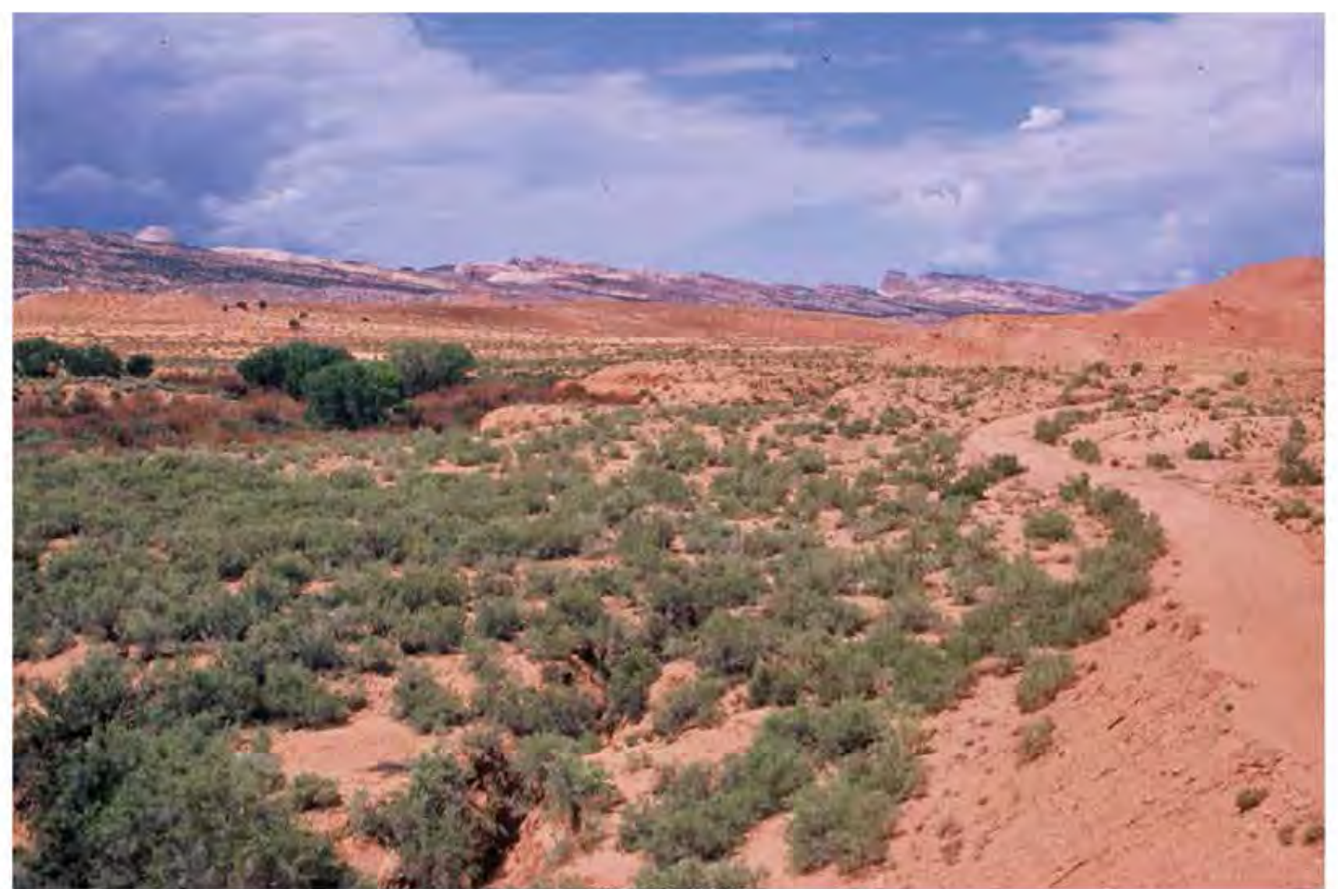




\section{Plate HM-533}

\section{Apple Brush Flat}

$1911 \because 2012$

Viewed southeast across Apple Brush Flat. Steel Butte is on the right skyline, and Mount Pennell is on the

skyline in the center. Pinyon-juniper now blocks the original photo point, so the retake was made from the nearest open area.

Pinyon and juniper have increased; fourwing saltbush has declined. Other species include Mormon tea, snakeweed, curly grass, Indian ricegrass, and needle and thread.

Original photograph taken by C.T. Lupton (No. 282) in 1911; retake made by Charles E. Kay on September 8, 2012 (Photo No. 6326-20). Section 8, Range 9 East, Township 31 South; UTM 504990E, 4219048N; elevation 5,789 ft. Original image held by the U.S. Geological Survey Photographic Library, Denver, CO. 


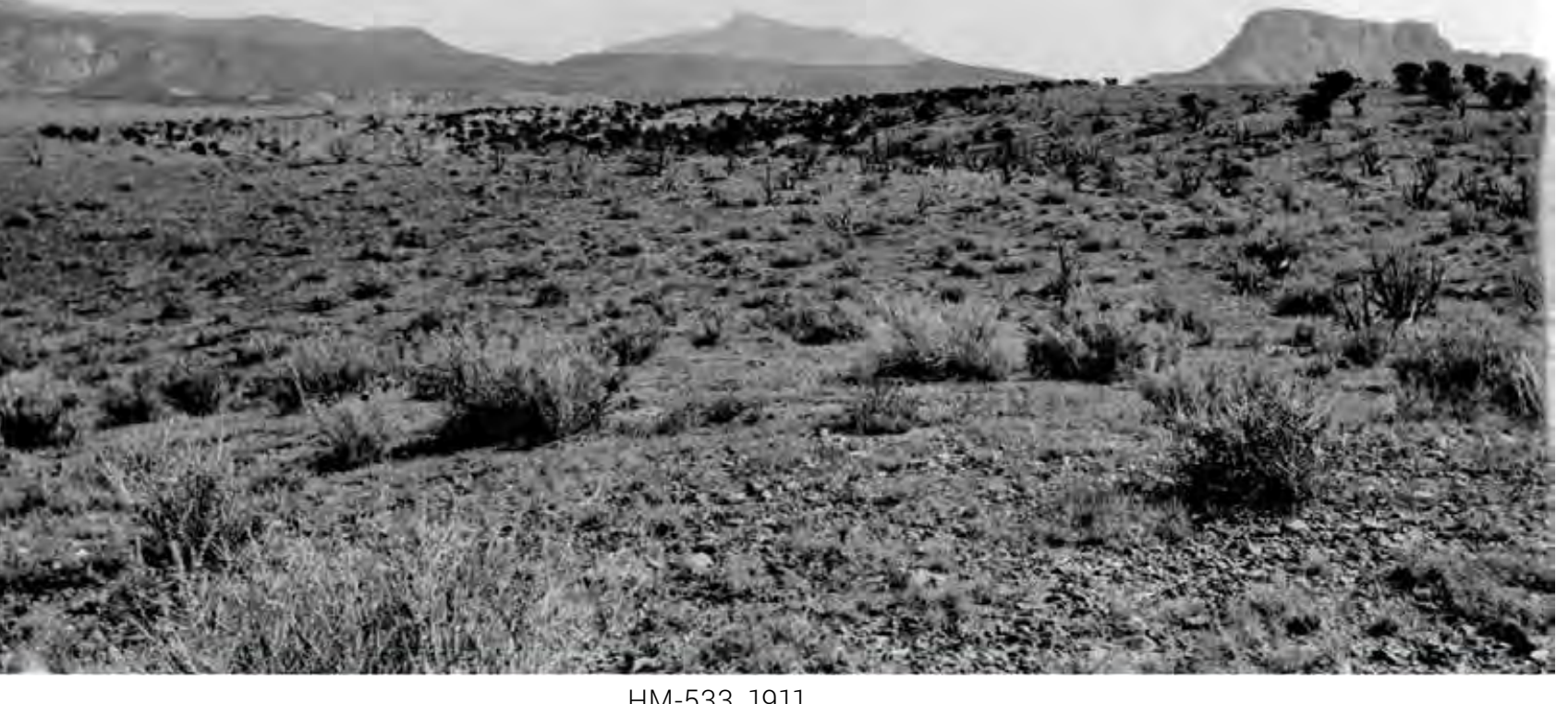

HM-533, 1911

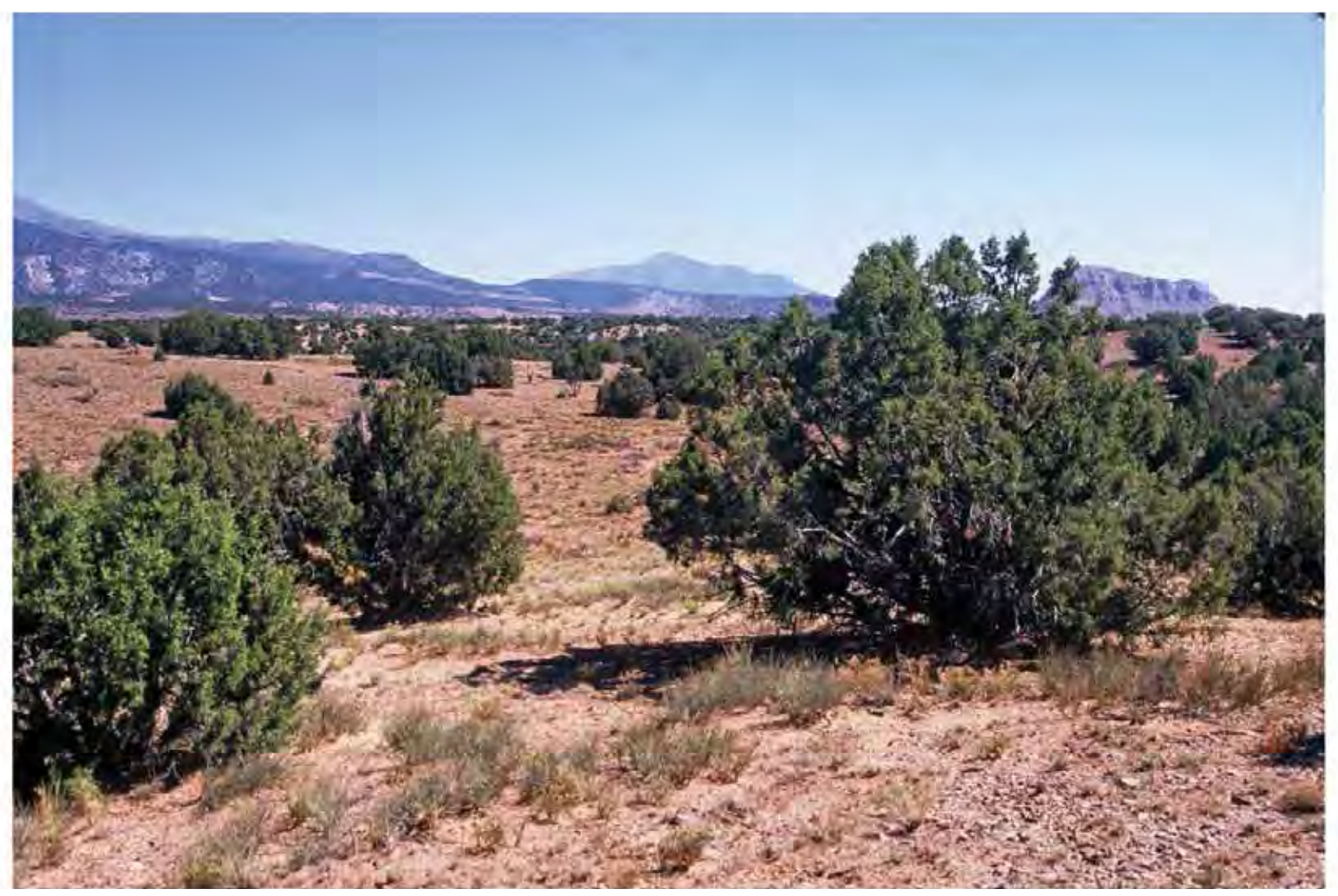




\section{Plate HM-543}

\section{EGGNOG}

$1940 \div 2012$

Viewed southwest down Bullfrog Creek to the line camp known as Eggnog. Note the small cabin in the 1940 image (upper-right-center) and the new, larger cabin surrounded by tamarisk in the retake.

The stream channel has narrowed, and cottonwoods have increased. As indicated by all the livestock trails in the 1940 photo, the area to the right of the creek was very heavily grazed. Today it is more vegetated. Common species include greasewood, rubber rabbitbrush, shadscale, and blackbrush.

Original photo made with camera tilted slightly to the right. Original photograph taken by the BLM in 1940; retake made by Charles E. Kay on September 10, 2012 (Photo No. 6328-30). Section 18, Range 10 East, Township 35 South; UTM 513678E, 4180468N; elevation 4,509 ft. Original image held in the BLM's range files, Hanksville, UT. 


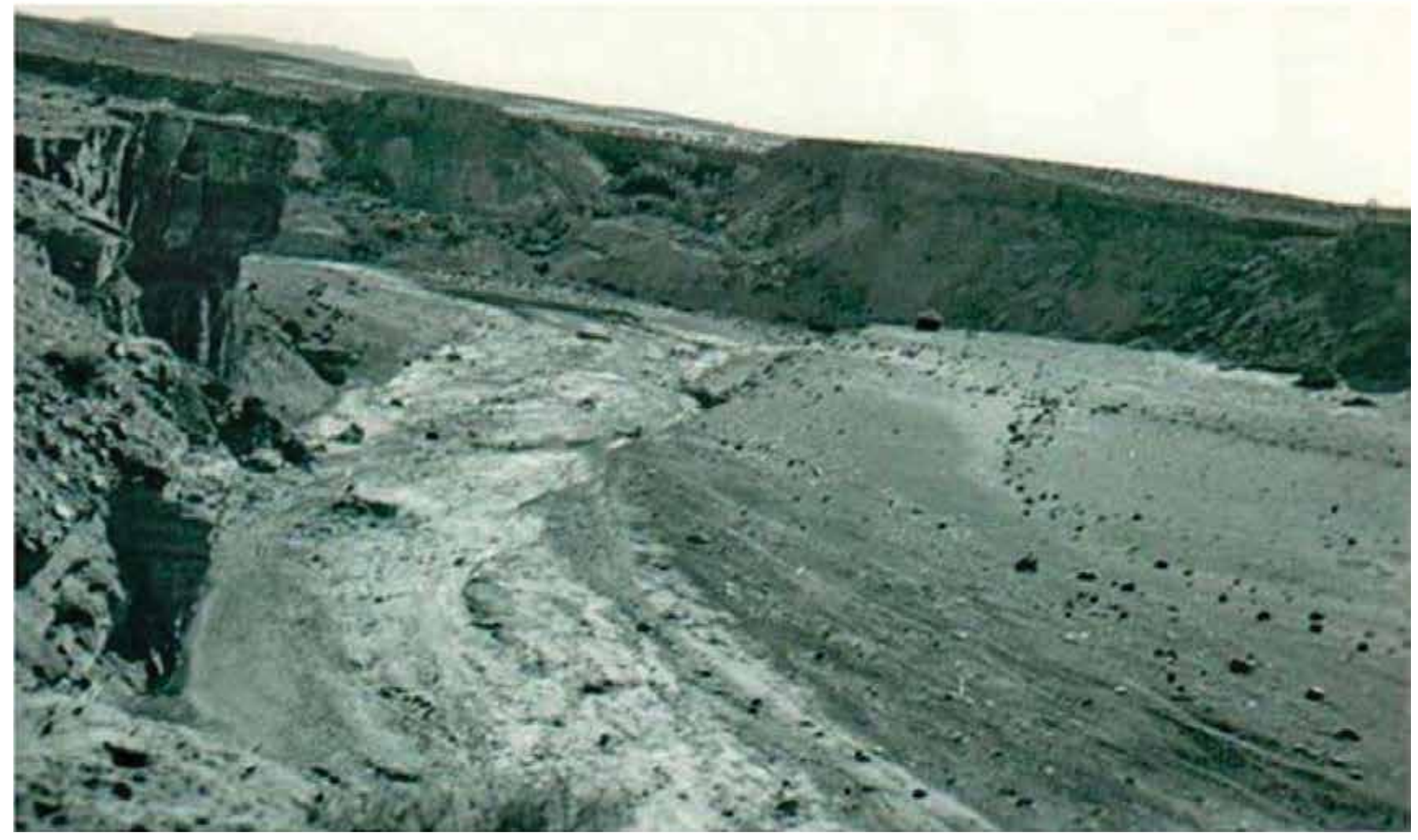

HM-543, 1940

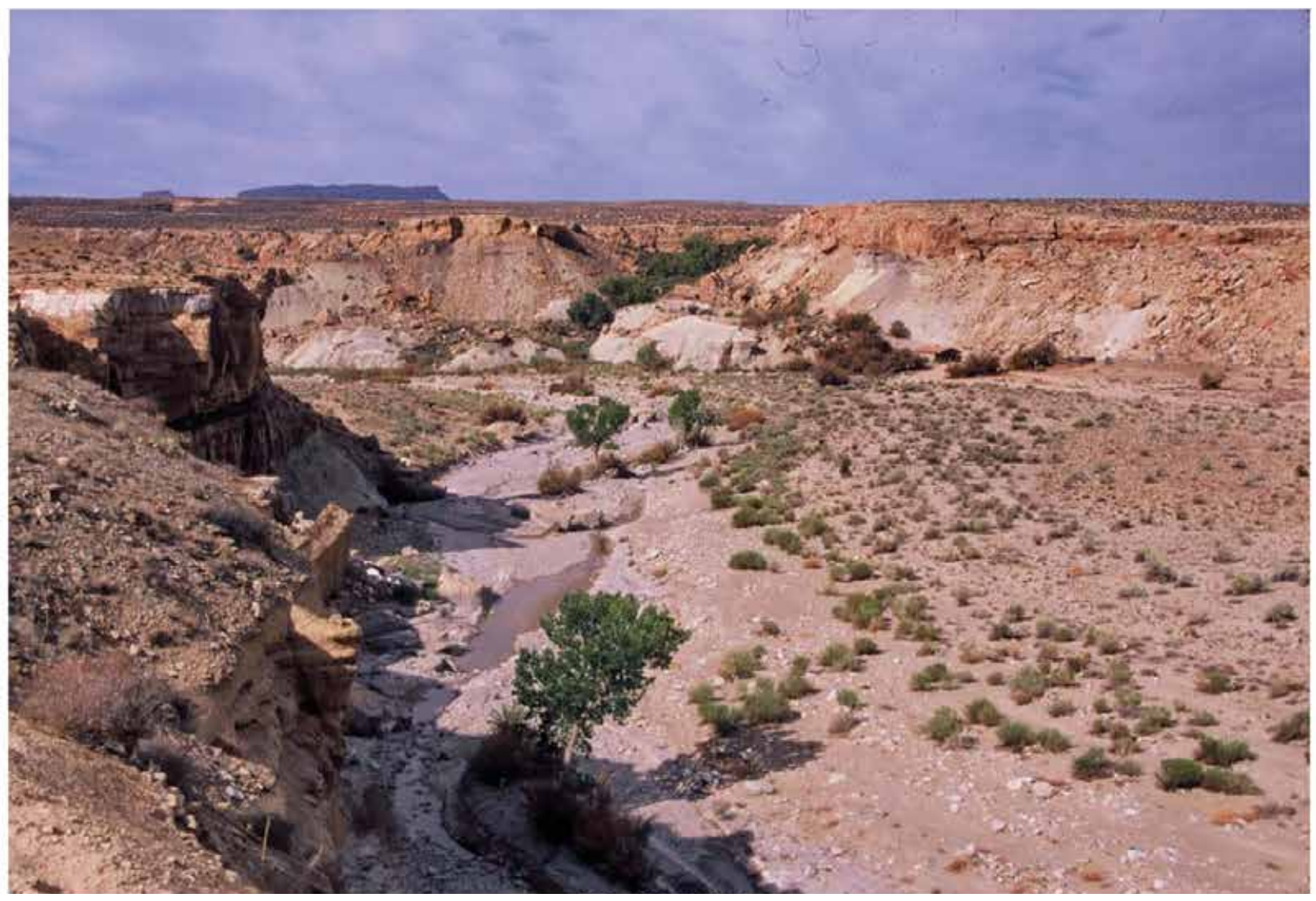

HM-543, 2012 


\section{Plate HM-560}

\section{HaLFWAY WASH}

$1959 \because 2012$

In 1959 the BLM established range monitoring site D-4-2 above Halfway Wash. The photo point is located south of the road that runs from Utah Highway 95 in the east to the Fairview Ranch in the west, south of Hanksville. The steel stake was relocated.

There has been a corresponding increase in blackbrush and a decrease in grass cover, mostly curly grass.

Mormon tea is also present.

Original photograph was taken by the BLM on October 1, 1959; retake made by Charles E. Kay on September 13, 2012 (Photo No. 6335-21). Section 11, Range 11 East, Township 30 South; UTM 526851E, 4229491N; elevation 5,076 ft. Original image held in the BLM’s range files, Hanksville, UT. 


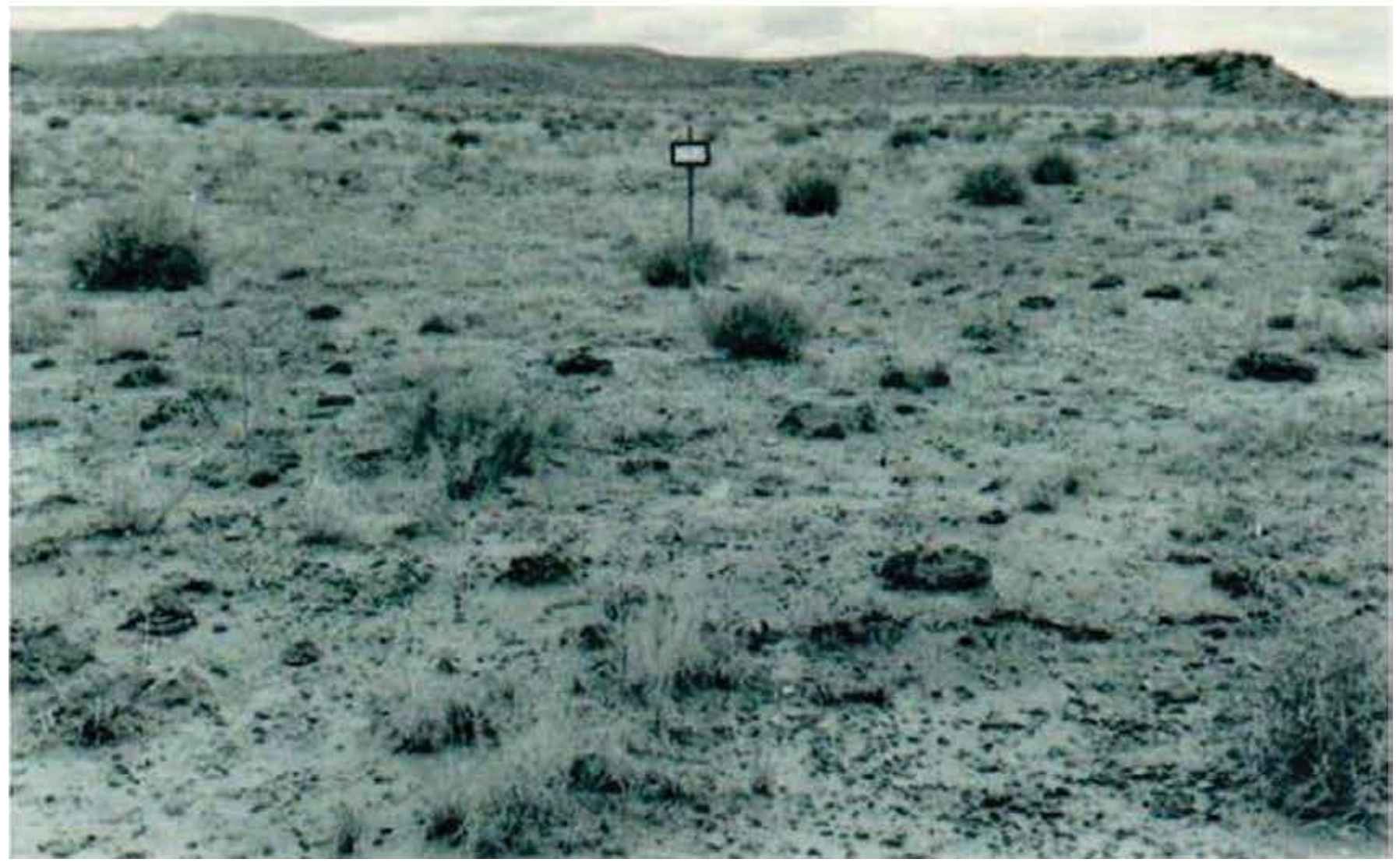

HM-560, 1959

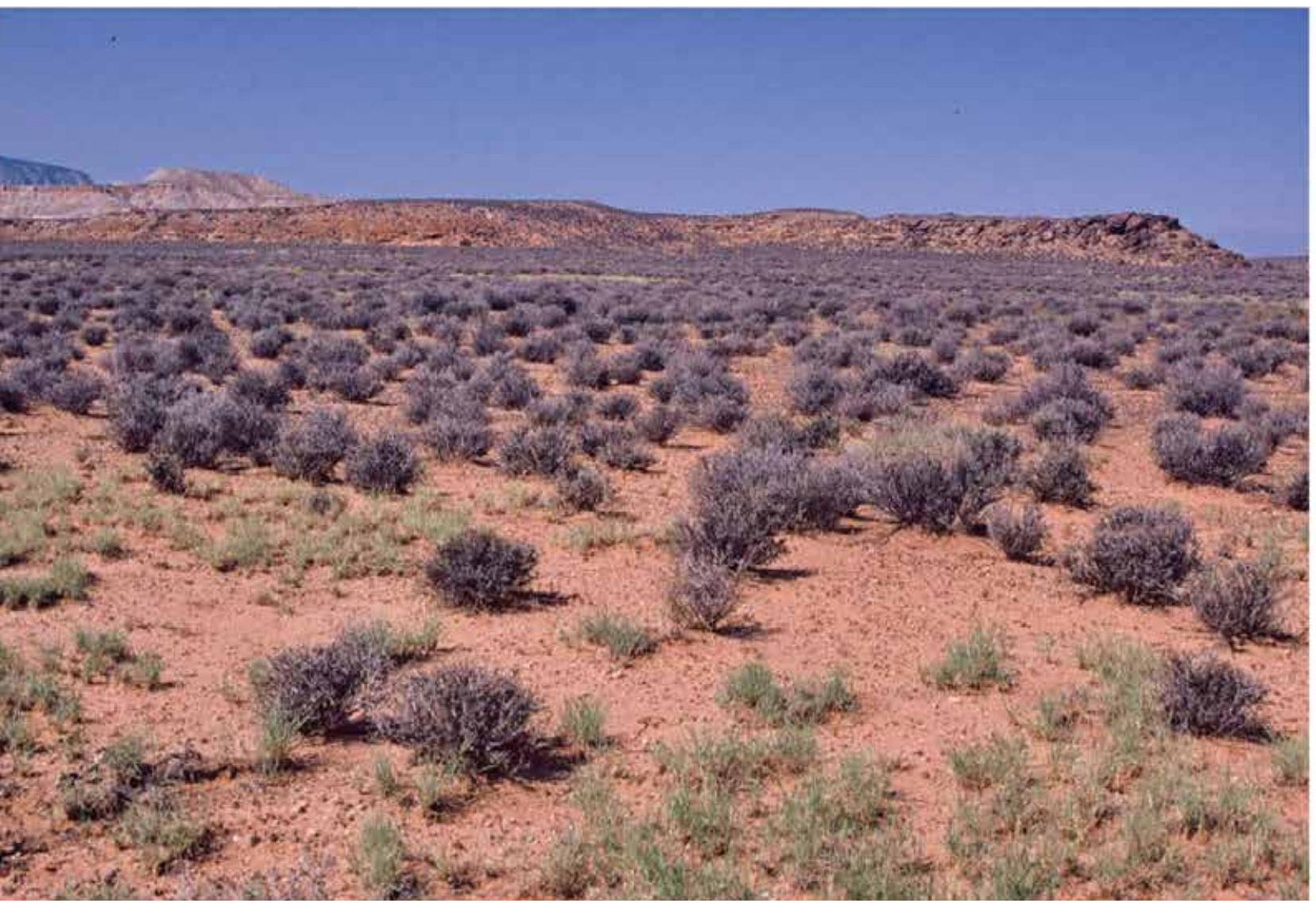

HM-560, 2012 


\section{Plate HM-563}

\section{Mount Ellen}

$1915: 2012$

Viewed north to Mount Ellen from North Summit Ridge.

The upper treeline has not changed. The dark-colored shrubs are currants.

Original photograph taken by David Rust ca. 1915; retake made by Charles E. Kay on September 14, 2012

(Photo No. 6335-32). Section 16, Range 10 East, Township 31 South; UTM 516321E, 4218324N; elevation

11,291 ft. Original image (David Rust Collections, Box 6, unnumbered negative) held by the LDS Church Archives, Salt Lake City, UT. 


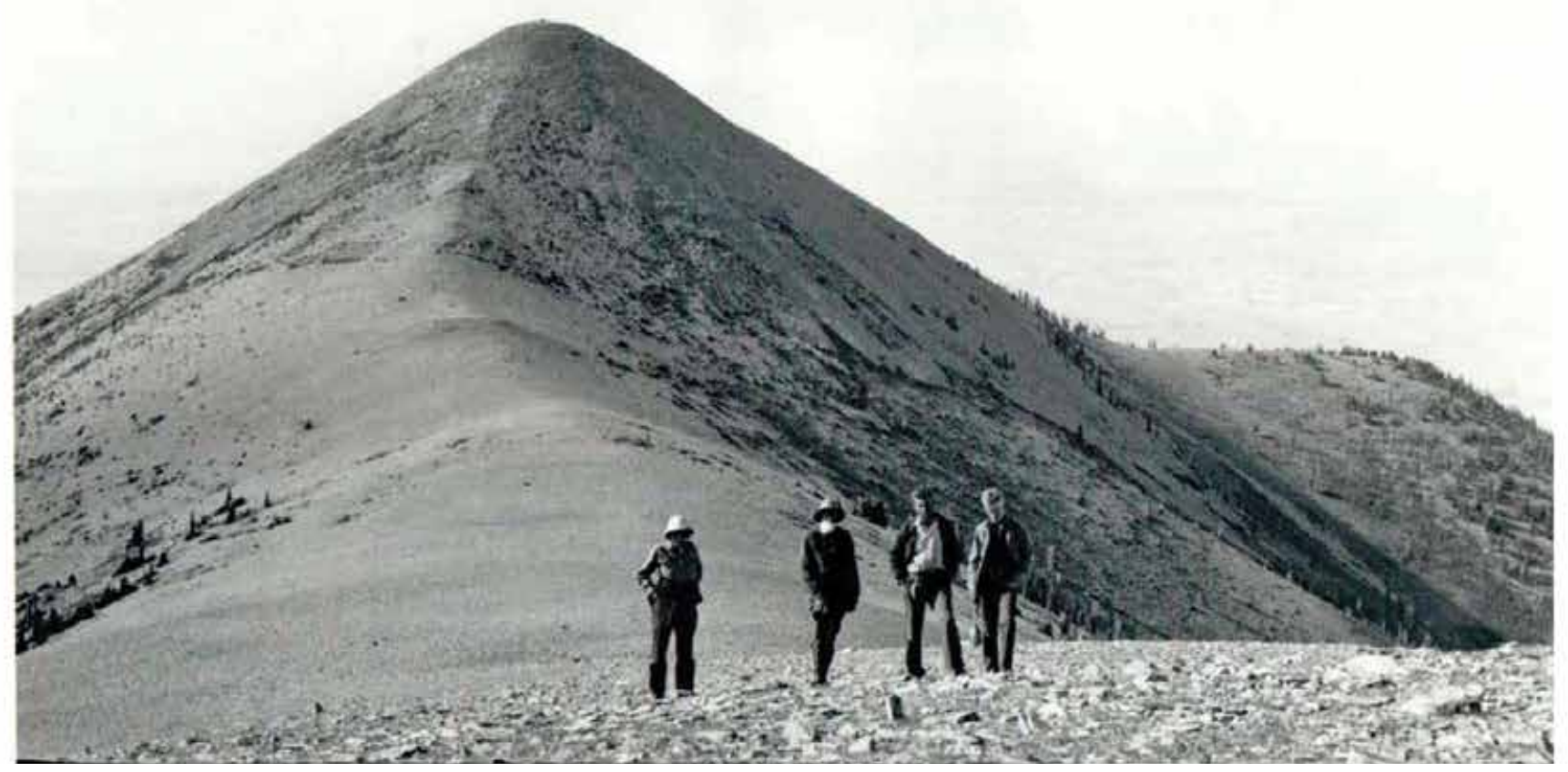

HM-563, 1915

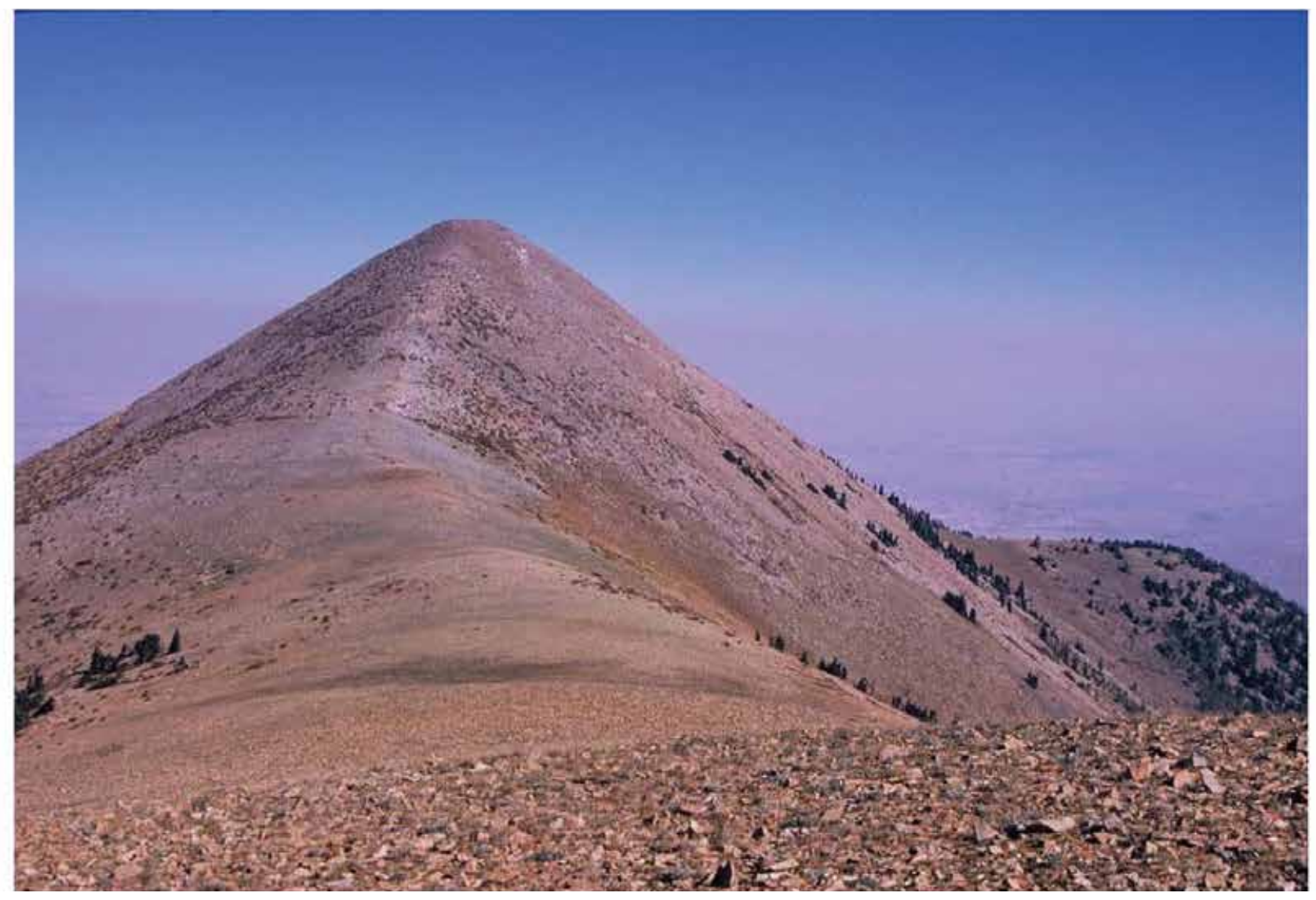

HM-563, 2012 


\section{Plate HM-567}

\section{Mount Ellen}

$1936 \div 2012$

Viewed northeast from the summit of Mount Ellen to East Saddle, Horseshoe Ridge (middle ground,

bare of trees in 2012), and Bull Mountain (tallest mountain on right).

Much of Horseshoe Ridge burned in the 2003 Lonesome Beaver Fire. Elsewhere conifers have increased, including pinyon, juniper, ponderosa pine, Douglas-fir, limber pine, and spruce. Conifers have also invaded aspen stands.

Original photograph taken by Charles Hunt (No. 735) in September 1936; retake made by Charles E. Kay on September 14, 2012 (Photo No. 6340-14). Section 9, Range 10 East, Township 31 South; UTM 516272E, 4219268N; elevation 11,477 ft. Original image held by the U.S. Geological Survey Photographic Library, Denver, CO. 


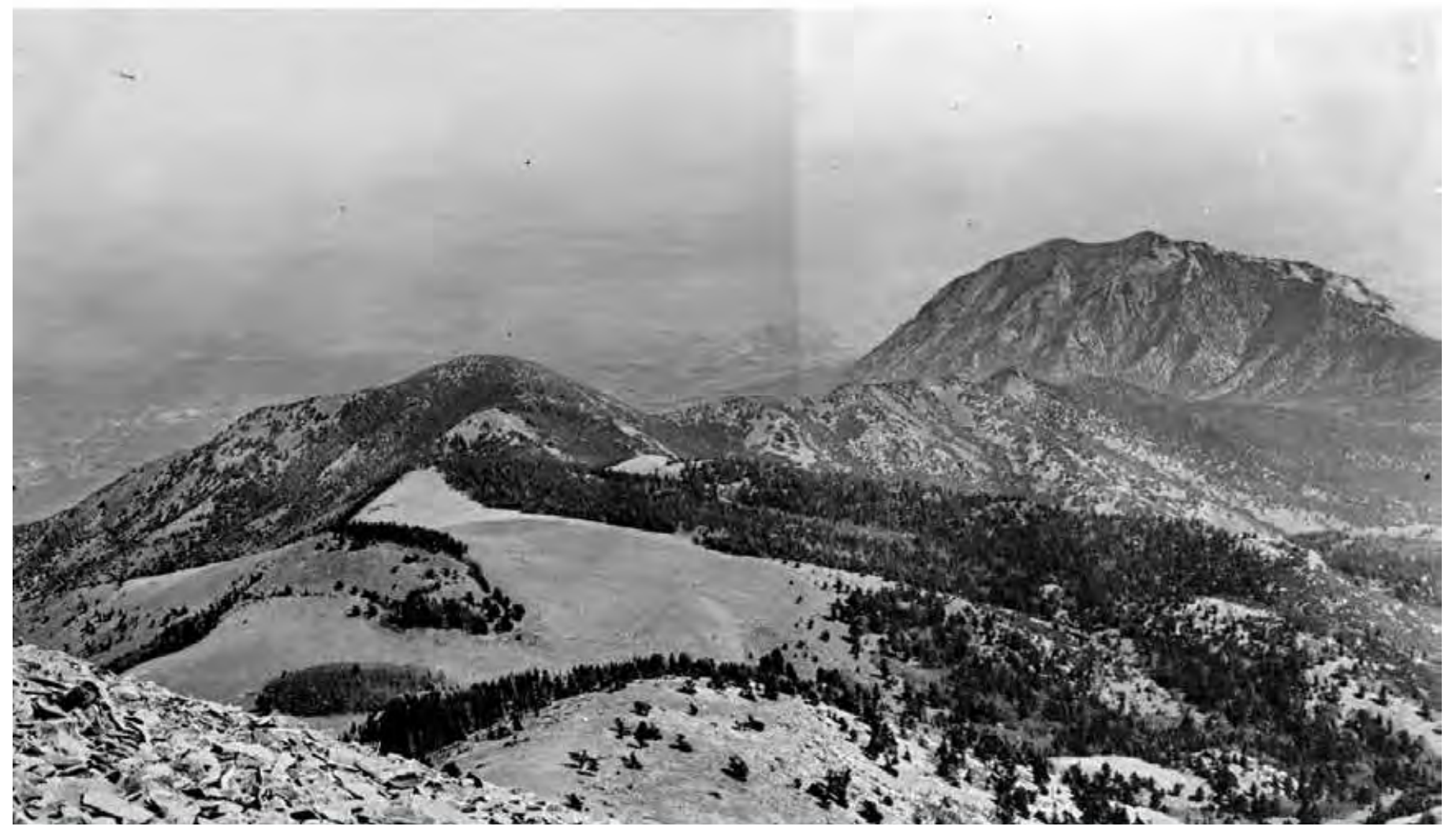

HM-567, 1936

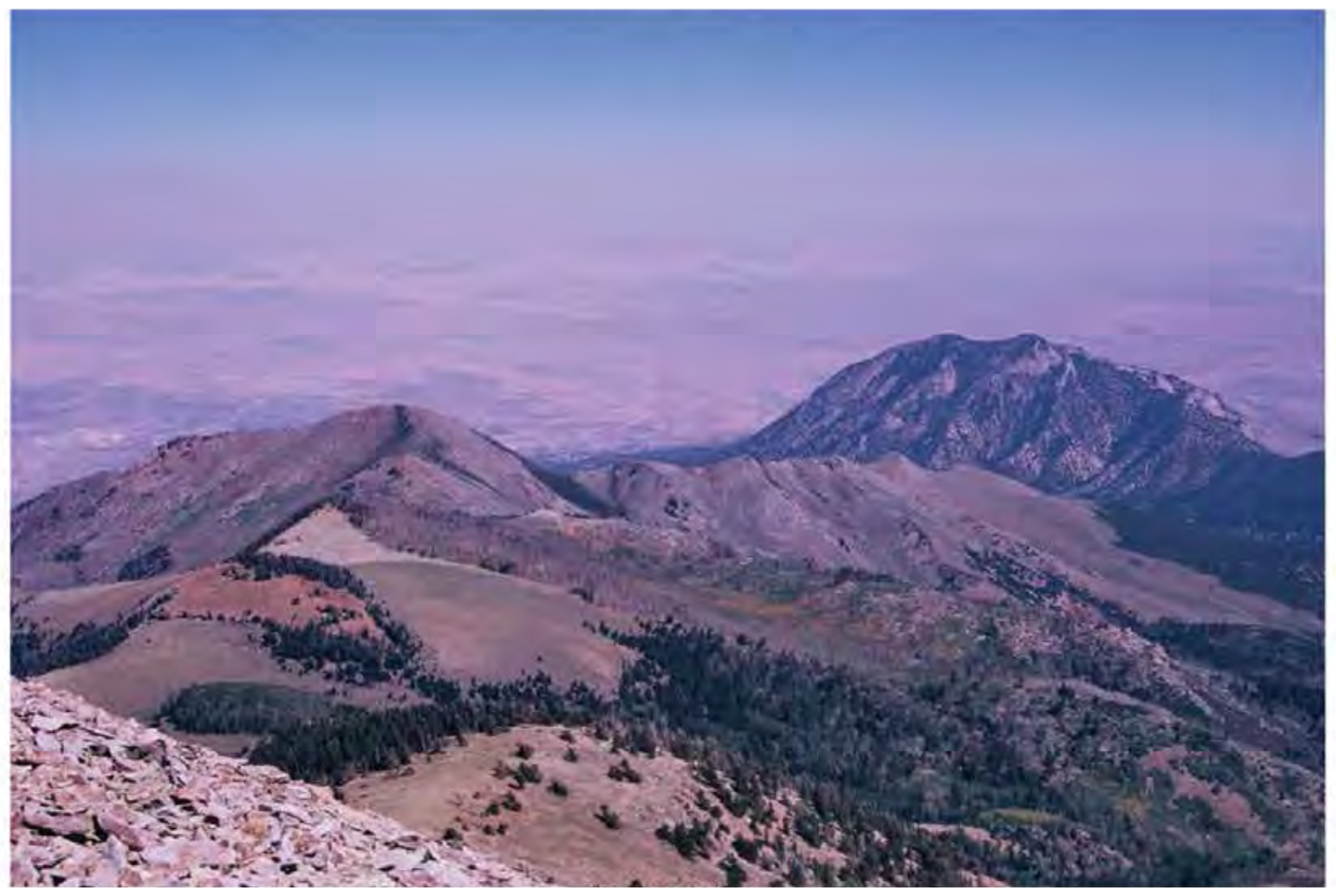

HM-567, 2012 


\section{Plate HM-568}

\section{North Summit Ridge}

$1936 \circ 2012$

Viewed south along North Summit Ridge from the summit of Mount Ellen.

The upper treeline has not changed, although conifers, mostly spruce and Douglas-fir, have increased in height and numbers. The dark-colored shrubs are currants. Conifers in the lower right of the retake burned in the 2003 Lonesome Beaver Fire.

Original photograph taken by Charles Hunt (No. 734) in September 1936; retake made by Charles E. Kay on September 14, 2012 (Photo No. 6340-15). Section 9, Range 10 East, Township 31 South; UTM 516272E, 4219268N; elevation 11,477 ft. Original image held by the U.S. Geological Survey Photographic Library, Denver, CO. 


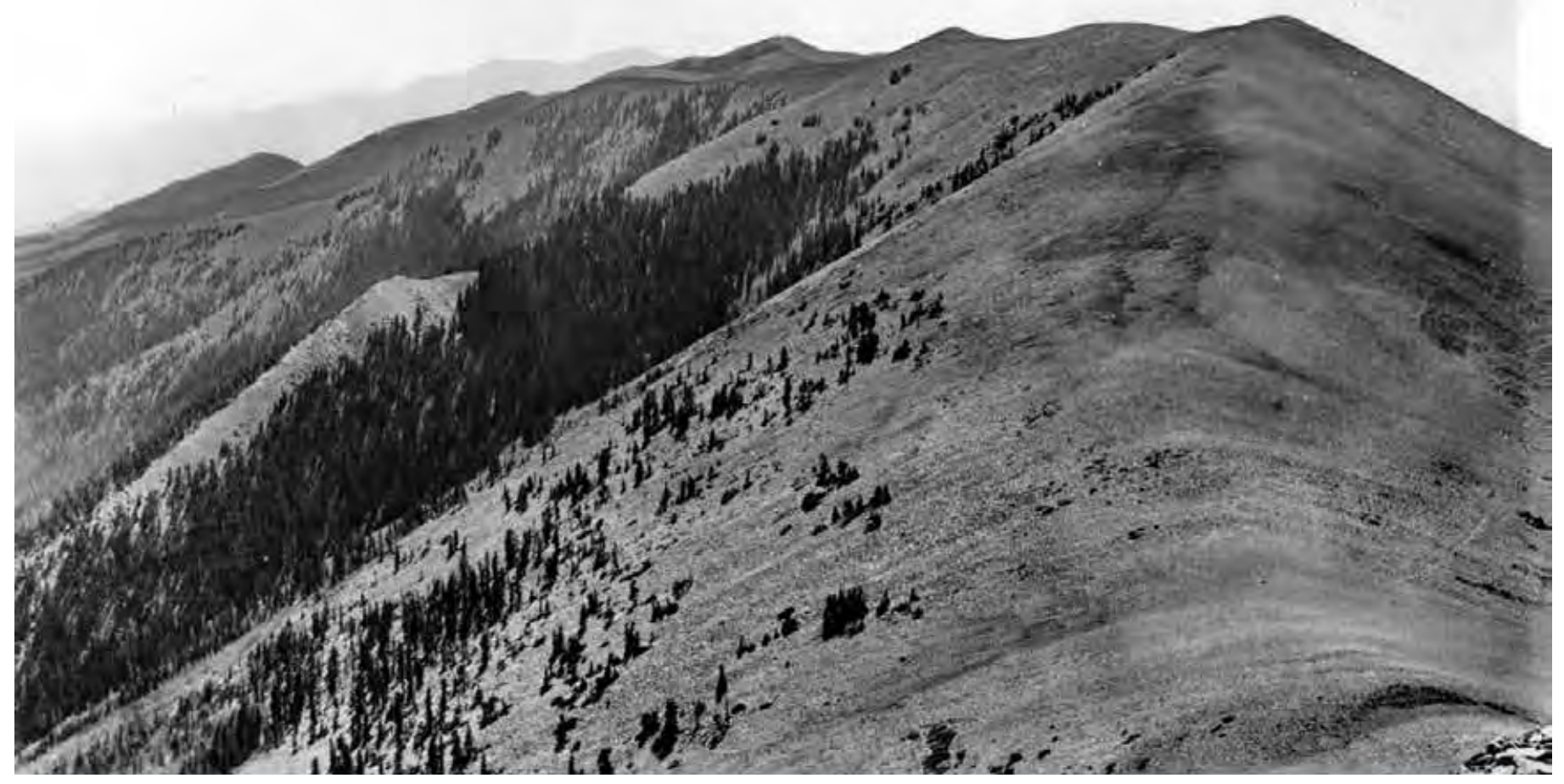

HM-568, 1936

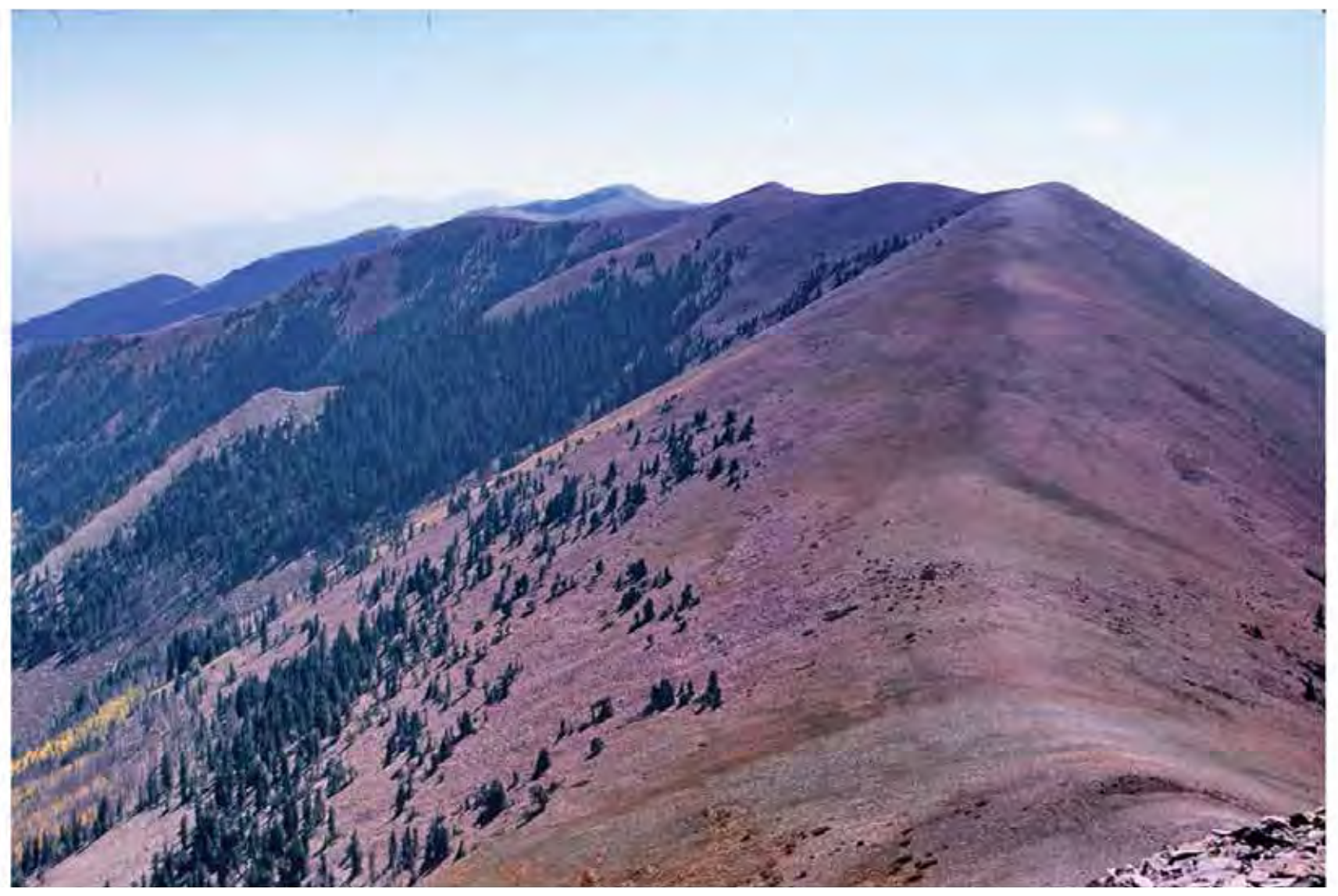

HM-568, 2012 


\section{Plate HM-573 and HM-574}

Straight Creek

$1937 \because 2012$

Viewed west-southwest up Straight Creek on the east side of Mount Pennell. Plates HM-573 and HM-574 form a panorama.

Except for a small patch of conifers on the uppermost ridge, the entire area was burned by the 2003 Bulldog Fire. Oak brush in the foreground has successfully resprouted, as has aspen across the creek.

Original photographs taken by Charles Hunt (Nos. 620 and 621) in July 1937; retakes made by Charles E. Kay on September 16, 2012 (Photo Nos. 6343-11 and 6343-13). Section 11, Range 10 East, Township 33 South; UTM 520147E, 4200306N; elevation 8,456 ft. Original images held by the U.S. Geological Survey Photographic Library, Denver, CO. Photo mosaic compiled by Doug Page, BLM, Cedar City, UT. 


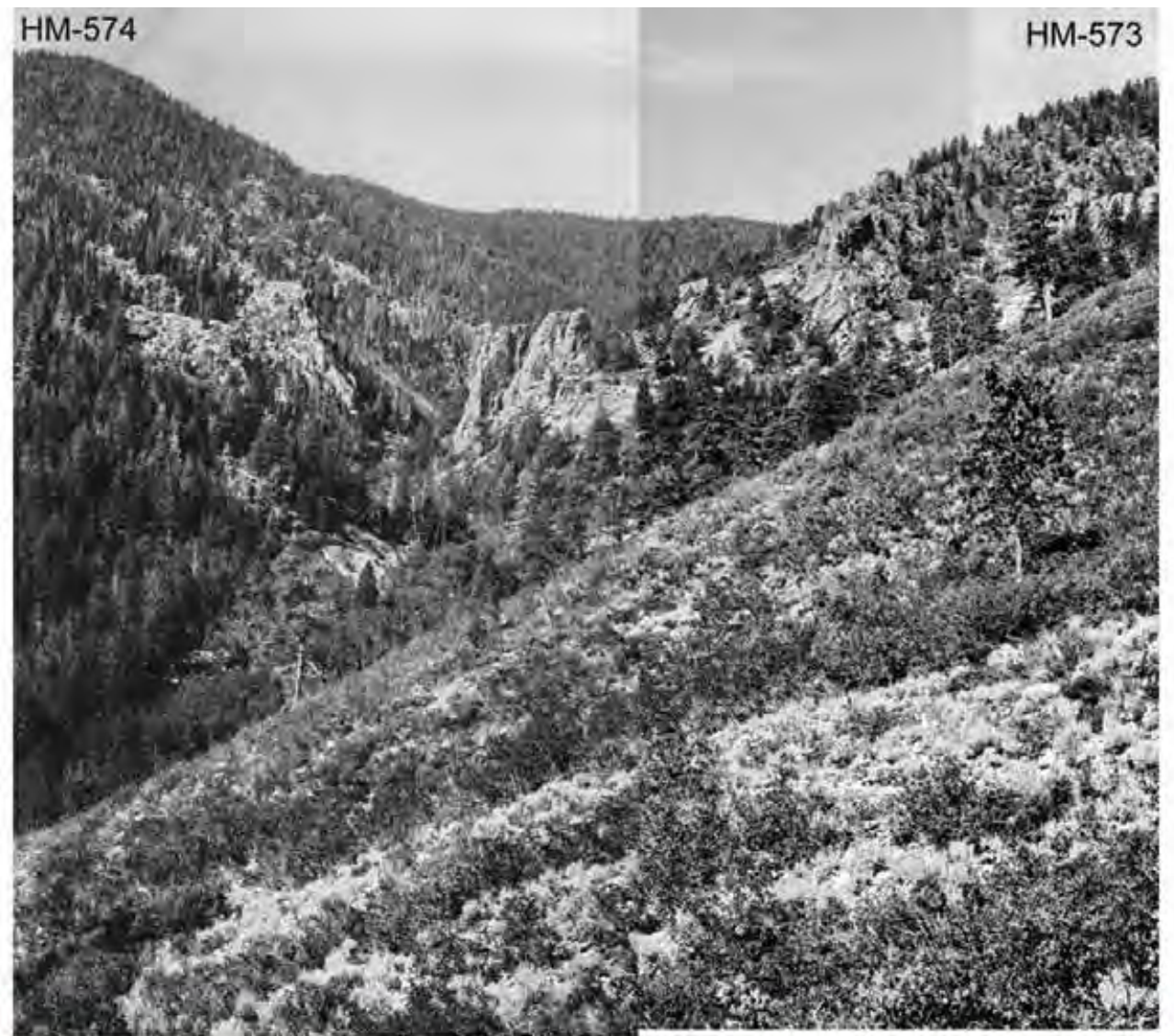

HM-573-574, 1937

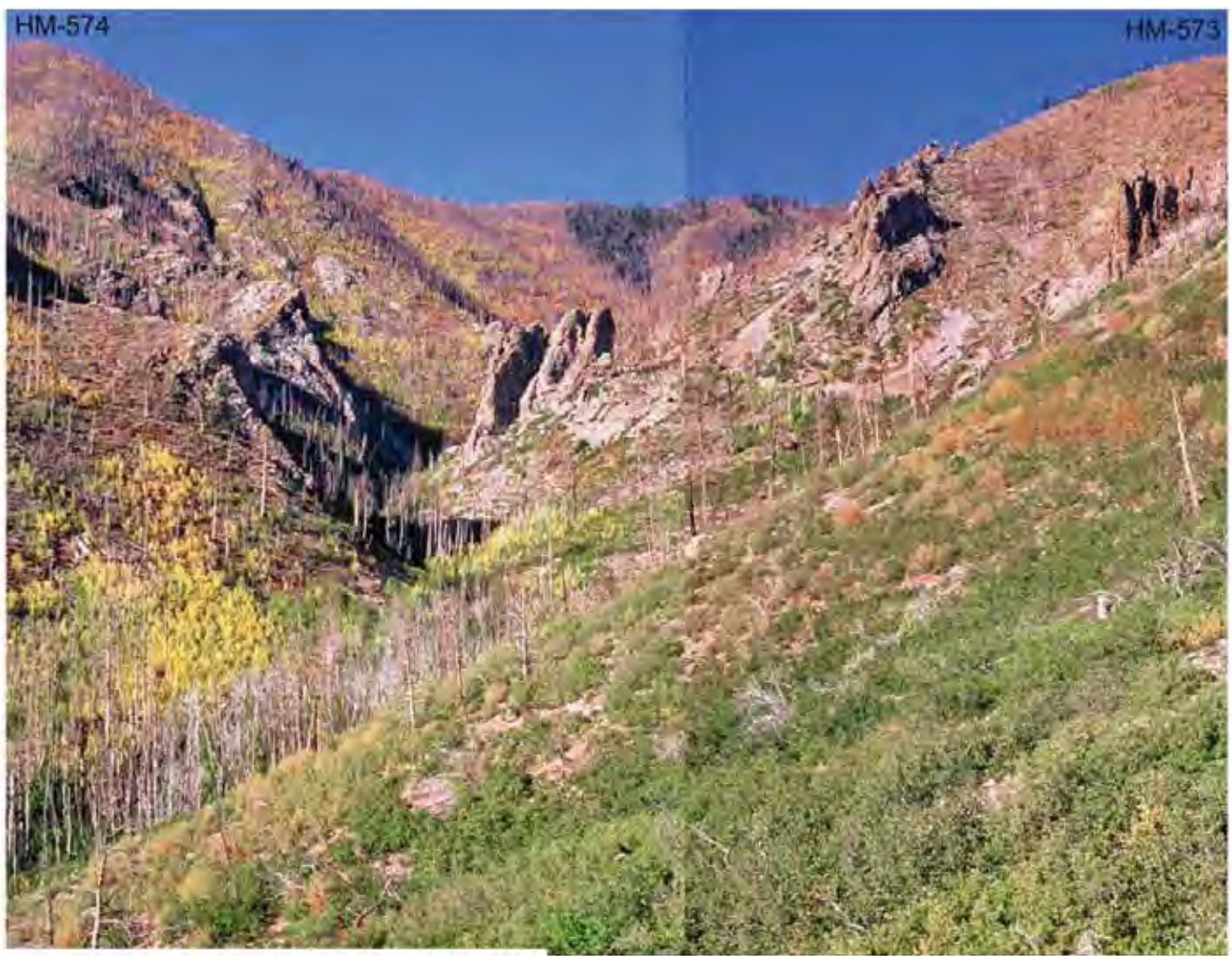

HM-573-574, 2012 


\section{Plate HM-577}

\section{Burr Desert}

$1959 \because 2012$

In 1959 the BLM established range monitoring site D-2-1 west of Adobe Swale reservoir in the Burr Desert.

The view is to the north. All the steel stakes were relocated.

Blackbrush has increased, while curly grass has declined. Other species include Mormon tea and pricklypear cactus.

Original photograph taken by the BLM on September 29, 1959; retake made by Charles E. Kay on September 16 , 2012 (Photo No. 6343-26). Section 28, Range 13 East, Township 30 South; UTM 543191E, 4224958N; elevation 5,325ft. Original image held in the BLM's range files, Hanksville, UT. 


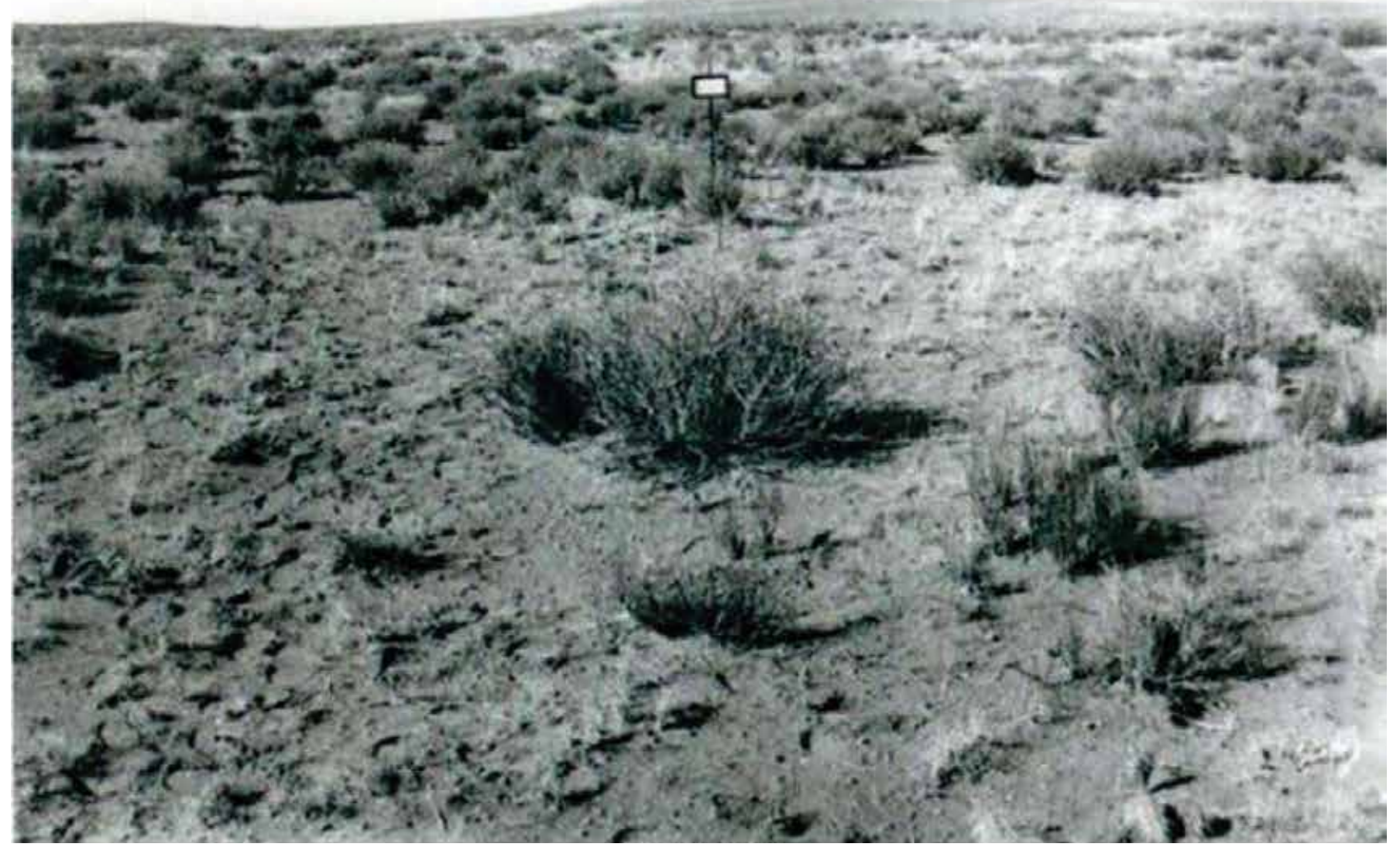

HM-577, 1959

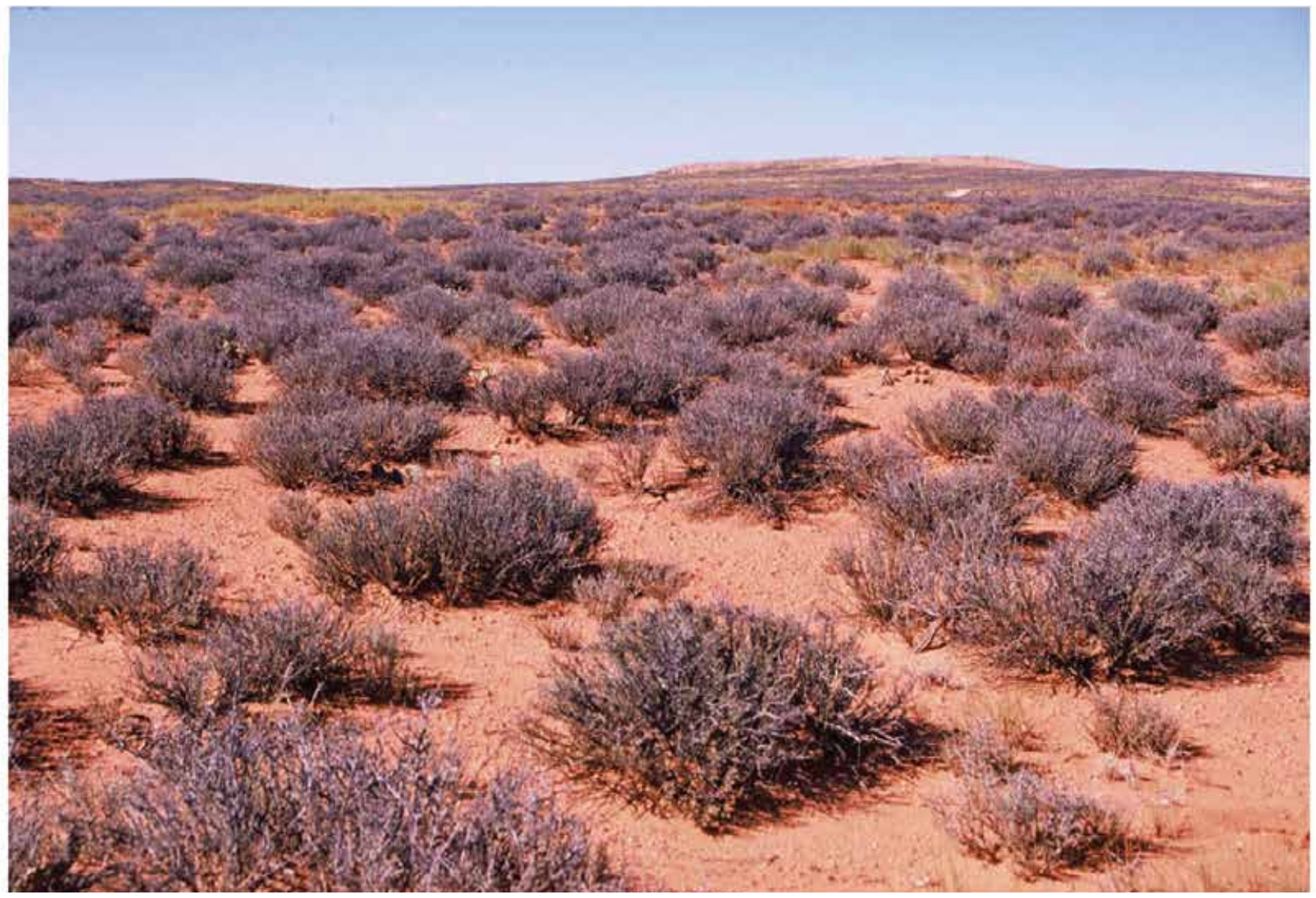

HM-577, 2012 


\section{Plate HM-582}

\section{Burr Desert}

$1972 \div 2012$

In 1972 the BLM established the Burr Point 3 range monitoring site on the Burr Point Allotment. The view is to the southeast, and all the steel stakes were located. The steel fencepost in the distance has been moved to the top of a sand dune on the left so that it is easier to locate.

The area is more vegetated today, and there is less wind erosion than in the past. Turbinella oak has increased, as has Mormon tea. Other species include Indian ricegrass and sand dropseed.

Original photograph taken by the BLM in 1972; retake made by Charles E. Kay on September 17, 2012 (print from a color slide). Section 23, Range 12 East, Township 30 South; UTM 537579E, 4226878N; elevation 4,990 ft. Original image held in the BLM's range files, Hanksville, UT. 


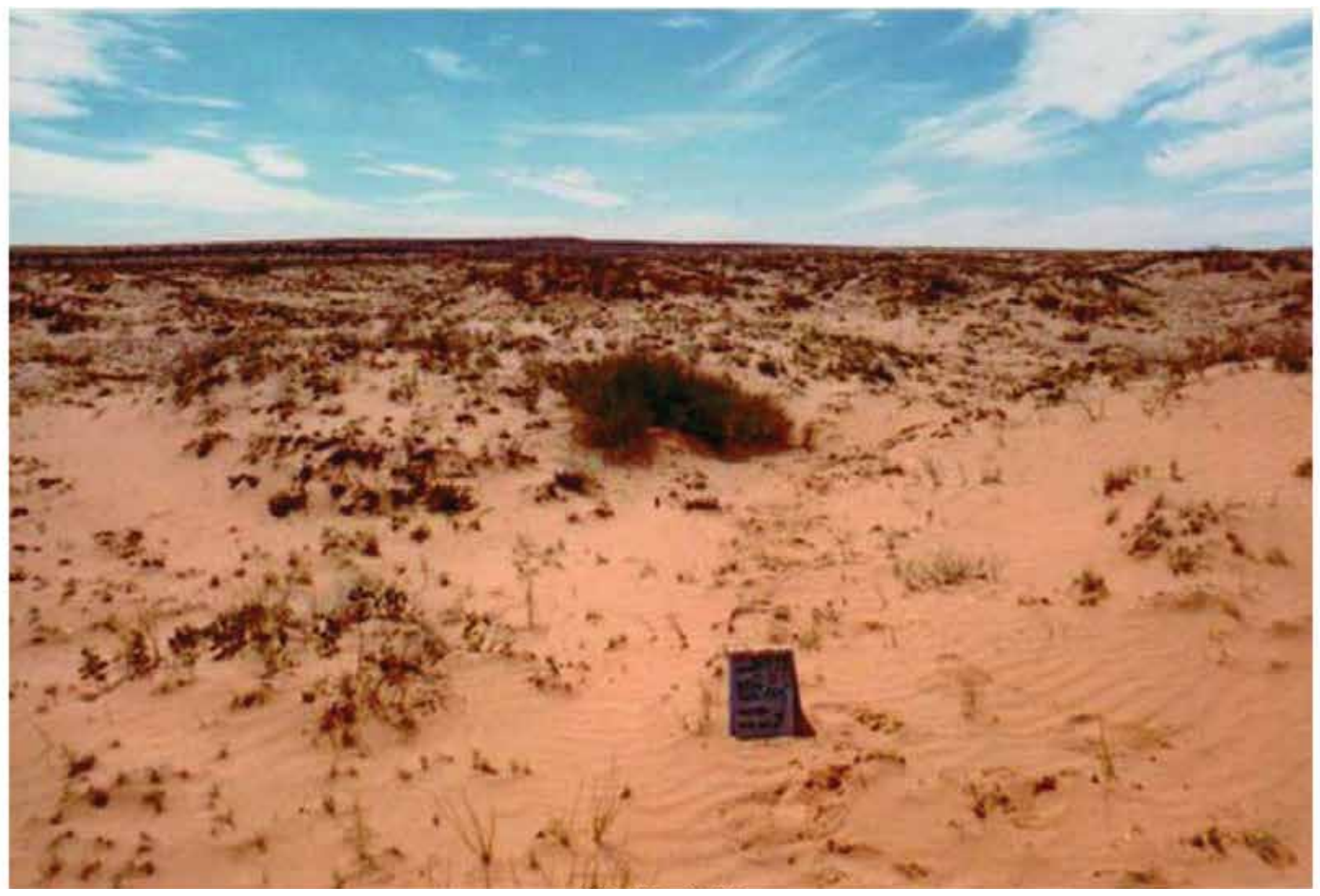

HM-582, 1972

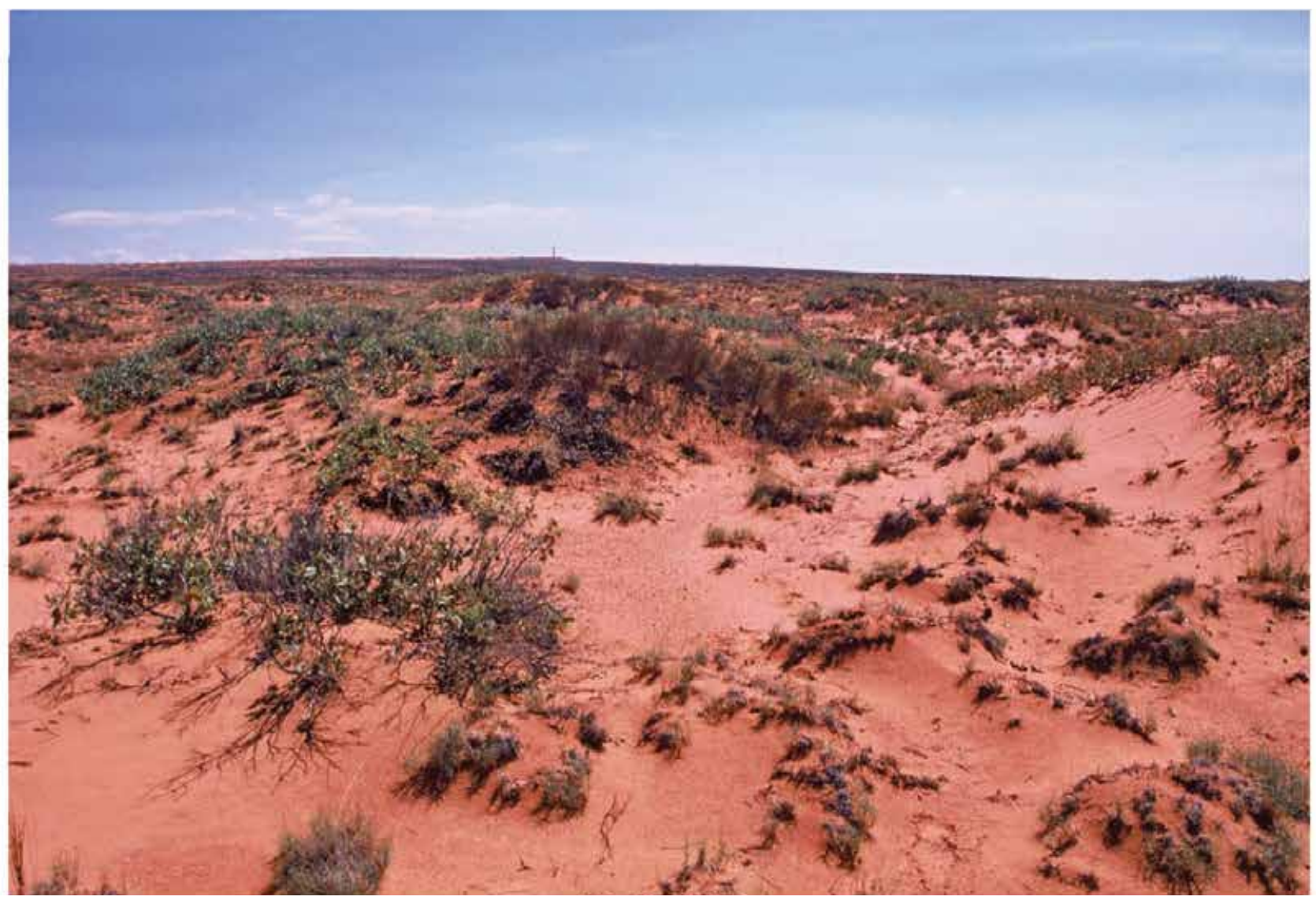


Plate HM-597

Big Thompson Mesa

$1959 \because 2012$

In 1959 the BLM established range monitoring site C-7-1 on Big Thompson Mesa. The view is to the north-northwest. Mount Pennell is on the right skyline. The steel stake was relocated.

Blackbrush has increased. Other species include juniper, Mormon tea, snakeweed, curly grass, Indian ricegrass, and pricklypear cactus.

Original photograph taken by the BLM on September 22, 1959; retake made by Charles E. Kay on November 16, 2012 (Photo No. 6358-14). Section 33, Range 9 East, Township 35 South; UTM 506603E, 4174164N; elevation $5,180 \mathrm{ft}$. Original image held in the BLM's range files, Hanksville, UT. 


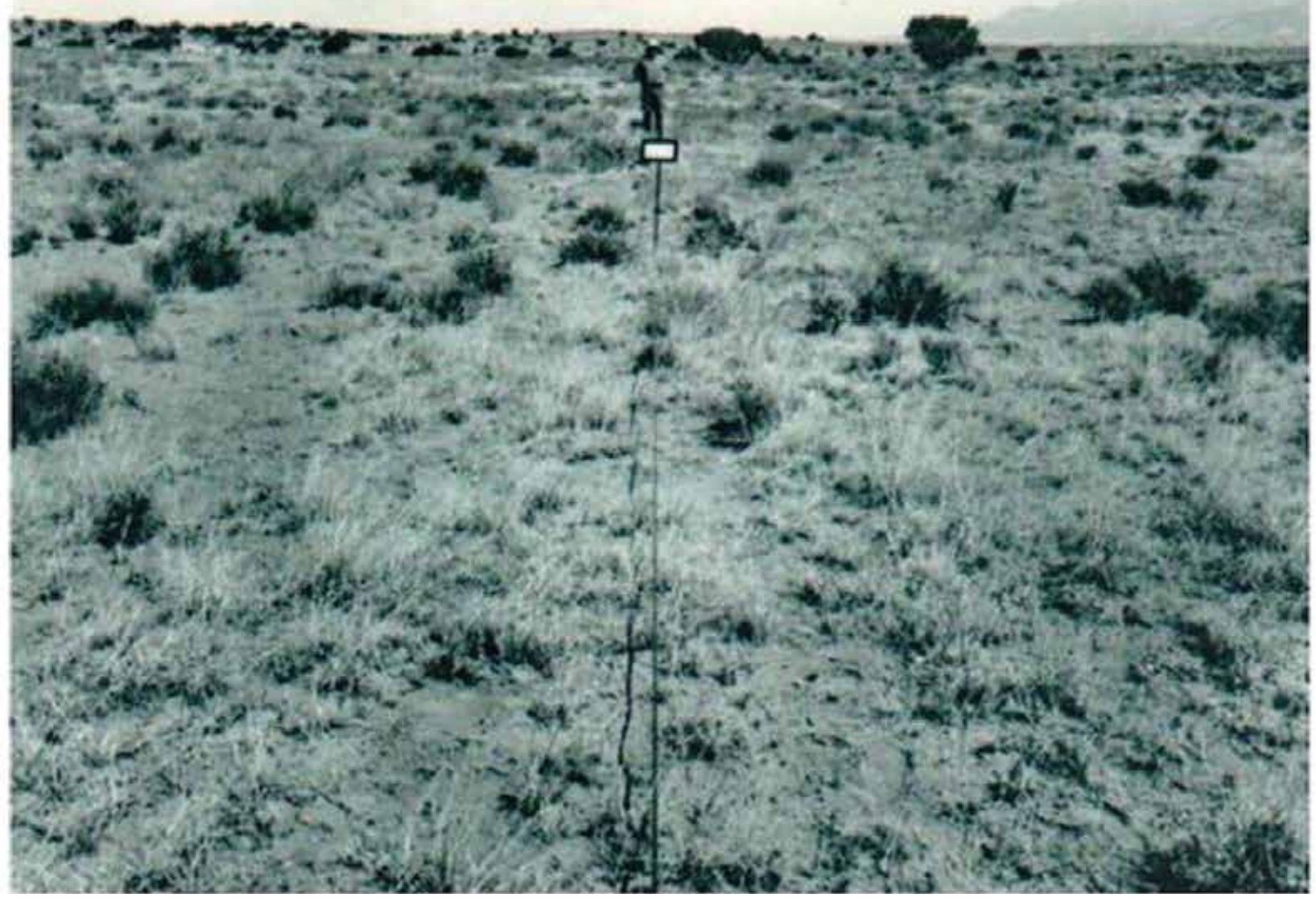

HM-597, 1959

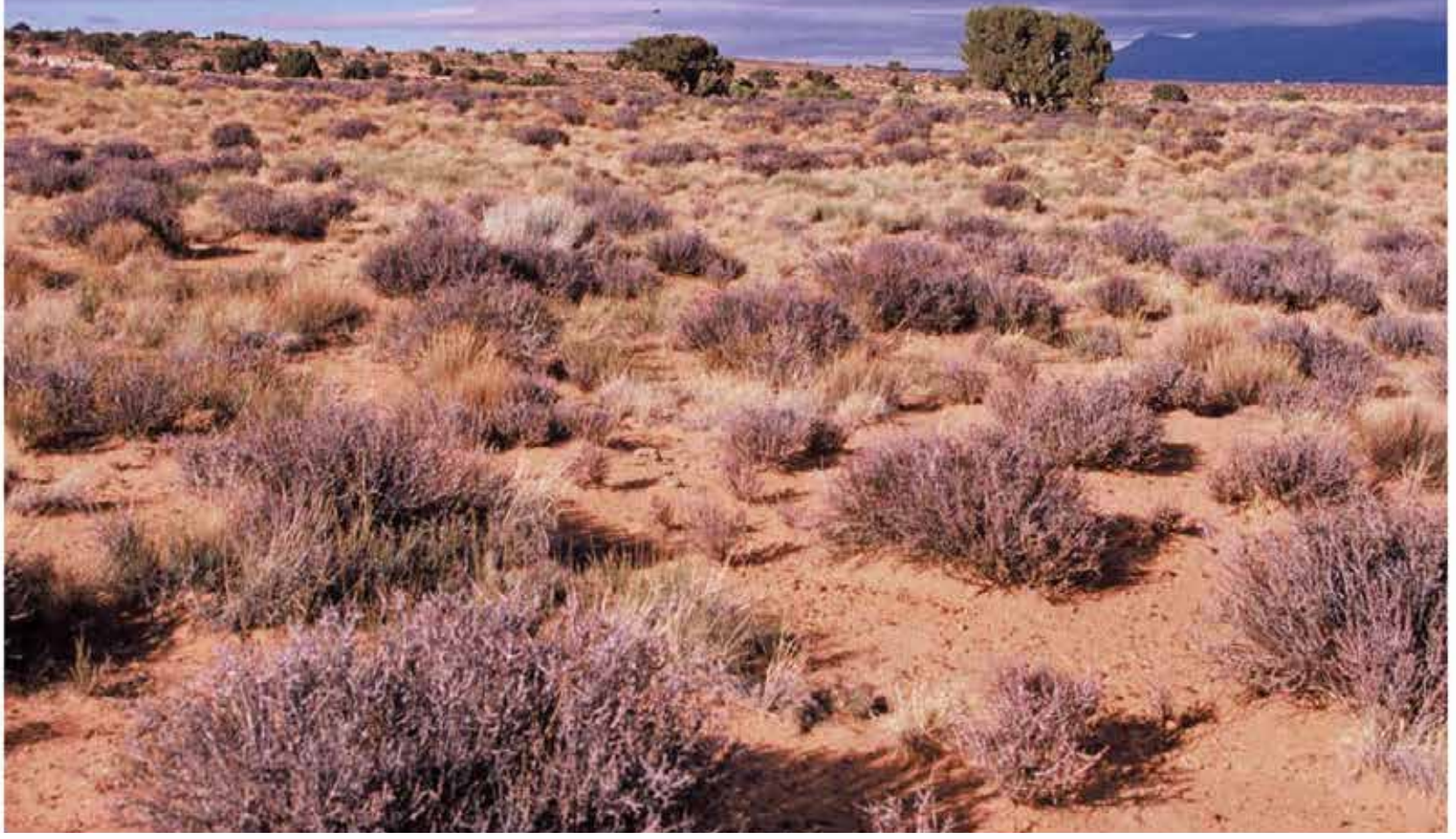

HM-597, 2012 


\section{Plate HM-599}

\section{South Big Thompson Mesa}

$1963 \because 2012$

In 1963 the BLM established range monitoring site C-15-2 on South Big Thompson Mesa (a.k.a.

Little Thompson Mesa). The view is west to the Waterpocket Fold. The steel stake was relocated.

Common species include blackbrush and curly grass, with a limited amount of snakeweed and Indian ricegrass.

This mesa top is waterless and surrounded by cliffs, and there was no sign of use by livestock or wildlife.

Original photograph taken by the BLM on July 16, 1963; retake made by Charles E. Kay on November 16, 2012 (Photo No. 6358-22). Section 22, Range 9 East, Township 36 South; UTM 508585E, 4168708N; elevation 4,980 ft. Original image held in the BLM's range files, Hanksville, UT. 


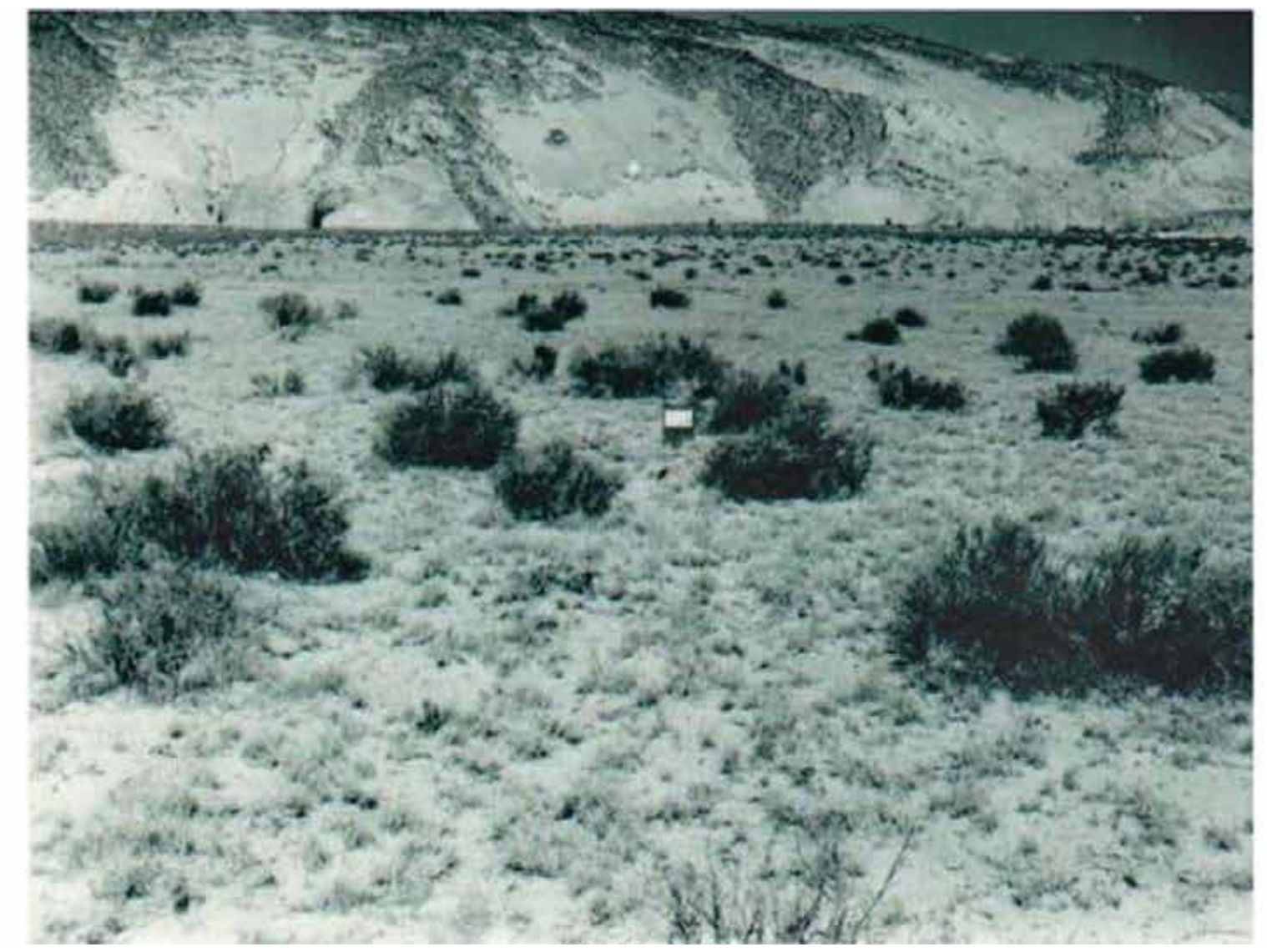

HM-599, 1963

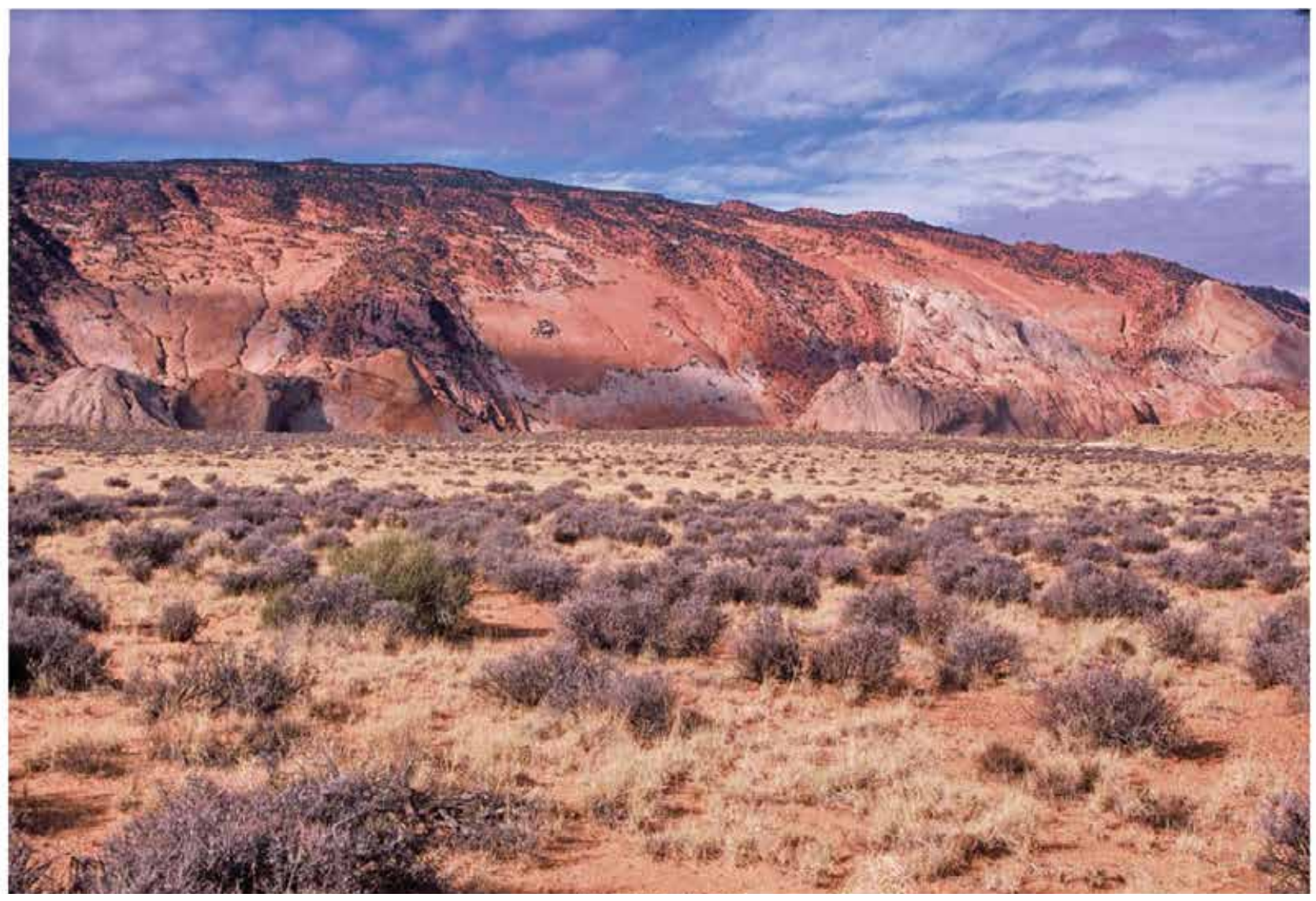




\section{Plate HM-603}

\section{Fairview Ranch}

$1920 \div 2013$

Viewed southeast just to the south of the Fairview Ranch. Bull Mountain is in the distance.

The original photo shows three freight wagons loaded with large bags of wool. In the past, thousands of sheep were sheared each year at the Fairview Ranch, and the surrounding area was heavily overgrazed by those animals (see Plates HM-363 and HM-365). The foreground is more vegetated now than in earlier times. Today, curly grass, rubber rabbitbrush, snakeweed, and pricklypear cactus are common.

Original image taken by an unknown photographer ca. 1920; retake made by Charles E. Kay on April 22, 2013 (print from a color slide). Section 8, Range 11 East, Township 30 South; UTM 522836E, 4229564N; elevation $5,227 \mathrm{ft}$. Original photo from Murphy $(1999,161)$. 


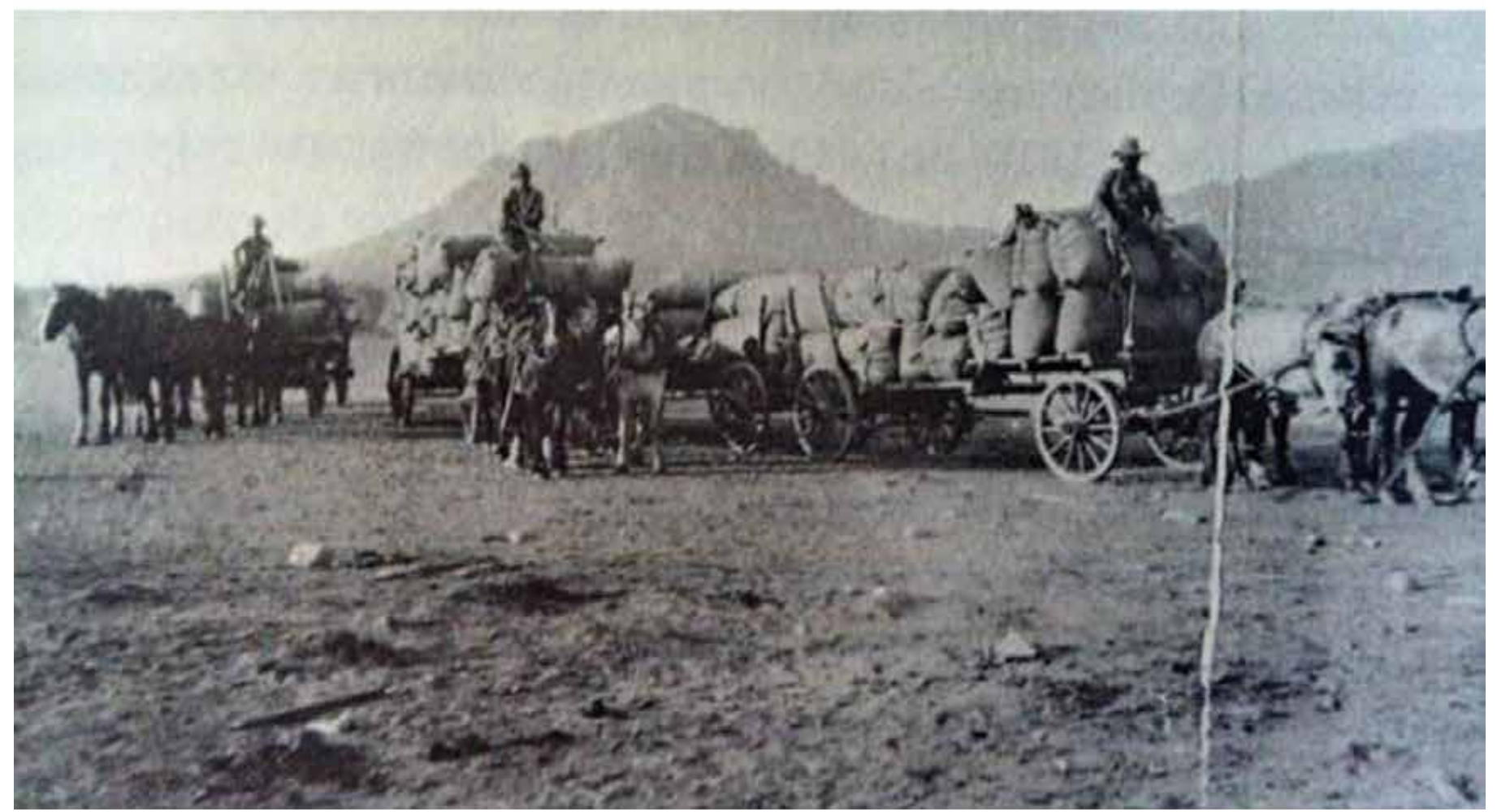

HM-603, 1920

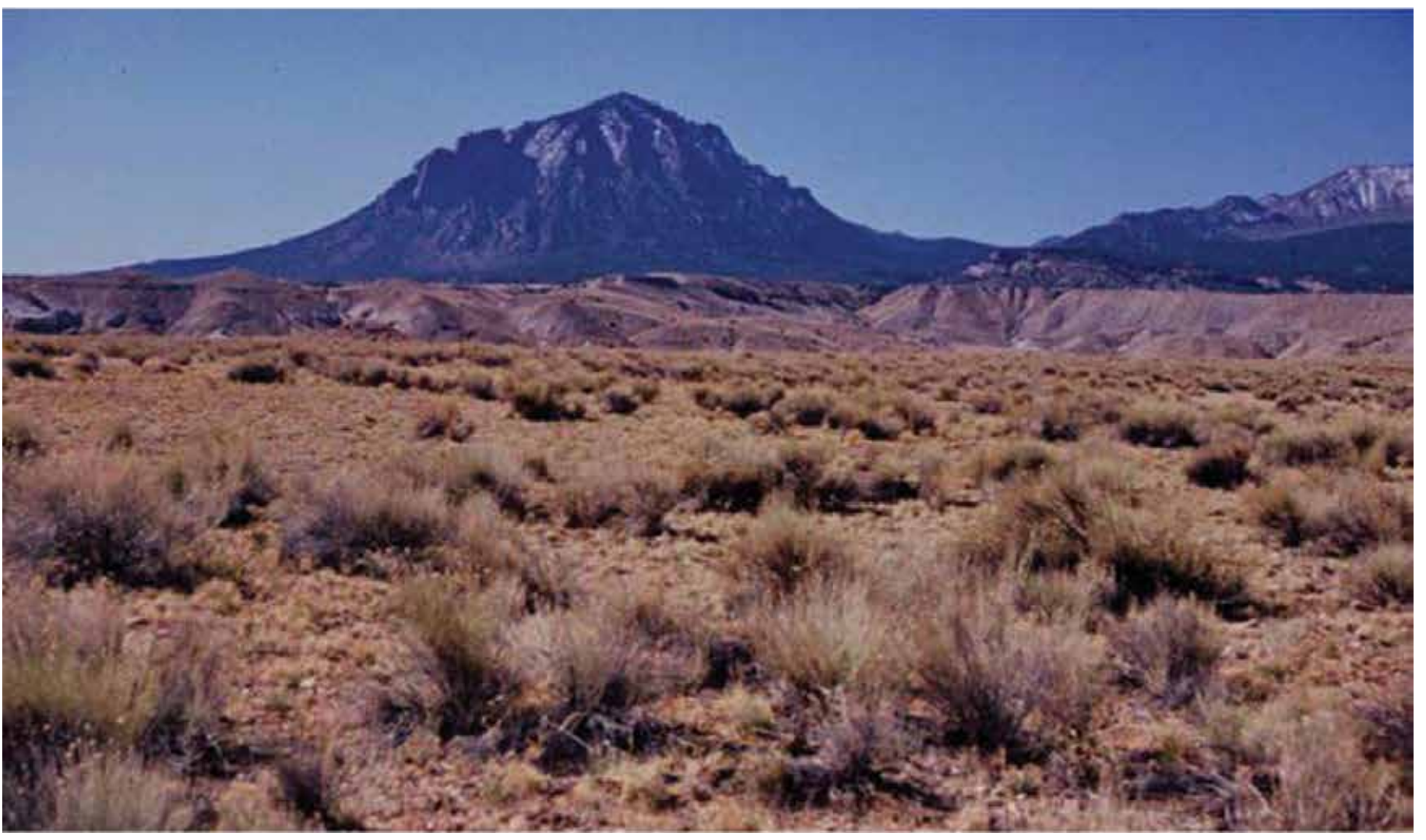

HM-603, 2013 



\section{) Literature Gited}

Amundson, M.A. 2013. Passage to wonderland: Rephotographing Joseph Stimson's views of the Cody Road to Yellowstone National Park 1903 and 2008. University Press of Colorado, Boulder, CO. 156 pp.

Anderson, M.K. 1993. Indian fire-based management in the sequoia-mixed conifer forests of the central and southern Sierra Nevada. Final contract report submitted to Yosemite Research Center, Yosemite National Park, CA. Cooperative Agreement Order No. 8027-2-002. 426 pp.

Andison, D.W. 1998. Temporal patterns of age-class distributions on foothills landscapes in Alberta. Ecography 21:543-50.

Arno, S.F. and G.E. Gruell. 1983. Fire history at the forest-grassland ecotone in southwestern Montana. Journal of Range Management 36:332-36.

---. 1986. Douglas-fir encroachment into mountain grasslands in southwestern Montana. Journal of Range Management 39:272-76.

Athearn, F.J. 1998. Habitat in the past: Historical perspectives of riparian zones on the White River. Bureau of Land Management, Colorado State Office, CO. Cultural Resource Series Number 23. 44 pp.

Bailey, R.W., G.W. Craddock, and A.R. Croft. 1947. Watershed management for summer flood control in Utah. U.S. Department of Agriculture Miscellaneous Publication 639. 24 pp.

Bailey, R.W., C.L. Forsing, and R.J. Becraft. 1934. Floods and accelerated erosion in northern Utah. U.S. Department of Agriculture Miscellaneous Publication 196. 21 pp.

Baker, W.L. 1987. Recent changes in the riparian vegetation of the montane and subalpine zones of western Colorado, U.S.A. PhD diss., University of Wisconsin, Madison, WI. 942 pp.

Baker, W.L., J.A. Monroe, and A.E. Hessl. 1997. The effects of elk on aspen in the winter range in Rocky Mountain National Park. Ecography 20:155-65.

Bartos, D.L. and R.B. Campbell, Jr. 1998. Decline of quaking aspen in the interior west - Examples from Utah. Rangelands 20 (1): 17-24.

Bates, J.D., R.F. Miller, and T.J. Svejcar. 2000. Understory dynamics in cut and uncut western juniper woodlands. Journal of Range Management 53:119-26.

Blackburn, T.C. and K. Anderson, eds. 1993. Before the wilderness: Environmental management by native Californians. Ballena Press, Menlo Park, CA. 476 pp.

Boyd, R., ed. 1999. Indians, fire and the land in the Pacific Northwest. Oregon State University Press, Corvallis, OR. 313 pp.

Bradford, D., F. Reed, and R.B. LeValley. 2004. When the grass stood stirrup-high: Facts, photographs, and myths of west-central Colorado. Allen Press, Lawrence, KS. 182 pp.

Bureau of Land Management. 1969. Land planning and classification report of the public domain lands in the middle Yellowstone River area, Montana. BLM Missouri River Basin Investigation, Denver, CO.

---. 1971. Land planning and classification report of the public lands in the Musselshell River area, Montana. BLM Missouri River Basin Investigation, Denver, CO.

---. 1979. Historical comparison photography: Missouri Breaks, Montana. Montana State Office, Billings, MT. U.S. Government Printing Office: 1979-699-337. 109 pp. 
---. 1980. Historical comparison photography: Montana foothills, Dillon resource area, Montana. Montana State Office, Billings, MT. U.S. Government Printing Office: 698-274. 120 pp.

---. 1984. Historical comparison photography: Headwaters resource area, Butte district. Bureau of Land Management, Butte, MT. 171 pp.

---. 2003. Bulldog-Lonesome Beaver, UT-RID-0095/0023, Narrative summary and discussion of incident management operations, July 10-July 21, 2003. Bureau of Land Management, Richfield Field Office and Utah Division of Forestry, Fire, and State Lands, Richfield, UT. Unpublished report. 10 pp + attachments.

Carr, S.L. 2009. The historical guide to Utah ghost towns. Reprinted 3rd Edition. Western Epics, Salt Lake City, UT. 174 pp.

Chappell, L. 1997. A fire history study conducted on the Monroe Mountain demonstration area. Unpublished report to the Richfield District, Fishlake National Forest, and BLM, Richfield, UT. 25 pp.

Clinger, M., J.H. Pickering, and C. Stevanus. 2006. Estes Park and Rocky Mountain National Park: Then \& now. Westcliffe Publishers, Englewood, CO. 272 pp.

Cook, C.W. and C.E. Lewis. 1963. Competition between big sagebrush and seeded grasses on foothill ranges in Utah. Journal of Range Management 16:245-50.

Cook, J.W., W.W. Brady, and E.F. Aldon. 1992. Handbook for converting Parker loop frequency data to basal area. U.S. Department of Agriculture, U.S. Forest Service, Rocky Mountain Research Station, Fort Collins, CO, Gen. Tech. Rep. RM-212. 22 pp.

Copeland, O.L. 1960. Watershed restoration: A photo-record of conservation practices applied in the Wasatch Mountains of Utah. Journal of Soil and Water Conservation 15 (2): 105-20.

Cottam, W.P. 1929. Man as a biotic factor illustrated by recent floristic and physiographic changes at the Mountain Meadows, Washington County, Utah. Ecology 10 (4): 361-63.

---. 1947. Is Utah Sahara bound? Bulletin of the University of Utah 37:1-40.

---. 1976. The impact of man on the flora of the Bonneville basin. Department of Geography, University of Utah, Research Paper No. 76-1. 8 pp.

Cottam, W.P. and F.R. Evans. 1945. A comparative study of the vegetation of grazed and ungrazed canyons of the Wasatch Range, Utah. Ecology 26:171-81.

Covington, W.W., R.L. Everett, R.W. Steele, L.I. Irwin, T.A. Daer, and A.N.D. Auclair. 1994. Historical and anticipated changes in forest ecosystems of the inland West of the United States. Journal of Sustainable Forestry 2:13-63.

Covington, W.W., P.Z. Fule, M.M. Moore, S.C. Hart, T.E. Kolb, J.N. Mast, S.S. Sackett, and M.R. Wagner. 1997. Restoring ecosystem health in ponderosa pine forests of the southwest. Journal of Forestry 95 (4): 23-29.

Donahue, D.L. 2007. Federal rangeland policy: Perverting law and jeopardizing ecosystem services. Journal of Land Use and Environmental Law 22:299-354.

---. 2010. Trampling the public trust. Environmental Affairs Law Review 37:257-316.

Ffolliott, P.F. and W.P. Clary. 1982. Understory-overstory vegetation relationships: An annotated bibliography. U.S. Department of Agriculture, U.S. Forest Service, Intermountain Research Station, Ogden, UT, Gen. Tech. Rep. INT-136. 39 pp. 
Fleischner, T.L. 2010. Livestock grazing and wildlife conservation in the American West: Historical, policy, and conservation biology perspectives. In: du Toit, J.T., R. Kock, and J.C. Deutsch, eds. Wild rangelands: Conserving wildlife while maintaining livestock in semi-arid ecosystems. Wiley-Blackwell, John Wiley and Sons, Oxford, UK. pp 235-65.

Fowler, D.D. 1989. The western photographs of John K. Hillers: 'Myself in the water.' Smithsonian Institution Press, Washington, DC. 166 pp.

Francis, R.E., R.S. Driscoll, and J.N. Reppert. 1972. Loop-frequency as related to plant cover, herbage production, and plant density. U.S. Department of Agriculture, U.S. Forest Service, Rocky Mountain Research Station, Fort Collins, CO, Research Paper RM-94. 8 pp.

Fraser, G.C. 2005. Journeys in the canyon lands of Utah and Arizona, 1914-1916. Edited by F.H. Swanson. University of Arizona Press, Tucson, AZ. 224 pp.

Frischknecht, N.C. 1963. Contrasting effects of big sagebrush and rubber rabbitbrush on production of crested wheatgrass. Journal of Range Management 16:70-74.

Fuchs, E.H. 2002. Historic increases in woody vegetation in Lincoln County, New Mexico. Vanguard Printing Company, Albuquerque, NM. 115 pp.

Gifford, B. and S. Terrill. 2000. Oregon then \& now. Westcliffe Publishers, Englewood, CO. 192 pp.

Goin, P. 1992. Stopping time: A rephotographic survey of Lake Tahoe. University of New Mexico Press, Albuquerque, NM. 134 pp.

Gottesfeld, L.M.J. 1994. Aboriginal burning for vegetative management in northwest British Columbia. Human Ecology 22 (2): 171-88.

Grafe, E. and P. Horsted. 2002. Exploring with Custer: The 1874 Black Hills Expedition. Golden Valley Press, Custer, SD. 285 pp.

Gray, W.R. 2011. Through the lens of Marcus Jones. Sego Lily 34 (6): 5-10.

Gruell, G.E. 1980a. Photographic record and analysis (Volume 1). In: Fire's influence on wildlife habitat on the Bridger-Teton National Forest, Wyoming. U.S. Department of Agriculture, U.S. Forest Service, Intermountain Research Station, Ogden, UT, Research Paper INT-235. 207 pp.

---. 1980b. Changes and causes, management implications (Volume 2). In: Fire's influence on wildlife habitat on the Bridger-Teton National Forest, Wyoming. U.S. Department of Agriculture, U.S. Forest Service, Intermountain Research Station, Ogden, UT, Research Paper INT-252. 35 pp.

---. 1983. Fire and vegetative trends in the northern Rockies: Interpretations from 1871-1982 photographs. U.S. Department of Agriculture, U.S. Forest Service, Intermountain Research Station, Ogden, UT, Gen. Tech. Rep. INT-158. 117 pp.

---. 2001. Fire in Sierra Nevada forests: A photographic interpretation of ecological change since 1849. Mountain Press Publishing, Missoula, MT. 238 pp.

Hall, F.C. 2002a. Photo point monitoring handbook: Part A - Field procedures. U.S. Department of Agriculture, U.S. Forest Service, Pacific Northwest Research Station, Portland, OR, Gen. Tech. Rep. PNW-GTR-526. 48 pp.

---. 2002b. Photo point monitoring handbook: Part B - Concepts and analysis. U.S. Department of Agriculture, U.S. Forest Service, Pacific Northwest Research Station, Portland, OR, Gen. Tech. Rep. PNW-GTR-526. 86 pp.

Hansen-Bristow, K.J., J.D. Ives, and J.P. Wilson. 1988. Climatic variability and tree response within the forest-alpine tundra ecotone. Annals of the Association of American Geographers 78:505-19. 
Hart, R.H. and W.A. Laycock. 1996. Repeat photography on range and forest lands in the western United States. Journal of Range Management 49:60-67.

Hastings, J.R. and R.M. Turner. 1980. The changing mile. University of Arizona Press, Tucson, AZ. 317 pp.

Heady, H. and P. Zinke. 1978. Vegetational changes in Yosemite Valley. National Park Service Occasional Paper No. 5. U.S. Government Printing Office, Washington, DC. 25 pp.

Hedrick, D.W., D.N. Hyder, F.A. Sneva, and C.E. Poulton. 1966. Ecological response of sagebrush-grass range in central Oregon to mechanical and chemical removal of Artemisia. Ecology 47:432-39.

Hersh, L.K. 2000. The Central Pacific Railroad across Nevada 1868 and 1997. Alexa A. Williams, Hollywood, CA. 127 pp.

Hessl, A.E. and W.L. Baker. 1997a. Spruce-fir growth form changes in the forest-tundra ecotone of Rocky Mountain National Park, Colorado, USA. Ecography 20:356-67.

---. 1997b. Spruce and fir regeneration and climate in the forest-tundra ecotone of Rocky Mountain National Park, Colorado, U.S.A. Arctic and Alpine Research 29:173-83.

Heyerdahl, E.K., P.M. Brown, S. Kitchen, and M.H. Weber. 2006. Fire regimes and forest structure of Utah and eastern Nevada: A multi-scale history from tree rings. Final report to Bureau of Land Management, Utah State Office. March 30. 241 pp.

---. 2011. Multicentury fire and forest histories at 19 sites in Utah and eastern Nevada. U.S. Department of Agriculture, U.S. Forest Service, Rocky Mountain Research Station, Fort Collins, CO, Gen. Tech. Rep. RMRS-GTR-261WWW. 192 pp.

Hindley, E. 1996. Riparian area management: Observing physical and biological change through historical photographs. Tech Ref 1737-13. U.S. Department of the Interior, Bureau of Land Management, National Applied Resource Sciences Center, Denver, CO, BLM/RFS/ST-96/008+1737. 32 pp.

Hindley, E.C., J.E. Bowns, E.R. Scherick, P. Curtis, and J. Forrest. 2000. A photographic history of vegetation and stream channel changes in San Juan County, Utah. San Juan County, Charles Reed Foundation, and Utah State University Extension, Logan, UT. 121 pp.

Houston, D.B. 1982. The northern Yellowstone elk: Ecology and management. Macmillan Publishers, New York, NY. 474 pp.

Hunt, C.B. 1977. Around the Henry Mountains with Charlie Hanks. Utah Geology 4 (2): 95-104.

1988. Geology of the Henry Mountains, Utah, as recorded in the notebooks of G.K. Gilbert, 1875-76. Geological Society of America Memoir 167. The Geological Society of America, Boulder, CO. 229 pp.

Hunt, C.B., P. Averitt, and R.L. Miller. 1953. Geology and geography of the Henry Mountains region, Utah. U.S. Geological Survey Professional Paper 228. U.S. Government Printing Office, Washington, DC. $234 \mathrm{pp}+$ maps.

Hutchings, S.S. and R.C. Holmgren. 1959. Interpretation of loop-frequency data as a measure of plant cover. Ecology 40:668-77.

Idso, C.D. and K.E. Idso. 2000. The greening of the American West: The atmosphere's rising CO2 concentration is stimulating woody plant growth in the U.S. forests, grasslands, and deserts. Center for the Study of Carbon Dioxide and Global Change, Tempe, AZ. 72 pp.

Jackson, W.H., J. Fielder, and Ed Marston. 1999. Colorado 1870-2000. Westcliffe Publishers, Englewood, CO. $224 \mathrm{pp}$. 
Johnson, E.A., K. Miyanishi, and J.M.H. Weir. 1995. Old-growth, disturbance, and ecosystem management. Canadian Journal of Botany 73:918-26.

Johnson, K.L. 1987. Rangeland through time: A photographic study of vegetation change in Wyoming, 1870-1986. University of Wyoming Agricultural Experiment Station, Miscellaneous Publication 50. 188 pp.

Kauffman, J.B., R.L. Beschta, N. Otting, and D. Lytjen. 1997. An ecological perspective of riparian and stream restoration in the western United States. Fisheries 22:12-24.

Kay, C.E. 1985. Aspen reproduction in the Yellowstone Park-Jackson Hole area and its relationship to the natural regulation of ungulates. In: Workman, G.W., ed. Western elk management: A symposium. Utah State University, Logan, UT. pp 131-60.

---. 1990. Yellowstone's northern elk herd: A critical evaluation of the "natural regulation" paradigm. PhD diss., Utah State University, Logan, UT. 490 pp.

---. 1995. Aboriginal overkill and native burning: Implications for modern ecosystem management. Western Journal of Applied Forestry 10 (4): 121-26.

---. 1997a. Is aspen doomed? Journal of Forestry 95 (5): 4-11.

---. 1997b. Aspen: A new perspective - Implications for park management and ecological integrity. In: Harmon, D., ed. Making protection work: Proceedings of the 9 th conference on research and resource management in parks and on public lands. George Wright Society, Hancock, MI. pp 265-73.

---. 1997c. The condition and trend of aspen, Populus tremuloides, in Kootenay and Yoho National Parks: Implications for ecological integrity. Canadian Field-Naturalist 111:607-16.

---. 1997d. Yellowstone: Ecological malpractice - photo excerpts from a forthcoming book. PERC Reports 15 (2): $1-40$.

---. 1998. Are ecosystems structured from the top-down or bottom-up? A new look at an old debate. Wildlife Society Bulletin 26 (3): 484-98.

---. 1999. Repeat photography and long-term vegetational change on the U.S. Sheep Experiment Station and other rangelands in the Centennial Mountains. Final report to U.S. Sheep Experiment Station, Dubois, ID. 300 pp.

---. 2000. Native burning in western North America: Implications for hardwood management. In: Yaussy, D.A., ed. Proceedings: Workshop on fire, people, and the central hardwood landscape. U.S. Department of Agriculture, U.S. Forest Service, Northeastern Research Station, Newtown Square, PA, Gen. Tech. Rep. NE-274. pp 19-27.

---. 2003. Long-term vegetation change on Utah’s Fishlake National Forest: A study in repeat-photography. Utah State University Extension and the Fishlake National Forest. U.S. Government Printing Office: 573-084/42159 Region No. 8. 175 pp.

---. 2007. Are lightning fires unnatural? A comparison of aboriginal and lightning ignition rates in the United States. Tall Timbers Fire Ecology Conference 23:16-28.

---. 2011. Why is aspen declining on Cedar Mountain? Measurement of aspen exclosures in southern Utah. Final report submitted to Cedar Mountain Initiative, Utah State University Extension, Cedar City, UT. 406 pp.

Kay, C.E. and D.L. Bartos. 2000. Ungulate herbivory on Utah aspen: Assessment of long-term exclosures. Journal of Range Management 53:145-53.

Kay, C.E. and C.R. Reid. 2011. Long-term changes in southern Utah upland shrub communities: A study in repeat photography. In: Wamboldt, C.L., S.G. Kitchen, M.R. Frisina, B.K. Sowell, R.B. Keigley, P.K. Palacios, and J.A. Robinson, eds. Proceedings - Shrublands: Wildlands and wildlife habitat. 15th Wildland Shrub Symposium. Jessie E. Quinney Natural Resources Research Library, Logan, UT. pp 229-38. 
Kay, C.E. and R.T. Simmons, eds. 2002. Wilderness and political ecology: Aboriginal influences and the original state of nature. University of Utah Press, Salt Lake City, UT. 342 pp.

Kay, C.E. and F.H. Wagner. 1994. Historical condition of woody vegetation on Yellowstone's northern range: A critical test of the "natural regulation" paradigm. In: Despain, D.G., ed. Plants and their environments Proceedings of the first biennial scientific conference on the Greater Yellowstone Ecosystem. U.S. National Park Service, Denver, CO. Technical Report NPS/NRYELL/NRTR-93/XX. pp 151-69.

Kay, C.E. and J.W. Walker. 1997. A comparison of sheep and wildlife grazed willow communities in the Greater Yellowstone Ecosystem. Sheep and Goat Research Journal 13:6-14.

Kay, C.E. and C.A. White. 1995. Long-term ecosystem states and processes in the central Canadian Rockies: A new perspective on ecological integrity and ecosystem management. In: Linn, R.M., ed. Sustainable society and protected areas. The George Wright Society, Hancock, MI. pp 119-32.

Kelsey, M.R. 2009. Hiking and exploring Utah’s Henry Mountains and Robbers Roost. 3rd Edition. Kelsey Publishing, Provo, UT. 288 pp.

Klasner, F.L. and D.B. Fagre. 2002. A half century of change in alpine treeline patterns at Glacier National Park, Montana, U.S.A. Arctic, Antarctic, and Alpine Research 34 (1): 49-56.

Klement, K.D., R.K. Heitschmidt, and C.E. Kay. 2001. Eighty years of vegetation and landscape changes in the northern Great Plains: A photographic record. U.S. Department of Agriculture, Agricultural Research Service Conservation Research Report No. 45.91 pp.

Klett, M., K. Bajakian, W.L. Fox, M. Marshall, T. Ueshina, and B. Wolfe. 2004. Third view, second sights: A rephotographic survey of the American West. Museum of New Mexico Press, Santa Fe, NM. 238 pp.

Klett, M., R. Solnit, and B. Wolfe. 2005. Yosemite in time: Ice ages, tree clocks, ghost rivers. Trinity University Press, San Antonio, TX. 140 pp.

Korner, C. 2012. Alpine treelines: Functional ecology of the global high elevation tree limits. Springer, NY. 220 pp.

Lesica, P. 1996. Using fire history models to estimate proportions of old growth forest in northwest Montana, U.S.A. Biological Conservation 77 (1): 33-39.

Lewis, H.T. 1973. Patterns of Indian burning in California: Ecology and ethno-history. Anthropological Papers No. 1. Ballena Press, Ramona, CA. 101 pp.

---. 1977. Maskuta: The ecology of Indian fires in northern Alberta. Western Canadian Journal of Anthropology $7: 15-52$.

---. 1985. Why Indians burned: Specific versus general reasons. In: Lotan, J.E., B.M. Kilgore, W.C. Fischer, and R.W. Mutch, eds. Proceedings - symposium and workshop on wilderness fire, Nov 15-19, 1983, Missoula, MT. U.S. Department of Agriculture, U.S. Forest Service, Intermountain Research Station, Ogden, UT, Gen. Tech. Rep. INT-182. pp 75-80.

Lewis, H.T. and T.A. Ferguson. 1988. Yards, corridors and mosaics: How to burn a boreal forest. Human Ecology 16:57-77.

Lloyd, A.H. and L.J. Graumlich. 1997. Holocene dynamics of treeline forests in the Sierra Nevada. Ecology 78 (4): 1199-1210.

Martineau, L. 1992. The Southern Paiutes: Legends, lore, language and lineage. KC Publications, Las Vegas, NV. $312 \mathrm{pp}$.

McGinnies, W.J., H.L. Shantz, and W.G. McGinnies. 1991. Changes in vegetation and land use in eastern Colorado: A photographic study, 1904 to 1986. U.S. Department of Agriculture, Agricultural Research Service, ARS-85. 165 pp. 
Moore, M.M. and D.A. Deiter. 1992. Stand density index as a predictor of forage production in northern Arizona pine forests. Journal of Range Management 45:267-71.

Murphy, M.B. 1999. A history of Wayne County. Utah State Historical Society, Salt Lake City, UT. 408 pp.

Murray, M.P., S.C. Bunting, and P. Morgan. 1998. Fire history of an isolated subalpine mountain range of the Intermountain Region, United States. Journal of Biogeography 25 (6): 1071-80.

Nelson, K.L. 1965. Status and habits of the American buffalo (Bison bison) in the Henry Mountain area of Utah. Utah State Department of Fish and Game Publication Number 65-2. 142 pp.

Newell, L.K. and V.L. Talbot. 1998. A history of Garfield County. Utah State Historical Society, Salt Lake City, UT. $424 \mathrm{pp}$.

Ogle, K. and V. DuMond. 1997. Historical vegetation on national forest lands in the Intermountain Region. U.S. Forest Service, Intermountain Region, Ogden, UT. 129 pp.

Pierce, J.R. 1982. A floristic study of the Big Hole National Battlefield. Master’s thesis, University of Montana, Missoula, MT. 265 pp.

Platts, W.S. 1991. Livestock grazing. American Fisheries Society Special Publication 19:389-424.

Progulske, D.R. 1974. Yellow ore, yellow hair, yellow pine: A photographic study of a century of forest ecology. South Dakota State University, Agriculture Experiment Station Bulletin 616. 169 pp.

Pyne, S.J. 1982. Fire in America: A cultural history of wildland and rural fire. Princeton University Press, Princeton, NJ. 654 pp.

---. 1991. Burning bush: A fire history of Australia. Henry Holt and Company, New York, NY. 520 pp.

---. 1993. Keeper of the flame: A survey of anthropogenic fire. In: Crutzen, P.J. and J.G. Goldammer, eds. Fire in the environment: Its ecological, climatic, and atmospheric chemical importance. John Wiley and Sons, New York, NY. pp 245-66.

---. 1994. Maintaining focus: An introduction to anthropogenic fire. Chemosphere 29 (5): 889-911.

---. 1995a. Vestal fires and virgin lands: A reburn. In: Brown, J.K, R.W. Mutch, C.W. Spoon, and R.H. Wakimoto, eds. Proceedings: Symposium on fire in wilderness and park management. U.S. Department of Agriculture, U.S. Forest Service, Intermountain Research Station, Ogden, UT, Gen. Tech. Rep. INT-320. pp 15-21.

---. 1995b. World fire: The culture of fire on Earth. Henry Holt and Company, New York, NY. 379 pp.

Reid, D.K. 1987. Fire and habitat modifications: An anthropological inquiry into the use of fire by indigenous peoples. Master's thesis, University of Alberta, Edmonton, AB. 169 pp.

Reid, E.H., C.G. Johnson Jr., and W.B. Hall. 1991. Green fescue grassland: 50 years of secondary succession under sheep grazing. U.S. Department of Agriculture, U.S. Forest Service, Wallowa-Whitman National Forest, R6-F16-SO-0591. 37 pp.

Reppert, J.N. and R.E. Francis. 1973. Interpretation of trend in range condition from 3-step data. U.S. Department of Agriculture, U.S. Forest Service, Rocky Mountain Research Station, Fort Collins, CO, Research Paper RM-103. 15 pp.

Riggs, R.A., S.C. Bunting, and S.E. Daniels. 1996. Prescribed fire. In: Krausman, P.R., ed. Rangeland wildlife. Society for Range Management, Denver, CO. pp 295-320.

Rittenhouse, L.R. and F.A. Sneva. 1976. Expressing the competitive relationship between Wyoming big sagebrush and crested wheatgrass. Journal of Range Management 29 (4): 326-27. 
Robinson, M.E. and C.M. Robinson. 2004. Echoes from the cliffs of Capitol Reef National Park. Ol' Gran'pa Stories, West Jordan, UT. 64 pp.

Rochefort, R.M., R.L. Little, A. Woodward, and D.L. Peterson. 1994. Changes in sub-alpine tree distribution in western North America: A review of climatic and other causal factors. Holocene 4 (1): 89-100.

Rochefort, R.M. and D.L. Peterson. 1996. Temporal and spatial distribution of trees in subalpine meadows of Mount Rainier National Park, Washington, U.S.A. Arctic and Alpine Research 28 (1): 52-59.

Rogers, G.F. 1982. Then and now: A photographic history of vegetation change in the central Great Basin Desert. University of Utah Press, Salt Lake City, UT. 152 pp.

Rogers, G.F., H.E. Malde, and R.M. Turner. 1984. Bibliography of repeat photography for evaluating landscape change. University of Utah Press, Salt Lake City, UT. 179 pp.

Rogers, P.C. and C.M. Mittanck. 2013. Herbivory strains resilience in drought-prone aspen landscapes of the western United States. Journal of Vegetation Science. DOI; 10.11ll/jvs.12099. 15 pp.

Sallach, B.K. 1986. Vegetation changes in New Mexico documented by repeat photography. Master's thesis, New Mexico State University, Las Cruces, NM. 73 pp.

Seager, S.T., C. Eisenberg, and S.B. St. Clair. 2013. Patterns and consequences of ungulate herbivory on aspen in western North America. Forest Ecology and Management 299:81-90.

Shea, D. and C. Key. 2006. Glacier's eastside grasslands: Photographic comparisons over time. Glacier National Park, West Glacier, MT. 112 pp.

Skovlin, J.M. and J.W. Thomas. 1995. Interpreting long-term trends in Blue Mountain ecosystems from repeat photography. U.S. Department of Agriculture, U.S. Forest Service, Pacific Northwest Research Station, Portland, OR, Research Paper PNW-315. 102 pp.

Smith, J.G. 1962. An appraisal of the loop transect method for estimating root crown area changes. Journal of Range Management 15 (2): 72-78.

Sneva, F.A. 1972. Grazing return following sagebrush control in eastern Oregon. Journal of Range Management 25 (3): $174-78$.

Sturges, D.L. 1983. Long-term effects of big sagebrush control on vegetation and soil water. Journal of Range Management 36 (6): 760-65.

Tanaka, J.A. 1986. Increasing grass production by reducing overstory competition - an optimization procedure. In: Johnson, K.L., ed. Crested wheatgrass: Its values, problems and myths. Symposium Proceedings, Utah State University, Logan, UT. pp 295-304.

Taylor, A.H. 1995. Forest expansion and climate change in the mountain hemlock (Tsuga mertensiana) zone, Lassen Volcanic National Park, California, U.S.A. Arctic and Alpine Research 27 (3): 207-16.

Thompson, G.A. 1982. Some dreams die: Utah's ghost towns and lost treasures. Dream Garden Press, Salt Lake City, UT. 194 pp.

Till, T. 2000. Utah: Then and now. Westcliffe Publishers, Englewood, CO. 168 pp.

Turner, N.J. 1991. Burning mountain sides for better crops: Aboriginal landscape burning in British Columbia. Archaeology in Montana 32 (2): 57-73.

Turner, R.M., R.H. Webb, J.E. Bowers, and J.R. Hastings. 2003. The changing mile revisited. University of Arizona Press, Tucson, AZ. 334 pp. 
Uresk, D.W. and K.E. Severson. 1989. Understory-overstory relationships in ponderosa pine forests, Black Hills, South Dakota. Journal of Range Management 42 (3): 203-8.

---. 1998. Response of understory species to changes in ponderosa pine stocking levels in the Black Hills. Great Basin Naturalist 58 (4): 312-27.

U.S. Forest Service. 1993a. Vegetation changes on the Manti-LaSal National Forest: A photographic study using comparative photographs from 1902-1992. U.S. Department of Agriculture, U.S. Forest Service, Manti-LaSal National Forest, Price, UT. 128 pp.

---. 1993b. Snapshot in time: Repeat photography on the Boise National Forest 1870-1992. U.S. Department of Agriculture, U.S. Forest Service, Boise National Forest, Boise, ID. 239 pp.

---. 1998. Fishlake National Forest prescribed natural fire plan. U.S. Department of Agriculture, U.S. Forest Service, Fishlake National Forest, Richfield, UT. 146 pp.

Vale, T.R. 1981. Tree invasion of montane meadows in Oregon. American Midland Naturalist 105 (1): 61-69.

Vale, T.R. and G.R. Vale. 1994. Time and the Tuolumne landscape: Continuity and change in the Yosemite high country. University of Utah Press, Salt Lake City, UT. 212 pp.

Vankat, J.L. and J. Major. 1978. Vegetation changes in Sequoia National Park, California. Journal of Biogeography 5:377-402.

Van Vuren, D. 1983. Group dynamics and summer home range of bison in southern Utah. Journal of Mammalogy 64:329-32.

Van Vuren, D. and M.P. Bray. 1983. Diets of bison and cattle on a seeded range in southern Utah. Journal of Range Management 36:499-500.

---. 1986. Population dynamics of bison in the Henry Mountains, Utah. Journal of Mammalogy 67 (3): 503-11.

Veblen, T.T. and D.C. Lorenz. 1991. The Colorado front range: A century of ecological change. University of Utah Press, Salt Lake City, UT. 186 pp.

Webb, R.H. 1996. Grand Canyon - a century of change: Repeat photography of the 1889-90 Stanton Expedition on the Colorado River. University of Arizona Press, Tucson, AZ. 290 pp.

Webb, R.H. and J.E. Bowers. 1993a. Changes in frost frequency and desert vegetation assemblages in Grand Canyon, Arizona. In: Redmond, K.T. and V.L. Tharps, eds. Proceedings of the ninth annual Pacific climate (PACLIM) workshop, April 21-24, 1992. California Department of Water Resources, Interagency Ecological Studies Program Technical Report No. 34. pp 71-82.

---. 1993b. The impact of grazing on plant demography in Grand Canyon. In: Young, D.D., ed. Vegetation management of hot desert rangeland ecosystems: Papers presented at a symposium. University of Arizona Press, Tucson, AZ. pp 210-33.

Webb, R.H., D.E. Boyer, and R.M. Turner, eds. 2010. Repeat photography: Methods and applications in the natural sciences. Island Press, Washington, DC. 337 pp.

Webb, R.H., S.A. Leake, and R.M. Turner. 2007. The ribbon of green: Change in riparian vegetation in the southwestern United States. University of Arizona Press, Tucson, AZ. 462 pp.

Webb, R.H., S.S. Smith, and V.A.S. McCord. 1991. Historic channel change of Kanab Creek southern Utah and northern Arizona. Grand Canyon Natural History Association Monograph No. 9.91 pp.

Weisberg, P.J. and W.L. Baker. 1995. Spatial variation in tree seedling and krummholz growth in the forest-tundra ecotone of Rocky Mountain National Park, Colorado, U.S.A. Arctic, Antarctic, and Alpine Research 27 (2): $116-29$. 
White, C. and E.J. Hart. 2007. The lens of time: A repeat photography of landscape change in the Canadian Rockies. University of Calgary Press, Calgary, AB. 312 pp.

White, C.A., C.E. Olmsted, and C.E. Kay. 1998. Aspen, elk, and fire in the Rocky Mountain national parks of North America. Wildlife Society Bulletin 26 (3): 449-62.

Woodward, A., E.G. Schreiner, and D.G. Silsbee. 1995. Climate, geography, and tree establishment in subalpine meadows of the Olympic Mountains, Washington, U.S.A. Arctic and Alpine Research 27 (3): 217-25.

Wuerthner, G. and M. Matteson, eds. 2002. Welfare ranching: The subsidized destruction of the American West. Island Press, Washington, DC. 346 pp.

Wyoming State Historical Society. 1976. Re-discovering the Big Horns: A pictorial study of 75 years of ecological change. U.S. Department of Agriculture, U.S. Forest Service, Bighorn National Forest, Sheridan, WY. 79 pp. 


\section{Appendix A}

\section{Henry Mountains Repeat Photo Locations and Elevations}

This table of UTM coordinates for the 608 Henry Mountains repeat photos of Charles E. Kay was provided by Doug Page, BLM, Cedar City, UT.

\begin{tabular}{|c|c|c|c|c|}
\hline Plate No. & Easting & Northing & Elevation & Subject-Location \\
\hline 1 & 480746 & 4237574 & $5,33^{8}$ & Fremont River - Capitol Reef National Park \\
\hline 2 & 477217 & 4237973 & $5,5^{10}$ & Sulphur Creek \\
\hline 3 & 477711 & 4237483 & 5,461 & Sulphur Creek \\
\hline 4 & $4835^{12}$ & 4236659 & 5,203 & Fremont River \\
\hline 5 & 480643 & 4237633 & 5,346 & Fremont River \\
\hline 6 & 480912 & 4237267 & 5,322 & Fremont River \\
\hline 7 & 480987 & 4237111 & 5,302 & Fremont River \\
\hline 8 & 478564 & 4237369 & 5,400 & Fremont River - Sulphur Creek \\
\hline 9 & 478229 & 4236969 & 5,426 & Fremont River Valley \\
\hline 10 & 479853 & 4233555 & $5,65^{2}$ & Capitol Reef National Park \\
\hline 11 & 479845 & 4233482 & 5,668 & Capitol Reef National Park \\
\hline 12 & 483667 & 4229239 & 5,630 & Capitol Wash \\
\hline 13 & 478294 & 4237561 & 5,480 & Sulphur Creek \\
\hline 14 & 480808 & 4237433 & 5,327 & Fremont River \\
\hline 15 & 478462 & 4237779 & 5,502 & Fremont River - Sulphur Creek \\
\hline 16 & 478507 & 4237653 & 5,440 & Fremont River \\
\hline 17 & 478008 & 4237589 & 5,640 & Fremont River Valley \\
\hline 18 & 483701 & 4236748 & 5,197 & Fremont River \\
\hline 19 & 478564 & 4237493 & 5,464 & Fremont River \\
\hline 20 & 481680 & 4229389 & 5,376 & Capitol Wash \\
\hline 21 & 479463 & 4237907 & 5,420 & Fremont River \\
\hline 22 & 497703 & 4188996 & 5,662 & Burr Canyon \\
\hline 23 & 497703 & 4188996 & 5,662 & Burr Canyon \\
\hline 24 & 497647 & 4189017 & 5,701 & Burr Canyon \\
\hline 25 & $4975^{18}$ & 4189091 & 5,816 & Burr Canyon \\
\hline 26 & 502499 & 4215593 & 5,508 & Sweetwater Creek \\
\hline 27 & 499220 & 4214955 & 5,583 & Blind Canyon Trail \\
\hline 28 & 499205 & 4214954 & $5,5^{82}$ & Blind Canyon Trail \\
\hline 29 & 496013 & 4238300 & 4,693 & Fremont River \\
\hline
\end{tabular}




\section{Henry Mountains Repeat Photo Logations and Elevations \\ (UTM ZONE I2N, NAD 83)}

\begin{tabular}{|c|c|c|c|c|}
\hline Plate No. & Easting & Northing & Elevation & Subject-Location \\
\hline 30 & 518782 & 4247009 & 4,380 & Fremont River \\
\hline 31 & 511238 & 4245731 & 4,424 & Skyline Rim \\
\hline $3^{2}$ & 495980 & 4238279 & 4,678 & Fremont River \\
\hline 33 & $4955^{61}$ & 4236923 & 4,904 & Blue Dugway \\
\hline 34 & 495561 & 4236923 & 4,904 & Blue Dugway \\
\hline 35 & 495682 & 4237063 & 4,888 & Blue Dugway \\
\hline $3^{6}$ & 495607 & 4236919 & 5,043 & Blue Dugway \\
\hline 37 & 495607 & 4236919 & 5,043 & South Caineville Mesa \\
\hline $3^{8}$ & 497083 & 4239153 & 4,669 & Fremont River \\
\hline 39 & 497083 & 4239153 & 4,669 & Fremont River \\
\hline 40 & 497265 & 4239619 & 4,679 & Fremont River \\
\hline 41 & 497492 & 4240679 & 4,654 & Fremont River \\
\hline 42 & 491794 & 4234306 & 5,067 & Caineville Reef \\
\hline 43 & 508042 & 4246408 & 4,603 & Fremont River \\
\hline 44 & 509425 & 4246581 & 4,637 & Factory Butte \\
\hline 45 & 508581 & 4246443 & 4,600 & Henry Mountains \\
\hline 46 & 508581 & 4246443 & 4,600 & Factory Butte \\
\hline 47 & 508581 & 4246443 & 4,600 & Factory Butte \\
\hline 48 & 516050 & 4246587 & 4,413 & Dakota Sandstone \\
\hline 49 & 515923 & 4246630 & 4,387 & Fremont River \\
\hline $5^{\circ}$ & $5^{22066}$ & 4247282 & 4,375 & Summerville Formation \\
\hline $5^{\prime}$ & 525320 & 4248528 & 4,290 & Fremont River \\
\hline $5^{2}$ & $5^{22466}$ & 4246900 & 4,322 & Fremont River \\
\hline 53 & 522504 & 4246886 & 4,319 & Fremont River \\
\hline 54 & 522446 & 4246842 & 4,364 & Fremont River \\
\hline 55 & $5^{23554}$ & 4247340 & 4,303 & Fremont River \\
\hline $5^{6}$ & $5^{26792}$ & 4250631 & 4,311 & Dirty Devil and Fremont Rivers \\
\hline 57 & $5^{26802}$ & 4250618 & 4,257 & Dirty Devil and Fremont Rivers \\
\hline $5^{8}$ & $5^{26802}$ & 4250618 & 4,257 & Dirty Devil River \\
\hline 59 & $5^{26789}$ & 4250503 & 4,243 & Dirty Devil River \\
\hline 60 & $5^{26117}$ & 4250179 & 4,259 & Fremont River \\
\hline 61 & $5^{26117}$ & 4250179 & 4,259 & Fremont River \\
\hline 62 & $5^{2405^{2}}$ & 4247404 & 4,310 & Fremont River Valley \\
\hline 63 & $5^{24340}$ & 4247407 & 4,299 & Fremont River Valley \\
\hline 64 & $5^{24327}$ & 4247409 & 4,296 & Fremont River Valley \\
\hline 65 & 524924 & 4247141 & 4,294 & Hanksville \\
\hline 66 & $5^{24924}$ & 4247149 & 4,324 & Hanksville \\
\hline
\end{tabular}




\section{Henry Mountains Repeat Photo Locations and Elevations \\ (UTM ZONE I2N, NAD 83)}

\begin{tabular}{|c|c|c|c|c|}
\hline Plate No. & Easting & Northing & Elevation & Subject-Location \\
\hline 67 & 524917 & 4247221 & 4,302 & Hanksville \\
\hline 68 & 525139 & 4247370 & 4,302 & Bull Creek \\
\hline 69 & $5^{235^{29}}$ & 4247573 & 4,305 & Fremont River \\
\hline 70 & 500520 & 4202238 & 5,061 & Trachyte Creek \\
\hline 71 & $5^{25386}$ & $419673^{2}$ & 8,174 & Bulldog Peak \\
\hline $7^{2}$ & 525411 & 4196733 & 7,434 & Bastian Reservoir \\
\hline 73 & 525411 & 4196733 & 7,434 & Bastian Reservoir \\
\hline 74 & $5^{255^{24}}$ & $41973^{20}$ & 7,065 & Mount Hillers \\
\hline 75 & $5^{255^{24}}$ & 4197320 & 7,065 & Big Ridge \\
\hline 76 & $5^{255^{24}}$ & 4197320 & 7,065 & Big Ridge \\
\hline 77 & $5^{24453}$ & 4196429 & 7,410 & Cass Creek Peak \\
\hline 78 & $5^{20794}$ & 4198944 & $8,35^{1}$ & Browns Knoll \\
\hline 79 & $5^{20794}$ & 4198944 & $8,35^{1}$ & Straight and Browns Creeks \\
\hline 80 & $5^{20794}$ & 4198944 & 8,351 & Bulldog Ridge \\
\hline 81 & 522684 & 4198774 & 8,163 & Mount Pennell \\
\hline 82 & 522684 & 4198774 & 8,163 & Coyote Benches \\
\hline 83 & $5^{21296}$ & 4198589 & 8,120 & Mount Pennell \\
\hline 84 & $5^{21356}$ & 4200705 & 7,910 & Mount Pennell \\
\hline 85 & $5^{21356}$ & 4200705 & 7,910 & Mount Pennell \\
\hline 86 & $5^{20376}$ & 4203612 & 8,376 & Mount Pennell \\
\hline 87 & 520355 & 4203498 & 8,403 & Mount Pennell \\
\hline 88 & 520724 & 4204159 & 8,094 & Ragged Mountain \\
\hline 89 & 517120 & 4203641 & 8,707 & Mount Pennell \\
\hline 90 & 517120 & 4203641 & 8,707 & Mount Pennell \\
\hline 91 & 518716 & 4205369 & 7,912 & The Horn \\
\hline 92 & 518710 & 4205423 & 7,938 & The Horn \\
\hline 93 & 516807 & 4203945 & 8,519 & Mount Ellen \\
\hline 94 & 516807 & 4203945 & 8,519 & South Creek Ridge \\
\hline 95 & 517023 & 4206986 & 7,860 & Pennellen Pass \\
\hline 96 & 517023 & 4206986 & 7,860 & Pennellen Pass \\
\hline 97 & $5^{1695^{2}}$ & 4208084 & 7,953 & Pennellen Pass \\
\hline 98 & $5^{1695^{2}}$ & 4208084 & 7,953 & Pennellen Pass \\
\hline 99 & $5^{1835^{2}}$ & 4209962 & 8,573 & Slate Creek \\
\hline 100 & 520168 & 4211405 & $9,05^{\circ}$ & Ragged Mountain \\
\hline 101 & $5^{20536}$ & 4211288 & 8,971 & Copper Ridge \\
\hline 102 & 520564 & 4211291 & 8,970 & Copper Ridge \\
\hline 103 & $5^{20518}$ & 4211198 & 8,935 & Mount Pennell \\
\hline
\end{tabular}




\section{Henry Mountains Repeat Photo Logations and Elevations}

(UTM ZONE I2N, NAD 83)

\begin{tabular}{|c|c|c|c|c|}
\hline Plate No. & Easting & Northing & Elevation & Subject-Location \\
\hline 104 & 521670 & 4211056 & 8,987 & Copper Ridge \\
\hline 105 & $5^{21682}$ & 4211039 & 8,969 & Ragged Canyon \\
\hline 106 & 520534 & $421197^{2}$ & 8,734 & Copper Basin Spring \\
\hline 107 & 520169 & 4217291 & 9,779 & Mount Ellen \\
\hline 108 & 520169 & 4217291 & 9,779 & North Summit Ridge \\
\hline 109 & 517333 & 4215361 & 10,482 & Bull Creek Pass \\
\hline 110 & 517367 & 4215317 & 10,482 & Bull Creek Pass \\
\hline 111 & 517367 & 4215317 & 10,482 & Bull Creek Pass \\
\hline 112 & 517289 & 4215499 & 10,503 & Bull Creek Pass \\
\hline 113 & 517291 & 4215597 & 10,507 & Bull Creek Pass \\
\hline 114 & 517369 & $421413^{8}$ & 10,344 & Upper Dugout Creek \\
\hline 115 & 515911 & 4213119 & 9,585 & South Summit Ridge \\
\hline 116 & $515^{183}$ & 4213802 & 9,590 & Durfey Butte \\
\hline 117 & $515^{183}$ & 4213802 & 9,590 & Durfey Butte \\
\hline 118 & $515^{183}$ & 4213802 & 9,590 & Durfey Butte \\
\hline 119 & $515^{183}$ & 4213802 & 9,590 & Durfey Butte \\
\hline $12 O$ & 517254 & 4213339 & 10,467 & South Creek \\
\hline 121 & 517254 & 4213339 & 10,467 & Nasty Flat and Durfey Butte \\
\hline 122 & $5^{16488}$ & 4211474 & 9,978 & South Creek \\
\hline 123 & $5^{16488}$ & 4211474 & 9,978 & South Creek \\
\hline 124 & 513271 & 4213970 & 8,383 & McClellan Spring \\
\hline 125 & 506466 & 4213024 & 6,025 & Steele Butte \\
\hline 126 & 504342 & 4217270 & 5,920 & Pete Steele Bench \\
\hline 127 & 504342 & 4217270 & 5,920 & Pete Steele Bench \\
\hline 128 & 512506 & 4212915 & 7,861 & South Creek Chainings \\
\hline 129 & 512506 & 4212915 & 7,861 & South Creek Chainings \\
\hline 130 & 512506 & 4212915 & 7,861 & South Creek Chainings \\
\hline 131 & 512506 & 4212915 & 7,861 & South Creek Chainings \\
\hline 132 & 518926 & 4226245 & 6,180 & Mount Ellen Peak \\
\hline 133 & 518926 & 4226245 & 6,180 & Mount Ellen Peak \\
\hline 134 & 527861 & 4224543 & 5,102 & Granite Ranch \\
\hline 135 & 532665 & 4213427 & 5,002 & Seep Wash \\
\hline 136 & 532665 & 4213427 & 5,002 & Seep Wash \\
\hline 137 & 532665 & 4213427 & 5,002 & Little Egypt \\
\hline 138 & 532808 & 4215593 & 5,034 & Seep Wash \\
\hline 139 & 546829 & 4198509 & 3,920 & North Wash \\
\hline 140 & 547595 & 4196089 & 3,797 & North Wash \\
\hline
\end{tabular}




\section{Henry Mountains Repeat Photo Locations and Elevations \\ (UTM ZONE I2N, NAD 83)}

\begin{tabular}{|c|c|c|c|c|}
\hline Plate No. & Easting & Northing & Elevation & Subject-Location \\
\hline 141 & $52537^{2}$ & 4214708 & 6,540 & Crescent Creek Bench \\
\hline 142 & $52537^{2}$ & 4214708 & 6,540 & Crescent Creek Bench \\
\hline 143 & 544498 & 4204280 & 4,253 & North Wash \\
\hline 144 & 544647 & 4203437 & 4,173 & North Wash \\
\hline 145 & 533153 & 4208713 & 5,012 & Cottonwood Wash \\
\hline 146 & 533911 & 4206183 & 5,012 & Cottonwood Wash \\
\hline 147 & $54457^{2}$ & 4202115 & 4,120 & North Wash \\
\hline 148 & 527873 & $4202007^{\prime}$ & 6,085 & Coyote Benches \\
\hline 149 & $5^{25533}$ & 4201796 & 6,465 & Coyote Benches \\
\hline 150 & $5^{25533}$ & 4201796 & 6,465 & Coyote Benches \\
\hline 151 & $5^{27882}$ & 4201903 & $6, o 76$ & Coyote Benches \\
\hline $15^{2}$ & 527882 & 4201903 & $6, o 76$ & Coyote Benches \\
\hline 153 & 533960 & 4193840 & 6,244 & Mount Hillers \\
\hline 154 & $5^{29976}$ & 4188974 & 6,091 & Star Ranch \\
\hline 155 & $5^{29976}$ & 4188974 & 6,091 & Star Ranch \\
\hline 156 & 529914 & 4188898 & 6,078 & Star Ranch \\
\hline 157 & $5^{26094}$ & 4241985 & 4,512 & Summerville Formation \\
\hline 158 & $5^{28770}$ & 4188166 & 6,225 & Little Rockies \\
\hline 159 & 529914 & 4188898 & 6,078 & Mount Holmes \\
\hline 160 & 529635 & 4206648 & 5,680 & South Fork - Slate Creek Divide \\
\hline 161 & 529635 & 4206648 & 5,680 & South Fork - Slate Creek Divide \\
\hline 162 & 529635 & 4206648 & 5,680 & South Fork - Slate Creek Divide \\
\hline 163 & 529635 & 4206648 & 5,680 & South Fork - Slate Creek Divide \\
\hline 164 & $5155^{16}$ & 4235556 & 4,872 & Bert Avery Seep \\
\hline 165 & 515516 & 4235556 & 4,872 & Bert Avery Seep \\
\hline 166 & $5155^{16}$ & $423555^{6}$ & 4,872 & Bert Avery Seep \\
\hline 167 & $5155^{16}$ & $423555^{6}$ & 4,872 & Bert Avery Seep \\
\hline 168 & 515517 & 4235573 & 4,879 & Bert Avery Seep \\
\hline 169 & 515618 & 4235602 & 4,872 & Bert Avery Seep \\
\hline 170 & $525^{6} 73$ & 4214186 & 6,514 & Crescent Creek \\
\hline 171 & 525673 & 4214186 & 6,514 & Crescent Creek \\
\hline 172 & $5^{20057}$ & 4211383 & 8,991 & Raggy Draws \\
\hline 173 & $5^{20057}$ & 4211383 & 8,991 & Raggy Draws \\
\hline 174 & $5^{26939}$ & $420795^{8}$ & 6,416 & South Fork Ridge \\
\hline 175 & $5^{26939}$ & $420795^{8}$ & 6,416 & South Fork Ridge \\
\hline 176 & $5^{26939}$ & $420795^{8}$ & 6,416 & South Fork Ridge \\
\hline 177 & $5^{26939}$ & $420795^{8}$ & 6,416 & South Fork Ridge \\
\hline
\end{tabular}




\section{Henry Mountains Repeat Photo Logations and Elevations \\ (UTM ZONE I2N, NAD 83)}

\begin{tabular}{|c|c|c|c|c|}
\hline Plate No. & Easting & Northing & Elevation & Subject-Location \\
\hline 178 & 526939 & $420795^{8}$ & 6,416 & South Fork Ridge \\
\hline 179 & $5^{26785}$ & 4209076 & 6,244 & South Fork Ridge \\
\hline 180 & $5^{2} 6785$ & 4209076 & 6,244 & South Fork Ridge \\
\hline 181 & $5^{26785}$ & 4209076 & 6,244 & South Fork Ridge \\
\hline 182 & $5^{26785}$ & 4209076 & 6,244 & South Fork Ridge \\
\hline 183 & $5^{26785}$ & 4209076 & 6,244 & South Fork Ridge \\
\hline 184 & $5^{26785}$ & 4209076 & 6,244 & South Fork Ridge \\
\hline 185 & 527103 & 4209639 & 5,779 & Pyserts Hole \\
\hline 186 & $5^{27103}$ & 4209639 & 5,779 & Pyserts Hole \\
\hline 187 & $5^{27103}$ & 4209639 & 5,779 & Pyserts Hole \\
\hline 188 & $5^{27103}$ & 4209639 & 5,779 & Pyserts Hole \\
\hline 189 & $5^{27103}$ & 4209639 & 5,779 & Pyserts Hole \\
\hline 190 & $49373^{1}$ & 4204565 & 5,607 & Sandy Creek \\
\hline 191 & $49373^{\prime}$ & 4204565 & 5,607 & Sandy Creek \\
\hline 192 & $49373^{\prime}$ & $420455^{\prime}$ & 5,610 & Sandy Creek \\
\hline 193 & 498355 & 4191030 & 5,021 & Halls Creek \\
\hline 194 & 497501 & 4189092 & 5,814 & Muley Twist Canyon \\
\hline 195 & 497809 & 4214379 & 5,463 & Blind Trail Wash \\
\hline 196 & 497809 & 4214379 & 5,463 & Blind Trail Wash \\
\hline 197 & 501507 & 4215513 & $5,55^{8}$ & Wildcat Mesa \\
\hline 198 & 477621 & 4237789 & 5,426 & Capitol Reef National Park \\
\hline 199 & 474421 & 4240013 & 6,128 & Capitol Reef National Park \\
\hline 200 & 482048 & 4229258 & $5,75^{2}$ & Capitol Reef National Park \\
\hline 201 & 497614 & 4241335 & 4,640 & Fremont River \\
\hline 202 & 520015 & 4247077 & 4,417 & Fremont River \\
\hline 203 & $5^{27127}$ & 4166045 & $4,5^{2} 6$ & Cane Spring Desert \\
\hline 204 & $53445^{8}$ & 4169272 & 4,577 & Cane Spring Desert \\
\hline 205 & 532227 & 4184086 & 5,257 & Milk Creek Pass \\
\hline 206 & 531686 & 4180486 & 5,316 & Mount Ellsworth \\
\hline 207 & 532901 & 4184615 & 5,172 & Mount Holmes \\
\hline 208 & 530625 & 4207463 & $5,47^{\circ}$ & Pinto Knolls \\
\hline 209 & 530347 & 4207271 & 5,557 & Pinto Knolls \\
\hline 210 & 530625 & 4207463 & 5,470 & Pinto Knolls \\
\hline 211 & 530535 & 4206816 & 5,487 & Pinto Knolls \\
\hline 212 & 535395 & 4190051 & 4,814 & Woodruff Hole \\
\hline 213 & 520829 & 4189180 & 5,580 & Cow Flat \\
\hline 214 & 518820 & 4185193 & 5,278 & Cow Flat Point \\
\hline
\end{tabular}




\section{Henry Mountains Repeat Photo Locations and Elevations \\ (UTM ZONE I2N, NAD 83)}

\begin{tabular}{|c|c|c|c|c|}
\hline Plate No. & Easting & Northing & Elevation & Subject-Location \\
\hline 215 & 524206 & 4196297 & 7,392 & Stanton Pass \\
\hline 216 & 523496 & 4190125 & 6,486 & Indian Spring Bench \\
\hline 217 & 523381 & 4190287 & 6,542 & Mount Hillers \\
\hline 218 & $5^{26057}$ & 4188323 & 6,039 & Copper Creek Bench \\
\hline 219 & 522019 & 4180319 & 4,778 & Hansen Creek Airstrip \\
\hline 220 & 518007 & 4172624 & 4,849 & Clay Point \\
\hline 221 & 513703 & 4180508 & 4,489 & Eggnog \\
\hline 222 & 492597 & 4206068 & 5,569 & Upper Sandy Creek \\
\hline 223 & 494347 & 4212504 & 5,359 & Sandy Creek Bench \\
\hline 224 & $49455^{\circ}$ & 4211059 & 5,407 & Sandy Creek Bench \\
\hline 225 & 496742 & 4215063 & 5,345 & Blind Trail Wash \\
\hline 226 & 499059 & 4211069 & 5,619 & Upper Blind Trail Wash \\
\hline 227 & 498848 & 4211181 & 5,576 & Upper Blind Trail Wash \\
\hline 228 & 495902 & 4218993 & 5,204 & Blind Trail Wash \\
\hline 229 & 493876 & 4214235 & 5,537 & Sandy Creek Benches \\
\hline 230 & 493618 & 4219022 & 5,215 & Lower Sheets Gulch \\
\hline 231 & 493618 & 4219022 & 5,215 & Lower Sheets Gulch \\
\hline 232 & 494781 & 4210684 & 5,333 & Lower Spring Canyon \\
\hline 233 & 488082 & 4214905 & 5,826 & Oak Creek Canyon \\
\hline 234 & 488164 & 4214891 & 5,818 & Oak Creek Canyon \\
\hline 235 & 487685 & 4215188 & 5,856 & Oak Creek Canyon \\
\hline 236 & 492728 & 4225177 & 5,185 & Burro Wash \\
\hline 237 & 490423 & 4228160 & 5,545 & Notom Bench \\
\hline $23^{8}$ & 498082 & 4218331 & 5,788 & Wildcat Mesa \\
\hline 239 & 505063 & 4216790 & 5,886 & Wildcat Mesa \\
\hline 240 & 503579 & 4221386 & 5,763 & Stevens Mesa \\
\hline 241 & 504349 & 4224468 & 5,759 & Stevens Mesa \\
\hline 242 & 503349 & 4227963 & 5,633 & Stevens Mesa \\
\hline 243 & 503349 & 4227963 & 5,633 & Stevens Mesa \\
\hline 244 & 508955 & 4219604 & 6,281 & Cedar Creek Bench \\
\hline 245 & $505^{226}$ & 4210092 & 5,871 & Sweetwater Creek \\
\hline 246 & 511854 & 4207891 & 6,665 & North Fork of Bulldog Creek \\
\hline 247 & 504998 & 4219046 & 5,789 & Apple Brush Flat \\
\hline 248 & 499474 & 4216084 & 5,671 & Poison Wash Flat \\
\hline 249 & 497206 & 4193103 & 5,131 & Oyster Shell Reef \\
\hline 250 & 498305 & 4191002 & 5,080 & Upper Halls Creek \\
\hline 251 & 498334 & 4191026 & 5,084 & Swap Canyon \\
\hline
\end{tabular}




\section{Henry Mountains Repeat Photo Logations and Elevations \\ (UTM ZONE I2N, NAD 83)}

\begin{tabular}{|c|c|c|c|c|}
\hline Plate No. & Easting & Northing & Elevation & Subject-Location \\
\hline $25^{2}$ & 478565 & 4237797 & 5,439 & Fremont River - Capitol Reef National Park \\
\hline 253 & 516567 & 4235813 & 4,806 & Lower Birch Creek Valley \\
\hline 254 & $5^{16124}$ & $423135^{\circ}$ & 5,184 & Blue Valley Bench \\
\hline 255 & 514955 & 4233597 & 4,991 & Blue Valley Bench \\
\hline 256 & 513807 & 4237034 & 4,835 & Blue Valley Bench \\
\hline 257 & 510582 & 4238763 & 4,861 & Lower Oak Creek - Cottonwood Creek Bench \\
\hline $25^{8}$ & 509875 & 4233774 & 4,969 & Lower Oak Creek Bench \\
\hline 259 & 512678 & 4230371 & 5,156 & Cottonwood Creek Bench \\
\hline 260 & 518733 & 4228003 & 5,685 & Dugout Bench \\
\hline 261 & 519722 & 4228723 & 5,501 & Lower McClellan Wash \\
\hline 262 & 520117 & 4230678 & 5,284 & Dugout Bench \\
\hline 263 & 520117 & 4230678 & 5,284 & Dugout Bench \\
\hline 264 & $5^{24774}$ & 4234777 & 4,784 & Cow Wash \\
\hline 265 & $5245^{29}$ & 4225861 & 5,742 & Bull Mountain \\
\hline 266 & 522846 & 4229769 & 5,175 & Fairview Ranch \\
\hline 267 & 522846 & 4229769 & 5,175 & Fairview Ranch \\
\hline 268 & $5^{28125}$ & 4242069 & 4,479 & Dry Valley Wash \\
\hline 269 & $5^{28345}$ & 4221421 & 5,445 & Upper Poison Spring Flat \\
\hline 270 & 527094 & 4221083 & 5,658 & Granite Creek \\
\hline 271 & 526796 & 4215131 & 6,215 & Crescent Creek Bench \\
\hline $27^{2}$ & 524075 & 4216071 & 6,866 & Butler Wash Bench \\
\hline 273 & 520066 & 4214917 & 9,292 & Granite Ridges \\
\hline 274 & $5^{20799}$ & 4211314 & 8,860 & Copper Ridge \\
\hline 275 & $5^{22222}$ & 4214224 & 7,864 & Eagle Bench \\
\hline 276 & 534287 & 4201962 & 5,006 & Trachyte \\
\hline 277 & 525426 & 4201679 & 6,467 & Coyote Benches \\
\hline 278 & 522083 & 4198357 & 8,011 & Browns Knoll \\
\hline 279 & 521106 & 4196187 & 7,731 & Mud Spring \\
\hline 280 & $5^{21411}$ & 4200816 & 7,840 & Upper Coyote Bench \\
\hline 281 & $5^{22601}$ & 4200478 & 7,295 & Coyote Bench \\
\hline 282 & 520249 & 4203429 & 8,438 & Willow Spring Flat \\
\hline 283 & 517785 & 4203840 & 8,850 & Horn Spring Basin \\
\hline 284 & $5^{16532}$ & 4207239 & 7,775 & Pennell Pass \\
\hline 285 & 515377 & $42085^{28}$ & 7,768 & Head of Bullfrog \\
\hline 286 & $51594^{2}$ & 4206008 & 7,787 & Airplane Spring \\
\hline 287 & 514245 & 4205610 & 7,035 & Lower Bullfrog Chaining \\
\hline 288 & 518967 & 4205384 & $7,77^{2}$ & Horn Creek \\
\hline
\end{tabular}




\section{Henry Mountains Repeat Photo Locations and Elevations \\ (UTM ZONE I2N, NAD 83)}

\begin{tabular}{|c|c|c|c|c|}
\hline Plate No. & Easting & Northing & Elevation & Subject-Location \\
\hline 289 & 518712 & 4207179 & 7,669 & Slate Creek \\
\hline 290 & 517237 & 4207388 & 7,726 & Ragged Mountain \\
\hline 291 & 510053 & 4220712 & 6,710 & Cedar Creek \\
\hline 292 & 509086 & 4219704 & 6,409 & Cedar Creek Bench \\
\hline 293 & 509086 & 4219704 & 6,409 & Cedar Creek Bench \\
\hline 294 & 515957 & 4213277 & 9,570 & Nasty Flat \\
\hline 295 & 515871 & 4211808 & 9,250 & South Creek \\
\hline 296 & 516528 & 4212793 & 9,596 & North Fork of South Creek \\
\hline 297 & 514667 & 4211801 & 8,608 & North Fork of South Creek \\
\hline 298 & 514667 & 4211801 & 8,608 & North Fork of South Creek \\
\hline 299 & $5^{12} 6_{3} 6$ & 4211257 & 7,631 & South Creek Chaining \\
\hline 300 & 512869 & 4213653 & 8,206 & McClellan Spring \\
\hline 301 & 514129 & 4213178 & 8,590 & Willow Spring \\
\hline 302 & 517878 & 4213769 & 11,267 & Bromide Basin \\
\hline 303 & 517878 & 4213769 & 11,267 & Bromide Basin \\
\hline 304 & 517878 & 4213769 & 11,267 & South Summit Ridge \\
\hline 305 & 517727 & 4213604 & 11,267 & South Summit Ridge \\
\hline 306 & $5177^{23}$ & 4213597 & 11,249 & Bromide Basin \\
\hline 307 & $5177^{23}$ & 4213597 & 11,249 & Bromide Basin \\
\hline 308 & $51755^{6}$ & 4213292 & 11,067 & South Summit Ridge \\
\hline 309 & $51755^{6}$ & 4213292 & 11,067 & South Summit Ridge \\
\hline 310 & $51755^{6}$ & 4213292 & 11,067 & South Creek \\
\hline 311 & $51757^{8}$ & 4212806 & 11,091 & South Summit Ridge \\
\hline 312 & 517633 & 4212776 & 11,005 & Bromide Basin \\
\hline 313 & 517633 & 4212776 & 11,005 & Bromide Basin \\
\hline 314 & 518474 & 4212704 & 11,086 & Bromide Basin \\
\hline 315 & 517956 & 4213861 & 11,409 & South Summit Ridge \\
\hline 316 & 517976 & 4213913 & 11,416 & South Summit Ridge \\
\hline 317 & 517955 & 4213979 & 11,400 & Granite Creek \\
\hline 318 & 513392 & 4218480 & 8,926 & Upper Cedar Creek \\
\hline 319 & 514534 & 4218312 & $9,5^{24}$ & Upper Cedar Creek \\
\hline 320 & 514534 & 4218312 & $9,5^{24}$ & Upper Cedar Creek \\
\hline 321 & 514534 & 4218312 & $9,5^{24}$ & Upper Cedar Creek \\
\hline 322 & 513710 & 4217714 & 8,856 & Star Flat \\
\hline 323 & 488511 & 4214690 & 5,659 & Oak Creek Canyon \\
\hline 324 & 508457 & $42043^{16}$ & 6,857 & Tarantula Mesa \\
\hline 325 & 498479 & 4202586 & 6,292 & Tarantula Mesa \\
\hline
\end{tabular}




\section{Henry Mountains Repeat Photo Logations and Elevations \\ (UTM ZONE I2N, NAD 83)}

\begin{tabular}{|c|c|c|c|c|}
\hline Plate No. & Easting & Northing & Elevation & Subject-Location \\
\hline 326 & 501312 & 4201292 & 6,443 & Tarantula Mesa \\
\hline 327 & 504062 & 4201117 & $6,57^{8}$ & Tarantula Mesa \\
\hline 328 & 488554 & 4214690 & $5,75^{1}$ & Oak Creek Canyon \\
\hline 329 & 488554 & 4214690 & 5,751 & Oak Creek Canyon \\
\hline 330 & 497284 & 4224275 & 5,111 & Bloody Hands Gap \\
\hline 331 & 497137 & 4226513 & 5,171 & Bloody Hands Gap \\
\hline $33^{2}$ & 474239 & 4239969 & 6,168 & Whiskey Flat \\
\hline 333 & 479466 & 4234565 & 5,595 & Grand Wash \\
\hline 334 & 483146 & 4229096 & 5,651 & Capitol Wash \\
\hline 335 & 483144 & 4229075 & $5,65^{2}$ & Capitol Wash \\
\hline $33^{6}$ & 483913 & 4228874 & 5,531 & Capitol Wash \\
\hline 337 & 491066 & 4232182 & 5,205 & Caineville Reef \\
\hline 338 & 491794 & 4234306 & 5,067 & Caineville Reef \\
\hline 339 & $49035^{2}$ & 4233046 & 5,227 & Notom Desert \\
\hline 340 & 495776 & 4237195 & 4,835 & Blue Dugway \\
\hline 341 & 494817 & 4236562 & 4,819 & Caineville Reef \\
\hline 342 & 512224 & 4246274 & 4,441 & Blue Valley \\
\hline 343 & 522249 & 4247591 & 4,327 & Dead Horse Butte \\
\hline 344 & 503298 & $42445^{16}$ & $4,55^{1}$ & North Caineville Mesa \\
\hline 345 & 502819 & 4244504 & 4,547 & North Caineville Mesa \\
\hline 346 & 521809 & 4227228 & 5,608 & Bull Creek \\
\hline 347 & $5^{22983}$ & 4225106 & 6,109 & Bull Mountain \\
\hline 348 & 527838 & 4224501 & 5,086 & Granite Ranch \\
\hline 349 & $5^{27195}$ & 4218894 & 6,184 & Granite Creek \\
\hline 350 & 527195 & 4218894 & 6,184 & Granite Creek \\
\hline $35^{\prime}$ & 533013 & 4192073 & 6,897 & Woodruff Airstrip \\
\hline $35^{2}$ & 515799 & 4177273 & 4,548 & Clay Point \\
\hline 353 & 537695 & $417173^{2}$ & 5,061 & Ticaboo Mesa \\
\hline 354 & 532398 & 4226547 & 4,937 & Burr Desert \\
\hline 355 & 544655 & 4201817 & 4,078 & North Wash \\
\hline $35^{6}$ & 542734 & 4214183 & 5,371 & Cedar Point \\
\hline 357 & 536054 & 4218346 & 5,028 & Cedar Point \\
\hline $35^{8}$ & 533557 & 4208589 & $4,95^{\circ}$ & Trachyte Point \\
\hline 359 & 529954 & 4188875 & 6,054 & Starr Ranch \\
\hline 360 & 533845 & 4190678 & 5,595 & Woodruff Hole \\
\hline $3^{61}$ & 533845 & 4190678 & 5,595 & Woodruff Hole \\
\hline 362 & $5^{29914}$ & 4188894 & $6,05^{2}$ & Starr Ranch \\
\hline
\end{tabular}




\section{Henry Mountains Repeat Photo Locations and Elevations \\ (UTM ZONE I2N, NAD 83)}

\begin{tabular}{|c|c|c|c|c|}
\hline Plate No. & Easting & Northing & Elevation & Subject-Location \\
\hline 363 & 522840 & 4229700 & 5,182 & Fairview Ranch \\
\hline 364 & $5^{22840}$ & 4229700 & 5,182 & Fairview Ranch \\
\hline 365 & 522840 & 4229700 & 5,182 & Fairview Ranch \\
\hline 366 & 498851 & 4211138 & 5,584 & Upper Blind Trail Wash \\
\hline 367 & 493929 & 4214205 & 5,487 & Sandy Ranch \\
\hline 368 & $49377^{8}$ & 4235836 & 4,795 & Sand Wash Bridge \\
\hline 369 & 493746 & 4235812 & 4,794 & Sand Wash Bridge \\
\hline 370 & 480984 & 4237213 & 5,210 & Fremont River \\
\hline 371 & 480788 & $42375^{12}$ & 5,307 & Fremont River \\
\hline $37^{2}$ & 477061 & 4238266 & $5,47^{2}$ & Sulphur Creek Bridge \\
\hline 373 & 476986 & 4238258 & 5,470 & Sulphur Creek Bridge \\
\hline 374 & 477023 & 4238311 & 5,470 & Sulphur Creek Bridge \\
\hline 375 & 474167 & 4239975 & 6,173 & Chimney Rock \\
\hline 376 & 474396 & 4239997 & 6,154 & Whiskey Flat \\
\hline 377 & 478114 & 4237697 & 5,440 & Sulphur Creek \\
\hline 378 & 484134 & 4226216 & 5,945 & Pleasant Valley \\
\hline 379 & 484134 & 4226216 & 5,945 & Pleasant Valley \\
\hline 380 & 484147 & 4226183 & 5,945 & Pleasant Valley \\
\hline 381 & 484147 & 4226183 & 5,945 & Pleasant Valley \\
\hline 382 & 484117 & 4226158 & 5,954 & Pleasant Valley \\
\hline 383 & 484117 & 4226158 & 5,954 & Pleasant Valley \\
\hline 384 & $495^{167}$ & 4236402 & 4,835 & West of Blue Dugway \\
\hline 385 & 501056 & 4244028 & 4,589 & North Caineville Mesa \\
\hline 386 & 501888 & $424435^{8}$ & 4,585 & North Caineville Mesa \\
\hline 387 & 507246 & 4246139 & 4,502 & North Caineville Mesa \\
\hline 388 & 495353 & 4236640 & 4,901 & West of Blue Dugway \\
\hline 389 & $4955^{82}$ & 4236925 & 4,913 & Blue Dugway \\
\hline 390 & $4955^{82}$ & 4236925 & 4,913 & Blue Dugway \\
\hline 391 & 495673 & 4237042 & 4,913 & Blue Dugway \\
\hline 392 & 479763 & 4233905 & 5,600 & Grand Wash \\
\hline 393 & $47855^{1}$ & 4235476 & 5,683 & Danish Hill \\
\hline 394 & 490716 & 4233383 & 5,173 & Old Notom Road \\
\hline 395 & 491121 & 4233885 & 5,119 & Old Notom Road \\
\hline 396 & 491712 & 4233989 & 5,112 & Caineville Reef \\
\hline 397 & 513034 & 4246812 & 4,413 & Blue Valley \\
\hline 398 & 509889 & 4246428 & 5,449 & Golden Stairs \\
\hline 399 & 497260 & 4238462 & 4,664 & South Caineville Mesa \\
\hline
\end{tabular}




\section{Henry Mountains Repeat Photo Locations and Elevations \\ (UTM ZONE I2N, NAD 83)}

\begin{tabular}{|c|c|c|c|c|}
\hline Plate No. & Easting & Northing & Elevation & Subject-Location \\
\hline 400 & 496538 & 4238304 & 4,678 & Fremont River \\
\hline 401 & 496406 & 4238316 & 4,685 & Fremont River \\
\hline 402 & 497607 & 4241407 & $4,65^{2}$ & South Caineville Mesa \\
\hline 403 & 498006 & 4242306 & 4,623 & South Caineville Mesa \\
\hline 404 & 498169 & 4242533 & 4,628 & Caineville \\
\hline 405 & 498242 & 4242897 & 4,663 & Caineville \\
\hline 406 & 495965 & 4238183 & 4,710 & Fremont River \\
\hline 407 & $5^{22479}$ & 4246961 & 4,331 & Fremont River \\
\hline 408 & $5^{22461}$ & 4246963 & $4,33^{6}$ & Hanksville Irrigation Dam \\
\hline 409 & $5^{22466}$ & 4246973 & $4,33^{\circ}$ & Fremont River Crossing \\
\hline 410 & $5^{22455}$ & 4246963 & 4,335 & Fremont River Dam \\
\hline 411 & $5^{225^{2} 6}$ & 4246937 & 4,306 & Fremont River Bridge \\
\hline 412 & $5^{22486}$ & 4246893 & 4,324 & Fremont River Bridge \\
\hline 413 & 521837 & 4247073 & 4,357 & Utah Highway 24 \\
\hline 414 & $5^{26195}$ & $42505^{2} 6$ & 4,294 & Muddy Creek \\
\hline 415 & $5^{26168}$ & 4250539 & 4,273 & Muddy Creek \\
\hline 416 & $5^{26205}$ & 4250492 & 4,260 & Muddy Creek \\
\hline 417 & $5^{26132}$ & 4250491 & 4,275 & Muddy Creek \\
\hline 418 & 520963 & 4232576 & 4,986 & Dry Valley \\
\hline 419 & 524699 & 4236413 & 4,760 & Bull Creek Road \\
\hline 420 & $5^{22} 65^{2}$ & 4223643 & 6,422 & Bull Mountain \\
\hline 421 & 528625 & 4231402 & 4,911 & Halfway Wash \\
\hline 422 & 522544 & 4246944 & 4,327 & Fremont River Bridge \\
\hline 423 & $5^{22488}$ & 4246888 & 4,346 & Fremont River Bridge \\
\hline 424 & $5^{26898}$ & 4250548 & 4,290 & Dirty Devil River \\
\hline 425 & $5^{26864}$ & 4250573 & 4,273 & Dirty Devil River \\
\hline 426 & $5^{26829}$ & 4250525 & 4,261 & Dirty Devil River \\
\hline 427 & $5^{26807}$ & 4250513 & 4,236 & Dirty Devil River \\
\hline 428 & $5^{26807}$ & 4250513 & 4,236 & Dirty Devil River \\
\hline 429 & $5^{26775}$ & 4250491 & 4,239 & Dirty Devil River \\
\hline 430 & $5^{2} 6563$ & 4250409 & 4,242 & Muddy Creek \\
\hline 431 & $5^{26809}$ & 4250632 & 4,262 & Dirty Devil River \\
\hline $43^{2}$ & $5^{26800}$ & 4250617 & 4,268 & Dirty Devil River \\
\hline 433 & 525086 & 4247026 & 4,312 & Bull Creek \\
\hline 434 & 525086 & 4247026 & 4,312 & Bull Creek \\
\hline 435 & 529666 & 4238508 & 4,594 & Halfway Bench \\
\hline $43^{6}$ & $5^{29931}$ & 4238477 & 4,596 & Halfway Bench \\
\hline
\end{tabular}




\section{Henry Mountains Repeat Photo Locations and Elevations \\ (UTM ZONE I2N, NAD 83)}

\begin{tabular}{|c|c|c|c|c|}
\hline Plate No. & Easting & Northing & Elevation & Subject-Location \\
\hline 437 & 529943 & 4238488 & 4,600 & Halfway Bench Exclosure \\
\hline 438 & 529891 & 4238487 & 4,594 & Halfway Bench Exclosure \\
\hline 439 & 529946 & 4238488 & 4,494 & Halfway Bench Exclosure \\
\hline 440 & 530024 & 4238384 & 4,585 & Halfway Bench Exclosure \\
\hline 441 & 535392 & 4194813 & 5,784 & Black Table \\
\hline 442 & 531056 & 4191223 & 6,214 & Mount Hillers \\
\hline 443 & $5^{29743}$ & 4189146 & 6,169 & Starr Springs \\
\hline 444 & $5^{2875^{1}}$ & 4188204 & $6,25^{2}$ & Mount Hillers \\
\hline 445 & $5^{27312}$ & $418803^{2}$ & 6,056 & Mount Hillers \\
\hline 446 & $5^{2} 6830$ & 4186509 & 5,722 & Copper Creek Bench \\
\hline 447 & $5^{27323}$ & 4188512 & 6,161 & Copper Creek Bench \\
\hline 448 & $5^{27075}$ & 4189743 & 6,624 & Upper Copper Creek Bench \\
\hline 449 & $5^{26966}$ & 4189428 & 6,443 & Upper Copper Creek Benches \\
\hline $45^{\circ}$ & $5^{26966}$ & 4189428 & 6,443 & Upper Copper Creek Benches \\
\hline $45^{\prime}$ & 525037 & 4188990 & 6,313 & Mount Hillers \\
\hline $45^{2}$ & 491940 & 4213942 & 5,592 & Lower Oak Creek Canyon \\
\hline 453 & 491407 & 4213618 & 5,625 & North Coleman Valley \\
\hline 454 & 491219 & 4213726 & 5,632 & Oak Creek Bench \\
\hline 455 & 491219 & 4213726 & 5,632 & Oak Creek Bench \\
\hline $45^{6}$ & 491219 & 4213726 & 5,632 & Oak Creek Bench \\
\hline 457 & 488569 & 4214387 & 5,809 & Upper Oak Creek Bench \\
\hline $45^{8}$ & 488081 & 4214907 & 5,826 & Oak Creek Canyon \\
\hline 459 & 488442 & 4214364 & 5,800 & Sandy Ranch Flume \\
\hline 460 & 505593 & 4212570 & 5,912 & King Ranch \\
\hline 461 & 511030 & 4207997 & $6,5^{24}$ & Stevens Narrows \\
\hline 462 & 508691 & 4216964 & 6,414 & Apple Brush Flat \\
\hline 463 & 491721 & 4224859 & 5,186 & Rock Formation \\
\hline 464 & 491939 & 4226476 & 5,233 & Burro Wash \\
\hline 465 & 491928 & $422647^{2}$ & 5,229 & Burro Wash \\
\hline 466 & 490026 & 4231045 & 5,289 & Grave, Notom, Utah \\
\hline 467 & 490026 & 4231045 & 5,289 & Grave, Notom, Utah \\
\hline 468 & 490026 & 4231045 & 5,289 & Grave, Notom, Utah \\
\hline 469 & 490026 & 4231045 & 5,289 & Notom, Utah \\
\hline 470 & 488378 & 4214307 & 5,800 & Sandy Ranch Flume \\
\hline 471 & 515853 & 4211360 & 9,427 & South Creek Ridge \\
\hline $47^{2}$ & $5^{21497}$ & 4211137 & 8,949 & Copper Ridge \\
\hline 473 & 519962 & 4214777 & 9,324 & Granite Ridges \\
\hline
\end{tabular}




\section{Henry Mountains Repeat Photo Logations and Elevations \\ (UTM ZONE I2N, NAD 83)}

\begin{tabular}{|c|c|c|c|c|}
\hline Plate No. & Easting & Northing & Elevation & Subject-Location \\
\hline 474 & 522178 & 4213980 & 7,779 & Eagle City \\
\hline 475 & 519518 & 4211482 & 9,376 & Copper Ridge \\
\hline $47^{6}$ & $5^{16} 735$ & 4210742 & 9,312 & Mount Pennell \\
\hline 477 & 515885 & 4211405 & 9,433 & South Creek Ridge \\
\hline 478 & 515955 & 4211412 & 9,479 & South Creek \\
\hline 479 & 517057 & 4208527 & 8,085 & The Horn \\
\hline 480 & 517940 & 4204166 & 8,716 & The Horn \\
\hline 481 & 515802 & 4206009 & 7,737 & The Horn \\
\hline 482 & 502816 & 4200284 & 6,594 & Tarantula Mesa \\
\hline 483 & 505811 & 4209576 & $5,94^{2}$ & Sweetwater Valley \\
\hline 484 & 505811 & 4209576 & $5,94^{2}$ & Sweetwater Valley \\
\hline 485 & 478434 & 4237429 & 5,390 & Fremont River \\
\hline 486 & 478243 & 4237725 & 5,379 & Sulphur Creek \\
\hline 487 & 478430 & 4237436 & 5,390 & Fremont River \\
\hline 488 & 477893 & $423793^{8}$ & 5,419 & Sulphur Creek \\
\hline 489 & 478537 & 4237469 & 5,439 & Fremont River \\
\hline 490 & 478222 & $423695^{1}$ & 5,433 & Fremont River Valley \\
\hline 491 & 478437 & 4237435 & 5,385 & Fremont River \\
\hline 492 & 478427 & 4237436 & 5,390 & Fremont River \\
\hline 493 & 478415 & 4237440 & 5,380 & Fremont River \\
\hline 494 & 478367 & 4237714 & 5,414 & Sulphur Creek \\
\hline 495 & 478367 & 4237714 & 5,414 & Sulphur Creek \\
\hline 496 & $47855^{2}$ & 4237591 & 5,413 & Fremont River \\
\hline 497 & $47855^{2}$ & 4237591 & 5,413 & Fremont River \\
\hline 498 & $4785^{24}$ & 4237626 & 5,393 & Fremont River \\
\hline 499 & 478578 & 4237612 & 5,393 & Fremont River \\
\hline 500 & 478754 & 4237787 & 5,390 & Fremont River \\
\hline 501 & 478430 & $423745^{1}$ & 5,390 & Fremont River \\
\hline 502 & 490313 & 4228048 & 5,487 & Notom Bench \\
\hline 503 & 490313 & 4228048 & 5,487 & Notom Bench \\
\hline 504 & $5^{20044}$ & 4213397 & 10,036 & Kimble and Turner Peak \\
\hline 505 & 520044 & 4213397 & 10,036 & Bartons Peak \\
\hline 506 & 520044 & 4213397 & 10,036 & Bartons Peak \\
\hline 507 & 520020 & $421337^{2}$ & 10,031 & Bromide Basin \\
\hline 508 & 519585 & $42133^{16}$ & 9,843 & Bromide Basin \\
\hline 509 & 519260 & 4213061 & 9,873 & Bromide Basin \\
\hline 510 & 518383 & 4201011 & 11,410 & Mount Pennell \\
\hline
\end{tabular}




\section{Henry Mountains Repeat Photo Locations and Elevations \\ (UTM ZONE I2N, NAD 83)}

\begin{tabular}{|c|c|c|c|c|}
\hline Plate No. & Easting & Northing & Elevation & Subject-Location \\
\hline $5^{11}$ & 518383 & 4201011 & 11,410 & Mount Pennell \\
\hline $5^{12}$ & $51493^{2}$ & 4216945 & 9,559 & Pistol Ridge \\
\hline 513 & 518106 & 4214721 & 11,128 & South Summit Ridge \\
\hline 514 & 518000 & 4214780 & 11,111 & South Summit Ridge \\
\hline 515 & $515^{211}$ & 4209700 & 8,260 & North Fork of Bulldog Creek \\
\hline 516 & $515^{211}$ & 4209700 & 8,260 & North Fork of Bulldog Creek \\
\hline $5^{17}$ & 515179 & 4209675 & 8,237 & North Fork of Bulldog Creek \\
\hline 518 & 525984 & 4242511 & 4,443 & Dry Valley \\
\hline 519 & $5^{22461}$ & 4246970 & 4,341 & Fremont River \\
\hline $5^{20}$ & $5^{24519}$ & 4246906 & 4,391 & Hanksville, Utah \\
\hline $5^{21}$ & 531265 & 4232756 & 4,764 & Halfway Wash \\
\hline $5^{22}$ & $5^{28939}$ & 4247615 & 4,497 & Hanksville Desert \\
\hline $5^{23}$ & $5^{283} 68$ & 4248989 & 4,382 & Hanksville Desert \\
\hline $5^{24}$ & $5^{28395}$ & 4248989 & 4,302 & Hanksville Desert \\
\hline $5^{25}$ & 530301 & 4237598 & 4,615 & Halfway Bench \\
\hline $5^{26}$ & 530303 & 4237576 & 4,616 & Halfway Bench \\
\hline $5^{27}$ & 534585 & 4243497 & 4,480 & Hell Hole Swale \\
\hline 528 & 495547 & 4236911 & 4,917 & Blue Dugway \\
\hline 529 & $4945^{16}$ & 4224107 & 5,084 & Burro Wash \\
\hline 530 & 492304 & 4234911 & 4,955 & Sand Wash \\
\hline 531 & 479806 & 4233611 & 5,643 & Grand Wash \\
\hline $53^{2}$ & 473803 & $424037^{2}$ & 6,132 & Chimney Rock \\
\hline 533 & 504990 & 4219048 & 5,789 & Apple Brush Flat \\
\hline 534 & 493179 & 4219753 & 5,354 & Sheets Gulch Benchlands \\
\hline 535 & 493131 & 4219734 & $5,35^{2}$ & Sheets Gulch Benchlands \\
\hline 536 & 495301 & 4211797 & 5,346 & Sandy Creek Bench \\
\hline 537 & 495301 & 4211797 & 5,346 & Sandy Creek Bench \\
\hline $53^{8}$ & 498816 & 4189993 & 4,990 & Halls Creek \\
\hline 539 & 519441 & 4173721 & 4,900 & Clay Point \\
\hline 540 & 519441 & 4173721 & 4,900 & Clay Point \\
\hline 541 & 517671 & 4172232 & 4,869 & Clay Point \\
\hline 542 & 517671 & 4172232 & 4,869 & Clay Point \\
\hline 543 & 513678 & 4180468 & 4,509 & Eggnog \\
\hline 544 & 509691 & 4178531 & 5,098 & Clay Canyon - Butt Canyon Bench \\
\hline 545 & 509262 & 4178429 & 5,107 & Clay Canyon - Butt Canyon Bench \\
\hline 546 & $53^{2} 647$ & 4191045 & 5,808 & Woodruff Flat \\
\hline 547 & 533646 & 4191723 & 5,778 & Woodruff Flat \\
\hline
\end{tabular}




\section{Henry Mountains Repeat Photo Logations and Elevations \\ (UTM ZONE I2N, NAD 83)}

\begin{tabular}{|c|c|c|c|c|}
\hline Plate No. & Easting & Northing & Elevation & Subject-Location \\
\hline 548 & 529513 & 4171668 & 4,486 & Cane Spring Desert \\
\hline 549 & $5^{29513}$ & 4171668 & 4,486 & Cane Spring Desert \\
\hline $55^{\circ}$ & 529606 & 4162412 & 4,253 & Cane Spring Desert \\
\hline $55^{1}$ & 529606 & 4162412 & 4,253 & Cane Spring Desert \\
\hline $55^{2}$ & $5345^{25}$ & $416817^{2}$ & 4,561 & Smith Fork Desert \\
\hline 553 & $5345^{25}$ & $416817^{2}$ & 4,561 & Smith Fork Desert \\
\hline 554 & 534942 & 4173548 & 5,376 & Smith Fork \\
\hline 555 & 537790 & 4171505 & 5,081 & Ticaboo Mesa \\
\hline 556 & $5^{22599}$ & 4190775 & 6,299 & Pennell Creek Bench \\
\hline 557 & 520746 & 4189393 & $5,63^{2}$ & Cow Flat \\
\hline $55^{8}$ & 520780 & 4189480 & 5,639 & Cow Flat \\
\hline 559 & 536910 & 4199311 & 4,995 & Black Table \\
\hline 560 & $5^{2} 685^{1}$ & 4229491 & 5,076 & Halfway Wash \\
\hline 561 & $5^{26849}$ & 4229548 & 5,077 & Halfway Wash \\
\hline 562 & 516666 & 4217490 & 11,493 & North Summit Ridge \\
\hline 563 & 516321 & 4218324 & 11,291 & Mount Ellen \\
\hline 564 & $5^{16302}$ & 4218420 & 11,240 & Mount Ellen \\
\hline 565 & $5^{16478}$ & 4218294 & 11,156 & Mount Ellen \\
\hline $5^{66}$ & 516647 & 4218302 & 11,182 & Mount Ellen \\
\hline 567 & $5^{1627^{2}}$ & 4219268 & 11,477 & Mount Ellen \\
\hline 568 & $5^{1627^{2}}$ & 4219268 & 11,477 & North Summit Ridge \\
\hline 569 & $5^{1627^{2}}$ & 4219268 & 11,477 & Mount Ellen \\
\hline 570 & 516226 & 4218671 & 11,054 & Mount Ellen \\
\hline 571 & $5^{16684}$ & 4217440 & 11,499 & North Summit Ridge \\
\hline $57^{2}$ & $5^{16674}$ & 4217423 & 11,500 & South Summit Ridge \\
\hline 573 & $5^{20147}$ & 4200306 & $8,45^{6}$ & Straight Creek \\
\hline 574 & $5^{20147}$ & 4200306 & 8,456 & Straight Creek \\
\hline 575 & 532638 & 4201966 & 5,337 & Farmers Knob \\
\hline $57^{6}$ & 541471 & 4222467 & 5,174 & Burr Desert \\
\hline 577 & 543191 & $422495^{8}$ & 5,325 & Burr Desert \\
\hline 578 & 543160 & 4224955 & 5,324 & Burr Desert \\
\hline 579 & 542997 & 4226604 & 5,449 & Burr Desert \\
\hline 580 & $53255^{6}$ & 4214810 & 5,002 & Little Egypt \\
\hline 581 & $53^{2} 5^{22}$ & 4214548 & 5,001 & Little Egypt \\
\hline 582 & 537579 & 4226878 & 4,990 & Burr Desert \\
\hline 583 & 531897 & 4229662 & 4,783 & Burr Desert \\
\hline 584 & $53^{2} 653$ & 4227026 & 4,816 & Burr Desert \\
\hline 585 & $53^{2} 626$ & 4227024 & 4,827 & Burr Desert \\
\hline
\end{tabular}




\begin{tabular}{|c|c|c|c|c|}
\hline \multicolumn{5}{|c|}{$\begin{array}{l}\text { Henry Mountains Repeat Photo Locations and Elevations } \\
\text { (UTM Zone i2N, NAD 83) }\end{array}$} \\
\hline Plate No. & Easting & Northing & Elevation & Subject-Location \\
\hline 586 & 518421 & 4234901 & 4,628 & Birch Creek \\
\hline 587 & 518421 & 4234901 & 4,628 & Birch Creek \\
\hline 588 & 512365 & 4231138 & 5,087 & Cottonwood Creek \\
\hline 589 & 512365 & 4231138 & 5,087 & Cottonwood Creek \\
\hline 590 & $5^{25421}$ & 4248410 & 4,313 & Fremont River \\
\hline 591 & 498607 & 4242888 & 4,667 & Caineville, Utah \\
\hline 592 & 498607 & 4242888 & 4,667 & Caineville, Utah \\
\hline 593 & 533812 & 4202457 & 5,049 & Trachyte Ranch \\
\hline 594 & 533880 & 4202348 & 5,095 & Trachyte Ranch \\
\hline 595 & 533880 & 4202348 & 5,095 & Trachyte Ranch \\
\hline 596 & 533728 & $420233^{6}$ & 5,037 & Trachyte Ranch \\
\hline 597 & 506603 & 4174164 & 5,180 & Big Thompson Mesa \\
\hline 598 & 506597 & 4174169 & 5,181 & Big Thompson Mesa \\
\hline 599 & 508585 & 4168708 & 4,980 & South Big Thompson Mesa \\
\hline 600 & 508585 & 4168708 & 4,980 & South Big Thompson Mesa \\
\hline 601 & 507362 & $417195^{\circ}$ & 5,017 & Big Thompson Mesa \\
\hline 602 & 513298 & 4246782 & 4,431 & Abbott Hotel \\
\hline 603 & $5^{228} 836$ & 4229564 & 5,227 & Fairview Ranch \\
\hline 604 & 522239 & 4247639 & 4,350 & Dead Horse Butte \\
\hline 605 & 521654 & 4241661 & $4,5^{6} 3$ & South Pinto Hills \\
\hline 606 & 534766 & 4207672 & 4,890 & Cottonwood Wash \\
\hline 607 & 534766 & 4207672 & 4,563 & Cottonwood Wash \\
\hline 608 & 510992 & 4181390 & 4,749 & Butt Canyon \\
\hline
\end{tabular}





\section{- Appendix B}

\begin{tabular}{|c|c|c|c|}
\hline \multicolumn{4}{|c|}{ Features and Elevations } \\
\hline Name & Elevation $(\mathrm{ft} .)^{\dagger}$ & Name & Elevation $(\mathrm{ft} .)^{\dagger}$ \\
\hline Bartons Peak & 10,036 & Kimble and Turner Peak & 11,143 \\
\hline Big Ridge & 8,423 & Mount Ellen Peak & 11,506 \\
\hline Big Thompson Mesa & 5,200 & Mount Ellsworth & 8,235 \\
\hline Black Table & 6,244 & Mount Hillers & 10,737 \\
\hline Blue Valley Benches & 5,000 & Mount Holmes & 7,998 \\
\hline Boulder Mountain & 11,082 & Mount Pennell & $11,43^{8}$ \\
\hline Bromide Basin & 10,300 & Navajo Mountain & 10,346 \\
\hline Browns Knoll & 8,162 & North Caineville Mesa & 6,000 \\
\hline Bull Creek Pass & 10,485 & North Pinto Hills & 4,646 \\
\hline Bulldog Ridge & 10,060 & North Summit Ridge & 11,491 \\
\hline Bull Mountain & 9,187 & Notom Bench & 5,500 \\
\hline Butler Wash Bench* & 6,800 & Oak Creek Bench & 6,200 \\
\hline Caineville Reef & 5,000 & Oyster Shell Reef & 5,300 \\
\hline Cass Creek Peak & 9,428 & Pennellen Pass & 7,818 \\
\hline Cedar Creek Bench & 6,300 & Pete Steele Bench & 5,900 \\
\hline Chimney Rock & 6,414 & Pinto Knolls* & 5,621 \\
\hline Clay Point & 4,900 & Pistol Ridge & 10,000 \\
\hline Copper Creek Benches & 5,800 & Ragged Mountain & 9,113 \\
\hline Copper Ridge & 9,180 & Sandy Creek Bench & 5,300 \\
\hline Corral Point & $9,85^{\circ}$ & Skyline Rim & 4,800 \\
\hline Coyote Benches & 6,600 & South Caineville Mesa & 5,942 \\
\hline Crescent Creek Bench* & 6,700 & South Creek Ridge & 9,424 \\
\hline Danish Hill & 5,818 & South Fork Ridge & 6,200 \\
\hline Dead Horse Butte* & 4,398 & South Pinto Hills & 4,800 \\
\hline Deer Heaven & 10,687 & South Summit Ridge & 11,419 \\
\hline Dry Lakes Peak & $10,45^{1}$ & Stanton Pass & 7,384 \\
\hline Dugout Bench & 5,600 & Steele Butte & 6,896 \\
\hline Durfey Butte & 9,580 & Stevens Mesa & 5,871 \\
\hline East Saddle (gap) & 9,945 & Summerville Formation* & 4,800 \\
\hline Factory Butte & 6,221 & Table Mountain & $8,5^{21}$ \\
\hline Farmers Knob & 5,460 & Tarantula Mesa & 7,124 \\
\hline Golden Stairs* & 4,500 & The Horn & 9,189 \\
\hline Granite Ridges & $9,15^{2}$ & Ticaboo Mesa & 5,000 \\
\hline Halfway Bench & 4,600 & Wickiup Ridge & 9,806 \\
\hline Horseshoe Ridge & $9,53^{8}$ & Wildcat Mesa & 6,030 \\
\hline Indian Spring Benches & 6,500 & ${ }^{\dagger}$ Elevation may be an aver & \\
\hline
\end{tabular}





\section{Appendix C}

\begin{tabular}{|c|c|c|c|}
\hline \multicolumn{4}{|c|}{ Common and Scientific Names of Plants in the Study } \\
\hline Common Plant Name & Scientific Name & Common Plant Name & Scientific Name \\
\hline alfalfa & Medicago sativa & narrowleaf cottonwood & Populus angustifolia \\
\hline aspen & Populus tremuloides & narrowleaf yucca & Yucca angustissima \\
\hline big sagebrush & Artemisia tridentata & needle and thread & Hesperostipa comata \\
\hline birchleaf mountain mahogany & Cercocarpus montanus & oak brush & Quercus gambelii \\
\hline bitterbrush & Purshia tridentata & phlox & Phlox spp. \\
\hline blackbrush & Coleogyne ramosissima & pinyon & Pinus edulis \\
\hline black sage or black sagebrush & Artemisia nova & ponderosa pine & Pinus ponderosa \\
\hline blue grama & Bouteloua gracilis & pricklypear cactus & Opuntia spp. \\
\hline broom snakeweed & Gutierrezia sarothrae & river birch & Betula occidentalis \\
\hline cattails & Typha spp. & rubber rabbitbrush & Ericameria nauseosa \\
\hline cheatgrass & Bromus tectorum & Russian olive & Elaeagnus angustifolia \\
\hline chokecherry & Prunus virginiana & Russian thistle & Salsola tragus \\
\hline curl-leaf mountain mahogany & Cercocarpus ledifolius & sagebrush & Artemisia spp. \\
\hline curly grass (galleta) & Pleuraphis jamesï & Sandberg bluegrass & Poa secunda \\
\hline currant & Ribes spp. & sand dropseed & Sporobolus cryptandrus \\
\hline desert trumpet & Eriogonum inflatum & scarlet globemallow & Sphaeralcea coccinea \\
\hline Douglas-fir & Pseudotsuga menziesï & shadscale & Atriplex confertifolia \\
\hline Engelmann spruce & Picea engelmannï & sheep fescue & Festuca ovina \\
\hline fleabane daisy & Erigeron spp. & snowberry & Symphoricarpos oreophilus \\
\hline fourwing saltbush & Atriplex canescens & spruce & Picea spp. \\
\hline Fremont cottonwood & Populus fremontii & squaw apple & Peraphyllum ramosissimum \\
\hline greasewood & Sarcobatus vermiculatus & squirreltail & Elymus elymoides \\
\hline groundsel & Senecio spp. & subalpine fir & Abies lasiocarpa \\
\hline Indian paintbrush & Castilleja spp. & tamarisk & Tamarix ramosissima \\
\hline Indian ricegrass & Achnatherum hymenoides & turbinella oak & Quercus turbinella \\
\hline intermediate wheatgrass & Thinopyrum intermedium & utah serviceberry & Amelanchier utahensis \\
\hline juniper & Juniperus spp. & wild Nootka rose & Rosa nutkana \\
\hline limber pine & Pinus flexilis & willow & Salix spp. \\
\hline locoweed & Astragalus spp. & winterfat & Krascheninnikovia lanata \\
\hline lupine & Lupinus spp. & woods rose & Rosa woodsï \\
\hline Mormon tea & Ephedra viridis & yarrow & Achillea millefolium \\
\hline mountain big sagebrush & Artemisia tridentata vaseyana & yellow rabbitbrush & Chrysothamnus viscidiflorus \\
\hline
\end{tabular}




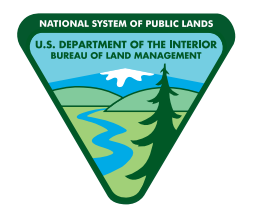

Long-Term Vegetation Change in Utah's Henry Mountains

A Study in Repeat Photography 